

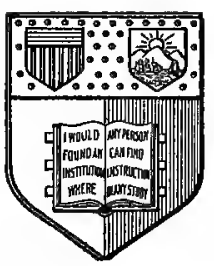

New York

State College of Agriculture At Cornell University

Itbaca, N. Y.

Library 
SB 615.P8O3 3 University Library

Report of the Prickly-pear Travelling Co

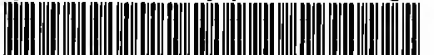

$\begin{array}{lll}3 & 1924002830838\end{array}$ 


\section{Cornell University Library}

The original of this book is in the Cornell University Library.

There are no known copyright restrictions in the United States on the use of the text.

http://www.archive.org/details/cu31924002830838 


1914.

QUEENSLAND.

\section{REPORT}

OF THE

\section{PRICKLY-PEAR TRAVELLING COMMISSION}

1 ST NOVEMBER, 1912-30Tн APRIL, 1914.

BY

T. HARVEY JOHNSTON, M.A., D.Sc., F.L.S., BIOLOGY DEPARTMENT, UNIVERSITY OF QUEENSLAND, BRISBANE;

AND

HENRY TRYON, GOVERNMENT ENTOMOLOGIST AND VEGETABLE PATHOLOGIST, DEPARTMENT OF AGRICULTURE AND STOCK, BRISBANE.

PRESENTED TO BOTH HOUSES OF PARLIAMENT BY COMMAND.

BRISBANE :

BY AUTHORITY: ANTHONY JAMES CUMMING, GOVERNMENT PRINTER, BRISBANE.

C.A. 91-1914. 



\section{CONTENTS.}

Letter of Appointment and Duties of the Commission

Letter of Transmission to Hon. Secretary for Public Lands

Summary and Recommendations

Section 1.-Investigations in Sydney, Java, Singapore, and Ceylon

Summary of Section 1 .

Section 2.-In Indis

Summary of Section 2 .

Section 3.-In South Africa

Summary of Section 3 ..

Section 4.-In Canary Islands

Summary of Section 4

Section 5.-In Europe and the Mediterranean Area

Summary of Section 5 ..

Seotion 6.-In the United States

Summary of Section 6 ...

Section 7.-In Mexico and Central America .

Summary of Section 7

Section 8.--In the West Indies

Summary of Section 8

Section 9.-In South America

Summary of Section 9 .

Section 10.-In the Hawailan Islands

Summary of Section 10

Section 11.-Summary of Information available in Australian States other than Queensland

Referenoes to Literature

Supplementary Notes 


\title{
APPOINTMENT OF COMMISSION.
}

\author{
Department of Public Lands, \\ Brisbane, 10th September, 1912.
}

To Messrs. Thomas Harvey Johnston, M.A., D. Sc., F.I.S., and Henry Tryon.

GENTLEMEN,-I am direted to inform you that the Governor in Council has been pleased to appoint you to be a Commission of Inquiry to visit countries in which prickly-pear plants are indigenous, or have become naturalised, for the purpose of ascertaining if there are present in such countries any natural enemies of the prickly-pear that may be utilised for the destruction of the plant in Queensland, and also of inquiring into the possibility of utilising prickly-pear for commercial purposes, and has also appointed Thomas Harvey Johnston to be Chairman of the Commission.

In conveying to you this decision I am desired to state that the Government wish you to give consideration to the following points (among others that may suggest themselves to you) with respect to the various species of prickly-pear and allied Cactaceæ, viz. :-

1. What diseases parasitic plant organisms and parasitic or predatory insects are injuriously related to these plants, and the nature, character, and extent, in each case, of the injuries.

2. The circumstances of the occurrence of all such agents affecting these plants.

3. The checks, if any, that control or impair the exercise of the full virulence of all such agencies, and the nature of such checks.

4. The introduction into Queensland, subject to the elimination of any such checks, of such diseases, parasitic plant organisms and parasitic or predatory insects, and their establishment therein in connection with the naturalised species of prickly-pear already growing at large within the State, having regard to the question of destroying, subjugating, or controlling them without ill effect on any object whatever other than prickly-pear.

5. The possibility of utilising prickly-pear for commercial purposes, and so destroying it by means of its utilisation.

I have the honour to be,

Gentlemen,

Your Obedient Servant,

P. W. SHANNON,

Under Secretary. 


\section{REPORT OF THE PRICKLY-PEAR TRAVELLING COMMISSION.}

\section{TO THE HONOURABLE THE SECRETARY FOR PUBLIC LANDS.}

Brisbane, 25th November, 1914. investigations.

SIR,--We have the honour to submit the subjoined report of our

$$
\text { We have, \&c., }
$$

T. HARVEY JOHNSTON, HENRY TRYON.

\section{SUMMARY AND RECOMMENDATIONS.}

\section{INTRODUCTORY.}

It may be pointed out that prickly-pears or opuntias, of more than one kind, are pests of agricultural and pastoral lands, locally, in many countries besides Australia - for example, India, Ceylon, and South Africa, as well as in North and South America and the West Indies. The pest pears of most of these regions, however, being especially spiny species, while the common pest pear of Queensland and New South Wales (Opuntia inermis) is comparatively unarmed, do not lend themselves so readily to spontaneous dissemination and propagation as does the latter, since cattle, one of the chief agents in these processes, are debarred from access to them, and as a result the ground does not become littered to any extent with fragments each capable of originating a new plant-individual. For the same reason, the fruits of the former are less likely to be partaken of and their contained seeds carried far afield with their germinating powers not only preserved but enhanced. These remarks do not apply, however, to prickly-pears of the class represented by $O$. aurantiaca, which are of a very brittle nature, for in their case this spininess of the joints actually brings about their adherence to, and transportation by, animals browsing amongst them.

\section{ITINERARY.}

The Prickly-pear Travelling Commission entered upon its inquiries on 1st November, 1912. In order to become more familiar with the problems to which it had been called upon to address itself, it visited Westwood, Rockhampton, Gayndah, and Dulacea where infestation was heavy. Thereupon it proceeded to Sydney to obtain advice and assistance from Mr. J. H. Maiden, Government Botanist of New South Wales, who has for many years been actively interested in opuntias.

Some investigations were made in Java whilst en route to Ceylon. After concluding our work in the latter island, India was visited. In order to cover the field more expeditiously the Commission divided its labours, one member proceeding to Northern and North-western India, while the other confined 
his attention to the Presidencies of Bombay and Madras and to the State of Mysore. South Africa was reached viâ the east coast of Africa. Here most of the time was spent in the infested regions of the eastern and south-eastern portions of the Cape Province.

The Canary Islands were toured while we were en route to Europe.

In order to economise time, it was decided to divide the work in the Mediterranean littoral, just as had been done in India. The Commissioners therefore separated after leaving Spain, one proceeding to Sicily and Italy and thence to England, where inquiries regarding utilisation were instituted, while his colleague travelled through the Barbary States, Malta, and Syria (viô Egypt), returning to England vi $\hat{a}$ Italy and Germany.

The United States were then visited, and its chief cactus regions examined for the presence of any agents controlling the spread of prickly-pear there. From that country the Commissioners travelled each by a different route to the West Indies, where, after some preliminary inquiries, it was decided to again divide forces, one member to more thoroughly investigate matters in these islands while the other instituted inquiry in South America.

The Commissioners met again in San Francisco, and left for Australia, viâ Honolulu, where some investigations were made while awaiting a steamer for Sydney, the latter port being reached on 27th April. We arrived in Brisbane at the end of that month.

As was to be expected from the nature of the work, a very large amount of time was necessarily spent in travelling. The duration of the stay in any particular country or island depended to some extent on the frequency of means of communication between it and others.

The itinerary, just indicated briefly, allowed the carrying out of investigations in countries where prickly-pears occurred as exotics and in those in which these plants exist as indigenous plants. In the former, it was already known to the Commission that they covered, more or less continuously, large areas, and were in some districts objects of cultivation; hence it was anticipated that, as usually happens with economic plants under similar conditions, natural enemies would have become manifest amongst them in some place or other. It was expected that the prickly-pears growing in their proper homes would harbour injurious insects or diseases, as native plants commonly do. Besides, collections of growing opuntias, in which there had been brought together plants emanating from various parts of the world, were inspected, with the hope that the enemies which affect them in those regions, had been transported along with them to their new homes.

*As might be inferred, the literature relating to the opuntias, although very scattered, is most extensive, and, moreover, deals with these plants from every point of view. Accordingly much time was devoted to searching it in order to ascertain channels in which the inquiry might be undertaken with promise of results. The list of works of reference appended to the report, and those cited in that section of it dealing with our work in India, will indicate to what extent this has been drawn upon.

Moreover, many authorities identified with researches bearing directly or indirectly on the subject of our inquiry were interviewed, and their opinions and advice sought; but since it was not practicable to meet some investigators without much delay, their experience and counsel could not be availed of to the extent hoped for. These inquiries and consultations occupied considerable time and involved visits, sometimes necessarily repeated, to various libraries, educational and scientific institutions, administrative and other official departments, \&c. 
In many instances those whom the Commission consulted had been accustomed to regard the prickly-pear as a botanical species, or as an economic plant serving one use or another, and could therefore scarcely be brought to regard it from the present Australian standpoint. The Commission was, however, greatly aided in dealing with this emergency, and in bringing home to its auditors the actual state of affairs in Australia with regard to it by an excellent series of photographs illustrating the different species of Queensland " pears," as well as their habits of growth and mode of occurrence, which had been procured by Mr. Temple Clerk, of the Department of Public Lands, Queensland, and considerately made available by him.

The Commission had been asked to visit both those countries where prickly-pears were indigenous and those in which these plants were naturalised. To have carried out that itinerary in its entirety would have involved a very protracted inquiry. Hence many countries were omitted, owing to the difficulties in reaching them-e.g., Bolivia, Peru, Northern Chile, Northern Argentina, Central America, many of the smaller West Indian Islands, as well as certain parts of the Mediterranean region. The civil war in Mexico, especially in the dry northern States, where the cactus flora is so rich, prevented the Commission from pursuing inquiries there, and consequently only a few of the cities within the northern frontier of Mexico were visited.

\section{THE PRICKLY-PEARS NATURALISED IN AUSTRALIA.}

There are at present naturalised in Queensland not less than eleven species of prickly-pear, viz. :-

1. The common pest pear, Opuntia inermis, DC., var. Its home is in the Greater Antilles (West Indies) and the adjacent coasts of the United States (Florida).

2. The spiny pest pear-an ally of that just named-which is especially prevalent in the Gayndah District, and occurs also in the Rockhampton area and elsewhere. It is this species which Mr. Maiden has identified in error as O. dillenii. It is also a West Indian plant.

3. O. monacantha, Haw.-A tree pear which occurs along the banks of the Suttor River, North Rockhampton, and elsewhere; but except in the localities named is sparsely distributed. Its home is Eastern and South-eastern Brazil and adjacent parts of the neighbouring Republics. This species prefers moister and more shaded conditions than do the other opuntias now occurring in Australia.

4. O. aurantiaca, Gillies.--This low-growing, very brittle plant, which occurs at Warwick and Roma, is the dreaded "jointed cactus" of South Africa. It should be immediately eradicated from our State by vigorous methods, such as systematic spraying and burning. Owing to the extreme ease with which the small spiny joints and fruits become separated and conveyed by flood water, and, moreover, attached to animals, the species is likely to become widely spread. By reason of its generally small size, the plant is likely to be overlooked until such time as it has obtained a strong foothold. It is a native of Uruguay, in South America.

5. O. tomentosa, S.D. - This "tree pear" may be found commonly in the Helidon District, and is especially prevalent in the Gogango District, a few miles west of Rockhampton, and to a less extent near Gayndah. Its home is Mexico. This plant is used in some countries as a " nurse" for raising the true cochineal.

6. Nopalea cochinelifera, Linn._- "The cochineal plant"; is also a tree pear, and may be found at Gayndah and Emerald. It is spineless and cannot be considered a pest. Its home is, doubtless, in Mexico. 
7. O. imbricata, Haw.--This is a Cylindropuntia, one of the so-called canecacti, whose habitat is Northern Mexico and the adjacent dry, arid, regions of the United States. It occurs naturalised at Laidley.

8. Opuntia, sp. (?) O. megacantha, SD. or O. chavena, Griff.-This large jointed, white-spined prickly-pear is known as the "Westwood pear," and is to be met with in the Rockhampton District. It is a Mexican species, and is related to the pest pear of South Africa, as well as that found in the Hawaiian Islands.

There is another Opuntia in the Rockhampton area which closely resembles this one and is perhaps identical with it.

9. Another white-spined Opuntia occurs near Rockhampton, where it is called the "yellow-fruiting Mexican pear." This species, which is of Mexican origin, is very like the spiny pest pear of South Africa, and resembles the spiny Barbary fig or Indian fig (O. amyclcea) of the Mediterranean coasts.

Mr. Maiden has recorded the occurrence in Queensland of two other prickly-pears, viz. :-

10. O. nigricans, Haw. ; and

11. Nopalea dejecta, S.D. The former, which is found at Yelarbon, is indigenous to certain parts of Brazil, while the latter, which is reported from Rockhampton, is regarded as being a native of Cuba, though perhaps Mexico is its true home.

New South Wales possesses-(1) O. inermis, DC., var.; (2) O. nigricans, Haw. ; (3) O. monacantha, Haw. ; and (4) O. ficus indica as well as (5) O. microdasys, Lehm. The lastnamed belongs to the drier parts of Mexico.

o. monacantha occurs naturalised in Victoria and South Australia, and the spiny pest pear of Queensland is also reported from the latter State.

\section{THE PRICKLY-PEARS NATURALISED IN OTHER COUNTRIES VISITED.}

The pest species in Northern Ceylon is O. dillenii, Haw., while in India there is, in addition to this one, $O$. nigricans, the former being especially prevalent in the Presidency of Madras, the latter in Bombay and Central India. Both occur in Northern India, but are not sufficiently beyond control to constitute pests. O. stricta, or a very closely related species, occurs fairly commonly in the Punjab. O. monacantha was formerly abundant in India and Ceylon but has been practically exterminated there by the action of a wild cochineal insect, Coccus indicus, Green.

In South Africa the pest species are the "doornblad" variety of $O$. decumana, and the "jointed cactus," $O$. aurantiaca. $O$. monacantha is also widely spread, but is controlled by the dry climate and by the action of another wild cochineal insect, Coccus confusus capensis, Green. Several other opuntias are naturalised there but are not yet a menace.

In the Canary Islands, certain species are still cultivated as host plants for the true cochineal insect Coccus cacti, Linn. (Dactylopius coccus, Costa).

In the Mediterranean region many species are naturalised, two of them being regarded as being of considerable economic importance. These are the two kinds of Indian or Barbary fig, $O$. ficus indica, Mill, and $O$. amyclea, Ten., which may perhaps be only varieties of one species. $O$. dillenii, though not especially abundant in any one locality, is widely distributed in the coastal areas. Some species are locally prevalent, e.g., O. inermis, DC., in the Balearic Islands, and 0. nana, Vis. ( = O. opuntia, L.) in parts of the Tyrol, Switzerland, and Dalmatia. 
IX.

The pest pear of the Oahu, Hawaii, closely resembles the "Westwood pear" of our own State.

Since America is the home of prickly-pears, they were there studied by us under their natural conditions. Still, species belonging to one region have become naturalised, especially if useful, in parts of the North and South American continents other than those to which they are indigenous.

\section{DESTRUCTION BY NATURAL ENEMIES.}

\section{A. Rodents.}

In the cactus regions of the United States and Mexico, there occur several species of so-called "wood-rats," belonging to the genus Neotoma, which at times cause great havoc to prickly-pear, utilising it as food to such an extent sometimes as to locally exterminate it. Occasionally this action involves its propagation. However, since they, as well as various other rodents, are not restricted in their dietary, to cactaceous plants, their introduction to Queensland would probably be attended with grave risks, and is therefore not recommended.

\section{B. Insects.}

Prickly-pears were found to be little if at all adversely affected by insect enemies in the Mediterranean region, the Canary Islands, and Hawaii, and only to a slight extent in the West Indies and in most parts of South America which were visited.

In Ceylon, India, and South Africa, only one species of Opuntia O. monacantha, was controlled in this way, the agent being in each case a wild cochineal insect. In the two first-named countries the result of the parasitism by Coccus indicus had been so disastrous to the host plant that extermination had been practically brought about, $O$. monacantha now being found. only in relatively few scattered situations, whereas it was formerly abundant, and in places so prevalent that this insect was actually employed in its subjugation. In a few isolated localities in both of these countries the wild cochineal is still exerting its baneful influence. The other naturalised species in India $(O$. dillenii and $O$. nigricans) and Ceylon (O. dillenii) were not attacked.

In South Africa the effect was much less marked, this result being due partly to the different specific action of the particular wild cochineal insect found there (Coccus confusus capensis), and partly to the presence of predatory insects which controlled the spread of the coccid. The other species of Opuntias found naturalised in South Africa were unattacked.

The interest of the foregoing remarks lies in the fact that $O$. monacantha, the plant victimised by this insect, is one of the Queensland prickly-pears, whereas $O$. dillenii, and also the South African pest pears, which were not affected, are related to certain other of our pest pears, viz., the common pest pear, the Gayndah pear, the Westwood pear, and $O$. aurantiaca. It is unlikely that any of these will be attacked by it, although they may have other species of Coccus similarly related to them.

As was to be expected, it was in the Western hemisphere that insect enemies were found to be prevalent. Most information regarding them was obtained in the United States, where a considerable amount of investigation concerning prickly-pear enemies had already been carried out by the Burean of Entomology of the United States Department of Agriculture, as well as by certain other institutions.

The most important insect enemies of cacti, known to them and to the Commission as occurring in America, are certain beetles, moths, plant bugs, and midges, all of which are restricted to the Cactaceæ. 
In regard to the Coleoptera, the following are capable of causing damage to prickly-pear :-The various species of Moneilema, Conopceus, and Gerstockeria.

The adult of Moneilema is a large black wingless longicorn beetle, which feeds gregariously on the young segments of the host plant, while the larva is a large grub living in tunnels hollowed out by it in the stems and joints. Moneilema is widely distributed in the drier parts of the United States and Mexico.

Coenopoeus is also a large longicorn with similar habits, its home being Southern California and the adjacent regions.

The various cactus weevils, Gerstockeria, spp. with the exception of $G$. hubbardi, do comparatively little damage to the joints, either in the larval or adult stages, though the injuries caused by the larva while feeding within the segments, may sometimes become the seat of secondary infection by microorganisms and certain scavenging flies. G. hubbardi was found to be usually associated with a very destructive moth, Melitara prodenialis, in its attacks on prickly-pear in Florida.

The lepidopterous enemies comprise a number of cactus moth borers, belonging to the Phycitidoe, found in North and South America and in the West Indies, as well as certain others, such as Mimorista and Marmara, found especially in North America and the West Indies.

The Phycitid enemies include the very destructive cactus moths belonging to the genus Melitara, found in the United States, Mexico, and the West Indies, and also certain moths, Zophodia, spp., occurring in Argentina and Uruguay, in South America.

The caterpillars of these insects live within the joints of the plant, and cause great destruction, partly on account of their eating out the tissues and partly on account of the rapidity with which attacked segments become invaded by secondary organisms, such as bacteria, fungi, and scavenging flies. The death of infected joints, and even plants, is a quite common result.

Mimorista causes a great destruction of young segments of prickly-pear, and therefore acts as an important agent in controlling the spread of this group of plants. This insect, or insects producing a similar effect, occur in Texas, the West Indies, in Brazil, and, no doubt, in Mexico also.

Marmara, whose tiny caterpillar is a "leaf-miner" causes very little injury as a rule, though sometimes secondary invasions may be serious.

Amongst the Hemiptera are certain prickly-pear enemies, especially the various species of wild cochineal insects, and the members of the genera Chelinidea and Narnia. These all more or less injure the species with which they are associated. There are also others, such as various Aphids and scale insects (Diaspis), but they are not of much importance, as a rule, in controlling or destroying Opuntias.

The wild cochineal insects found attacking prickly-pear in India, Ceylon, and South Africa have already been referred to. Those seen in the United States, West Indies, Brazil, and Argentina had very little effect on their host plants. This might be accounted for in great measure by the presence of parasites. It is known that some of them, e.g., the true cochineal, and certain wild cochineals, cause very little injury by feeding, whereas others, e.g., those in Ceylon, India, South Africa, and some in Mexico, cause serious constitutional disturbances which may result in the death of the affected plant.

The "Cactus bugs" Chelinidea and Narnia attack the joints and fruit respectively, and are regarded as being very serious enemies of prickly-pear. They are found in the United States, Mexico, and the West Indies, and related forms occur in Brazil. 
The chief dipterous insects which infest prickly-pear are certain gall midges belonging to the genera Itonida and Asphondylia. The former produces galls under the areoles, and, under hot-house conditions at least, these not infrequently become the seat of secondary infection which leads to the destruction of the attacked plant. The species of Asphondylia which infest Opuntias, live during their larval stage within the fruit or the flower bud, and either destroy the seeds or else cause a proliferation, so that there is produced an "abnormal fruit" from which a joint or a flower bud arises. In either case seminal increase is prevented or restricted, and thus these insects are capable of acting as important agents in controlling the spread of various species of prickly-pear.

Notwithstanding the insect fauna of the Opuntias of the United States is relatively large in the matter of distinct insects, it may be pointed out that our knowledge concerning it-both that derived from the records of others and from the Commission's own observations-relates only to a limited section of the cactus area, and that, therefore, other more or less potent insect enemies of this group of plants may await discovery. This may be more especially the case with regard to the cactus regions outside its limit, e.g., Mexico, Central America, and South America. Accordingly it is anticipated that additional natural enemies of the class, some of them quite as injurious as any yet discovered, may exist and be utilised.

In view of what has been stated above, we recommend that, for the time being, the following insects be introduced into Queensland:-Moneilema, spp.; Conopcus palmeri; Gerstoeckeria hubbardi; Melitara, spp. ; Mimorista flavidissimalis ; Chelinidea, spp.; Narnia, spp.; the wild cochineal insects; Itonida opuntioe and Asphondylia opuntice, from the United States: Zophodia cactorum and its ally, the "Mendoza moth borer," from the Argentine Republic:

The Commission has already introduced into Queensland certain destructive wild cochineal insects, from Ceylon and South Africa. These have become established, and have maintained their character for destructiveness, at the Prickly-Pear Experimental Station, Dulacca. They should exert a powerful influence in controlling $O$. monacantha. Zophodia, which is destructive to a large number of prickly-pears, including several of the Queensland pest species, was also brought to this State, but most of the larva have died.

The insects whose introduction is recommended may prove more harmful or less harnoful to cacti in Australia than in their native home. Then, again, they may not be able to adapt themselves to our climatic conditions.

In their native country they are more or less controlled by predators and parasites, and therefore cannot exercise their full influence. It is consequently a matter of great importance that, before admission into Queensland, parasites should have been eliminated. It was for this reason, amongst others, that the Commission consulted Dr. L. O. Howard, the chief of the Bureau of Entomology, Department of Agriculture, U.S.A., and one of his senior officers, Mr. W. D. Hunter, who suggested that comparatively few individuals of each species, free from any parasites likely to control their activity, should be introduced to our country, and these subjected to careful attention. This, of course, would necessitate the providing of a suitable insectary under the control of an entomological staff with experience in this kind of parasitological work, as well as in the technical details involved in receiving, multiplying, and distributing such insects.

The question of collecting, breeding, eliminating parasites from and transporting desired insects to Queensland from the United States was discussed with Dr. Howard and Mr. Hunter. It was assumed that the Government of this 
State would bear whatever expense was necessary. The Bureau of Entomology offered to supervise and be responsible for the work, which would be placed under the control of an officer who had had experience in the field, and was familiar with cactus insects and with parasitological work. Assistance would be required for him, hence the suggestion that a trained entomologist belonging to the Dallas Experiment Station of the Bureau might be seconded for this purpose. About $£ 40$ per month would be required to pay salary and expenses.

Mr. F. W. Maskew, the Chief Inspector of the Board of Horticultural Commissioners, San Francisco, who is also an officer of the Bureau of Entomology, offered to attend to the transmission to Australia of any parcels of cactus insects which might be forwarded to him by the officers of the Bureau.

Professor J. J. Thornber, of Tueson, Arizona, and Professor D. E. Merrill, of Mesilla Park, New Mexico, also expressed their willingness to co-operate with the Bureau of Entomology in any way desired.

Dr. C. Spegazzini, La Plata, Argentina, informed the Commission that he was willing to assist in regard to any insects which it was desired to obtain from that country.

We desire to emphasise the necessity for such provision, already alluded to, being made in Queensland in good time, so that any insects whose introduction is authorised by the Government, may, on arrival, at once receive the proper care and attention needed for their propagation and for their serviceable employment.

\section{The Policy of Introducing Insects.}

On the general policy of introducing living insects at all when regard is had to the fact that so many imported ones are already highly destructive to vegetation, the Commission may make a short pronouncement.

It may be affirmed with regard to the Cactus insects that in some respects they are as peculiar as are the Cactacex themselves, and that hence the association is often very close between plant and insect. This statement, however, is not of general application, but it is obviously true as regards certain kinds. It especially applies to the true Cochineal Insects-Coccus cacti and its congeners. So close indeed is it that not only are these insects incapable of living on plants outside the Cactaceous Order, but they will often live only on particular species of prickly-pear. Thus of the two Opuntias named, cochinelifera to indicate the association referred to, the Precious Cochineal insect (Coccus cacti) will subsist on that so designated by Miller, whereas it will not attach itself to that named cochinelifera by Linneus (our Nopalea cochinelifera). Similarly the Cochineal of the latter, Coccus confusus Newsteadi is confined to it. So again another wild Cochineal Insect is restricted as far as we know to Opuntia monacantha. This statement as regards the cochineal insects is based on recorded observations and experiences of upwards of a hundred years standing and extending to many different countries. The last remark cannot be made respecting certain other prickly-pear loving insects, but these, too, from other considerations, however, we conclude are restricted to cacti.

With regard to other prickly-pear insects mentioned in this Report, we can pronounce on their exclusive cactus relationship almost with equal confidence. Not only have they and their habits formed the bases of special memoirs implying diverse and extended observation, but the special insect-groups in which they are embraced have received the exclusive attention of entomologists of the highest repute living in the country where they occur: moreover, they are included in the comprehensive lists detailing all the food habits of insects amassed by the Division of Entomology of the United States. From the sources thus indicated has been derived our knowledge-confirmed as it has been by our own observations-on which this conclusion is based. 
However, there are a good number of Cactus insects that in their feeding habits are not invariably confined to the Prickly-pears as is known from actual observation or as may be inferred on reasonable grounds. Amongst these may be mentioned the fruit fly-Ceratitis capitata, Wied.; the Mealy Bugs Pseudococcus obscurus, Essig. ; Rhizococcus multi-spinosus, Kuhlg; the Cuban Cactus Coccid Palceococcus, Sp. ; the Plant Bug-Stylopidia picta, Uhler ; the blossominjuring Beetle - Trichochrous texanus, Le Conte; the Calandrid root-borers Cactophagus, spp.; the Cactus Aphis-A. gossypii, the Cactus Red SpiderTetranychus, sp., \&c.

Now with regard to these three categories under which the Cactusinjuring insects may be distinguished, we are of opinion that those embraced in the first and second may with perfect safety be introduced into Australia; whereas those included in the last division should be rigorously excluded.

No entomologist consulted with regard to this matter has expressed a different opinion, except a distinguished Australian one who has pronounced strongly against the introduction, on any consideration, of any plant-eating insect for such work as is here contemplated.

The experience of the Hawaiian Islands in subduing Lantana, has shown that in certain cases plant-eating insects may be advantageously introduced for weed destruction without detriment in any way to other vegetation. This we have been able to confirm by personal inquiry. Moreover, we do not know of any destructive insect of exotic origin accidentally or ignorantly introduced here or elsewhere, whose destructiveness evinced in its new home, could not have been anticipated from a consideration of its habits in its country of origin.

\section{Disease.}

As a result of its investigations the Commission is led to conclude that disease does not play a very important part in checking the spread of pricklypear when growing under natural conditions. However, we have seen and studied a number of maladies caused by parasitic agency, as well as others due to unsuitable environment, including climatic conditions. The latter are of no importance from the point of view of our inquiry, and moreover, some of them are already present in Queensland.

There is apparently only one disease which the Commission regards as being of sufficient value to warrant its introduction. This is the "anthracnose," "shot hole," or "black rot" malady, caused by a fungus Gloosporium lunatum, E. and E. Ordinarily this organism has but little effect on the plant, but under conditions such as obtain on warm moist days it causes a considerable and rapid destruction of young segments, while older joints previously infected, may also succumb to the "black rot" conditions set up. Cultures were brought to Queensland by the Commission and handed over to the Dulacca Experimental Station.

In the Argentine Republic there is a very serious disease, "the white rot" caused by a fungus Sclerotium (or Sclerotinia) opuntiarum, Speg., which brings about the destruction of joints and stems of various cacti. As the habits of this parasite are not sufficiently known the Commission does not, for the present, recommend its introduction.

There are other parasitic diseases known in the West Indies, United States, Mexico, and the Mediterranean region, but their effects are not of much importance in controlling the spread of prickly-pear. 


\section{DESTRUCTION BY UTILISATION.}

Considering the importance of finding uses for the prickly-pears in the industrial arts, and the extent to which the questions involved may depend on the outcome of exact scientific research, especially into the methods of isolation of their constituents or derivatives and into the properties thereof, the Commission suggests that the Government might wisely offer a series of premiums by way of encouragement of such investigations, and that these, whilst covering in the aggregate a very wide field, should be severally limited to specific inquiries, none being excluded on the ground that they do not from their nature appear to present immediate prospect of a profitable outcome.

\section{A. As Food for Man.}

The fruit of certain species of prickly-pear is used as human food in many parts of the world, but more especially in Mexico and the Mediterranean littoral. In the former country, various food products, such as "miel" and "queso," are derived from these edible fruits, which contain a high percentage of sugar. These various methods of utilisation would not be of much value in compassing destruction of Opuntias in Australia. They suggest, however, that an abundant source of nutritious food, availed of in other countries, may have been entirely lost sight of here.

\section{B. As a Fodder for Stock.}

The experience in other parts of the world, India, South Africa, the Mediterranean region, and America, regarding prickly-pear as a food for stock is, as a rule, similar to that in our own country. It is generally regarded merely as a roughage or as an emergency fodder which can be drawn upon during times of scarcity. Owing to its high water content, and its low-feeding value, some more concentrated fodder, such as lucerne, bran, cotton-seed meal, oilcake, \&c., should be added in order to form a balanced ration. The composition of several such rations has been published in India, Italy, the United States, and elsewhere. One or two of these may be given here. For a 1,000-lb. milch cow it has been suggested in America that the ration might consist of $50 \mathrm{lb}$. of prickly-pear, $10 \mathrm{lb}$. wheat bran, $10 \mathrm{lb}$. of lucerne; or of $40 \mathrm{lb}$. of " pear," $10 \mathrm{lb}$. wheat bran, and $12 \mathrm{lb}$. of corn stover, the nutritive ratio being $1: 5 \cdot 4$, which is the standard European ratio for dairy cattle. In India it has been found that when the cotton-seed has been incorporated with prickly-pear to the extent of constituting 6 per cent. of the weight of the mixture, that not only will cattle subsist on the ration, but they will regain condition should they have become poor from semi-starvation, the average daily consumption being $72 \mathrm{lb}$. of prickly-pear per 1,000 lb. live weight. In Sardinia and elsewhere dry grass or foliage and small branches of certain edible trees may be added to the opuntia.

The fruit has much more nutriment than the other parts of the plant, but the greater part of this is contained within the seeds, and since these pass through the intestine of the animal, this supply of food material is not available.

The amount of pear used per animal daily, along with other food, may vary in parts of the United States from 40 to $70 \mathrm{lb}$. If more than this be employed there is a likelihood of scouring. Some preparation is generally necessary, the amount varying in the case of the different species. As a rule the stems and joints are singed and chopped up, but sometimes dairy animals are turned into the "pear" paddocks to feed on the scorched standing plants. In parts of the United States and the Mediterranean littoral, certain species of prickly- 
pear are grown as a range crop for cattle, while in some localities they are actually planted as a farm crop. In Queensland, however, Opuntias are already in possession of the ground, hence their employment as part of a cattle ration, if more widely adopted than at present, would bring about a considerable amount of destruction of the pest. Since cattle are, in our opinion, a very important, if not the most important, factor in the spread of the pest, both by the breaking down of standing plants, and by the distribution of seeds in the excreta, we consider that they should, as far as possible, be kept away from growing pear, the material which it is proposed to utilise as part of their fodder being brought to them, preferably in a prepared state.

It has been proved experimentally elsewhere that succulence, owing to its influence on lactation, is an important factor in fodder for cattle, especially milch cows. The presence in the ration of the succulent under consideration-i.e., prickly-pear-not only had no detrimental effect on the composition of the milk, but, on the other hand, led to an increase in quantity without any depreciation in quality, so that there was a very distinct gain in regard to the total yield of dairy products. Further, it has been demonstrated in Mexico that this class of succulent food under the same circumstances reduces, too, the diminution in these that is due to a lowering of atmospheric temperature.

A suggestion was made to the Commission, while in Australia, that it should be possible to make a transportable fodder from prickly-pear, chopped up finely by machinery, and then sun-dried, either with or without the addition of other food substances. No evidence of its use in this way was obtained, nor did the Commission meet with anyone who could express an opinion based upon experience and observation regarding the merits of the proposal. In South Africa, a project to convert chopped prickly-pear into a "feed-cake" for cattle by adding molasses, bran, and other nutritive substances was brought under our notice.

It should be pointed out that the matter of utilising prickly-pear as cattle fodder is still in a more or less experimental stage. It must be admitted, however, that within certain limits the prickly-pears vary considerably in their composition-even so with regard to a single species as is evident from the published chemical analyses relating to the different species. Accordingly it must not be inferred that results obtained in feeding stock in one country, and on one kind of prickly-pear, will apply generally to Australia.

It appears, therefore, to the Commission that it is expedient for the Government to undertake investigations, similar to those that have been carried out in other countries, to test in a comprehensive manner to what extent the commoner prickly-pear plants of this State can also be utilised to supplement the various fodders at present in use for stock. A dairy herd consisting of a sufficient number of animals should be employed, and such investigations should be controlled at every stage by exact scientific methods, so that whatever results be obtained these may be attributed to their true factors, the variations affecting lactation arising from recognisable causes ordinarily obtaining being eliminated in estimating them.

The attempts to utilise prickly-pear as ensilage have not as a rule been a success. However, a satisfactory result has been attained from a complex one in which are laid down alternate layers of Opuntia and maize or sorghum. Since prickly-pear is available throughout the year, there does not appear to be any necessity to convert it into ensilage, except in cases where the object in view is a readily transportable fodder. 


\section{As a Soil Fertiliser.}

Prickly-pear has been used to considerable advantage in Ceylon, India, South Africa, and the Mediterranean littoral, as a green manure, and since this method of utilisation involves the destruction of the plant, we submit that it might be employed to a much greater extent in our own country than at present. Our arable Western lands readily lose more or less of their humus-always relatively small in amount-under their climatic conditions. It is considered that this deficiency might be remedied by the use of prickly-pear as a "leaf manure."

By this procedure, too, there might be added to the soil not only humus but also potash, since succulents, including Opuntias, are always rich in this constituent. A method found to be very satisfactory in India consisted in digging series of wide trenches, almost filling them with broken plants, and then covering the latter with a layer of earth some 18 inches or 2 feet in thickness. Any new growth which may make its appearance should, of course, be removed and buried. After séveral months the "pear" becomes converted into humus, a valuable addition to the soils there also.

In many localities the joints are distributed over the field and then turned under, as are other so-called leaf manures.

Lands in other parts of the world, treated in the ways mentioned, have also given much better crops than untreated areas.

It is recommended that experiments be conducted in this State, to ascertain in what way and to what extent our naturalised prickly-pears could be suitably employed for similar purposes, especially with reference to the conditions prevalent in our Western lands, which are deficient in the soil constituent referred to.

\section{As a Source of Alcohol.}

In dealing with the following methods of utilisation of prickly-pear in the industries, the Commission has necessarily in mind the fact that the end in view is the destruction of the pear, and that the undermentioned methods of using what are thus really by-products are looked upon as a means by which the cost of clearing may be lessened.

Some investigations have been carried out in regard to utilising the whole plant as a source of alcohol, but these have shown that the amount to be obtained is practically negligible, since only about 10 per cent. of the total weight of the green plant consists of carbohydrate, in which the amount of sugar is small, while starch is practically absent.

The fruit of various species of prickly-pear, however, has been used for alcohol production, especially in the Mediterranean littoral (Italy, Sicily, and Spain), where the manufacture was a commercial success until the imposition of an excise rendered the concern unprofitable.

The amount of sugar present in the fruit varies in different species, and even in the same species may be increased by cultivation. In the best Mexican varieties, from 10 to 15 per cent. is usually present. It is estimated by some American chemists that about $140 \mathrm{lb}$. of fruit, with 10 per cent. sugar, is necessary to produce 1 gallon of alcohol. By the addition of active distillery yeast practically all the sugar was found to have become converted into alcohol in laboratory experiments. However, in order that the production of alcohol might bc carried out profitably, it was considered necessary that there should be the 
production of a large amount of fruit from small areas, e.g., about 10 tons per acre, and also some rapid method of collecting the fruit. It may be added that the pest pear of the Burnett Valley is especially prolific in fruit.

Investigations in Italy, where the fruit of $O$. ficus indica was used, showed that Saccharomyces opuntice, the yeast ordinarily associated with it, sets up a slow and incomplete fermentation, but if another ferment, S. pastorianus, be allowed to operate on sterilised must, complete conversion takes place. However, the extra cost involved in sterilising was regarded at the time as being a serious hindrance to commercial success. Later investigations have, however, overcome this difficulty.

Still it must be mentioned that potable spirit, not raw alcohol, was the article manufactured commercially from this prickly-pear fruit, notwithstanding the fact that in those countries it has considerable market value as an edible product. In Queensland, on the other hand, the fruit at present has no marketable value, but is a waste product. Accordingly, if alcohol could be produced from it, such action would probably lower the cost of eradication. We, therefore, recommend that investigations be carried out in our own State, especially since some of our commoner pest species are prolific in fruit production.

\section{E. Utilisation of the Fibre.}

Some years ago paper-makers examined samples of the fibre of $O$. dillenii from India, and considered the material valueless for their purposes when compared with other equally plentiful materials.

As a result of most methods of destruction employed in this State, the woody tissue of the plant is left intact, and it was recognised that if this fibrea by-product-possessed any value, then the cost of clearing infested land could be correspondingly decreased. Therefore, paper-pulp manufacturers and paper technologists were interviewed, and their opinion sought regarding its possible utilisation in the manufacture of the various cruder kinds of "boards," e.g., roofing boards, millboards, leather boards, trunkboards, strawboards, \&c., rather than of paper proper; and even floor-cloths might be mentioned in this connection.

It was ascertained that the shortest fibre used for paper proper was that of esparto, and that any shorter fibre could be employed only as a filling material, and even for that purpose only if its cost were very low.

American plants are stated to have an average of $84 \cdot 3$ per cent. water and $2 \cdot 4$ per cent. of crude fibre, and the latter, yielding about 42 per cent. of its own weight of dry pulp, so that about 100 tons of green plant would be needed to produce one ton of pulp of low quality, worth not more than a few pounds per ton.

The Imperial Institute, London, carried out some investigations concerning the common pest pear of New South Wales and Queensland, and reported that its fibre, which has an average length $(0.029$ inch), only a little more than half the average for esparto grass $(0.045 \mathrm{inch})$, is readily converted into a darkbrown pulp, from which a coarse paper of poor strength may be made. It was considered that it would not be remunerative to produce the pulp in Queensland for export, and it was regarded as being unlikely that it could be profitably used locally even in admixture with materials of better quality, though this could only be decided by actual trials on the spot, and a consideration of the results in connection with the prices of chemicals and labour in Queensland. 
The Commission submits that this matter should be investigated more fully, especially as regards its use for other purposes than the manufacture of paper proper, and, therefore, recommends that Messrs. R. W. Sindall and W. Bacon, the well-known paper technologists in London, be asked to report on the potentialities of the fibre of our prevalent prickly-pears. If such report be found satisfactory, having in mind that the fibre is from our point of view a by-product, then the establishment of pulp manufactories in the dense pricklypear areas might be considered.

\section{F. Utilisation of the Mucilage.}

Some samples of mucilage from the Queensland pest pear were submitted to the Imperial Institute for examination, but as they had undergone some fermentation it was not proceeded with in detail.

An American investigator, who has given attention to the mucilage occurring in the stem of one of the New Mexican Opuntias, found that in a dry condition it contained galactan ( 15 per cent.) and a pentosan ( 31 per cent.), as well as 12 per cent. of ash, whereas the ripe fruits had only a trace of galactan, and 1.57 per cent. of pentosan, but a large quantity of fructose and glucose. A 10 per cent. "solution" was found to be very viscous, but had poor adhesive qualities, and did not prove satisfactory as a paper glaze. It is suggested by the Imperial Institute that the mucilage might serve as a glaze for cheap cotton stuffs.

It has been used in Northern India as an addition to whitewash, while in Southern India it is employed in the making of a kind of plaster, which is largely used in the internal decoration of edifices, and is said to have a fine texture and to be capable of receiving a fine polish.

Other methods of employing this body, which is so conspicuous a feature in the composition of prickly-pear, might be suggested. However, the question of determining the commercial value of the mucilage is one for a chemical technologist.

\section{G. As a Source of Oxalic Acid.}

All parts of the prickly-pear, as has been indicated by one of us, including even the root system, contain in relatively large amount oxalate of lime in a crystalised condition, as well as other salts of oxalic acid in a dissolved state. There are grounds for concluding that the former could be readily isolated by mechanical means only. As is well known, oxalate of lime is the principal source for the manufacture of oxalic acid that finds so large a place in the industrial arts. In practice this salt is decomposed with sulphuric acid, yielding under the process sulphate of lime and oxalic acid--bodies that are readily separable. At present ordinary sawdust is employed as a source for the body referred to, but contains oxalate of lime in far less amount than do prickly-pear plants.

\section{H. Utilisation of the Colouring Matter in the Fruit.}

The fruit of many prickly-pears, including most of those naturalised in Australia, contains a magenta colouring matter. That obtained from $O$. dillenii is used in Sicily as a dye for basketware, while in the Andean region, and in Mexico and adjacent parts of the United States, the coloured juice of local species is used to colour various beverages and foodstuffs.

The dye obtained from a New Mexican species of Opuntia has been investigated by an American chemist. The mucilaginous matter was first pre- 
cipitated by means of alcohol, and then the pigment obtained from the filtrate on the addition of acetone. The syrupy magenta precipitate was then dried. The colour was found to be permanent. Experiments were made with wool, silk, and cotton, mordanted and not mordanted, but the dye was not sufficiently fast. However, the pigment was found to be of use as a colouring matter for confectionery, icecreams, beverages, and fruit preserves, but could not be retained in foods and drugs in the presence of oxidising agents or light.

\section{Minor Uses.}

Various proposals to malke different products, e.g., coffee, cattle food-cake, vinegar, soap, \&c., have been suggested, but as far as we are aware no articles of commercial value and importance, other than those already referred to earlier in the report, have been made.

Prickly-pears are made use of in other ways, e.g., as host plants for the true cochineal insect; as hedges; as fuel ; for timber; as protection for sandy soil against wind; as cover for young trees; for supplying curios, \&c.; but none of these methods of utilisation are of value from our point of view.

\section{DESTRUCTION -BY OVERGROWTH.}

It has been suggested that the introduction of a certain fodder grass from Brazil might be of service, as on account of its very rapid growth it would probably choke the prickly-pear. The Commission has had no experience of the efficacy of this method, and is therefore not prepared to make any recommendation concerning it.

In a northern portion of South America a rapidly-growing climbing leguminous plant is used. The twining branches form a network enclosing the prickly-pear clump around which the seeds of the plant have been sown, and then the stems are cut. After the climber has become sufficiently dry, it is set alight and the prickly-pear becomes seriously scorched. A repetition would probably destroy the latter.

\section{DESTRUCTION BY CHEMICAL MEANS.}

Although the Commission was not specially asked to look into the question of destroying prickly-pear by chemical means, it has obtained whatever information was available. This has been incorporated as an appendix to that section of the report which deals with our investigations in South Africa. It may be pointed out, however, that no method superior to those already in vogue in Queensland either was suggested or was found to be practised.

\section{DESTRUCTION BY MECHANICAL MEANS.}

Proposals for the destruction of the prickly-pear by mechanical means have, from time to time, been voiced in Australia. The actual factors as regards prickly-pear occurrence therein, involved in the devising of such processes and their application, have not, however, been defined and made public. Accordingly, no data relating to them has been forthcoming for submission to the mechanical engineer's of the countries visited, that they might be confronted with the nature of the problem at issue. We have, therefore, refrained from consulting them with regard to this important matter. 


\section{ACKNOWLEDGMENTS.}

In the body of the report we have acknowledged the help afforded us by others in different parts of our journey. In addition to those named we are indebted to His Majesty's Foreign Office, and to His Britannic Majesty's Ambassadors, Ministers, and Consular Officers for letters of introduction, and, in many cases, for personal assistance ; also to Sir Thomas Robinson, the AgentGeneral for Queensland in London, for many acts of kindness; to Mr. J. C. Brünnich, the Chemist to the Department of Agriculture and Stock, Brisbane, for supplying us with important information regarding the analyses of Queensland prickly-pears, his report being included as an appendix to section 5 of our report; to the Department of Agriculture and Stock, Brisbane, for taking many of the photographs used in illustrating this report; and to the Government Printer for the care which he has taken in the printing and illustrating. We desire also to express our appreciation of the manner in which our Secretary, Mr. C. W. Holland, has carried out his duties.

To the report there is added a summary of information available in the Eastern Australian States other than Queensland, as well as certain Supplementary Notes compiled after the report was in the Press.

The delay in presenting this record of our investigations is due to the fact that both members of this Commission entered upon their ordinary public duties immediately after their return to Queensland, so that the preparation of this report had to be undertaken at such times as opportunity afforded.

Progress reports of the work during the earlier period of the investigations were forwarded from time to time. 


\section{PRICKLY-PEAR TRAVELLING COMMISSION.}

\section{INVESTIGATIONS IN SYDNEY, JAVA, CEYLON, ETC.}

\section{SYDNEY.}

The Commission at the commencement of its work visited Sydney, in order to confer with Mr. J. H. Maiden, F.L.S., Government Botanist and Director of the Botanic Gardens, and a recognised authority on matters relating to Pricklypear. Representative specimens and photographs of Queensland species, with which the Commission had provided itself, were utilised during the discussion.

The information gained as the outcome of this conference may be summarised as follows:-

As the Commission had already concluded, there are now more than one species of Pricklypear oceurring as a pest in Queensland. These several species, so far as they have been identified, are-

1. Opuntia inermis, D.C., var.

2. O. dillenii (Haw.) of Maiden. The Queensland form differs from that growing under this name in the Botanic Gardens, Sydney.*

These two species are the commonest of the pest pears, the former being found at Dulacea and elsewhere, while the latter occurs especially in the Gayndal district.

3. O. monacantha, Haw. (the Suttor River pear of Mr. Temple Clerk).

4. O. tomentosa, Salm-Dyck, a Tree-pear occurring plentifully at Westwood, at Helidon, and elsewhere.

5. 0 . aurantiaca, Gillies, the small and very spiny form occurring at Roma and Warwick.

6. o. imbricata, Haw., not common in Queensland.

* The spiny pest-pear of Queensland is distinct from, though related to, $O$. dillenii which we have seer naturalised in Ceylon, India, the Canary Islands, and the Mediterranean littoral, as well as growing indigenously in the West Indies.
7. O. nigricans, Haw. (? O. elatior, Mill.); not common in Queensland, though more prevaleut in New South Wales, and apparently capable of developing into a serious pest.

8. Nopalea cochinelifera, Mill., a food plant of the true cochineal insect. The Treepear of Emerald, but occurring sparingly elsewhere.

9. Nopalea dejecta, Salm-Dyck, specimens of which Mr. J. H. Maiden has received from Rockhampton.

In addition to these species, there are in Queensland others whose identification had not been settled at the time of the Commission's visit. "Joints" of these were brought by it to Sydney and have been planted in the Botanic Gardens by Mr. Maiden, in order that their names may be ascertained. They include the two (possibly three) thick-jointed spiny species, bearing large edible fruits, occurring in the Central district, where they are known locally as the " Red Mexican " or "Westwood," and " Yellow Mexican" Prickly-pears. The latter is apparently related to $O$. amyclea.

In the course of the interview he brought under notice a statement made to him that in Southern Italy, where the hillsides are dovoted to the culture of certain species of Opuntia, a breed of cattle, habituated to feeding on the Prickly-pear and to chewing the spines without any apparent injurious result, had been evolved by crossing Holsteins and Jerseys. As the question of utilisation has been referred to the Commission, he suggested that this matter might not be overlooked.

He also referred to his introduction of spineless species of Prickly-pear as a possible method of solving the problem of using to better advan. tage, for the purpose of grazing, the dry western lands of New South Wales. These spineless rarieties, howerer, developed spines under the dry climatic couditions existing there. A fine collcction of these fodder forms, belonging to the 
O. ficus-indicus, Mill., group (i.e., O. decumana, according to Burkill) was seen growing in the Gardens.

Owing to the courtesy of the Director, the Commission was afforded opportunity for studying the specimens growing in the Gardens, as well as those contained in the Herbarium, and for consulting many important works of reference. He, moreover, furnished it with letters of introduction to prominent workers in other parts of the world interested in the problems connected with the mission.

A visit was paid to the Government Entomologist, Mr. W. W. Froggatt, F.L.S., who had lately travelled in countries where Prickly. pear is indigenons or naturalised, but as he had not given attention to it no information of value relating to the purposes of the Commission was obtained.

\section{JAVA.}

The voyage to Ceylon and India was made viâ Java, where some inquiries were instituted whilst awaiting an opportunity to resume the journey.

It was known that in 1828 a cochineal insect had been introduced into Java, the industry associated with its culture being maintained until 1865 , and that at least one species of Opuntia, Nopalea cochinelifera, had been established for its propagation. It was, therefore, considered advisable to ascertain the variety of cochineal insect introduced and its influence on the host species of Prickly-pear. At the same time inquiries bearing on the possibility of utilising the plant, as well as the occurrence of Opuntia diseases, \&c., were not lost sight of. In this work the Commission received every assistance from the Government officers at Buitenzorg, including Dr. H. 'J. Lovinck, the Director of Agriculture; Dr. J. C. Konigsberger, the Director of the Botanical Gardens; and Dr. T. H. Valeton, the chief of the Herbarium.

It was learnt from old records that the insect and its host plant, $N$. cochinelifera, were introduced from Cadiz in 1828 by J. Bisch. At some time prior to 1847 there had been imported into Java a second Prickly-pear, which de Froideville referred to as Cactus tuna L., but which was known locally as Nopalea docrie or "etang-etang"-a form possessing long thorns and used as a hedge plant.

There seems to be little doubt but that the insects introduced were the true cochineal, Coccus cacti $\mathrm{L}$., which are not injurious to their host plant. In support of this belief it might be mentioned that their source was Cadiz, to which place the "grana fina" insect had been brought eight years previously (1820) from Mexico (Burkill, 1911, p. 304). Two living insects cared for by de Serière constituted the basis of the industry which up to 1865 yielded a commercial product of considerable value. The experimental area for the growth of the Nopalea and the cochineal in connection with the Buitenzorg Botanical Gardens was situated on the Tjidam River, but operations ceased there about 1867 . That the wild cochineal insect (Grana sylvestre) had not become established in Java may be inferred from the fact that de Froideville in writing of the injurious insects of the Nopals, makes no mention of it.

Having discovered, from these old records, the places in Java where the cochineal industry formerly thrived, and where possibly the insect still survived, one of these (Krawang) was visited by a member of the Commission, with the result that, although examples of the Nopal ( $N$. cochinelifera) were still to be met with growing sporadically there, no cochineal or other insects were found to occur in connection with them.

In the Buitenzorg Herbarium there are specimens labelled $O$. dillenii, Haw., from Batavia (1909) and O. tuna, Mill., from Bondowoggo (1846). They are both $O$. dillenii and no doubt represent the plant referred to by de Froideville as Cactus tuna. It was found by inquiry that this species in addition to growing in several places as a hedge plant, was still to be found naturalised to the south of Sourabaya, on sand dunes along the coast near Glendong (Kretig), and in the Preanger Regencies (between Soekaboemi and Naugela). As there was no evidence of the pear being held in check by any enemy, these localities were not visited during the short period available. $O$. dillenii may be met with also along the sea front in the neighbourhood of Batavia.

The small collection of Cactacer in the Buitenzorg Gardens was examined, but no natural enemy was detected. The humid tropical climate seemed to be prejudicial to all Opuntias except Nopalea cochinelifera and Opuntia nigricans.

Dr. J. C. Konigsberger pointed out a peculiar natural enemy of the Lantana that occurred in Sumatra, at Deli, and suggested that this occurrence might yield a new outlook in connection with the work. This was a weed belonging to the composite genus Eupatoria, which grew with great vigour and literally choked the plant in question.

\section{SINGAPORE.}

A delay of about twenty-four hours in Singapore, whilst waiting for a boat leaving for Ceylon, gave an opportunity of interviewing $\mathrm{Mr}$. I. H. Burkill, M.A., F.L.S., formerly Economic Botanist to the Botanical Survey of India, but now Director of the Botanic Gardens at Singapore. He is a well-known writer on the Pricklypears of India. and was able to give information regarding the distribution of the various species occurring therc. He stated that $O$. monacantha," which is the main pest pear of Northern India, has been held in check by the Wild Cochineal Insect in certain places that he mentioned. To assist the work of the Commission, he was good enough to suggest an itinerary, indicating the special features of each locality in their bearing on the inquiry.

\section{MALAY STATES}

En route to Ceylon, the steamer called into Port Swettenham for a few hours. This gave an opportunity to visit the Agricultural Department of the Federated Malay States at Kuala Lumpur. The Commission was unable to see the

* Mr. Burkill informed the Commission that $O$ dillenii occurs along the coast of Singapore. 
Director, Dr. Lewton Brain, who was formerly Pathologist to the West Indian Department of Agriculture, and whose special investigations of plant diseases in that locality, it was hoped, might have been extended to those of the Opuntias growing there. In a letter he referred to Dr. Wàtts, the Imperial Commissioner for Agriculture at Barbados, as one who would no doubt be able to render assistance to the Commission in its inquiry.

\section{PENANG.}

The small collection of Cactaceæ in the Penang Botanic Gardens was inspected, but here, as at Java and Singapore, the hot moist climate had a detrimental effect on all but a few species. An unidentified white superficial fungoid growth appeared to be able to attack and injure Cactaceæ under these climatic conditions.

\section{CEYLON.}

Visits were paid to the Royal Botanical Gardens at Peradeniya, where assistance was obtained from Mr. R. N. Lyne, the Director of Agriculture, Mr. E. E. Green, the Government Entomologist, and Mr. T. Peteh, the Mycologist.

The lastnamed investigator informed us that Prickly-pear was very prevalent in the Northern Province of the island and was found to some extent in the dry zone along the south-eastern coast from Tangalla to Hambantota. He was not aware of the occurrence in Ceylon of any fungoid or bacterial disease of Opuntias, such as might be utilised in destroying them.

Mr. Green, who is an anthority on Coceidse and who has recently published a paper on the cultivated and wild forms of cochineal insects (1912), gave us an opportunity to examine mounted specimens of the species Coccus indicus, Green, naturalised in India and Ceylon, as well as of $C$. confusus capensis, which is now found in South Africa. Living examples of the latter were seen growing in his garden on Nopalea cochinelifera, and were generously placed at the disposal of the Commission for transmission to Queensland. He believed that $C$. indicus was now a rare insect since he had found it only on a few isolated plants at Hambantota and Tangalla (1912, p. 85). Its destructive work had already been referred to in his paper, where the host plant is quoted as $O$. dillenii since that was the only species of Opuntia recorded from the island. He was not aware of any other insect enemies of Prickly-pear in Ceylon.

From information already available (Lewis, 1895, p. 279) it was known that Mr. P. A. Dyke, formerly Government Agent for the Northern Province, had in 1865, as well as prevlously, introdnced a cochineal insect from Jaffna, at the extreme north of the island, and from Trincomalee on the eastern coast, to Mullaittivu, where Pricklypear referred to as $O$. dillenii was very common." The destruction of Opuntia caused by these parasites was said to be so considerable that it was a difficult matter to find a plant three years later. Insects sent from Jaffna had also brought about great havoc near Mattalau and Chinnaru,

* The Tamil term naka kalli, with variations, is applied indifferently at the present day to $O$. dillenii and O. monacantha. The same remark is true for the Sinhalese name patuk or katu patuk (thorny patuk). while those which destroyed the Prickly-pear in the Vanni district (Chemmalai) had come from Trineomalee by way of Nuwarakkalawiya. From a reference to Dyke's Diary, 1865-68, given by Lewis, it would seem that this coccus, which appears to have been the wild cochineal, was derived from Madras.

The destruction just referred to was witnessed by Sir William Twynam, K.C.M.G., who was then Assistant Agent at Manaar under $\mathrm{Mr}$. Dyke (vid. Tryon, 1910, p. 188; 1911, p. 11).

Mr. Thos. Steele, while acting as Government Agent in the Hambantota district (1872) recorded the presence of this insect there as well as elsewhere in the island, as a very destructive enemy of Prickly-pear. On comparing it with specimens of the true cochineal from Mexico, he recognised that the Ceylon coccid was distinct from it, though perhaps allied.

After making the necessary preliminary inquiries, it was decided to visit the northern province where the insect had in $1865-8$ proved itself an exterminator; and also the district which included Hambantota and Tangalla, where more recent destruction was known to have been occasioned.

\section{Visit to the Northern Province.}

From Pallai, 222 miles from Colombo along the Northern Railway, to Kankesanturai, 34 miles further on, Prickly-pear was found to grow sporadically, but in some places quite thickly; and from the latter place westward to Kayts Island and eastward to Point Pedro the same noxious weed was found to be quite prevalent, causing in some quarters much concern. The area embraced by these limits affords the home of an agricultural Tamil community, which in some localities was already taking steps to extirpate it. Prickly-pear was also found to grow in large patches adjacent to the tobacco fields on the island of Mandativu, and near the town of 'Jaffna. Moreover, testimony received suggested that it had a much wider distribution in the Northern Province than even this personal investigation disclosed.

It was found that the pear was almost exclusively Opuntia dillenii, Haw., which is the only species of Prickly-pear recorded as being naturalised in Ceylon. $t$

Though $O$. dillenii had been referred to as the host of the Wild Cochineal insect in Ceylon, first by Lewis (1895, p. 279) and lately by Green (1912, p. 85), yet Burkill (1911) has stated that the coccid which is found in India and which Mr. Green has identified as also being Coccus indicus, has been met with by him exclusively on another species, $O$. monacantha, which is not recorded as a naturalised plant in Ceylon. A careful search was made and though

* Steele, Thos., Assist. Govt. Agent, in "Annual Report on the Hambantota district, 1872," Administration Reports, Ceylon, 1872, Colombo, by authority, 1873p. 165.

+ H. Trimen (" Handbook of the Flora of Ceylon," IT p. 267) states that $O$. dillenii is the common cactus found It occurs rarely in the moist regions, but is abundant in the drier coastal districts. In parts of the Northern Province it is a nuisance. It is called Katu-patuk by the Sinhalese and and Nom South America. species is an old introduction from South America. He in Ceylon. 
O. dillenii was seen in abundance yet not a single specimen of Coccus indicus was seen. In regard to $O$. monacantha, only a few isolated plants were noticed in the areas traversed, these occurring at Vallalai, near Kankesanturai, and near Jondamanar, where they were growing under circumstances which suggested that they were "survivals." None of these coccids were seen nor were local residents able to find any after searching for them.

Evidence obtained from the oldest residents in the district showed that the plant had been more plentiful, and that the insects introduced by IIr. Dyke had caused its destruction. This coccid they named Tambalam pouchee, the term proper to a related red-dye-yielding insect occurring about the roots of grasses at Jaffna and elsewhere.

A visit to Sir William Twynam, at Jaffna, served to elicit a statement of facts corroborative of what has been already recorded regarding the work of the Wild Cochineal Insect in the Northern Province under the Government Agent, Mr. Dyke. He also referred to its being liberated by him at Valviddaturi, which is adjacent to the place where $O$. monacantlea was found by us still growing, though almost extinct.

Although this inquiry in the Northern Province failed to bring to light a single dying Prickly-pear plant, or an insect capable of destroying it, yet from the evidence available we may conclude:-That formerly opuntia monacantha was a prevalent plant in the district; that it had gradually disappeared through the attacks of the parasite named; and that another species common in Southern India-i.e., $O$. dillenii, Haw.-has supplanted it there, and is itself not now victimised by any natural enemy. Sir Wm. Twynam, indeed, stated that, owing to the recent aggressiveness of this weed in the division named, he had represented to the Government at Colombo the desirability of taking measures to exterminate it

It might be added that, many years subsequent to P. A. Dyke's successful employment of the Wild Cochineal Insect in the subjugation of Prickly-pear plants in the Northern Province, an undue development of Opuntias there suggested resort to the same remedy again. Thus, in November, 1902, the Assistant Government Agent of the Hambantota district of the Southern Province, in reporting on a special question submitted by the Colonial Secretary, stated that this insect appeared to have been especially prevalent in the Hambantota district that year, and undoubtedly killed the Prickly-pear. Moreover, he despatched a quantity of plants affected with the cochineal insect to his colleague at Jaffna, for use in that division of the colony of which it is the metropolis.

With regard to this consignment, the Northern Province Government Agent, writing in November, 1903-i.e., after a lapse of some months-reported that the specimens previously sent when tried on some Prickly-pear bushes had proved a failure. Accordingly, a further supply of Opuntia affected by coccids was sent him, but the result seems to have been similar to the first; for in July 1904, J. R. Lewis, Government Agent, writing from Jaffna, requisitioned for still another consignment. This third supply was forwarded to Kankesanturai, at the extreme north of Ceylon, in August of the same year. These insects appear to have been all derived from Kahawatti, near Tangalla.

When visiting Kankesanturai and othor parts of the Northern Province in the course of this inquiry, we could neither find, nor hear of inquiry, we could neithe locality a single living cochipeal insect, much less learn of any destruction of Prickly-pear that may have resulted from their introduction.

The unsatisfactory outcome of all these attempts to reinstate the Opuntia-destroying in sect in the North, appears to be fully accounted for by the fact that the Prickly-pear that had now become prevalent in the district was Opuntia dillenii-a distinct kind from that previously occurring there as a pest ( $O$. monacantha) and, therefore, one distinct from the host-plant of Coccus indicus.*

Although this investigation yielded negative results so far as its main purpose was concerned, it served to indicate how complete might be the destruction of a particular kind of Prickly-pear when once it.was confronted with a natural enemy so prolific and virulent as is the Wild Cochineal Insect (Corcus indicus, Green) when living under conditions favourable to its existence. It is, therefore, reasonable to expect a similar result should this association between it and its proper host, which is one of the Queensland pest species, be brought about, even in another country.

\section{Southern Ceylon}

Matara was first made a centre for investigation in the Southern Province. The train journey from Colombo along the south-western shores of the island revealed the presence of Prickly-pear ( $O$. monacantha), growing either as hedges or as scattered plants, at or near Colombo, Mt. Lavinia, Angulana, Moratuwa, and other villages as far south as Induruwa. A little was found at Weligama.

At Matara, the terminus of the South Coast Railway, there were found a few plants belonging to the same species, a fair proportion of which was parasitised by the Wild Cochineal Insect. These occurred in great numbers on some of the specimens. In every case the presence of the insect had caused disease, the result of heavy infection being the death of the hostplant, which either rotted through decomposition setting in or else dried up into a hard mass. The first indication of disease could be recognised by the presence of bleaching or chlorosis at the spot where the insect had applied itself. This yellow area increased in size, and, where a joint harboured many coccids, the entire surface became yellow, death supervening. No other disease-producing agencies were detected. Evidence was fortheoming that 0 . monacantha, which, as far as our observation has indicated, is the only pest species present in the Southern Province, was formerly much more abundant, but that some white disease (i.e., Wild Cochineal) had appcared on it and had killed it.

* The Commission is indebted to the Archives of the Hambantota Kachcheri, to which it was courteously permitted access by the Assistant Government Agent, Mr. T. A. Carey, for a knowledge of the repeated transmission of the Wild Cochineal from that district to the Northern Province. 


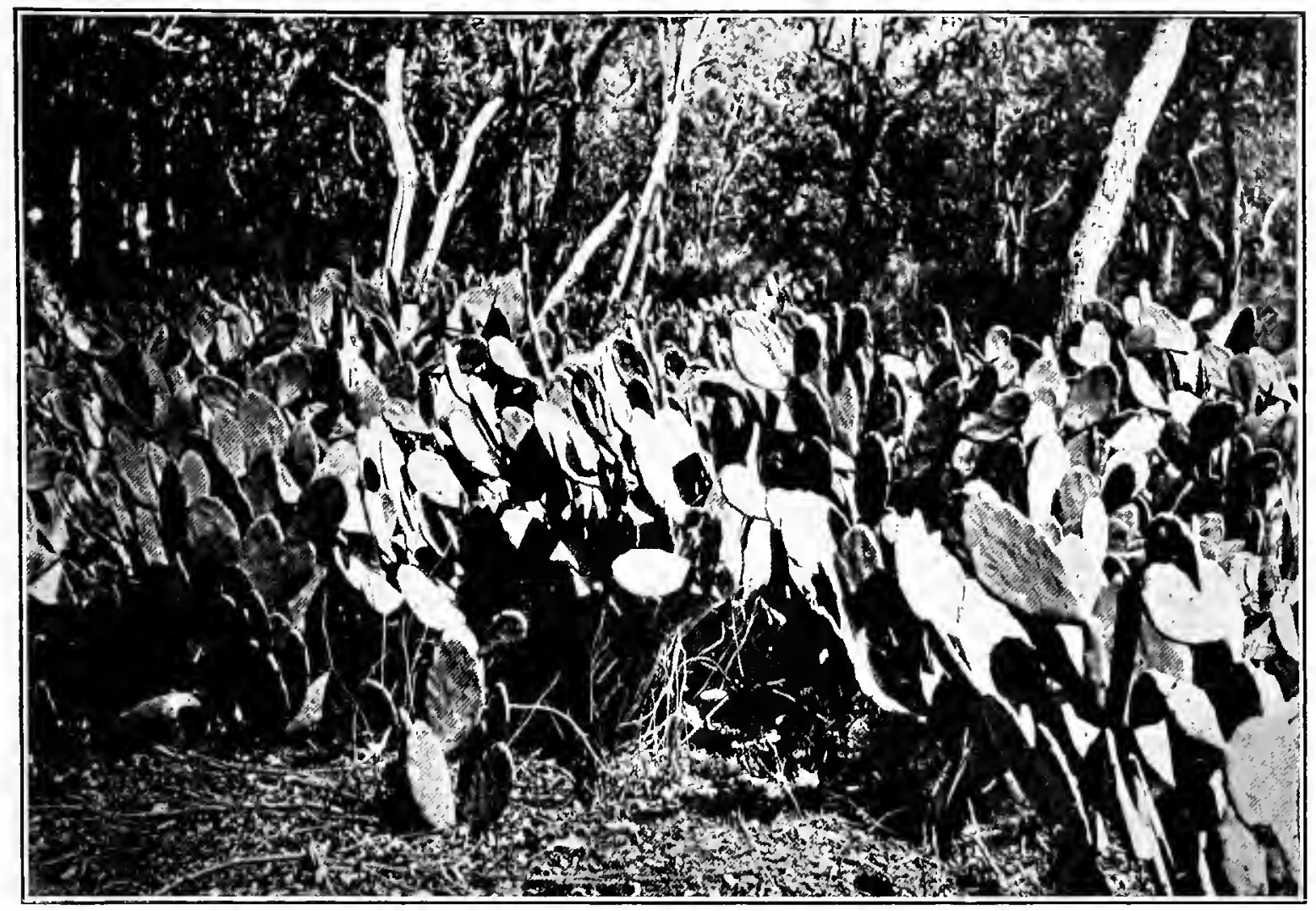

Photo. 7"y t I. Corris

Fig. 1.--The Common Pest Pear.-O. inermis, DC, var. Specimens from Rosalie, Toowoomba district.

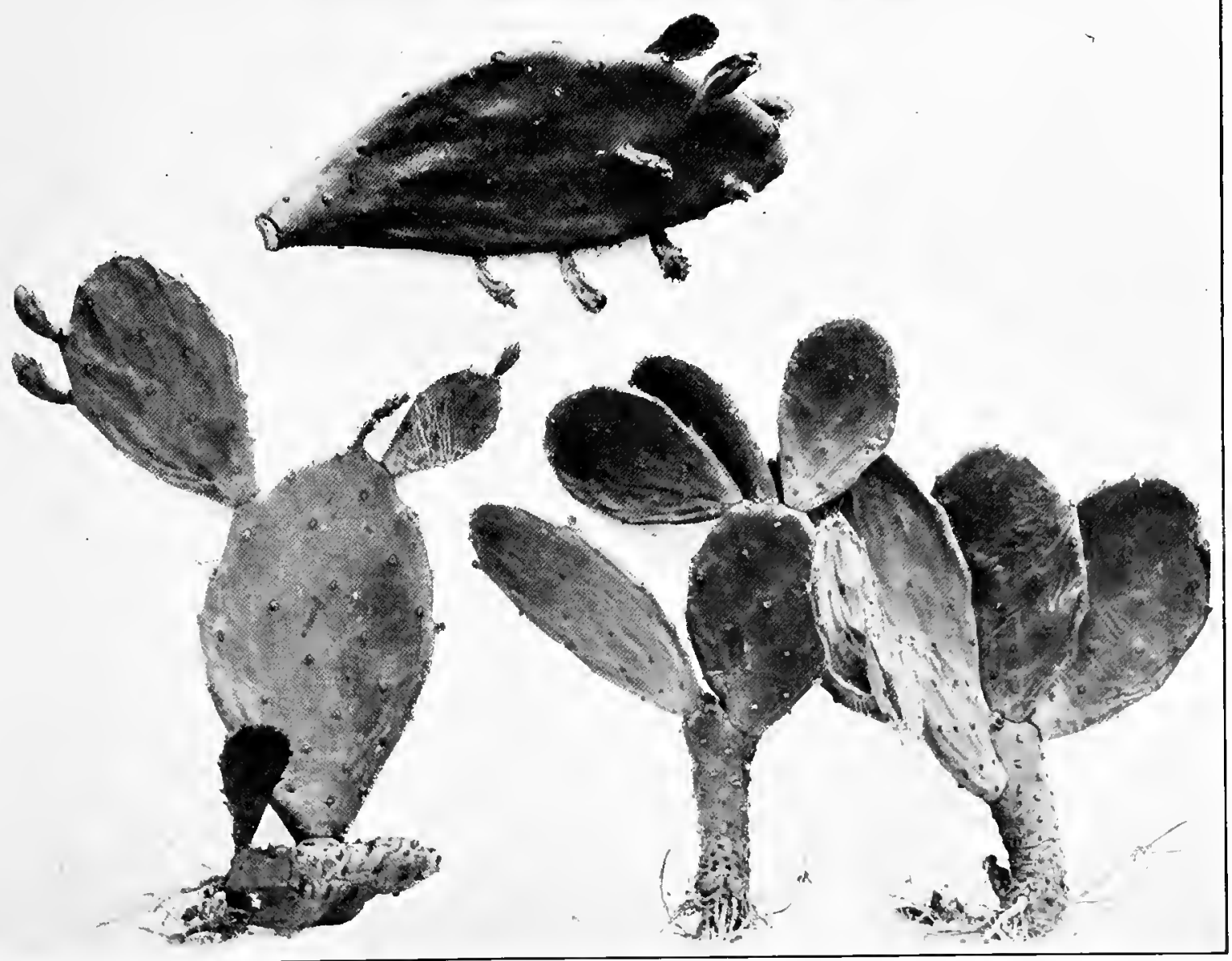

Photo. In yt Ariculture, Brisbane.

Fig. 2.-The Common Pest Pear. Specimens from Goondiwindi and Miles. The scale, wherever shown in these Plates, is in inches. 

The finding of the insect here in some quantity was unexpected, as the information available pointed to its rarity in Ceylon.

The Commission then prose ented its inquiries in the Hambantota district further northwards along the south-east coast of Ceylon, the report made by Thomas Steele, when stationed there in 1872, suggesting that important results might follow an investigation in that locality.

Along the road thither from Matara as far as Tangalla, plants of a single Prickly-pear species (Opuntia monacantha) were seen growing here and there on the banks on either side. Apparently owing to the presence of shade conditions, these were generally small and spindly. They were not found to be infested by the Wild Cochineal Insect, one small clump near Gandara being the sole exception. This observation would tend to indicate that, under the circumstances stated, the insect lias very limited powers of spreading from an infested centre when the plants grow widely separated from one another.

Beyond Tangalla, an abrupt change in prevalent climatic conditions obtains. Here Prickly-pear plants were almost absent from the roadside except at a place distant 2 or 3 miles from Hambantota, where two plants of Opuntia monacantha were growing vigorously. At Hambantota itself a few isolated clumps of this Opuntia were found in the vicinity of the Government buildings. These were in a vigorous condition, and were not affected by injurious insects or disease. A survey of the district within a radius of 2 to 3 miles of the town did not bring to light any additional plants, but some may have been growing in the low dense jungle without their presence being remarked.

On interviewing the Assistant Government Agent, Mr. T. A. Carey, stationed at Hambantota, he courteously accorded the Commission an opportunity for consulting the official records, in which it was stated that as recently as 1902 the cochineal insect appeared to have been especially prevalent in this district during that year. Although coccid-infested pear was sent by request to the Northern Province in 1902-4 for employment in subduing an Opuntia there, it appears to have been derived exclusively from Kahawatti, a place inland from Tangalla.

Mr. Carey also introduced to the Commission several of his subordinate officers who gave important testimony as to the former abundance of Prickly-pear in the district, and the means by which its diminution had been brought about.

Amongst these was Mr. H. E. Ameresekere, the Mudaliyar or official representative of native affairs, whose province of work embraced an area of 640 square miles. He not only mentioned the circumstances regarding the decadence of the plant referred to, but attributed it to the cochineal insect that he designated "Latti" a word, which he stated, suggested its natural affinity with the producer of the Lac of commerce. He also mentioned the interesting fact that about a year ago he had procured some of these cochineal insects on Prickly-pear growing near Hambantota and conveyed them to Tissamaharama, some 20 miles distant, where he placed them on a quantity of the plant which died, through their increase and attacks, within six months or so.

Messrs. R. de Zilva, J. E. Amarasinhe; and 11. H. Jayman, of the IIambantota Kacheheri, refereed to the presence of the cactus (Opuntia monar'antha) as a pest in the district ten years ago. Thry statel that it then occurred along the sea-coast as well as in the jungle, but that it was sinee destroyed by a white insect similar to that shown them by the Commission. One of these officers referred to the Mudaliyar's experiment already mentioned. The parasite was said to be still active at Mrijjawala some miles away.

Transmission of the Wild Cochineal Insects.-A considerable amount of coccus infested pear ( 0. monacantha) was collected at Matara and taken to Peradeniya where it was carefinlly examined for the presence of any parasites associated with the cochineal insects, but none were found.

On returning to Colombo, the infested pear, together with fresh, healthy specimens of the same species, was taken to the Museum, the Director, Dr. J. Pearson, kindly affording every assistance in packing.

The excessively moist conditions prevailing during the period occupied by these investigations in Ceylon has rendered satisfactory packing a matter of difficulty. Hence, several methods were adopted in order to increase the probability of the material arriving in Queensland in good condition, since it was a matter for experiment as to which was the most suitable. As the receipt of living insects did not necessarily mean their establishment in Queensland, a " $\mathrm{Me}$ morandum of measures to be adopted with the cochineal-infested pear on its arrival "**was forwarded at the same time as these consignments.

Some of the insects (Coccus indicus) reached Queensland in a living condition and have been propagated at Dulacca, particulars regarding this matter having been mentioned by Dr. Jean White $\dagger$ in her Report for 1912 (p. 72-3).

The Commission contemplated that it might be necessary to provide for several successive shipments of the Wild Cochineal Insect to Queensland in order that their establishment might be brought about in more than one centre and as promptly as possible. Since the available supply of insect-infested Prickly-pear appeared to be small, and occurred at a spot 100 miles distant from Colombo, it was accordingly deemed necessary for the development of this proposal that some sniall area of land should be secured, where the host plant could be raised and the Wild Cochineal bred in quantity on it.

On consultation with the Colonial Secretary's Office it was suggested that the assistance of the Director of the Department of Agriculture should be sought. Mr. R. N. Lyne, the officer referred to, met the Commission's proposal in a singularly friendly and sympathetic

* See Appendix.

† The small consignment of Coccus confusus capensis from Ceylon did not lead to their establishment in our State, as the insects died, but, as mentioned in a later section of our report, further samples were sent from South Africa, Dr. White's Report for 1913 giving an account of their establishment and propagation at the Prickly-pear Experiment Station, Dulacca. 
manner, offering to make provision for the work immediately at the IIenaratgoda Institution, and later on at the projected Agricultural Experiment Station at Anuradhapura. This considerate offer the Commission accepted, offering on behalf of Queensland to meet all necessary cost. The Director arranged that the officer in charge of the latter institution should assist in the project. He also proffered the services of an officer from the head office at Peradeniya to supervise its development.

In eonnection with the project the Commis: sion had thought fit to endeavour to habituate the Wild Cochineal Insect to feeding on certain other kinds of Prickly-pear, including the commoner one of Queensland, Opuntia inermis. It had, indeed, conveyed to Colombo living plants of one or more of these kinds, in order to test the possibility in this country in which the insect had been found to develop with special vigour and apparently unaffected by any parasites. Mr. Lyne, however, was, in the interests of Ceylon, naturally averse to the introduction of these plants, being most eager to avoid all risk of establishing by any ehance such notorious pests there. This attitude the Commission fully appreciated, and therefore did not urge this portion of the proposal.

A visit was paid to the Henaratgoda Experiment Station, an institution connected with the Ceylon Department of Agriculture, where the Conductor pointed out several places on the station which could be made available as a nursery for Prickly-pear plants and for raising the Wild Cochineal Insect. One of these was selected, and an area of about a quarter of an acre arranged for, to be exclusively set apart for the work. This officer, by request of the Commission, also undertook to have the area fenced and the ground prepared for planting also, to receive the Prickly-pear destined for this purpose. The eultivation of the species of Prickly-pear naturalised in Ceylon-viz., $O$. monacantha, $O$. dillenii, and Nopalea cochinelifera-was planned, the lastmentioned to be grown to a very limited extent. Infection of all three was attempted.

Some time later, one of the members of the Commission revisited Ceylon and found that the insects had become well established on $O$. monacantha and to a less extent on Nopalea, but had not attacked $O$. dillenii. It is, therefore, likely that they will not infest our Australian pest pears which are more allied to this last-mentioned species than to the firstnamed.

Whilst in South Africa, the Commission asked that a further consignment of the Coccusinfested pear $(O$. monacantha) be packed and forwarded from Ceylon to Queenslaud aecording to directions supplied.*

Species of Prickly-pear Occurring in Ceylon.

In regard to the species of pear occurring in Ceylon, O. monacantha, with its parti-coloured petals, is present in scattered patches along the southern, south-eastern, and south-western seaboards. A few specimens were also seen at Heneratgoda, at Kandy, and also along the coast in the Northern Province.

* This has led to a second establishment of that epecies of Wild Cochineal, Dr. White referring to it in her report for 1913 ( $p 72$ ) o. dillenii is the common pear occurring in the coastal distriets of the north of the island, and found occasionally as a hedge plant in the vicinity of Colombo.

Nopalea cochinelifera is found here and there growing in gardens and occasionally at large. Whilst at Hambantota there were diseovered three or four very large plants of this species, on which the precious cochineal of commerce the Grana fina, is said to thrive. These occurred within a mile of the settlement, and, although in the jungle, were in ground that may have previously been under cultivation. They were evidently many years old. It appeared likely that they may have been procured and planted by Thomas Steele, Assistant Government Agent, when it was thought by him that the Wild Cochineal Inseet that he had observed might be the true Coccus cacti of commerce.

While at the Royal Botanical Gardens, Peradeniya, opportunity was embraced for examining the small collection of Cactacer in cultivation there. In this the most prominent and vigorous species were Nopalea cochinelifera and 0 . monacantha. Opurtia dillenii, as known to us, was not comprised amongst the kinds grown.

\section{UTILISATION.}

The Commission has not witnessed the employment in Ceylon of either of the prevalent species of Prickly-pear-in any manner that would suggest that they might be of any great use in the industries or arts.

In no place was it remarked that the plants were used as a stock food; and although in the Northern Province, where, as one of the members of the Commission noticed, goats occasionally nibbled the tender growth of Opuntia dillenii, the possibility of the plants being used for fodder, when represented to its inhabitants, seemed to be in the nature of a revelation-a cireumstance all the more remarkable in view of the difficulty, often experienced there, of providing their working cattle with ordinary sustenance.

One interesting use for it had, however, been diseovered by the Tamil agriculturists of Northern Ceylon-viz., as a souree of supply of humus for soils depleted of this valuable component. Thus, it was not unusual to see fallowed ground destined for the growth of tobacco, brinjal, or other crops, covered completely with the stem-joints of Opuntia dillenii, which were about to be dug under by their implements, which combine the features of spade and hoe.

This use for the Prickly-pear is one whose importance cannot be overlooked in a comparatively dry tropical country, where the development of humus in the soil so essential to the agriculturist, is diffieult to bring about, and where climatic conditions are so favourable to its dissipation.

In the Maranoa wheat-growing area in our own State, as one of the Commission has seen, our more prevalent Prickly-pear is occasionally employed in this manner, and with good results; but observations in Ceylon confirm his previous conclusion that it is a practice which might be more commonly pursued in Western Queensland, where the arable soils are naturally poor in humus and soon become bereft of it. 
The common use of the Prickly-pear ( $O$. dillenii and 0 . monacantha) in Ceylon is as a hedge component. Such a method of employment has nothing to commend it from the standpoint of Australian circumstances.

In some places, e.g., Mount Lavinia, O. monacantha was planted around the bases of cocoanut trees as a protection against thieves, while it was not uncommon in the coastal districts to find the same species of pear fastened around the trunks of these trees for the same purpose.

\section{The Ceylon Investigations Summarised.}

These do not seem to assist to any material extent in solving the problem of destroying Prickly-pear by utilising it.

Previous to the visit of the Commission to Ceylon facts had already been recorded by one of its members indicating that formerly a Wild Cochineal Insect had proved highly destructive to a particular kind of Prickly-pear naturalised there and, in fact, had locally exterminated it; also, that it had done the same where purposely disseminated. It has now elicited testimony and made observations corroborative of these facts.

Moreover, the investigations in Ceylon have proved that these incidents, which occurred in the middle of the last century, are still happening in a certain portion of the island.

But that the insect is not really an enemy of a variety of Prickly-pear (i.e., O. dillenii, typical form) whose existence in Queensland is open to some doubt, but of one (O. monacantha) which is actually naturalised there and is locally very abundant--e.g., in the Suttor River Valley.

Consignments of the insect were sent to Queensland. This has led to the establishment of Coccus indicus in our State.

\section{APPENDIX.}

MEASURES TO BE ADOPTED WITH COCHINEAL-INFESTED PEAR FORWARDED BY THE PRICKLY-PEAR (TRAVELLING) COMMISSION (FIRST CONSIGNMENT) ON ITS ARRIVAL IN QUEENSLAND.

Forwarded to the Under Secretary for Public Lands with Letter from the Commission dated 10th January, 1913.

\section{INTRODUCTORY.}

In the district of Ceylon, in which the Wild Cochineal Insects referred to hereunder were procured, these natural enemies of the Pricklypear were found by us to be capable of keeping one of the Queensland Prickly-pear pests in subjection and generally destroying it. It is possible that they will in time prove similarly baneful to one at least of the other kinds that constitute such notorious weeds in North-eastern Australia--e.g., Opuntia inermis. The Prickly-pear species that at present claims their attention in Ceylon is Opuntia monacantha, which we learn from Mr. Temple Clerk is so prevalent in the Valley of the

The Wild Cochineal Insect will in appearance recall the form of an ordinary Mealy Bug, and, like it, is slowly active when young; but it is without the filamentary processes of this insect.
Suttor River, and also occurs sporadically not only in other parts of Queensland, but in New South Wales, Victoria, and South Australia as well.

Since the unsuitable conditions that have obtained at the time of shipment will necessarily reduce the number of insects arriving alive, it is of high importance that every care be taken of the consignment on its receipt in order that it may result in this Wild Cochineal becoming established in Queensland and destroying Prickly-pear plants there as it has done and still does in Ceylon. It is, therefore, recommended as follows:-

Arrival of the Consignment.

1. On arrival of the consignment, it should be taken over with as little delay as possible by one of the Entomologists attached to the Department of Agriculture and Stock.

2. This officer should open the boxes and at once ascertain the extent to which living cochineal insects are present, noting, for future report under the several numbers by which the different packages are marked, the facts in this regard. At the same time he should take prompt measures-

(a) To protect the insects and their progeny (eggs and larvæ) from access of ants and cockroaches, both of which may consume them;

(b) To place them, as far as practicable, under conditions that will admit of their retaining their former vigour and multiplying. For this purpose he should have for his work a small site, secluded from public access (? at Stock Institute, Yeerongpilly), and either rooted examples of the favoured host plant of the insect-i.e., Opuntia monacantha-or recently established cuttings whose continuous growth may be anticipated. As much young growth as possible is a desideratum in this connection, and this should be dry and free from dust;

(c) And to transfer the Wild Cochineal to such fresh food-plants. Two procedures might be adopted-

(1) Little loose masses, not more than $1 \frac{1}{2}$ inches in diameter and composed of cocoa-nut fibre (coir from matting) or fine Raphia, and two or three fullydeveloped cochineal insects enclosed in their centres, so that when the young issue they may crawl forth; or

(2) Small pieces of the Prickly-pear leaf having insects upon them should be cut out.

In either case the material bearing the insects should be fastened to the leaf of the growing plant by means of an Opuntia thorn, choosing preferably, as a site for this implanting, a surface little exposed to cutting wind or to rain, and preferably near some young growth, this being especially favoured by the larval cochineal insects on hatching out.

(d) It is further to be observed that, in the Brisbane area at least, the Wild Cochineal Insect may meet with a formidable enemy in a small beetle and its larvæ, Cryptolamus Montrouzieri, that naturally preys on mealy bugs. Accordingly, 
these operations, having in view the continued existence and reproductive increase of the Wild Cochineal, will need to be carried out under conditions that will prevent the access of this probable natural enemy. To this end a small enclosure covered with serim (hessian) should be erected to cover growing plants that are being used in these experiments, access to its interior being gained by a properly secured door. This enclosure might also aid in over-wintering the insect before its transmission to localities where it is to be employed.

(e) Since several methods of transmitting the Coccus-infested Prickly-pear have been followed, these remarks presuppose that many individual insects will arrive in a living condition. Should any in fested pear arrive in a condition suitablo for planting, such pieces should be directly grown and their condition noted.

(f) It is possible that only a limited number of insects exhibiting vitality may be $r^{2}$ ceived. Having in view the fact that the Cochineal Industry in Java was formerly based on the receipt at Batavia of two living individuals only, it will be recog. nised that even from a comparatively small beginning much may be accomplished, should the entomologist realise the importance of the undertaking and bring to bear on the work ordinary skill and be afforded the fullest opportunity for excreising it.

Insects apparently dead may still give birth to living young, since the act of reproduction is usually followed by the death of the parent insect.

(g) However, anticipating the possible failure of the first experiments in tránsmission; provision is being made for'continuous supplies of this Wild Cochineal Insect of Ceylon (Coccus indicus) until it shall become established in Queensland.

A report of the conditions of the contents of the several packages forming this first consignment should on its arrival be prepared and early placed at our disposal.

One of the packages (narked II.-4) contains a particular Opuntia (Nopalea cochinelifera) infested by a second Wild Cochineal Insect.* This Opuntia is the Tree Prickly-pear growing at large at Emerald and elsewhere. It is suggested that endeavour be made to maintain its development on any cuttings sent which arrive in a condition suitable for planting. Ceteris paribus, similar action to be taken with regard to this insect as prescribed for the foregoing one.

* Coccus confusus capensis, the species occurring naturalised in Cape Colony.

\section{INDIA.}

The itinerary followed by the Commission during its stay in India was practically that outlined for it by Mr. I. H. Burkill, M.A., now Director of the Botanic Gardens, Singapore, but formerly Economic Botanist to the Botanical Survey of India. A few modifications were made at the suggestion of certain officers interviewed during the journey in India.

Travelling by rail from Tuticorin, in the south of the Pensinsula, to Madras, Prickly-pear 1 as noticed more or less frequently, occasionally on waste areas, but usually growing as hedges. The species occurring in the more southerly portion of the railway route was recognised as Opuntia dillenii, which, as already referred to in the Ceylon report, is found in the northern part of the island as well as at a few other isolated places such as Anuradhapura and at Kollupitiya, near Colombo. As Madras was approached it was noticed that the main pear was 0 . nigricans, ${ }^{*}$ a species occurring near Sydney, New South Wales, and at Yelarbon, in South-western Queensland.

Both of these cacti, as well as Nopalea cochinelifera, may be found growing as hedges and also in a naturalised state in the city of Madras and the surrounding district.

In order to render possible, within a reasonable time, the covering of the large area suggested by Mr. Burkill, it was deemed necessary for the members of the Commission to separate at Madras-one travelling through

* o. elatior, Burkill. northern and north-western India, the other proceeding through southern and south-western India as well as revisiting Ceylon in order to inspect the wild cochineal station established by the Commission with the consent and assistance of the Director of Agriculture, at the Government Experiment Gardens, Henaratgoda.

\section{A. Itinerary and SPECIES Met With in} NORTHERN INDIA.

Madras to Calcutta.-Whilst travelling northwards from Madras towards Calcutta, masses of Prickly-pear were noticed more or less commonly. The main species first seen was Opuntia dillenii, extending from Madras to near Bezwada, where it became more or less replaced by $O$. nigricans. The zone of the latter extended as far north as Vizianagram and Vizagapatam, and even further. Near Naupada $O$. dillenii again became predominant. In the neighbourhood of Cuttack and Puri (Jugganath) 0 . nigricans was plentiful. Sometimes the infestation was moderately dense-a great deal more dense than was seen in any portion of Northern India, except perhaps in a few small areas. such as at Jaipur and near Delhi. This oceurred only on poor waste land, since in arable country Prickly-pears have had very little chance of surviving on account of the large agricultural population to be supported. In nearly all cases the pear was used for making hedges. On the outskirts of Indian villages it is no uncommon sight to see cacti which have been allowed to run wild, but they are not permitted to invade the neighbouring fields to any extent. 


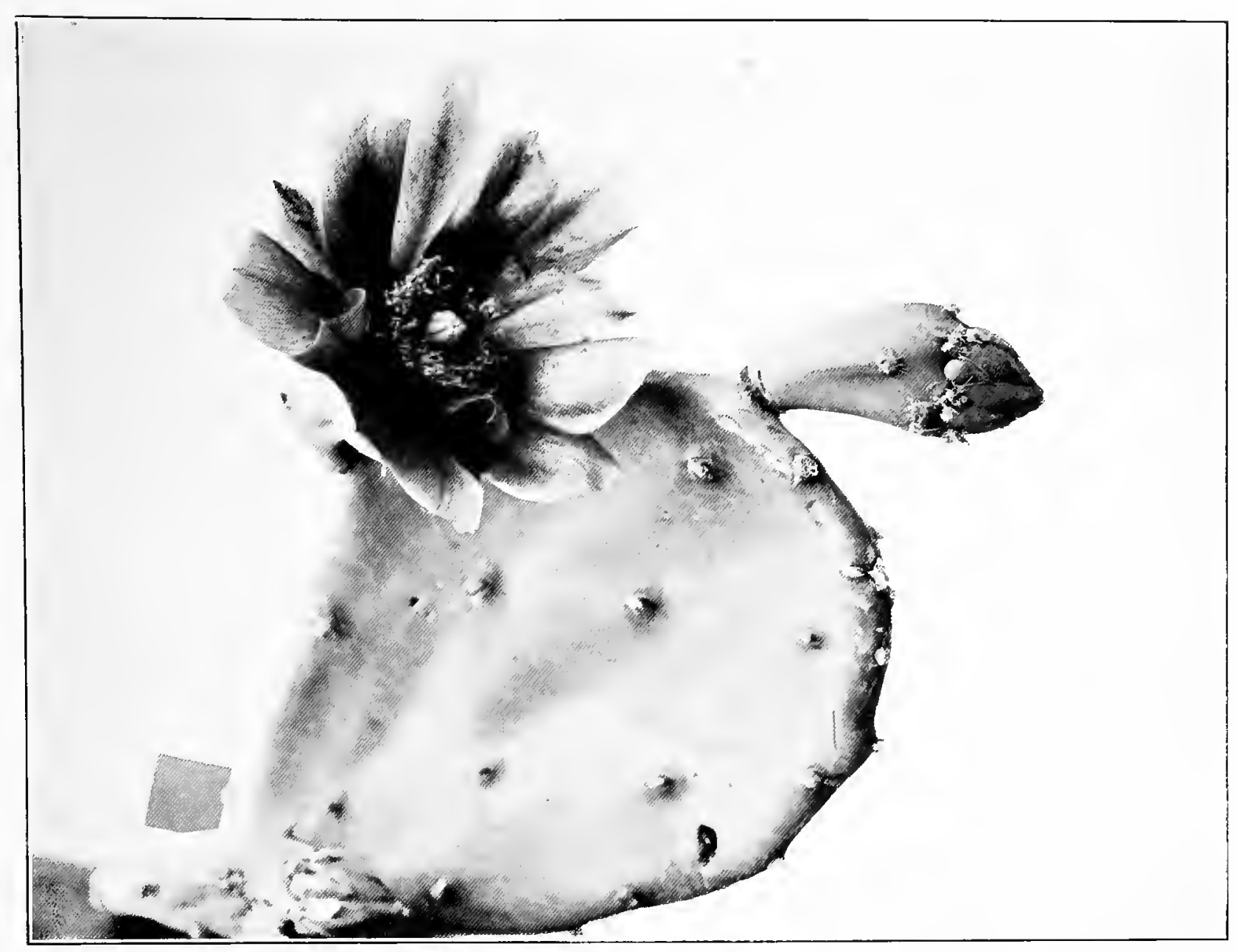

Photo., Dept. Asriculturc, Brisbune. Fig. 3.-Segment, flower, and bud of O. incrmis, var. Goondiwindi.

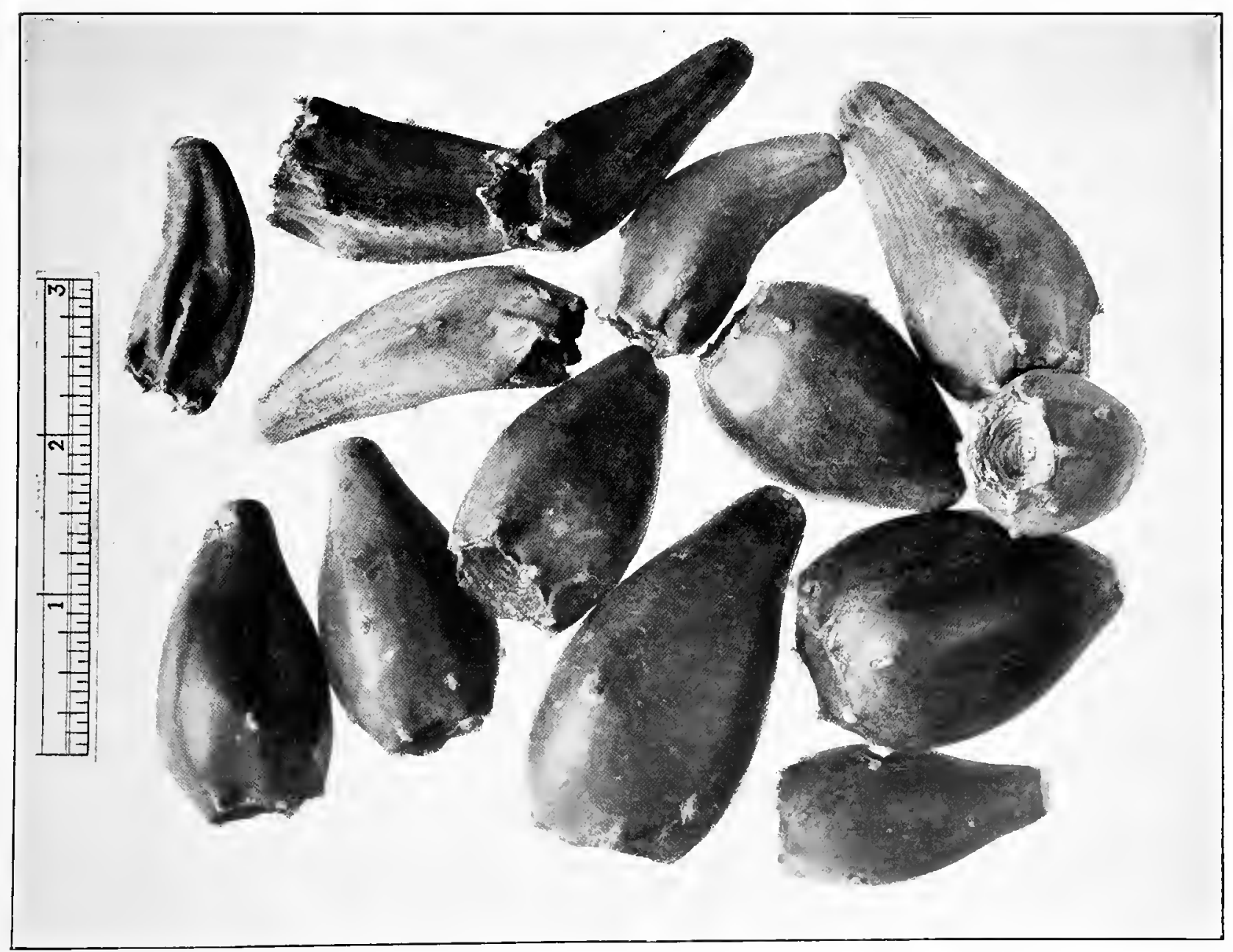

Photo., Dept. Agriculture, Brisbane.

Fig. 4.-Frnit of the plant shown in the above photograph. For comparison with Fig. $\bar{\tau}$. 

Calcutta.-The Commission visited the Indian Museum, interviewing the Director, Dr. N. Annandale, and his scientific staff, who were, however, unable to materially assist in the inquiry. Mr. D. Hooper, Acting Botanist to the Botanical Survey of India, kindly allowed an inspection of the Cactaceæ in the Herbarium.

A visit was paid to the Caleutta Botanie Gardens at Sibpur, where the Deputy Director, Mr. Calder, and the Curator, Mr. G. T. Lane, showed the Commission the small collection con taining the species found naturalised in India, this having been made and named by Mr. Burkill. The four species are $O$. monacantha, $O$. nigricans (labelled as $O$. elatior), $O$. dillenii, and Nopalea cochinelifera.*

Mr. Lane mentioned that specimens of certain of Luther Burbank's varieties had been imported by the authorities at the Gardens for Mr. J. Laurie, a tea-planter at Akbarpore, South Sylhet, Assam. In reply to a letter from the Commission, Mr. Laurie stated that, with the exception of one variety, " anacantha," $f$ the imported cacti developed spines and were not made use of by him for feeding to cattle, and that, moreover, the excessively wet climate did not favour the spreading of cacti ; besides, they soon rot when hoed under ground, and hence are easily lept in check.

In the neighbourhood of Caleutta, Opuntias are not common, $O$. monacantha being the species more usually met with, especially at Serampore. $O$. dillenii and $O$. nigricans are much less frequently seen.

No information regarding the presence of cochineal or of fungoid diseases affecting Pricklypear was available.

Through the kindness of Dr. Annandale, the Commission was able to meet Mr. Wm. Kirkpatrick, of Messrs. Bird and Co., Calcutta, who had had experience in regard to the feeding of Opuntias to his ostriches near Delhi. His information is summarised later under the heading of "Utilisation."

Calcutta to Delhi.-Prickly-pear was noticed more or less frequently along the railway route, also as hedges surrounding villages and fields, between Mokameh and Allahabad. In certain centres Opuntias were fairly common, such as at Bukhtiarpur ( $O$. dillenii) ; Patna ( $O$. dillenii and $O$. nigricans); Bankipur (O. nigricans, $O$. dillenii) ; Dinapur (both species); Arrah (both species); Buxar (both species); Sakaldiha ( $O$. dillenii); Moghal Sarai (O. dillenii); Mirzapur (O. dillenii); and Allahabad ( $O$. dillenii). Between Allahabad and Delhi scarcely any Prickly-pear was seen along the line.

Delhi.-A visit was made to Delhi in order to present the official credentials, the Commission being courteously received by the Hon. Sir R. W. Carlyle, and the Hon. Sir E. D. Maclagan, Members of the Government of India and of the Department of Public Revenue and Agriculture.

* Mr. Burkill has recorded the occurrence of another Opuntia, $O$. decumana, a large jointed, more or less spineless species. As we shall see later, there is a widespread Opuntia not listed by Mr. Burkill.

† A variety resembling $O$. decumana in its general characters.
These Officials had eaused a letter to be circularised amongst the chief officers of the Department of Agriculture and Foresty through. out British India, asking them to render the members of this Commission any assistance within their power. Besides, the Governments of certain of the native States were also invited to further the inquiry. 'Sir Edward Maclagan had gone to the trouble of collecting certain literature relating to Opuntias for our information.

The Prickly-pear in the Delhi distriet was examined, but the presence of disease could not be detected. There were two very common species -O. dillenii and $O$. nigricans, the former being plentiful on the outskirts of the town and amongst the ruins near the city, while the common form on the Delhi Ridge was $O$. nigricans, $O$. dillenii!sbeing met with less frequently there. The latter species was, however, extremely common for some miles along the railway line across the river to Shahdara and Ghaziabad. O. nigricans occurred quite frequently to the north-west at Jahazgarh, and to the south at Gariharsura and Faruknagar, attention to the "salt-wall," consisting of this particular species of Prickly-pear, planted to prevent the smuggling of salt, having been called by Mr. Wm. Kirkpatrick during the Commission's visit to Calcutta.

Cawnpore.-From Delhi a journey was made to the Agricultural Research Institute, Pusa. On the way thither, a halt was made at Cawnpore, where the Agricultural College and Experiment Station at Nawabganj were visited. Some information was given by the Principal, Mr. A. W. Fremantle, and the Botanist, Mr. H. M. Leake, regarding the experiments carried out with Prickly-pear at Cawnpore, as well as at a branch station at Orai, in Bundelkund, Central India. These are referred to later.

Opuntias are very rare in the Cawnpore district, the only species seen being $O$. monacantha, of which there is not sufficient to be used for making hedges.

Agricultural Research Institute, Pusa, Behar.-Here the Commission was afforded assistance by Mr. B. Coventry, C.I.E., the Director of the Institute and Agricultural Adviser to the Government of India, as well as by the officers of his scientific staff, especially Dr. E. J. Butler, Mycologist, Mr. F. Howlett, Pathological Entomologist, and Mr. A. Grove, Acting Entomologist. As there had not been occasion to deal seriously with the question of Prickly-pear since the establishment of the institute, no information of value for the purpose of the inquiry was available, with the exception of some notes by Dr. Butler on a disease occurring in Southern India, and partly investigated by him (see later).

A hurried journey through parts of Beliar, the United Provinces, and Bengal revealed the fact that cacti are not by any means common plants in these districts, where the agricultural population is very dense. Practically the only species seen was $O$. monacantha, which occurred usually as isolated plants. It was seen at Parbatipur, Katihar, Lakhminia, Narayanpur, Waini, Muzaffarpur, Samastipur, Sonepur, \&e. Some $O$. dillenii was seen near Barauni. 
Bankipur.-Both $O$. dillenii and $O$. nigricans were found to be common in and around Bankipur, but no disease was discernible. Mr. Burkill $(1911$, p. 315$)$ has stated that $O$. elatior, $O$. nigricans, and $O$. dillenii occur here, the two last being uncommon. He distinguished the first from the second by the colour of the flowers, which he stated to be orange in $O$. nigricans and lemon-yellow, changing to rose-pink, in $O$. elatior. In this district, as well as elsewhere in India, all of these colours may be met with on the same plant, the more common colour being orange. There is thus little doubt that these two names as used by Mr. Burkill apply to the same cactus, which is designated in this report as $O$. nigricans, since the plant agrees fairly fully with the description given by Karl Schumann in his "Gesamtbeschreibung der Kakteen," $O$. elatior being quoted by this author as an insufficiently characterised species. As already mentioned, $O$. nigricans occurs near Windsor, New South Wales, and in at least one locality in Queensland. Mr. J. H. Maiden has figured and described it in the "Agricultural Gazette," New South Wales (1912, a, p. 208; $1913, b$, p. 865). The species recorded by $\mathrm{Mr}$. Maiden (1913, $d$, p. 1073) under the name $O$. dillenii, as being the common pest pear of the Gayndah district in Queensland, is distinct from, though allied to, the true $O$. dillenii, which occurs so widespread in India.*

Dehra Dun.-From Bankipur a visit was paid to the Forestry School and Research Institute at Dehra Dun, at the suggestion of Mr. F. B. Bryant, the Inspector-General of Forestry (Delhi), but no information of any value for the purposes of the inquiry was available. The small collection of Cactaceæ in the Herbarium was examined by permission of $\mathrm{Mr}$. Hole, the Forest Botanist. Most of the staff were away, being engaged in field work in various parts of India. The Director, Mr. L. Mercer, stated that Prickly-pears were not forest pests, and were rare in Northern India. The Forestry Department used them occasionally for marking the boundaries of forests, but preferred agaves. The very moist climate of Dehra Dun is unfavourable to most Opuntias. $O$. monacantha was recognised amongst the local specimens, but it is, however, a rare plant in the district. On the south side of the Siwalik Hills, towards Saharanpur, $O$. dillenii occurs.

J. F. Duthie, in his " Flora of the Upper Gangetic Plain and the adjacent Siwalik and SubHimalayan 'Tracts"' (Calcutta, 1903, p. 384), refers only to $O$. dillenii.

Lucknow.-En route to Dehra Dum, the Lucknow Horticultural Gardens were visited. Although Prickly-pear (O. dillenii) was quite common at Moghal Sarai and Benares, none was seen between the latter city and Lucknow. Cacti are not very common in the district, though both $O$. dillenii and $O$. nigricans are used for making hedges. The fruits of the latter are eaten, and the juice is used by the villagers as a medicine. Mr. H. J. Davies, the Superintendent of Public Gardens, stated that Prickly-

* In some of his papers $(1898,1913)$ Mr. Maiden has referred incidentally to some of the prickly-pear's of India. pear and agaves were originally employed to mark the railway boundaries between Lucknow and Allahabad, fences being built later.

Mr. Gill, Superintendent of the Naini Tal Gardens, who happened to be in Lucknow at the time of the Commission's visit, mentioned that Opuntias were extremely l'are in his district.

Neither of these officers knew of the presence of any pest controlling the spread of cactus.

Mr. Burkill (1911, p. 314) mentions that $O$. decumana was grown successfully at Lucknow. In the Gardens we saw a few plants still growing, but the species does not seem to be utilised in any way in the locality.

Punjab.-A journey was made from Dehra Dun to Lahore; from the latter place to the Kangra Valley; and thence back to Delhi. Opuntias were fairly frequently met with in the regions travelled through, between Saharanpur and Lahore. As already mentioned, the species occurring at the former place was $\boldsymbol{O}$. dillenii. This became replaced by another species which, at first sight, might be taken for $O$. monacantha. It has evidently been overlooked by Mr. Burkill. o. monacantha is comparatively rare in many parts of the Punjab, having been almost exterminated by the ravages of the Wild Cochineal Insect, as is referred to later. A short description of this Punjab species has been given by Mr. R. N. Parker, in a paper entitled " Notes on Cacti in North-West India" (1912, p. 1095). His account runs thus:- " About 4 feet in height, as a rule spineless, occasionally 1 (-3) spines in some of the tufts of bristles. Leaves oneeighth of an inch long, conical, green or reddish. Joints dull, greyish green, thick, very uniform in size, usually about 6 by $21 / 2$ inches. Flowers yellow." The species reminds one very strikingly of the Queensland pest pear of the Rockhampton district. The rather small thick, rounded and elongated joints are generally spineless, but some joints, on an otherwise unarmed plant, bear numerous spines, usually one, but sometimes two or even three on each cushion. The purple pyriform fruits are much alike in each case. Though Mr. Parker identifies this Punjab species as $O$. ficus-indica, it is certainly not a member of the group of Opuntias usually associated under that name or $O$. decumana. It appears to be $O$. stricta or a l'elated species. Mr. Parker mentions that it is the commonest species in the Plains of the Punjab between the Jhelum and the Sutlej, but elsewhere appears to be less common than the other species (i.e., O. monacantha), which is widely distributed, but not common, in the Plains.

The Punjab Opuntia was seen growing either on waste land or else as hedges along roads and fields and surrounding villages, being common at Ludhiana, Phillour, Chiberu, Jullundur, Dhilwan, Butari, Hamira, Beas, Kartarpur, Jandiala, Amritsar, and Khasa.

O. monacantha was seen sparingly at Phillour, Amritsar, and Jandiala; and (). dillenii at l'hillour and Amritsar.

At Laliore, Mr. R. N. Parker, the Deputy Conservator of Forests, who is interested in Opuntias, showed the Commission the Prickly- 
pears of the district.* The commonest is the Punjab Opuntia, which has been used for covering some hillocks (formerly native brick kilns) in the gardens. 'This species has been allowed to run wild on this particular spot, and in company with it are both $O$. nigricans and $O$. dillenii. The latter is used occasionally in the city for hedges, and in places may be secn occupying waste land in and near the town and cantonment. $O$. monacantha occurs rather rarely at Lahore. Growing under cultivation in the Lahore Gardens were both spiny and spineless varieties of $O$. ficus indica, which were being propagated for fruit and fodder purposes, but they had not yet arrived at a stage at which feeding experiments might be carried out. Certain varieties of the same species were also being propagated in Sind with a view to utilisation ultimately as a fodder plant. Mr. Parker pointed out an interesting hedge composed of Nopalea cochinelifera, $O$. monacantha and $O$. dillenii, surrounding a private house.

Mr. Parker (p. 1096) was able to corroborate Mr. Burkill's statements as to the activity of the Wild Cochineal Insects in the Kangra Valley. He pointed out that although $O$. monacantha was attacked, the Punjab Opuntia growing by its side was not.

As both of these investigators suggested that an inspection should be made of this Sub-Himalayan region, a visit was paid to the Kangra Valley. A small amount of $O$. monacantha was recognised at Pathankote, while at Nurpur, in a spot indicated by Mr. Parker, there was found a composite hedge consisting of $O$. monacantha, the Punjab Opuntia, $O$. dillenii, and $O$. decumana. All of these, except the first, were growing quite well, though the altitude is about 3,000 feet. $O$. monacantha was found to be attacked by the Wild Cochineal Insect with the same disastrous results as had already been found to be the case in Ceylon. None of the other Opuntias, even though growing beside infected plants, was found to be attacked. $O$. monacantha occurred sparingly in the district, but was seen to be much more common at Sharpur, a district higher up the valley. At the latter place the cochineal insect was not detected.

Rajputana.-After returning to Delhi, a short visit was made to Jaipur, where Mr. Parker had recorded that $O$. nigricans was particularly abundant. This species was seen to be very common at Gariharsura, Jataoli, and Rewari. At Jaipur it was found to be used very extensively for hedges along the streets and around fields, and in many places occupied waste lands, this being especially the case at Amber, a few miles away. At the latter place, this cactus has been allowed to spread in such a way that it covers practically the whole district, including the adjacent hillsides. The Opuntias were particularly vigorous in this locality, the only sick plants noticed being so situated that they were unable to prosper under the hot, dry climatic conditions on account of lack of moisture. 0 . monacantha was also found sparingly at Jaipur and at Amber generally as a hedge plant.

Jaipur to Bombay.-The journey to Bombay, from which port the Commission had decided to

* Chitta thor is the general Punjabi name for Opun tias, Nagphan or Nagphani or Phenimoonsha being the common Hindustanj names. leave India for South Africa, was made viâ Agra and Central India. At Agra, Opuntias were quite rar", the only species notieed being $O$. mona canlha, which was used in a few places as a hedge plaut. $O$. nigricans was seen at Jhansi, but no carcli were detected botween that place and Agra. It was noticed that this latter species was very common at Manmad, Lasalgaon, Nihad, Kherradi, Nasik, Devlali, \&c., becoming rather less common, though still frequently seen, as Bombay was approached. $O$. nigricans was recognised on waste lands of the suburbs of that city.

\section{B. Prickliy-pear in Southern India.}

The investigations in Southern India were carried out in the Presidencies of Madras and Bombay, as well as in the States of Mysore and Hyderabad (Deccan), ready assistance being afforded by administrative, agricultural, and forestry officers belonging to the Government of India, as well as to that of the Presidency of Mysore.

Madras Presidency.-For forty years and upwards it had been a matter of complaint that Prickly-pear (Opuntia dillenii, Haw.) already covered one-eighth of an important district, situated at the southern extremity of the Peninsula-in fact, it was this occurrence that led to a recommendation being made at this time by the Madras Government that compensation should be accordingly granted for lands taken up by the Tuticorin Extension of the Great Southern India Railway. Moreover, the "disastrous spread of Prickly-pear" in the Trichinopoly and other areas was then matter for complaint also.*

In 1892 the extent of occurrence of Opuntia in the Madras Province was specially reviewed by the Government with a view to devising measures for coping with its presence and spreading. In the document dealing with this work it is stated that-" Prickly-pear is reported to have become a formidable evil throughout the whole or in parts of the following distriets:-Kistna, Nellore, Anantapur, Bellary, North Arcot, Salem, Trichinopoly, and Madura." +

In 19130 . dillenii still existed in the parts of India referred to. One may, in fact, traverse hundreds of miles from Tuticorin northwards and from Trichinopoly westwards, especially along the Valley of the Caveri, and have this prickly-pear almost continually in view, but not, as a rule, encroaching to any extent on the good agricultural land, the watchfulness of the ryot (agriculturist) guarding against such extension. Of the more northern parts of the Madras Presidency the same is also true. Again, in several districts, its habit of blocking up public roads is proving objectionable, and, moreover, the obstacle that its presence constitutes to the sale of "waste lands" is remarked-in fact, it was commonly stated that Prickly-pear was, in Southern India, becoming yearly more pronounced its spread reducing the area of land available for grazing purposes; whilst at the same time it was proving locally harmful to forestry enterprises.

* Pennington, J. B., Actg. Collector, 3rd June, 1872.

$\dagger$ Vid. Proceedings Board of Revenue, Madras, No 697, 7th Dec., 1892. 
Bumbay Presilnuy.-There was also a considerable development of l'rickly-pear locally in the Bombay distriet, the specics represented in thesc infestations being exclusively $O$. nigricans (O. elatior). At Ahmednagar, lying to the east of Poona, it was very plentiful throughout an area of 5 square miles or more, while in the Belgaum district, again, miles and miles of country had been rendered useless by reason of its dense occurrence. This occurred also at Nargard, in the Dharwar district, south of Belgaum. Generally speaking, it was quite common in the precincts of many towns and villages.

Mysore.-In the Mysore State Prickly-pear (O. dillenii) was seen to be cuite prevalent in the vieinity of Nanjangud, Grundulpet, and Chamrajnagar, while amóngst other places in which it was still very prevalent, Kolar and Chitaldrug were mentioned. Its rapid growth in many areas is viewed with apprehension." It is, however, by no means of general occurrence in this State, and it is a matter for congratulation that, with respect to localities in which it is now prevalent, the Government of Mysore has already made provision as follows :-

In the first place, it appointed a Special Commissiont of some of its leading officials, to consider the question of the occurrence of Lantana and Pricklypear, and then made (18-11-10) a comprehensive Order based on its report. In this Order the Forest Department is held responsible with respect to lands under its control for the clearance generally of Prickly-pear "wherever it has extended itself to the prejudice of more useful growtli." It is also asked to see that Prickly-pear grown on the reserved lands under its control does not spread to neighbouring areas, and has to report from time to time concerning the measures adopted by it for the extinction of the pest, and the progress made in this direction.

To encourage people to take up other lands whose assessment is below a definite limit and already infested with Prickly-pear, and so render them fit for cultivation by its removal, the Government provides that such lands, as may be conveniently made available for cultivation, may be granted to applicants, free of assessment, for a period not exceeding twelve years, at the discretion of the Deputy Commissioner, who may lay down the conditions under which this provision may be taken advantage of by landowners. Similarly, under certain circumstances, remission of assessment. subject to prescribed condition, may be granted for a period not exceeding five years with respect to lands already under occupation and pear-infested.

District funds may in some cases be drawn upon to meet the cost of clearing Prickly-pear 'on commonages, wbile definite grants for its destruction may be bestowed in special instances of pear-infestation.

* Vid. M. Karitarajurs, Proc. Gov. of H.H. the Maharaja of Mysore, 10-11, p 16, 1 Rev Sect. 1. 1909 .
In villages where Opuntia is rampant, Village Sanitation Regulations may be brought into force for compelling its destruction, the state of being " overgrown with weeds or noxious vegetation" constituting an unsanitary condition. The cost of the work in some instances is recoverable, if necessary, as an arrear of land revenue. Municipal bodies may be required by Regulation to remove noxious vegetation, including Prickly pear."

This method of coping with the evil may have some interest to the Australian administrator, and is set forth since it is described in a document not generally accessible.

ItINERARY, \&C., IN SOUTHERN INDIA.

Madras.-As the Government Central Museum had previonsly published information relating to the action of cochineal on prickly-pear, a visit was paid to that institution, but its Superintendent, Mr. J. R. Henderson, was not able to supply any additional facts.

Sir Alfred Bourne, formerly Professor of Biology, Madras University, was also interviewed. He had in 1897 investigated the habits of this same species of insect, called by him Coccus cacti, var. grana sylvestris, his material having been derived from a certain species of Opuntia from Ganjam. Consequently it was considered advisable to ascertain what particular prickly-pear had claimed his attention in this inquiry. The local collections of Opuntias were examined in his company.

$O$. dillenii, $O$. nigricans, and Nopalea cochinelifera were found occurring naturalised in the neighbourhood of the eity.

Bombay.-From Madras the journey across the peninsula direct to Bombay was undertaken. Westward of Guntakal Junction 0 . nigricans seemed to be the only prickly-pear present and in the drier parts of the Deccan was seen to be seriously affected by the arid climate, some plants being killed outright. No evidence was obtainable regarding the prevalence of natural enemies in this region.

Whilst in Bombay information was received froni MIr. G. Carmichael, the Chief Secretary to the Government, regarding the official measures taken to restrict the growth and spread of Opuntias in the Presidency. He mentioned that natives were not allowed to plant prickly-pear near cantonments, and that municipalities had "uithority to order its destruction where already occurring. He also dwelt upon its use in the Poona district as a green manure.

Mr. C. W. Turner, Under Secretary of the Department of Revenue and Finance. tendercel information regarding the use of Opuntia as fodder for stock. R. B. Vakil, Khan Babadur, Assistant Secretary to the Government, also rendered assistance.

It was in the Bombay Presideney that a wild eochineal insect had been locally prevalent and destructive to prickly-pear some time ago. In 1837-8 J. Bell had reported its occurrence betwcen Cossipore and Dum Dum. Its presence

*Vid. 1910-11, Gov. of His Highness the Maharaja of Mysore-Land Revenue, Sect. 1, Proceedings 18th Nov.,
1910 . 


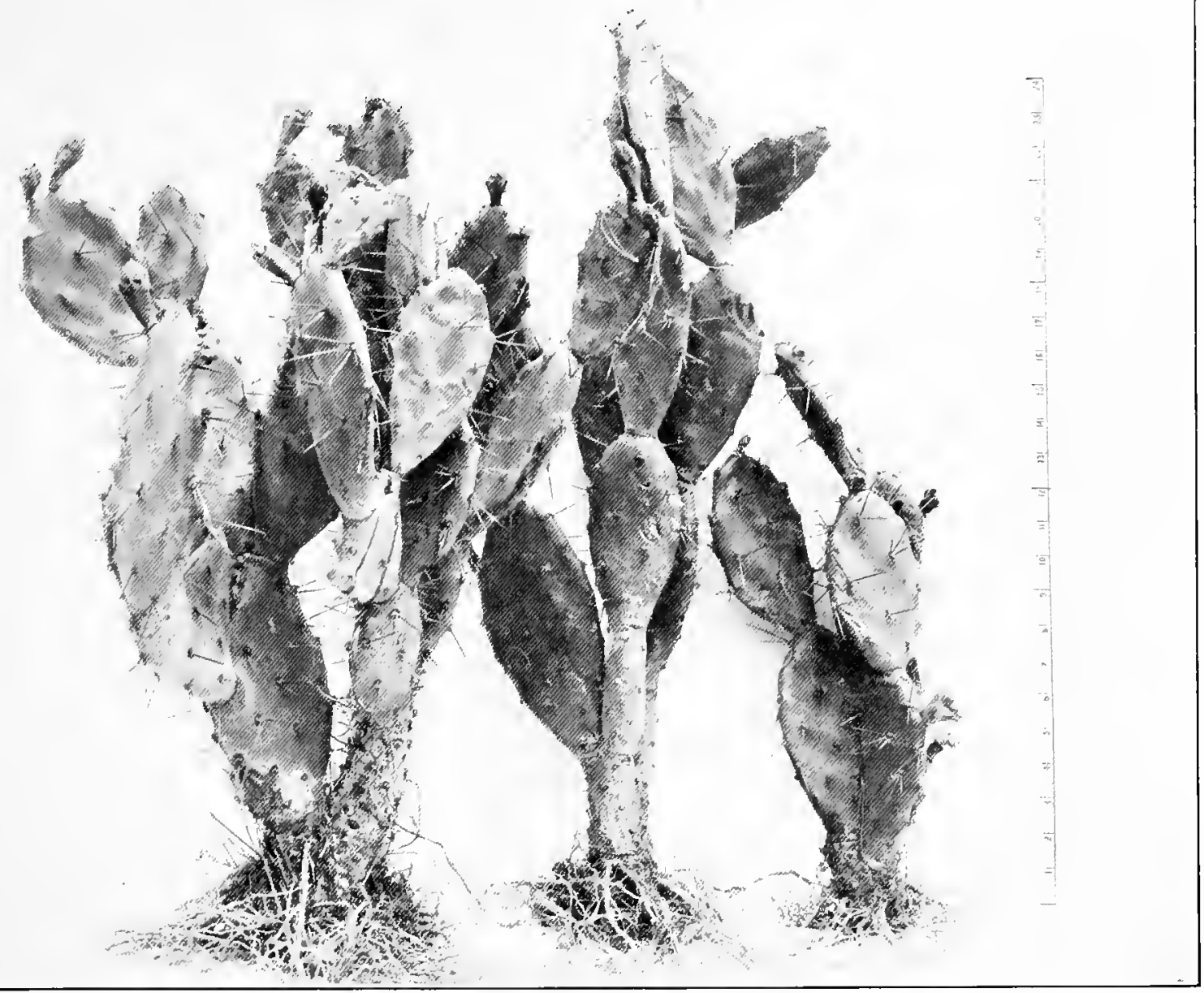

Fig. 5.-The Spiny Pest Pear. Specimen from Gayndah.

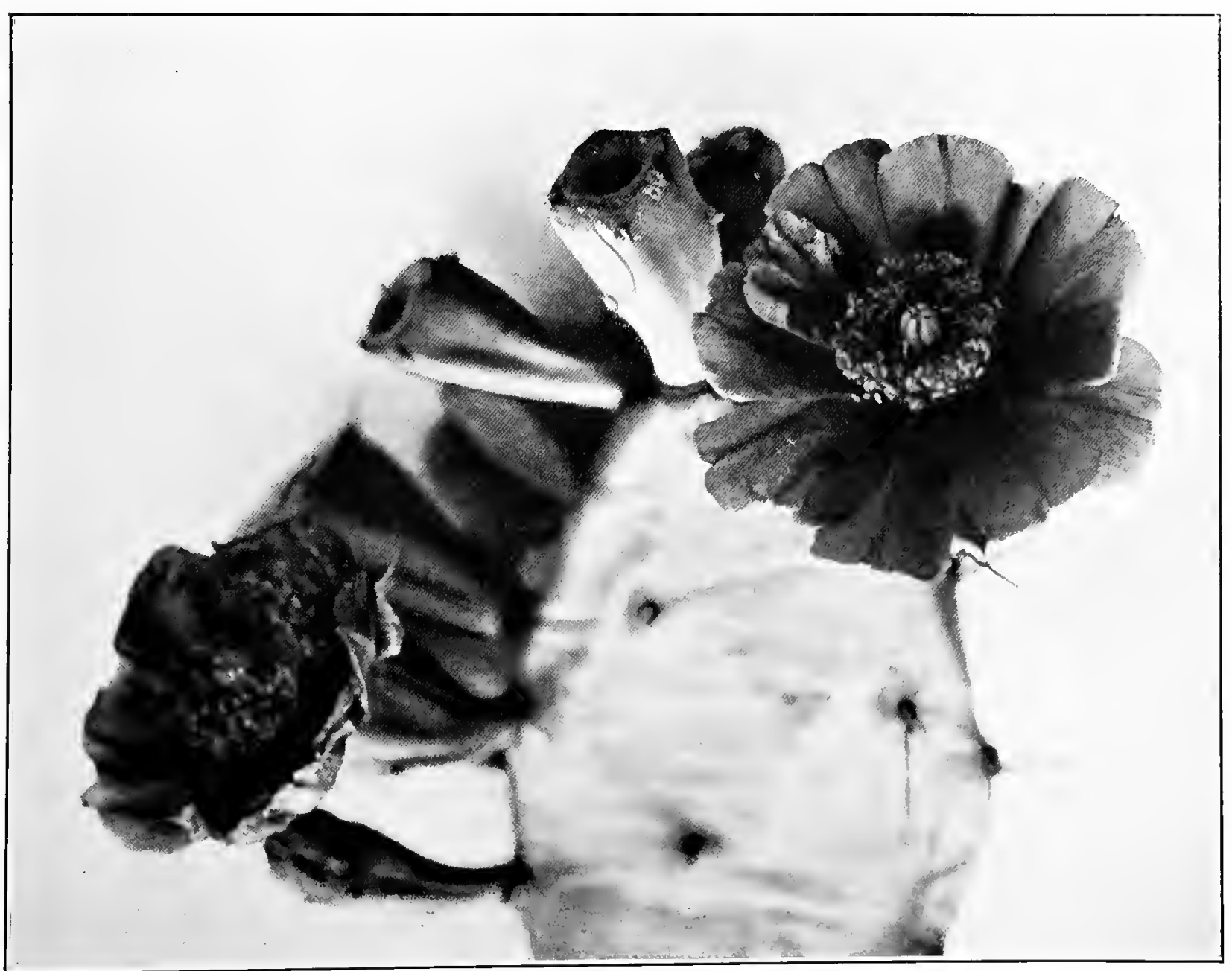

Photo., Dept. Agriculture, Brisbane.

Fig. 6.-Flowers and developing fruit of the Spiny Pest Pear, from Gracemere. 

at Candeish, Poona (in 1839) and Belgaum (in 1859 and 1863) had also been recorded. These occurrences suggested that it might still be discoverable in these localities, but inquiry in Bombay did not afford any hope of such being likely.

Poona.-In the absence of Mr. G. Keatinge, the Director of Agriculture, his Deputy, Mr. T. F. Main, gave us access to certain official records. Mr. H. Mann, the Principal of the Poona Agricultural College, brought under notice a report by a member of his staff relating to the action of a scale insect, Diaspis cchinocacti, on pricklypear.

Professor J. B. Knight placed at the disposal of the Commission his reports on the experimental feeding of Opuntia to stock in the Poona area. In his company, visits were made to the Experiment Station of the College, and to the Government Farm at Kirknee, where these trials were being carried out; and also to Mr. A. Norton's farm at Dhond, where pricklypear had been utilised to a considerable extent as a cattle fodder, the incident having received notice in the Indian and Australian Press.

Professor G. A. Gamie, who is the Imperial Cotton Expert, was interviewed regarding tho use of prickly-pear as a soil fertiliser.

The prevalent cactus at Poona was found to be 0 . nigricans. In one locality there was seen another Opuntia, which was evidently a more useful fodder plant.*

Belgaum.-In this district $O$. nigricants occurred commonly, and was regarded as a nuisance by the agriculturists. Nopalea cochinelifera was also found in the neighbourhood. No sign of insects or disease affecting prickly-pear was noticed here.

Mr. L. Napier, the Deputy Conservator of Forests, stated that he was not aware of the presence of any natural enemy of $O$. nigricans, nor of the alleged occurrence of the wild cochineal in that region. In regard to utilisation fifty or sixty years ago, he stated that the only use made of it was as a hedge plant, except under stress of circumstances when the fruit was eaten by man and beast. The difficulty of preparation and a conservative distrust of a new method of feeding cattle were the chief obstacles to its employment as a'stock fordder.'.'Pe mentioned that when once the plant had obtained a firm hold in the forests in the district, no steps were taken to subdue it on account of the prohibitive cost.

Mr. R. S. Mudakattee, of the Forestry Service, also rendered assistance.

Dharwar.-The Collector, Mr. E. Maconochie, informed us that prickly-pear was regarded as a pest in the district, and was especially prevalent at Nargand, to the south. He also wrote: "As far as $\mathrm{I}$ know, we, in India, have no results of any value to communicate; no means of removal. is practised beyond the primitive one of cutting

* This prickly-pear is to be seen growing in the yard of the Police quarters adjacent to the offices of the Depart ment of Agriculture at Poona. Here it forms a lofty hush, but no in lications of flower or fruit were noticeable on it when indications of flower or fruit were It is evidently the Opuntia decumana dealt with by Burkill (1912, pp. 314-5), who expresses the opinion that it is identical with Roxburgh's Cactus chinensis. It may be here pointed out that the latter received it from Dr. James Anderzon, who, after having obtained it from China and propagatcd it in his nopalry at Madras, had distributed it widely in 1788 (vid. "Letters to Sir Joseph Banks," 1789, p. 15). and burning; and as to econonic use, it has been employed to a limited extent as a subsidiary cattle fodder in time of famine, but it requires careful preparation for which the Indian ryot has no inclination or aptitude.'

The Deputy Collector, Mr. G. R. Balehundri, nade available certain information contained in reports, and submitted specimens of the cacti naturalised in the district, these being determined as O. nigricans, Nopalea cochinelifera, and Cereus pterogonus. Inquiry failed to bring to light the accurrence of $O$. monacantha or of the wild cochineal or other insect affecting any of the prickly-pears there.

Bellary. - It was in this part of the Madras. Presidency that A. Sabhapathi, in 1876-7 and 1891-2 had earried out some feeding experiments with stock during periods of famine.

Mr. G. F. Paddison, the district Collector, rendered considerable service in placing at our disposal all the available official information relating to prickly-pear, and brought under notice the local Opuntias, $O$. nigricans and $O$. dillenii. which were prevalent in some places and might be seen growing commingled. $\mathrm{He}$ also commissioned one of his officers, Mr. M. R. Ekambiiah, to accompany us. No natural enemy was known to him or was detected by us while there.

Guntakal.-It had been our intention to travel from Guntakal to the Kurnool country lying to the north-west, where cochineal insects had been obtained in 1865 and subsequently, but it was found impracticable.

Anantapur.-A visit was paid to this town since it was reported that prickly-pear had been destroyed there at about the same time as at Kurnool, but no information was available from the Collector or his officers regarding the occurrence.

Bangalore (Mysore State).--On arrival here, it was found that Sir Hugh Daly, the British Resident, who is also the Chief Commissioner of Coorg, had kindly arranged for assistance beingr afforded us in Coorg, in the event of our visiting that State, but this we found impracticable, in view of the limited time available.

Dr. L. C. Coleman, Director of the Mysore Departnıent of Agriculture, Bangalore, placed at our disposal reports-some of which are quoted above-relating to the methods adopted by the Mysore Government for coping with the pricklypear problem. He also suggested employment of the plant for manurial purposes, though in his publication on "Green Manuring in the Mysore State" $\dagger$ he had not mentioned the utilisation of Opuntia in this way.

The collection of prickly-pears in the local Botanical Gardens, in charge of Mr. Gr. Koumbiegel, was examined, but neither disease nor injurious insects were found.

In our further investigations in Mysore we were accompanied by the Assistant Mycologist. Mr. Venkata Rau, for whose services we are indebted to Dr. Coleman.

Mysorc.-It was here that cochineal insects had been formerly established on an acclimatised

* Indian Museum Notes IV., 1899, p 212

† Bull. 1, Dept. Agrio., Mysore, Bangalore, 1912. 
"cactus" brought originally from Teneriffe," but our inquiries did not lead to the obtaining of any intormation during our visit to that city.

Nanjangud.-Early in the nineteenth century, Buchanan Hamilton had reported that wild cochineal insects had injured prickly-pear plants near Beilura, about 30 miles sonth of Mysore. It was decided to examine the neighbouring region, and accordingly journeys were made to Nanjangud and Grundulpet, near the foot of the Nilghiri Mountains. No traces of the insect were encountered, but a few living specimens of its host plant, $O$. monocantha, were met with under circumstances which would suggest that they were survivals. The species prevalent in these two localities was $O$. nigricans, which at Grundulpet was seen to be commonly infested by the white cactus scale insect Diaspis echinocacti, but no perceptible damage was causcd.

Coimbatore.-It was at Coimbatore that Grimes in 1884, at the instance of Surgeon-Major G. Bidie, Superintendent of the Central Museum, Madras, experimented with some cochineal insects introduced from Algiers, $\dagger$ but no record of the facts discovered, or of the action on the host plants, was found to be available.

The District Forest Officer, Mr. Punchapicasa Iyer, though interested in prickly-pear matters, was not able to supplement our information to any extent, except with an account of the ordinary local method of destroying $\boldsymbol{O}$. dillenii by hand labour. He mentioned that $O$. monacantha grew in the district.

Mr. R. C. Wood, Principal of the Agricultural College, informed the Commission that the problem in that district was directly opposite to our own, that it was there a question of utilisation -as a hedge plant and as a protection for treesrather than destruction.

Mr. T. Rainbridge Fletcher, the Entomologist to the Government of India, who was met here, drew attention to certain insects, mentioned later, whose attacks on Opuntias caused some slight injury.

In addition to $O$. dillenii, which was found growing commonly in this district, $O$. decumana was met with occasionally.

Trichinopoly.-This city was reached from Coimbatore, viô the valley of the Caveri. In the absence of the Collector, his deputy, V. Pathasaradtry Chetty, gave serviceable information regarding the local use of prickly-pear as a soil fertiliser, and also allowed the perusal of official reports relating to the plant.

Professor H. Sampson, the Director of Agriculture, who is stationed at Trichinopoly, referred to the use of Opuntias as green manure, and mentioned that the mucilage from prickly-pear plants was utilised in the malking of a kind of plaster called chunar.

The species found growing in this locality were 0 . dillenii as well as, occasionally, $O$. dec $u$ mana.

From Trichinopoly, Ceylon was revisited, viâ Tuticorin, for work in connection with the experiment relating to the propagation of the wild cochineal insect. The return journey to Bombay was made vi $\hat{a}$ Madras.

* Ceylon Handbook and Dictionary, Edit. 1885-6, p. 84. Colombo, A. M. and J. Ferguson.

† Rep. Govt. Central Museum, Madras, 1883-4.
DESTRUCTION BY NATURAL ENEMIES.

\section{A. Insects.}

\section{The Wild Cochineal (Coccus indicus, Green.)}

As a result of investigations it was found that at least one species of Opuntia (O. monacantha) has suffered greatly from the attacks of the wild cochineal insect (Coccus indicus, Green). A great deal of evidence regarding this matter has been collected by Sir G. Watt (1889 and 1908), by one member of this Commission (Tryon, 1910 , p. 188), and by Mr. I. H. Burkill (1911), formerly Reporter on Economic Products to the Government of India. A summary of information published by them, as well as of facts contained in less accessible writings and of those obtained by the Commission, will now be given.

In 1786 Dr. J. Anderson, of Madras, drew the attention of the East India Company to the desirability of introducing the coehineal insect into India on acount of its commercial importance at the time, the actual introduction being made in 1795 by Captain Neilson, who brought it to Calcutta from Rio de Janeiro, Brazil.* The specimens were transferred to the various species of Prickly-pear growing in the Calcutta Botanic Gardens under the care of Dr. Roxburgh, but it was found that the insects throve only on the so-called indigenous Opuntia, which we now know as $O$. monacantha, Roxburgh calling it $O$. indicus. A portion of this introduced Wild Cochineal Insect was sent from Calcutta to Madras, addressed to Dr. J. Anderson, who was the Company's Physician-General. $\dagger$ There were other importations of the Wild Cochineal Insect into India-one by Prinsep into Bombay from Campeachy in 1821 and 1822 , and the other by Perotet into Pondicherry from Bourbon, his stock coming originally viâ Cadiz. From Bourbon a supply was sent in 1837 to Calcutta, this being the second introduction there. In the same year a box of insects on Opuntias ( 0 . monacantha) was forwarded from the Cape. There does not appear to be any evidence that these later introductions were successful, as either the insects or the plants, or both, soon died.

Very soon after its introduction to Calcutta in 1795 , and its transmission to Madras, it was disseminated through the Madras Presidency under special Orders issued to its Collectors by the East India Company.

Previous to this-in 1787-1788-Dr. Anderson had formed a plantation at Madras of the Opuntia (i.e., $O$. monacantha), which he had found growing wild in several localities and which he believed to be a native plant. From this garden he brought about its establishment throughout the province of Madras, as he had assumed that when the Cochineal insect was introduced, this Opuntia, adapted to local conditions, would be found to constitute a suitable p. 60

* Royle. "Produotive Resources of India," 1840,

$\uparrow$ This introduction of the Wild Cochineal Insect from South America has been briefly dwelt upon by E. Balfour in 1871 (vid. Cyclopedia of India, 2nd Ed.. Vol. I., p. 278, Madras, 1871, s.v. "Cochineal "), and more fully in 1889 by Sir G. Watt, in his "Dictionary of Economic Products of India," pp. 398-409, s.v. " Coccus Cacti." therein. 
host plant for it. The insect introduced not being, as was afterwards discovered, the Precious Cochineal (Grana fina), but the wild one (Grana sylvestre), the correctness of his assumption was established by future happenings, but this would not have been the case had the more valuable insect been introduced as intended."

As it is a material contribution to our knowledge of the history of this Wild Cochineal Insect, and its action on destroying Prickly-pear, the work of this East India Company's officer may be here deseribed.

Dr. James Anderson recorded, in 1787, $\uparrow$ lliat an Opuntia grew wild everywhere in the neighbourhood of Madras, possessing, amongst others, the following characters:-The petals much longer than the stigmas, and when closed entirely covering them; they were yellow, streaked with red; the fruit never red-coloured, nor has it red juice.§ The prickles on the stem joints perfectly straight.|l In addition to the Madras district he mentions its occurrence as a native plant at Chingleput, Tanjore, Chiniapapaigpollam, $\mid$ also at Coimbatore and at Pondicherry, where the gardens were enclosed with it. I He stated that it bore the vernacular name Naga. kulli, and the technical one Cactus opuntia.

This plant he cultivated at his Priclly-pear Farm at Madras, since he had (he wrote, 29th May, 1787) " not yet been able to find the Cactus cochinilifer." " Dr. A. Berry, who had charge of this "Nopalry" under Dr. Anderson, wrote regarding "the country Opuntia that wanted red juice" : that he had planted 1,000 to have something in readiness to receive foreign insects till such time as the plants that were better recommonded as host plants for the cochineal should be brought to perfectiontt (the true Opuntia cochinilifer having been meanwhile received from an exotic source).

In addition to cultivating this Opuntia at Madras, Dr. Anderson sent it to Masulipatam, Madipullam, Ganjam, Nellore and Samateota, Vizagapatam, Samal-Cotah, and Calcutta.+1 $\mathrm{He}$ also stated that he expected to get plantations made of it in more sheltered situations amongst the great ranges of hills at Vellore, Santgurry, and Ambor. $\S$ From this we may assume that he sent the plant to these also, and

- The publications in which Dr. Anderson degcribes thie long-sustained work have been overlooked by all subsequent writers, although mentioned by Hooykaas (J.C.) and du Rieu (Dr. W.N.) in their " Repetorium of de Koloniale Litteratuur," Vol. II., Amsterdam, 1877 (s.v "Cocchenille," op. cit. pp. 449-451). As evidently they are now scarce, their full titles may be cited :-

(1) Letters to Sir Joseph Banks, Baronet, President of the Royal Society on the Subject of Cochineal Insects discovered in Madras. Madras, Charles Ford, 1788 (pp. 1-36, Plate 1, Nopalry).

(2) Letters on Cochineal (continued) by James Anderson, M.D. Madras, Charles Ford, 1789.

(3) The conclusion of Letters on Cochineal, by James Anderson, M.D. (pp. 1-21). Madras, Charle日 Ford, 1790 .

+ Letters, 1788, p. 8.

$\ddagger$ Op. cit., p. 10 .

\$ "Letters," 1789, p. 24.

|| "Letters," 1788, p. 8.

\Op. cit., p. 9.

* "Letters," 1788, p. 11.

†† " Letters," 1789, p. 24.

¥¥ " Letters," passim 1788 to 1790 .

§§ "Letters," 1788, p., 11. perhaps even prior to the date of the letter in which this intention is mentioned-i.e., July, 1787.

Evidently in reference to this and other species of Prickly-pear sent out by Dr. Anderson, the East India Company, as early as 1799, granted a special remission of dues with respect to land on which it was cultivated:- One-sixteenth of the ordinary rate of towns will be required for lands growing mulberry, the Mauritius Cotton, the Opuntia." "*

The introduced insect evidently found congenial conditions, as we are informed by Prinsep (Burkill, 1911, p. 302) that large quantities of prepared cochineal were exported in 1797 and 1798. The decline in value of cochineal and the fact that the Grana sylvestre had only one-fourth of the colouring properties of the true cochineal or Grana fina, caused the industry to be of less importance and to finally disappear. The insect, however, continued to spread and to exercise a destructive influence on its host plant. Dr. W. Ainsliet stating that such quantities of the Sylvestre appeared on the Coromandel coast that it almost rendered extinct one of four kinds of Opuntia growing there at the time. A similar event occurred about the years 1859-1863 in the southern part of the Bombay Presidency about Belgaum and elsewhere.

Mr. Burkill (1911, p. 301) mentions an interesting account of such Prickly-pear extermination on the part of this insect, in Southern India, given by Wilks in his " Historical Sketches of the South of India," Vol. III., 1817, p. 84. Wilks referred to the former existence at Poongur, on the banks of the Caveri, of fences, \&c., composed of a Pricklypear, the straight-thorned Opuntia, + sufficiently grown to cause the entanglement of Tippoo Sultan's horse there on September, 1790; but that afterwards, when its removal was contemplated, it was found that "the Sylvestre cochineal introduced into Coromandel, shortly after the order had been given, had devoured not only the "leaves" but the root of the plant with such avidity as nearly to have terminated its existence in the south-eastcrn provinces," and not alone in these fences.

Moreover, when the Wild Cochineal Insect was distributed the plant was already established, and it not only multiplied but did so to the extent of killing its host plant. Thus Dr. Francis Buchanan, another officer in the Medical Service of the East India Company, writing in 1807 of the new cochineal-raising industry, in which " the Cochineal of the bad kind lately introduced" and the "Cactus-the aboriginal of the country" figured, states, with reference to operations at Bailura, on the Caveri River, and about 20 miles north of the small State of Coorg, that " the young insects . . . put upon the new hedges, will have in six months increased so that they may begin to be collected, and that, after a year more has elapsed, the whole plants are consumed." Also that, "so

- Vid. Circular issued by Col. A. Reid, Salem embodying a Kaulnama or Proclamation dated 15tb Nov. 1796, in the name of the Kudds, Vastagans, and other Ryote of the district of Tirupatur-quoted by H. le Fanu, "Manual of the Salem Districts," I., p. 222. Madras, 1883.

+ W. Ainslie. Materia Medica of Hindustan, 1813.

$\ddagger$ Cactus ficus-indica, Lin., Ainslie (i.e., O. monacantha). 
soon as all the plants have been consumed, such of the insects as have not been collected will perish.",*

There exist good grounds for concluding that instances of the destruction of Prickly-pear in Southern India, by this introduced Wild Cochineal Insect, might be greatly multiplied, as the outcome of examining the archives relating to events in India during the first half of the last century.

Lately, however, instances of the Wild Cochineal occurring in injurious relation with the Prickly-pear plant have occurred quite sporadically in Southern India. Balfour reported such an occurrence at Vizagapatam; E. Thurston, in the Kurneool, Anantapur, and Ganjam districts; whilst $K$. Rangachara, Botanist to the Mysore Agricultural College, informed the Commission that he had found it at Sandur, near Bellary.

Inquiry, supplemented by personal observations, in the course of extensive journeys in the Madras and Bombay Presidencies and in the State of Mysore, failed to bring to light any quite recent instance of the Wild Cochineal In. sect's occurrence. More protracted search, especially in the region north of Madras bounded by Ganjam and Vizagapatam, would doubtless have resulted in finding it sparingly.

In addition to the above mentioned occurrences in Southern India, the insect evidently spread (presumably from Calcutta) over Northern India, extending along the Ganges Valley to the Punjab, since Dr. A. Fleming (1857, p. 200) referred to its presence in 1848 on Prickly-pear hedges near Jindiala, the cochineal dye being sufficiently common to be an article of commerce.

Mr. Baden Powell (1872, p. 194), in referring to the rapid increase of Prickly-pear in the Jullundur Doab district, mentioned that rewards were offered for its extermination, but that a kind of coccus appeared and soon destroyed the plant so effectively that the pear was then only occasionally met with. The species referred to is certainly $O$. monacantha, which at the time of the Commission's visit was rather uncommon, while the "Punjab Pear," which has replaced it, is quite conmon at Jullundur and is not affected by the cochineal. Powell also referred to the destruction caused by the insect in 1849 and 1850 in the Ludhiana district.

Sir G. Watt stated, in 1889, that, though located for twelve years in Bengal, he did not remember having seen cochineal on the cactus hedgerows of the Lower Provinces. He seems to have shown conclusively that the only form introduced was the wild coccus or Grana sylvestre. Stewart mentioned (1869, p. 101) that from 1844 to 1852 the cochineal insect was destroying Opuntias in the Punjab, the destruction at Ludhiana being practically complete, a fact referred to by Baden Powell in 1872. At the present time the "Punjab Pear" is common near this town.

* Buchanan, Francis (M.D.). "A Journey from Madras through the Countries of Mysore, Conara, and Malabar," pp. 399-400. Madras, 1807. Also, ib., 2nd Edition, Vol. II., p. 479. Madras, 1870,
Mr. Burkill (1911, p. 308) mentioned that Purdon had seen the insect west of Gujrat in 1851, and that he himself had noticed it at Kangra in 1902.

Mr. Parker (19.12, p. 1096) has recently stated that he saw the cochineal insect on $O$. monacantha throughout the Kangra and Hazara districts, the attacked plants as a rule dying. The "Punjab Pear" (which he regards as $O$. ficus-indica or a closely allied species) was not, however, attacked.

The visit of a member of the Commission to Kangra Valley confirmed the reports of Messrs. Burkill and Parker. The cold moist climate of the Lower Himalayas does not prevent the insect from exercising its detrimental effect on its hostplant.

Lieutenant-Colonel J. G. Balman is said to have sent to the Madras Government in 1862 an account of the destruction caused by the Wild Cochineal. Owing to the spread of Opuntia in Southern India, a native official in 1863 suggested its use for destroying the Prickly-pear, so prevalent then in the neighbourhood of Trichinopoly. The Collector of that district, Mr. Wathouse, accordingly procured the insects from Madras, and "these were sprinkled on the Prickly-pear trees." In former procedures this would have been all that was necessary, but now the operation was " with no effect."

The Acting Collector, Trichinopoly, again, in 1872, expressed his desire to experiment in Prickly-pear destruction with the insect, " having heard that the insects were found wonderfully successful in some districts." * The experiment again gave negative results. Its use was also tested at Bellary, and found a failure. $\dagger$

In 1896 the Madras Government commissioned Mr. E. Thurston, Superintendent of the Government Museum, Madras, "to institute an inquiry, in consultation with the Board of Revenue, as to the practicability of destroying Prickly-pear (Opuntia dillenii) by means of the Cochineal Insects and other parasites." This officer accordingly approached the Collectors at Ganjam, Vizagapatam, Bellary, Kistna, South Canara, Malabar, Nilgiris, North Arcot, South Arcot, Nellore, Madras, Tanjore, Trichinopoly, and Tinnevally - i.e., all the districts in the Presidency-"to cause inquiry to be made as to whether any animal or vegetable parasite had been anywhere observed, or could be found, feeding upon the Prickly-pear." Accordingly, it was elicited that the Cochineal Insect still existed at Ganjam, Maliahs, where "a small elump of Prickly-pear was fed upon by some kind of cochineal insect, and in the course of a year or two the greater portion of the clump was destroyed," and had apparently existed a few years previously in a certain part of the Chingelput district, near Madras. He reported that " no parasites, animal or vegetable, have been observed living on Prickly-pear in such a manner as to warrant a hope that they might be used as an agency for the destruction of the plants."

The Board of Revenue pronounced accordingly that " there are no parasites known to the Presidency which can be relied on to destroy

* Proc Bd. Revenue, Madras, No. 3, 4th Jan., 1873.

$\dagger$ Vid. Balfour, Cyclopedia of India, Vol. I., p. 278. Madras, 1871. 


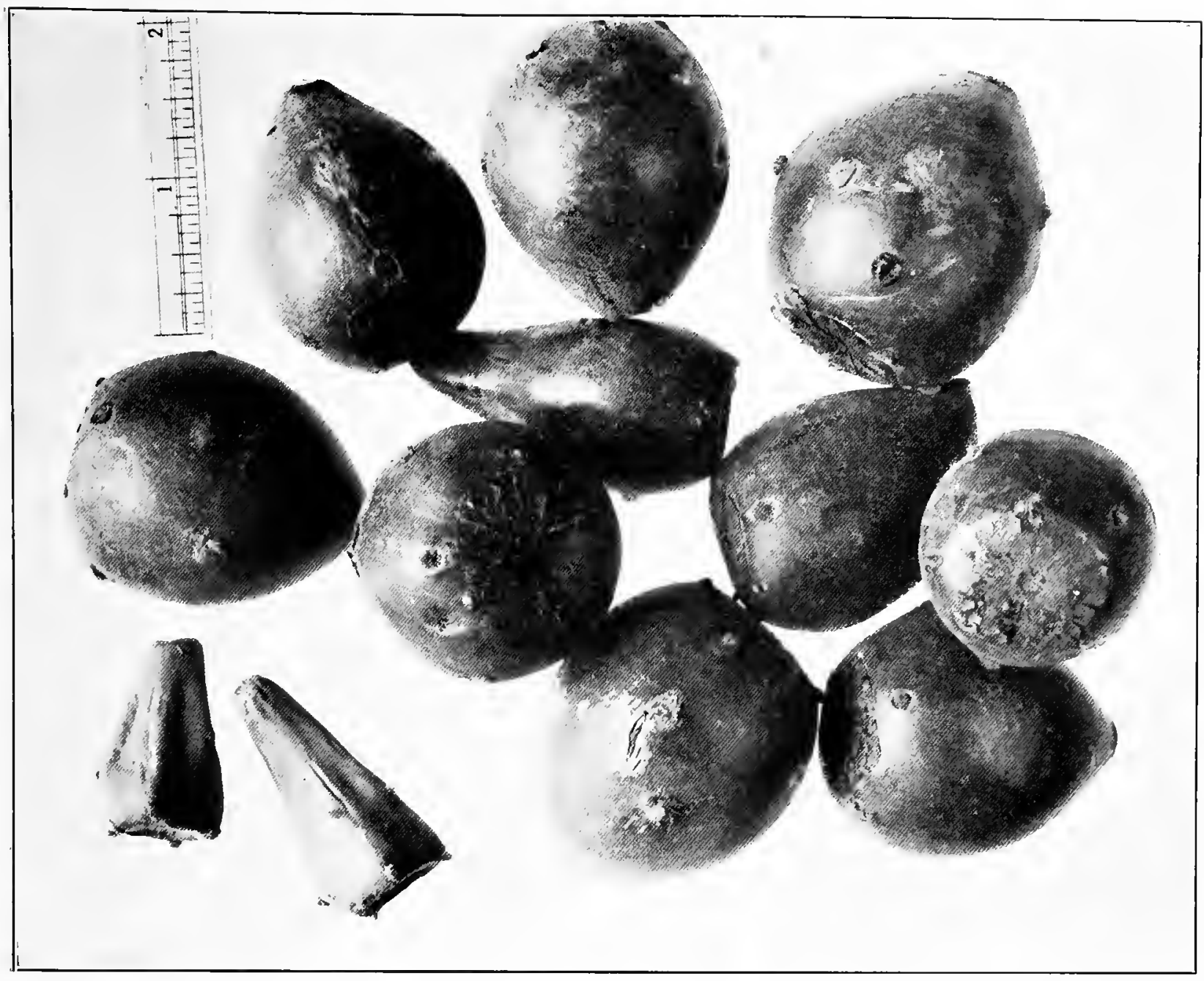

Fig. 7.-Fruit of the Spiny Pest Pear (Fig. 5), from Gayndah. For comparison with Fig. 4.

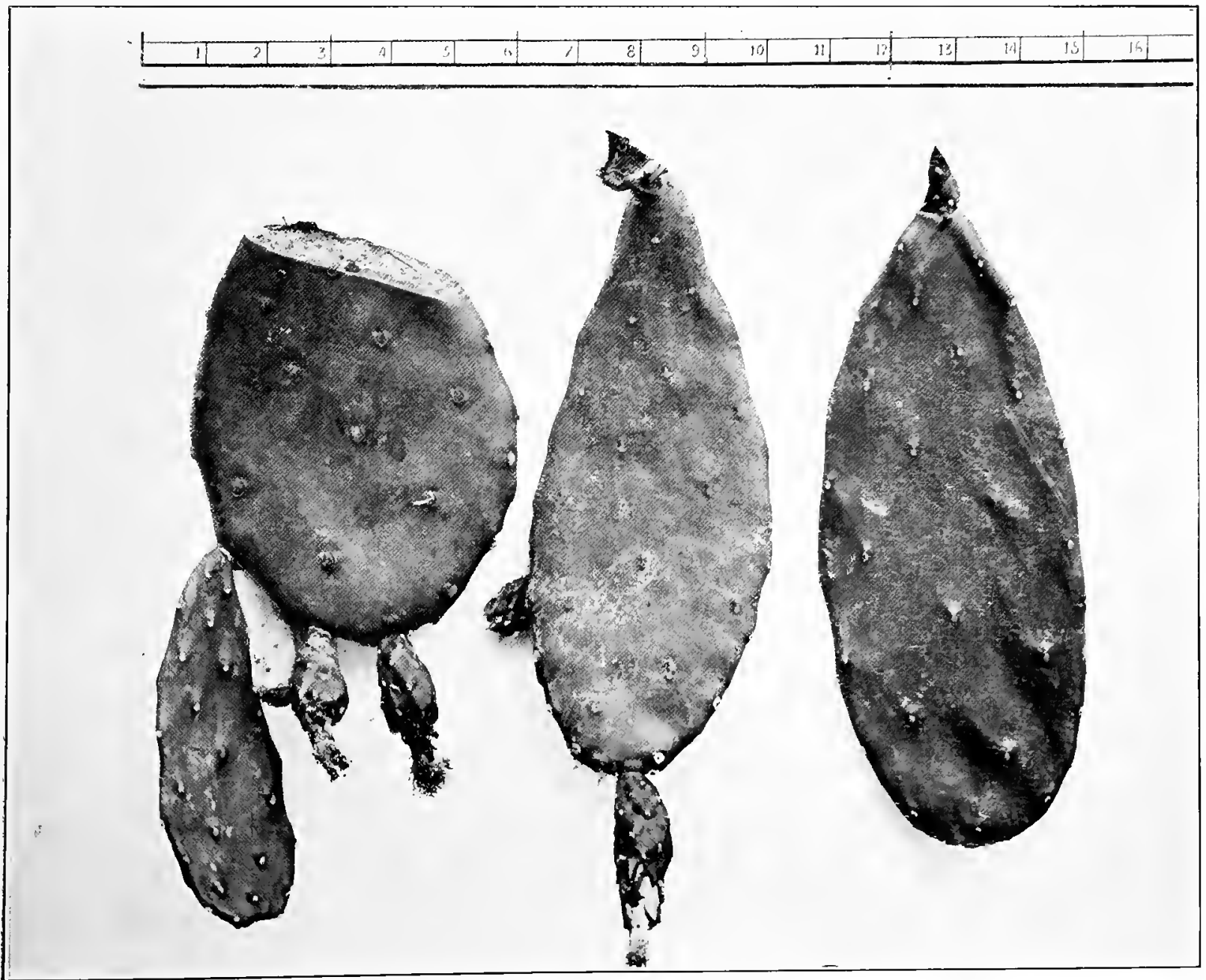

Fig. 8.-A Spineless Tree Pear-Nopalea cochinclifera, L.-from Emerald. 

Prickly-pear growth," but suggested " procuring specimens of the cochineal insects, and making experiments." "*

The specimens of "Wild Cochineal Insect," which Mr. Thurston named Coccus cacti, var. Grana sylvestris, were accordingly obtained from Ganjam and handed over to Dr. A. G. Bourne (now Sir Alfred Bourne), Professor of Biology, Madras University, who tested their feeding habits on "a clump of the yellow-flowered Prickly-pear (Opuntia dillenii), and on plants, secured from the Horticultural Society's Garden, of the red-flowered species (Opuntia (Nopalea) cochinelifera), and three other species ( $O$. decumana, $O$. monacantha, and $O$. spinosissima). The specimens sent were all attached to the redflowered Cactus ( $O$. cochinellifera)." Dr. Bourne, however, arrived at negative results. The brief report embodying his findings is entitled "Destruction of Prickly Pears with the aid of the Cochineal Insect or other Parasites." $\dagger$

On interviewing Sir Alfred Bourne at Madras (on 26th January, 1913), it was elicited that he was not able to add to what he had written, nor to definitely identify the Opuntia spp. that has bcen used in his experiments.

The foregoing statements indicate that in Southern India three things had been early brought about:-(1) A plant (one of the Prickly-

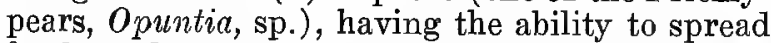
freely and already occurring in several localities, was widely disseminated, and its development and increase encouraged; (2) an insect especially partial to it was similarly propagated; and (3) the destruction of the former $\ddagger$ by the latter occurred whenever and wherever they became associated. Also, that in more recent times (1862-1872) the last event was apparently not always realised.

During the extended travelling in Southern India only a single instance of the occurrence of Opuntia monacantha growing at large came under notice. This was afforded by the discovery of a few plants growing isolatedly near Grundlupet, at the extreme south of Mysore. Again, to the various Government officials that were consulted in Madras, Bombay, and Mysore, Opuntia monacantha, as a locally-growing plant, was apparently unknown. Special inquiry amongst intelligent ryots was equally fruitless in bringing a growing plant to light. Nor were specimens included in the Herbaria attached to the Poona, Bangalore, and Coimbatore Agricultural Colleges. However, M. Punchapicasa Iyer, the District Forest Officer of the Western Circle. Coimbatore, mentioned, as growing at the Thara-

* Vid. Proc. Board of Revenue, Madras, Res. No 135, 17th June, 1896; and E. Thurston's Report, dated 15th June, 1896, published (pp. 2 and 3) therein; also, Proc. Board of Revenue, Misc. No. 3844, 4th Aug., 1896.

†Administration Report, Madras Government Museum, for the year 1897-1898. Appendix J., op. cit., pp. 28-29.

+ One member of the Commission (Tryon, 1910) has pointed out that this was Cactus indicus, Roxburgh, and followed others in erroneously identifying "indicus" with Haworth's Opuntia, dillenii, instead of pointing out, as I. H. Burkill has since done (1911), that it was only another name for Opuntia monacantha Haw. Burkill has, moreover, accumulated abundant ovidence in support of the conclusion that this plant-in India, at least-is its exclusive host plant, the Manila Opuntia mentioned in the "Asiatic Register" and elsewhere as "one which the Wild Cochineal Insect would eat" not being identifiable. gam Reserve, 15 miles away, a few bushes of a species of Prickly-pear distinct from Opuntia dillenii and which apparently was referable to this species.

Hence it may be inferred that the species once common in Southern India and so freely distributed to many districts by $\mathrm{Dr}^{\text {r }}$. Anderson in the eighteenth century, as has been already mentioned, is now on the verge of extinction there.

Its virtual extermination may, therefore, be attributed to the insect referred to; the insect becoming rare as its host plant has become rare. The failure of the Coccus to act as a cacticide is accounted for by its not being confronted with its proper host plant-Opuntia monacantha.

Burkill (1911, pp. 318-9) may be quoted as confirming this conclusion:- "The Wild Cochineal Insect introduced into India in $\mathbf{1 7 9 5}$ spread so rapidly on Opuntia monacantha as to destroy it, branch and root, out of the countryside. The insect was introduced into both Bengal and Madras, but, owing to the action of the Government of Madras in encouraging its propagation, it spread more rapidly there than in Bengal. It had almost done its work of destruction in Southern India in twenty years. Opuntia monacantha, thanks to the Cochineal Insect, which is still with us (referring to its occurrence in Northern India), is now a comparatively scarce plant."

Referring to species of Prickly-pear other than $O$. monacantha that are now endemic in India, Burkill expresses a hope "that his work will prevent any waste of money in fruitless attempts to destroy Prickly-pear by means of the Cochineal Insect; such attempts as have been made in the past have been made in ignorance of the true food plants of that little insect."

As already mentioned, the "Punjab Opuntia," which closely resembles one of the Queensland pest pears, is not affected by the parasite. Moreover, it is known that none of the following species is attacked by it in India:- $O$. nigricans, $O$. dillenii, and $O$. decumana; while the Commission's attempt to infect $O$. dillenii experimentally at the Henaratgoda Gardens in Ceylon has not succeeded.

With reference to the insect itself, Mr. E. Green, the Entomologist to the Government of Ceylon, has pointed out that this "Wild Cochineal Insect" attached to Opuntia monacantha in India, and that he named in 1908 Coccus indicus, Green, is identical with the one now occurring in Ceylon on a plant that he erroneously identifies with Opuntia dillenii, but that is actually, as we have seen, the same as its Indian host plant (1912).

The interest of the foregoing remarls consists in the fact that Opuntia monacantha is one of the Prickly-pear pests of Queensland (Suttor River and Rockhampton), and occurs in New South Wales, Victoria, and South Australia also. The insect spoken of was despatched in quantity by the Commission from Ceylon to the firstnamed State, where it should accomplish, in destroying Opuntia monacantha, what has been enacted through its instrumentality in British India as well as in Ceylon. 
Other Insects.

This Coccus is not the only insect that subsists on Opuntias in India."

An armoured scale insect, belonging to the genus Diaspis, was observed occurring very thickly on Opuntia nigricans near the Manri State Farm, Poona district, and on varieties of Opuntia decumana under eultivation at Dhond. It was also met. with at Grundlupet, Southern Mysore, on 0 . dillenii throughout a rather large area, and in some spots plentifully. The coccid in all these occurrences seemed referable to a single species. In no instance was a plant observed to be destroyed or even checked to any extent in its growth by it.

However, Ram Rao S. Kasargode, Lecturer in Entomology at the Poona Agricultural College, stated that this plant-lonse has been identified by E. E. Green as Diaspis echinocacti, Bouché and has been found in the Bombay Presidency on Opuntia on both sides of the flat stems. It is widely distributed, and occurs especially during the months of March and April. It was observed to be destructive in only one instancethat of a hedge-in Ahmednagar district.

A species of Diaspist was found on a few specimens of an Opuntia in the Calcutta Botanie, Gardens and on the "Punjab Pear" growing in the Lucknow Gardens, but it had no visiblc detrimental effect.

In the Brisbane district this, or an allied species of cactus-loving Diaspis (referred to as Diaspis calyptroides, Costa, var. Cacti, Comstock), occurs on Opuntia and other Cactaceæ so plentifully as almost to whiten the stem-joints. Occasionally under experimental conditions it has been found to kill badly-rooted individuals of Opuntias inermis there (Tryon, 1911, p. 17).

Two other insects injuriously associated with Prickly-pear in Southern India, but not to the extent of destroying it, were brought under notice by T. Rainbridge Fletcher, Government Entomologist, Agricnltural College, Coimbatore, Madras. They were:-

A large Cantharid beetle named Mylabras pustulata. This, it was stated, consumed the flowers of Opuntia, but not so commonly, or in such a manner, as to affect in any way its spread. The yellow blooms of many other yellow-flowering plants it was also partial to, and was especially addicted to attacking Hibiscus in this manner. It is related to an insect that we have observed in Natal as harmful to cultivated Leguminosæ, by similarly attacking their blossoms.

An Erotylid Beetle (gen. et sp. undeterm.). This was said to feed in the dead stemjoints of Prickly-pears. Again, it was an insect that was not an exclusive enemy of Opuntia, being more partial to Euphorbia than to it. In this latter plant it usually followed the injuries due to Pyralid moths.

* Burkill (1911, p. 305) has given an account of the unsuccessful attempts to introduce the true cochineal insect or grans fina into India.

$\dagger$ Mrs. Fernald, in her Catalogue of the Coccidre of the world, mentions India as a locality for Diaspis echinocacti, Bouché, as well as its subspecies cacti, Comstock.

\section{B. Distases.}

No disease of a parasitic nature capable of destroying Prickly-pear was met with in India.

Moreover, no instance of a special pernicious influence being exerted by any higher plant on it was observed; although, in travelling through the Caveri Valley, it was noted that when Jatropa and Opuntia were associated in growth on the same site the latter usually presented a depauperated habit.

Local conditions were at times, however, decidedly prejudicial to it, and occasionally fatal. The excessively moist climate of certain parts of Assam and Bengal is detrimental to most species, the only one able to withstand such conditions being $O$. monacantha, which, however, is not a pest in any part of India, as far as is recorded.

The very hot, dry season experienced in most parts of India during some part of the year checks growth of most plant life, and even such Prickly-pears as $O$. dillcnii and $O$. nigricons suffer, becoming drooped and chlorosed, many dying, especially those growing in poor land on hillsides or along hedges, the drainage in these cases being such that little, if any, moisture remains available in the soil for plant growth. In a large area, of which Trichinopoly may be regarded as about the centre, many clumps of 0 . dillenii were observed where the growth of individuals had evidently almost ceased, and their surfaces had become brown and suberised-the dead epidermis supporting various micro-fungi. This state of things appears to coincide with uncongenial conditions of growth, being especially evinced where the plants were older and where the soil was shallow and reposed on a stony or otherwise unsuitable substratum. This gradual local decadence of the Prickly-pear recalled a state of things very noticeable within the town of Gayndah and to a less pronounced extent elsewhere, within the State of Queensland.

In a memorandum (6th December, 1912), prepared by Mr. R. C. Wood, Principal of the Agricultural College and Research Institute, Coimbatore, in view of the Commission's projected investigations, and addressed to the Conservator of Forests, Western Circle, it is stated as follows:- "The Government Entomologist and Government Mycologist report that, so far as their knowledge goes, there is no insect nor fungns in this country that is likely to prove valuable in the destruction of Prickly-pear."

Some years previous to this-in 1886-the Madras Government requested the Superintendent of the Madras Government Museum (Dr. E. Thurston) "to institute an inquiry .. . as to the practicability of destroying Prickly-pear (Opuntia dillenii) by means of Cochineal Insects or other parasites," this officer reporting on 15th June, 1896, as follows:-" No parasites, animal or vegetable, have been ovserved living on Prickly-pear in such a manner as to warrant a hope that they might be used as an agency for the destruction of the plants." "The Board accordingly concludedt that "there are no parasites known to the Presidency which can be relied on to destroy Prickly-pear growth."

* Vid. Proceedings Board of Revenue, \&c., No. 135, 17th June, 1896.

$\dagger$ Vid. l.c. Resolution No. 1. 
Dr. Thurston, as his report indicates, made no personal investigations, but submitted the question to the Collectors of the several districts of the Presidency for consideration. Amongst the replies that he publishes, the following may be mentioned:-

The Collector at Cuddapah reported that spots of a rusty colour appear on the green plant and increase in size. They may cover the whole plant and destroy it.

The Collector at Chingleput submitted a letter from Lieutenant-Colonel W. G. King, in which the following statement occurs:- "In the course of my inquiry as to the existence of Cochineal Insects I ascertained that considerable destruction of Prickly-pear had occurred in a village south of Samiapagunta (of Ponneri taluk), on the border of the Pulicat Lake, which my informant believed might be the Cochineal Insect." . . . The Tahsildar of Chingelput sent a special messenger for specimens for Dr. King; and the latter states that he " confirmed what I had heard as to the destruction proceeding in this neighbourhood, and brought me a specimen." Dr. King then submitted this to a "Madras expert". .. "who, however (as Dr. King states), could only state that it was a nameless mycelial growth." Evidently the specimen was in an advanced state of decay when he received it, for it is stated that " the whole substance of the plant underwent a process of decomposition by liquefaction." "**

The Collector (W. J. H. le Fanu) at Salem forwarded the following observations made by some of his subordinate officers :-

1. "The occurrence of an orange-coloured disc-shaped fungus attacking the Prickly-pear," and " such parts of the plant as are attacked by it are eventually partially or entirely killed out by it," is reported by S. C. Moss, Extra Assistant Conservator of Forests, Hosur and Dhamapur Ranges. It is further stated that specimens illustrating the occurrence of this fungus were sent to J. S. Gamble, Director of the Imperial F'orest School, Dehra Dun, who on examination "expressed doubts as to the dises being an insect." $\uparrow$

2. With regard to Salem also, the District Forest Officer reports the existence of an "orange-coloured fungus or parasite, not unlike Coffee Leaf Disease, destroying the Prickly-pear. This fungus seems to attack the plant more readily in shady or moist situations. I have seen it very frequently withering away with the said yellow spots, and have invariably noticed that this was the case when the soil was bad. I do not believe there is any fungoid disease which will damage Prickly-pear in good soil, and generally it is prolific in such soil.'

3. The Head Assistant Collector, again, with reference to the same place, reports the existence of "two kinds of disease amongst Prickly-pear." The first he

* Lieut.-Col. W. G. King, 9th Dec., 1895, Board of Revenue, Madras, No. 2316, 1895. Vid. Mr. Wood's conolusions previously cited, since they relate also to a "disease" of Prickly-pear ocourring at Chingelput.

$\dagger$ Vid. Dr. Thurston'e Report, p. 3. mentions as presenting the following symptoms:-The plant becomes at first yellow, then brownish spots appear on it extending over the whole plant. When the last stage has been reached, "the pulpy matter becomes dry and brittle and the plant is dried up and destroyed." This is said to be a very common disease, which " everitually destroys the Prickly-pear." Of the second he states that when the plant is "affected by it, it keeps its green colour. but presents a very dried appearance and looks as if it had no humidity in it. In the course of time white spots appear, and the plant looks as if it were bitten off in places. This disease is said to be rare, and it is not known whether it ultimately destroys the plant."

These references to Prickly-pear affections, mentioned in 1896 in those reports of several Collectors of the Madras Presidency, serve to describe two Prickly-pear maladies, both of which appear to be of a non-parasitic nature and noncommunicable. One of these, the second Pricklypear trouble mentioned by the Head Assistant Collector of the Salem district, appears to correspond to one elsewhere described (Tryon, 1908) as " Dry Rot." The other, in which the earlier symptoms are the appearance of " rusty-coloured spots," " yellow spots," " brownish spots," or "an orange-coloured disc-shaped fungus"' (?), with more or less chlorosis, is evidently one the subject of official unprinted reports by one of us (H.T.) on Prickly-pear maladies in the Westbrook and Nudgee districts of Southern Queensland, and considered to be due to the immediate action of some locally-produced irritant of a chemical nature acting under permanent or transitory defective soil conditions, and in its origin is not explicable by any parasitic microorganism-fungus or otherwise-evidence of whose presence is not fortheoming.

Both of these constitutional derangements were met with in the Madras Presidency, the former only occasionally at Bellary and elsewhere.

The prolonged investigation necessary for the proper elucidation of the latter disease could not be entered upon in the course of this inquiry, and was, moreover, not a work quite within the scope of the Commission. Some light may, however, be thrown upon it by the following statements made in the course of a paper by one of us (Tryon, 1911, p. 7) :-

The symptoms exhibited at an early period in the history of this Prickly-pear affection are, generally speaking, compatible with the action of some parasitic organism-of a fungus or bacterial nature. However, microscopical investigation fails to bring to light the presence of any such agent. Moreover, when kept under conditions favourable to their growth and manifestation, no microfungi capable of acting as parasites are found occurring, much less any one of the several kinds that are know to consort with Opuntia as a host plant.

The features that are the earliest to be displayed suggest the action of some toxic fluid, formed within the plant tissue, 
and acting sporadically on the more superficial cells of the cortical layer of the plant and on their contents.

No micro-chemical action of this character has, however, been determined, and it can, therefore, be conjectured only-if. it, indeed, actually takes place-in what it consists.

In this connection it may be remarked that in the Prickly-pear a singular feature is exhibited, consisting in the presence of a layer of cells, intervening between the chlorophyl containing palisade cells and the epidermis, each of which contains a large sphœrolith of oxalate of lime, and this is denotive of the fact that during the growth of the plant a large amount of oxalic acid is formed, probably in connection with the special metabolisn involved.

Could we conceive that under exceptional circumstances the reduction of this oxalje acid takes place to form poisonous bodies-e.g., glycollic or glycoxylic acids that are created in the course of this process prior to its being rendered inert through union with lime-such action would account for the figure that characterises the initial changes when first apparent-that of a drop of fluid flattened out. However, as I am assured, such action as is referred to is unknown to the physiology of plant-life.

Some attention has been given to the same disease by the Imperial Mycologist, Dr. E. J. Butler, who kindly placed the following note at the disposal of the Commission, which, though inconclusive, is of much interest:-

" Early in 1904 I received specimens of Prickly-pear* from the Conservator of Forests, Central Circle, Madras.

The Conservator stated that they were affected by a disease which he had traced over a stretch of country 150 niles long, and that, in the drier soils and wherc fully exposed to sunlight, it certainly resulted in the death of one-third to one-half of the plants. His description was that small spots appeared on the "leaves," around which developed cir. cular brown patches; the "leaf" became yellow, wax-like, and translucent, and then the lower stems turned brown and decayed. The blossoms were few, and the flowers and fruit were unhealthy and rotten. When growing in shade, the plants did not succumb so readily, the "leaves" not becoming translucent, and the main stems not decaying so completely, and reviving and resuming growth when moistener.

Later information from the same source indicated that the area infected included part of Salem, Trichinopoly, North

* The species is $O$. dillenii. Dr. Butler showed one of us a few tiny pieces (diseased) which he had at Puss.
Arcot, and Cuddapal districts. It was stated to have been known in Salem since 1896 .

In October, 1904, I visited Manaparai, a little south of Trichinopoly, to examine the disease on the spot. I also carried out more detailed examinations, and tried to reproduce the disease in my laboratory at Dehra Dun.

The results of this work were to throw doubt on the condition observed by the Conservator being due to a definite dis. ease or being capable of entirely killing the plant.

Nany of the spots were found to be rlus to insect punctures, through which semiparasitic fungi and bacteria entere 1 the "leaf" tissues and sometimes set up a rot. In severe cases the rotting appeared to spread over the whole plant. cxcept the root stock; and in such euses bacteria appeared to be the cause of the rotting. The root stock, however, was always found uninjured and capable of throwing out new stems. Even halfdead "leaves," which had broken avay from the rest of the plant, were found rooting freely and sending out new sound shoots. In several cases seen the effect of the "disease" was actually to multiply the pest by breaking up a single plant into a number of independent units.

My conclusions were that the constant renewal of growth from plants wholly or partially rotted in their above-ground parts put it out of the question that any permanent lessening of the pest could be hoped for from the disease.

In this opinion I was supported by the natives whom I questioned, and by the Forest Ranger at Manaparai, all holding that the rot was only temporary ind that the plant ultmately revived."

The Principal of the Agricultural College and Rescarch Institute, Coimbatore, informed the Commission that an instance of a so-called disease was afforded by an occurrence at the Saltpans of Chingelput, a place situated a little to the south of Madras; and that in this case it has a peculiar economic bearing, since the occasion of its being noted was the inability of the local manager to maintain intact a hedge of Prickly-pear that surrounded the factory buildings there. Mr. Cecil Wood, to whom the matter had been thus referred, inclined-as he stated-to the opinion that it was merely a case of the action of unsuitable soil conditions, arising from an undiue proportion of saline material being present. A superficial examination of a specimen, derived from an affected plant that he exhibited, was not inconsistent with this explanation. However, he was having this minutely examined by a mycologist on the staff of his department, since microfungi were to be noted on the dead tissue. It is uncertain whether the diseases mentioned by Lieutenant-Colonel King, as ocvirring in 1895 in the Chingelput also, be identis with the one now under review or be a distinct affection. 


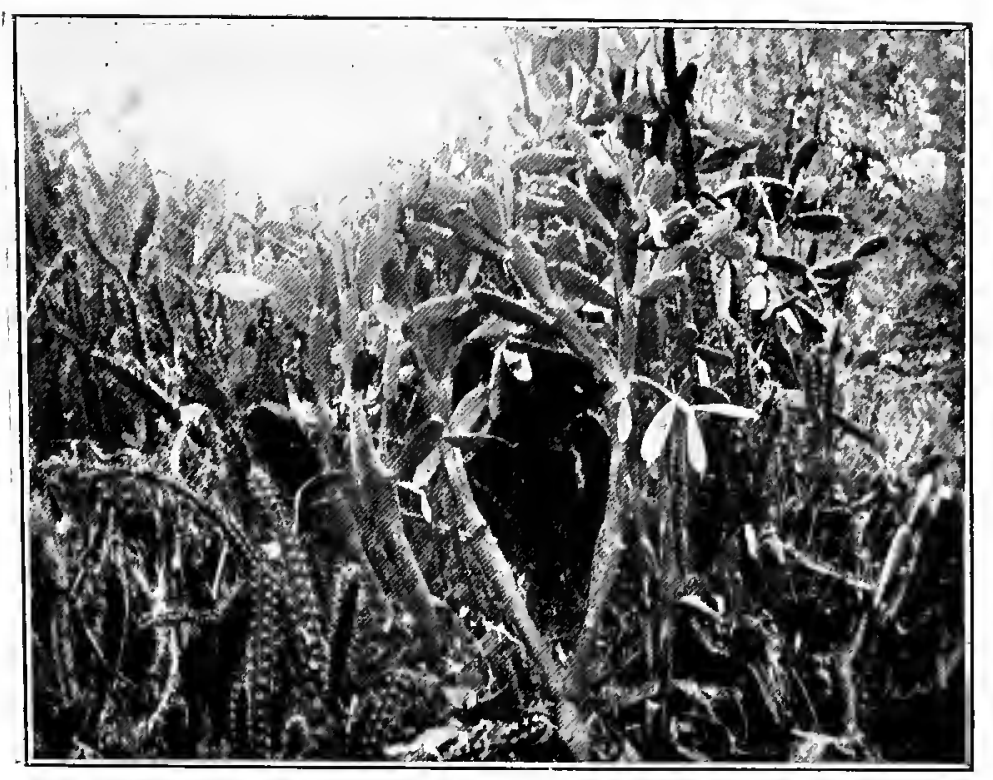

Fig. 9.--Nopalca cochinelifera and Cereus, sp. Burnett River, Gayndah.

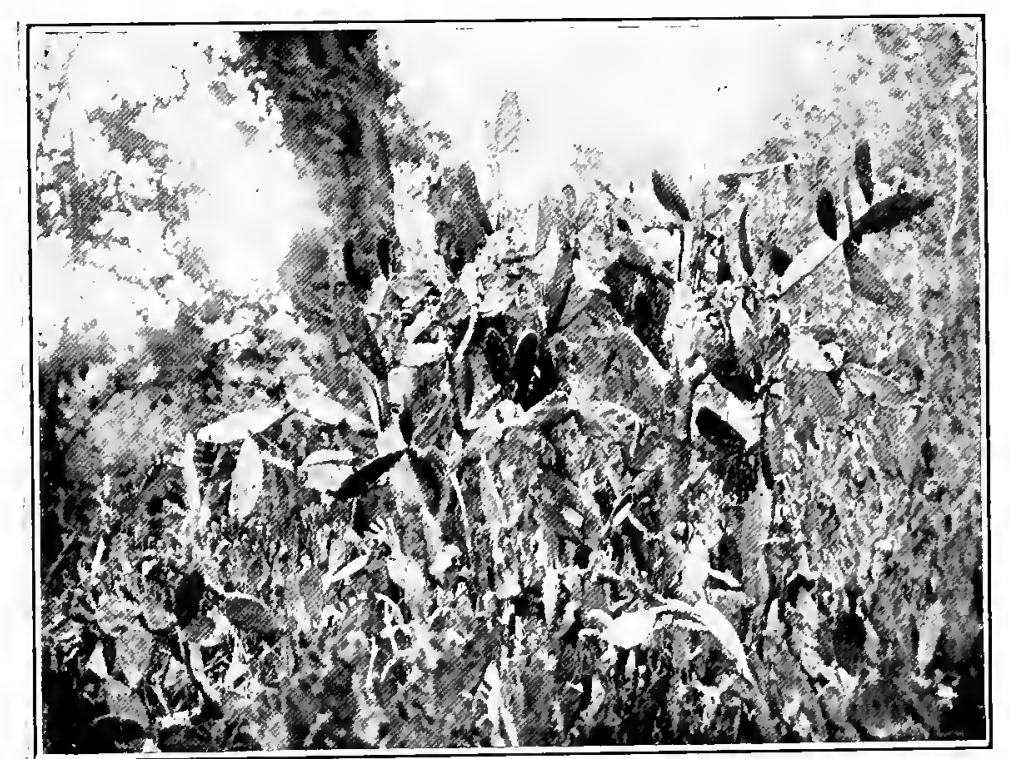

Fig. 10.-Nopalca cuclimelifra and Pest Pear. Gayndah.

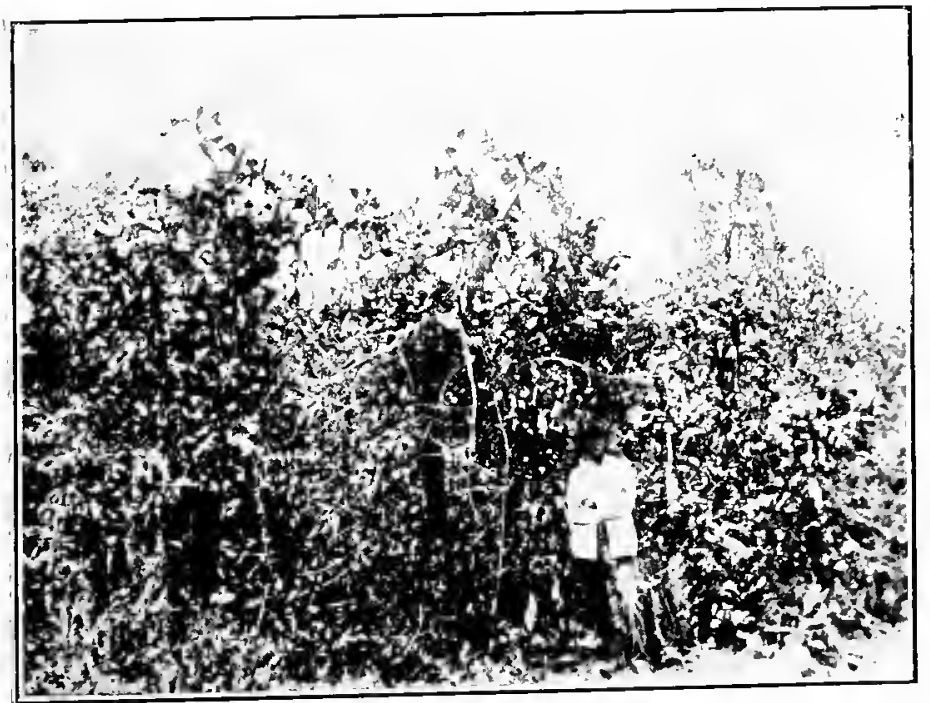

Fig. 11.-Tree Pear-O. monacantha. North Rockhampton. 



\section{DESTRUCTION BY UTLLISATION AS FODDER.}

Northern India.

The question of utilising as fodder such succulent plants as Prickly-pears occurring in abundance in certain parts of India, especially the Presidencies of Madras and Bombay, where dry conditions often prevail and drought and famine are not uncommon, has received considerable attention. There is little doubt that, as is already admitted in Queensland, cacti have some value as food, this being especially the case during times of scarcity.

In the report of the Nagpur Experiment Farm for 1892-3* it is stated that cattle were fed on Prickly-pear (presumably O. nigricans), and, in spite of the fact that they were worked during the whole time of the experiment, actually increased in weight.

In the report on the Cawnpore Agricultural Station, United Provinces, for the year ending June, 1907 (Allahabad, 1908), Dr. J. M. Hayman, the Deputy Director of Agriculture, mentioned that spineless varieties of a cactus (Opuntia ficus-indica) were being propagated for use on waste land as a possible fodder in times of drought, but regarded it as an open question whether the spiny forms would not be better, as they were self-protecting and hardier, and their spines could be, and were in that province, scorched off in a manner similar to that employed in Mexico, Arizona, and Texas. Although it was admitted that cactus was a poor fodder, yet it might be supplemented by other food, and, moreover, it contained a considerable quantity of moisture at a time when water was scarce. Its drought-resisting properties were well known, but it became withered by the hot winds and drought of the province. Some were grown in Bundelkund, but did not propagate readily and, in order to plant out large areas, he stated that it would be necessary to send supplies of joints or seedlings. Later reports do not contain any reference to Prickly-pear, but in the report on the Agricultural Station at Orai (Bundelkund) for the year ending June, 1909) Mr. B. C. Burt mentioned that Prickly-pear plants were being propagated at Cawnpore with a view to planting out an area at Orai. In the report for the next year he stated that the spineless cactus ( $O$. ficusindica) sent from Cawnpore had been planted out in certain waste lands on the station, and had become established, though growth was very slow during the hot weather. No further information was either available in reports or known to the officials at Cawnpore Agricultural College. The species referred to was seen at the latter place. It was Nopalea cochinelifera, and not $O$. ficusindica.

A few working cattle were fed at Cawnpore for a month on singed cactus chopped up and mixed with wheat straw without any ill result. About 3 parts of the latter were added to 1 of the former.

\section{Madras Presidency.}

In 1866-that is a considerable time after Sir G. le Marchant had proposed the use of cactus as a fodder for cattle in India, the Agri-

* Not available. cultural and Horticultural Society of Madras making the experiment, but with negative results -Mr. H. S. 'Thomas, the sub-Collector of Salem* prepared fodder by adding bran or hay to segments of $O$. dillenii which had been sliced after the clusters of thorns had been removed. The animals (bullocks and milch cows) were given in addition to the hay, as much cactus as they would eat.

During the great famine of 1876-1877, considerable use was made of Prickly-pear. A. Sabhapathi, of Bellary, kept cattle alive during the period by feeding them on cut up pear, from which the thorns had been removed by hand tools, and to which one or two pounds of rice straw were added. Sometimes the pear was fed alone, sometimes dry hill grass and cotton hulls were added in the case of working cattle. $\dagger$ The ration was simplified by J. H. Cox, t so that each animal received a daily allowance of $40 \mathrm{lb}$. of pear with $1 \mathrm{lb}$. of rice straw, no injurious result from this diet being noticed. In the case of animals new to this diet and to the end that they might relish it, the pear on being cut was sprinkled "with a handful of horse gram flour or the flour of some other pulse, mixed with a little common salt."

This use of Opuntia in combination with certain other vegetable products in a dry condition (grass, rice straw, \&e.), or without such addition, in the extensive Bellary district in 1876 1877, initiated apparently by Sabhapathi, was adopted by many of the local agriculturists. Thus the Collector (J. N. Master), reporting in July and August, 1877, stated that many ryots about Bellary had been feeding their cattle on Prickly-pear for months past. $\S$

Reviewing at the time the evidence regarding this method of utilising Opuntia dillenii, the Madras Government concluded that "experience in the [Bellary] district generally was the same as elsewhere-viz., that cattle can be induced to eat the plant after a time, and will thrive on it." $\|$

In addition to the Bellary experiences of the use of Prickly-pear as a food-stuff for cattle, those of other Divisions of the Madras Presidency during the Famine period, 1876-1877, may also be referred to, summarising what is contained in various official reports. T

The favourable results obtained at Bellary led to the carrying out of similar experiments in the Cuddapah district, a large number of cattle being carried through the period of famine as a result.**

In the Kurnool Collectorate demonstration experiments were carried out on a small farm obtained for that purpose. Here the "encouraging results obtained induced many people to seek admission for their cattle," and applications to this end had to be rejected eventually, owing to the difficulty of obtaining Prickly-pear there

* Thomas, H.S., in lit. 3, VII., 1866 (Proc. Bd. Rev., Madras, 30, VII., 1866).

$\uparrow$ Letter, 26th Jan., 1900.

$\ddagger$ Proc. Bd. Rev., Madras, 7th Mar., 1877.

$\S$ Proc. Bd. Rev., Madras, 20th July, 1877, and 22nd Aug., 1877.

O Op. cit., 22nd Aug., 1877.

T Proceedings Revenue Dept., No. 2, 539, pp. 1-17, 21st Aug., 1877, Madras.

** Actg. Collector, 30th Mar., 1877. 
after a while. In this work animals were fed daily on l'rickly-purar" and dry grass, " 20 to $22 \mathrm{lb}$. of caetus leaves to about 4 lb. of hill grass," being the daily ration.

At Matura, the work was only of an experimental character and on the lines followed by Sabhapathi, positive results being obtained.

At Coimbatore, "the cattle (under experiment eonditions) lived on the fodder for a month, and improved in condition. The mileh cows yielded an inereased quantity of milk."

The reports from the Chingleput and Budwali Collectorate, again, adduce similar results. With regard to the former, it is of interest to learn that the diffieulty arising from the presence of thorns was overeome by removing them by roasting, and not solely meehanically, as had been done hitherto by Sabhapathi at Bellary and by others elsewhere.

During the Famine period, 1891-1892, the use of Prickly-pear was again under the consideration of the Madras Government, demonstrations of the method of using the segments as fodder being conducted by offieials in the Kurnool district. . . . The Colleetor at Bellary reported:- "Fifty head of valuable cattle, and 100 head of mnunicipal cattle in hard daily work, were for several months continuously ' fed on a daily ration of $20 \mathrm{lb}$. of Prickly-pear and $1 \mathrm{lb}$. of hill grass, supplemented, in the case of Mr. Sabhapathi's eattle, by 9 seers of cotton refuse and 3 seers of oil eake." "For the maintenanee of ordinary cattle, the Collector stater that " he had been trying to introduee the system of feeding cattle on Prickly-pear with a small addition of grass.'

To further bring about its use, "Instructions," prepared by Sabhapathi, and dated 24 th January, 1892, were cireulated.

During the Famine period, 1896-1897, Priekly-pear again came into use, but not to the same extent as before, by reason of the faet that there was not the same pressing need as in 1876 1877, the visitation being far less severe.

No one appears to have suggested this method of employing the Prickly-pears of the Madras Presideney in ordinary seasons-i.e., in those free from drought conditions.

\section{Bombay Presidency.}

In the Bombay Presidency the species of Opuntia (O. nigricans) is distinct from that ( $O$. dillenii) used in Madras as an emergency fodder for stock.

The Great Famine of 1876-1877 and the consequent starvation of eattle which, where not realised, was imminent, led to the Bellary (Madras) method of utilising eactus as an emergeney fodder being made known by the Bombay Government, to which a letter from Messrs. Harvey and Sabhapathi, with whom it appears to have originated, had been communieated. $\uparrow$

In the year in whieh this information was disseminated, stock-feeding experiments with Prickly-pear were carried out at Kalagi by the

* Collector Bellary Division, in Proceedings Board of Revenue, Madras, No. 836, 30th Dec., 1891.

$\dagger V i d$. Revenue Dept., Bombay, Resolution No. 6476,
Collector of that district. Moreover, the Revenue Commissioner, Mr. A. Guy, having these facts before him, impressed on the Collectors of botlı Belgaum and Dharwar (Southern Division) the desirability of adopting similar measures for preparing Prickly-pear for cattle.*

In 1892 the Bombay Government again made public the availability of Prickly-pear for stockfeeding purposes, publishing a report on the subject from the Superintendent of Farms, Bombay, to the Director of Lands. The Inspector of Government Farms (Mr. Mollison), writing from Poona, reported favourably as to its undoubted value as an auxiliary cattle-food in famine times.

In 1896, appended to its special Resolution $\$$ entitled "Famine: Adoption of Measures for the Preservation of Agrieultural Cattle in the Affeeted Distriets," there was issued by the Government another one-No. 1241. Here, as the outeome of experiment, we find it reported upon "favourably as to its undoubted value as an auxiliary cattle food in famine time."

The experiments alluded to were carried out at the old Botanical Gardens, Kanish Kind, and were continued only for thirty-two days, being confined to three animals, which were tied up to exclude aceess to other food. Seven and a-half pounds of Prickly-pear, |l deprived of thorns anil eut up aceording to Sabhapathi's method, were given to each animal three times a lay. A piuch of salt and, during the first part of the experiment, 11/2 1b. of mixed dal husk and bran was allowed daily. This was mixed well through the pear. In the evening each animal received also $7 \mathrm{lb}$. of hay. During the last of the three weeks the cattle rererived the Prickly-pear without any admixture. Under this diet there was an increase of $41 \mathrm{lb}$. in weight, to which one animal principally contributed. These cattle were in good eondition originally. A second experiment of froding pampered milch eattle on the pear was praetically a failure. When the animals were fed with Opuntia alone they were inclined to scour.

During the famine of 1899-1900 the Bombay Government again rerived the projeet of saving the lives of cattle by utilising the Prickly-pear" plant, and issned for public information a large number of reports from the Famine Department draling with the facts established in the different listriets affeeted by it. It also issued instructions " to press on the Colleetors of the Decean, particularly the Collector of Khandish, the desir-

* Vid. Revenue Comm., Bombay, 15th December, 1896, and Rev. Dep., Bombay, Resolution, 7th December, 1896 .

† Vid. Revenue Dept., Bombay, Resolution No. 199, 1st April, 1892.

$\ddagger V i d$. Rev. Dept., Bombay, Resolution 3946, 11th June, 1892.

$\S$ No. 8939, 14th Nov., 1896, Rev. Dep.

II In the Bombay Presidency the Prickly-pear often. dies under the influence of drought. At other times it assumes yellow or brownish-yellow colour; the leaves get thin and stiff, and become almost brittle through loss of water. "Hedges of this plant are to be seen shrivelled and withered away," wrote the Commissioner of the Northern Division of the Presidency in 1900 in allusion to the famine of 1900 . Accordinglv the weight of the plant mentioned as used would fall far beneath that of Prickly-pear growing under normal conditions. 
ability of sparing no efforts to get Prickly-pear prepared for forage in the places where fodder is very scarce."

of the reports published, the following have been perused:-

Belgaum.-From the District Deputy Collector, N. C. Soman. In the experiments on which the conclusions arrived at were based, only three animals were used. These cattle were under observation some time. In the first report (Dec, 1899 ) it is stated that they were fed entirely on Prickly-pear, a little salt being added to render the fodder appetising. In the second (Feb., 1900) N. C. Soman mentioned the use of grass, chaff, and pulse (chuni) as adjuncts. Referring to the experiment where Prickly-pear alone was used, he stated that it appeared to be a complete success, and that in his opinion any number of cattle could be saved by feeding entirely on Prickly-pear.

The costliness of removing the spines was overcome by substituting the scorching method for that of Sabhapathi which involved the use of special tongs and pincers; this procedure being afterwards adopted elsewhere in the Presidency. $\dot{+}$

Poona.--In the earlier investigations the Mámlatdár of Khed êmployed people in preparing fodder for cattle from Prickly-pear.s

Gajarat (Northern Division).-Here, as reported by the Commissioner, the use of the plant was already known to the people, and cultivators were generally keeping their cattle alive at the time on Prickly-pear. An experiment, in which a few cattle were used, gave results that seemed to show that Prickly-pear is a useful fodder if supplemented with other more substantial diet.§

Nasik.-Here, as the result of the pervading drought, the stem-joints of the Prickly-pear were yellowish and dry. Thin and famished bullocks were fed, each receiving $30 \mathrm{lb}$. per day. During the first three days the ration had gram flour and salt incorporated with it, but afterwards no such addition was used, whereupon the bullocks gradually gave up eating it, and soon declined to touch the segments whether scorched or not. This want of success was attributed to the dry condition of the pear as above notjced."

Nevasa.-Here experiments of a very limited nature were carried out, and only unsatisfactory results were reported.

Shevgasaon.-Only an experiment with four bullocks was carried out. Eventually each consumed $18 \mathrm{lb}$. of Prickly-pear, with which was mixed $11 / 2 \mathrm{lb}$. of bran and about $2 \mathrm{lb}$. of kadbi daily. They were fed three times per diem. The thorns were removed by mechanical means. The report stated that there was no deterioration, but a noticeable improvement in the condition of the animals. I

* Mem. to Commra. C.D., 25th April, 1900.

† Vid. Revenue Dept., Bombay, Resolutions 92, 22nd Jan., 1900, and 1331, 7th Mar., 1900.

$\ddagger$ Vid. Collector, 29th May, 1900, Famine Dep., Bombay, Res. 2787, 11th July, 1900. 1905 .

\$Vid. Rev. Dep., Bombay, Res. 4177, 17th April,

|l Vid. Mámlatdár of Sinnar, 13th June, 1900, Famine Dept., Bombay, Res. 2950, 28th July, 1900.

T Dep. Collector, 16th July, 1900, vid. op. cit.
Sholapur.-In this case the thorns were removed mechanically before the leaves were cut up. Gram flour was mixed with this for the first three days to cause it to be relished. An average bullock was found to need a daily ration of $40 \mathrm{lb}$. of the prepared fodder. In the latest report it is stated that for the first four or five days the bullocks ate somewhat less than their usual quantity, but after that they began to eat freely and required between 72 and $80 \mathrm{lb}$. per day. On the experiment being protracted, it was found that the animals did not improve in condition but remained the same, thus proving that bullocks can live exclusively on Prickly-pear (Opuntia nigricans) for any length of time, though in a somewhat reduced condition, and can regain strength and be fit for work a short time after they have again received ordinary fodder.*

Planting Prickly-pear.-As the outcome of these experiments in 1900-1901 regarding the use of "Cactus" (Opuntia nigricans) as an emergeney cattle foodstuff, the Bombay Government, in 1901, $\dagger$ proposed that the growth of Prickly-pear be encouraged in barren areas, in or out of forests, in the Dharwar, Nasik, and Ahmednagar districts, the object of the proposal being to rear in land, which, at the time, would not grow anything more valuable, a shrub which would be useful, and also to test the possibility of thus being able to improve the land and so obtain more valuable forest.

The proposal met with considerable opposition from Collectors and Forest Officers alike, especially in the Sholapur district, where the District Forest Officer (28th January, 1901) and the District Deputy Collector (5th August, 1901) were both against it. Hence it was planted--to test this adaptability-only at Khandish. Two years afterwards the Commissioner of the Central Division wrote deprecating any further expenditure being incurred on the propagation of a plant of which the advantages were at best so uncertain, and which would probably become an intolerable nuisance.§

The Bombay Government then (in 1902) resumed its experimental inquiry, the firstfruits of which was a report dated 16th April, 1903, from P. R. Mehta, Deputy Director of Agriculture, entitled "Note on Prickly-pear and Aloe as fodder for Cattle during Scarcity.'"I These experiments were carried out at the Poona Farm, and the Surat Farm. In the former two bullocks of the small hardy Decean breed, two buffalo heifers, and one calf were the subject of investigation. The experiment lasted five months. Its result is thus summed up by P. R. Mehta:- "The result of our extended and thorough trial proves conclusively that Pricklypear has hardly any value as a cattle food. It is only when given with a moderate quantity of ordinary fodder that the animals can just manage to live for a period of four or five months. This

* Vid. Dep. Collector, Sholapur, 17th Sept. and 8th Dec., 1900, and Collector, 14th Dec., 1900, Famine Dept., Bombay, Res. 1296, 26th April, 1901.

+ Vid. Rev. Dep. Bombay, R. 3946, 11th June, 1901. 1902 .

$\ddagger$ Vid. Rev. Dep., Bombay, R. No. 909. 12th Feb.,

\$ Vid. Commr. C.D., 28th Mar., 1903, Rev. Dep., Res. 6th May, 1904.

|| Vid. Addendum to Revenue Dept., Bombay, Res No. 3396, 6th May, 1904. 
period, however, is too short during a fämine which extends over a year." The Deputy Director submitted a sample of the Opuntia "after it had been sull dried for four days, when it lost 80 per cent. of its water," to Dr. Leather for analysis, and states in his report that "the analysis confirms the results of the feeding trials as to the poor quality of the Prickly-pear as a cattle food: water, $16 \cdot 96$; organic matter, $60 \cdot 64$; ash, $22 \cdot 40$." Unfortunately, the report itself lacks details regarding the procedure followed in this investigation.*

In 1911 the latter published a leaflet entitled "Prickly-pear as Fodder," in which he mentioned that it may be uscd along with other fodder for cattle, and the amount fed may be gradually increased in about a fortnight to $20 \mathrm{lb}$. per day per animal, but that it can never entirely replace dry fodder for cattle. The dry fodder must amount to at least half the weight of the Prickly-pear, or else the animals will become loose and unhealthy. $\dagger$

In the meantime J. B. Knight, Professor of Agriculture of the Poona Agricultural College, carried out feeding experiments with Opuntia nigricans on more scientific lines than any previously in India. The author intimated to the Commission that inasmuch as they led to no practical result, the information was never published. Moreover, he now considers that the conclusions at which he then arrived may need modification, although the facts on which these were based may stand. The experiments were conducted along two lines- $(a)$ to find out the best method of preparing the food; and $(b)$ to find out, if fed as an additional food to the usual rations given to milch cows and to working bullocks, whether any advantage would be derived thereby. Of several methods employed for removing the spines, singeing over the blue flame (of a primus stove) was most convenient, and soaking (which facilitates the detachment of these) the cheapest.

Feeding Operations at Dhond. $¥-D u r i n g$ 1912-1913 renewed interest in the method of utilising Prickly-pear was experienced by an instance of its being prosecuted by Albert Norton at Dhond, in the Poona district; and, as this interest extended to Queensland as well as to other parts of Australia, it is a matter to claim attention in this report. $\S$

* P. R. Mehta's report was issued in the form of Bulletin No. 22, 1903, by the Department of Agriculture of Bombay

$+V i d$. Dep. of Agriculture, Leaflet No. 7, 1911, Gov. Centr. Press.

$\$$ Dhond is situated in a very dry part of the country. During 1912, 9 inches of rain had fallen; and up to 5th February, 1913, 2 inches more. The ill-effect due to absence of rain would, of course, be minimised by the time of incidence of the little falling. Thus, if 9 inches were properly distributed there, enough cereal and fodder crops for the year might be secured. This did not happen in 1912.

$\$$ The stock-feeding operations at Dhond have been previously made known in the following publications :(1) Norton (Albert), "Experience with Cactus as an "Emergency Fodder" in India," a letter, "Bombay Guardian," 10th August, 1912. (2) Knight (Prof. J. B.), "Note on Mr. Norton's Experiments of Feeding Pricklypear," Bombay Press, December, 1912. (3) Anon. (Rev. H. Fairbank, fide A. Norton), "Times of India," 25th Jan., 1913. Contents: The foregoing letter (1) and extracts from publications on the use of Prickly-pear in stock-feeding generally. (4) Anon., "Daily Telegraph," Sydney, New South Wales, 7th Sep., 1912. Contents : Reprint of No. 3. (5) Anon., The "Courier," Brisbane, Queensland, 11th Sep., 1912. Contents : Reprint of No. 3.
From A. Norton's letter (1) the following account of his operations is elicited. His experience in preparing cactus for fodder began in 1907; and for three years previous to August, 1912 , he had been feeding it to the animals of the farm as an emergency feed, but this must not be taken as signifying continuous feeding for the period mentioned.

During the eight months ending August, 1912, he had kept alive a herd of about twenty oxen and buffaloes on 1,000 lb. of eactus daily, the thorns having been previously removed.

Professor Knight's "note" relates to observations made by himself during a visit to $\mathrm{Mr}$. Norton's farm. The eighteen animals there were seen to eat the ration greedily, this daily ration consisting of $1,000 \mathrm{lb}$. of prickly-pear which had been passed through a circular chaffcutter after its thorns had been burnt off, and $60 \mathrm{lb}$. of cotton seed, the mixture being fed twice a day. No other food had been given to the animals for eleven months, but a small amount was evidently obtained by grazing, even though the rainfall was so low. The additional fodder obtained was at times sufficient to reduce the consumption of prickly-pear by 40 per cent. The animals were found to be maintained in good condition.

These feeding operations at Dhond were evidently not regarded as sufficiently conclusive, since the Department of Agriculture, at the instance of Professor Knight, planned and instituted other Prickly-pear stock-feeding experiments. These were being prosecuted at the time of our inquiry, at the Civil Dairy, Kirknee, Poona, with E. W. Horne as manager. A visit was paid to the institution on 3rd February, 1913, in company with Professor Knight, but, as the experiments had only recently been commenced, further reference to them may be postponed.

Since Mr. Norton was still using Prickly-pear as an emergency stock food at the time of this inquiry, a call at the " Orphanage Farm," Dhond, was made on 5th February, 1913, on which occasion the fullest information to hand was courteously furnished. He stated that he was now. feeding twenty-one cattle on the emergency ration as described above. The animals, not being within the precincts of the homestead, were not seen. The species of Prickly-pear nsed was the prevalent Opuntia nigricans. This material was much drier, owing to prevalent drought, than Prickly-pear of the same species growing at Poona, and accordingly had a much lower water and higher solid eontent. The cotton seed mixed with the prepared Prickly. pear at the time of feeding was usually, as was stated, ground first in a bone-mill operated by tread power. No difficulty was found to persuade eattle to consume this diet after a little preliminary coaxing. Mr. Norton, moreover, stated that he was now giving to each of the grown cattle at night, in addition to the cactus and cotton seed, a bundle of dry sorghum stalks, each weighing, say, 3 to $5 \mathrm{lb}$. A heap of harvested sorghum stalks from which the supply was evidently drawn was noticed in a small yard. The cattle had access, it was noted also, to a small sorghum cultivation, where they could obtain what little stalks the stubble still yielded there.*

* Those who have watched Indian cattle being fed in the Deccan will have observed the extent to which coarse dry fodder enters into the dietary. 


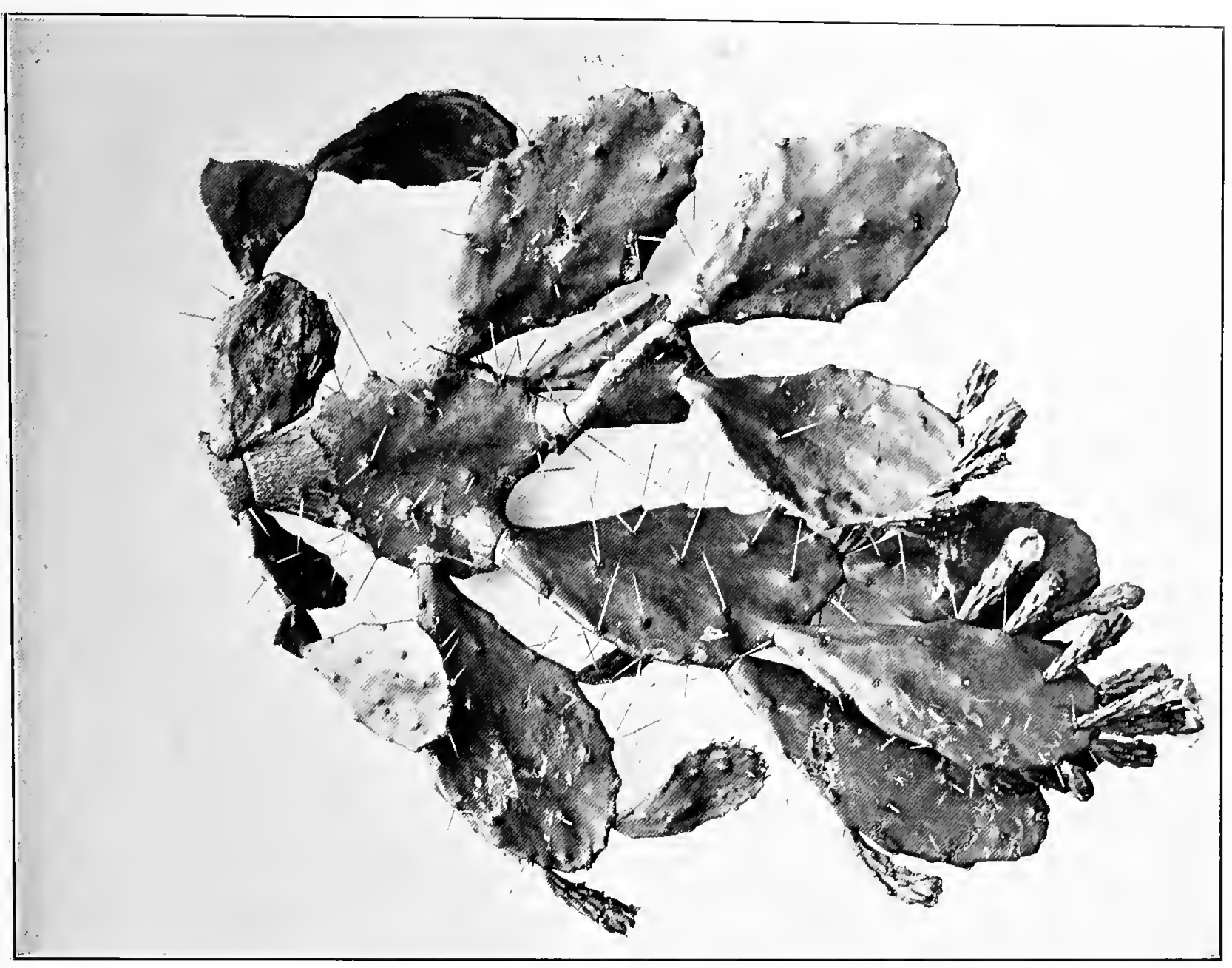

Fig. 12.-O. monacantha, from Gympie.

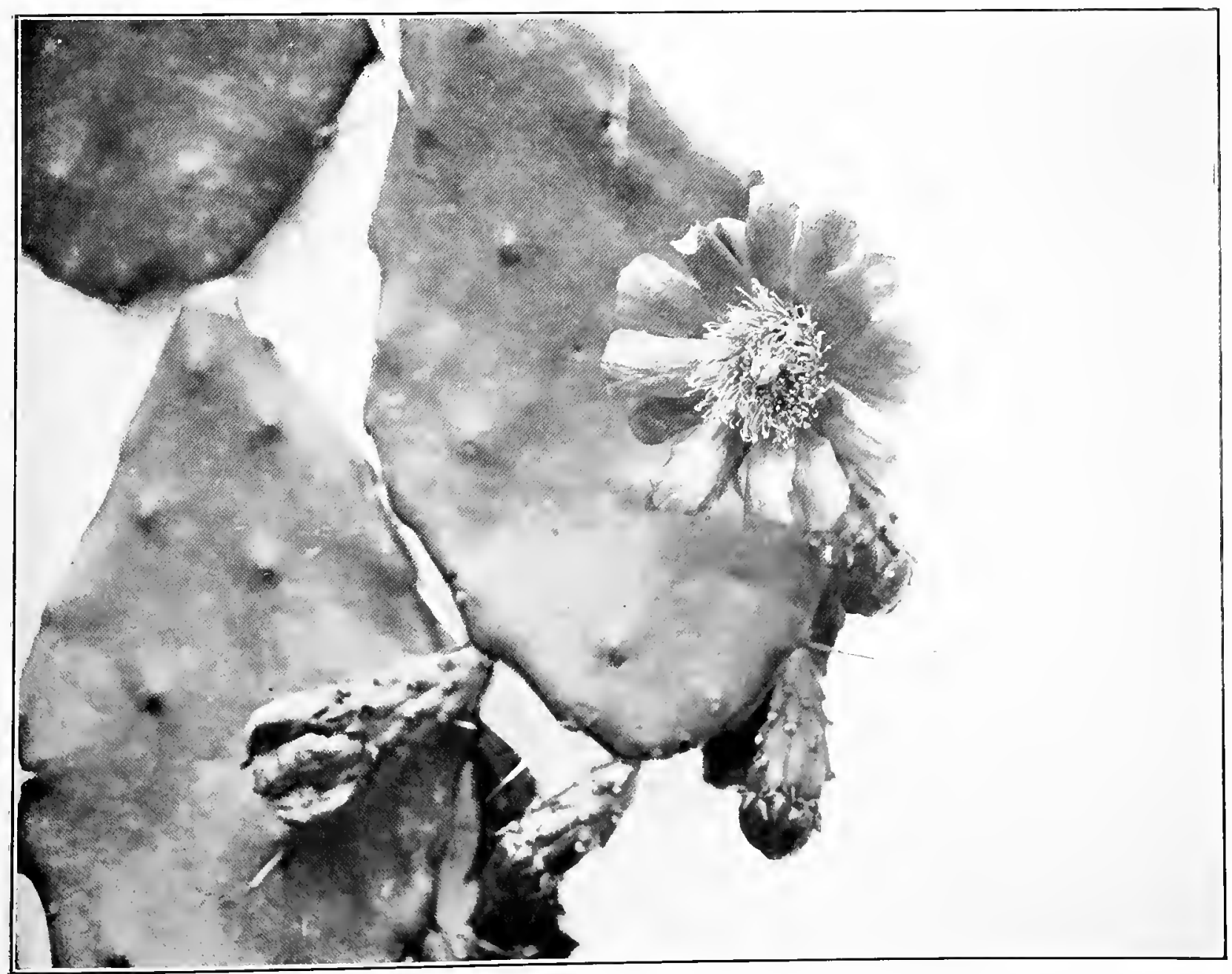

Photo.. De pt. Agriculture, Brisbane.

Fig 13.-O. monacantha, from Kangaroo Point, Brisbane. 

During 1912, Mr. Norton remarked, the cattle got very little of these stalks, and their feed was much the same this year. For the last sixteen months the food had been composed mostly of cactus-say from 97 to 98 per cent. of it. No evidence of animals having suffered from scouring was remarked in the feedingshed, and it was stated that this did not occur, the relative dryness of the Prickly-pear, perhaps, furnishing the explanation of this. The single ox that was pointed out as pear fed, and that could be closely inspected, was in fairly good condition.

It was found that Mr. Norton had had imported in 1907, euttings of some of Luther Burbank's "spineless cacti" as well as specimens from elsewhere. Several of these had not been propagated by him, but of those that were, a practically thornless variety of $O$. decumana, obtained from the old Horticultural Gardens at Poona, and Nopalea cochinelifera were the most suitable, both being readily eaten by stock.

Much attention has been given to the so-called " Norton Experiment Feeding." It should, however, be remarked that the fodder actually received by the animals apparently accords with the "W. Standard" for a cattle ration, and that in this ration Prickly-pear actually contributed a not very large proportion of the components.

In nearly all the experiments already alluded to, involving the almost exclusive employment of Prickly-pear, the duration appears to have been too short to admit of definite conclusions being arrived at as to the efficiency of Prickly-pear during "famine times."

Dried Prickly-pear as a fodder.-In regard to the possibility of using dried Prickly-pear as fodder, N. C. Soman, of Belgaum, reported in 1910 that it was eaten by cattle when moistened with salt.* At Athni it was found that animals ate the plants when scorched and dried as grcedily as when fresh. Such instances led to the suggestion that dried segments might be imported into Gujarat to be utilised in this way. $\dagger$ The proposal was not acted upon owing partly to the extra expense necessary, and partly to doubts as to the feeding value of such dried pear. +

Prickly-pear as fodder for Ostriches.-Mr. Wm. Kirkpatrick, of Messrs. Bird and Co., Calcutta, was kind enough to supply some particulars regarding the feeding of his ostriches near Delhi with Prickly-pear (O. nigricans), the birds coming originally from South Africa and from Somaliland. His information was corroborated by Mr. Jugal Kishore and a native assistant who carried on the farm for Mr. Kirkpatrick. The spines were removed from the plants either by plunging the "joints" into hot ashes in an ashpit or else by holding them over a fire and singeing them. The singed joints were then sliced. The Prickly-pear being insufficient by itself, to it was added herbs and gram, but not wheat or maize. About 1 part of cactus was

* Vid, Famine Dep., Bombay, Res. No. 226, 14th Feb., 1900, and Res. No. 1331, 7th Mar., 1900.

† Vid. Memorandum No. 1558, Bombay, 16th Mar., 1900 ; also "Use of Prickly-pear as Fodder in Gujarat," ib. No. 2293, May, 1900.

$\ddagger$ Vid. Commr. N.D. 25th April, 1900, Famine Dep. Res. 2293, May, 1900. added to about 2 parts of gram, while other green fodder was added as found necessary for the comfort of the birds. Though the latter did not require much water when cactus formed part of their diet, it was considered advisable to have water available in case the birds needed it. Prickly-pear was not fed to ostriches until they were at least 40 days old, and then only in small quantities, on account of the danger of causing intestinal trouble.

Objections to the use of Prickly-pear.-The Indian farmers commonly showed a very marked aversion to the use of cactus as fodder (even during times of scarcity), this attitude being largely based on ignorance and distrust of any novelty.* It was, however, in part due to a belief that its use was not attended with any beneficial results, but rather was the cause of looseness of the bowels, as well as a general debility. $\dagger$ Besides this, there was the danger of personal injury by the thorns, as well as the cost of removing them from the segments during the preparation of stock fodder. Since these were at first often dug out with a knife by hand labour, a great deal of time and expense was involved, but later, Messrs. Harvey ani Sabhapathi, of Bellary, introduced a form of iron pincers for the purpose. As already mentioned, burning was also resorted to in some districts, the spines being singed.

Use as Ensilage.-A few attempts have been made in India to utilise Opuntias in the making of ensilage. At Nellore, in 1888, it was found that the product was not eaten at all by stock, probably on account of the thorns.t Quite recently (1910) an article appeared in the "Indian Agriculturist,"' mentioning that in New South Wales the most practicable method for dealing with Prickly-pear was to convert it into ensilage, the thorns becoming softened during the process. This report led to attempts being made in the Anantapur district, Madras (June-October, 1910), but the resulting material was too rotten to be used, the condition being attributed at the time to access of rain water. It was mentioned that it was useless to attempt any silage work in India on account of the destructive effects of white ants. No cases of utilising Prickly-pear as ensilage were met with or heard of, during the Commission's tour in India.

\section{DESTRUCTION BY UTILISATION AS A SOIL FERTILISER.}

Should it be found practicable to restore to the soil whatever the prickly-pear plant has aceunulated during its growth, it is obvious that in many instances this course would add to value of the soil as a yielder of crops of one kind or another. That this is so, has been long recognise 1 by the agriculturists of Sonthern India, $O$ dillenii being thus utilised in Madras and Mysore, and $O$. nigricans in the Bombay Presidency. Moreover, this method of employing prickly-pear involves its destruction.

* Vid. Famine Dep., Bombay, Res. 1296, 26th April, 1901.

$\dagger$ Master, J. N., Proceedings Board of Revenue, Madras, 20th July, 1877.

† Rep. Bd. Rev. No. 209, May, 1888.

§ Indian Agriculturist 34, I., Feb., 1909, p. 61. 
Mudras, - In 1893-4 when the collector at Coimbatore raised the question of destroying Opuntias in this way, the Government of Madras stated that this method had been under consideration for a long time. In 1896 it was suggested that the matter should be investigated.

The usual method of using priekly-pear as a soil fertiliser is as follows:--Shallow pits are dug, the pear being thrown into them during the rainy season and then covered with a layer of carth 18 inches to 3 feet in depth. After some six or more months, the plants are more or less fully converted into humus, the thorns alone remaining. Fields thus treated have been found to produce more and better sorghum, plantains, and sugar-cane than untreated land* at Veleapatty and Kunnathur in the Coimbatore district. M. R. Punehapicasa, Forest Department, Coimbatore, told us that this praetice is still followed there, and is found especially useful in obtaining a good erop of sorghum. Mr. H. Sampson, the Director of Agriculture at Trichinopoly, informed the Commission that he had frequently seen loeal farmers using decaying plants with benefit as a manure for Pennisetum and sorghum erops. He also mentioned that his predecessor, Mr. Butterworth, had reported that in one district pricklypear was so extensively used as manure that people could not obtain sufficient of it to meet their requirements.

G. Girimaji Rao, of Kolar, Mysore, in an article on Priekly-pear written in 1911, $\uparrow$ gave details of a similar local procedure.

He stated that the plants are eut down and then thrown into large trenehes, a layer of earth about 2 feet in thickness being used to cover them. Care is taken to destroy any new growth whieh makes its appearance on the surface. After about six months' decay, a very good manure is obtained, its quality improving if it be left for a longer period. This manure was found to be especially beneficial for sueh crops as ground nut, rabi, sugar-eane, betel vine, and dry-land paddy. Owing to its use in this way, Priekly-pear has been almost eradicated in the Kolar district, Mysore.

Dr. Coleman, Director of the Mysore Department of Agriculture, informed the Commission that investigations were to be carried out to test the value of the plant as a fertiliser.

In the Bellary district, where prickly-pear has been similarly used, inquiry elicited the fact that its decay was found to be promoted by the application of a eertain amount of lime.

Bombay Presidency.-W. H. A. Wallinger, the Deputy Conservator of Forests, Poona, had, as early as 1876 , in a pamphlet "Concerning the Opuntia vulgaris -the priekly-pear-as a natural preserver of plants and trees, as a powerful and valuable vegetable manure, . . . . " ealled attention to this method of utilising $O$. nigricans, whieh he had found to be beneficial in the ease of poor soils. He also mentioned that the superintendent of the Goverument Botanical Gardens at p. 3.

* Proc. Bd. Revenue, Madras, No. 135, 17 June, 1896, † Translation from the "Mysore Revenue and Agrioultural Gezette," VI., Nov. 1911, p. 23, sqq.

$\ddagger$ Folio, Gov. Central Press, Bombay, 1876.
Ganesh Kind, near Poona, had deposited the pedr in the irrigation tanks, where it decomposed readily, the resulting material being distributed in the irrigating water.

Professor Knight, of the Poona Agricultural College, informed the Commission that he had carried out experiments with $O$. nigricans as a f(rtiliser, but that the results obtained so far had hardly paid for the cost of the work. Mr. Gamie, the Imperial cotton expert, who also was seen in the Poona district, stated that this method of employing Prickly-pear did not add much humus to the soil.

The Commission noticed that, though the practice of using Opuntias in this way was not general, yet it is carried on in many places, as, for example, in the Caveri Valley. That they are not used to a much greater degree, is due to the presence of abundant spines on both species of Priekly-pear prevalent in the drier regions of India. These thorns remain intact, even after having been embedded in the ground for a long time, and consequently would constitute a danger to the barefooted agriculturists, especially in the case of wet cultivation (e.g., rice growing).

It may be added that this drawback to the use of Prickly-pear as an ameliorator of the soil would, by reason of a lesser development of spines on its prevalent species, be far less felt in Queensland than in India, should its employment for the purpose mentioned be found expedient.

The following account of an attempt to overeome this difficulty was brought under our notice by V. Patthasaradhy Chetty, Deputy Collector of the Trichinopoly district:-

Recognising the value of the pulped plant for rice fields, an English company, having a Mr. Miller as its Direetor, had, some ten years previously, leased from a Zemindary at Sivagunga, in the Madras district, certain lands infested with Priekly-pear, which it was proposed to pass through rollers so heary that not only would the Prickly-pear be reduced but that the thorns would be crushed. It was not ascertainable at the time whether these operations had been suecessfully earried out by the eompany.

The aeeessibility of other plants eapable of supplying humus-e.g., the "Neem" (Melia), Pongamia glabra, Cassia auriculata, Calatropis sp.. the wild indigo, \&c., has in many districts rendered unnecessary the use of the locally growing Opuntias for the purpose.

\section{UTILISATION OF THE FIBRE.}

It was not observed during the limited time available, that the woody fibrous portion of the Prickly-pear was anywhere put to an economic use other than its limited one as a fuel constituent. Sir G. Watt (1891) has not only included Prickly-pcar amongst "The Economic plants of India," but concerning its fibre has stated as follows :- -

"A eoarse kind of fibre can be obtained from Opuntia dillenii which it has been suggested might prove useful as a paper material, and Dr. Bride, speaking of this 
fibre, wrote:-' The Prickly-pear, which so abounds and has become such a nuisance in the country that large sums are expended annually in cutting it down and burying it, might prove valuable as a paper material.' Liotard, in his 'Materials in India Suitable for the Manufacture of Paper,' describes it as a coarse fibre, easily cleared of extraneous matter, which he is inclined to think would pulp well. The samples of fibre shown at the Colonial and Indian Exhibition were, however, by the papermakers who examined them pronounced quite worthless as compared with other equally plentiful materials."

We have no evidence that the material has as yet been examined by manufacturers of wood pulp, much less has wood pulp derived from prickly-pear been tested as a constituent in the many trade articles (other than paper proper) into which wood pulp enters. This matter is again referred to in the section of our report dealing with the investigations in Europe and the Mcditerranean area.

\section{MINOR USES OF PRICKLY-PEAR OR ITS CONSTITUENTS.}

Mucilage.-Amongst other uses of the Prickly-pear may be mentioned one to which attention was drawn by Mr. H. Sampson, Director of Agriculture, Trichinopoly. This consisted in employing the mucilage of the plant suspended in water in making the chunar forming the surface of walls, \&e., in various stone edifices. By this means, it was stated, a plaster was obtained of singularly close texture capable of taking a high degree of polish. This is a matter that may be further looked into.

Fruit.-In some places the natives use the fruit as a food, while in a few districts it was said that the juice was used as a medicine for colds, \&c.

Use as a Hedge Plant.-Prickly-pear is the plant most commonly used for making hedges throughout India. In some distrirts the natives use aloes or agaves, as well as certain species of Euphorbia, and occasicnally the columnar cacti (Cereus spp.). Surrounding each field or group of fields there is generally an embankment; and it is on this that the hedge plants are grown. In the case of the various species of Prickly-pear employed, those in general use are the spiny, sturdy species such as $O$. nigricans and $O$. dillenii, both of which grow commonly to a considerable height, and form a strong protection against the entrance of man, cattle, and hedgehogs into the fields. They possess the disadvantage of affording a harbouring place for snakes, so many of which are venomous. Should any plants die during the hot, dry season, they become replaced by the planting of others.

A similar embankment is built around each of the young trees planted out in fields or along the main roads, Prickly-pear (O. dillenii or $O$. nigricans) being laid on the top of and against the outside of these small circular walls. This prevents cattle eating down the plants. It is quite a common occurrence in India to see trees surrounded by a mass of cactus which originally protected it. Gamble, in his " Manual of Indian Tinibers," (1902, pp. 382-3) refers to the use of Prickly-pear as hedges for marking forest bounclaries and for protecting avenues of trees along roadsides against injury by cattle.

Relative to this practice, G. Girimaji Rao writes:- 'It must also be stated that when this bush (Opuntia dillenii) is planted around fruit trees the trees come to bear very soon on account of the moisture stored in the soil by it. Fruit trees so surrounded by Prickly-pear do not need any watering at all, even in summer. Anybody can grow any kind of fruit tree here in this way. In our experience, tamarind trees grown in this way have come to bearing sooner than have trees grown in the usual way."

Mr. Wm. Kirkpatrick called our attention to the huge "saltwall" built to the south of Delhi. This high, dense mass of Opuntia nigricans extends for very many miles along the borders of Rajputana, being originally erected to prevent the smuggling of salt. Portions of this hedge were seen by the Commission at Gariharsura and Faruknagar. At Dharwar, this species is used as a formidable gaol fence.

Prickly-pear plants are occasionally used in olher ways as a neeas of protection; for example, many of the inhabitants of Benares place $O$ dillenii on the tops of their huts to prevent the monkeys, which enjoy full liberty in this "Sacrerl City of Hinduism," from stripping off the roof. Sometimes this species, as well as $O$. nigricans, is spread over setting cement to protect it against intruders.

Use as a Cover Crop.-A further method for employing Prickly-pear was followed in Madras Presidency from 1874 onwards, which doubtless served to widely propagate these notorious weeds. This was to purposely cultivate it as a cover to protect growing seedlings of economic trees. This scheme, attributed to $\mathbf{H}$. S. Thomas, was strongly advocated by the Deputy Conservator of Forests of South Arcot (Mr. Woolridge), who reported that " there could be no doubt of the result of the system," and compared it to that of using dwarf date plants then in vogue. He also reported that as the trees grew the Prickly-pear plants on their part died. "In his experience the increased shade and moisture from the growing trees have been found to destroy the cactus in time--a view also held by Mr. Steavenson." $t$

However, the Madras Government had submitted this proposed method of using Prickly. pear to the various Collectors, whose replies up till 1883 werc nearly all inconclusive, since either insufficient time had elapsed for results from experiments to be shown or opportunity for carrying these out had not presented itself. $\$$ Later reports also showed that further experiments were for various reasons also inconclusive. § ||

*Vid. " Prickly-pear," "Mysore Revenue and Agricultural Gazette" (Vernacular), Vol. VI., No. 2, Nov. 1911 (Translation); also, Wallinpir, W.H.A., "Concerning the Opuntia vulgaris." Bombay, 1876.

+ Vid. Proceedings Board of Revenue, Madras, No. 1135, 20th April, 1882.

$\ddagger$ Vid. Proceedings Board of Revenue, Madras, No. 1777, 10th June, 1883.

\$ Vid. Proceedings Board of Revenue, Madras, No 732 (Forest 143), 25th Mar., 1886.

il Vid. Proceedings Board of Revenue, Madras, Resolution 27, 15th April, 1887. 
Land Protcclion.-Prickly-pear, especially opuntia dillenii, has been purposely planted in some places to prevent the transportation of sand and light soils by the wind and other agenciesa practice that again has aided in its permanent oceupancy of some areas.

Entanglements.-In visiting the mountain fortress of Bellary and remarking the abundanec of the formidably-armed Prickly-pear (Opuntia dillenii) still clothing some of its ramparts, one is reminded of another use for the plant that the exigencies of circumstances in India have discovered. In this connection one may recall Bishop Heber's description of Rampoor, " a large town chiefly remarkable for its sort of fortification which surrounds it. This is a high, thick hedge, or rather plantation, of bamboos, set as close to each other as possible, and faced on the outside by a formidable underwood of Cactus." * In this connection one may mention the small enelosures bounded by hedges of Euphorbia and Opuntia referred to by Wilks in his "Historical sketch of the South of India," vol. III., p. 84, 1817 (quoted by Birkill), " as having eaused the entanglement of Tippoo Sultan's horse in the battle of Poongar on the banks of the Caveri on September 12th, 1790."

\section{SUMMARY OF INVESTIGATIONS IN INDIA.}

There are two species of Prickly-pear occurring in Southern India which may be considered as pests. These are Opuntia dillenii and $O$. nigricans. Both of these are very common in Madras Presidency and other parts of Southern India, while $O$. nigricans occurs plentifully in the Bombay Presidency and in certain areas of Central India.

In Northern India both of these species are to be met with more or less frequently, but do

* Heber R., "Narrative of a journey through the Upper Provinces of India from Calcutta to Bombay," 1824-5, Vol. 2, London 1829.

\section{SOUTH AFRICA.}

\section{EAST COAST OF AFRICA.}

The Commission left Bombay for South Africa, the steamer calling into various East African ports, at some of which Prickly-pears were found to be growing naturalised. The species met with on Zanzibar Island, also on the outskirts of Beira, in Portuguese East Africa, as well as in and near the town of Lorenzo Marques, on Delagoa Bry, was Opuntia monacantha. As already stated, this species occurs in various Australian States and is especially abundant on the Suttor River in Queensland. It is able to withstand a much moister elimate than the other speeies so far met with by the Commission. In none of the three places referred to was the cactus a pest plant. A species of Dactylopius was found on it at Lorenzo Marques, but no detrimental effect was observable. There was no evidence of any disease affecting the pear in the localities visited. not constitute a pest. The Punjab Opuntia though common in North-western India, has not yet reached such a stage that it can be regarded as a pest pear.

One species (O. monacantha) has evidently been very widespread throughout India in years past, but is now relatively uncommon in North India and practically extinct in South India. This result has been brought about by the Wild Cochineal Insect (Coccus indicus, Green).

No disease of a fungoid or bacterial origin has been met with, or heard of, in India by the Commission which is likely to be of value in checking the spread of Prickly-pear.

There exists in India-rarely now, but formerly in abundance-an insect, the Wild Cochineal, which is capable of controlling and destroying one particular species, $O$. monacantha, in the same way as in Ceylon.

In regard to utilisation as fodder, various species have been employed in different parts of India during times of scarcity. Their use has been attended, as a rule, with some good result, more particularly when other food of a dry nature has been added. Experiments have generally been carried out over too short a period to allow of opinions being expressed as to their applicability to Queensland conditions. The matter is regarded by the Indian authorities as being still in an experimental stage, and investigations are being continued by them. The removal of thorns in the case of spiny species is necessary, though tedious and relatively costly. This objection is not so important in Queensland, as our commonest pest pear is less formidably armed.

In certain districts Prickly-pears have been used as a fertiliser of soils.

Though the fibre of $O$. dillenii has been pronounced as being worthless as a substance for the production of -paper, when compared with other equally abundant materials, we have no evidence that manufacturers of paper pulp have as yet examined it. 


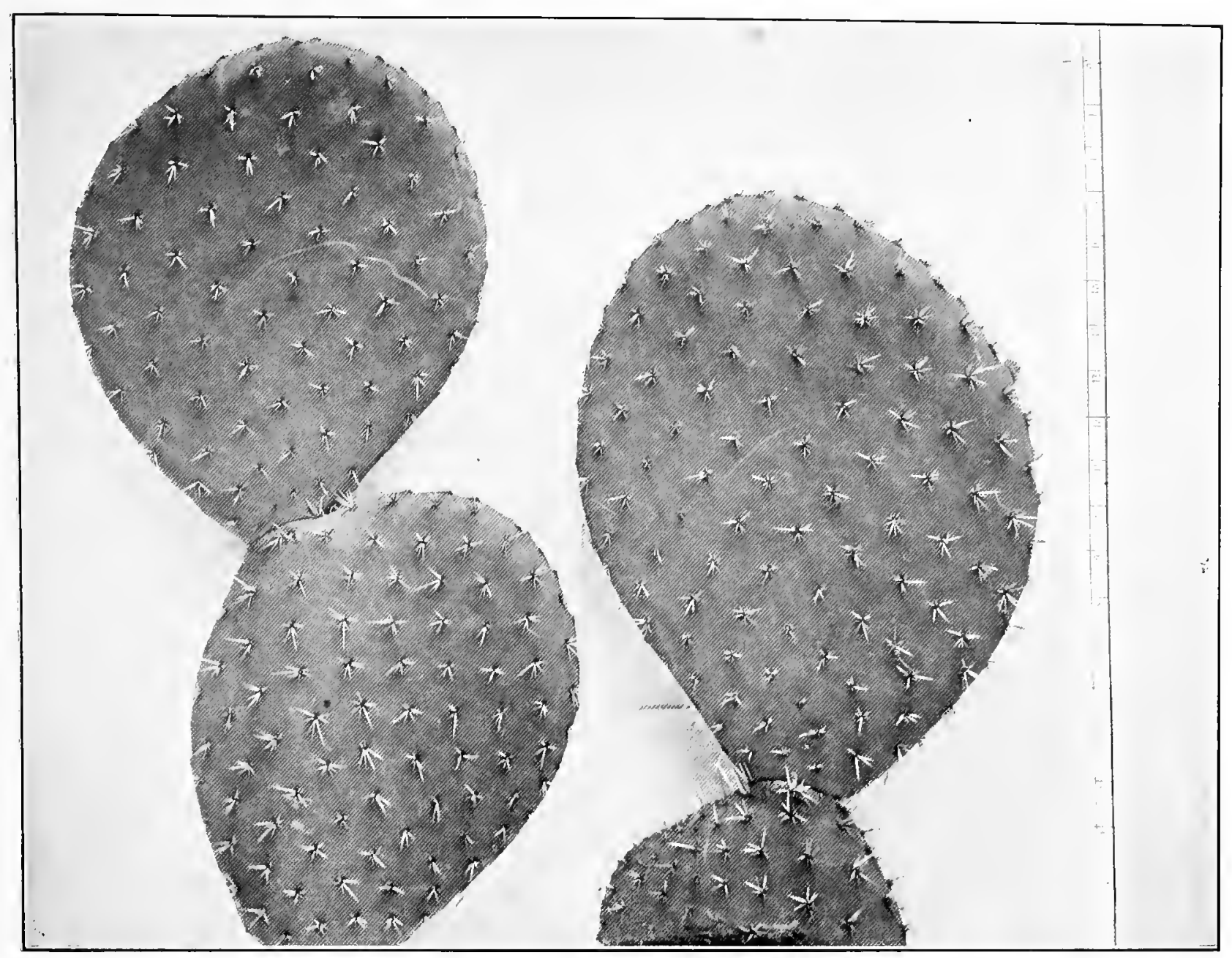

Photo., Thept. Agriculture, Brisbane.

Fig. 14.-A large-jointed white-spined Prickly Pear resembling the "Westwood Pear" (Fig. (15), from Gracemere.

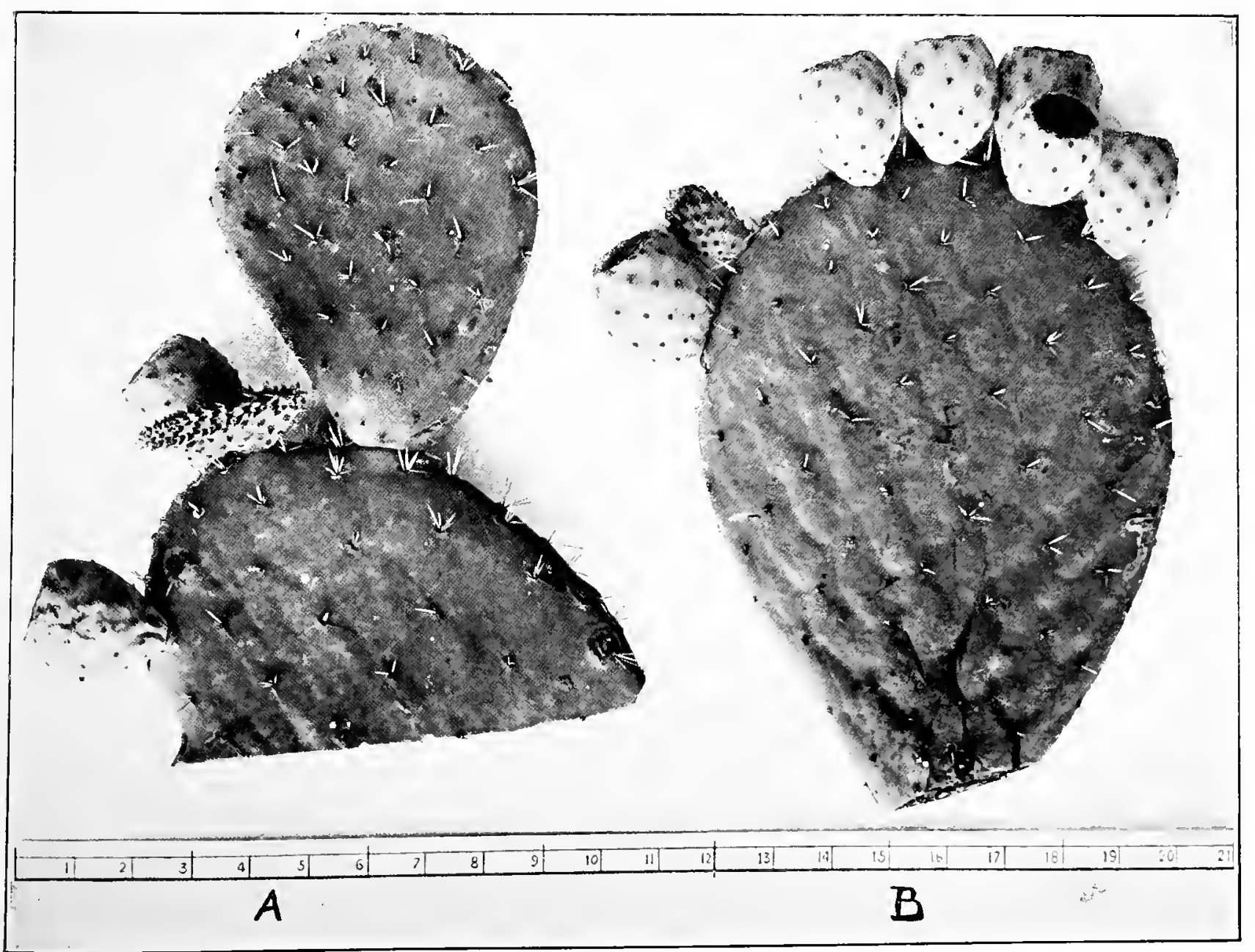

Photo.. Dipt. Almiculture, Brisbanf.

Fig. 15. -The "Westwood Pear," from Gracemere. 



\section{SPECIES OF PRICKLY-PEAR.}

Historical.-There appears to be considerable confusion as to the number and actual names of the species of Opuntia found naturalised in South Africa. P. MacOwan, in 1888 (1897, p. 2), referred to several-viz., O. tuna, $O$. vulgaris, $O$. dillenii, and $O$. aurantiaca; but mentions only the first and third as actually occurring there. $\mathrm{He}$ also stated (p. 5) that he had sent hundreds of cuttings of $O$. tuna to Angra Pequina, in German South-West Africa, Schumann (1899 a, p. 30) referred later to the fact that $O$. tuna is wild in Namaland, but he associated the name with a quite distinct type of Opuntia, $O$. dillenii, Haw., being regarded by him $(1899$, p. 724$)$ as a synonym of his $O$. tuna.

In July, 1891, A. C. Macdonalł (1891), a, p. $21 ; 1891$ b; 1892 a, p. 22; 1897 a, p. 28) referred all the South African Prickly-pears to one species, $O$. tuna, of which there exist two varieties-the "thorny-leaved" form locally called the Doornblad, and a much less spinyjointed pear called the Kaalblad. He included also that form on which the Wild Cochineal Insect occurs. This, we know, is a distinet species-0. monacantha. Next year Dr. Marloth (1892 a, p. $11 ; 1892$ b, p. 18) showed that there were four species found naturalised-viz., $O$. monacanth $a, O$. tuna (the two above-mentioned varieties), a species resembling $O$. dillenii, and another, probably $O$. pusilla.

In 1892 (1897 b, p. 36) Macdonald referred to the last-named as a possible dangerous pest.

I. H. Burkill (1911, p. 290) has stated recently that the Cape contains $O$. monacantha, $O$. decumana, perhaps $O$. triacantha, and possibly 0 . elatior, or, if not, a very kindred species. The first-named was collected by Oldenburg in 1772 (Burkill, l.c.).

The observations and inquiries of the Commission in South Africa point to the presence of two species occurring commonly-viz, O. monacantha, found mainly along the coastal regions; and 0 . decumana,* the pest pear of South Africa. Of the latter there are two forms, the spiny and the comparatively spineless, these having been formerly determined by Kew authorities as 0 . triacantha $\dagger$ and $O$. decumana, respec-

* The name $O$. decumana is used in this section with a considerable degree of doubt. The South African doornblad and kaalblad belong to the same group of species as $O$. ficus indica, $O$. decumana, and the "red and yellow Mexican species" of our Rockhampton district. 'These together with many others, are Mexican white-spined forms, a large number of which have not as yet been satisfactorily defined, though Dr. Griffiths, of Washington Satisfactorily defined, though Dr. Griffiths, of Washington entiating the various species and varieties growing wild in the Mexican highlands. The term O. decumana should probably be restricted, as has been done in the preceding section of this report, to certain almost or quite spineless forms possessing very large segments-much larger and more variable in shape than the kaalblad. It is often regarded as being merely a variety of $O$. ficus indica. The common South African species or varieties, kaalblad and doornblad, are, however, quite distinct from the $O$. ficus indica of the Mediterranean littoral. The name $O$. decumana is retained for convenience, as it expresses a nearer relationship to the forms under consideration than does the name O. tuna, which is now applied by Dr. Britton to the common Jamaican spocies which is allied to, and grows in company with, $O$. dillenii on that island.

+ The term O. triacantha is now restricted to a rather low-growing, brittle species, native to certain of the West Indian Islands. tively. In addition to these two species, there is another, $O$. aurantiaca, whose growth has caused alarm in certain districts.

Besides these three, certain others have been met with, but they are comparatively rare.

MacOwan's and Wallace's (1896, p. 88) 0. tuna is the same as that called $O$. decumana in this Report. O. vulgaris, * of the former, is probably only a variety of the same species. His $O$. dillenii and $O$. aurantiaca we do not know; $O$. aurantiaca did not eall for attention until much later. The four species mentioned by Dr. Marloth are quite distinct. That described by him as resembling $O$. dillenii in many ways, and said to occur in a certain spot in Capetown, has now been entirely destroyed and, therefore, as far as known, does not exist naturalised in South Africa. It is probably the same as that referred to as $O$. dillenii by MacOwan. Mr. Burkill's O. elatior (?) is evidently this species, photographs of which were sent to Kew Herbarium by Dr. Marloth, and were recently inspected by Mr. Burkill ( fide Mr. N. E. Brown, Assistant Keeper, Herbarium, Kew). No trace of $O$. elatior was found. Macdonald's and Marloth's $O$. pusilla is $O$. aurantiaca.

The prickly-pears occurring in South Africa are thus:-
O. monacantha, Haw.
o. decumana, Mill.
o. aurantiaca.
O. fulgida?
O. microdasys.
opuntia lindheimeri?
Opuntia spinulifera.

In addition to these, there are others found growing in gardens, while Nopalea cochinelifera is being grown near Pretoria and at Niddelburg, Cape Province, as fodder for cattle and ostriches.

OPUNTIA MONACANTHA.- -0 . monacantha calls for slight mention, as it has already been referred to in this report. In South Africa it is commonly called the Sour Prickly-pear, either from the fact that it grows on "sour" land or from the fact that its fruit remains sour-both explanations having been published. As already mentioned, it was for a time regarded in Sonth Africa as being merely a variety of the spiny form of $O$. decumana (Macdonald, 1891 a, b; Marloth, Roy. Soc. S. Afr., 1906, p. 15). This species has evidently been naturalised in the country for a long time, as Oldenburg had collected it in 1772 (fide Burkill).

Although 0 . monacantha was seen to be utilised oceasionally for making hedges in Pietersburg and Pretoria in the Transvaal, it was mainly along the coastal regions of Cape Colony and Natal that the plant was found wild. It may be seen in more or less isolated patches near Durban, Pietermaritzburg, and Avoca in Natal, while in the Cape Province one may find it scattered along the coast between Capetown and East London. It does not apparently thrive on the soils of the Karoo, these being comparatively rich in lime. It may be met with at or

* O. vulgaris may probably refer to $O$. monacantha as well, judging from the scant account of it siven by Macdonald (189l a, p. 21). 
near East London, Port Alfred, Alexandria, Albany, Bathurst, Port Elizabeth, Grahamstown, King Williamstown, Uitenhage, Humansdorp, and Hankey, the valley of the Gaintoos River, Fort Beaufort district, Capctown, Stellenbosch, Paarl, and Malmesbury.

Macdonald's "Doornblad" (1897 a, p. 28), with spines two inches long, from Addo and Grahamstown, is evidently this species. He mentions (p. 29) the occurrence of the Cochincal Insect on the form with small "leaves" and long spines.

OPUNTIA DECUMANA.-The history of the introduction of the Prickly-pear into South Africa is briefly given by MacOwan (1891) and by Macdonald (1891 a, p. 21), who stated that it was brought viâ India by Dutch East Indiamen.

The Western Province of Cape Colony was first invaded, the pcar becoming spread eastwards by human agency. Thunberg, in his work published in 1823, recorded its presence; and Sparrman found a cactus, which appears to have been the pest pear, in the Sneeuberg in 1776 . Macdonald (1891 a, p. 21) has traced the introduction of the pest in 1750 from Capetown to Buffels Hoek, and a little later from this place to the Pearston district, which has now become the centre of a densely-covered area. The slow progress of the invasion is no doubt accountable for the fact that Drege has not included this eactus amongst his list of plants found in the locality between 1826-1834 (see Bolus " Flora of South Africa," 1886, p. 23). In 1847 the pear had established itself in the Cookhouse and Somerset East districts (R.S.C., 1898, p. 19), whence it gradually spread.

It has already been mentioned that a great deal of confusion has arisen regarding the name of this pest pear (O. decumana) of South Africa. In that country it has been called $O$. vulgaris (Grobelaar, 1891; MacOwan, 1881), O. tuna, $O$. triacantha, $O$. decumana, and $O$. cochinelifera. It is usually known under the names of its two more or less well-marked varieties-Doornblad or "thorny-leaved" pear, and Kaalblad or "smooth-leaved" pear. There scems now to be little doubt that the two forms belong to the same species, as it is not a difficult matter to obtain a series in which the specimens may be ranged in such a way that one passes from the typical Doornblad to the Kaalblad. Intermediate forms are quite common.

A good description of the two varieties of $O$. decumana was given by Dr. Marloth in his report on "The Prickly-pears of South Africa" (1892 b, pp. 19-20), where the species is regarded as o. tuna or $O$. ficus-indica. Both names are held to belong to the same plant, but on account of the confusion of names he has adopted the former (R.S.C., 1906, pp. 22-3). He also referred to some well-marked variations which may be met with, all of which have also come under the notice of the Commission. For a long time the Kaalblad and the Doornblad were held to be distinct, though the possibility of hybridisation was recog: nised. With a view to settling the question, which, as will be seen later, was one of much importance in the matter of destruction, experiments were suggested by Dr. Marloth and carried out by the Department of Agriculture (Nobbs, R.S.C., 1906, p. 89; Fischer, 1892, p. 18 ;
Marloth, 1906, p. 16). There is now little doubt but that the thorny variety or Doornblad is simply a reversion from the cultivated Kaalblad or " smooth-leaved" form.

The two kinds differ in a few particulars. In the latter instance, sometimes spoken of by Dutch farmers as the female Prickly-pear (wyfeije), the joints are less sweet, but rather thicker, more succulent, and less spiny, and may in large plants be spineless. The fruit is stated to be rather less sweet and less spiny, but somewhat larger. The general appearance of the plant and the flowers is similar. The young joints of both varieties are equally spiny, but as they mature, the spines persist in the case of the Doornblad (the mannetje or male Pear of the Dutch farmers), while they become more or less aborted in the case of the Kaalblad. The flowers vary from yellow to orange in both, the usual colour being orange. The Kaalblad is gencrally restricted to the rich soils found in valleys, while the Doornblad thrives just as well amongst the rocky hills as in those.

Wallace (1896, p. 90) recognised that the Kaalblad was the true Cochineal Cactus, and mentioned that specimens of the insect might be seen living on it in the Botanical Gardens at Capetown.

Distribution.-In regard to the agencies which are at work in distributing this species in South Africa, undoubtedly the chief is man. Before the scriousness of the introduction was realised, farmers commonly took joints from one centre and planted them in another. Then, again, the fruits being edible and abundant they have formed an important article of diet for natives and for the "poor white" population, and as a result the seeds have become distributed in the cxcreta. Cattle, birds, goats, horses, pigs, baboons, \&c., are responsible for much of the distribution.* Though ostriches are fed at times on the joints and fruit of this cactus, they are probably not responsible for spreading the pest by means of the seed in their excreta, owing to the pulverisation of the contents of the digestive tract of the bird. Rivers have also assisted in scattering the pest pear. Then again, the Boer hereditary system (R.S.C., 1906, p. 55; Macdonald, 1891 , b, p. 27 ; 1897, a, p. 31) has been partly responsible for the neglect which has allowed the weed to obtain such a strong foothold.

In regard to the distribution of the pest pear, there is an area in the Karoo, in the Eastern Province of Cape Colony, where 0 . decumana has spread to such an extent as to constitute a very serious pest, to which public attention has been called on many occasions (R.S.C., 1890, 1891, 1898, 1906). This area langes from about 1,000 feet to 4,500 feet in height, receives a low annual rainfall, and possesses a soil rich in lime. Though this species is widely spread in South Africa, it has not proved itself a pest except in certain regions.

It occurs abundantly in the following districts in Cape Colony:-Graaff Reinet, Aberdeen, Pearston, Willowmere, Jansenville, Humansdorp and Hankey,

* The weight of evidence in regard to the germina. tion of the seed appears to be in favour of the conclusion that it is hastened by the passage through the alimentary canal of a bird or mammal. 
Steylerville, Uitenhage, Bedford, Fort Beaufort, Fort Brown, Alexandria, Albany, Cradock, Cookhouse, Somerset East, and to a less extent at Middelburg, Stockenstroom, Tarkastad. Victoria West, Gamtoos, Loerie, Oudtsloorn, Swellendam, Queenstown, and East London. In other areas occasional patches of this pear may be seen-c.g., Malmesbury, Stellenbosch, Capetown, Tulbagh Road, Vogelsvlei, Malan, Hex River, Biesjespoort, Kabeljaauws, Thornhill, Port Elizabeth, Perseverance, Ladysmith, Richmond, Philipstown, Stutterheim, Uniondale, King Williamstown, Beaufort West, Steynsburg, Murraysburg, Lady Frere, Naunpoort, Aliwal North, Colesburg, Conway, Rosmead, Glenleath, and Cypress Grove.

It has been found a difficult task to grow the Kaalblad variety of this species at Kirnberley and in many parts of the Western Karoo (R.S.C., 1906, p. 11, \&c.). It is cultivated as a fodder plant for ostriches in certain parts of this region-e.g., Richmond, the neighbouring portion of Griqualand West and Orange Free State, Fraserburg, Victoria West, \&c.; irrigation being resorted to in some cases (R.S.C., 1891, pp. 16, 18, 19)

In the Orange Free State, $O$. decumana may be seen at Fauresmith, Vredefort: Bethlehem, Bloemfontein, Springfontein, Brandfort, Glen, Edenburg, and Donkerpoort; but it has not yet become a pest.

In the Transvaal clumps may be noticed thriving at Pretoria and Johannesburg at an altitude of over 5,000 feet; while near Pietersburg there are masses which, though well established, have not, as a rule, spread to any appreciable extent. At Mpatlele, in the Zoutpansburg district, about 40 miles from the town of Pietersburg, there is a large clump occupying a considerable area, having been originally planted by the natives around their settlements as a protection and as a hedge. Prickly-pear may not infrequently be seen around the sites formerly occupied by native huts. Burtt Davy (1909) has published a photograph of a thicket in this district.

In the Transvaal and in the northern part of the Orange Free State, it is the Kaalblad which is usually met with; while in Southern Orange Free State and in Cape Colony, it is the Doornblad, which is rather more common. Hybrid forms are classed as Doornblads.

The Kaalblad is cultivated in certain parts of the Western Karoo, in Cape Colony, as well as in a few places in the Orange Free State and Transvaal, as a supplementary fodder for cattle and ostriches. In addition to this form, two other varieties-"anacantha" and "manado"are being experimented with at Groenkloof (Transvaal) and Middelburg (Cape Colony), and will probably be of value for the same purpose.
Opuntia aurantiaca, Gillies.- This small plant is known in South Africa as the Jointed Cactus or $O$. pusilla, and has been figured by E. Nobbs (1906, p. 812) and J. Burtt Davy (1913, p. 13). It was originally introduced into Cape Colony as an ornamental plant, just as has been done in the case of some of the pests now existing in Australia. A. C. Macdonald (1892 b, p. 93; 1897 b, pp. 37-8) and, later, Dr. Nobbs (1906, p. 813 ; R.S.C., 1906, p. 7) referred to its introduction into the Bedford district of Cape Colony, R. Leonard (R.S.C., 1906, p. 44) having supplied the information to Dr. Nobbs.

This cactus has been proclaimed as a noxious weed in very many districts of Cape Colony (Nobbs, 1908, p. 341) as well as generally in the Transvaal and Orange Free State (Burtt Davy, 1913, p. 15).

Its presence was first reported by Dr. Marloth (1892 a, p. 112; 1892 b, p. 21), who believed it to be $O$. pusilla, this being the name by which it has come to be known in South Africa. Macdonald (1892, p. $93 ; 1897$ b, p. 37) and Nobbs, as well as others, have dealt with this pest, which will be referred to later. (See Appendix.) Mr. Maiden (1912, d, p. 888) has recently referred to the occurrence of $O$. aurantiaca in South Africa.

Distribution.-It was thrown out from a private garden into the Kaga River in 1874 . Soon after the river became flooded and distributed the cactus, so that it now extends down to the river mouth and has spread widely, being found in many districts-Albany, Alexandria, Bathurst, Bedford, Cradock, Fort Beaufort, Humansdorp, King Williamstown, Peddie, Somerset East, Stockenstroom, Uitenhage, and Victoria East, \&c. (Nobbs, 1906, p. 813; 1908, p. 341). In addition to the places mentioned by Nobbs, some occurs at Grahamstown; while at Graaff Reinet a small patch which existed previously has been eradicated by the municipality. It is now more or less under control at Bedford, Somerset East, Alice, \&c. It appears to be really troublesome only in a few places, such as Uitenhage and Hankey (Humansdorp district).

It was introduced as a garden plant into the latter town by a lady belonging to the staff of the Hottentot Mission at that place, but has now spread from the village down to the Gamtoos River, and has become a rather serious pest.

The plant is so developed that its small joints and fruits are readily detached and, by reason of their long barbed spines, become attached to cattle, \&c., and may thus be transported over very great distances. On several occasions the Commission noticed mules and cattle carrying pieces of jointed cactus attached to their limbs and faces. The joints and fruits readily sprout to give rise to new plants. Owing to their small size, it is no easy matter to thoroughly cleanse an area of the fragments of the pest. It generally forms small low elumps, and is not nearly so evident as the large-jointed species of Opuntia. It grows much higher and the joints are longer when protected by undergrowth.

Opuntia FULGiDA (?):-At Uitenhage, a Cylindropuntia is beginning to spread on the town common, but as yet it has not obtained a strong footing. It resembles 0 . imbricata, 
which occurs in certain places in New South Wiles aul noir Gatton, in Queensland, but is rather more spiny. It is probably 0 . fulgida. There is a specimen in Kew Herbarium from Barkly Wrest (Cape Colony) which has been identified as $O$. arborescens (?). It belongs to the same species as the plants seen by the Commission at Uitenhage.

OPUNTIA MICRODASYS, LEHM.-This dwarf species is occasionally met with growing naturalised in certain districts of the Orange Free State, where there is a low rainfall, specimens being forwarded by $\mathrm{C}$. van der Merwe.

Nophlea COCHINELIFERA, MILL.-This spineless tree-pear does not, as far as is known, occur naturalised in South Africa, but is cultivated at the Experiment Farm at Groenkloof (Pretoria), and Grootfontein (Middelburg, Cape Colony) as a possible fodder crop.

MacOwan (Fischer, 1891, p. 43) has, evidently in error, applied the name 0 . cochinelifera to the Kaalblad, but in this respect has followed high authorities.

Opuntia, SP.-Dr. Marloth (1892 a, p. 111; $1892 \mathrm{~b}$, p. 18) referred to the presence in Capetown of a Prickly-pear used for making hedges, this species resembling $O$. dillenii in many ways, but differing in the character of the flower. In company with him, the Commission visited the locality, but found that this cactus had been entirely eradicated. Photographs were sent to Kew in 1892 by him, and it was these that Mr. Burkill (1911, p. 290) consulted (fide Mr. N. E. Brown, of Kew Herbarium) and based his record of the occurrence in Sonth Africa of $O$. elatior or of a kindred species.

Opuntia, sp.-At Tidbury's Toll, ncar Bcaufort, attention was drawn to another species, which occurred in isolated patches in the district as well as at King Williamstown. The following description will serve to characterise it:-

It forms a compact hemispherical shrub of from 4 to 6 feet in height. The joints are deep green, circular to sub-circular with the base narrowed and prolonged to form a short stalk-like portion. The terminal segments are 7 or 8 inches long and about 6 inches wide, while those bearing fruit are typically larger, being about 12 inches long by 10 inches in width and half an inch in thickness.

The spines are not numerous, but occur singly, occasionally in pairs, being situated mainly along the edge of the upper half of the joint, while a few may be distributed here and there on the upper half of one or both faces. The spines are very short, $11 / 4$ to $11 / 2$ inches in length, and project prominently, being more or less curved but sometimes straight. They are of general orange colour with their bases more of an orange-red, but become light coloured or white with age. The fairly prominent cushions or areolæ are generally surrounded by a darker green rim. Each bears a dense tuft of numerous short grey-brown bristles or glochidia, amongst which the large spine, if present, lies eccentrically.
Flowers were not seen, but fruit was in abundance (April-May). The latter arise chiefly from the appendages of the joints, from 4 to 22 being counted on each, the average number being 7 or 8 . Their uniform purple colour contrasts strongly with the general hue of the plant. They are pyriform with a concave apex, and from 2 to $21 / 4$ inches long by $11 / 4$ to $11 / 2$ inches broad. The spinules of the cushions on the fruit are generally much smaller than those on the joint. The grooves present on the green fruit disappear at maturity. Deeper purple longitudinal markings, indicating the position of the vascular bundles, show through the purple skins. The sub-acid "flesh" is firm, the cortical portion being red-purple, while the pulp in which the seeds are embedded is colourless. The juice is purplish. The seeds are discoidal with wide, red, rims.

A local farmer, Mr. C. H. Every, stated that birds do not distribute it, as they do not feed on the fruit. Though ostriches will eat it, they prefer the other species. Cattle do not willingly feed upon either the fruit or the joints.

The species appears to be $O$. lindheimeri, Eng., or an allied form.

OPUNTIA SPINULIFERA, S.D.-This occurs in at least two widely-separated localities, namely, at Wylie's Siding, Capetown, and near Tidbury's Toll, in the Fort Beaufort district. It is naturalised in both places, but has not spread to any extent.

\section{DESTRUCTION BY NATURAL ENEMIES.} INSECTS.

The Wild Cochineal Insect of South Africa (Coccus confusus capensis, GREEN).

According to Vauxhall and Prinsep, Baron Ludowigne received at the Cape from Hamburg, about 1832, specimens of a Wild Cochineal Insect (Grana sylvestre), which, after its introduction, showed a preference for the Opuntia growing there rather than for the species on which it had been brought. This local pear was designated as $O$. vulgaris, Mill. (syn. Cactus opuntia, Linn.), a name amongst others formerly bestowed on $O$. monacantha, Haw. It was from South Africa that the Wild Cochineal was taken in 1836 by Captain Charlton to India and established in the East India Company's Garden, Caleutta (Tryon, 1910).

Its presence in South Africa does not appear to have been referred to again till 1891, when Macdonald (1891 b, p. 40) recorded its occurrence at Grahamstown and Capetown. It was further mentioned incidentally in 1906 (R.S.C., 1906, p. 19). In 1911 one member of this Commission recorded that $\mathrm{Mr}$. Thomas O'Hagan informed him of the presence of a Cochineal Insect near Port Elizabeth which attacked, and was sometimes capable of destroying, one of the two species of Prickly-pear growing in that district. This evidence as to its occurrence in South Africa was corroborated by Mr. C. Lounsbury. Government Entomologist of the Union, who, however, stated that he had never seen any of 


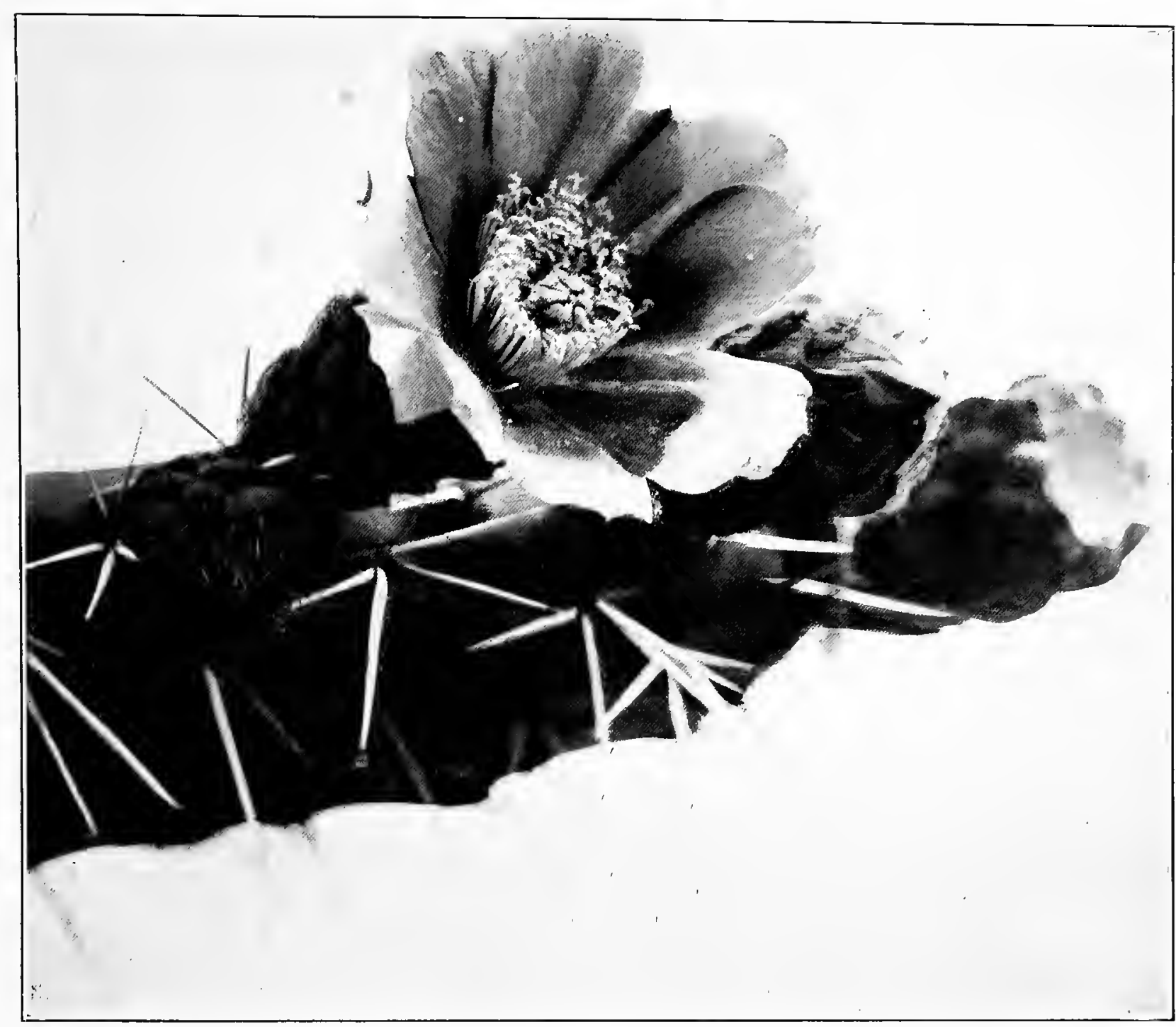

Photo, Dept. Aqriculture, Brisbane.

Fig. 16.-Flower, buds, etc., of the "Westwood Pear" (Fig. 15), from Gracemere.

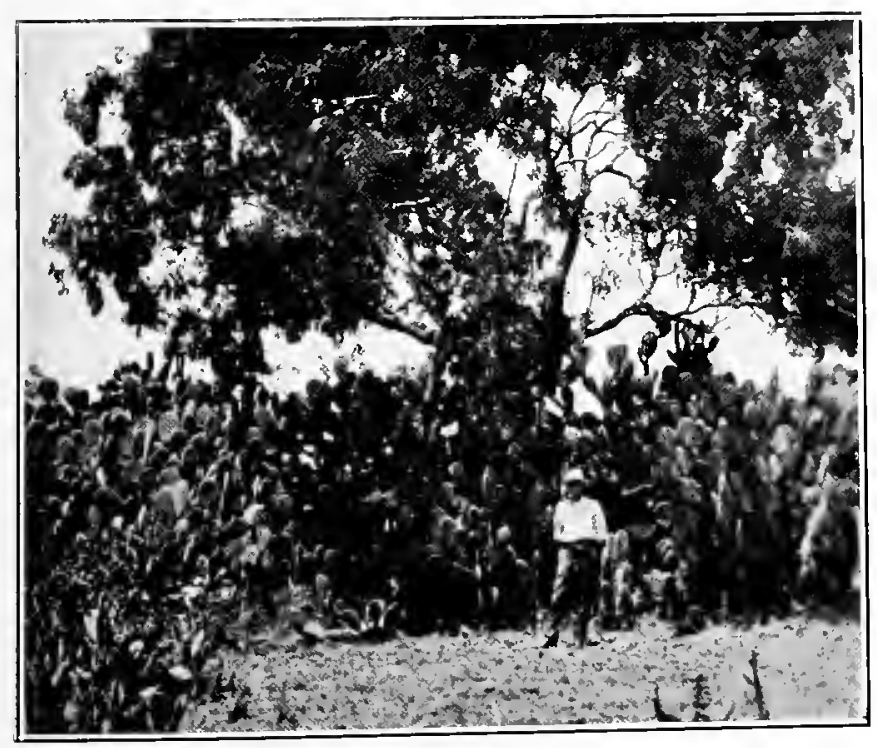

Fig. 17.--The "Westwood Pear." Spring Creek, Westwood. Pest Pear in the foreground.

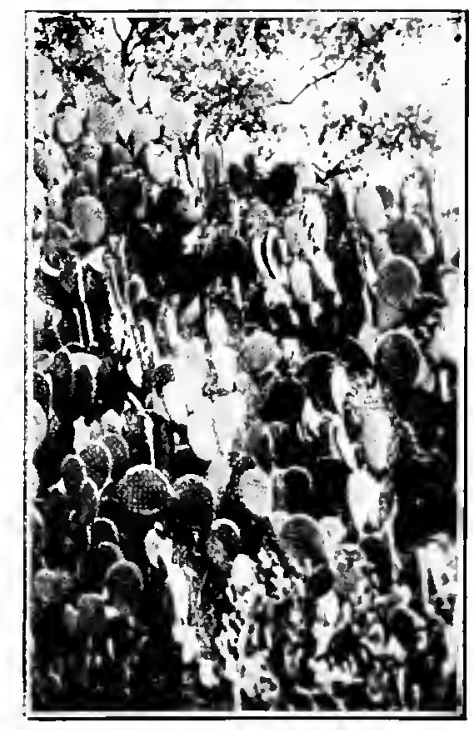

Fig. 18.-The Westwood Pear." Spring Creek, Westwood. 

the plants* killed by the insect (Tryon, 1911, p. 18). Specimens forwarded by hith to Mr. E. E. Green, late Govermment Entomologist of Ceylon, were established on Nopalea cochinelifera at Peraleniyit. They were found to be somewhat different to the trpical Wild Cochineal Inscet of India and Ceylon, and hence were described as belonging to a distinct variety-Coccus confusus capensis, Green (1912). $\dagger$

Independently of T. O'Hagan's testimony regarding this well-known insect, since reiterated, as announced by the Queensland Acclimatisation Society, one might have inferred that it would probably destroy its host plant in South Africa, since another varietal form of Coccus confusus, Ckrll.-viz., indicus, Green-had carlier been found to do this in British India, as shown in a detailed account of the circumstance given by Watt and by Tryon, and since confirmed by Burkill (1911) and by the personal inquiries of this Commission. However, neither Captain Charlton's introduction of the insect to British India in 1836, nor that of John Bell two years later, seems to have resulted in any such injurious effect on Prickly-pear as having been occasioned there by Coccus indicus.

During the present inquiry, this South African "Wild Cochineal Insect," when associated with Prickly-pear growing at large, was found to attack exclusively plants of one species, 0 . monacantha; and it was met with in this connection, in the vicinity of Capetown, Paarl, Fort Beaufort, Bathurst, Grahamstown, Port Elizabeth, Hankey, Humansdorp, and Gamtoos River Valley, Por't Alfred (Kowie River), and Uitenhage. It also occurred near Durban.

It was, nevertheless, found, on Nopalea cochinelifera, as well as on $O$. monacantha, in a garden attached to the laboratory of the Government Botanist at Pretoria, having been purposely established on them. Although $O$. decumana and some of its varieties were growing there beside the infected plants, it had not spread to them.

With regard to the action of the Wild Cochineal Insect as a cacticide in South Africa, the conclusions arrived at, as a result of the Commission's personal inquiries in the several districts in which it was met with, harmonised generally with those of Mr. Lounsbury and his colleagues. The Officer in Charge of Prickly-pear Destruction at Uitenhage, J. E. Butler, however, deposed that he had seen plants practically destroyed by the insect, which caused the segments of the plants attacked to rot. Mr. P. Rademeyer, whose work is connected with the destruction of Prickly-pear, stated that the insect not only destroyed its host, but was purposely

* Although Mr. Lounsbury's brief description shows that he is referrin to $O$. monacantha, this name was used by him as denoting the pest pear of South Africa-evidently a lapsus calami, since a little later Mr. E. E. Green (1912, r. 9l) quoted his-statement that "the Wild Cochineal is found only ipon the wild Prickly-pear, Opuntia monacantha,"

$\dagger$ Messrs. Hunter, Pratt, and Mitchell (1912, p. 42), in their list of Cactus Insects, refer to the occurrence of Dactylopius (Coccus) sp. on $O$. polyantha at Capetown. This Opuntia, according to Schumann $(1899, \mathrm{~b}, \mathrm{p} .724)$, is allied to 0 . dillenii. The South African records doubtless refer to the occurrence of Coccus capensis on $O$. monocantha. distributed by farmers of his district (Gamtoos River Valley) with this end in view, some ycar's being necessary for its al"unplishnumt

A nember of the Seleut Committee on Prickly-pear, 1906, Mr. Niland, druosed that he had seen the variety with the purple fruit and purple juice (i.e., $O$. monacantha) being destroyed by a parasite, referring to the Cochineal, and remarked that he wondered if it could not be introduced on to the fruit of the ordinary kind of Prickly-pear-i.c., the pest pear of South Africa (R.S.C., 1906, p. 19).

The Commission itself observed that there was, generally speaking, a very marked difference betwcen the condition of growth of $O$. monacantha that was not being attacked by the Wild Cochineal Insect and that which was; also, that the Prickly-pear which had evidently been infested for some time differed again in development and vigour from that which had been recently attacked. In illustration of these alleged differences, one has only to compare the masses of $O$. monacantha growing along the sea-front at the foot of Table Mountain, where there is as yet no wild cochineal, with the plants to be met with at the entrance of the Plaat Klip Gorge, Capetown, where they have been established for a long time past; and, again, to contrast the appearance of the Prickly-pear in this latter spot with that forming a hedge along the main road through Constantia, where infestation has evidently been recent. In the former case the ground beneath the insect-laden plants was strewn with dead stem-joints, and the dried up portions were here and there still attached to the " ragged" old plants, whose appearance was suggestive of some vigorous pruning agency at work; whilst at Constantia, save for the white patches of Coccus that were very evident, the plants were of almost normal appearance.

Again, it was to be remarked that in many localities where Cochineal-infested pear occurred, the isolated manner in which these were often distributed suggested that the destruction of plants occurring in the intervals had taken place by some abnormal agency; otherwise, seeing that there is no seminal increase of $O$. monacantha, and that it is not utilised by grazing animals, as $O$. decumana is, this mode of occurrence would be difficult to account for. The Commission has itself seen quite small plants of $O$. monacantha whose destruction had been certainly brought about by the insect, and, if this result was commonly realised, such action on its part alone would prevent the spreading of the plant. It was also observed that in many places a considerable number of large plants, notwithstand. ing that they were grossly infested, were still alive, some of them presenting little evidence of injury.

The season of the year when the inquiry was made was not one during which the Wild Cochineal Insect actively propagates, and, therefore, affected plants might not be the victims of active injury at the time, but might be main taining a stationary condition as regards health. Moreover, that old plants with much woody tissue would succumb to its attack is improbable. Under the conditions of South Afriea, the effect on the host plant is certainly not nearly as marked as that caused by the allied Coccus confusus indicus. Green, in India and Ceylon. The amount of 
chlorosis produced by individual insects is negligible when compared with what is occasioned in those regions by the latter variety. The experience of $\mathrm{C}$. Lounsbury and of his colleague at the Cape, C. W. Mally, is that attacked plants are not killed hut are made sickly, recovering when congenial climatic conditions return. It would appear, then, that some influence of climate may account for the difference in the mode of action of the Wild Cochineal Insects in India and South Africa respectively. In the latter region, at any rate, it appears to exert some influence in preventing the increase and spread of the plant it affects-one identical with the Suttor River "pest pear" of Queensland.

In order to test whether this difference in result was due to the presence of some check operating against the South African Cochineal, specimens of the latter were kept under observation by the Commission and by Messrs. Lounsbury and Fuller at Pretoria, but no parasites were found to be present in the material obtained locally. In Capetown, however, $C$. capensis is commonly preyed upon by a Ladybird Beetle identified by Mr. C. Lounsbury and by Mr. Mally as Exocomus nigromaculatus. This was seen in abundance feeding on the inseet in that locality. No parasitic hymenoptera, diptera, \&c., were found, though frequently looked for.

Despatch of the Cape Wild Cochineal to Queensland.-A small consignment of $C$. capensis was colleeted by the Commission and forwarded to Qneensland by Mr. C. W. Mally, the Cape Entomologist. This arrived in July, 1913, and, according to Dr. Jean White's recent report (1914), has led to the establishment of the species in our State, the small consignment of $C$. capensis which was forwarded on Nopalea from Ceylon having died out.

It may be pointed out, in dealing with the Wild Cochineal Insects-different forms of the species Coccus confusus named indicus and capensis-referred to in this Report, that their exclusive plant-relationship is well known to all entomologists. Moreover, so special is their dietary that it may be confined to a few species within the cactaceous genus that they affect. A member of the Commission has already dwelt upon the "question as to the harmfulness to vegetation other than Prickly-pear following the introduetion of the Wild Cochineal" (Tryon, 1910). In faet, the great Alexander Humboldt, writing nearly a hundred years sines, used this feature in their economy as suggestive of the fact now known-that the insects comprised under the term Grana fina (Precious Cochineal) and those designated Grana sylvestre (Wild Cochineal) were distinet species of Coccus (Humboldt, 1818, p. 432). This matter is dwelt upon to allay any suspicion that may arise that the Wild Cochineal cannot be introduced to a new country (e.g., Australia) without prejudice to other vegetation than Prickly-pear plants.

Establishment of the Ceylon Wild Cochineal in South Africa.-The Commission supplied to the Entomological Division of the South African Department of Agrieulture, Pretoria, and also to the Cape Entomologist, colonies of Coccus indicus from the Henaratgoda Station, Ceylon. Part of this material was handed over to the Natal
Museum, where the insects were propagated, the result being reported on by Dr. E. Warren (1914, p. 387) in a recent number of the South African Agricultural Journal. The common species of Prickly-pear, the Doornblad (called $O$. tuna by him), was found to remain unattacked, while O. monacantha was seriously affected, some plants being destroyed (p. 390). He considered that these insects may be of use in keeping the prickly. pear within bounds, and that if they can stand the winter climate and also remain free from attacks by their own enemies, that they might become sufficiently numerous to cause the extermination of the latter Opuntia. A summary of this paper has appeared recently in the Review of Applied Entomology (Ser. A, vol. 2 (7), July, 1914, p. 440).

\section{The True Cochineal.}

The true Cochineal (Coccus cacti) thrives in the Capetown Munieipal Gardens on O. tomentosa, Nopalea cochinelifera, and $O$. decumana; but it exists rather as a curiosity. Though introduced from the Azores about 1880 (fide Dr. Peringuey of the Capetown Museum), it has not been the means of destroying any of the plants.*

\section{Diaspis, sp.}

A species of Diaspis was found attacking $O$. monacantha at Capetown and $O$. decumana (Kaalblad and Doornblad) in various parts of Cape Colony (Bedford, Cradock, Cookhouse, Graaff Reinet, \&c.) ; but though the degree of infection was sometimes considerable and had been operating for many years, yet no detrimental effect was noticed. In one case, near Graaff Reinet, Diaspis was very common, and, though acting for sixteen years (fide Mr. R. W. Thornton), had not eaused any disease or " leaf" destruction. The experience of $\mathrm{Mr}$ Lounsbury and Mr. Mally confirms the Commission's finding.

\section{DESTRUCTION BY NATURAL ENEMIES.}

\section{DISEASE.}

The Commission interviewed at Pretoria Mr. Pole Evans, Plant Pathologist to the Union of South Africa, with reference to the possible occurrence of diseases of the Prickly-pear and to the question of utilising any that might be found to occur in the subjugation of these plants. He stated that lie had not met with a single fungus parasite on Opuntias in South Africa; also, that he lad not seen or had brought under his notice any Prickly-pear disease. Where specimens presumed to be disease-affected had been submitted to him, the appearances presented had been found to have been occasioned by insects. The Opuntias in South Africa commonly grew in sueh arid areas that the occurrence of fungi in association with them was little to be expeeted. Regarding the inquiry from the point of view of the plant pathologist and mycologist, there did not appear to be mueh hope from what might be discovered in the Union. However, the Aloe, a plant that, like the Opuntia, was met with in comparatively

* Green (1912, p. 84) refers to the presence of Coccus cacti at the Cape, where Mr. Lounsbury informed him that it grew on O. tuna, a species which, Burkill stated, did not occur there. The confusion regarding the identity of $O$. tuna has already been mentioned in this report. 
dry areas, was practically wiped out in South Africa by a fungus parasite-a kind of Rust; and if an organism similar to this was to be found in association with Prickly-pear, there was something to be expected from the discovery in aecomplishing what was desired.

In several places Prickly-pear plants wero remarked showing lack of vigour and evidenee of general constitutional derangement-e.g., various degrees of etiolation, areas of skin discoloration, \&c. This phenomenon suggested soil imperfection of one kind or another as a probable eause. In official reports (unpublished) to the Department of Agriculture of Queensland, relating to the occurrence of alleged Opuntia diseases at Nundah and Westwood respectively, one of the Commission has pointed out the influence of this factor in occasioning ill-health in the class of plants under consideration (Tryon, 1908, 1911, p. 9). Further, in South Africa it has been found that there is a distinct connection between a comparatively high lime content in the soil and the presence of at least one kind of Opuntia-i.e., the pest pear, $O$. decumana. Dr. G. F. Juritz, the Agricultural Chemist to the Union Department of Agriculture, and whose work on the soils of South Africa gives weight to any statement from him regarding South African soil eomposition, informed the Commission that most of the land on which the plant was trouble. some possessed a high lime content, instaneing the eastern part of the Karoo-e.g., Cradock and Somerset East, outside which area, i.e., " in districts defieient in lime," it was grown only as a hedge plant or for its fruit, and, although $O$. decumana was also said to be plentiful along the eastern coastal belt where the soils did not contain much lime, other faetors there might be concerned in determining its prevalence. With this exception, generally speaking, "where the land was poor in lime pear did not become a pest." The influence of this particular eharacter of the soil on the occurrence of Priekly-pear might be taken into consideration in any forecast of the direction of its future extension, as well as explain defects in its growth such as are alluded to.

\section{DESTRUCTION BY UTILISATION.}

The only naturalised species which has been utilised to any extent is $O$. decumana, the Kaalblad variety having been made more use of than the thorny form or Doornblad. As already mentioned, certain other varieties-" anacantha" and "manado," as well as a distinct species, Nopalea cochinelifera-have been grown as an accessory fodder crop for ostriches and stoek, while $O$. monacantha is used occasionally as a hedge plant either alone or in company with the Doornblad. The succeeding remarks regarding utilisation refer to $O$. decumana, and as they have reference to a plant related to one of the Queensland Prickly-pears their inclusion appears juștified.

\section{Utilisation as FODDER for Stock.}

There is a considerable amount of literature published in South Africa (mainly Cape Colony) on this subject, and much evidence has been collected by the Commission; but it can be summarised in a short space.
Owing to the fewness or absenee of spines on the joints of the Kaalblad, this variety has been used much more extensively than the more thorny form, though it appears from experiments earried out by Mr. Thornton, Principal of the Grootfontein Agricultural College, Middelburg, Cape Province, as well as from the experience of many farmers (R.S.C., 1898, p. 21; Adams, 1895, p. 447 ), that the Doornblad segments are sweeter and more nourishing, but the labour involved in removing the spines by singeing or otherwise is a serious consideration. Hence it is the Kaalblad whieh is used; while the Doornblad remains and fruits, and has become the dominant form. The pest pear. of South Africa is thus the Doornblad variety of $O$. decumana, the form which had been determined as $O$. triacantha by the authorities at Kew. The singeing is usually done over a kind of gridiron, and is rather overdone than underdone.

Prickly-pear has been used to a considerable extent as fodder, more especially during times of seareity. As a rule, some other material is added to it (Maedonald, 1891 b, p. 29). From evidence obtained in various parts of South Africa, it appears that stock, ostriches, cattle, pigs, \&e., can be maintained on a ration of pear, and can actually thrive on it if the ration be supplemented by "mealies" (maize), hay, lucerne, grain, linseed meal, \&c. If suffieient fruit of the plant be added, then stock may be actually fattened on a Priekly-pear diet.

In some places farmers, having removed the pear, have replanted in a feneed-off area so that it might be available as a stand-by in seasons of drought. In a few cases, sueh as on certain Prickly-pear farms in the Cookhouse and Graaff Reinet districts, no supplementary fodder had been used, and the cattle and pigs from these farms survived right through drought conditions and maintained their condition. It is well known that some animals become confirmed pear-eaters. Besides this, there is a large amount of Kaalblad in these loealities, henee the injuries which commonly follow as a result of feeding on Prickly-pear are not serious. The Commission saw eonsiderable areas of dense pear land at Cookhouse, where the cattle were browsing on the Kaalblad and keeping it quite short, while the Doornblad remained untouched.

It is admitted that pear will keep stock alive, and this has been made a reason against the elimination of the Kaalblad. On the other hand, it is pointed out that the mere oceupation of the land by the pear prevents the growth of other plants which might be utilised for the same purpose during drought conditions, with less danger.

Many farmers have retained a elump of pear on their farms, but have securely feneed it, so that live stock cannot distribute the secds or joints and thus be the means of scattering the pest still further. This clump of reserve fodder is thus regarded as a form of insurance against the evils following drought.

Prickly-piar is fed quite commonly under certain conditions to cattle and ostriehes, also to pigs and goats, and occasionally to horses. 
All of these animals are fond of the fruit. Before feeding to ostriches, the joints must be chopped up, special machines being utilised for the purpose. When used as food for other stock, liaalblad niay be chopped up or may be fed whole, but tlie Doornblad must be treated in such a way that the spines become less dangerous. The latter may be done by singeing in various ways or to a certain extent by chopping up the pear. Boiling or steaming the joints is frequently done before using them as fodder for pigs.

In some districts-e.g., Uitenhage, which is rather fertile and rarely experiences a drouglitthe pear is held to be worthless on account of its low feeding value, though American aloes may be chopped up and used to form part of the diet of ostriches and cattlc.

The utilisation of Prickly-pear for fodder during droughts is not unattended with disadvantages. Unless care bc exercised, purging of the animals, whether ostriches, sheep, cattle, goats, or pigs, frequently occurs (R.S.C. 1898, p. 36 ; R.S.C., 1890 , p. 22 ; R.S.C., 1906, p. 69 ; MacOwan, 1897, p. 3). Then, again, the small spines from the fruit penetrate the tongue, jaws, $\& c .$, and give rise to inflammation which may extend even to the stomach and cause death (Grobelaar, 1891, p. 246; Macłonald, 1891, b, p. $26 ; 1897$, a, p. 30 ). A similar result may follow the eating of the joints of the more spiny plants, but usually cattle suffer less than smaller stock, such as goats and sheep (Wallace, 1896, p. $90)$. These injuries often prevent the animal from being able to feed on harder stuff (such as grass), supplying the animal with soft food, such as lucerne, being then resorted to with much success. Ulceration often results from the wounds and not uncommonly is followed by fly infection, the maggots aggravating the condition. Sometimes the mouth of the affected animal becomes so bad that grazing is impossible, and death by starvation frequently follows (R.S.C., 1896 , p. 9). Some beasts become so fond of the plant that they, " even when suffering acutely from the injury which it produces, have been known to remain beside a pear-tree with the tongue hanging out and to continue to eat the fruit until they have actually died of the effects" (Wallace, 1896, p. 90). Hutcheon (R.S.C., 1906, p. 6) referred to the same matter, mentioning that it is not the Prickly-pear joint but rather the spinules on the fruit which cause most of the
injury.

The actual direct loss of stock caused by injuries resulting from feeding on the pear has been estimated to be $£ 200,000$ annually (R.S.C., 1890 , p. 2, 7, viii.; R.S.C., 1891, p. 111, Appendix, p. 1; Wallace, 1896 , p. 90, \&c.). On one farm at Graaff Reinet, in one year, 1,200 goats died from its effects (R.S.C., 1898, p. 69). Ostriches, cattle, and cven human beings have become blinded temporarily or permanently by the tiny spines blown from the fruit by the wind (R.S.C., 1890 , p. 22 ; R.S.C., 1898, p. 9; Grobe- laar, 1891, p. 246 ; R.S.C., 1891, p. 25; Marloth, 1892, p. 111).

J. Burtt Davy (1909) has referred to the subject of Prickly-pear as a stock food, and has summarised the matter (pp. 14, 15). He states that it is a useful though not very nutritious form of stock food, but the presence of spines means an element of great danger and expense. The chief value of the plant seems to be(1) its use as a food during prolonged drought, when other and more nutritious food is searce; (2) its use as a roughage along with more concentrated foodstuffs for cattle; (3) or as an accessory to ordinary rations of concentrated food and hay, as it supplies succulence which is difficult to secure in semi-arid regions during a large period of the year; and (4) in the fact that working oxen can be maintained for an indefinite period on a ration consisting largely of Prickly. pear. The amount used varies from 125 to $200 \mathrm{lb}$. daily for a full ration to an adult animal, to from 40 to $70 \mathrm{lb}$. per day as part ration for a dairy cow. He refers to the danger of feeding Pricklypear alone, owing to the tendency of the fibre to form balls within the digestive canal-this sometimes causing the death of the animals-and mentions that the spinules frequently cause irritation of the eyes, sometimes resulting in total blindness.

Mr. R. W. Thornton carried out careful feeding experiments at the Robertson Agricultural Experiment Station, Cape Colony. He used the chief kinds occurring locally (Kaalblad, Doornblad, and $O$. monacantha) as well as a number of imported species.

An extract from his report (29-4-13) reads as follows:-

"With regard to our feeding experiments, I may say that these were carried out with cattle, ostriches, and pigs; and Prickly-pear was fed to these animals pulped and boiled, with the thorns removed by burning and with the thorns on. A second series was tried by supplementing with lucerne hay, and a third by supplementing with maize.

" The ostriches did well in all cases, but did best when the Prickly-pear was supplemented with lucerne hay. The draught cattle, whilst doing no work, did fairly well on Prickly-pear alone, but became very thin when worked. The milch cattle did not do at all well on the Prickly-pear alone, and neither did the pigs; but in all instances where the Prickly-pear was used as roughage and supplemented with other good food the results were very successful. The older stems were found to be more nutritious than the younger leaves."

[The experiments referred to were carried out and reported on in 1908 with twenty-five different cacti, those which were found to possess some value being the varieties of $O$. decumana and Nopalea cochinelifera.] 


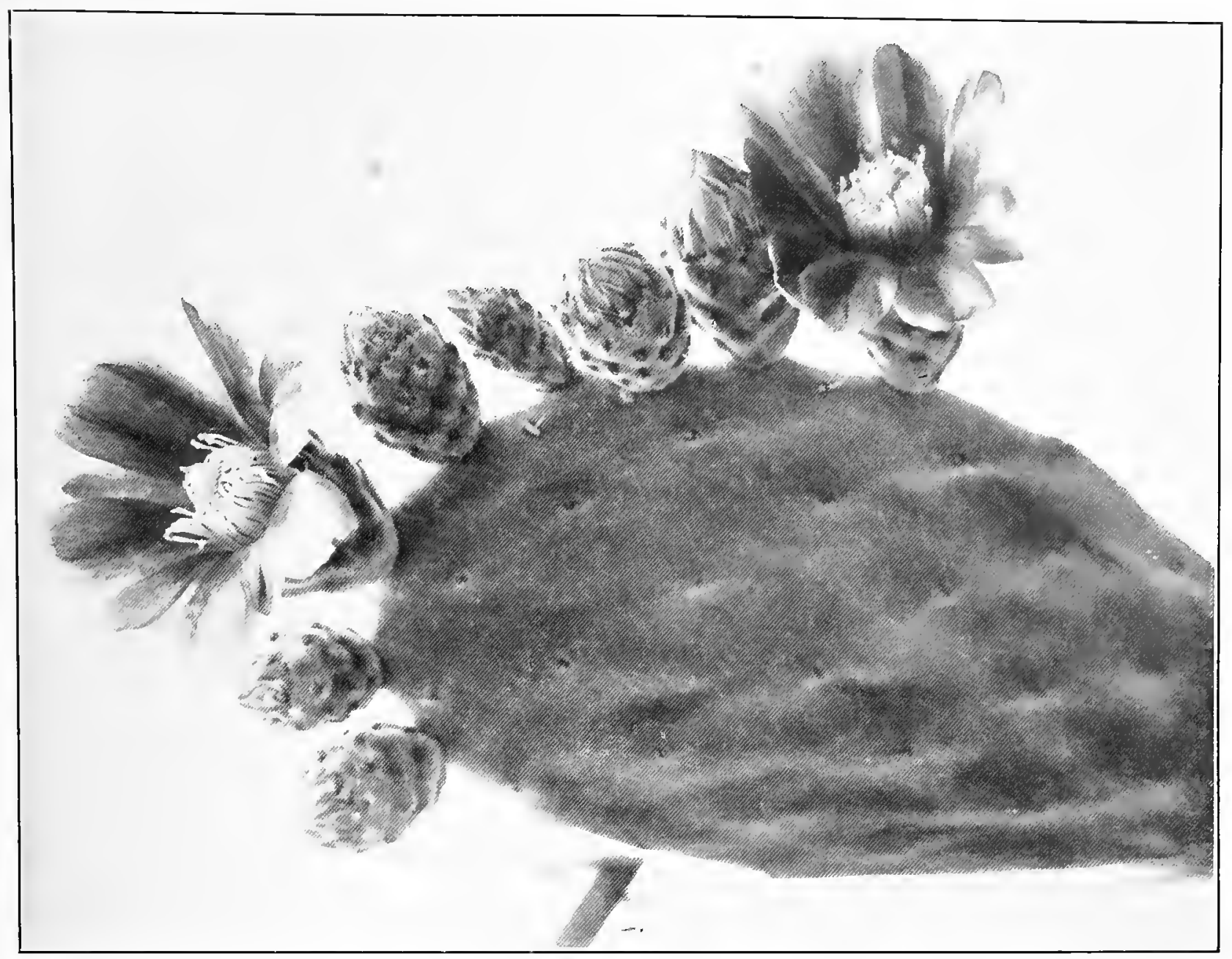

Photo., Di pt. Atriculture, Brisbune.

Fig. 19.-Segment, flowers, and buls of the "Helidon Tree Pear" (1. Hmentosa-from Rockhampton.

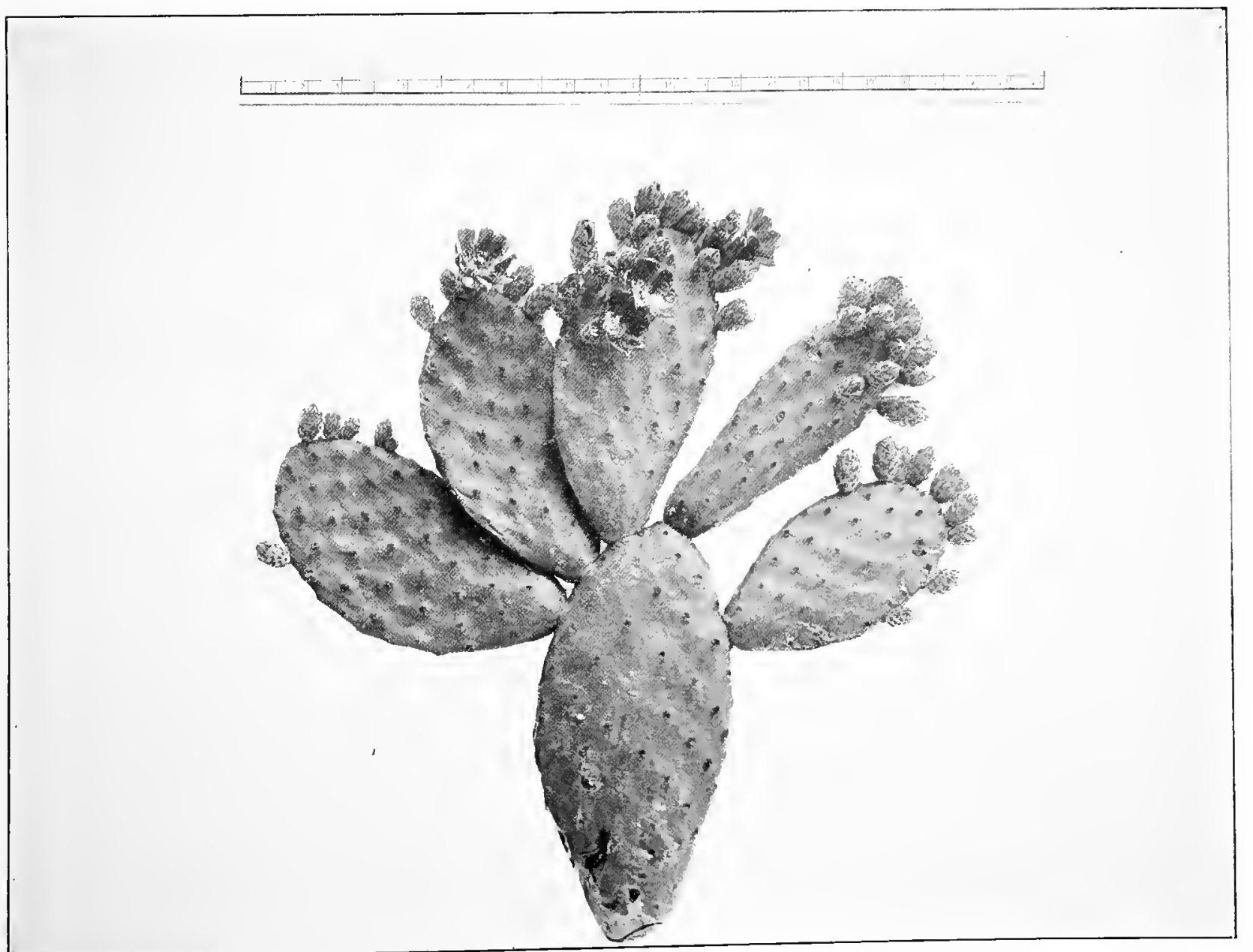

Thoto., Dept. Agriculture, Brisbrne

Fig. 20.- Joints of O. tomentosa, with buds and flowers, from Rockhampton. 

"The percentage results of the analyses" of tables, being calculated-(I.) upon the-fresh leaf these samples are given in the two following in each case, and (II.) upon the dried leaf:-

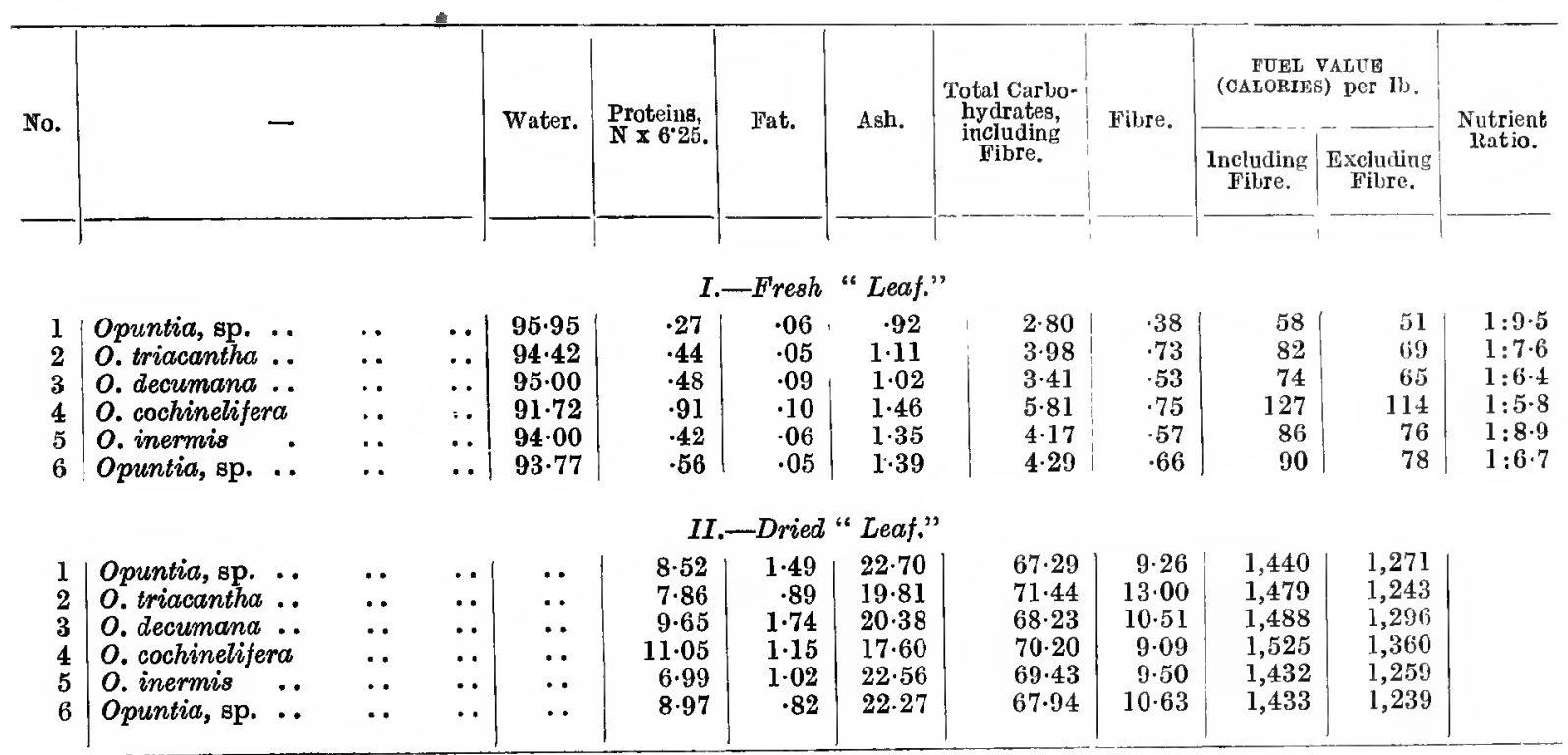

The names given in the tables are those used by Mr. Thornton. No. 1, Opuntia, sp., is a eultivated form of o. decumana, obtained from California. No. 2, O. triacantha, is the Doornblad of South Africa, and is also a variety of 0 . decumana. No. 3 is the Kaalblad form of 0 . decumana. No. 4 is correctly named. No. 5 is a spineless species said to occur in Mexico and West Indies; it is possibly another variety of $O$. decumana, and is not related to the Australian pest. No. 6. Opuntia, sp.- - thormless form-was obtained from Madeira, and is also probably a variety of 0 . decumana.

* These chemical data ovilently do not refer to the oomposition of the entire Prickly-pear planis to which they relate.

"The fuel values and nutrient ratios given in the above tables lave been calculated in the manner described in Vol. 33 of the "Agricultural Journal of Cape of Good Hope," July, 1908, pp. 100-1. The variations in the fuel values in Table I. are due mainly to the differing proportions of moisture eontained in the fresh leaves. No. 4, it will be seen, is, when fresh, considerably in advance of the rest in food value-a fact which is owing partly to its lower moisture content, but also to the lower pereentage of fibre and the higher proportions of proteins and digestible carbo-hydrates. For the latter reason it also occupies the premier position amongst the dryleaf results in Table II.",

Warren (1914, p. 388) mentions that, in addition to the naturalised Opuntias, certain Burbank varieties-viz., Anacantha and Manada -are grown for feeding cattle during dry seasons.

Lamont (1914, p. 386) has published the average composition of various fodders. amongst them being the Kaalblad, which is stated to contain 94 per eent. water, 1.35 per cent. ash, .42 protein, .57 fibre, .06 fat, and 3.7 earbohydrates. This represents five food units, whereas lucerne hay has 80 , green lucerne 20 , maize ensilage 17 , and oats 99 .

Ensilage.-The attempt to use Prickly-pear as ensilage has not been satisfactory (R.S.C., 1898, Appendix, p. v.; Nobbs, 1908 a, p. 26). though it has been suggested that the addition of an equal weight of chaff would make the mixture of some value, $340 \mathrm{lb}$. of which would be equivalent in feeding value to $225 \mathrm{lb}$. of hay as a cattle fodder. It has also been suggested that an ensilage might be made of Prickly-pear fruit mixed with lucerne, hay, or oat ehaff. A kind was made at Bloemfontein from the joints and fruit, but, having too mueh acidity, grass or linseed meal was fed along with it (R.S.C., 1898, p. 15-6).

UTILISATION AS FOOD FOR MAN.

The fresh ripe fruit forms a very important part of the food supply of the "poor whites" and the natives (R.S.C., 1891, p. 13; 1898, pp. iv., 41, \&e.; 1890 , p. 18). It is stated that the latter live for many months of the year on it; hence there is a scarcity of farm labour during that period (Nobbs, 1906 a, p. 26; Wallace, 1896, p. 91). Many of the farmers also use it as part of their diet, just in the same way as the fruit of certain prickly-pears is utilised in the Canary Islands, around the coast of the Mediterranean, and elsewhere. It is an ordinary article of commerce during certain seasons of the year. Sometimes payment for native labour is made in Prickly-pear fruit, and at times the latter is given in exchange for mealies (maize) grown by the natives. Sometimes the fruit is dried or converted into preserves, jams, or jellies (R.S.C., 1898 , p. $41 ; 1891$, p. 15 , \&c.).

Alcohol, vinegar, syrup (molasses), and even sugar are made from Prickly-pear occasionally by the farmers (R.S.C., 1891, pp. 15, 19 ; Maedonald, 1891 a, p. 23, \&c.). In the case of the syrup, chicory or ginger may be added to destroy the, flavour. The natives and the "poor whites" make a liquor from the fruit, and this appears to have an intoxicating and demoralising effect which has called for public comment on many occasions (Wallace, 1898, p. 90; R.S.C., 1898, p. viii., p. 2, \&c.; Macdonald, 1891 a, p. 23). The vili., p. 2, \&c.; Macd thickets have become hidingplaces for stolen stock (R.S.C., 1898, pp. 32, 42; 1891 , pp. 3, 8, Appendix, p. i. ; 1890 , p. 2, 16). Besides this, the growth and extension of the pest have greatly depreciated the value of infected properties, and have led to loss in revenue (R.S.C., 1991, p. 1, 41, Appendix, p. i. ; 1890, p. 7 , p. vii.; 1898, pp. 31, 37, \&c.). Hener it can be readily understood that, in evidence given before the several Select Conimittees of the Cape Parliament which were inquiring into the question 
of the eradication of Prickly-pear, many farmers declared that the disadvantages were so great that the plants should be eradicated in spite of the lew advantages m'esented by them (R.S.C., 1906, p. 30, 51; R.S.C., 1898, p. 5, \&e.; R.S.C., 1906, p. 11; Wallaee, 1896, p. 90 ; Grobelaar, 1891, p. $246)$.

\section{Vines on Prickly-PeAr.}

It was suggested by an anonymous correspondent in the "Agrieultural Journal of the Cape of Good Hope," Vol. IV., 1891, p. 73, that the stumps of Prickly-pear plants might be utilised as stoeks for vines, as had been done in eertain parts of the United States of Ameriea. The attempt in Cape Colony was not a suecess; and the Secretary for Agriculture (Mr. A. Fiseher) stated that, since vincyards could be established with comparative ease, it was doubtful whether the experiment was worth repeating.

\section{Prickly-pena as a Green Manure.}

On some farms in the Zoutspanberg distriet, Transvaal, Priekly-pear has, aeeording to local evidenee, been employed as a green manure for eitrus trees. Its use is said to have been beneficial.

\section{DESTRUCTION BY UTILISATION IN THE INDUSTRIES.}

Priekly-pear does not appear to have been as yet utilised for the preparation of eommereial artieles in South Africa. Mr. William Frost, of Graaff Reinet, has been experimenting for some time past, and has reeently patented a number of artieles prepared either wholly or in part from the pest pear, $O$. decumana. A large acreage of land forming part of the town eommon of Graaff Reinet has been plaeed under the eontrol of $\mathrm{Mr}$. Frost, who has undertaken to elear off and utilise the dense pear infesting it, his profit to be made out of the sale of the products which he expeets to prepare from the plants. At the time of the Commission's visit the work had not been commenced.

During the course of an interview, Mr. Frost brought under the notice of the Commission a number of smal? samples of his preparations whieh he believed eould be manufaetured on il eommereial seale. Amongst them were food balls made from the stems and joints with or without the fruit. The patented proeess by which these are proposed to be made is thus deseribed: - ln order to convert the Priekly-pear to a fodder, the parts of the plant are slieed, dried, and pulped; then the juice is separated from the fibrous matter and concentrated. This eoncentrated juiee is added as required to the fibrous material, and the mixture eonverted into dry balls or eakes capable of being utilised as fodder for eattle and ostriehes. They may be fed entire $\mathrm{ol}^{\circ}$ broken up or else moistened with water, and are said to be an alternative to lueerne as a diet for ostriehes, as they eounteraet the eonstipating tendeney of the latter.

It was stated that eoffee made from the seeds and eertain other parts of the plants mixed eould be produced at a very low eost. Syrup or molasses was obtained from the fruit, and from this a crude sugar was manufaetured, which substances it was proposed to utilise for the manufacture of sweets.
$\Lambda$ kind of meal, vinegar, acetic acid, soaps, \&c., were to be made wholly or in part from the plant. Samples of a fertiliser were made from Priekly-pear mixed with farm manure.

The matter of eommereial utilisation has not, as yet, passed beyond the experimental stage.

An early proposal to make soap by boiling Prickly-pear "leaves" with fat was shown by MacOwan, 1890 , p. 61 , to be of no practical value.

\section{Prickly-pear as Hedges.}

It has alrcady been inentioned that the various speeies are oceasionally used as hedges; but this, of course, does not involve its destruction.

\section{APPENDIX.}

\section{DESTRUCTION OF PRICKLY-PEAR BY MECHANICAL AND CHEMICAL} MEANS.

The following compilation of available literature, although not devoid of interest, will suggest that Queensland has nothing to learn from South Afriean past proeedure in its own efforts to subjugate the plants under consideration :-

The spread of Prickly-pear in Cape Colony beeame so serious that on four oeeasions (1890, $1891,1898,1906$ ) Seleet Committees of the Cape Parliament were appointed to inquire into the question of eradieating the pest.

The first report (R.S.C., 1890) referred to the great depreciation of public and private lands, the large annual loss of stoek, the demoralising influence of the fruit and the liquor made from it on the natives, eaused by the presence of Priekly-pear. Amongst the recommendations were the proelamation of eertain distriets as infeeted areas, each of these to be taken over by a Commissioner, who should be given power by an Aet providing for complete extirpation of the plant. These Commissioners should have power to enforee obedience to the proposed Act. "In such eases where the proprietors are not able themselves to meet the expenses, the Commissioners shall investigate and reeommend sueh pro rat $\hat{a}$ assistance as they shall deem just. In those eases where a proprietor cannot possibly elear his land, such land to be expropriated, and the fair value deeided upon by arbitration to be given to him for it. Then this land to be either eleared at the expense of the Government and then sold; or sold with a speeial stipulation that it shall be eleared immediately by the purehaser."

The report of the Seleet Committee appointed next year (R.S.C., 1891) again refers to the alarming spread of the pest and to the economie losses eaused by it. Owing to the lack of information as to the identity or otherwise of the Kaalblad and Doornblad, experiments to deeide the question were suggested. Until such results were available, the Committee did not feel justified in recommending the total eradication of the former. It was also suggested that experiments as to the efficacy of various sprays should be carried out. The drafting of a Bill for the eradication of the thorny Prickly-pear (Doornblad) was urged. 
Anongst the evidence received by this Committee was that of Mr. A. C. Macdonald (1891 b), who reviewed the question of "Prickly-pear in South Africa, and made a number of suggestions to the Government with regard to its eradication (pp. 34 and 35), most of these being supported by the Secretary for Agriculture (Fischer, 1891, pp. 42-3).

In 1898 another Select Committee made its report (R.S.C., 1898). The serious economic results of the spread of the pest, which have been referred to carlier, are again emphasised. It was considered that " compulsory legislation for the eradication of the weed was not desirable, but that the free supply of serub exterminator by the Government would be the most effectual means of attaining the object sought."

A much longer report was furnished by the Select Committee appointed in 1906 (R.S.C., 1906). After reiterating the effect of the spread of Prickly-pear on the general community, and drawing attention to the seriousness of the presence of the jointed cactus, the report goes on to state that the Committee was of opinion that the State should now assist the private individual to exterminate both of these pests. Though eompulsory eradieation alone was considered undesirable, it was believed that " a system of obligatory cleansing coupled with graduated State aid and encouragement would bring about the desired result." It was suggested that every farmer troubled with the pest should elear his land within a reasonable period, and, after producing a verified statement of the cost, should be reimbursed according to a scale, the following being suggested :-

\begin{tabular}{|c|c|c|}
\hline Cost of Eradica & & Proportion \\
\hline Under $£ 100$ & & $121 / 2$ per \\
\hline$£ 100$ to $£ 500$ & & 25 per cent. \\
\hline 500 to & & per e \\
\hline $1,000 \mathrm{a}$ & & 50 \\
\hline
\end{tabular}

It was further recommended that arsenite of soda be sold at cost price; that the carrying of Prickly-pear or jointed cactus from an infested to a clean area be punishable witl a heavy penalty; that the planting of these two pests be prohibited; that farmers whose lands were free from pear be compelled to keep them clean; and that lands eleansed with Government assistance be kept elean at the owner's cost. Moreover, all public lands, whether belonging to the Crown, to municipal bodies, or to railways, should be brought under similar conditions. Further experimentation with mechanical and chemical means was urged.

The earlier methods of elearing Prickly-pear were purely manual, the plants being chopped down and then stacked. After a time the inner portion of the mass would decompose, while the new growth from the outer parts was broken off and thrown on the heap. Ultimately the heap became dry enough to burn. The hardness of the Karoo soil prevented the burial of the plants (R.S.C., 1890, pp. 10-12 ; R.S.C., 1891, p. 4). Cooper's sheep dip was tried as a means of destroying Prickly-pear (Agr. Journ. Cape of Good Hope, I., 1888, Nos. 9, 12, 14).

About this time (Fischer, 1891 a, p. 443; Maedonald, 1891 a, p. 24) it was proposed to earry on experiments with scrub exterminator, which had been found a suceess in India. This, on analysis, was found to consist mainly of arsenic and certain alkaline substances (Fischer, 1891 a, Appendix, p. 11; Juritz, 1892, p. 15). The experimental work was initiated by $\mathbf{A}$. Fischer (1891 b, p. 133), who reported that eertain solutions of the Australian Serub Exterminator and also of arsenite of soda destroyed the above-ground portion of the pear. The work was carried on by A. C. Macdonald (1892 a, pp. 21-3; 1892 e, pp. 112-3), who used, in addition, other sprays such as copper sulphate and corrosive sublimate. The general result was rather unfavourable, as new growth was produced by the semi-deeayed plants, on account of the failure of the ehemicals to destroy the roots. This result coincides with that obtained in Southern India (Fawcett, in Fischer, 1892 a, p. 24). The cost of clearing per acre in the latter country, when using the scrub exterminator, has been worked out by Fischer (1891 a, Appendix, p. iv.) to be over $£ 84$ per acre.

Macdonald's experiments were continued by himself and Palmer (1892, pp. 276-7) and others were carried out by Holmes and Davenport $(1893$, p. 64).* As a result of the work of these men it was found that the arsenical sprays are not very effective against growing Prickly-pear. but that if the latter be chopped down and heaped, or if the bark be well pierced before spraying, then destruetion follows in a short time, and the dead plants may be burnt. A considerable saving in time and expense was found to occur. The most effective strength of solution was shown to be obtained by dissolving 1 Ib. of the arsenic compound in 8 or 9 gallons of water. The poison was found to act more rapidly if applied to the heaps after the plants had been chopper down, winter time being the most suitable time for using it (Macdonald, 1894, p. 285). The Government, as a result of these experiments, imported a supply of the arsenite of soda and scrub exterminator and sold it to farmers at $2 \frac{1}{2} \mathrm{~d}$. per $\mathrm{lb}$., this being about half cost price (Tooke, 1898, II., IV.; Macdonald, 1894, p. 285).

Acting on the recommendation contained in the report of the Parliamentary Select Committee $(1898$, p. v. $)$, the Government, in 1898 , distributed arsenite of soda free (R.S.C., 1906, p. 2 ; Nobbs, 1906, a, p. 9); but the supply was

* Macdonald's work has been referred to by Mr. Maiden (1898, pp. 984-7). 
intermittent, as the amount of money voted for this purpose was insufficient. Moreover, there appcars to have been a eonsiderable amount of waste going on. From 1905 the poison was sold at cost price (R.S.C., 1906, p. 2; Nobbs, 1906 a, p. 10).

Dr. Hutcheon, Acting Director of Agriculture (R.S.C., 1906, p. 3), stated that it was more effective to dig out the pear, collect it into heaps, and then spray thoroughly, than to inject the poison into the standing plants. Many South African farmers have agreed with this statement (R.S.C., 1906, pp. 52, 57).

About this time certain local proprietary preparations came to be used. The most satisfaetory was that of a Mr. Pienaar (R.S.C., 1906, pp. 13, 29, 36). This poison was patented, its composition being given (p. 60) as copper sulphate, 14 oz.; sodium hydroxide, $20 \mathrm{oz}$; water, $160 \mathrm{oz}$. Two solutions were made separately and then mixed together. A tablespoonful of the liquid was placed in a hole bored into the stem and main branches at a distance of three joints from the end (p. 61), and the hole was then plugged up. Soon the pear began to die from the tips downwards (p. 13), the joints remaining on the plant if proper care were taken during the injection. This was found by Dr. Nobbs to be effective and to be more easily applied where plants were sparse (p. 13). The objection to the use of this preparation was its costliness (6s. per gallon plus cost of railage), though it was stated that the ingredients cost about 1s. per gallon at Capetown. On the other hand, this remedy was tried by the Municipality of Uiten. hage, which eleared portions of its densely infested town common of 5,000 "trees" at a cost of $\mathfrak{f} 4$ (p. 67) and 8,675 at a cost of $£ 26$ 8s. (p. 35). This works out at a cost of about $\frac{1}{5} d$. and $3 / 4$ d. per tree, respectively. All the expenses cannot have been included, since a later account given by Dr. Nobbs (1906 a, p. 29) refers to the destruction of 18,989 trees at a total cost of $£ 119$ 18s., the work thus costing the municipality about $1 \frac{1}{2} \mathrm{~d}$. per tree. In a Departmental report (October, 1906) Dr. Nobbs stated that over 25,000 trees had been destroyed at a total cost (for labour, material, and cost of supervision) of $£ 16813$ s., which still works out at about $11 / 2 \mathrm{~d}$. per tree. The plants were said to average 8 feet in height. So successful was this remedy deemed to be that the Uitenhage Council proposed ( $p$.

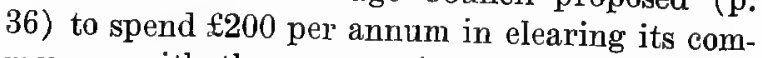
monage with the preparation. Though successful at all seasons, its action was found to be more rapid during summer (p. 63), decomposition setting in about a fortnight after injection. In winter time this oceurs in abont three weeks.

Exhaustive experiments were carried out during 1906 and 1907 by Dr. Noblss (1907). He used samples of eighteen preparations then in use, each being used-(1) as a spray on heaps of pear which had been grubbed out; (2) as an injection into standing trees; (3) as an injection into stumps; and (4) as a spray against standing trees. The substances tried were arsenite of soda, proprietary preparations (Steyn's, Pienaar's, Cairns', Duplessis', Mares, Atlas), Cooper's Dip, common salt, blue vitriol, green vitriol, arsenate of lead, potassium cyanide, sulphur, eaustic soda, and paraffin. As regards efficiency, arsenite of soda proved itself to be the best and cheapest cacticide.

The most efficient and economical method of using this poison (Nobbs, 1907, b, p. 4) was to fell the trees, spray the heaps with $1 \cdot 1$ per cent. solution ( $1 \mathrm{lb}$. arsenite to 9 gallons water), and then inject about 1 to $1 \frac{1}{2}$ tablespoonfuls of a 10 per cent. arsenite solution into the butts of the stumps projecting above the ground. Spraying standing trees with a 5 per cent. solution of arsenite of soda is " recommended for use in checking the progress of the Prickly-pear on steep hillsides" and other places " where more thorough work is impracticable, but where extirpation is very desirable," since these act as redistributing centres for the pest. The main objection is the difficulty of water supply in these spots.

The success following a demonstration of the efficacy of a proprietary compound made by Mr. Jansen (Edit., 1909) led the Government to purchase the secret of its composition. It was made as follows :-

1. Boil thoroughly for 30 minutes half a pound of good finely powdered lime and half a pound sulphur in one gallon of water. An extra quart of water shoula be added to above to allow for evaporation whilst boiling.

2. Dissolve half a pound of salt and half a pound of arsenite of soda in one gallou boiling water.

3. Mix the above Nos. 1 and 2 together, which will then equal two gallons fluid stuff.

4. To be applied as the tree stands, as follows:-Make an incision with a knife, with a sharp point, two to three inches deep into one or more leaves, according to size of tree, and inject the poison.

The number of incisions necessary for a tree can soon be gained after a short experience with the extirpator. For instance, if a tree of medium size contain one stem with no branches, one injection at the top of the tree will be sufficient to destroy the whole tree. Thus it only needs a little foresight to enable the work to be done with the least expense. 


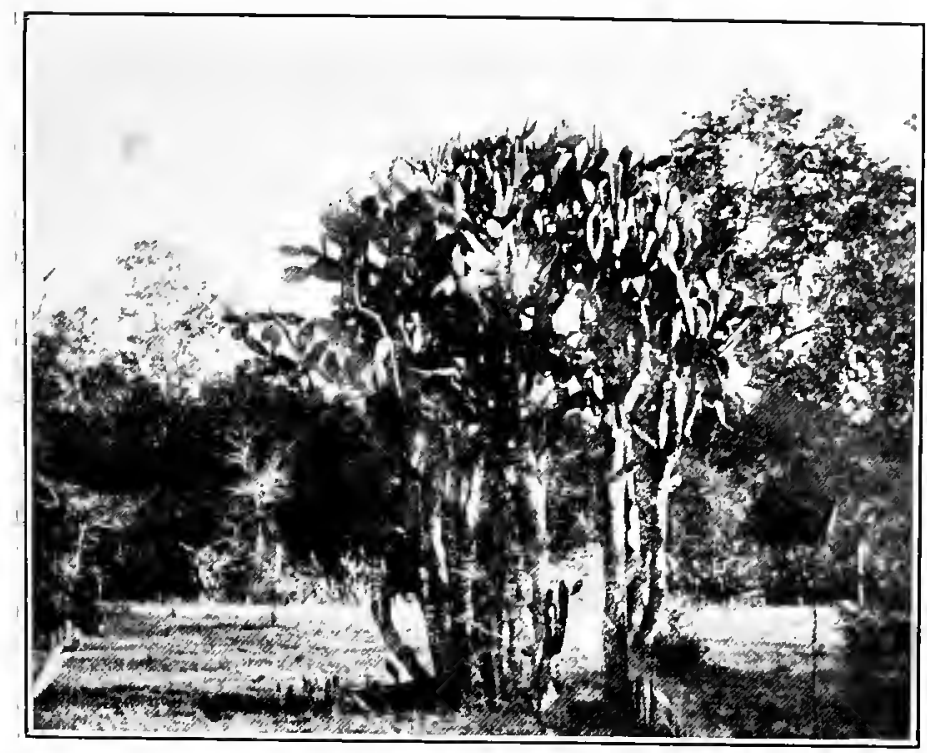

Fig. 21.-O. trmentosa. Near Rockhampton.

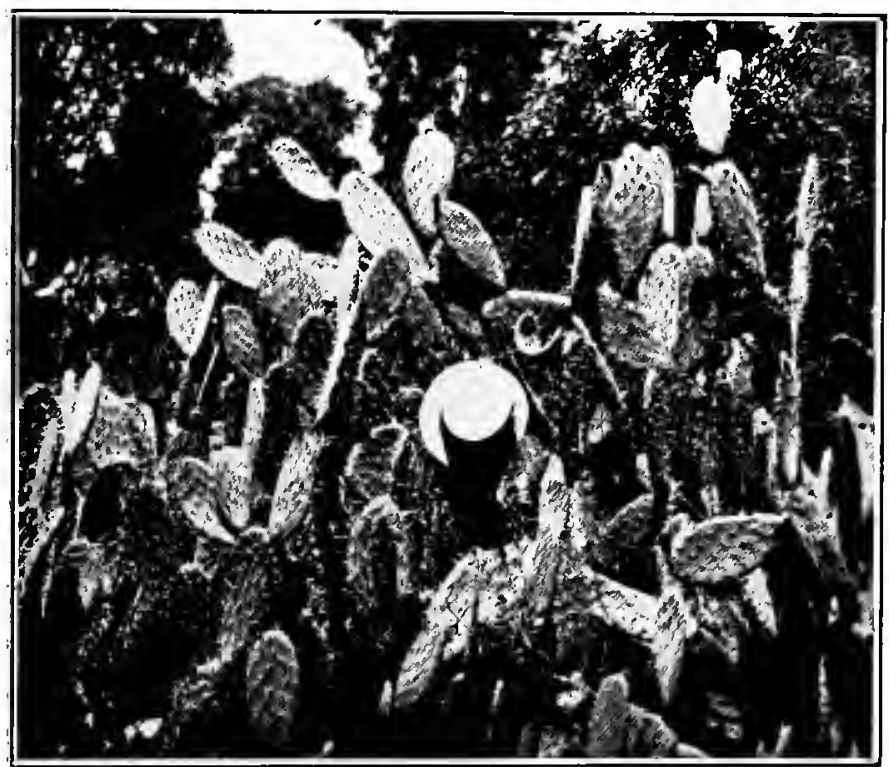

Fig. 22.--The "Yellow-fruiting Mexican Pear." North Rockhampton. Compare with the "Doornblad" of South Africa (Fig. 32).

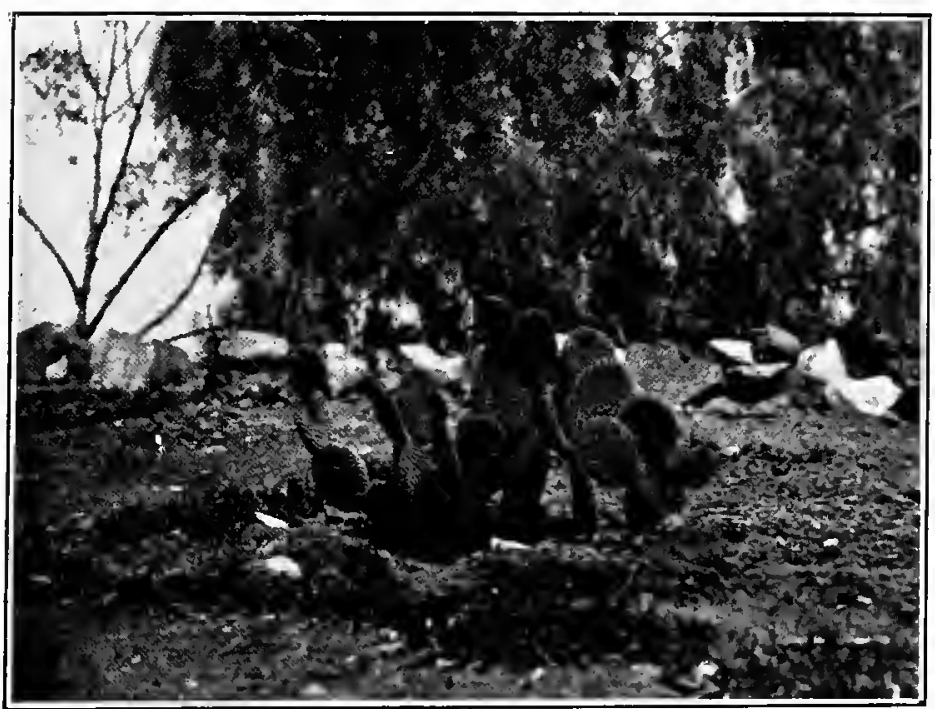

Fig. 23.-O. micrmlasys, from Teneriffe, Canary Islands. This low-growing species is reported as being naturalised in the Pillaga Scrub, New South Wales. 

The method of injection is as follows:-The leaf which is selected for the injection is pierced with the sharp-puinted bnife at the top side of the apex, and the knife is then moved backwards and forwards to enlarge the incision. The knife is given a half-twist to open the incision made, and to keep it open a pebble is dropped into the opening. A little of the extirpator is then poured from a kettle into the opening, care being taken, however, to keep the fluid well stirred before pouring it out. The poison travels down the stem, inoculating the leaves as it passes. In doing large dense patches the outside fringe must first be treated, and as these die down the work is repeated on the next fringe, and so on till the centre is also treated.

This preparation is not meant to be sprayed, and can only be used as per instructions. (Edit., 1910 a, b).

Another proprietary poison-a spray-has been experimented with (Edit., 1910 c)-viz., that of a Mr. St. O'Gorman. Though apparently an efficient one, its cost seems to be an objection.

Still more recently, a Mr. Rademeyer has patented a mixture which, though intended to be used as a spray chiefly against the Jointed Cactus, is claimed to be a destroyer of Prickly-pear also. The Commission visited the small experimental areas where it had been used two mouths previously. The plants were not completely destroyed, as they were then putting forth new growth. Mr. Rademeyer stated that injuring the plants before spraying was beneficial. $\mathrm{He}$ is now engaged in clearing infested land by contract.

The Municipality of Graaff Reinet lets out to farmers for a period of 25 years, free of rent, portions of the town common, for grazing purposes, on condition that the land be cleared ond kept clear of Prickly-pear.

\section{Destruction of Jointed Cactus.}

From what has already been stated in this section of the Report regarding $O$. aurantiaca, known as the Jointed Cactus (O. pusilla) in South Africa, it will be recognised that this species may become a very serious pest. Such has occurred in certain districts in Cape Colony, and may happen in Queensland unless the infested area in the Roma district be thoroughly cleansed.

The Uitenhage Municipality has for many years been persistently fighting this pest as well as the Prickly-pear, $£ 200$ per annum being expended in these directions under the control of Mr. J. Butler. The method at first adopted was to spray the standing plants with a solution of 4 per cent. arsenite of soda (Nobbs, R.S.C., 1906, p. 33; Nobbs, 1908 , p. 343); but at the time of the Commission's visit the plants were ding ont, collected into a heap, and then sprayed, the mass being burnt when diy. This latter nethod had already been used against the pest by some farmers in the Bedford district (R.S.C., 1906, p. 44, 47; Bowker, 1907, p. 343). The enclosing of infected areas to keep out cattle is a means to prevent the spread of the cactus.

Experiments were carried out by Dr. Nobbs and Mr. R. W. Thornton during 1907, the results being published in 1908 (Nobbs, 1908). Arsenite of soda, as well as the proprietary preparations claimed to be efficacious against the Prickly-pear, were tried, the first-named being found to be the cheapest and most effective, a 4 per cent. or 5 per cent. solution being the most satisfactory. No material advantage was gained by breaking the cactus down before spraying. The results thus corroborated those obtained at Uitenhage by Mr. Butler.

Just prior to the Commission's visit to South Africa, the Department of Agriculture had instituted experiments in order to test the value of a preparation made by Mr. P. M. Rademeyer as compared with arsenite of soda. Agricultural Assistant K. M. Johnson carried out the work at Hankey, and reported that "Rademeyer's exterminator" destroyed Jointed Cactus more effectively and more cheaply than a 5 per cent. solution of arsenite of soda. The Commission visited the treated areas, but did not find any perceptible difference between them, as in both places many plants were sprouting vigorously. There is great difficulty in destroying the "bulb" of this Opuntia.

The information obtained regarding the destruction of Prickly-pear by chemical and mechanical means, indicates that the most satisfactory and economical results have been obtained by using arsenitc of soda solution or "Jansen's Extirpator," these poisons being supplied to farmers at cost price by the Government.*

\section{SUMMARY OF SOUTH AFRICAN INVESTIGATIONS.}

There appear to be seven or eight species of Prickly-pear naturalised in South Africa, two of which, $O$. decumana and $O$. aurantiaca, have become a pest in certain areas. The former is represented by two varieties-a smooth-jointed and a spiny-jointed form-the latter being the troublesome one. O. monacantha, though widely distributed, occurs scattered chiefly around the coastal area.

o. monacantha, O. aurantiaca, and an ally of o. decumana occur naturalised in Queensland.

No evidence was fortheoming as to the presence of any fungoid or bacterial disease controlling the spread of any of these South African Opuntias. A variety of the Wild Cochineal Insect, Coccus confusus capensis, was found to attack and, at times, seriously injure $O$. monacantha ; but as far as the experience of the Commission went, the general effect produced was not nearly so marked as that seen in India and Ceylon as the result of the attack of an allied form, C. confusus indicus. This may be due, in part at least, to the presence of parasites. It is known,

* Under the title "The Prickly-pear Problem, Clearing by Gas," there appears in the South African Agricultural Journal, 1914, pp. $392-5$, a reprint of an article in the Queenslander, giving an account of Mr. Roberts' experiments with arsenious chloride as a cacticide. 
however, that different species of coccids produce different results on their host-Opuntias. This insect was forwarded to Queensland, and has now become established at the Experiment Station at Dulacca.

Nonc of the other insects found attacking Prickly-pear, appeared to produce any detrimental effect.

In regard to the destruction by utilisation as a fodder for stock, the experience of South Africa agrees with that of Eastern Australia. Prickly-pear is of some value as an accessory food supply during times of drought. It is used at other times to some advantage as a roughage for cattle and ostriches.

Its utilisation in the arts and industries has not yet passed beyond an experimental stage.

In regard to the destruction of Pricklypear by chemical and mechanical means, the most satisfactory and economical results have been obtained by using arsenite of soda solution, or "Jansen's Extirpator," these poisons being supplied to farmers at cost price by the Government.

\section{THE CANARY ISLANDS.}

The Commission prosecuted inquiries in the Canary Islands, which were visited while en route from South Africa to England, remaining there from 21st to 28th May, 1913, and visiting for this purpose both Teneriffe and Grand Canary. Whilst on the former island, attention was devoted to the condition of occurrence of locally-developed Prickly-pears in the immediate neighbourhood of Santa Cruz, and between that city and Orotava. At Grand Canary, the neighbourhood of Las Palmas afforded the Commission good scope for its inquiry, but it also inspected the infested country extending along the north coast of the island to Agaete and including Arucas, the still important site of the cochineal industry.

\section{SPECIES OF PRICKLY-PEAR}

The species of Prickly-pear occurring naturalised in the Canary Islands have been specified with more or less comprehensiveness by-(1) Barker-Webb and Sabin Berthelot (1840); (2) V. Perez and P. Sagot (1867); (3) R. Lowe (1868) ; (4) P. Jose de Viera y Clavigo (1899); (5) R. Pitard and L. Proust (1908); (6) I. H. Burkill (1911) ; (7) M. Burkill, Miss (1912) ; and others. They are as follows:-

1. Opuntia ficus-indica, * Mill., named as such by Webb and Berthelot, by Perez and Sagot, by Pitard and Proust, and by $M$. Burkill; $O$. tuna by Lowe, Cactus cochinelifera by de Viera y Clavigo, and Nopalea cochinelifera by Brown (1901, p. 278). It is designated amongst the inhabitants of the Canary Islands, according to de Viera y Clavigo, Higuera, Chumbra, Higuera de Indias, Tunera or Roque, and Nopalera or Palatera.

2. Opuntia dillenii, Haw., named $O$. tuna by Perez and Sagot and by Pitard and Proust; Cactus cochinelifera by de Viera y Clavigo, and $O$. dillenii by Lowe and M. Burkill.

3. Opuntia robusta, Wendl.

4. Opuntia monacantha, Haw.

5. Opuntia tomentosa, Salm-Dyck; the Tunera de Terciopelo (fide Perez and Sagot).

* It is different to the common species in South Africa, its segments being more symmetrpecies in South Africa, respect those of the Barbary fig of the Mediterranean coasts for which Mr. Burkill (1911) uses the name $O$.
In addition to the foregoing, Miss Burkill has recorded-(6) an Opuntia from Grand Canary, "a plant with rather long dark thorns"; (7) another Opuntia (from Teneriffe) with straight spines; and (8) Opuntia brasiliensis, Haw., as a garden plant at Orotava, Teneriffe. These last thrce species were not, however, met with by the Commission, it evidently not having visited the spots where they are known to occur.

The first-mentioned is related to the most prevalent "pest pear" of South Africa, while one growing near Rockhampton, Queensland, may be a variety of it. The fourth one, 0 . monacantha, has already been referred to as being widely distributed in Australia. The fifth, 0 . tomentosa, is the Tree-pear of the Central area of Queensland and the Helidon district.

By far the most generally spread and prevalent species in the two islands visited is 0 . ficus-indica, a plant of large and robust habit, and one that is to be distinguished by its orange or flame-red flowers and oblong-ovoid fruit of a yellowish-green colour and with greenish-white pulp (Lowe). In the Canary Islands, as in South Africa, we find commonly both a less copiously and shorter-spined form which is almost unarmed, and a more spinous one. R. Lowe, who has well described this plant (1868, I, p. 314) does not admit that the two varietal forms are distinct. $\mathrm{He}$ mentioned that the less spiny form passes gradually into the more spiny variety, and that both conditions may be met with on the same plant at different periods and even in different parts of the one plant at the same period. Perez and Sagot $(1867$, p. 21) referred to the diminution of the spiny conditions as a result of careful cultivation of this cactus.

The third kind of Prickly-pear referred toi.e., O. robusta, Wendl.-is one of even coarser habit than is the last. It was found to be quite prevalent at Teneriffe, along the road between Santa Cruz and Orotava, as well as at various localities in the north of Grand Canary. It is readily distinguished from the species abovenamed by its larger, more discoidal, and more greyish-green stem-joints and by its yellow flowers. It is the plant referred to by Drs. V. Perez and P. Sagot $(1867$, l.c.) as one having large rounded joints, a smooth epidermis devoid of spines or only possessing small ones, and red edible fruits.

The awl-spined Prickly-pear-O. dillenii, Haw.-was also locally prevalent, usually along the boundaries of different tenements, both 
at Teneriffe and Grand Canary. It was found growing wild in many places in both of these islands, more especially in the latter. It was observed to have the outer petals of its flowers commonly rufous, especially when growing in drier situations, as near Las Palmas, in the latter island. On the high ground to the west of the latter city, this Priekly-pear was found possessing small shortly-pyriform, deep-purple fruit rcsembling that of the commoner Gayndah (Queensland) Prickly-pear that has, too, been regarded as a form of the species under notice.

O. monacantha, Haw., was observed only on Teneriffe, and appeared to occur quite locally at a spot near Laguna.

o. tomentosa, Salm-Dyck.-This tall darkgreen velvety species was observed near Orotava. as well as in isolated localities in the north of Grand Canary.

The time at the disposal of the Commission for investigations in the Canary Islands being necessarily short, only a limited survey was practicable.

The facts regarding the prevalence of Prickly-pear ( $O$. ficus-indica) on the two islands visited confirmed the opinion formed from the investigations in South Africa-that there is grave danger that, under the conditions of soil and climate existing in Queensland, especially in the Central district, plants belonging to the varieties included under the abovenamed species may become widely spread and constitute a very formidable pest. Our experience in the Hawaiian Islands also confirms that opinion, since, in Oahu, a species closely resembling the "Westwood" pear has become firmly established. Hence those growing at large in the Rockhampton area shonld receive the attention of the anthorities.

\section{NATURAL ENEMIES.}

\section{DISEASE.}

No individual plants of any of the several kinds of Prickly-pear mentioned as growing in these islands were observed to be dead or even dying as the outcome of disease of any kind, parasitic or otherwise. In certain limited areas, where the climate was more arid, many had failed to thrive; a remark that especially applies to $O$. ficus-indica and $O$. robusta, and even to O. dillenii, which is able to withstand very dry conditions.

Our inquiries as to the occurrence of local Prickly-pear maladies were equally barren of results. Owing to their temporary absence it was impracticable to interview two of the authorities on Grand Canary, who, is was expected, might throw light on this question; but the districts in which they respectively reside were traversed and inspected with negative results.

\section{INSECT ENEMIES.}

The insects noticed feeding on Prickly-pear were:-

1. The common widely-distributed Opuntia Scale Insect (Diaspis, sp.), already met with in the Brisbane district. This was observed on the single plant (O. robusta) at Orotava, and evidently produced little ill-effect on its host.
2. Opuntia Aphis found on a plant of the species named, growing near Orotava also. It was restricted to the tender shoots and flower buds, but apparently inflicted no noticeable injury. This insect is apparently identical with one already met with by a member of the Commission on $O$. incrmis at Westwood and Goondiwindi, where also its presence is unattended with ill-effect to the plant. It apparently is referable to a species that is not restricted to a single host, as happens with so many kinds of Aphidæ.

3. Precious Cochineal Insect (Coccus cacti, Linn., typical).-The species of Pricklypear on which this insect will thrive having been already introduced to the Canary Islands for the sake of its fruit, the Precious Cochincal was imported in 1826 (Benitez, 1912, p. 17c) and established upon it. This importation led to the creation of an industry which for a time, at least, was most important. However, in some districts its introduction was opposed, notably at Guimar, Teneriffe (Barker-Webb and Berthelot, 1840, pp. 208-9 ; Lowe, 1868, p. 316), for the alleged reason that the insects destroyed the erop of fruit through rendering the plants sterile. It was sought, then, to discover to what extent the Precious Cochineal Insect injured the Prickly-pear plant with which it was associated; but, although apparently stunting it and retarding its growth to a small extent, the injury due to its presence was almost unappreciable. Sometimes, in spots where the insects had densely congregated, there occurred a dark and more or less superficial dis coloration. This absence of injury was noticed in cases where insects lived in the open and had spontaneously distributed themselves amongst plants growing uncared for, as well as when it existed in Nopalries, where both it and the host plants were sedulously looked after, and where the insect, indeed, had developen to such an extent as to whiten the Opuntia with which it had become associated. However, the Precious Cochineal Insect, even were it injurious to the Prickly-pear, is restricted in its dietary to eertain species, amongst which the Queensland "pest species" are not included.

Wild Cochineal (Coccus, sp.).-None of the insects coming within the definition of Grana sylvestre was observed.

\section{UTILISATION.}

No instance of the prosecution of any procedure for utilising the Prickly-pear involving its destruction came under notice. Available literature relating to the Prickly-pears of the Canary Islands makes no mention of any such employment. Dr. G. V. Perez, of Orotava, Teneriffe, stated that locally in the drier regions, where very little water was available, Pricklypear (O. ficus-indica) was used as a food for cattle, the few spines present being rubbed off or removed by singeing. It, at least, was found to keep alive cattle that received it. 
Methods of ntilisation not involving its destruction may be bricfly alluded to-

(a) Fruit Production.-The fruit of the commonest speeics, which is referred to as $O$. ficus-indica, enter's largely into the dictary of the people, and is a common marketable commodity, being used fresh and in a dried state, after the manner of ordinary figs. In fact, this kind of Prickly-pear was extensively cultivated formerly for its fruit production alone.

(b) Cochineal Industry.--Since the introduction of Coccus cacti, L., from America, in 1826, the business of raising cochineal attained very great prominence, the insect being carefully farmed on special areas, named "Nopalries," devoted exclusively to the growth of this particular form of $O$. ficus-indica. In fact, for a time the cultivation of the vine, interfered with by numerous "troubles" affecting the plant, was in great measure superseded locally by it. A writer in the "Diccionaria Enciclopedico HispanoAmericano" (1890, p. 357) stated that in 1850 the exportation of cochineal from Teneriffe to England, alone exceeded 800,000 lb. In 1869 the enormous total exportation of $3,000,000$ kilogrammes was reached (Benitz, 1912, p. 17c); and Sir Samuel Brown stated that, as late as $1893, £ 50,000$ worth of cochineal was despatched from a single district-Orotava (Ward, 1903, p. 56)-the price then being as much as $5 \mathrm{~s}$. per $\mathrm{lb}$.

De Nobrega (1849) and Martins (1855) have given an account of the cultivation and preparation of cochineal.

Shortly after the discovery of the aniline colours, the industry of raising cochineal declined in the Canary Islands as elsewhere, although even at the time of the Commission's visit it was still being maintained to some extent on both islands, but nore particularly at Arucas, on Grand
Canary, the industry for preparing the "Grana" heing a still noticeable feature at Agaete. Major Swanston, Vice-Consul at Las Palmas, stated that, as recently as $1911,68,803 \mathrm{lb}$., valued at nearly 20,000 dollars, had been despatched from that port to the United States of America. The lucrative banana industry is now replacing the raising of cochineal.

The conditions inseparable from successful cochineal production finding no place in Australia, the suggestion that the Prickly-pear plants of Queensland might be used for this purpose need not be entertained.

In connection with the industry, two kinds of Opuntia plants, in addition to the one on which the insect is raised, are employed-viz., $\boldsymbol{O}$. tomentosa, used as a nurse plant for the growing insect, and $O$. dillenii, whose stout thorns are employed for attaching the tissue containing the egg-laden females in the process of establishing the Coccus cacti on fresh plants.

The latter Prickly-pear is used locally as a hedge plant, this mode of employment accounting for its presence and for its persistence.

Occasionally, where Prickly-pear has to be exterminated to make way for some special crop plant, it is the custom simply to dig it out and destroy it. Owing to the habit of bringing almost every foot of ground that will support the growth of one economic plant or another under cultivation, the Prickly-pear, or indeed any other weed, is little likely to ever become a pest in these islands.

\section{SUMMARY OF INVESTIGATIONS IN THE CANARY ISLANDS.}

Neither disease nor insect enemies having any value as destroyers of Prickly-pear appear to be present.

The methods of utilisation are not such as would lead to the destruction of the plants.

\section{V.-EUROPE AND THE MEDITERRANEAN AREA.}

During the stay in England, the Commission made its headquarters at th? office of the AgentGeneral for Queensland, where Sir Thomas Robinson as well as Mr. Dillon and the members of his staff did all they could to assist us in carrying out our inquiries.

Several visits were made to the Royal Botanic Gardens, Kew, whose Director, Sir David Prain, afforded us every opportunity to consult the botanists connected with this famous institution and study the collection of Cactaceæ in the herbarium as well as those growing in the garden. The fine library was also made use of.

Under the guidance of Mr. N. Brown, who is in charge of the collection of succulent plants, some progress was made in clearing up the nomenr. 3 ture of the naturalised prickly-pears which had already been met with in India, South Africa, and the Canary Islands, as well as in our own State.
Mr. G. Massee, the well-known plant pathologist and mycologist at $\mathrm{Kew}$, informed the Commission that he had not given any attention to the diseases of Opuntia.

It was at Kew that Mr. Alwyn Berger was first interviewed. This botanist. who is one of the leading authorities on Opuntias, extended an invitation to visit Lady Hanbury's Gardens at La Mortola, Ventimiglia, famous for its collection of prickly-pears and other succulents growing in the open, Mr. Berger being the Curator.

In addition to the collection of Cactacex in the Royal Botanic Gardens, Kew, that in the University Botanic Gardens, Cambridge, in charge of $\mathrm{Mr}$. Lynch, and the fine Darrah collection in the Alexandra Park, Manchester, controlled by Professor Weiss, were examined. Various scientific institutions were visited, and the advice and assistance of many prominent workers in 


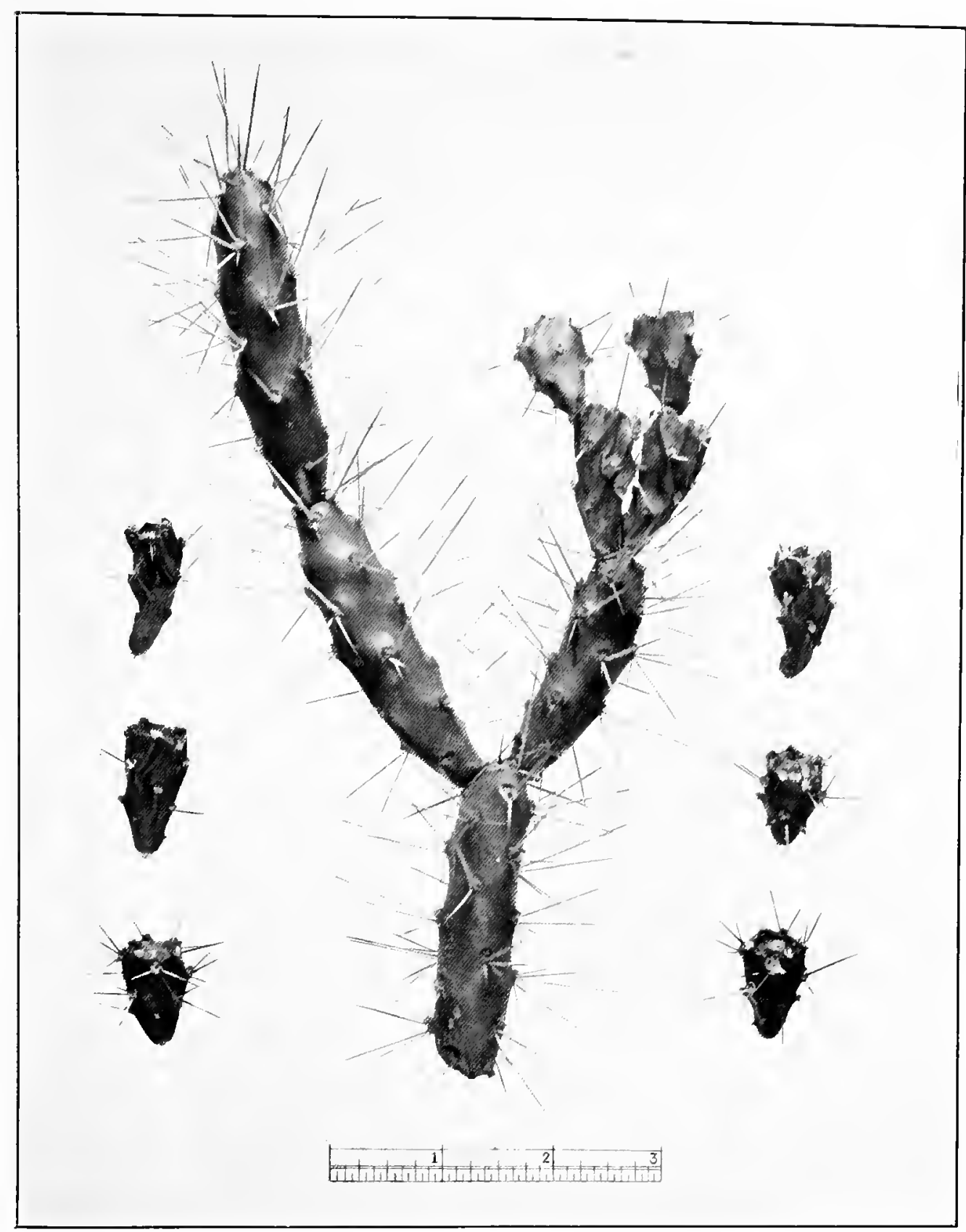

1'loto., Dhet. Agriculture, Bristane.

Fig. 24.-Segments and fruits of O. aurantiaca, from Roma. This low-growing brittle prickly pear is the notorious "Jointed Cactus" of South Africa

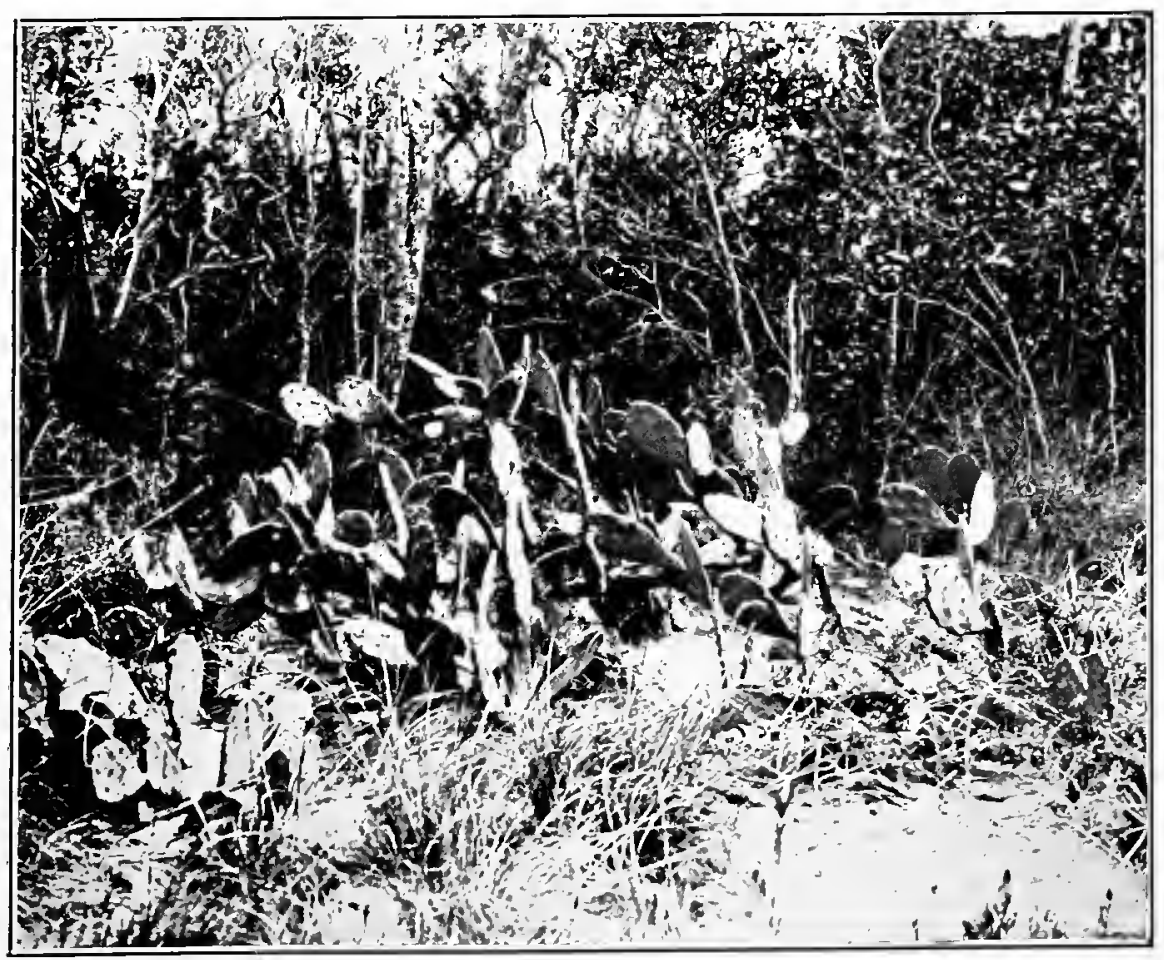



entomology, botany, and plant pathology were sought, but as this group of plants has not received much attention from scientists in the mother country, little information of value relating to the inquiry was obtained. The libraries of the British Museum and the Linnean Society of London were made full use of by the Commission.

Sir David Prain was kind enough to furnish the members of the Commission with credentials to scientific workers and institutions in various parts of the world, while Sir Thomas Robinson, Agent-General for Quecnsland in London, procured from the British Foreign Office the necessary letters of intraduction to diplomatic and consular representatives of His Majesty's Government in foreign countries which it was proposed to visit.

Owing to the fact that one or more kinds of Opuntia had been growing for a long period in the Mediterranean area, especially in Spain and more particularly in Italy, and had not spread in such a way as to constitute a pest, it was thought that there might exist in those countries some controlling factor which, if parasitic, could be of use in the struggle against the prickly-pear in Queensland. Hence it was deemed important that, in pursuance of the work of the Commission, inquiry should be instituted in this area, more particularly in Italy. In order to save time the members separated after traversing Spain, one proceeding direct to Italy and Sicily, where there was reasonable hope of obtaining scientific assistance, while the other visited the Barbary States, Malta, and Syria (vîa Egypt), returning to London through Italy and Germany.

Whilst in Madrid, a visit was paid to the Minister for Agriculture, who, after consulting some of the senior members of his department, recommended that visits should be made to Seville, Valencia, Jerez, and Murcia, as well as Melilla in Morocco, letters of introduction to the director of the local experiment stations and prominent residents being courteously supplied by him. It was found practicable to visit only Seville, Jerez, Cadiz, and Granada, the lastmentioned locality being known to have a considerable development of naturalised pricklypear.

In the search for natural enemies, not only were the species found growing naturalised examined, but, owing to the possibility of the introduction of diseases or insects along with the host-plants from their native home, the chief public and private gardens also received attention. Amongst the morle important of those visited were the collections in the Botanic Gardens at Palermo (by courtesy of Professor Borzi) ; Rome (Dr. Pirotta) ; Monaco ; Bortighera (L. Winter); La Mortola, Ventiniiglia (Lady Hanbury); Darmstadt (A. Purpus); Berlin (Prof. Urban and Dr. Vaupel) ; Tangier (J. Goffart); and Algiers. The study of the extensive collection at La Mortola was particularly helpful, more especially as its Curator, Alwyn Berger, is a well-known worker on the Cactaceæ.

Certain countries such as Cyprus, Greece, the Balearic Islands, Sardinia, and Corsica were not visited, on account of the amount of time required and the small chance of gaining additional information by doing so, and many of the scientific men with whom the Commission had hoped to come into touch were absent from their institutions on summer vacation.

The following is a sketch of the itinerary in Italy and Sicily :-

The Commissioner landed at Naples, and, after consulting H.B.M. Consul, S. T. A. Churchill, proceeded to Palermo, Sicily, where he interviewed Sig. A. Romano, Prof. Lojacomo Pojero, Prof. T. de Stefani Perez, and Dr. C. Tropea, of the University; Prof. G. E. Mattei, Royal Botanical Gardens. Sig. Romano mentioned the possibility of utilising the fibre of prickly-pear in paper manufacture, and also referred to a local disease, which was apparently the "male dicancro"; while Prof. de Stefani Perez gave information regarding certain enemies of Opuntia. In company with Prof. Lojacomo Pojero, prickly-pear plantations at La Favorita were examined, and a special disease inquired into there, and visits made to the Villas of Messrs. T. L. and R. Whittaker, where Cactacex were grown.

A return was made to Naples and a visit paid to the Royal Agricultural College, Portici, which was found to be in recess. Its Director, Prof. Comes, was absent at the time, but Prof F. Silvestri, the well-known entomologist, and Dr. G. Leonardi were met. They had not, however, given any special attention to the insects of Opuntia, though Dr. Leonardi stated that he had found Diaspis echinocacti in Italy on o. dillenii.

The journey to Reggio, in South Calabria and thence to Arcireale, in Sicily, was undertaken, and at the latter place, Prof. L. Savastano was interviewed. In company with this investigator, Catania was reached, where it was hoped that a disease previously described by him as "el marciume" would be seen, but the quest was unsuccessful, owing no doubt to the malady being at the time in a dormant condition.

Rome was then visited, and it was found that the British Ambassador had approached the Italian Minister for Foreign Affairs with a view to obtaining assistance for the Commission during its inquiries in Italy. By courtesy of the Department of Agriculture, help was afforded by some of its officers. The Chief Inspector of Viticulture, Dr. M. Carlucci, was interviewed, and a visit was paid to the Vegetable Pathological Station, but most of its officers were found to be absent on vacation.

The International Institute of Agriculture was also visited, and its Director, Dr. A. Hermes, Dr. J. M. Saulnier, and also Dr. V. de Tivoli were met. Dr. A. Bruttini and Dr. E. Borghesini, two of the members of the staff, had published papers regarding paper manufacture, but, owing to their absence at the time, their advice conld not be received. Dr. Saulnier supplied a list of Italian investigators whose technical knowledge he though would probably be of use to the Commission, if there were an opportunity to interview them. Dr. de Tivoli referred to the commercial manufacture of alcohol from pricklypear in Catania, and also to Dr. Sotyia's investigations in Sardinia regarding the use of the plant as a cattle fodder.

At the Gabinetto Botanico, the Director (Dr. R. Pirotta) and Dr. C. Spegazzini were met. The latter, a well-known botanist, who was then on a visit to Italy from Argentina, gave 
much useful information regarding prickly-pears, their diseases and natural enemies in the Argentine, and strongly advised that an investigation should be carried out there. Though many of the facts referred to by him had already been published in Australia (Tryon, 1911), yet their confirmation by him was deemed of value. The subsequent visit to South America was largely due to his offer to render every assistance. In company with him, the collections of Cactaceæ in the Royal Botanical Gardens were carefully examined.

At Florence, Prof. A. Berlese, Director of the Royal Entomological Station, was interviewed. It had been hoped to have met at Pisa Prof. Giglioli, who had devoted considerable attention to the chemistry of $O$. ficus-indica, but matters could not be conveniently arranged at the time.

The Museum and Library at Genoa were visited, and thence the journey was undertaken to Ventimiglia, where the well-known Hanbury Gardens (La Mortola) are situated. It was there that, through the courtesy of Lady Hanbury and under the guidance of its able curator, Mr. Alwyn Berger, some time was spent in studying the large collection of living cactaceous plants, so many species of which it was expected that the Commission would meet with in America. The neighbouring gardens at Monaco and Bordighera were visited.

The return journey to England was made viâ Milan, where a number of principals of firms interested in paper and "board" manufacture were interviewed regarding the possibility of utilising prickly-pear fibre in that way.

\section{SPECIES PREVIOUSLY REPORTED AS NATURALISED IN EUROPE AND THE MEDITERRANEAN COUNTRIES.}

Mr. Burkill (1911, pp. 287-8) has given a brief resumé of the distribution of Opuntias in this area. He mentions that $O$. nana Visiani, occurs naturalised in Central Europe, Switzerland, Tyrol, and North Italy; while the Nediterranean coast of France, Italy, and Sicily is said to contain $O$. nana, $O$. ficus-indica of Gussone and most authors, $O$. dillenii, $O$. inermis, and $O$. amyclaea, Tinore. He appears to agree (p. 289) with Berger (1903, p. 93) in regarding the lastmentioned species as being merely a form of $O$. decumana, which name he prefers to use rather than $O$. ficus-indica (p. 288). O. decumana is stated to be grown for its fruit on the Riviera, in Italy, Malta, Sicily, and elsewhere. His short account of it (p. 289, footnote) shows that he is referring to the smooth-jointed species known along the Mediterranean coasts as the Barbary or Indian fig. He goes on to say that Spain contains this species and apparently $O$. nana, while North Africa possesses both of these Opuntias, introduced, no doubt, by the Moors on their expulsion from Spain into Morocco.

Dr. Schumann (1899 a, p. 34) had referred to the presence of $O$. nana under the names $O$. ''ulqaris and $O$. vulgaris, var. nana, at Bozen (Tyrol) and in certain parts of Southern Europe (e.g., Dalmatia). He also mentioned that $O$. inermis and $O$. leptocaulis may often be met with in quantity in Southern Europe, the former species occurring in South France, CataJonia, and the Balearic Islands. In his monograph (1899) published in the same year he repeated the above information regarding the European distribution of $O$. nana (p. 715) and $O$. incrmis (p. 718), but O. leptocaulis is not mentioned as being found wild in Europe. $O$. ficusindica is given (p. 719) as the name of the common species cultivated in Spain, Italy, Sicily, and Greece for the sake of its fruit.

The various Opuntias above referred to have been quoted under these or other names by earlier writers on the botany of the Mediterranean countries (Gussone, Tinore, and others).

Holmes (1903, p. 24) has recorded the presence of $O$. decumana (i.e., $O$. ficus-indica) in Algeria; while Gennadius (1898) referred to the occurrence of the spiny form in Cyprus, and Bourde (1894) to its presence in Tunisia.

\section{SPECIES NOW KNOWN TO OCCUR NATURALISED IN THE MEDITER- RANEAN REGION.}

Ten or eleven species have been recognised, some of them being common and widespread, others being quite rare. In no case were these plants so far beyond control as to constitute a serious pest, though in a few localities one species might occur in moderately dense patehes.

The following is a list of the Opuntias met with :-

1. O. monacantha, Haw.

2. O. tomentosa, Salm-dyck.

3. O. bergeriana, Weber.

4. O. robusta, Wendl.

5. O. spinulifera, Salm-dyek.

6. O. nana, Vis.

7. O. dillenii, Haw.

8. 0 . inermis, DC.

9. Common Indian or Barbary Fig, known under various local and scientific names. It will be referred to in this report as 0 . ficus-indica, Linn. Many varieties of this species are known.

10. The white-spined Barbary Fig (O. amyclaca, Tinore).

11. Nopalea cochinelifera, L.

1. O. monacantha, Haw.-This species, which has been referred to earlier in this report, and which is one of the pest pears of Queensland, was seen growing wild, but sparingly, in the neigh bourhood of Nice and Monaco in Southern France. The plants were evidently derived originally from local gardens. Risso (1844, p. 295) mentions that this species occurred as an introduced plant as Nice.

2. O. tomentosa, S.D.-A few plants belong. ing to this species were seen growing wild near San Remo in the French Riviera, but, like the above-mentioned $O$. monacantha, were evidently garden escapees.

3. O. bergeriana, Weber.-According to Mr. Alwyn Berger, this species, though locally abundant, occupies a very restricted area in the Riviera. It was seen in that region by the Com-
mission. It was originally a garden escapee. 
4. O. robusta, Wendl.-This variable species, with large rounded grey joints and purplish-red fruits, was met with occasionally in a few localities in the south-west of Spain-e.g., Jerez, Seville, Cordova. It does not appear to have spread to any extent.

5. O. spinulifera, S.D.-There was seen near Seville and Jerez, in Spain, a species of pear identical with that met with by us at a few spots in Capetown and near Fort Beaufort in Cape Colony. This Opuntia, which is related to the Westwood pear of Queensland, appears to have a quite local distribution and is not at all abundant.

6. O. nana, Vis. This low-growing species, possessing small rounded transversely wrinkled joints, thrives under colder conditions of climate than any of the other Opuntias met with in this region. It is known under various names, Schumanu (1899, p. 714) calling it $O$. vulgaris, Mill., and quoting amongst its synonyms, Cactus opuntia, Linn., 0 . italica, Tinore, and $O$. opuntia, Coulter. This author regards $O$. nana, Visiani, as being merely a variety of $O$. vulgaris. If this species is the same as that described by Linnæus -and of that there can be little or no doubtthen the correct name is $O$. opuntia as stated by Coulter. Linnæus (1753, p. 468) referred to the occurrence of his 0 . opuntia in Spain and Portugal, while Miller (1768) mentioned its presence (as 0 . vulgaris) along roadsides in Spain, Italy, and Sicily. Visiani named specimens from Dalmatia as 0 . nana. Tinore called it 0 . italica, using the name vulgaris for a very different plant, viz., O. ficus-indica. It is figured by Dr. A. Fiori (1896-8, plates fig. 1066). Risso (1844, p. 295) recorded two varietal forms of it, 0 . parviflora and 0 . latifolia.

Schumann (1899 a, pp. 29, 34; 1899, p. 715) stated that this species had run wild in Central Europe, more particularly at Bozen in the Tyrol and in pairts of Switzerland as well as in Dalmatia, its native home being the eastern portion of the United States of America, from Massachusetts to Georgia and Florida. Mr. A. Purpus, of Darmstadt, informed us that this prickly-pear is to be found commonly in Tessine, Switzerland. Burkill (p. 289) has referred to the apparent occurrence of this species in Spain, quoting Boissier (1839) as his authority.

7. 0 . dillenii, Haw.-This West Indian species, which has been already referred to in this report as being naturalised in Ceylon, India, and the Canary Islands, is known to occur along the Mediterranean coasts of France, Italy, and Sicily (Burkill, p. 288). In 1872 Insenga mentioned its presence in the maritime regions of Messina, Catania, and Syracuse, in Sicily.

The Commission found it growing quite commonly on the low-lying country in the neighbourhood of Algeciras, Cadiz, Jerez, and the mouth of the Guadalquivir River, in Southwestern Spain; in Calabria, in Southern Italy; in isolated spots from Messina to Palermo in Sicily; and at Beirut, Syria.

8. O. inermis, DC.-This species is closely related to the pest pear of Queensland and New South Wales, and resembles in some ways the species which is now so widely spread in the Punjab, India, and has been referred to already as the "Punjab Pear." Its presence in a naturalised state in South France, Catalonia (North- east Spain) and the Balearic Islands has been recorded by Schumann (1899 a, p. 30; 1899, p. 718). Some of his material from the last-named locality was seen in the herbarium of the Berlin Botanic Gardens. This author has included amongst its synonyms 0 . stricta, Haw., a form cultivated in Europe*; O. acrampo, Mill., a Peruvian species; and $O$. vulgaris, var. balearica, Weber. The habitat was unknown to him though he had seen dried specimens from the West Indies. Tussac believed that Haiti was its native home.

The species differs from the common pest pear of Queensland and New South Wales in several particulars, as has been already stated by Mr. J. H. Maiden (1912, p. 716). The latter plant has a more shrubby habit, while its joints are larger, relatively thinner, and of a much lighter green colour.

Though not uncommonly met with as a garden plant and occasionally growing wild in parts of Europe, it has not spread in such a way as to constitute a pest as its relative has done in Australia.

9. The common Barbary Fig, 0 . ficus indica, L.-This species is very widely spread around the Mediterranean littoral, where it is known generally as the Barbary Fig or Indian Fig (figue de Barbarie; fico di India). In Spain it is usually called the "Tuna castiliana," "Tuna malagana," $\dagger$ or " Higo chumbo," while Arabs often call it "Al hindi." In Sicily it is also known as "Fico d'India mansa," i.e., the domesticated Indian Fig. The scientific name commonly applied to it is $O$. decumana (see Burkill, 1911), though the names $O$. vulgaris and $O$. ficus-indica are also frequently used.

It is almost spineless and resembles the Kaalblad (?O. decumana, Haw.) of South Africa in many ways. An obvious difference is in the form of the joints, which in the former are practically symmetrical and relatively wide, while in the Kaalblad they nearly always have one side less curved than the other, so that their shape is almost broadly lanceolate. Then again the flowers of the Barbary Fig are generally yellow, orange-coloured flowers being the exception, whereas in the Kaalblad the reverse is the case.

Schumann (1899, p. 719) retains Miller's name 0 . ficus-indica for the plant, and quotes as synonyms Cactus ficus-indica, Linn., O. vulgaris, Tinore, and Cactus opuntia, Gussone. He also mentions that Weber regards $O$. decumana, Haw., and certain other species as additional synonyms. A distinct form, $O$. amyclae a, Tinore, the spiny Barbary Fig, has been regarded by many authors as being merely a variety of the above Opuntia (e.g., Berger, 1903, p. 93). Burkill (p. 288) uses the name $O$. decumana in preference to $O$. ficus-indica, Linn., on account of the confusion regarding the identification of the plant named by Linnæus. Mr. Berger (1912) has recently proposed a new name, $O$. ficus-barbarica, for the same reason.

* O. stricta, Haw., is a different plant whose native home is probably in the southern half of South America. It closely resembles, and is, perhaps, identical with $O$ anacantha, Speg., of North-eastern Argentina, and is apparently the same as the "Punjab Pear." O. acrampo apparently the same as the "Punjab Pear. O. acrampo
(i.e. $O$. airampo) is distinct from either $O$. stricta or $O$. inermis.

+The term "chumbera" appears to be used in Spain for either of the "Indian figs." 
Owing to the fact that the plant produces a large edible fruit, it has been widely cultivated and distributed, and many varieties of it exist in the Mediterranean countries.

That it was introduced very early into this region is evident from the writings of $P$. A. Mattioli, who stated that the plant was called an Indian fig beeause it was brought from the West Indies (1570, p. 211), while in an Italian edition of his work published apparently in 1604 it is remarked that the species was introduced during his time, i.e., 1500-1577.* It may be remarked here that in some of his editions the figure indicates the presence of spines on the plant, while in other editions the Opuntia is drawn as if unarmed. He evidently knew both the spiny and relatively spineless forms.

It was seen either cultivated or growing naturalised more or less commonly in the French and Italian Riviera; Spain (more partieularly in the southern portions, Andalusia, Granada, Seville, Algeciras, Gibraltar, \&c.); Morocco (Tangier); Algeria (along the coastal region); Tunisia (less common); Malta; Lower Egypt; and at Damascus in Syria. It was seen to be present here and there all along the Mediterranean coast of Italy from Mentone to Calabria, and also throughout Sicily. In the latter region $O$. ficus-indica is used quite commonly as a hedge along the railway lines, and in localities, e.g., at Mt. Pellerino, near Palermo, is very common, even growing spontaneously.

This species is cultivated not only for the sake of its fruit, but also on account of its joints, which are widely used as fodder for stock. Owing to the importance of this plant one is not surprised that the literature referring to it is somewhat extensive.

10. The Spiny Barbary Fig, O. amycloa, Ten. (or perhaps more correctly, $O$. ficus-indica, var. amyclaca, Ten.).-This Opuntia is very widespread in its distribution in the Mediterranean and was seen, sometimes cultivated but more usually either wild or growing as a hedge-plant, in Southern Spain; Italy (especially in Calabria and Apulia); Sicily; Morocco; Algeria; Tunisia; Beirut and other localities in Syria. It occurs commonly in Cyprus, in Palestine (Jaffa, Haifa, Acre, \&o.) and in parts of Asia Mlinor (Smyrna). Gennadius' account. (1898) leaves little doubt that the species found in Cyprus is $O$. amycloa. In Tunisia and Moroceo it is much more eommon than ficus-indica, while along the coast of Syria and Palestine it appears to be the only species usually met with. Its wide distribution is probably due partly to the presence of welldeveloped spines which protect the plant from most stock and make it a more suitable hedgeplant, and partly to the fact that its fruit is edible, being scarcely inferior to that of the ordinary "Indian fig."

The main difference which one can readily recognise between these two species is the presence of stars of white spines on the joints of $O$. amycleca, while $O$. ficus-indica is almost unarmed. The shape of the cladodes is practically the same, the flowers are similar and the

* There is little doubt that various species of Cactacer were introduced into Spain very shortly after the discovery of the West Indies and adjacent parts of the mainland of America, fruits very much alike at first sight, though in amycloe $a$ the last-mentioned are usually somewhat smaller and possess more seeds.

The Spaniards term this species the "Tuna americana," while the Moors of Morocco generally use the name "Al hindi" for both species. Sicilians know it as "Fico di India mascolino," or "Fico di India selvaggio." The Syrians use the name "Sbyr" or "Sobbeyr" or else the French term "Figue de Barbarie," no distinction being made between the two kinds of prickly-pear.

It has been mentioned above that this Opuntia is regarded by many authors as being merely a variety of the smooth-jointed Barbary Fig. Though Mattiolus (1570, p. 211) had long ago already distinguished these two kinds, it was not until 1826 that Tinore (1826, p. 15) named the spiny form as $O$. amycloca. Archangeli (1882, p. 248), Labouret (1850, p. 468), and Schumann (1899 b, p. 719) thought it a distinet species. Cupano and Bonanno (quoted by Biuso, 1879, p. 25) have named it $O$. major, while Fiori $(1896-8$, p. 328$)$ refers to it as his variety maxima of $O$. tuna, Linn. On the other hand A. Berger (1903, p. 93) believes $O$. amycloea to be merely a cultural variety of his 0 . ficus-barbarica (i.e., o. ficus-indica), a name which he $\mathrm{h}$ as given (1912) to the smooth-jointed Barbary Fig. Berger's view is supported by Biuso (1879, p. 24) and by Eichlam (1910, p. 68).*

It is a coincidence that in South Africa also one meets with two common species side by side, viz., the "Kaalblad" and the "Doornblad," which have the same shape of joint and similar flowers and fruits, but the former is practically unarmed, while the latter is armed. Intermediate forms may be seen, so that one is led to believe either that there are two species capable of hybridising, or else that there is one variable species, the latter view being held by us in regard to the South African prickly-pear.

11. Nopalea cochinelifera is met with occasionally in certain of the warmer parts of the Mediterranean, e.g., Southern Spain, in a more or less cultivated condition.

While studying the rich collection of Cactaceæ at La Mortola, certain prickly-pear plants were observed which possessed eharacteristies recalling, those presented by the two commonest species in Queensland. They were as follows:- $\dagger$

(1) "Opuntia, sp.-Cuba." This is evidently identical with our commonest Opuntia, 0 . inermis.

(2) "O. inermis, DC.-Florida (Dr. J. N. Rose)." The same remark applies to this one also.

(3) "O. inermis, DC. (Hort. Mortol., p. 411)-Mexico."

(4) "O. tuna, West Indies." Evidently the same as our $O$. inermis.

* The following observations by one of us (H.T.) may be worth noting:-Though the spineless form almost invariably grows true to type, both when propagated from stem-joints and when raised from seed deposited by birds, as on Mt. Pellerino, yet at La Favorita, Palermo, a series of spine-bearing joints corresponding to the typioal $O$. amycloea form were observed growing from discarded cladodes of the spineless variety.

$\uparrow$ It must not be concluded that the names used represent Mr. Berger's final conclusions regarding their nomenclature. 


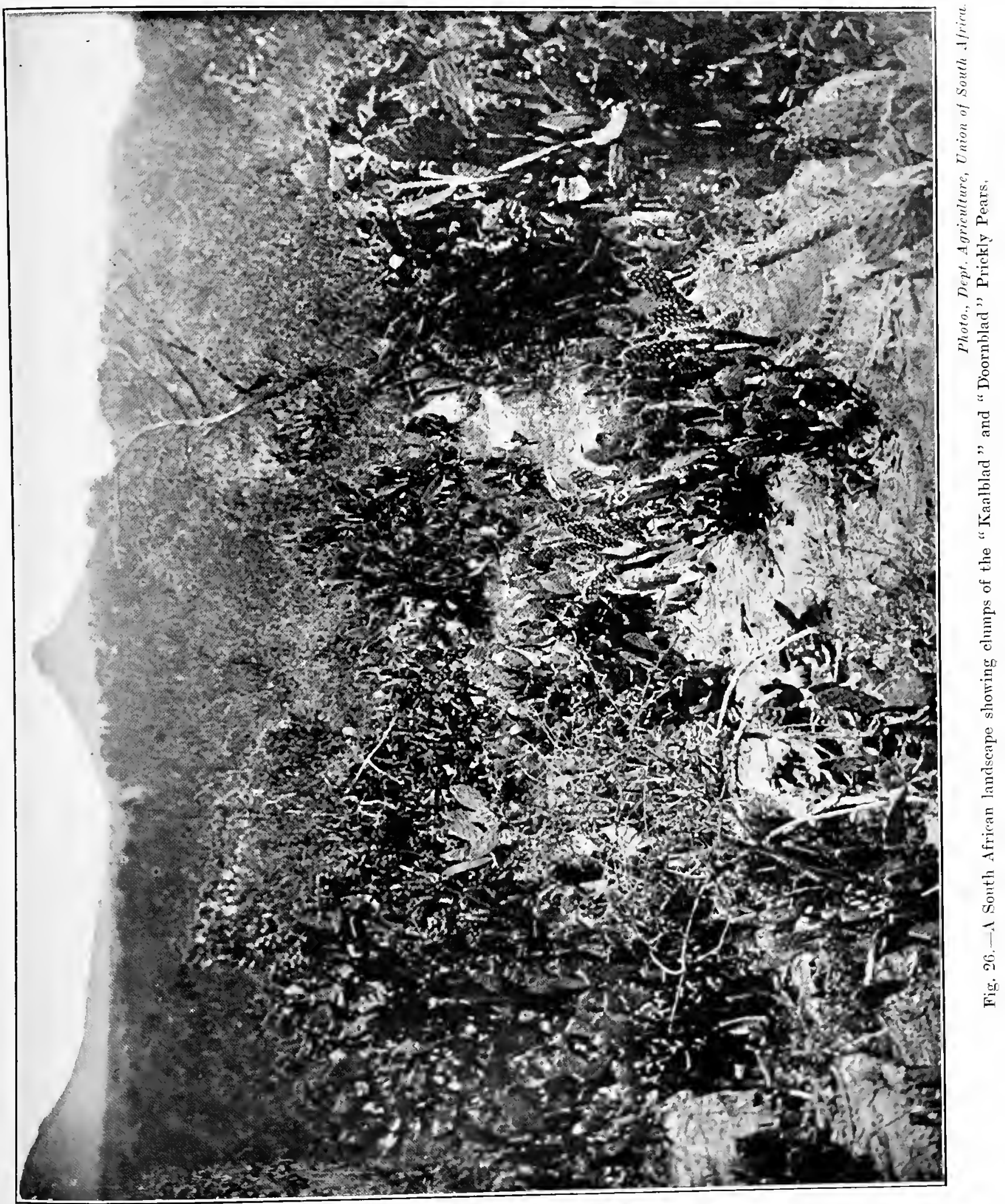



(5) "O. elata, Lk. and Otto-from Dr. Weber, Paris-thorn-bearing
variety."

(6 "O. elata, L. and 0.-from Vienna Botanical Garden." This and the foregoing recall our spiny pest pear, now naturalised in the Burnett Valley (Gayndah, Degilbo, etc.).

(7) "O. stricta, Haw., syn. O. anacantha, now referred in "Hortus Mortolensis"' (p. 411) to O. inermis, DC.

(8) The commoner Queensland pricklypear represented by a plant labelled o. inermis, DC.-from New South Wales.

In the Palermo Botanical Gardens, plants evidently identical with our commonest pest species (O. inermis) were labelled as 0 . glaucophylla.

\section{DESTRUCTION BY INSECT AND OTHER ENEMIES.}

No destructive insect was found, nor did inquiry reveal the presence of any which produced perceptible injury on the attacked plants.

Diaspis.-A species of Diaspis was seen mor. or less commonly and plentifully on $O$. ficus indica and 0 . amycloca in Spain and Italy, and on the latter in Syria and the three Barbacy States visited, but, even though heavily infested, plants did not show any ill effect. It was also met with on $O$. monacantha in some English collections. This insect was seen more commonly in Italy in garden collections than on plants growing in the field. It is referred to earlier in this report and has already been recorded as accurring in Queensland (Tryon, 1911 b, p. 18). Fernald (1903) has mentioned the presence of Diaspis echinocacti, Bouché, in Europe and Algeria.

Coccus spp.-The true cochineal insect Coccus cacti, similar to that raised in the Canary Islands, was seen growing well on cultivated plants of $O$. tomentosa in the Jardin d'Essai at Algiers, but not on the smooth Barbary Fig plants ( $O$. ficus-indica) growing in abundance close by. $O$. tomentosa is the species used in the Canary Islands as the "nurse plant" for the young insects, and is identical with the tree-pear occurring at Helidon and elsewhere in Queensland. No detrimental effect was noticeable. Trabut (1910) has referred to the presence of this insect in Algiers. Coccus cacti was formerly cultivated in the warmer parts of Spain, but, as far as known, does not occur there now. Inquiry in the various districts failed to gain any information regarding its existence there at the present time.

- A mealy bug (Rhizococcus, sp.) was occasionally seeil on Opuntias, especially $O$. monarantha, in European green-houses, but from information received, it is known to be a general feeder.

Kuhlgatz (1898) and Hirseht (1899) have given an account of certain Coccids, e.g., Rhizococcus multispinosus Kuhlg., and Dactylopius longifilis Comstock, which are known to attack cactus plants in European glass-houses, where artificial conditions exist.
According to Prof. Stefani Perez, another coccid, Icerya purchasi, occasionally attacks o. ficus-indica in Sicily.

Diptera.-M. J. Goffart informed the Commission that a small reddish insect larva at times attacks the ripening fruit of $O$. ficus-indica near Tangier, Morocco, but none was found, nor were signs of insect injury to any part of the plant detected at the time of our visit. No observations as to the character and life-history of the larva were made by this botanist. It is probably a Cecidomyiid.

Prof. Perez, Palermo, referred to the fact that a fruit-fly, Ceratitis capitata, attacks the fruit of o. ficus-indica; but it scarcely, if at all, injures the plant, except as a crop-producer. Even if it were injurious to Opuntias, its introduction into Queensland could not, for other reasons, be advocated.

Red Spider.-Hirscht (1899,.p. 797) gives an account of the ravages of the so-called "red spider," Tetranychus telarius, which causes the formation of yellowish, reddish, or rusty spots which soon extend so widely as to cover the surface of the infested plant. As a result of the injury, growth ceases and eventually the attacked portions may fall to the ground. This mite is, however, not restricted to the Cactacex, but is a general feeder.

Snails.-A small species of snail (? Helix pisana) known locally as babbaluci, has been referred to by Biuso (1879, p. 104) as feeding on the edges of young tender joints of $O$. ficusindica in Sicily. It occurs most commonly in districts whose soils are rich in lime, and is especially evident after heavy rain. Biuso states that these molluses are collected and destroyed before the time of egg deposition. Prof. Perez, of the University of Palermo, mentioned that this snail was at times a serious pest to the cactus in the neighbourhood of that city. As the animal attacks other plants, its introduction into Australia need not be considered.

\section{DESTRUCTION BY DISEASE.}

Near Tangier, Morocco, a few clumps of very old prickly-pear (O. ficus-indica) were found to be suffering from a disease which caused many of the plants to die. An examination of the affected plants, which were all close together, led to the belief that the condition was probably due to deficient root action. Most of the diseased pears were, however, producing young joints quite vigorously at the time of the Commissions's visit. The malady is probably the same as that referred to later as "cancer," the symptoms being similar.

Much more attention has been given to prickly-pear diseases in Italy than elsewhere in the Mediterranean area, but an examination has shown that none of these would be of much value in controlling the pest pears of Queensland. They are termed-(1) Male nero; (2) Rot or gangrene (Male di cancro; Marciume. or Krebs) ; (3) Male di verme; (4) Leaf scab.

\section{Male Nero.}

This malady was brought under notice by Sig. A. R. Ragusa, of Palermo, who mentioned that the name was applied to it on account of 
the presence of a dark, tear-like fluid which issued from the affected parts. The disease, which was not regarded as being very detrimental, was usually seen on older plants, more especially during seasons of low temperature. Sig. Ragusa thought that the condition was due to a root-malady, and was probably identical with the "cancer" described by Buiso (1879, pp. 102-3) under the name of "Male di cancro." A grower at La Favorita, near Palermo, used the term "Male nero" for a similar, if not identical, disease whose presence was indicated by the death and decay of individual joints or portions of a joint, from the edges inwards, the alteration being often accompanied by the exudation of drops of dark, sticky material. Low temperatures and rainy weather favoured the development of the malady. The symptoms and effects of this trouble are similar to those described as occurring in Queensland (Tryon, 1908, p. 143; 1911 , p. 6) in plants suffering from " dry rot," a disease which is suggested as being due to unsuitable soil conditions interfering with healthy root action. It is not, however, a malady which can be utilised in destroying prickly-pear in Australia.

\section{Cancer.}

This disease, which has been referred to by Biuso as Male di Cancro, by Savastano as Marciume, and by Sprenger as Krebs, was noticed near Palermo. Affected plants were chlorosed, showed no signs of growth, and possessed little or no fruit. On being pushed it was observed that there was a tendency to topple over, thus indicating that root decay had set in. Those which were attacked died, as also did those planted to replace them, and the disease tended to spread outwards from infected situations. An examination of the roots and base of the stem showed that there had occurred a decomposition of the tissues between the woody structure and the epidermis, these becoming translucent and yellow, changing to dark brown.

Although the affected plants of $O$. ficus indica examined near Palermo did not present general symptoms corresponding in all particulars with those described as occurring in specimens of the Queensland pest pear suffering from " sleeping sickness " (Tryon, 1908, p. 143; 1911, p. 7), there is little doubt that the two diseases are the same, and are probably caused by a root-destroying organism, which later unpublished investigations indicate to be a species of Pythium.

Biuso (1879, pp. 102-3) has given an account of a contagious malady which seems to be the same disease as that just referred to. $\mathrm{He}$ mentions that the gangrene produced usually manifests itself in the basal portion of the stem, generally in spring or autumn, as an alteration of the woody tissues, extending gradually to the more internal tissues, which decompose into a fetid yellowish-green mass.

The same malady is described by Savastano (1897, p. 110) under the name " Il marciume," as occurring near Catanzaro (Calabria) and in Sicily. An English summary has already been published by one of the members of this Commission (Tryon, 1908, p. 143; 1911, p. 15). It is stated that the disease travels rapidly from the roots along the vascular region of the trunk and branches to the joints. Here the cellular structures undergo alteration so as to become translucent. Besides, there is a formation of tubercles in groups along the course of the conducting tissues, each tubercle being composed of transparent cells surrounded by other cells with thicker walls so as to form a capsule. No external swellings are noticeable, however. The disease is regarded by Savastano as being due to a bacillus, which on inoculation is capable of reproducing the disease under certain conditions, but it was found that healthy plants on inoculation did not contract the malady. He did not regard soil-water as a necessary agent for its transmission.

Sprenger (1901, p. 78) has referred to a disease under the name "Krebs," occurring in South Italy, which is probably the same as that referred to above. The rotting of the whole plant is the result of its activity.

Mr. Berger related the symptoms of a disease formerly attacking prickly-pear plants, 9 or 10 years old, at La Mortola. It was probably the same malady as that just mentioned.

Male di Verme.

Insenga (1879) has given attention to a disease which is known in Sicily under this name. Biuso $(1879$, p. 101) states that it is locally believed to be due to the attacks of an unidentified caterpillar-hence the name given to the malady -and that the appearance of affected plants suggests the reasonableness of this idea. He goes on to say that Insenga has proved it to be due to a fungus which invades the joints and arrests the activities of the conducting tissues, thus producing chlorosis and other evidences of plant starvation.

\section{Minor Diseases.}

Leaf Scab.-This disease is regarded as being due to a fungus (Phyllosticta opuntice, Sacc. and Speg.), but it is suggested that this organism only becomes established on injured areas. It is local in its distribution on the plant and has very little effect except when it covers a great portion of the surface of the joints. Comes (1891, p. 53); Voglino (1905), p. 232); Briosi and Cavara (1890); and Sprenger (1901, p. 78) refer to it.

This fungus is widely distributed throughout the Mediterranean coasts, being commonly seen on $O$. bergeriana, in a plant now naturalised in the Italian Riviera. A similar, if not identical, organism is met with on the pest pear in Queenslaind.

Phytophthora cactorum, Leb and Cohn, a serious pest of Cactaceæ, especially young plants, occurs in some European greenhouses, where it causes a rotting that commonly ends in the death of the infested host, the decay usually extending upwards from the lower portions of the plant. An account of the parasite, which was not met with by the Commission, is given by Hartig, by Prillieux, and by Hirscht $(1899$, p. 795). P. cactorum is allied to many dangerous enemies of economic plants, and its own attacks are not restricted to the Cactacese.

The black wart fungus, Diplodia opuntice, Sacc., has been recorded as a parasite of cultivated Opuntias in Europe. Cooke (1905, p. 125; 1906, p. 168), in referring to the occurrence, mentioned 
that the injury is sometimes severe (Tryon, $1911 \mathrm{~b}, \mathrm{p} .16$ ). It is not, however, likely to be of much use in controlling the Australian pest pears.

Phoma torrens, Sacc., has been referred to by Saccardo as an enemy of Cactaceæ in the Rome Botanic Gardens, but its effects do not appear to be sufficiently serious to justify its introduction into Australia.

Certain minor maladies were met with at La Mortola. Amongst them was a "sun scald" affecting 0 . bergeriana and other species, especially when grown in exposed situations. The joints were yellowish and spotted with pale rusty-brown markings, which later became larger and greyish, when the perithecia of a fungus related to Mycoprion were to be observed within the diseased area. As a rule, no further results were brought about, though occasionally the affected segment ceased to produce new growth. The condition resembled one met with on pricklypears at Gayndah, in our own State.

A few plants showed the presence of pale brown areas with lighter coloured centres, individual spots coalescing to form large discoloured patches with a simple wavy outline. Ultimately the superficial tissues may die, when the perithecia of a fungus make their appearance. This malady appears to be unimportant.

A single specimen of $O$. megacantha, S.D., was found to have some of its segments affected by a malady for which the name " zone spot" may be employed. There were well-defined redbrown concentric areas, which were of a lighter colour at the margin of each ring. These patches may continue to widen and eventually coalesce with other spots, so that discoloured areas several inches across may be produced. The affected epidermis may become grey and flake off, exposing brownish scars, but the underlying tissue does not seem to be injured to any degree, so that the malady is not of any importance there.*

The occurrence of etiolation and chlorosis in Opuntias has been referred to by a few writers such as Meyen, Hallier (1868, p. 100), and Hirscht $(1899$, p. 796). These affections, which are also met with in Queensland (Tryon, $1911 \mathrm{~b}$, p. 17) do not appear to be the result of parasitic agency.

Besides these, various other fungi have been recorded by Saccardo, Rolland, and other mycologists, as attacking $O$. ficus-indica and other prickly-pears in Southern Europe.

* F. von Thumen, when dealing with the fungi of fruit trees $(1887$, p. 70) enumerates the following fungi as occurring on 0 . ficus-indica :-

On the fruit.-Aspergillus africanus, Dur. and Mntg.

On the stem joints.-Diplodia opuntice, Sacc. ; Nectria jucunda, Mntg. ; Phyllosticta opuntice, Sacc. and Speg.; Sphoeria cacti, Schweinz.

On the stem. - Diderma vaccinum, Dur. and Mntg.; Didymospharia opulenta, Dur. ; Leptospharia sicula, Sacc. and Beltr.; Mycoprion licatense, Sacc.; Perisporium wrightii, Berk. and Curt.; Phoma cacti, Berk., var. Opuntice, Sacc.; Pleurotus opuntias, Dur.; Rhytisma cacti, Schweinz; Sclerotium cactearum, Speg.; Teichospora inverecunda, Sacc. ; Aposphoria fibrisequa, Sacc.; and cunda, Sacc.; Aposphoria

\section{DESTRUCTION BY MECHANICAL MEANS.}

Of the species occurring wild in the Mediterranean littoral, only two are really common. Owing to the value of their fruit and joints as food they are widely cultivated, and the question of destruction is not often raised. There are several factors which control to a large extent the spread of Opuntias in this region, one being the relatively large agricultural population engaged in rclatively small areas, another being the hot, dry climate which is experienced during a considerable part of the year, more particularly in Spain, Southern Italy, Sicily, Northern Africa, Syria, and Palestine.

When destruction is deemed necessary the plants are cut down by manual labour, allowed to dry for a few days under the influence of the hot sun, and then burnt. Occasionally a trench is dug, the plants are thrown into it, and on decay serve as manure. Even if cut down during the summer and left alone, few of the joints grow again in the Barbary States on account of the dry heat.

It is worthy of remark that, although the fruits are so much used as food and the seeds thus distributed widely, one very seldom meets with seedling plants. This may be due to a destruction of the germinating power of the seed by the intestinal juices, or to the detrimental effect of the summer elimate.

\section{DESTRUC'ION BY UTILISATION.}

Just prior to our leaving Europe for the United States, there was received from Mr. J. C. Brünnich, the Chemist to the Department of Agriculture, Queensland, a tabulated statement of the result of his analyses of specimens of-(1) green plants, (2) air-dried plants, and (3) the fruit of the various kinds of prickly-pear occurring in Queensland. This report, which was kindly prepared by him at the request of the Commission, was asked for so that we might be acquainted with the amount of fibre, galactan, sugars, etc., present in our commoner naturalised Opuntias, and therefore in a better position to discuss with those technically interested the possibility of utilising these constituents in the arts or industries. Owing to its value, it is printed in extenso at the end of this section of our report.

\section{Utilisation as Food for MaN.}

As $O$. ficus-indica and $O$. amycloea are not naturalised in Australia, and more especially since the remarks would not necessarily applv to the pest pears there, there is no need to enter extensively into the matter of the utilisation of these plants in the Mediterranean zone as articles of food for man. The fruits of both species are esteemed as an article of food br the peoples of the Mediterranean littoral, and since the plants are usually readily grown and vield abundance of fruit during certain seasons, it is not surprising that these Opuntias have a considerable economic value there. In drier regions-e.g., Egvpt. Algeria, and Tunisia, as well as in parts of Morocco and Andalusia, O. ficus-inficn is care- 
fully propagated from joints; irrigation, cultivation, and manuring being often resorted to in order to produce good plants. In Syria it is a common practice to renew the plants every five to ten years, since older specimens are regarded as being less efficient fruit-bearers. In some places-e.g., in Italy, Sicily, and Damascus (Syria), this species is planted out and cared for in much the same way as an orchard. In some parts of the Barbary States men are employed to guard the ripening fruit against thieves. It is not uncommon in Algeria to see plantations of this cactus, intended mainly for cattle fodder, but also for fruit-production, surrounded by a hedge of the spiny $O$. amyclcea or of thorny mimosa as a protection against stock. $O$. amycloca is generally grown as a fruit-producing hedge.

In the Mediterranean countries, especially Spain, Italy, and Sicily, there are numerous wellestablished varieties of 0 . ficus-indica, the fruits having certain characteristics and varying in value according to their edible qualities.

Fruits are sold in great quantities and at a very low cost for about four months of the year. They constitute a very important part of the food supply, especially of the poorer people. Many are eaten at a time, the seeds being swallowed, sometimes with ill result. At Jerez (Spain), according to Senor P. Gonzales, of that city, and no doubt elsewhere, there have been many cases of intestinal obstruction, necessitating medical treatment and even surgical operations as a result, and death has followed in some instances.

It is worthy of note that large quantities of prickly-pear fruit are being exported from Italy to the United States.

Owing to the very important place held by the Indian or Barbary Fig as a cheap and abundant article of diet, a good deal of literature has been written regarding its cultivation, uses, varieties of fruits, \&c., the most important perhaps being the works of Biuso and Guastella.

\section{Utilisation as FODDER For Stock.}

As already mentioned, both species are commonly used in nearly all the Mediterranean countries as fodder for animals, very little use being thus made of them, however, in Italy and Sicily. Of course, the smooth-jointed $O$. ficus-indica is preferred, and is usually fed without any treatment to cattle, goats, sheep, pigs, and camels, whereas the spiny species, O. amycloca, can bo fed only to camels unless the spines be first scorched off, as is done in Cyprus, a few parts of Spain, and the Barbary and Syrian coasts. Though utilised all the year round, it is during seasons of drought that these plants have a particular value-a fact already known to Australian stock-owners. The summer in the Mediterranean region is a relatively rainless period, and it is not an uncommon sight to see both species of Opuntias more or less shrivelled or even killed as a result of the very hot, dry climate, this being especially the case in the Barbary States, where these plants are confined to the coastal and lower upland regions.

Professor L. Trabut, Director of the Botanical Service of Algeria, has endeavoured to improve the feeding properties of prickly-pears. A spineless species, $O$. anacantha, Speg., was forwarded from Argentina by Dr. C. Spegazzini for use in that country as a cattle fodder. In Tunisia. the matter has also called for attention. Mr. P. Bourde dealing with it in a paper published in 1894. Amongst others, Baillaud (1910), Jehanne (1904, 1906), and Perkins (1912) have referred to this method of utilising prickly-pears in Mediterranean countries.

As it is generally recognised that cacti do not possess a sufficiently high nutritive value to be used as a complete ration for stock, Professor Tucci, of Palermo, in 1890 formulated a number of cattle rations for use at different times of the year, various substances of higher nutritive value being suggested as additions to the Opuntia. Chemical data relating to $O$. ficus-indica have been published by Ferrero (1874) and Mancusolima (cf. Guastella, 1913), and calorific equivalents of the different constituents by Giglioli in 1903, while the value of prickly-pear as a stock food has been considered by Chicolo $(1871,1874)$, Biuso (1879, pp. 152-174), and Guastella (1913, pp. 48-54). Sotyia (1898, pp. 113-167) has also dealt with this latter aspect in its application to Corsica and Sardinia, where the same two species of Opuntia are also met with. Bourde in 1896 advocated the use of prickly-pear as a forage plant in Tunis, and suggested the employment of equal parts of the cactus and chaff. Biuso (1879, pp. 162-3) has given a description of a special cutting machine devised for reducing prickly-pear to a state suitable for cattle feed.

Dr. G. Sotyia's work has reference to the utilisation of the local Sardinian prickly-pear as fodder for milch cattle in an island where drought conditions are by no means uncommon. The animals are compelled to subsist for some months on stubble and dry grass stalks scorched by the hot sun, and, as a result, their milk yield decreases, and may even cease, especially during August and September. Dr. Sotyia points out that this is caused by. a deficiency in albuminous matter in the ration, brought about by the absence of succulence in the fodder, and quotes Wolff to the effect that it is due to this fact that even hay of the best quality will not maintain a high milk yield unless some succulent food be present, on account of influence of the latter in increasing the absorption of water and albuminous matter, both of which are favourable to abundant lactation.

The prickly-pear, which was used finely cut up, was found to have an average food value in protein substance, fat, and other carbohydrates, which fell below the standard ration and was therefore supplemented by an adequate amount of bran or dry grass of known composition, so that the constituents of the mixture corresponded approximately in amount to Wolff's standard ration for milch cows, viz., protein, $1.250 \mathrm{~kg}$.; carbohydrate, $6.250 \mathrm{~kg}$.; and fat, $.200 \mathrm{~kg}$. per $500 \mathrm{~kg}$. of live weight. On this basis, the amount of " pear " used varied for individual cows from 24.37 to $31.25 \mathrm{~kg}$. daily. The ration was readily eaten by the animals.

The milk yield was examined daily, and the results compared with those obtained both before and after the experiment, and in one instance with that yielded by animals which had been deprived of their quota of prickly-pear, although given a ration generous in other respects. In 


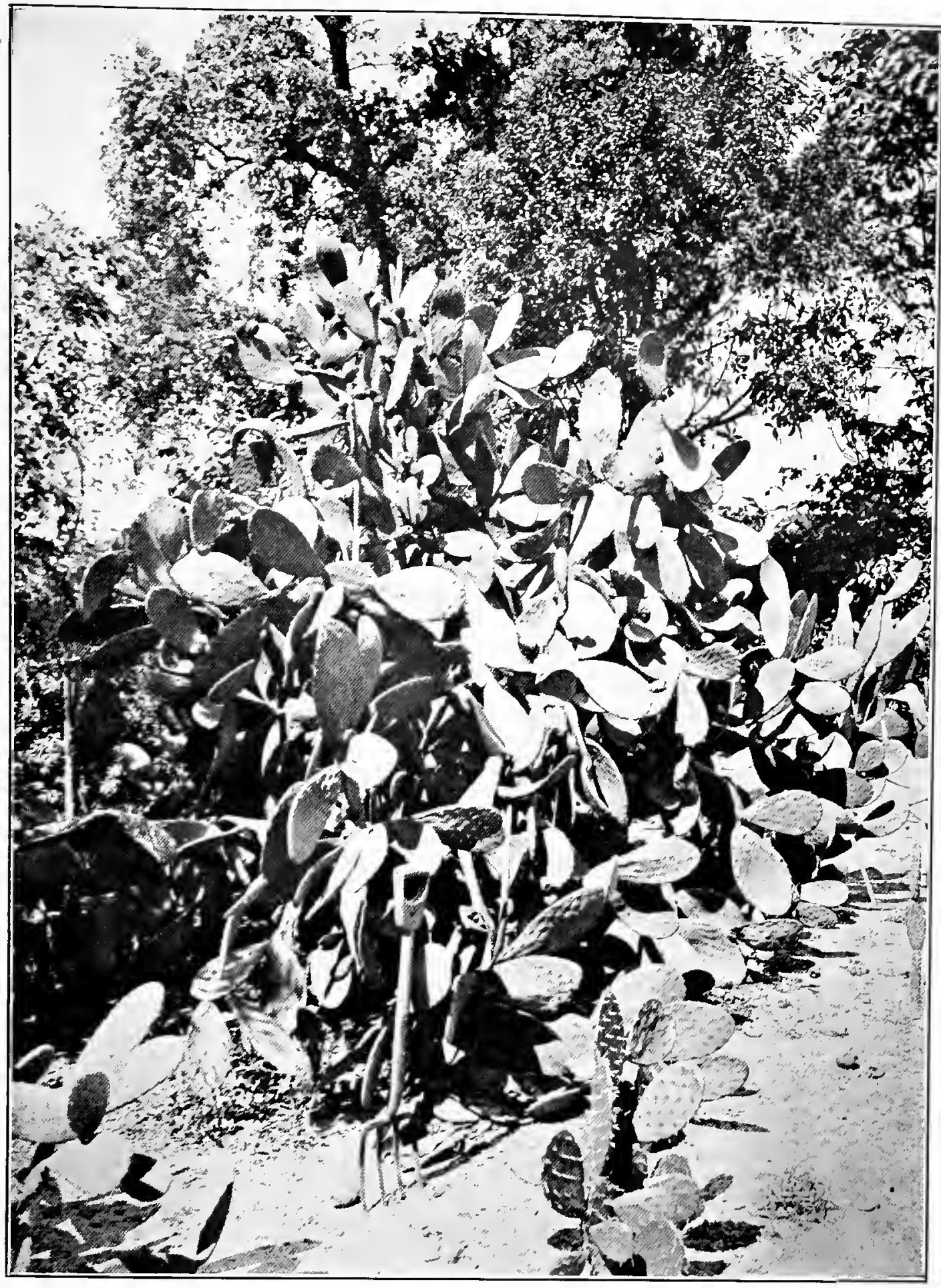

Photo. J. $H$.

Fig. 27. The "Indian Fig"-O. ficus-indica-from a specimen in Sydney Botanic Gardens. This

species produces edible fruit largely nsed in the Mediterranean conntries and elsewhere.

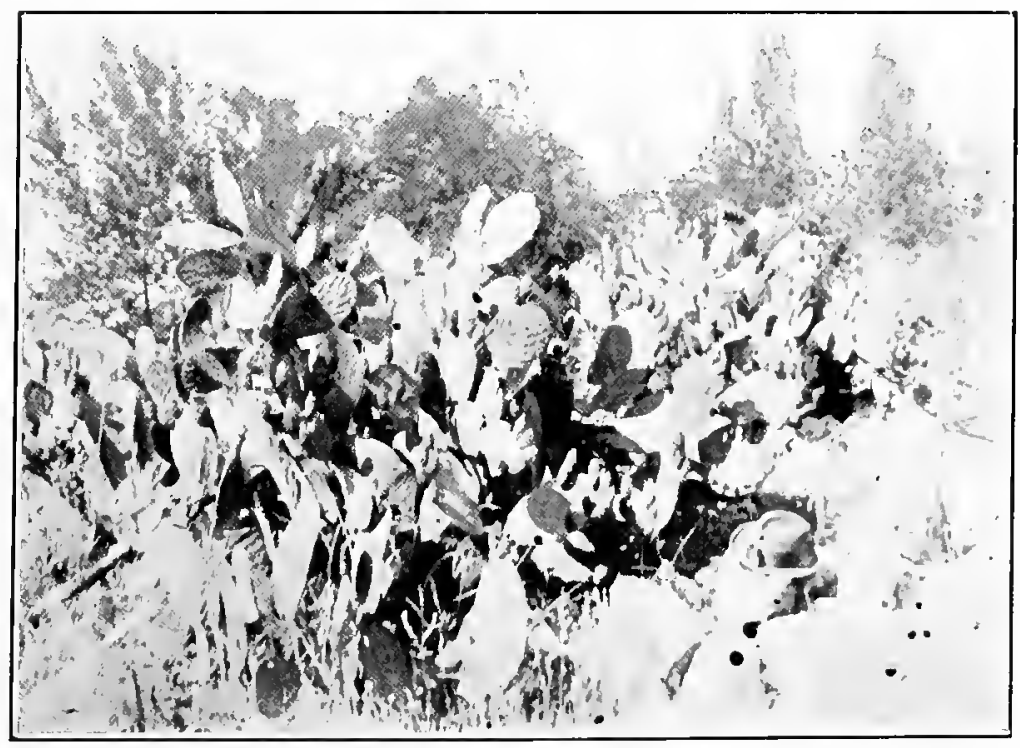



addition to comparing the amount of milk obtained in a given time, there were estimated the density of the milk and of the whey as well as the proportionate amounts of butter-fat, total solids, water, casein, milk sugar, protein, ash, albuminoids in the total solids, nitrogen in the total solids, albuminoids in the milk, and nitrogen in the milk.

As a result of many analyses it was found that, although the composition of the milk varied in accordance with several factors which ordinarily determine such variation, e.g., race, individuality of cow, time in period of lactation, hour of milking, health, etc., there was little or no influence exerted on it by the pear contained in the ration. On the other hand, there was a marked increase in the quantity of milk produced, and since the composition remained the same, except for normal differences just indicated, the aggregate amount of butter-fat and other constituents of the milk was correspondingly increased.

Dr. Sotyia estimated that the average daily appetite of a cow for " pear" (O. ficus-indica) might be taken as 25 kilogrammes, which would contain about $0.135 \mathrm{~kg}$. of protein, $0.032 \mathrm{~kg}$. of fat, and $0.650 \mathrm{~kg}$. of other carbohydrate. In order to bring this up to Wolff's standard ration for a cow weighing $500 \mathrm{~kg}$., he would add $1.115 \mathrm{~kg}$. protein, $0.168 \mathrm{~kg}$. fat, and $5.600 \mathrm{~kg}$. of carbohydrate, these amounts being yielded by about $14 \mathrm{~kg}$. of good meadow hay. In view of the abundance in Sardinia of such succulent food as prickly-pear, this author believed that his investigations had shown how the difficulties experienced there regarding milk production might be overcome.

\section{Utiuisation for Alcohol Production.}

In Algeria the juice of the fruits is often fermented to make a low-grade liquor used by some of the poorer Arabs. Mr. J. L. Abrines, of Gibraltar, informed the Commission that the manufacture of alcohol from prickly-pear was tried in Granada (Spain) some years ago, but, owing to the heavy excise imposed by the Spanish Government upon all alcohol, the venture did not become a commercial success. Bourde (1896, p. 652) made a brief reference in 1896 to the distillation of prickly-pear fruit in Spain.

Considerable attention has been given to the question of using the "Indian Fig " in this way in Italy and Sicily, Biuso (1879, pp. 139-151) Sprenger (1901), and Guastella (1913, pp. 55-59) dealing with it. Biuso (p. 116) quoted an analysis by Mancuso-Lima $(1878$, p. 51), in which the amount of glycogenic matter as produced in ripe fruit of 0 . ficus-indica is given at 36.64 per cent.

Ulpiani and Sarcoli (1901, p. 57) found that the juice expressed from its crude pulp contained 12.8 per cent. of sugar; the pulp itself, containing the seeds, 10.34 per cent.; and the complete fruit when dried, 7.9 per cent. They found that the ferment (Saccharomyces opuntioe) ordinarily associated with the fruit does not bring about the production of the full amount of alcohol theoretically possible from the quantity of sugar present. Another yeast (Saccharomyces pastorianus) was ascertained to be quite effective if allowed to act on sterilised fruit, but if acting along with $S$. opuntio its action became inhibited. It was recognised that the expense incurred in sterilising the fruit to destroy $\$$. opuntice before the addition of $S$. pastorianus would not be justified when regarded from a commercial point of view.

Guastella has given an account of V. Florio's establishment in 1856 at Catania (Sicily) of a distillery to extract potable spirit from the fruit of $O$. ficus-indica, the imposition of a heavy excise by the local municipality being the cause of the failure of this undertaking, though an average of about 8.6 litres of alcohol was produced from each kilogramme of fruit. An attempt made by Messrs. P. and A. Atanasio at Palermo proved a tailure, partly on account of their using an unsuitable variety, and partly on account of the high price of the fruit, due to a strong demand for it as an article for human consumption.

Since Ulpiani and Sarcoli carried out these experiments, other Italian investigators have given attention to the question of alcohol production from the fruit of 0 . ficus-indica. In 1908 A. Sanna (1908, pp. 550-561) published additional analyses of the fruit, and described a method of preparing from it a spirit corresponding to a true cognac.

Within a few weeks of the Commission's visit, Prof. S. Cettolini (1913, p. 456-9) furnished an account of further investigations, the following summary of this work being published by the International Bureau of Agriculture, Rome (1913, p. 1295).

The writer recalls the experimental results obtained some years ago by Dr. Sanna and Colladel, of Cagliari, in their attempt to distil prickly-pears, which grow in Sardinia, without any cultivation. The fruit was small but heavy, averaging $3.6 \mathrm{oz}$. each, owing to the large number of seeds and the consistency of the pulp. When peeled, crushed, and submitted to pressure, $432 \mathrm{lb}$. yielded 26.8 gallons of a somewhat viscous juice having a density of 1.0548 . Skins represented 37.64 per cent. of the weight, and seeds 4.2 per cent., leaving a little under 59 per cent. for the material to be used for alcohol extraction. The analysis yielded the following results:Whole fruit--albuminous substances, 6.75 per cent.; oily substances, 0.278 per cent.; cellulose, 1.342 per cent. Juice-extractable material, 15.54 per cent.; acidity, 0.0102 per cent.; ash, 0.692 per cent.; saccharine substances, 11.20 per cent. It was remarked that the saccharine substances were essentially aldehydic in character and present in sufficient quantity to be distilled economically, whereas the acidity was insufficient.

After a series of trials the best results were obtained by crushing the unpeeled fruits and putting the pulp thus obtained into bags and subjecting it to high pressure. The lack of acidity was then corrected by the addition of 0.32 oz. of tartaric acid per gallon, and the liquid inoculated with a good alcoholic ferment in a very active condition. The fermented liquid contained 5.98 per cent. of alcohol, showing that the saccharine material was well utilised. By distillation and subsequent rectification, there was obtained a spirit with a pleasant ethereal odour, which would render it unsuitable for various industrial purposes. It is estimated roughly that 100 lb. of the fruit of this prickly-pear would produce 0.6 gallons of alcohol, and taking $120 \mathrm{cwt}$. of fruit 
as an average yield per acre, 80 gallons of alcohol may be obtained per acre. The cake, consisting of the refuse after pressing, could be used as a stock food. When one considers that this matter of so utilising $O$. ficus-indica has been inquired into in Italy, where the fruit has a commercial value as an article of food, and is therefore not a waste product, it seems that research, from the same standpoint, into the potentialities of the fruits of Queensland prickly-pears, which are certainly waste products from our point of view, should merit some attention, particularly as our pest pears, especially the "Gayndah pear," are so prolific in their fruit production.

Whilst in England the advice and assistance of Professor W. R. Dunstan, Director of the Imperial Institute, London, were sought in regard to the question of the utilisation of Opuntias or of their constituents in the industries. $\mathrm{He}$ informed the Commission that the matter had been brought before the institute on various occasions previously by the Governments of Australia, South Africa, and St. Helena. Neither he nor Dr. T. Henry, the Superintendent of the Laboratories, was favourably impressed with the commercial possibilities. Their investigations led them to believe that Opuntia fibre could not compete with other cheap fibre plants which were more suitable for paper-pulp making; nor could the plant compete with other substances as a possible alcohol producer. The possibility of making use of the mucilage had not been taken up by the institute.

Professor Dunstan kindly furnished the Commission with a report dated 27th June, 1913 , the following part dealing with the question of alcohol production :-

" In 1908, the remarkable announcement was widely published that a chemist in Brisbane had discovered valuable commercial possibilities for the prickly-pear, which led him to conclude that, instead of the plant being ruthlessly destroyed, its cultivation onght to be encouraged. The prineipal elaims put forward were-(1) That from one ton of prickly-pear seven gallons of alcohol could be prepared at a cost not exceeding 3s. 6d. per gallon, whilst the refuse conld be made into a nutritious cattle-food; (2) that the plant yields an excellent sugar, two tons of prickly-pear yielding as much sugar as three tons of sugar-cane, and of equal quality ; and (3) that the fibrous nature of the material renders it suitable for the manufacture of paper, strawboard, and other articles, and that these could be more cheaply produced from prickly-pear than from any product now used for the purpose.

"The suggestion with regard to utilising the plant for the manufacture of alcohol is not new. Proposals of this kind have been made previously in New South Wales, Mexico, Spain, India, and other countries, but it does not appear that alcohol has ever bcen obtained from this source on a commercial scale. The juice of the fruit contains saccharine matter, and undergoes spontaneous fermentation; the alcoholic liquid thus obtained is used by the natives of Mexico and other countries as a beverage. It seems improbable, however, that this liquid could be profitably employed as a source of alcohol, for the following reasons :-

"Alcohol of 90 per cent. strength can be manufactured from eheap materials, such as maize and potatoes, at a cost of from $6 \mathrm{~d}$. to $1 \mathrm{~s}$. per gallon, depending on the market price of the raw materials and other local factors. It is evident, therefore, that the production of spirit from prickly-pear juice could only be remunerative in a country which had no other crops available for the purpose, and which had a heavy duty on imported alcohol. Moreover, the researches of Ulpiani and Sarcoli in 1902 have shown that not only would the manufacture of alcohol from prickly-pear juice be unprofitable, but also that is it scarcely practicable. These chemists found that the juice of the fruit of the prickly-pear contains 12.8 per cent. of sugar, which consists not of sucrose (or cane-sugar), but of a mixture of glucose and fructose. The spontaneous fermentation of the juice is due to the action of a natural yeast which occurs on the fruit, and has been termed Saccaromyces opuntioe. This yeast does not ferment cane-sugar, but only glucose and fructose. The fermentation takes place very slowly, and even after a long time the proportion of alcohol is not equivalent to the amount of sugars originally present. Added yeast, however, is rapidly suppressed by $S$. opuntio, and it would therefore be necessary to kill the latter by sterilising the juice before introducing the ordinary yeast. On account of the expense of sterilisation, it is regarded as desirable to find a yeast capable of producing alcohol rapidly in the presence of the natural yeast ( $S$. opuntice), as only in this way could the manufacture of alcohol from the juice become practicable.

" With regard to the manufacture of sugar from the prickly-pear, it is obvicus that, if the contention of Ulpiani and Sarcoli that the juice contains only glucose and fructose is correct, no cane-sugar could possibly be obtainable. . . ."

However, the opinion embodied in this report, notwithstanding experimental data, would seem to point to an opposite conclusion.

\section{Utilisation of the Fibre for Making Paper Pulp, BonRds, \&c.}

Don P. Gonzales, of Jerez (Spain) mentioned that the thick trunks of the common species of Opuntia, $O$. ficus-indica and $O$. amycloea, had been tried as possible materials for paper-making, but had not proved a success. Further particulars were wanting.

Whilst in Italy, one member of the Commission devoted considerable attention to the possibility of utilising prickly-pear fibre in this way, visiting the chief centres for the manufacture of paper pulp. A journey was made to Milan, the most important Italian centre of the paper manufacturing industry, where visits were paid to the Milan house of Ambrozio Binda and Co. Sig. A. Binda stated that the technical manager, Sig. L. B. Donzelli, thought that it would not be practicable to use the woody fibre of the local prickly-pear for paper pulp, owing to the great deal of refining that would be necessary for it to undergo, and that even for making " boards" it would not be likely to compete with the cheap material already in use there. Interviews were also held with the eity representatives of the following companies or paper mills:-Carmignano Mill, Brenta-Padova; J. Sesana and Co. Crusinallo; Bagatella and Co., Milan; The Rossi Cartiera, Milan; Sig. E. Pirola, of Pirola and Co. 
The material used in the Italian paper and strawboard mills was either " reorganised" old paper or else wood pulp, most of which came from Germany, where it was made from poplars and pines. The technical experts visited were generally interested in the possibility of a new source of fibre for this purpose, but the absence of samples from the Australian plants prevented them from giving an expression of opinion as to their value. Owing to their absence from Rome at the time of the Commission's visit, Dr. G. Borghesani and A. Bruttini, of the International Institute of Agriculture, both of whom have written on certain phases of wood-pulp making, could not be consulted.

Professor Dunstan's Report (June, 1913), previously referred to, also dcals with this matter, and runs as follows :-

"With reference to the utilisation of the prickly-pear for paper-making, experiments at the Imperial Institute have shown that a pulp can be prepared by the process of heating the fibre of the plant with caustic alkali under pressure, but that the product so obtained consists of very short fibres (about $\frac{2}{85}-\frac{1}{90}$ inch long), and would therefore be of comparatively low value.

" Samples of the fibre of a South American species (Opuntia dillenii), which occurs in India, were shown at the Colonial and Indian Exhibition which was held in London in 1886. Papermakers who examined these samples, however, regarded them as worthless in comparison with other cheap and plentiful materials. It is probable that the collection of the raw materials would be a costly operation. Moreover, a little consideration will show that an immense quantity of the plant would have to be dealt with in order to produce a comparatively small amount of paper pulp. Analyses of various parts of the prickly-pear at different ages in the United States of America (Bureau of Plant Industry, Bulletin No. 102, Part I., United States Department of Agriculture, 1907) have shown that, on the average, the fresh plant contains 84.3 per cent. of water and 2.4 per cent. of 'crude fibre.' Experiments at the Imperial Institute have proved that 100 parts of dry prickly-pear fibre yield about 42 parts of dry paper pulp. Hence from 2.4 parts of the crude fibre about 1 part of pulp could be obtained. It is true that the 'crude fibre' of the analysis was extracted by a different process from that used in the preparation of the fibre employed in the Imperial Institute experiments, but this would not greatly affect the results arrived at. It is evident, therefore, that for the manufacture of one ton of paper pulp it would be necessary to cut about 100 tons of the fresh plant. When to the cost of collecting and handling this mass of material is added that of the chemicals and labour required for the extraction of the fibre and its conversion into paper pulp, it seems evident that the project could not possibly be remunerative, especially as the product is of low quality and would not in any case be worth more than a few pounds per ton.

"In conclusion, it appears that the only purpose for which the prickly-pear could be used successfully is as a cattle food. Opinions with regard to the value of the material for this purpose are, however, very conflicting, and, at best, it would constitute a product of low nutritive value, and could only be used in conjunction with richer feeding stuffs, such as wheat, bran, or cotton-seed meal."

In regard to the account published above it should be noted that some of the species examined are not named. This renders it more difficult to form a correct estimate of the value of the common Australian species, as different Opuntias (and even different parts of the same plant) vary in composition. It may be remarked, however, that the $O$. dillenii, whose paper-yielding qualities were not favourably regarded, is related to the pest pear of the Rockhampton, Gayndah, and Brisbane districts, as well as to the common pest pear of Queensland and New South Wales.

A report (May, 1909) on Queensland samples made by Mr. J. S. Remington, a technical chemist in Liverpool (England), was not of a very encouraging nature. Fresh material was sent, its composition being determined as-Water, 87.16; dry matter, 12.84; fibre, 2.98 ; and ash, 2.01. It was stated that " the large amount of water and the small amount of fibre would preclude its use as a paper-making material, as no material would be economically suitable unless it contained at least 30 per cent. of fibre and even in that case would he considered a very poor, third-rate article. On finding the material was unsuitable for paper-making purposes, we hydrolysed some with 2 per cent. sulphuric acid and the substance yielded under this treatment 3 per cent. of reduc ing sugar, which only partly fermented. On boiling the original substance with water for two hours and straining, a liquid was obtained which partly gelatinised on cooling, showing the presence of substances of the nature of pectin.

"These facts are quite sufficient to show that the prickly-pear is unsuitable for either the manufacture of paper or the production of alcohol on a commercial scale. It might be to the advantage of someone living in the colony to investigate this material, as regards its gelatinising or pectin properties, as possibly some industrial use might be found from this point of view. As a paper-making material it is, however, absolutely useless."

This report expresses an opinion as to the value of the whole prickly-pear plant rather than of its constituent fibre as a paper producer, or its fruit as an alcohol producer. It must not be overlooked that any treatment for the destruction of Opuntia which will rob the plant of its high water-content must increase the percentage 
of fibre in the remainder. The value of this fibre, if found suitable for manufacturing paper, strawboards, \&c., would then lower the total cost of destruction of the plants. It may be added that the original suggestion to employ the woody fibre of prickly-pear for the purpose under consideration actually emanated from a technical paper, the "World's Paper Trade Review," of 1909, published in the interests of paper production. (Fide Imperial Trade Commissioner, F. Finucan.)

When the plant has died or been killed, and its contained water dissipated by evaporation, the material remaining is largely composed of ligncous tissue and other dry substance. This remains as a "waste material," after the carrying out of any of the methods in vogue for destroying the plant, and is of no value on the spot, in fact, costing money for its removal, for which there is no return.

In the industries identified with paper manufacture in the most general acceptation of the term, and more particularly in those manufacturing processes which turn out the pulp needed for these industries, enormous quantities of ligneous tissue are used, principally derived from wood, some forty different kinds of trees being drawn upon for this purpose. To give an idea of the extent to which wood-pulp is employed, it may be stated that in 1907, amongst the materials for paper manufacture, England alone imported no less than 500,000 tons (Cross, Bevan, and Sindall), an amount that has continuously received a large annual increment. Again, the United States, in the year ending 30th June, 1910, imported 423,721 tons. This, however, was only 17 per cent. of the quantity manufactured in that country during the year 1909 (Forest Products, Bureau of the Census, U. S. Dep. Com. and Lab., 1911), which thus must have totalled 2,457,581 tons.* The United States itself produced 2,533,976 tons in 1910 .

At the present rate of consumption of wood for this paper-making, the devastation of forest areas has become so serious a matter that the Governments of the various countries in which these forests exist, are taking vigorous steps in the first instance to prevent their absolute destruction, but further to secure a systematic upkeep (Cross, Bevan, and Sindall). This fact has been emphasised as regards the United States by the Bureau of Plant Industry, which mentions that by 1950 it will be impossible to supply local requirements in wood-pulp from its own forests, if the continuous increases in its use now in vogue are continued. (C. J. Brand, Physiologist, Circular 82, Aug., 1911, No. 19.)

Accordingly, not only is afforestation urged in the interests of these requirements all the world over, but attention is actually turned to

* Short tons-2,000 lb. the expediency of growing agricultural crops to meet the requirement, and the suitability of cornstalks, brown millet stalks, sugar-cane megass, cotton-hull fibre, \&c., has been urged for this purpose (C. J. Brand, op. cit., p. 16, \&c.) ; and it has been pointed out that they can be probably grown at a profit to both the grower and the manufacturer. To meet the necessities of the case, however, the paper manufacturer or pulp manufacturer not only wants suitable materials, but "some assurances upon the subject of adequate supplies before he is disposed to try a material on an extensive scale, for he knows perfectly that there are many wood fibres from which he could make paper provided they can be obtained in sufficient quantity to make the enterprise a financial success" (Clayton, Beale, and Stevens, Journ. Bd. Agr., 1914, p. 915).

Certain descriptions of paper and pulp are manufactured from the erudest materials. Thus "paper-board" for boxes which now figure so largely in trade,* is made of materials, including not only old paper of all descriptions that is "reworked" for the purpose, but refuse from pulp-mills, screenings, straw, old rope, old bagging, low-grade wood-pulp, \&c. The same materials are used for other forms of boards, \&c.-e.g., roofing-boards, mill-boards, leatherboards, trunk and portmanteau boards, panelboards, straw-boards, \&c., \&c. Accordingly it has been considered advisable, in the interests of this inquiry, to discover whether this waste material yielded by prickly-pear can in a measure fulfil this demand and be manufactured into some kind of brown pulp. It is not a question of whether prickly-pear can be profitably converted into paper-pulp, but whether the ligneous fibre available can be manufactured into a commodity that may fetch a price that will be an adequate set-off to the cost of destroying the plant. Much less is it a question of manufacturing a high-class wood-pulp or paper such as that on which these words are printed.

In approaching manufacturers and dealers in the raw materials employed in the manufacture of the various kinds of paper-boards and of the coarser and tougher varieties of paper (e.g., mill-boards, leather-boards, tip, trunk, box, panel, drawing, fibre boards, \&c.), in order to ascertain how far the ligneous tissue yielded by the prickly-pear might, if available in suffcient quantities, fulfil the conditions demanded of, and possess the essential features embodied in such substances, the drawback of having no samples of this to submit to them militated against any suceess from the inquiry, for they beforehand knew nothing regarding the characteristics of the prickly-pear yielding substance

* The manufacturers of fibre-boxes (alone) in the United States use approximately 116,000 tons of fibre-board a year (U.S. Department of Agriculture, Forest Service Cir. No. 177, May, 1911). 

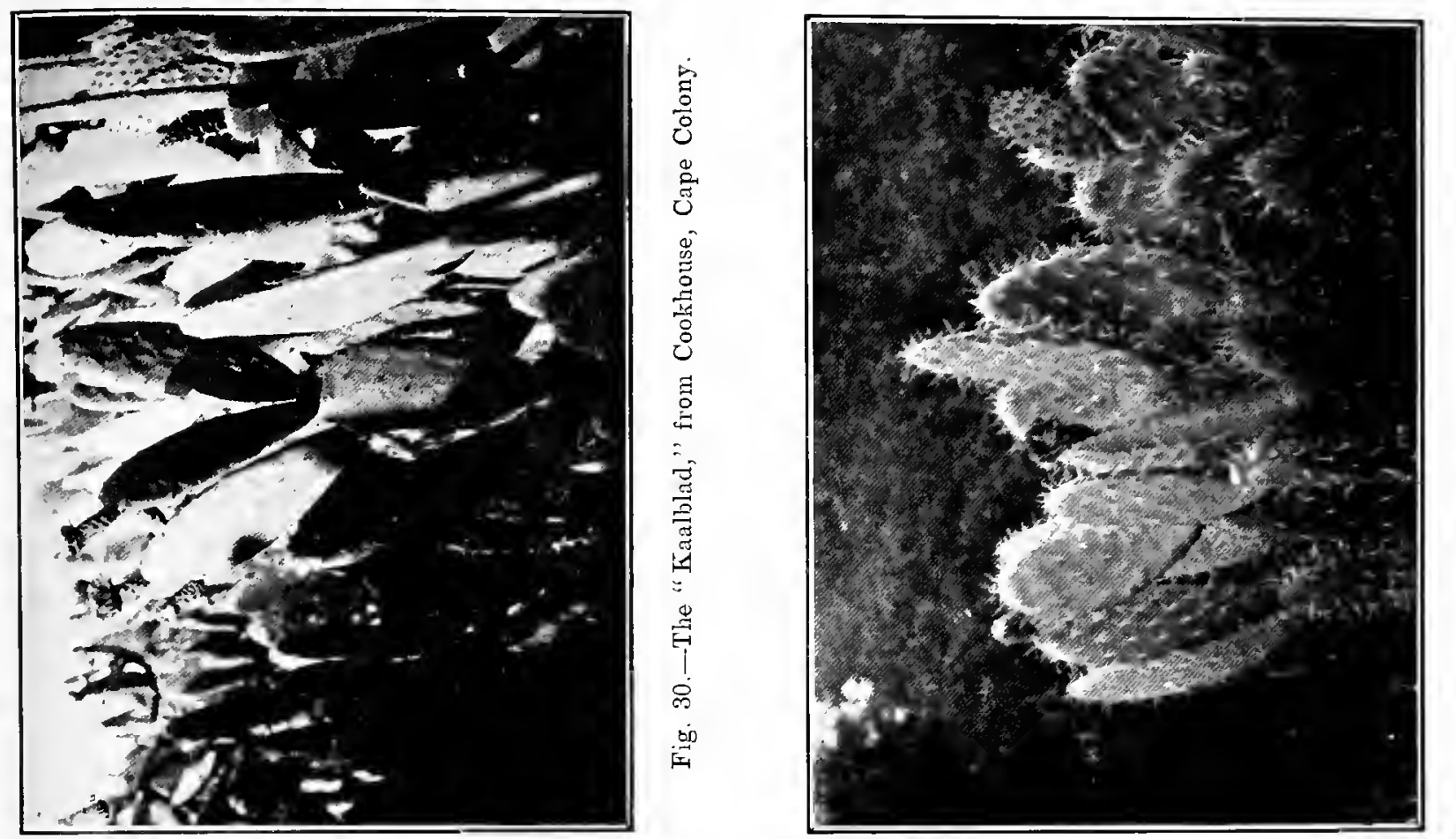

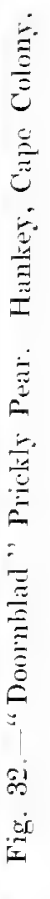

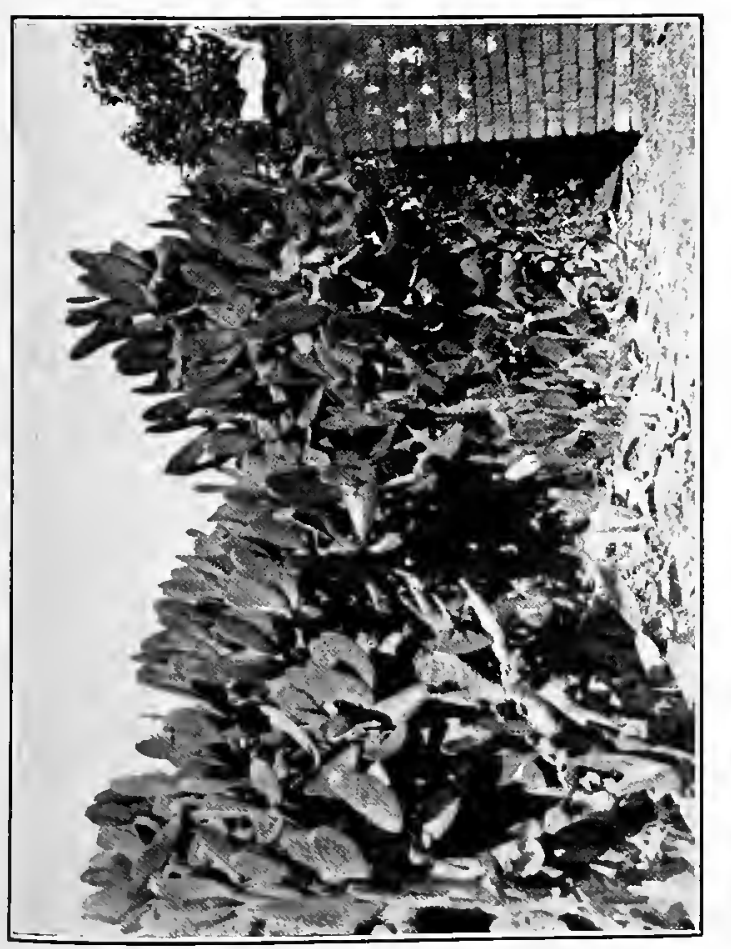

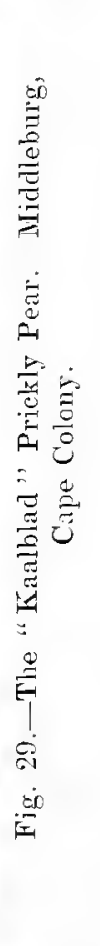

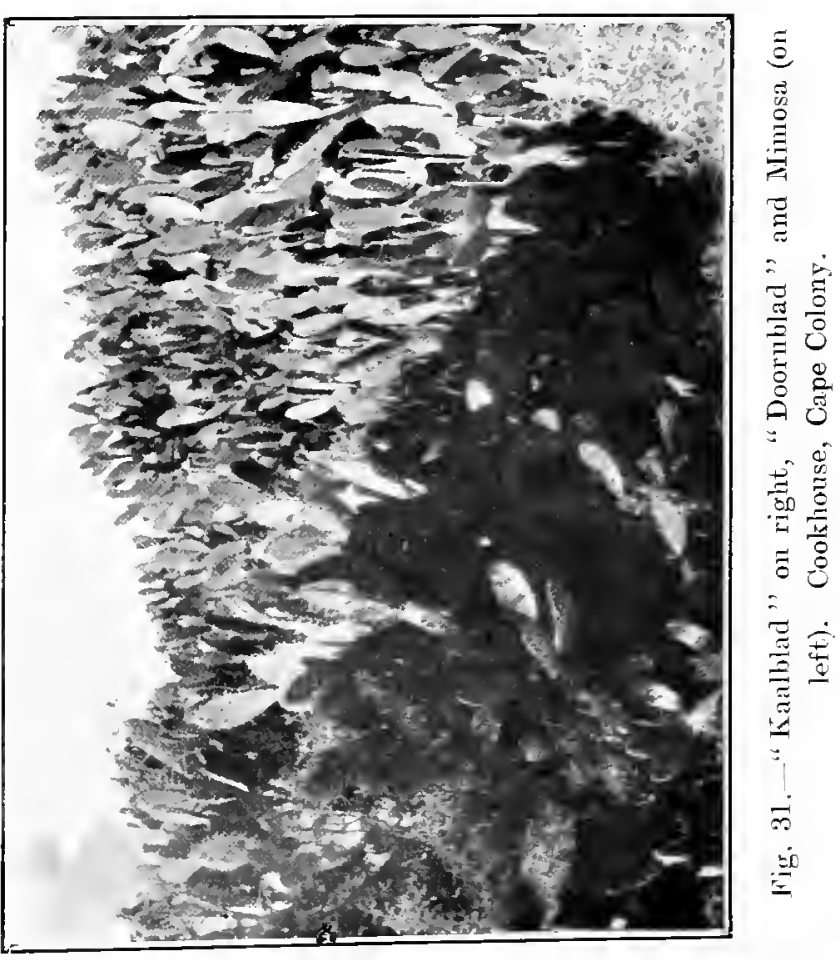



referred to, nor were there any ascertained facts regarding it available for submission to them. Under these circumstances, and recognising their willingness to promote our inquiry, several of them were invited to furnish us with specimens of the various so-called woodpulps with which, if possible, to institute comparison-the other material, e.g., waste paper, old ropes, \&c., being already known to us. Amongst these thus approached were the following London firms:--Messrs. Churchill and Sons; W. G. Taylor and Co., Ltd.; Andrews and Co., Ltd. ; Castle, Gottbeil, and Overton; and Alsing and Co. 'These submitted samples of mechanical and kraft pulps and chemical pulps, including sulphite pulp bleached and unbleached, and sulphate pulp bleached and unbleached.

Further, the manufacturers of the different papers alluded to were themselves asked similarly to assist, and replies were received from the British Paper Company, Hempstead, Herts.; Garwood and Muddiman, Ltd., London; T. and J. Makin, Manchester; Johnson's Millboard and Paper Co., Ltd., Walworth; Thames Paper Company, Ltd., Purfleet, Essex; the West Drayton Millboard Mills, Ltd., Middlesex; and G. H. Hedley, Ltd., Hedge Mill, Londwater, Bucks. Interviews were also held with the principals in some instances. From all of these it was elicited that there was always an opening for any new material, even if it were not superior to those already in use, providing it was available in quantity and of fairly uniform quality, and the cost compared favourably with them. It must, however, possess the special features that alone could establish its utility in manufacture, and regarding these, only those conversant with the processes of manufacture and with the exact methods of estimating these features could pronounce the extent to which they were present.

The value of the ligneous tissue of our prickly-pears being still then an open question, it was suggested that Mr. R. W. Sindall, of Messrs. Sindall and Bacon, London, the wellknown specialists in these matters and authors of several treatises on paper technology should be consulted. This course was especially urged by Mr. Jackson, of Jackson's Millboard and Paper Co., Ltd., Bucks., and by the director of the Thames Paper Co., Ltd., of Essex, two of the largest British manufacturers of the classes of vegetable fibre matters referred to.

At this time samples of the material referred to as being derivable from the prickly-pear were not to hand, although requisitioned some time previously. Nevertheless, the advice was acted on, and Mr. Sindall was interviewed.

Mr. Sindall, who is a recognised authority on matters connected with the manufacture- of wood pulp and paper, emphasised the fact that, before expressing any opinion regarding the use of prickly-pear fibre in the arts, it would be necessary for the material to be examined and its qualities ascertained, both pulp and paper being made if found necessary. He referred to the various uses to which the material might be put, if not suitable for paper making, e.g., bookbinders" boards, trunk boards, friction boards, \&c. Boards were commonly made of waste paper, as it was cheaper to work up than ropes, cocoanut fibre, old rags, spinners' waste, \&c., which were available for the purpose. Where a very short fibre was needed, esparto was used, this possessing the shortest fibres that were of any value. In pulp-making, the fibre generally had to be reduced to a specific length,* but esparto fibre was so short that the process of reduction did not reduce it any further. Any raw substance that yielded a shorter fibre than esparto would be available for use only as a filling material, and even then only if its cost was very low. The cost of converting the fibre into pulp would also have to be taken into consideration. If found suitable, he thought that the pulp should be made in Australia.

He went on to state that his firm' was prepared to carry out the necessary examination and to report upon the value of the material and the uses to which it could be put. In order to carry out this inquiry it wonld be necessary for the firm to be supplied with not less than two or three pounds of the woody fibre of any one specics or variety of prickly-pear. This fibre should not have undergone any chemical treatment whatsoever, but should have been carefully dried at an ordinary temperature. The material should not be decayed or in process of decay.

In regard to the question of utilising the mucilage, Mr. W. Bacon (Mr. Sindall's partner) stated that the firm was prepared to examine that also. The material sent should not have been coagulated or prepared by any reagent, but should be the residuum of evaporation at a comparatively low temperature. He mentioned that a 2 per cent. solution of galactan was then worth $£ 6$ per ton.

After this portion of our inquiry had proceeded to the length indicated, the specimens of ligneous tissue asked for by us were received from Queensland. The material had evidently undergone a certain amount of decay. Selected specimens, however, were submitted for examination to the technological branch of the Imperial Institute, pending the carrying out of the proposal outlined by Mr. Sindall when better material should be available. This latter business was referred to the Agent-General for Queensland, since the Commission, being about to leave England for the United States, could not undertake it.

Dr. Henry, who took charge of these specimens, stated that the fibre appeared to him to be

* 0.5 to $3.0 \mathrm{~mm}$., "for the majority of paper; a length of 1-2 mm. is a working optimum" (Bevan and Sindall). 
a much better sample than those submitted from Queensland some years ago. The report (dated 19th November, 1913), kindly supplied by the Director, Dr. W. R. Dunstan, is as follows :-

\section{"Description of Sample.}

"Fibre.-This consisted of $2 \frac{3}{4}$ lb. of dried and withered cactus. The joints of the stem measured from about 6 inches to 1 foot in length and from about 3 to 5 inches in diameter; in many cases the cuticular and pithy matter had been more or less removed, leaving a woody fibrous skeleton. No information was furnished as to the origin of this material, but it was assumed to be merely prickly-pear cut and allowed to dry.

\section{"Results of Examination.}

"The "fibre" was examined with the following results, compared with corresponding figures for commercial esparto grass :-

\begin{tabular}{|c|c|c|c|c|}
\hline & & & $\begin{array}{l}\text { Present Sample of Prickly } \\
\text { Pear. }\end{array}$ & $\begin{array}{c}\text { Esparto Grass from Oran, } \\
\text { Algeria. }\end{array}$ \\
\hline \multicolumn{3}{|c|}{ 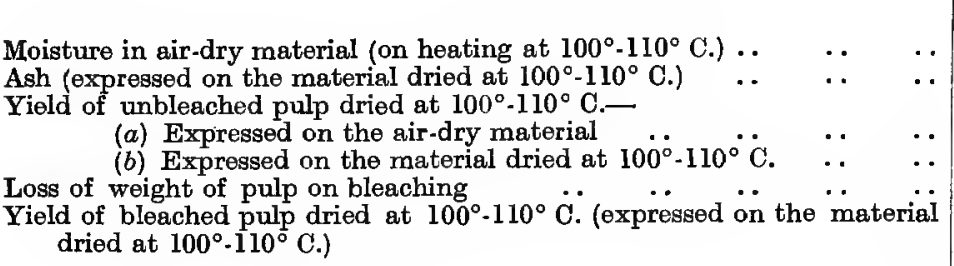 } & $\begin{array}{c}\text { Per cent. } \\
12 \cdot 9 \\
11 \cdot 8 \\
\\
21 \cdot 5 \\
24 \cdot 7 \\
23 \cdot 0 \text { (approx.) } \\
18 \cdot 0\end{array}$ & $\begin{array}{c}\text { Per cent. } \\
8 \cdot 8 \\
3 \cdot 0 \\
\\
29 \cdot 5 \\
32 \cdot 3 \\
1.3 \\
32 \cdot 0 \\
3\end{array}$ \\
\hline Length of ultimate fibres & - & - & $\begin{array}{l}0.014 \text { to } 0.04 \text { inch : } \\
\text { average, } 0.029 \text { inch }\end{array}$ & $\begin{array}{l}0.012 \text { to } 0.12 \text { inch : } \\
\text { average, } 0.045 \text { inch }\end{array}$ \\
\hline
\end{tabular}

"The ultimate fibres of a specimen of pricklypear fibre from New South Wales previously examined at the Imperial Institute measured from 0.012 inch to 0.032 inch, with an average of about 0.028 inch.

"The material was readily converted into pulp, which was dark brown in colour with darker specks. It was bleached with some difficulty to a cream colour.

"Laboratory trials showed that the paper made from the pulp was coarse and of poor strength. Samples of the paper are enclosed with this report.

"The foregoing results confirm the statement in the Bulletin of the Imperial Institute, vol. VIII. (1910), p. 46, that prickly-pear would be of comparatively low value as a paper-making material, owing to the low yield of pulp and the inferior quality of the product. It would certainly not be remunerative to produce the pulp in Queensland for export to the United Kingdom, and it seems very unlikely that it could even be profitably used locally in admixture with materials of better quality. This latter point, however, could only be decided by actual trials on the spot and a consideration of the results in connection with the prices of chemicals and of labour in Queensland."

\section{Utilisation of Prickly-Penr Mucllage.}

Samples of "mucilage" were submitted to the Imperial Institute at the same time as the fibre, and that portion of the report forwarded by Dr. Dunstan (November, 1913) dealing with the examination is as follows:-

\section{"Description of Samples. \\ “ 'Mucilage.'-Two samples of the mucilage} were supplied: (1) a small greyish mass of soft coagulated mucilaginous matter in alcohol, and (2) about $8 \mathrm{oz}$. of a clear yellow viscous fluid with a dirty grey deposit. No particulars were furnished to the Imperial Institute regarding the method employed in preparing these samples.

\section{"Results of Examination.}

"The liquid gum, as received at the Imperial Institute, had an acid reaction and a fairly strong smell; it thus seemed probable that fermentation had occurred. In view of this and of the small quantity of material supplied it was not considered that a detailed examination of the samples would furnish results of practical value.

"It is certain that the gum obtained from prickly-pear could not be sold in Europe in competition with other gums which are available in large quantities at low rates. There seems little prospect even of finding a local use for the material in Queensland, though this point could only be determined satisfactorily by the investigation of fresh samples on the spot.

"If as the results of such further investigation it were found possible to obtain the gum in 
large quantities, and not only of pale colour, but free from foreign matter and without any unpleasant smell, it might perhaps be possible to utilise it as a sizing material in the textile industry; but if it had to be transported any considerable distance for this purpose it would have to be evaporated to a solid condition, and the cost of this would probably be prohibitive, unless on technical trial the gum were found to lave special properties which would make it a desirable substitute for starch and other cheap sizing materials, which seems unlikely."

\section{MinOR UsES.}

In addition to the abovementioned uses there are a few others in the Mediterranean littoral which may be mentioned.

As Hedges and Fuel.-The use of 0 . ficusindica, and especially $O$. amycloe a and occasionally $O$. dillenii, as hedge-plants is very widespread. In Morocco, villages are often surrounded by $O$. amyclcea in such a way as to remind one of a similar condition seen commonly in India. In many localities, old stems are used as fuel.

As Manure.-In many parts, e.g., Algeria, Spain, and Sicily, the plant is used as a green manure, a very valuable addition in the case of poor, dry soils such as are met with in many localities. The moisture contained in the joints is gradually set free, and of course humus is also added to the soil by their decomposition. In parts of Spain it is used in this way to improve soils on which vineyards are being raised. The Arabs in Moroceo and in Algeria frequently distribute the joints underground about the roots of trees for the same purpose. They also commonly place them in holes in which it is proposed to plant fruit trees or sow melons a little later, the result being said to be decidedly advantageous. Biuso has referred to similar practices in Sicily, where arenaceous soils seem to receive more benefit than clay lands. C. Casey* has mentioned that he saw the joints of prickly-pear used as a "leaf" manure near Naples.

As a Dye.-The colouring matter derived from the fruit of $O$. dillenii is used in Sicily for colouring toys and various articles of basket ware (Sprenger, 1901, p. 80). It is almost identical with that contained in the fruit of the two common prickly-pears of Queensland.

\section{SUMMARY.}

Of the many kinds of Opuntia occurring in the Mediterranean, only two are commonly met with, and even these are regarded by many authorities as being varieties of one species, o. ficus-indica. p. 190 .
They are not considered as a pest in any portion of tlis region, while the Barbary or Indian Figs ( $O$. ficus-indica and $O$. amycloea) are regarded rather as valuable plants capable of producing fruit for human consumption, the stems and joints themselves being used for the feeding of stock.

The prominent place given to Prickly-pear (O. ficus-indica) in stock-feeding in Algeria, Tunis, Sardinia, and Corsica should not be without significance for Queensland, especially in view of the prevalence of drought conditions.

No insect pest or disease was met with whose introduction into Queensland would be desirable.

Alcohol production from the fruit proved to be a commercial success in this region, until fiscal changes interfered with the industry. Investigations are still being prosecuted in Italy.

The mucilage was not examined in a detailed manner. It is suggested by the Imperial Institute that the gum, if obtained in a sufficient quantity and pale in colour, might perhaps be of use commercially in local textile industries as a sizing material, but would not be able to compete abroad with other gums. It should be mentioned that the samples submitted had apparently undergone some decomposition. We think that this possible use of mucilage in the arts is worthy of special inquiry.

The low percentage of fibre, the shortness of individual fibres, and the poor quality of the papel produced from the pulp all seem to indicate that prickly-pears cannot be considered as paper-pulp producing plants from a commercial point of view. There are, however, other fabrics of value which may be made from a pulp which would produce only a poor paper or be unsuitable even for any paper.

Although Professor Dunstan has stated that the pulp produced would not be worth more than a few pounds per ton, yet when we consider that, as a result of certain processes of destruction, the fibre is left in a condition more or less suitable for pulp-making, the possibility of pulp being made on a commercial scale from what is really a by-product is greatly increased. The profits derived from the sale of such dried pulpproducing fibre would lessen the net cost of clearing the land infested with prickly-pear. The opinion of an expert is necessary if we are to regard the matter from this point of view.

\section{APPENDIX TO SECTION $V$.}

Mr. J. C. Brümnich's analyses of prickly-pears naturalised in Queensland. 


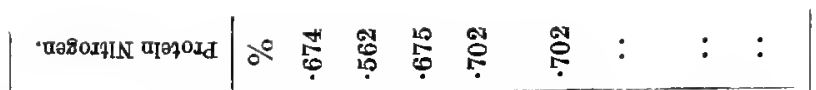

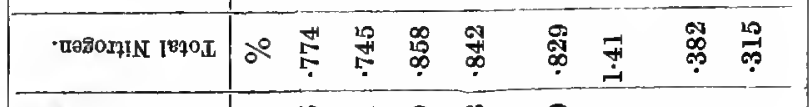

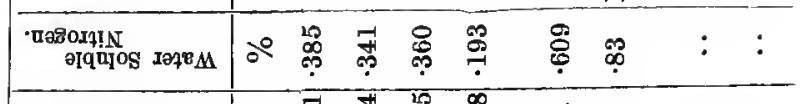

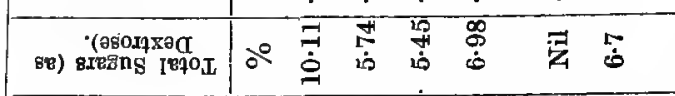

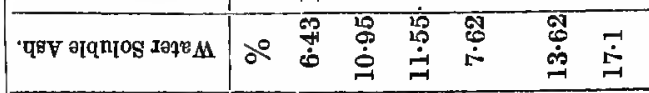

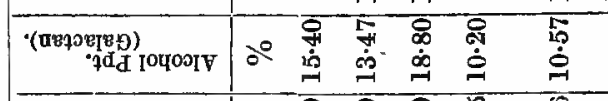

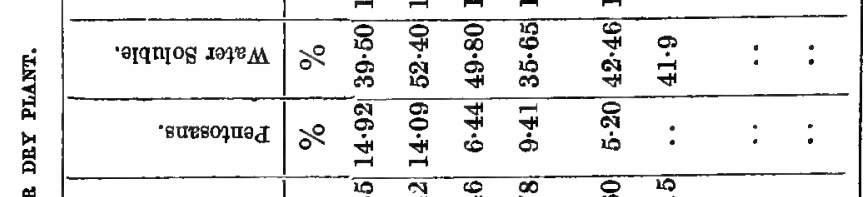

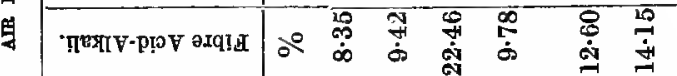

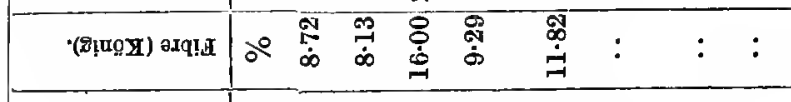

\begin{tabular}{|c|c|c|c|c|c|c|c|c|c|}
\hline 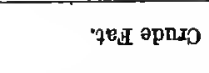 & of & ب़่ & $\underset{\dot{H}}{\vec{H}}$ & $\stackrel{g}{\stackrel{9}{-}}$ & in & $\begin{array}{l}\infty \\
\dot{10} \\
\dot{\sim}\end{array}$ & & : & : \\
\hline 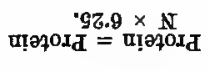 & $\partial^{\circ}$ & $\begin{array}{l}\text { g̀ } \\
\dot{+}\end{array}$ & $\begin{array}{l}\text { 10. } \\
\text { के }\end{array}$ & $\stackrel{\substack{* \\
+}}{+}$ & $\begin{array}{l}\text { कृ } \\
\text { சै }\end{array}$ & 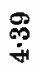 & : & : & : \\
\hline 'पsV әрпxว & a & $\dot{\infty}$ & 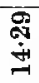 & ஓூ & 占 & $\bar{\infty}$ & 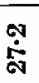 & $\begin{array}{l}\stackrel{0}{1} \\
\dot{\vec{f}}\end{array}$ & $\begin{array}{l}\mathscr{8} \\
\dot{E} \\
0\end{array}$ \\
\hline 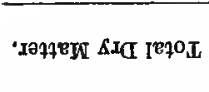 & a & $\begin{array}{l}\text { 위 } \\
\dot{\delta} \\
\text { ᄋ }\end{array}$ & $\begin{array}{l}\hat{0} \\
\dot{\mathbf{D}} \\
\text { ô }\end{array}$ & $\begin{array}{l}10 \\
0 \\
0 \\
0\end{array}$ & $\begin{array}{l}+ \\
0 \\
0\end{array}$ & 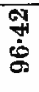 & $\begin{array}{l}\text { o̊ } \\
\stackrel{0}{8}\end{array}$ & $\begin{array}{l}8 \\
\dot{8} \\
\dot{8}\end{array}$ & $\begin{array}{l}\text { @̊ } \\
\text { }\end{array}$ \\
\hline
\end{tabular}

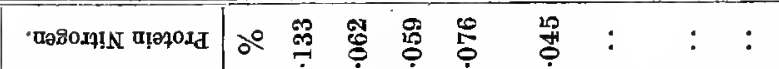

\begin{tabular}{|c|c|}
\hline 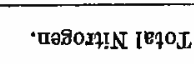 & م0 点 \\
\hline
\end{tabular}

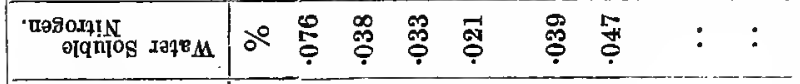

\begin{tabular}{|c|c|}
\hline 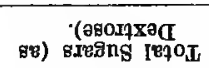 & م0 \& \\
\hline
\end{tabular}

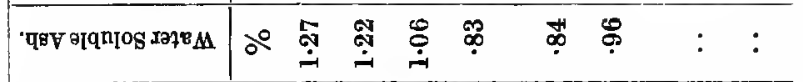

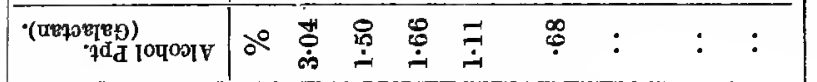

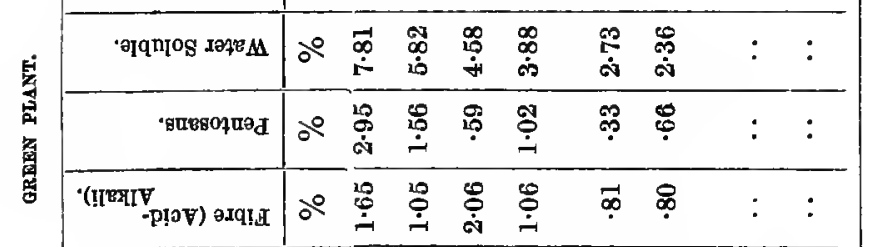

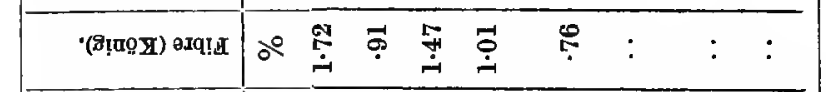

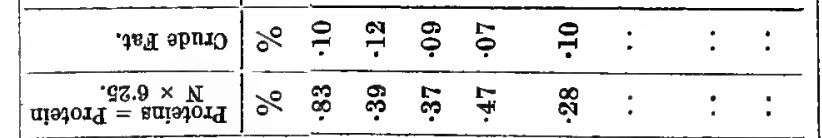

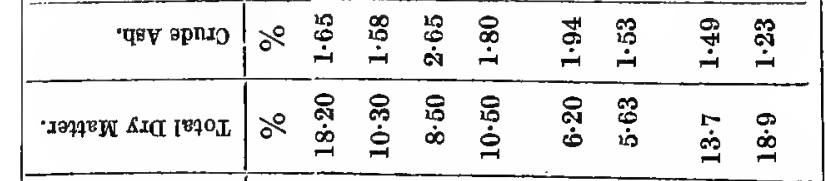

\begin{tabular}{|c|c|c|c|}
\hline 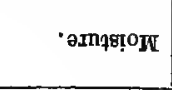 & 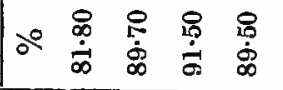 & 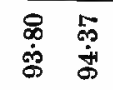 & $\stackrel{\infty}{\dot{\infty}}$ \\
\hline 竞 & 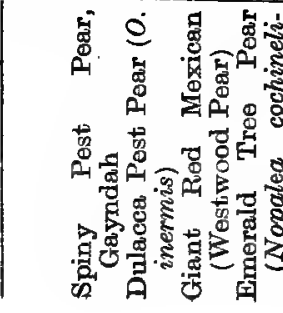 & 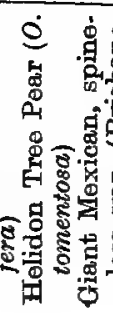 & 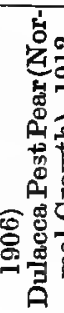 \\
\hline
\end{tabular}

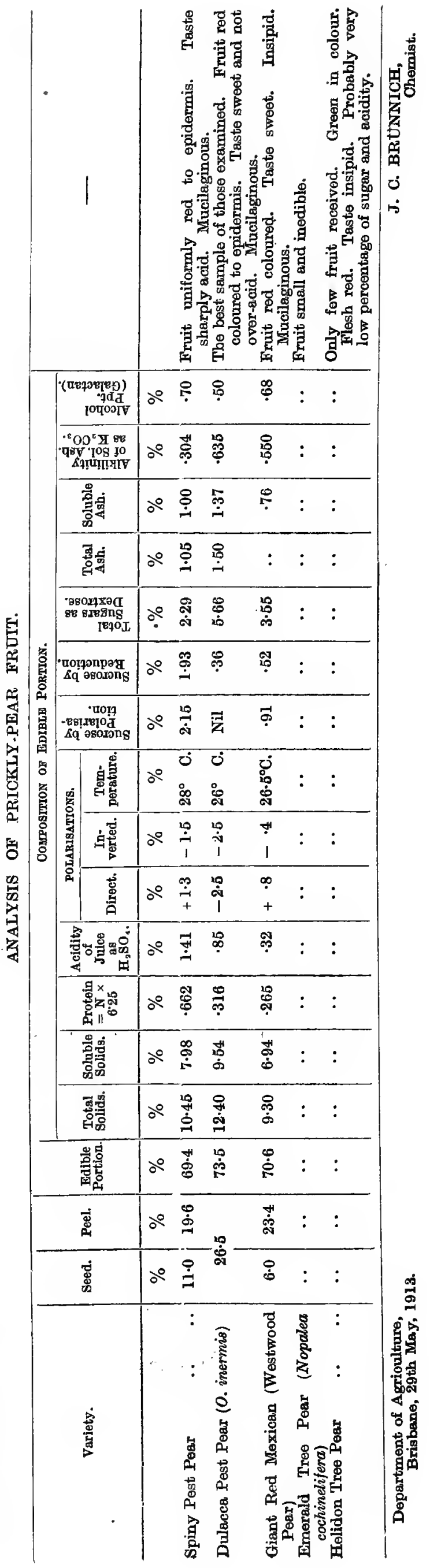




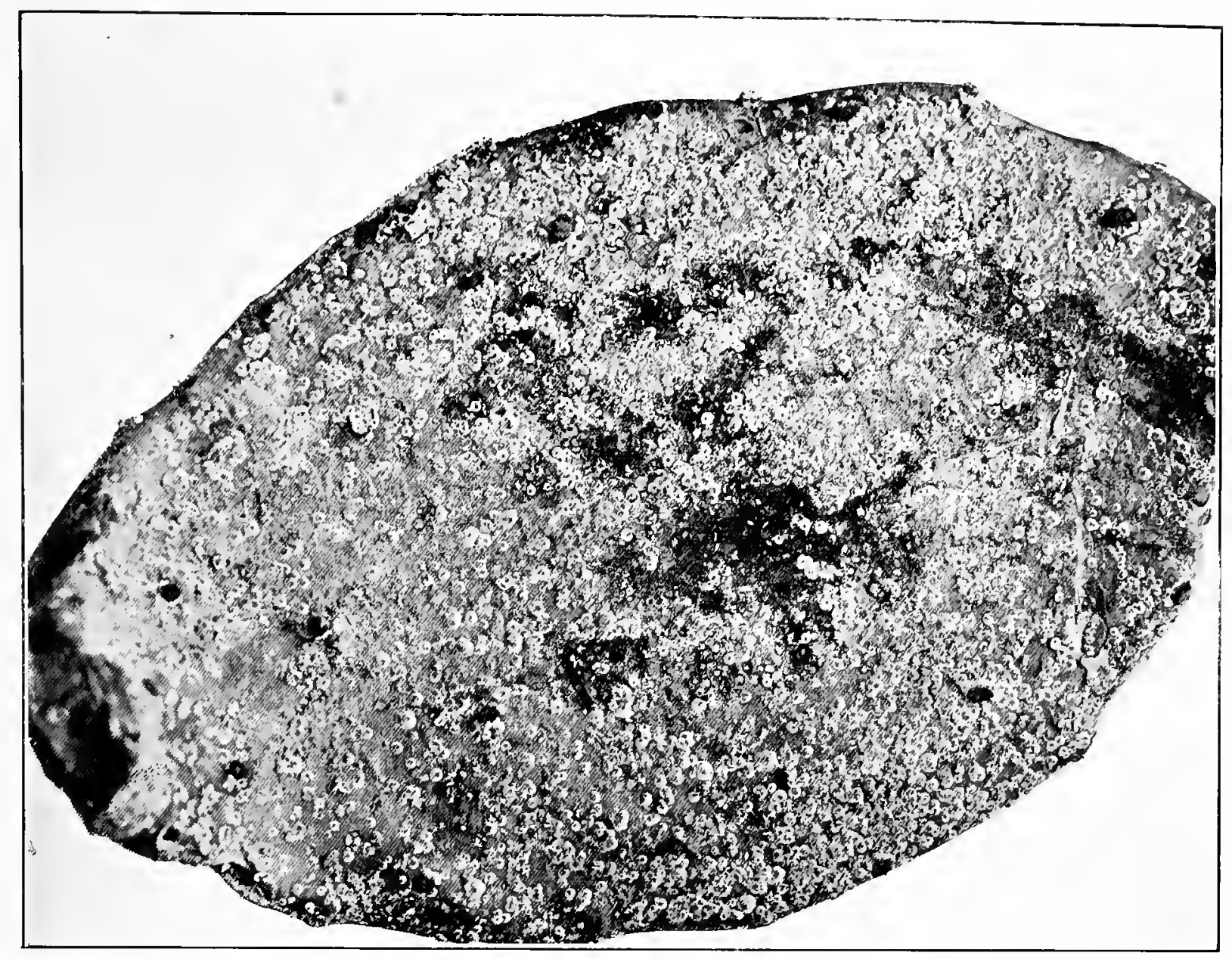

Photo. Ilopt Agriculture, Brisbane.

Fig. 33.-The Opuntia White Scale-Diaspis crlinocacti-on a joint of the pest pear, Brisbane.

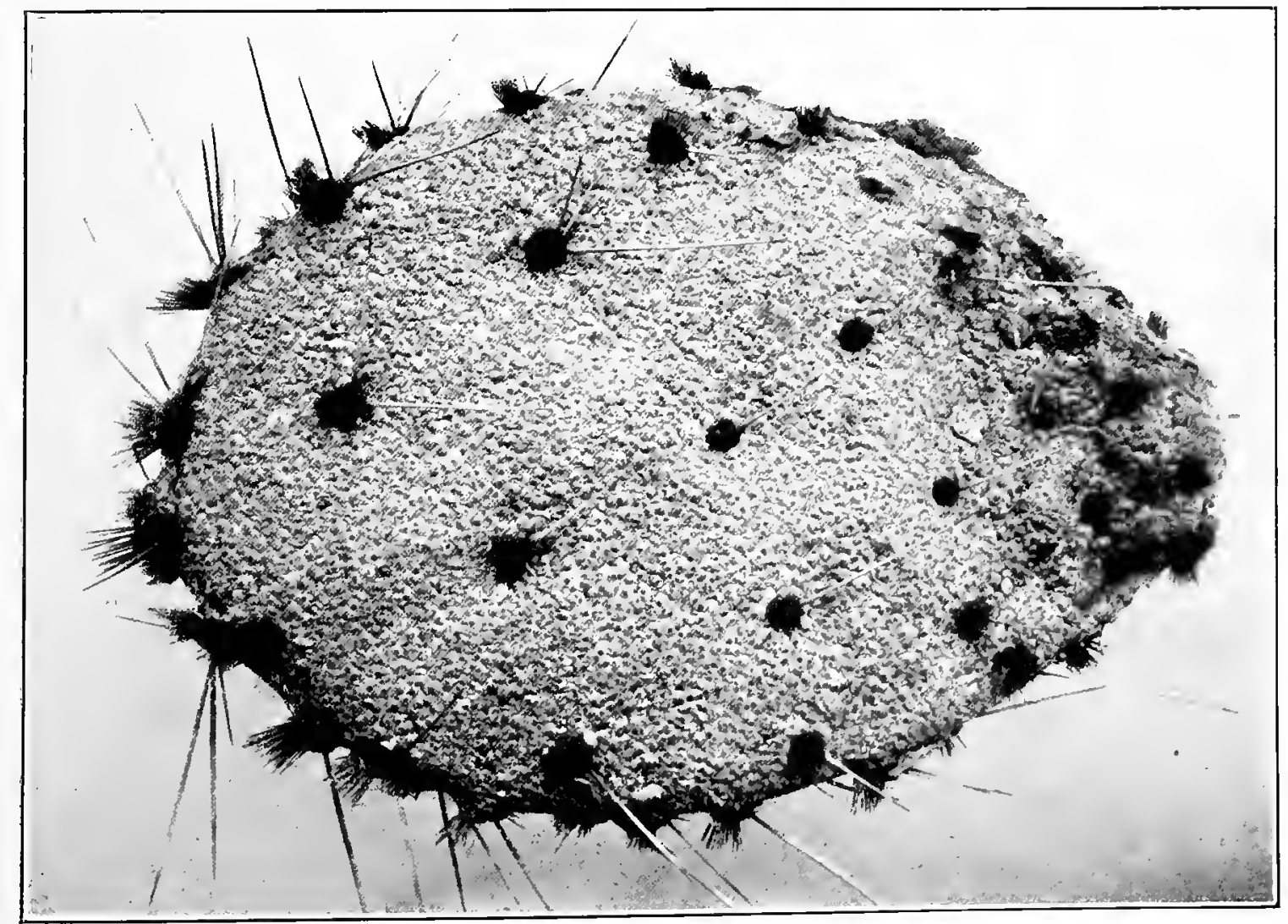

Fig. 34.-Diaspis celinncacti cacti on an Opuntia, Texas. 



\section{THE UNITED STATES OF AMERICA.}

\section{INTRODUCTORY.}

The Bureau of Entomology of the United States Department of Agriculture has devoted considerable attention to the study of the insect enemies of cacti, particularly in Southern Texas. Moreover, some investigations regarding the prevalent diseases of prickly-pear in the latter region had been carried out by Mr. F. A. Wolf.

The Cactaces of the United States have received considerable attention from European authors such as De Candolle, Schumann; and others, but particularly from local botanists who have studied them in the field, amongst the latter being Engelmann, Bigelow, Griffiths, Britton, Rose, Coulter, Thornber, Wooten, MacDougall, Cannon, Wolf*, Mackensen, and Toomey. The economic side of the group has been carefully studied by Griffiths (1905-1913), Hare (19061911), Thornber (1911), Wooten (1911), and Vinson (1911), especially by the two first named. The chemical side has received much care at the hands of Dr. Hare (1906-1911), while Goss (1895, 1903) has also published some data. Mr. Luther Burbank has devoted a great deal of attention to the raising of varieties of Opuntias with a view to increased succulence and size of joints, and a diminution of their spininess, to make them more valuable as a cattle-fodder. He has also succeeded in improving the fruit production of certain kinds.

Itinerary.-The Commission arrived in New York on 10th October, 1913. At this city considerable assistance was rendered by the Director of the Botanic Gardens, Dr. N. L. Britton, who, in collaboration with Dr. J. N. Rose, of the Carnegie Institute, Washington, is actively engaged in the study of Cactacer. Since both of these naturalists had studied this group of plants in various parts of North America and the West Indies, their help and advice were much appreciated.

Visits were then made to the parasitological laboratory of the Bureau of Entomology at Boston, controlled by Dr. A. F. Burgess, and to Albany, where the New York State Entomologist, Mr. E. P. Felt; was consulted, this investigator being an authority on a group of insects, some members of which are known to be serious parasites of prickly pear.

At Washington, D.C., the Commission received every assistance from Hon. H. F. Houston, Secretary for Agriculture; from Dr. L. O. Howard, Chief of the Bureau of Entomology, and his assistants, particularly Messrs. W. D. Hunter and W. D. Pierce; from Dr. Taylor, Chief of the Bureau of Plant Industry, and Dr. D. Griffiths, Dr. W. A. Orton, and Miss E. C. Field, members of his scientific staff; Dr. Merriam (former Chief), Messrs. H. W. Hanshaw (Chief) and V. Bailey, of the Bureau of Biological Survey; and from Dr. Dyar and Messrs. F. Knab, E. A. Schwarz, A. Busck, O. Heidemann, and A. Caudell, of the entomological staff of the National Museum. Some of these

* Wolf (1912 a, 1912 b) has given some account of the anatomy of one of the prickly-pears, $O$. lindheimeri. Solereder many years ago published a good deal of information regarding them, and in his work quotes from the labours of many other botanists regarding this group of plants. Quite recently in our own State, Dr. Shirley and Mr. Lambert (1914) have examined anatomically some of the species naturalised in Queensland. men, notably Dr. Griffiths, Mr. Hunter, and Mr. Pierce, have had considerable experience with certain phases of Prickly-pear questions, their work being referred to later in this report.

In order that the Commission might utilise its time to the best advantage, Dr. Griffiths kindly outlined an itinerary which was in the main followed, the only modifications being those suggested by Dr. Howard, and those which were found to be advisable during the journey. Dr. Howard very generously placed at the disposal of the Coinmission, during its work in Texas, the services of one of his officers, Mr. J. D. Mitchell, who has had a very long experience of pricklypears in the field, and who, in conjunction with Messrs. Hunter and Pratt, is the author of a paper on "The Principal Cactus Insects of the United States." His assistance is gratefully acknowledged.

The journey to Texas was made viâ St. Louis. Here Dr. Rose was interviewed, and a visit was paid to the "Shaw" Botanical Gardens, where Dr. S. T. Moore, the Director, and Dr. J. M. Greenman, keeper of the herbarium, were consulted. Dr. Engclmann's types of Opuntias are located in this institution.

The itinerary in Texas included the following districts:-Dallas, San Antonio, Laredo, Alice, Robbstown, Brownsville, and Sinton.

At Dallas, a visit was paid to the Entomological Experiment Station, under Mr. F. C. Bishopp, where the greater part of Messrs. Hunter, Pratt, and Mitchell's work on cactus insects was carried out. Mr. W. Sinclair's farm near San Antonio was inspected, since it was at this place that Dr. Griffiths carried out much of his experimental work regarding the feeding of cactus to dairy cattle. Mr. B. Mackensen's collection of Opuntias was also examined during our stay in San Antonio. It was at this city that Dr. F. Chittenden, of the Bureau of Entomology, was interviewed. While at Brownsville, the assistance of Mr. M. Vickery, Entomologist at the Plant Introduction Garden of the Bureau of Plant Industry, was sought. It is here that Dr. Griffiths has one of his large experimental cactus plantations.

In addition to visiting the abovenamed individuals and institutions, the Commission examined the Cactacex in the surrounding country as far as circumstances allowed.

From Texas the journey was made westward to Mesilla Park in New Mexico, where Professors R. F. Hare, D. E. Merrill, and H. S. Hammond were interviewed. Dr. Hare has devoted considerable attention to the chemistry of the prickly-pears, and in conjunction with Dr. Griffiths has published much information, while Mr. Merrill has given some notice to the insect fauna of local Opuntias.

At Tucson in Arizona, very willing assistance was given by Professor J. J. Thornber, of the University of Arizona, who is interested not only in the purely botanical side, but also in the matter of using Opuntias as a stock-fodder. The published work of himself and his colleague, Dr. A. E. Vinson, is referred to later. A visit was paid to the Carnegie Institute's Desert Laboratory, near Tucson, where Dr. D. T. MacDougall, its Director, Dr. Cannon, and others are carrying 
out physiological experiments with many plants, including the Cactaceæ.* ${ }^{*}$ The surrounding country with its rich cactus flora was examined.

In California the following localities were visited:-Riverside (Botanic Gardens), Los Angeles (East Lake Park), Palo Alto, San Francisco, San Diego, Sacramento, Chico, and Santa Rosa.

At Palo Alto, a visit was paid to Prof. V. L. Kellogg, who had had some experience regarding the destruction of prickly-pears by insect enemies. At San Francisco, a number of workers were consulted in reference to our inquiry, amongst them being Messrs. F. Maskew, chief deputy quarantine officer, and $G$. Compere, chief inspector, California Horticultural Commission; Prof. C. M. Woodworth and Dr. E. C. van Dyke, University of California; F. E. Blaisdell, J. R. Slevin, and Mr. Fuchs. Mr. Maskew and Mr. Compere kindly offered to facilitate the transportation of any cactus insects whose introduction into Australia this Commission might think fit to recommend.

San Diego was visited as a result of information tendered by Dr. van Dyke and Mr. Blaisdell, the local thickets of flat and cylindrical Opuntias being carefully examined for the presence of certain injurious insects. Messrs. E. O. Essig and E. J. Vossler, of the California Horticultural Commission, were interviewed at Sacramento, but it was found that they had not given any attention to the insect fauna of prickly-pears. At Chico the Plant Introduction Garden belong. ing to the Federal Department of Agriculture was visited, and in company with Messrs. Beagles and Krieger, Dr. Griffith's large cactus plantation was examined. Mr. Luther Burbank, the well-known plant-breeder, was seen at his nursery in Santa Rosa.

The return journey to Washington, D.C., was made viâ Kansas, in the western portion of which State field work was undertaken as a result of information tendered by Mr. C. H. Popenoe, of the Bureau of Entomology, during our stay in Laredo, Texas. At Washington further interviews were held with officers of the Bureaux of Entomology, Plant Industry, and Biological Survey, as well as with members of the staff of the National Museum, in reference to pricklypear enemies. From Washington the Commission travelled southwards to Florida, where one member carried out some investigations while the other proceeded to the West Indies to initiate inquiry there. The following localities were visited in that State:-Key West, Crescent City, and Lake Worth.

Species of Prickly-pear Examined.-The chief species which were examined by the Commission in South-Eastern Texas were the $O$. lindheimeri and $O$. ferruginispina, groups of species (including $O$. cacanapa, O. texana, O. leptocarpa, and their allies), $O$. leptocaulis, and certain lowgrowing forms (Echinocereus, spp.) known collectively by Mexicans as pitalla. In the dry regions occuring in Arizona and New Mexico, attention was given mainly to the various species of Cylindropuntia--the so-called tree cacti-such as $O$. fulgida, $O$. arbuscula, $O$. mammillata, $O$. versicolor, $O$. spinosior, etc., to the flat Opuntias, $O$. engelmanni, $O$. arizonica, and their allied species, and to the giant cactus Carnegiea gigantea. Others, such as $O$. wootoni, 0 . chlorotica,

* Ann. Rep. Director of Botanical Research, Carnegio Institution of Weshington, Year-book No. 12, for 1913, pp. 57.87. and $O$. lcevis were also examined. In Southern California, the species of prickly-pear ( $O$. occidcntalis, E. and B.; O. prolifera, Eng.), occurring commonly on uncultivated lands, were overlooked, while in Kansas the low-growing $O$. missouriensis received most attention.

At Key West, Florida, an Opuntia was met with which differed from the typical form of $O$. dillenii* growing in the same locality. It was a glossy green plant, whose spines were rather longer, being commonly 4.5 to $5.5 \mathrm{~cm}$. in length, rarely curved, more gradually attenuated, and, when young, were wholly reddish coloured, but became brown with age. The spines were less numerous, each areole bearing from one to three, whereas in the case of $O$. dillenii, there may be as many as eight. This Opuntia, which was not in flower or fruit during the time of our visit, attained the stature of $O$. dillenii when the soil was rich in lime, but not otherwise. It was found to be less common than the latter. At Lake Worth (Palm Beach) both $O$. dillenii and another prickly-pear were seen, the latter resembling a stunted form of the above-mentioned Opuntia met with at Key West. A short visit to Crescent City failed to reveal the presence of prickly-pear. It was in this locality that Opuntias were stated to have been destroyed by a burrowing moth caterpillar, Melitara prodenialis, Walker (Hubbard, 1895, p. 129). The site of this former activity was visited, but no cacti were seen there, though it was afterwards ascertained that similar effects were still being produced in a neighbouring district. At Boat Key, which we did not have an opportunity to visit, there occurs an Opuntia which Dr. N. L. Britton has indentified as $O$. inermis, and is quite distinct from any of the prickly-pears seen by us in Florida.

Localities in which prickly-pear was said to be abundant, but which were not visited for want of time, were the Indian River, near the sea, and at Fort Pierce. Dr. Britton informed us that a tuberous-rooted species, $O$. austrina, grew thickly in areas in Southern Florida.

In addition to the various species mentioned above, any others which came under notice were also examined, among them being $O$. bentonii, Griffiths (1912 b, p. 26), an Opuntia from the Southern States (Florida to Texas) very closely resembling the Queensland $O$. inermis.t Various species or varieties included under the name of "Mission Pear" were met with along the southern border of the United States, but always in a state of cultivation or semi-cultivation. Attention was given to the collections of Cactacex in the botanic or other public gardens in New York, Washington (D.C.), St. Louis, San Antonio (Texas), Riverside (California), and Los Angeles (Cal.), and in the plant introduction gardens at Brownsville (Texas) and Chico (California).

* A variety of $O$. dillenii was met with in Florida, with spines paler and somewhat more slender than those occurring in the typical plant. It evidently approached in character Opuntia tuna as interpreted by Britton. It grew along with the typical form of $O$. ditlenii, and was apparently indistinguishable from it except in respect to the character mentioned. $O$. opuntia is more commonly known under the name $C$. vulgaris, Mill. Mr. Burkill (1911, p. 287) refers to it as O. nana, Visiani, and mentions, apparently in error, that its home is Central America, instead of Eastern U.S.A.

$+O$. allairii, Griffiths $(1909 b$, pp. 83, 84), from Eastern Texas, also seems to be related to our Dulacce pest pear. Specimens of $O$. bentonii were seen in the New York Botanical Gardene. 
FUNGOID ENEMIES OF THE PRICKLY PEAR.

"BLACK ROT" OR "SHOTHOLE."

These are two different manifestations of a disease produced by the fungus Gloosporium lunatum, Ellis and Everhart (1891, p. 82). It has been briefly referred to by Dr. Griffiths ( 1908 a, p. 28) and by Messrs. Hunter, Pratt, and Mitchell (1912, p. 17), the causal fungus being indicated by them as a Perisporium. It was the most destruetive priekly-pear malady notieed by the Commission, though its full effeet was not seen, as its attaeks are partieularly dangerous to its host-plant during spring, more especially if weather eonditions be humid during that season of the year. Dr. Griffiths, Mr. Hunter, and Mr. Mitehell, all of whom have had long experience in priekly-pear matters, regard this Gloosporium as being eapable of doing more damage than any other fungus which they have seen attacking Opuntias.

The disease, whieh oeeurs quite eommonly in Texas, was first seen by the Commission on Mr. W. Sinelair's farm, near San Antonio, Texas, where it was found to attaek the varions Texan species of Opuntia, $O$. lindheimeri, $O$. ferruginispina, and their allies. Here, as elscwhere, a gummy exudate was eommonly found assoeiated, but it does not seem to be a neeessary symptom or effeet of the malady. No serious effects were seen during the visit of the Commission (Oetober, November, 1913).

It usually manifests itself by the presence of greyish areas of dead plant tissue extending through the joint, these portions being eut off from the living tissues of the Opuntia by a layer of eorky material. Not infrequently the diseased pieee drops out, and then one observes the "shothole" effeet produeed on the attaeked segment. These holes may be few or numerous; they may be quite small or they may reaeh an ineh or more in diameter.* The malady may be assoeiated with the presenee of small spots whieh are generally eonfined to one surfaee. Each of such spots is seen as a rounded, sunken, grey area on whose ary surface there may usually be seen abundant tiny, dark, fruiting bodies (ieervuli) of the fuugus. When these "spots" are very numerous they do not extend deeply into the plant tissue, whereas when they are relatively few they penetrate the joint, the fungus myeelium readily finding its way through the segment, its lateral ramifieations being usually limited by the layer of corky material whieh is produced by the host tissues in response to the injury. $\dagger$ In some eases the fungus was found to have developed too rapidly for the plant tissues to prevent the advanee, and in sueh cases the "blaek rot" stage had taken plaee. It is this eondition whieh is produced in humid weather during spring.

Some dead and dried joints were placed under moist conditions, and it was found that the diseased areas soon produeed abundanee of salmon-coloured conidia or spores, differing from those generally met with in Glœosporium in that they were uniseptate. The myerlium is apparently able to survive in the dead tissues, and to

* Dr. Griffiths's photograph of $O$. pachona shows the presence of a large "shot-hole" evidently produced by this Glœosporium (1910, plate 22).

$\dagger$ The development of this protective layer is brought about by mechanical injury also. produee crops of spores when the more favourable conditions of springtime return.

Dr. Wolf has published a good aeeount of the malady, whieh he had under eareful observation for a long time (1912a, p. 116). He mentions that the disease at first eanses the formation of soft, sunken, brownish areas on which in a few days abundanee of flesh-eoloured aeervuli appear. A few weeks later these areas beeome dry and hard and the aeervuli blaeken. When infection oceurs late in the season or upon old joints, the formation of eonidia in these aeervuli does not oeeur. He goes on to say that under favourable conditions of teniperature and moisture young segments are readily attacked, rotting setting in very rapidly, and from a single eentre of infeetion only a few days may be neeessary for the fungus to prodnee a deeay extending through the joint. Infeetion was found to oeeur in the spring, and to depend entirely on the elimate and on the age of the segment. $\mathrm{He}$ did not observe the occurrence of new infeetion in the field on old joints, and stated that the fungus was able to gain admission only while the plant tissues were quite young and searcely differentiated. Rainy or eloudy days in spring were found to be favourable to the growth of the fungus as well as the Opuntia, and it is on sueh days that the Glœosporium is able to invade the host and produee a serious rotting. The effeet is thus to destroy the young growth. Even on old infeeted segments, the fungus is eapable of developing further during rainy weather, and may bring about the destruetion of the joint.

Wolf made repeated attempts in greenhouses and in the laboratory to inoeulate segments of various ages by planting myeelinm on the surface of the joint, as well as by applying eonidia by means of a spraying apparatus. These were all unsuceessful, but if a wound were made with a sealpel or needle infeetion followed, the fungus developing very rapidly, and penetrating through the segment in the ease of young joints, but spreading slowly and not penetrating deeply in the ease of older segments. He also enelosed some eaetus bugs Chelinidea vittigera, Uhler, nnder a belljar along with healthy and diseased young segments, but there was no evidenee that the inseets had infeeted the former. However, he thinks that they may be the eause of some of the infection in the field, especially sinee they are abundant during the spring. Mr. Hunter (1912, p. 17) also believes that Chelinidea may aet in this way.

Dr. W. Orton and Miss E. C. Field of the Division of Pathology, Bureau of Plant Industry, Washington, D.C., kindly made eultures of this Glœosporium from speeimens forwarded by the Commission from San Antonio, Texas, and found the eultural characters of the fungus to fully agree with the account given by Dr. Wolf (pp. $118,119)$. The latter failed to attain the aseigerous eondition in his eultures, even after three years, but commonly found it in the field about a month after the formation of the areas ( $p$. 122), the peritheeia oceurring on both surfaees of the joint, and arising from the stroma of the old aeervuli. This stage was reeognised as Sphcerella opuntice, Ellis and Everhart. Miss Field was unable to find the aseigerous or Glomerella stage of the Glœosporium, but found a speeies of Colletotrichum fruiting in abundance in one of the speeimens sent from Texas. 
In forwarding cultures of the fungus grown on string-bean agar, Miss Field wrote as follows :-

"I have grown this organism on the following media:-Corn-meal musb, corn-meal agar, Irish potato cylinders, Irish potato agar, rice, synthetic agar, and wheat-heads. I find that it fruits best on string-bean agar, wheat-heads, and Irish potato agar. The following is the formula we use in making up the string-bean agar:-

"To each 500 grams of clean string-beans (rinsed in tap and distilled water) add 1,000 c.c. of distilled water. Steam one hour. Filter through paper. Let cool, add 20 grams of agar-agar to each liter of solution, let stand till powder is moist, stir and steam for one-half hour.

"Stir, tube, plug with cotton and sterilize for 15 minutes at $11 \mathrm{lb}$. pressure.

"The wheat-heads are simply placed in tubes, water added and sterilized for 20 minutes at $11 \mathrm{lb}$. pressure."

These cultures have been handed over to Dr. White, the officer in charge of the Pricklypear Experiment Station at Dulacca.

\section{Sun Scald.}

A disease very commonly met with in prickly-pear regions in Texas is that known as Sun Scald, which is usually confined to the older parts of the plant. Affected joints give rise to quite healthy segments.

The symptoms, which are described by Wolf (1912a, p. 128), are as follows :-Discolouration commences around the areoles as well as elsewhere, and then a series of more or less concentric brownish zones makes its appearance around each of these areas, frequently extending in such a way as to meet other "spots" so that quite commonly the whole segment may be "scalded" and greyish-brown in appearance. The surface becomes scaly, and on some of these scales one may recognise small dark areas indicating the presence of fungi. A cursory examination made by us revealed the presence of dark-brown hyphæ as well as a few spores of a Cladosporium or Macrosporium type of fungus, but it appears doubtful whether the condition is due to the presence of fungi as Wolf suggests. It seems probable that the popular idea is correcti.e., that the disease is due to unfavourable climatic conditions. These would tend to cause the development of corky tissue below the epidermis in order to prevent excessive loss of moisture. The fungoid infection would thus be secondary.

Wolf (1913a, p. 128) found on $O$. lindheimeri a fungus associated with this condition, and has identified it as Hendersonia opuntia, Ellis and Everhart, which was originally described in 1902 from $O$. ficus-indica from Alabama. This fungus, which he regards as being the cause of the disease, is said to gain an entrance through the stomata, ramifying through the epidermal cells and eventually blocking the stomata, giving rise to the scalded appearance. As a result of the presence of the parasite in the epidermal tissue system, the cuticle and the upper part of the epidermal wall become ruptured and pushed up, allowing air to enterlien'e the grey colour and flaky appearance of the diseased areas. Besides, there is a formation of corky issue by the plant, ${ }^{*}$ the fungus thus being prevented from invading the deeper portions of the joint. The pycnidia are developed in the aggregations of fungoid tissue in the stomata. He goes on to say that this is a very serious disease of the prickly-pear, since the fundamental tissues gradually disintegrate, and the segment dies as the result of the formation of fungoid plugs in the stomata and of the corky layers below the epidermis, all photosynthetic activities being prevented.

The fact must not be overlooked, however, that unfavourable weather conditions may account for all the symptoms of sun scald, the fungi being then regarded as secondary. In a later paper, Wolf (1912 b, p. 295) seems to have modified his opinions slightly, as he states that, though Sorauer is of opinion that it may be due to unfavourable atmospheric conditions, it "may also be due in part at least. ... to the presence of a fungus, Hendersonia opuntice."

Heald and Wolf (1912, p. 101) briefly refer to sun scald, and mention that a species of Rhabdospora may sometimes be associated with the Hendersonia, but that it is apparently only of secondary importance.

\section{Black Spot Disease.}

This malady, which is due to the presence of a fungus, Perisporium wrightii, Berk. and Curtis, is not serious, nor is it as commonly met with as the other two diseases of prickly-pear. It was seen on various species of flat Opuntias near Robbstown, Brownsville, and San Antonio, in Texas. As already mentioned, Dr. Griffiths (1908a, p. 28), as well as Messrs. Hunter, Pratt, and Mitchell (1912, p. 17), refer to the Glœosporium disease under the name of Perisporium.

In its early stage the black spot malady resembles that caused by Glcosporium, both appearing as small, rounded, smoky areas below the epidermis of the joint. Later on these spots become quite dark, on account of the formation of abundance of black-fruiting bodies or perithecia which become elevated above the general surface of the joint. These perithecia may be readily seraped off the surface, when a smoky area is seen below, indicating the presence of darkcoloured myeelium within the plant tissues, the fruiting portion of the fungus having developed through the stomata. Surrounding each "black spot" is a yellowish or chlorosed zone. Later on, there appears in the diseased area a brown discolouration somewhat similar to that seen in sun scald, and this is no doubt due to the formation in each case of a cork layer below the injured tissues. As a rule by this time the black spot condition has disappeared. One may find all stages on the same segment, and even when abundant no appreciable damage appears to be done to the plant.

* Wolf allowed some segments to partially dry out in the laboratory, and found that a cork layer was developed as a means of checking the loss of water, this layer being similar to that found in joints affected by "Sun Seald." He suggests that the fungus, by destroying part of the cuticle and epidermis, exposes the underlying tissue, and in order to prevent excessive evaporation the plant protects itself by interposing a layer of corky tissue. 


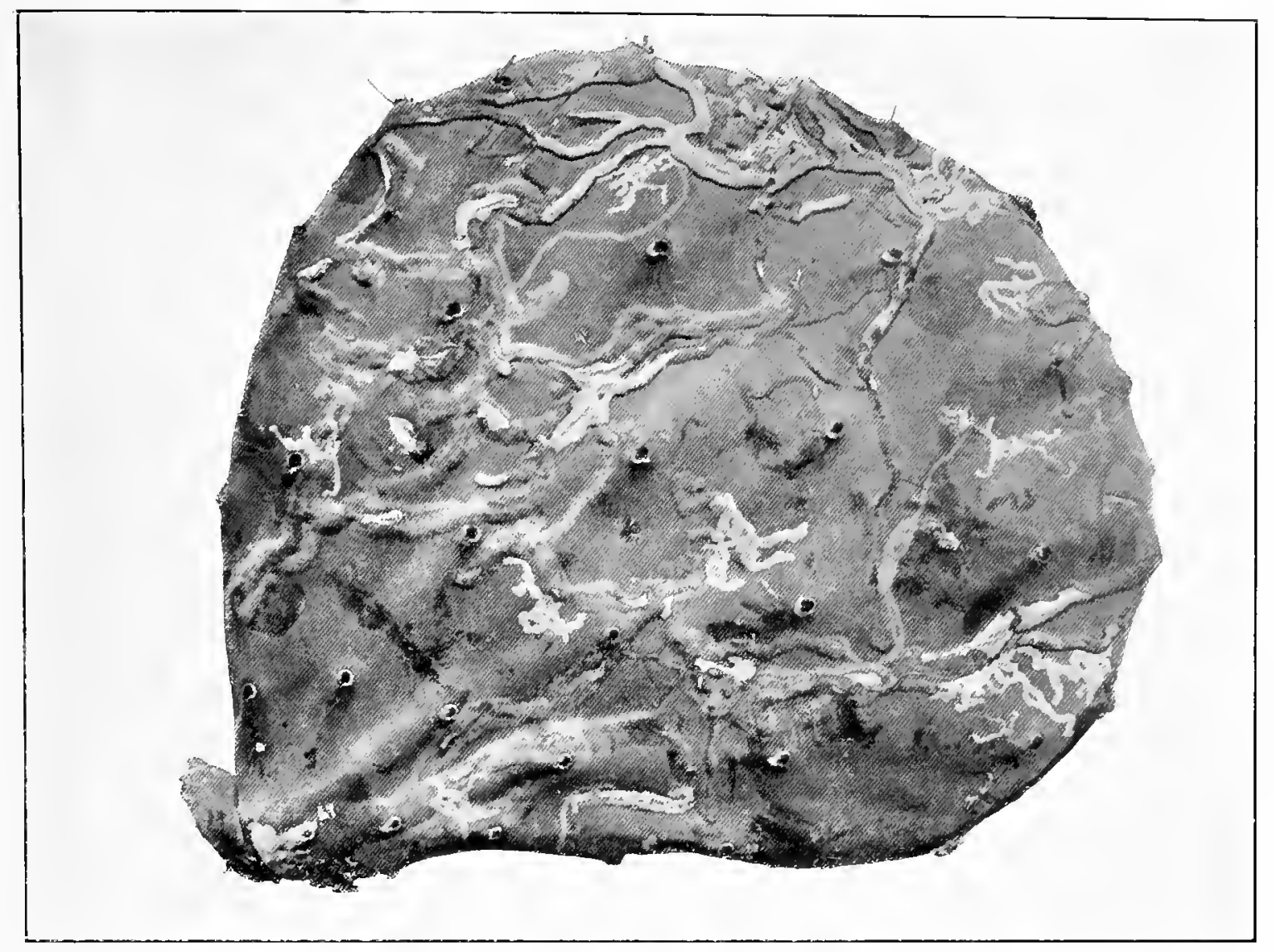

Photo., Burau of Eintomology, Thept. Agriculture, C.S.A.

Fig. 35.-Joint of an Opuntia from Marble Falls, Texas, showing the work of Marmara npunticlla.

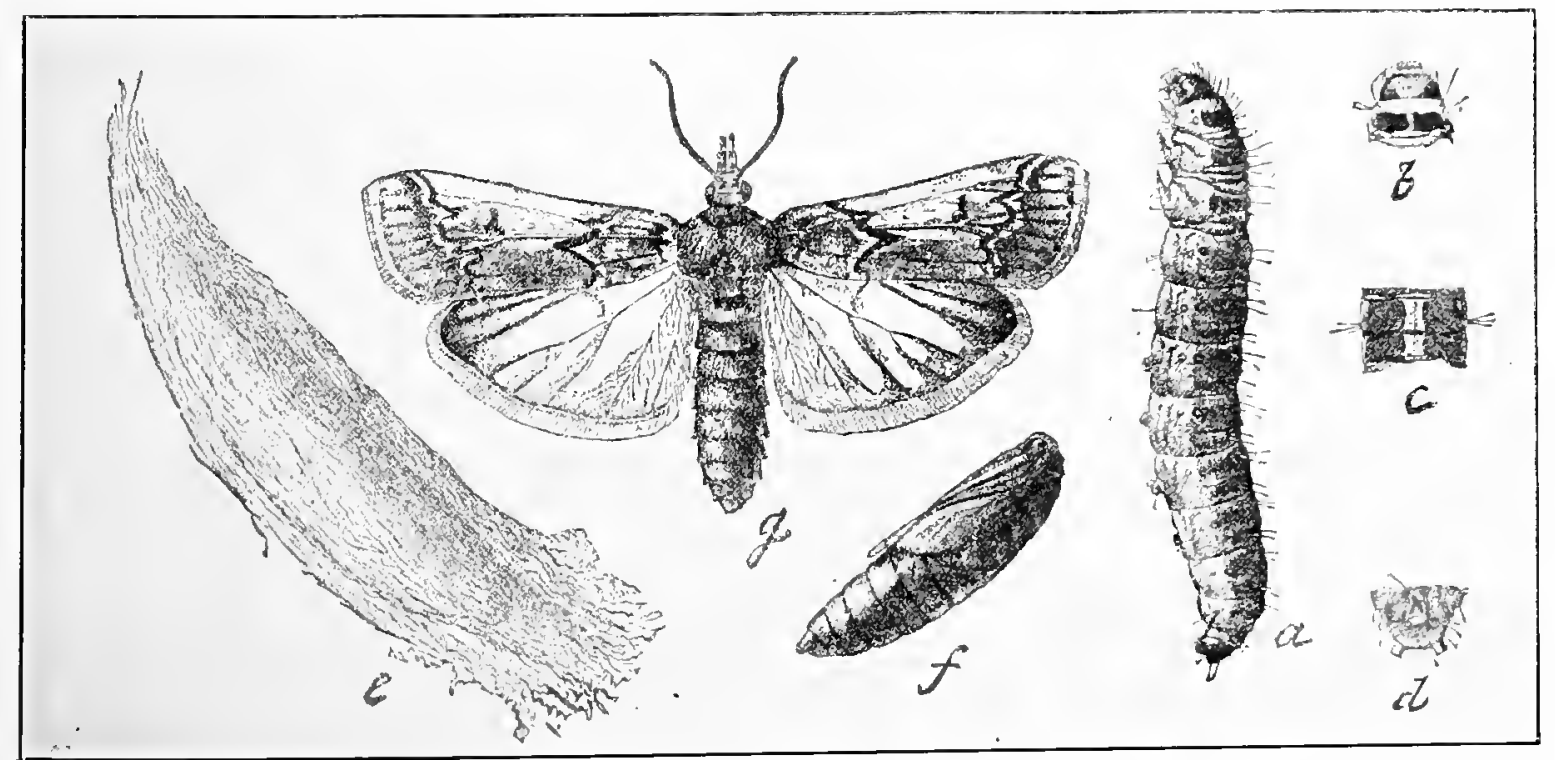

Fig. 36.-An Opuntia Moth-borer-Mclitara prodenialis-which attacks Prickly Pear in parts of the United States and the West Indies. $a$, larva; $c$, cocoon : $f$, pupa; $q$, moth. (Reproduced by IIr. O. Swezes, H.I.S.P.A., Honolulu, from the original in the Proc. Entomol, Soc., Waslington, iii., 1896, p. 132). 

Dr. Wolf (1912 a, pp. 124-7), who gives some good figures relating to this disease, mentions that new infections may oceur on the segment regardless of its age, entry of spores probably taking place through the stomata.

\section{Mould.}

Professor Hammond, of the New Mexico Agricultural College at Mesilla Park, referred, during an interview, to the presence locally of a black mould, a Phycomycete, which carssed damage to 0 . arborescens, one of the Cylindropuntias.

\section{Diseases of Uncertain Origin.}

In addition to the abovementioned diseases, there are some others whose cause is not known. Dr. Griffiths informed the Commission that in the spring (April) in the vicinity of San Antouio, Texas, after a period of vigorous growth followed by a stretch of cold wet weather, pricklypear plants may lose 70 per cent. of their joints, but he could not suggest a satisfactory explanation. He has referred to it in one of his publications (1908a, p. 30).

Gumming.-A Gummosis was seen frequently in South-Eastern Texas, where it did not appear to be accompanied by either fungoid or insect injuries. In other parts of the United States one often meets with gumming associated with the activities of the larvæ, and occasionally adults, of certain beetles (Gerstæckeria and Moneilema) and moths (Melitara), 万ut in the Brownsville area definite insect injuries were not found to be connected with the condition, though in some cases there seemed to be indications of bug punctures. Near San Antonio, gumming was seen to occur along the extremities of 0 . monacantha (cultivated) and $O$. lindheimeri. In some cases no other condition was found to occur along with it, though in others either Gloeosporium disease or "scald " might be present. A casual microseopic examination failed to reveal the presence of any organisms in the exudation, which was found to be confined within the plant to certain vessels of the vaseular bundle.

In the Brownsville distriet the gummosis was seen more commonly and was associated with other maladies. Its earlier stages could be detected by the presence of small disc-like swellings whose yellowish colour showed through the translucent overlying tissues. On puncturing them, a quantity of yellowish-white gummy fluid oozed out quite readily. These apparently burst under certain conditions, the wounded area becoming infected by various organisms, Gloeosporium being one of them. Moisture seemed to favour the malady. Certain species, e.g., $O$. robust $a$ and its allies, appeared to be more susceptible and to be more injured by the succeeding infection, death of the joints oceurring in many cases observed, as a result of the rot which set in.

In some instances very early stages were found in which the first indication seen in section was the presence in the central tissue of the joint of a watery-looking isolated area. The normal parenchyma became converted into a clear translucent tissue which degenerated into a gum-like substance, the latter being surrounded and limited by a well-marked callus formed by the surrounding plant-tissues. The central parts of the diseased area became brown. When the gum was able to exude, the injury was slight, and the part healed over or else a cavity formed and the progress of the disease wass arrested. The gum after escape hardened and commonly blackened, as a result of the attacks of saprophytic fungi.

Sometimes the swellings were very considerable, and suggest those described by Messrs. Hunter, Pratt, and Mitchell (1912, p. 25) as being caused by the presence of the larva of a moth, Melitara junctolineella. Since it appeared to be quite local on the plant, it is suggested that this gummosis, which was insufficiently investigated, may in part be due to the introduction of some ferment by a plant bug. It may, in part at least, be due to excessive root pressure during wet seasons, as the so-called "fat pear" is. The Commission saw cases of the latter in SonthEastern Texas, the segments being considerably swollen in their mid-region. The fact that escape of the excess of fluid is generally followed by a return of the plant to a healthy condition tends to confirm this opinion.

Many fungi, some of which are said to be pathogenic, other than those referred to above, have been recorded from North American Opuntias. These have been listed by Farlow and Seymour $(1888,1891)$. One of us has already published an extended list (Tryon, 1911, p. 16-17).

\section{DESTRUCTION BY RODENTS.}

It was noticed that in certain districts in Texas, e.g., near Alice, Brownsville, and Sinton, more or less damage had been done to species of Opuntia by a so-called "blue rat" or "wood rat,", more commonly known locally as the " pear rat." A captured specimen has been identified for the Commission by Mr. V. Bailey, of the United States Bureau of Biological Survey, as Neotoma micropus, Baird.*

The "house" is a characteristic structure piled up around the roots of an Opuntia or of a mesquite tree (Prosopis glandulosa), and consisting of a mass of dead twigs and prickly-pear débris such as fibre, spines, and dead joints. In addition one may notice the presence of cotton, horse and cow dung, and any available rubbish. The mound varies in height from a few inches up to three or four feet, and may be a few feet in width. Below the "house" is an excavation which may be roofed over with earth or debris to form a tunnel with several entrances, and it is in this chamber that the nest is located. The latter is earefully lined with grass or mesquite leaves, though other plants and even cotton wool may be used as well. In order to still further protect the rat against its numerous enemies such as hawks, owls, snakes, and carnivora, prickly-pear spines may be strewn around and above the entrances as well as for a short distance along the paths leading to the "house." At Brownsville and elsewhere, it was noticed that the animals had carefully gnawed around the areoles of certain spiny species in such a way that the spine clusters were removed, and these were then distributed around the cntrances to the nest so as to afford an efficient

* Although these rodents are spoken of as "rats," and are included in the Muridœ, their habits, as stated by Mr. Bailey (1905, p. 111), are quite different from the animals to which the term rat is generally applied. These animals to which the term and feed on vegetable food. Their flesh is said to be very good eating. 
defence.* Fragnents of the small-jointed eactus (O. leptocaulis) were also used for the same purpose. Occasionally partly eaten prieklypear segments were seen close to mounds built around mesquite stumps, and had evidently been brought from a distance Jy the rat, as there were no Opuntias near by.

Joints are readily devoured in situ, and, as just mentioned, some may be carried a considerable distance to the "house." The stomach contents of a captured animal appeared to consist entirely of cactus pulp. Some weeds close to a nest were found to have been caten down by some rodent, presumably a pear rat.

This animal gnaws into the stems and bases of the plant around which the house is built, often entirely ringbarking them. Sometimes the injury does not extend inwards beyond the woody cylinder, but at other times the branch may be almost or entirely eut through. In spite of the rapidity with which the Cactaceæ can form a hard callus to protect an injured surface, it often happens that decay sets in which may lead to the destruction of the entire branch. More usually, however, the branch bends over, allowing the distal parts to reach the ground, where they may strike root, and thus it is quite a common sight to see a cactus clump with the centre entirely destroyed and often containing a conspicuous rat mound, while the surrounding mass really consists of a large number of independent but intermingled plants which have originated in this way. Thus the animal may act as a distributor of prickly-pear. However, many instances were met with where it had been a very efficient destroyer. It was quite common to see areas near Alice where scarcely an Opuntia remained alive, though the presence of abraded stumps and numerous " nests" told of former activity of these rodents. In this locality, within a radius of about 30 feet one could frequently count nearly twenty such stumps. Though extensive damage was seen at Brownsville, the most marked results were noticed in the more open country which was lightly timbered with mesquite trees-e.g., near Alice and Sinton.

In order to become fully acquainted with the food habits of the Neotoma, local inquiry was made at each of the Southern Texas towns visited. Some observers referred to the widespread destruction of prickly-pear by rats at certain times, the animals migrating in large numbers at intervals of some years. Some Mexicam inarmers stated that they found these rodents occasionally attacking cultivated plants, more especially beans, but that they generally confined themselves to a diet of Opuntia. Another staterl that they ate house refuse and also grain such as maize, invading the barns for the latter. $M r . ~ R$. E. Moore, a farmer near Sinton, informed the Commission that these pear rats fed on cactus and mesquite, but occasionally entered his barn and took away some corn, though they did not do any appreciable damage, nor did they attack his growing crops as far as he knew. They would however, take cotton bolls, use the seeds, and

* Certain other wood rats have a similar habit, e.g. Neotoma mexicana, Baird, in and about whose nest Dr. Merriam (1890, p. 67) has mentioned that cactus spine are distributed in abundance, no doubt as a protection against coyotes and skunks. distribute the eotton on their mounds. He did not think them eapable of exterminating the pear, though they greatly injured it. Another farmer, however, was positive that they had eaten out the cactus completely from his farm. Another tarmer, Mr. J. J. Love (from Alice district), referred to the great destruction of prickly-pear occasioned by the periodical visits of swarms of these animals, whose presence he considered benefieial on account of their activity in eliminating cactus, though they might take grain or cotton.

Prof. D. E. Merrill, of the New Mexico A gricultural College at Mesilla Park, referred to the occurrence of an allied species, Neotoma albigula, Hartley, known locally as the "pack rat", on account of its habit of constructing a mound resembling that of $N$. micropus referred to above. This rodent fed on the joints and fruit of both fiat and cylindrical Opuntias, and would enter granaries in search of grain, sunflower seeds, \&e.

In company with Prof. J. J. Thornber, of the ['niversity of Arizona, the Commission visited some localities near Tueson, and found that this species, $N$. albigula, was not uncommon. Its habits were seen to be similar to those of its Texan relative, though the destruction of prickly. pear was not nearly so great. The stem-joints and fruit of both flat and cylindrical Opuntias were attacked, though the most damage appeared to be occasioned to such shrub-like species as $O$. arizonica.

Rats, probably belonging to a species of Neotoma, were seen occasionally amongst clumps of o. occidentalis near San Diego in Southern California.

Mr. Vernon Bailey, in his "Biological Survey of Texas" (1905), referred to the distribution and habits of certain wood rats (Neotoma, spp.) in that State. The nests or mounds of all are, as a rule, similar to that of $N$. micropus referred to earlier, though some species-e.g., $N$. albigula, $N$. mexicana, and others-prefer to build in gullies and along cliffs. The species and varieties referred to by Mr. Bailey are-(1) $N$. floridana rubida, Bangs. (East Texas and Louisiana); (2) $N$. floridana baileyi, Merriam (North Texas and Oklahoma to North Nebraska); (3) $N^{T}$. floridana attwateri, Mearns (West Texas); (4) N. micropus, Baird (Western and Central lexas, New Mexico, Oklahoma, and parts of Mexico and South Texas); (5) N. albigula, Hartley (West Texas and New Mexico); (6) $N$. mcxicana, Baird (Texas). This enumeration does not include all the species of Neotoma occurring in the United States, since Dr. Merriam (1899, p. 94) mentions two wood rats, $N$. fuscipes and $N$. cinerea, as occurring in the northern part of California. The food of the various species mentioned by Bailey consists of acorns, green leaves and berries of various kinds, wild grapes, walnuts, fruits, stems and joints of Cactaceæ, seeds, nuts, mesquite bean-pods, and grain of any kind.*

In an interview, Mr. Bailey referred to the diversified character of their food, which included, in addition to those already mentioned, maize, cotton-seed, pine-nuts melon-seeds-in fact, any kind of wild or cultivated seed which

* At least one species, N. drummondii, Richardson, lives in the far north-west of Canada and British Columbia, beyond the regions where Cactacer occur. (Preble, 1908, p. 176.) This species has been removed from the genus Neotoma and made the type of the genus Teonoma Gray (Palmer, 1909, p. 859). 
could be stored up for winter use. $\mathrm{He}$ also stated that these animals fed largely on cactus during dry seasons, depending on it for much of their supply of moisture. In his work (p. 112) he mentioned that ordinarily these rats were of little economic importance, owing no doubt to their spread being controlled by their natural enemies, e.g., hawks, owls, rattlesnakes, and carnivora. During the interview he stated that in some parts of Texas and Arizona wood rats had become sufficiently numerous to lead to the receipt by the Bureau of Biological Survey at Washington, D.C., of requests for information regarding means for their destruction, this result being no doubt due to the diminution in the number of carnivora and snakes frequenting those localities.

Both Mr. Hanshaw, the Chief of that Bureau, and Mr. Bailey were of opinion that the introduction into Australia of any of these rodents would be dangerous, since they would not confine would be dangerous, since they would not confine their attention to prickly-pear, nor would they destroy it except locally during seasons when other food was scarce, so that the total injury which they might occasion would be quite insufficient justification for such action.

Dr. Merriam, formerly Chief of the Bureau, also stated that reliance could not be placed on the cacticidal habits of any of these rodents, and moreover, that these animals occasionally served indirectly to spread prickly-pear.

Though prickly-pear enters very largely into the diet of certain species, it will be recognised that the introduction of these rodents could not be recommended on account of the probability of their becoming a nuisance.

Besides the various species of Neotoma, other rodents such as jack rabbits, cotton-tail rabbits, and some gophers, were mentioned by Professors Thornber, Merrill, and Hammond as being destructive to prickly-pear, particularly the less spiny species, during winter and early spring, and especially during dry seasons, more suitable food being scarce during such times. Mr. J. D. Mitchell had observed the same result in Texas. while the Commission noticed injuries to Opuntias caused by various rodents in Texas, New Mexico, Arizona, California, and Kansas. Dr. Griffiths (1909a, p. 19) and also Dr. Wooten (1911, pp. 14-17) referred to their destruction of young and relatively spineless plants.

Mr. Bailey in the work mentioned earlicr (1905) has stated incidentally that he found parts of prickly-pear, especially the fruits or seeds, in the alimentary tract of certain squirrels, Ammospermophilus interpres (p. 83), Citellus varicgatus buckleyi, Slack (p. 85), C. variegatus gramma'us, Say (p. 86), and $C$. tridecimlineatus pallidus, Allen (p. 87).

Amongst the rodents which may utilise prickly-pear plants for shelter and oceasionally for food are the Texan cotton rat, Sigmodon hespidus texanus, Aud. and Bach. (p. 115) ; certain gophers, Thomomys aureus lactuquilla, Bailey ( $\mathrm{p}$. 134), and T. perditus, Merriam; Dipodomys elator, Merriam (p. 148), and D. merriami (p. 150); the jack rabbits, Lcpus texanus, Waterhouse (p. 153), and $L$. floridanus chapmani, Allen (p. 156); as well as the so-called prairie dog, Cynomys ludovicianus, Ord. It must be remarked that the above list of rodents refers to the species found in Texas, and would doubtless be greaty lengthened if work similar to that carried out by Mr. Bailey were undertaken in other parts of America. The common jack rabbit of Arizona, which is known to feed on prickly-pear when other food is scarce, is Lepus arizonice.

Mr. Bailey (1905, p. 75) found parts of prickly-pear plants in the digestive tract of the mountain sheep, Ovis mexicanus Merriam.

\section{DESTRUCTION BY INSECT ENEMTES.}

In Dccember, 1912, the U.S. Department of Agriculture published a bulletin by Messrs. Hunter, Pratt, and Mitchell, dealing with the principal eactus insects of the United States. It contains a short account of some of the more important of them, as well as some fine illustrations of the insects and their work. It also includes a list of injurious species, together with their known parasites, and of the scavengers and other insects more or less incidentally associated with cacti. This work has been freely used in the writing of this portion of the report.

The chief enemies of the prickly-pears are either beetles, plant-bugs, moths, or diptera.

\section{The Coleopterous Pests.}

Cactus Longicorns, Moneilema, spp.

The members of this genus of " Cactus Longicorns " are rather large, wingless, generally black beetles (C.I., pl. 1),* which in the adult stage feeds on the segments of Opuntias, but which in the larval condition bore down into the joints and stems and even the roots, feeding on the internal tissues, a large tumnel being formed. The presence of larvæ is often indicated by the occurrence of a hard, black, gummy-like exudate from the plant at the point of entry of the larva (C.I., pl. 2). Pupation takes place in an imperfect cocoon, generally just below a joint lying on the ground. This coeoon, in the case of $M$. crassum at least, is made of fibre of the foodplant and covered externally with sand. There is said to be one generation per season. The adults (of $M$. crassum) are commonest in April and May, and again in September (C.I., pp. 13-14), or even later according to our observations. This suggests the occurrence of two broods.

It is stated that eight species are known to affect the roots and stems, but some of these are recorded only from Mexico. The eommon species in Texas are M. crassum (Le Conte) and M. ulkei (Horn), M. spoliatum (Horn) being less common. In Kansas there oceur $M$. anulatum (Say) and $M$. semipunctatum, Le Conte (Popenoe, 1877, 1878). The abovementioned species are recorded as injuring Opuntia, $M$. crassum, attaeking Eehinocerens also. Hubbard (1899) found M. gigas (Le Conte) to be an enemy of the giant cactus (Carncgiea gigantea) in Arizona. Sehwarz (1896, 1899) has also referred to some of these species of Moneilema as injuring cacti.

G. H. Horn in his monograph (1885, pp. 180-190) refers to the following species:-M. anulatum, Say (Colorado, New Mexico, Texas); M. appressim, Le Conte (Arizona, New Mexico); I. gigas, Le Conte (Arizona) ; M. semipunctatum, Le Conte (Lower California); M. lovigatum,

* The abbroviation "C.I." is used to indicate Messrs. Hututer Eatur Insecte of the Evitad States," 1912. 
Blanch. (New Mexico) ; M. armatum, Lee (Colorado, Texas) ; 1 . obtusum, Lee (Utah) ; M. spoliat um, Ilorn (Lower California) ; M. forte, Lee; M. subrugosum (?), Blanch. (Lower California); M. ulkei, ITorn (Texas) ; M. variolare, Thoms. (Mexico) ; H. albopunctatum, Lee; M. crassum, Lee (S.W. Texas).

They are often gregarious and may be met with in large numbers. Individuals may reach a considerable size, an example of $M$. armatum eolleeted at Tueson, Arizona, measuring $32 \mathrm{~mm}$. in length and $23 \mathrm{~mm}$. in breadth.

The Commission saw no definite evidence of the action of this genus of beetles during its investigation in the eactus belt in the United States (October, November, and early December), though individual adults of $M$. crassum were taken near Sinton, Texas, on $O$. lindheimeri, and of $M$. armatum, near Tueson, in Arizona, under plants of $O$. arbuscula, $O$. spinosior, and $O$. fulgida, apparently overwintering under the latter cireumstances. Fragments of a Moneilema were found under $O$. missouriensis at Wallace, in Kansas. Injuries resembling those described and illustrated (C.I.) were seen in the stems of $O$. fulgida and allied Cylindropuntias, but the larva whenever met with, which was seldom, was found to be a Melitara (vide infra). Being wingless and therefore endowed with but indifferent means for extending its range, its size and local prevalence would suggest that it might prove bighly destructive within a cireumscribed area.

Prof. D. E. Merrill, of the New Mexieo Agricultural Station at Mesilla Park, kindly supplied the following information regarding the local species, $M$. armatum, which he found to attack $O$. arborescens, $O$. whipplei, and allied species of Cylindropuntias, but not, as far as he had observed, any of the flat Opuntias. An adult, under experiment, was found to feed on any species of Opuntia, but under natural conditions the Cylindropuntias constituted the foodplants. The eggs (35 to 50) are laid in June and July, each one being placed in a slit made by the female in the upper edge of a joint, the larvæ, on hatching, boring their way down into the stem-joints. They commonly come out of the plant near the ground, the stalk being frequently killed as a result of the attack. The inseet passes through winter as a larva. The chrysalis period is short, amounting apparently to some two or three weeks. The adult breeds out during the latter part of June, and will remain alive for many months. On account of these facts, he suggested that the adult would be the best stage for transportation should it be decided to send living speeimens to Australia.

Mr. C. H. Popenoe, of the Bureau of Entomology, referred to the widespread destruction of the common prickly-pear, $O$. missouriensis, caused by $M$. armatum near Wallace, in Eastern Kansas. A visit was paid to the loeality early in December, but only a few fragments of the insect were seen. Though a great deal of injury had been caused to the Opuntia, at least a great part of it was due to a species of moth, Melitara dentata (vide infra).

Mr. E. A. Sehwarz, the Coleopterologist at the National Museum, Washington, D.C., stated that the genus Moneilema was restricted to the
Cactacex, and occurred in the United States in every section of the dry cactus belt, its species being important enemies of this group of plants. Voneilcma spp. could be safely introduced into any other country, though he did not know whether they would prove to be effective there. The stunting of the plant was a common result of the attack.

Mr. W. D. Hunter, the senior autbor of the bulletin mentioned above (C.I., 1912), referred to the fact that Moneilema in its adult eonditinn may act as a planter on aecount of its habit of congregating on young joints, which are often eaused to fall to the ground, where they may take root.

Mr. J. D. Mitehell, who accompanied the C'cmmission during its tour in Southern Texas, and who is also part author of the bulletin on Cactus Insects, stated that Moneilema is not sufficiently abundant in Texas to cause much diestruction of Opuntias there.

No parasites of the genus are listed by Nessrs. Hunter, Pratt, and Mitchell.

Dr. Merrill mentioned the occurrence at Mitsilla Park, New Mexico, of an unidentified C'erambycid about two-thirds of the length of Noneilema and attaeking the same species of Opuntia.

\section{Conopceus palmeri, Le Conte.}

Horn $(1889$, p. 162) bred out the adult from Opuntia bernardina (Southern California), vithin whose joints the larvæ feed. It is not referred to in the text of the bulletin on Caetus Insects, so that it may be assumed that it had not come under offieial notice as a serious enemy. iil. Schwarz, however, when interviewed, stated that this large longicorn breeds readily in the jcints and could be easily transported. He had seen it at times in great numbers at Fort Grant, Arizona.

A second species of this genus, C. niger, oecurs at San José, Southern California, according to information tendered by Mr. Sehwarz, but its food-plants were nnknown to him.

The Commission did not have an opportunity to investigate the habits of either of these beetles.

\section{Allorhina mutabilis, Gory.}

This scarabeid is reported to attack com. monly the frnits of Cereus in Arizona, but as it is destruetive to various other fruits (C.I., p. 35), its introduction need not be eonsidered.

\section{Disonycha varicornis, Horn.}

Both adults and larvæ of this flea-beetle are found in Texas on 0 . leptocaulis and 0 . arborescens, but are not known to attack any of the flat Cpuntias. They are surfaee feeders, and mar oeviur in such numbers as to kill the hostplant (C.I., p. 22, pl. 4).

As the greater number of Queensland priekly. pears are flat Opuntias, and as $O$. imbricata, an ally of $O$. arborescens, is very loeally distributed in that State, the introduction of Disonycha would be of little value. 


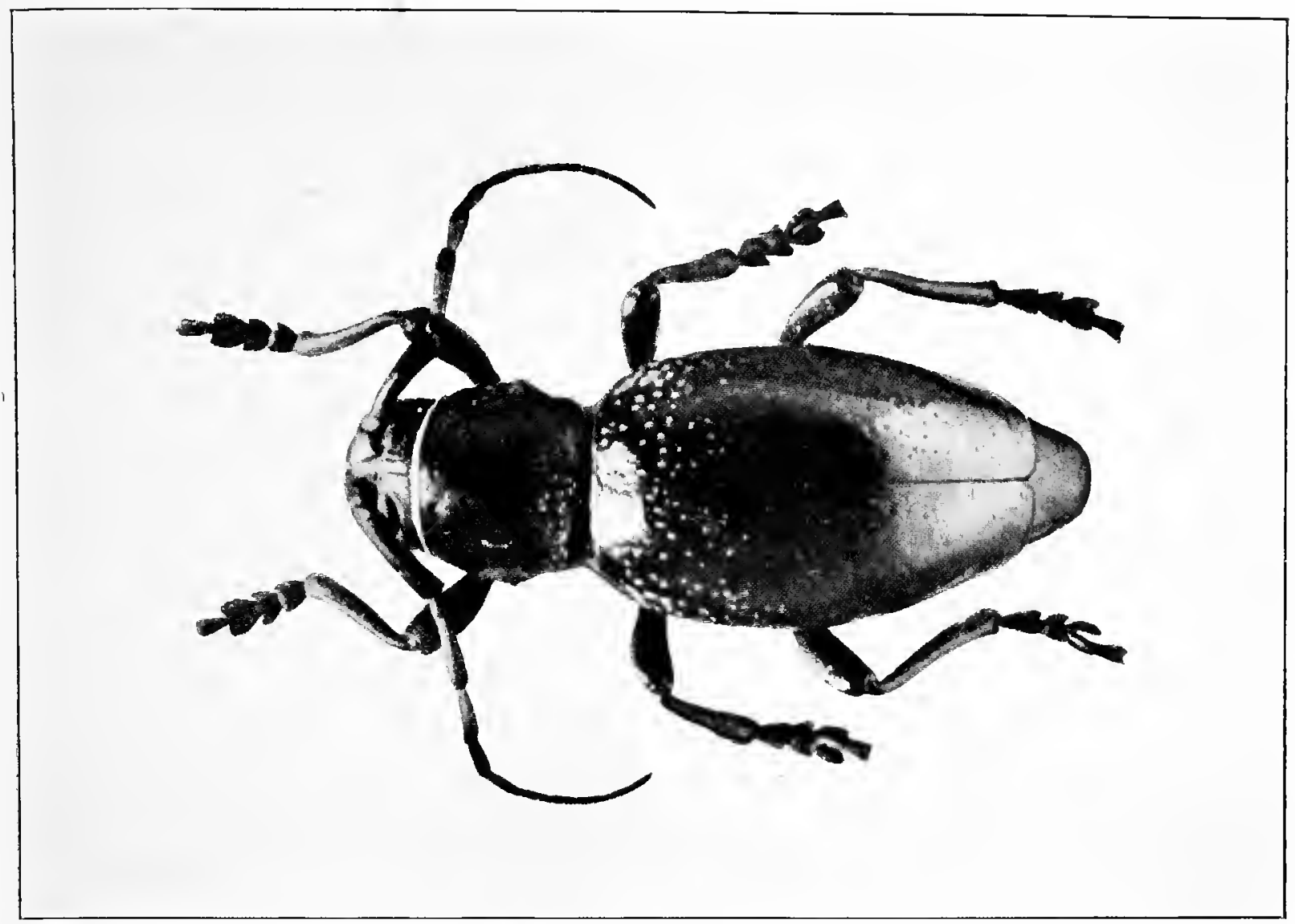

Fig. 37.-A Cactus Longicorn Beetle-Moneilema crassum-which, in Texas, feeds on the joints of cacti, the larva destroying the internal tissues of the attacked plant. (From "The Principal Cactus Insects of the U.S.A.," Bulletin 113, Bur. Entomol., U.S.D.A., 1912, plate 1.)

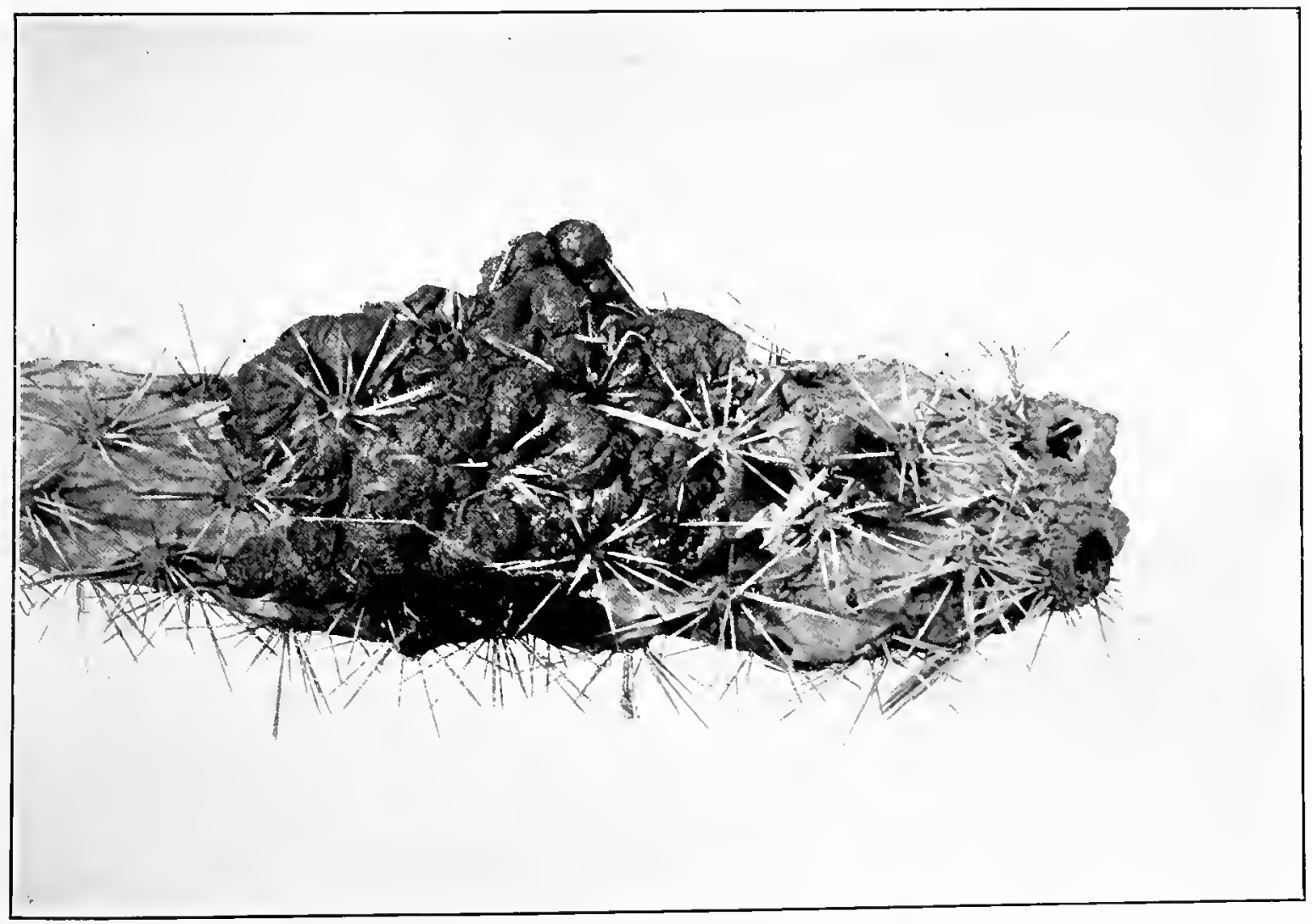



The Cactus Weevils, Gerstackeria, spp.

This group of weevils, which feed exclusively on cacti, has received the special attention of $\mathrm{Mr}$. W. D. Pierce, of the Bureau of Entomology (1907, 1911). The genus consists of about twenty-two species-eleven in the United States and eleven in Mexico and Central America.

The adults feed more or less superficially here and there on the joints, whilst the larve live within them.* The latter do not cause much injury, as they derive their food-supply from the neighbourhood immediately surrounding the spot where they were hatched, the larva undergoing its transformation into the adult within the cavity which it has made in the segment. They do not produce any serions effect on the attacked joint, as a callus is formed by the plant tissue. In the case of the larva of $G$. porosa, which breeds in the flat portion of the joint, the injury may exterid from one surface to the other, and then a "shot hole" effect may be produced. At times, the injury may be aggravated by the presence of scavengers, more especially fiies, but this does not appear to happen often. Hibernation takes place under fallen joints (Pierce).

G. (Philopuntia) porosa, Le Conte.-G. porosa is a wide-spread species, being recorded from Colorado tó Arizona, Texas, and New Mexico (C.I., p. 30, Pierce, 1911, p. 165). Eggs are deposited singly in or on the surface, the larva on hatching living within the flat portion of the segment. Eventually the grub makes a small oval cocoon, about $8 \mathrm{~mm}$. long, from agglutinated fragments of excreta, where it undergoes its transformation. The injuries eaused by the insect or its larva were found by the Conmission on $O$. lindheimeri at Laredo and San Antonio, while at Wallace, Western Kansas, injuries similar to those caused by the adult weevils wire noted. In the last-named district the species was prohably either $r$. porosa or $G$. basalis, judging from its known distribution. Adults of $G$. porosa wire taken near Tucson, Arizona, on O. arizonica, O. fulgida, O. spinosior, O. mammillata, and $O$. arbuscula. Mr. Pierce, who identified the specimens, mentioned that this species was greatly parasitised by undetermined hymenoptera, a statement which we were able to confirm by personal observations at Laredo, Texas, where several hymenopterous larvæ were collected from a cocoon of this species.

G. (Philopuntia) nobilis, Le Conte--This species is rather larger than the former, and measures about $7 \mathrm{~mm}$. in length. Its eggs are deposited singly at the base of an areole preferably on the upper edge of a joint. Hence the larval injuries are more or less terminal, and associated with them there is, in addition to the insect excreta, a black exudation of the hardened mucilage of the plant. The latter is said (C.I., p. 30) to interfere with the development of new growth. The blackening is due to the growth of fungi.

The adult and larval stages were seen by us near Sinton attacking $O$. lindheimeri and related species. The adult is black, clothed with brownish-coloured scales and with five conspicuous patches of white scales. The elytra have

* This remark does not apply to $G$. hubbbardi açcording to our observations, seven costie. The larva is a small, white, oblong, footless grub with a glossy brown head and with transverse folds or wrinkles on each body-segment, there being isolated short brown hairs on Each side of the last two segments. In the Bulletin on Cactus Insects (p. 43, and Pierce, 1911, p. 164) the host is quoted as $O$. engelmanni, and the distribution given as Southern and Eastern Texas (p. 30). Since O. engelmanni does not oceur in those distriets, the name evidently refers to $O$. lindheimeri and its numcrous allied varieties and species commonly met with in that region. It is figured in C.I., p. 30, fig. 3 .

\section{G. (Opuntiaphila) hubbardi, Le Conte.*-In} a conversation, Mr. E. Schwarz referred to extensive destruction of the common Opuntia at Lake Worth and Crescent City in Florida, and Sclina, Alabama, which be said was caused by this species, whose larva breeds in the joints. The host-plant is recorded by Le Conte as $O$. vulgaris (C.I., p. 30). In the Bulletin on Cactus Insects (pp. 30, 43) it is mentioned that the weevil appeared to follow the work of a moth, Melitara prodenialis.

A visit was paid to Florida, and the beetle found on prickly-pears, probably $O$. austrina at West Palm Beach. The attacks of the Melitara and $G$. $h u b b a r d i$ were seen to cause serious injury to infested plants, some of them having been killed. The sparse distribution of the Opuntias in the locality may have been occasioned by insect devastation. In all observed cases the moth and the weevil were associated.

* The insect is a very stout-bodied beetle, $8 \mathrm{~mm}$. long and nearly $6 \mathrm{~mm}$. broad, and when seen from above has an ovoid profile. It is of a general black colour with numerous brown acales, the small areas on the surface where these are absent appearing as black points. Commonly individuals appear almost black, owing to the loss of their white scales by abrasion. Conspicuous patches of white chalk-like scales are disposed as follows :One pointed above on forehead and extending downwards between the eyes; an elongated one on each shoulder uniting with the suture, the two forming the commencement of the firstmentioned; a sinuate band crossing the elytra at their declivity; and a band also on their hinder slope. The femora, tibia, and tarsi of the lega are variously spotted with patches of these white scales. The elytra are coarsely ribbed, the interstices containing large punctures and transverse rings. The rostrum is curved, and when folded under the insect reaches just beyond the anterior coxa. The thorax is much narrowed and coarsely punctured, and has a single longitudinal dorsal keel occupying the anterior two-fifths.

The egos are laid singly each in a perforation made in the tissue of the joint. These injuries, arising from oviposition, result in the formation of a well-defined grey circular spot. The egg is smooth and oval, of a dull yellowish-white colour, and measures $2 \mathrm{~mm}$. in length by about $1 \mathrm{~mm}$. in breadth.

The larva is an elongate, trangversely wrinkled, footlese grub with a glossy brown head and piceous mandibles. There are three rows of low conical tubercles on each side below the level of the spiracles. Small solitary brown hairs occur on the hinder segments. The larva feeds within the joints, and appears to be able to carry on its operations in moist, discoloured, and even semi-fluid broken-down tissues.

The cocoon is a pale yellowish oval body $15 \mathrm{~mm}$. long by $10 \mathrm{~mm}$. wide, of firm consistency, having a rough anterior end, and composed of dry plant tissues within anterior end, and composed of dry plant tissues within which pupation tamstance that is due to the larva having fed on the dark disorganised tissue of the host-plant, as it fed on the dark disorganised tis has been formed on the commonly does. Again, when it has been ficles of sand interwoven in its walls, and be accordingly of a hard consistency. 
G. (Philopuntia) clathratus, Le Conte.-In 1903 Prof. Townsend referred to the finding of this species in abundance in Southern Texas, breeding in the ends of joints of $O$. leptocaulis. The larva eats out the tissues, killing the part affected, and then forms a eell in which it pupates. Its range is given (C.I., p. 30) as Colorado to Brownsville (Texas) and Arizona. Mr. Pieree $(1911$, p. 165) stated that a elumping of the branches takes place if the infestation be heavy. Though the "witeh's broom" condition of $O$. leptocaulis was seen by the Commission near San Antonio (Texas), the weevil was not found.

Other speeies of Gerstæcliteria mentioned in the list given in the Bulletin on Caetus Inseets (pp. 43-44) or in Mr. Pierce's paper (1911), as oceurring in U.S.A., are G. bifasciata, Gerstæcker, reared from larvæ infesting Echinocactus setispinus (San Antonio, Texas); G. basalis, Le Conte, from Colorado and Nebraska; $G$. turbida, Le Conte, and $G$. alternata, Pieree, from Arizona ; $G$. opuntice, Pierce, and $G$. cactophaga, Pierce, from Southern Texas; G. fasciata, Pieree, from Florida; $G$. tessellata, Pierce, from Colorado; $G$. profusa, Casey, from Texas, and $G$. dilitata, Casey (probably a variety of $G$. $h u b$ bardi), from Florida.

\section{The Black Cactus Weevils, Cactophagus, spp.}

These are large blaek weevils allied to Calandira and Sphenophorus. Dr. C. Riley (1888, p. 199 ), in his article on the "Food Habits of North American Calandrinæe," stated that, as far as known, C. validus was restricted to Opuntias.

The Commission found beetle larvæ, eorresponding in size and appearance to those of a large Sphenophorid, feeding in the roots of the common low-growing prickly-pear (O. missouriensis), near Wallaee, in Western Kansas. In one instance the plant had almost succumbed to its attacks.

Mr. F. Blaisdell, a Californian entomologist, was understood to say that he had found $C$. validus in great abundanee around the bases of prickly-pear near San Diego in Southern California. A visit to the locality failed to reveal the presence of this or any other weevil assoeiated with Opuntias there (November, 1913).

Cactophagus spinola, Gyll. (syn. G. validus, Le Conte) has been reeorded from California and Arizona. C. hubbardi, Schwarz, whieh forms tunnels in the giant cactus Carnegiea gigantea, in Arizona (Hubbard, 1899; Schwarz, 1899), is capable of living for at least four years, aeeording to observations reeorded by Sehwarz (1901, p. $368 ;$ p. 431 ).

T. L. Casey published in 1892 a systematie arrangement of the genus Cactophagus.

Sphenophorus acupunctatus, Gyll., was stated by some local entomologists to have been foind assoeiated with prickly-pear in the region between San Bernardino (Southern California) and Arizona, but Mr. Blaisdell said that both this species and its ally, S. yucca, Horn, were assoeiated exclusively with Yucea plants. Speeimens were not found by the Commission during it ahe visit to the San Diego distriet.
Even if these Sphenophorids were cactus destroyers, their introduction into Australia would be unwise, as one species of the group feeds indifferently on palms, bananas, and sugar-cane, and another on the two lastnamed plants. Some, however, appear to be $\mathrm{I}^{\prime}$-strieted in their dietary to one plant-e.g., those infesting Yucca spp.

\section{other beetles.}

Other beetles whieh have been mentioned (C.I., pp. 42-44) as enemies of eaeti are the following :-

Onychobarius mysticus, Casey, on O. leptocaulis in Texas, Arizona, and New Mexieo, and on o. fulgida in Arizona.

Trichochrous texanus, Le Conte, sometimes iujures the flowers of Opuntias in New Mexieo and Texas to such an extent that fruiting is prevented, but it is probably not confined to the Gactaeen for its food (C.I., p. 32).

\section{The Lepidopterous Enemies.}

Amongst the moths whieh feed on prieklypears, there are some which are very serious enemies-viz., Mimorista and the various speeies of Melitara.

\section{Mimorista flavidissimalis, Grote.}

This small yellowish or straw-coloured Pyralid moth is briefly deseribed, and an illustration of its work given, in the Bulletin on Cactus Insects (p. 21, plate 3). From one to seven eggs are placed by the female moth on the upper edge of the stem-joint. On hatching, the minute grubs make tiny holes through the skin of young segments of the host-plant, and so bore their way into the interior. The caterpillar is a smooth, glossy, yellowish-white insect which when fully grown measures about $11 \mathrm{~mm}$. There are a few long white hairs oeeurring sparsely on the anterior segments especially. The head and cervical shield are yellow, the latter bearing two very small black spots. When fullfed, the larva emerges from the joint and forms a coeoon resembling paper, within which it transforms into a shiny, light-brown chrysalis about $9 \mathrm{~mm}$. long.

The site of this injury is marked by an exudation of the cell-sap, which, becoming mixed with silky threads and exereta from the insect, forms a proteeting eover beneath which further damage is exeeuted. In eases where the wounds have healed, this foreign matter persists on the injured areas as dry brown or grey flakes. If only a few larvæ be present, the injury caused by them is likely to heal, a deformed segment being the result. If, however, several larvæ attaek, then the death of the joint is usually the result, as decay sets in and the part blaekens, dries, and falls. Their importanee in eheeking the growth of prickly-pear depends upon the faet that they will attaek the youngest shoots as well as those which are rather older.

Since there are several broods in a season, this moth is a serious enemy to Opuntias. Mr. Mitchell has estimated that from 50 to 75 per cent. of all new growth is destroyed through its agency over considerable areas in Southern Toxus. It is stated that in the restrieted region 
where it occurs it is by far the most injurious cactus pest, and with the exception of the bugs Chelinidea, spp., is the most destructive enemy of the prickly-pear in the United States. It is found commonly in Southern Texas, being abundant from May to September, but is rare in vore westerly localities as far as Arizona. Mimorista is parasitised by a hymenopteron, Eiphosoma texana, Cresson (C.I. pp. 20-22, 44).

The work of this moth was seen commonly on 0 . lindheimeri and allied species near San Antonio, Alice, and Brownsville, where there were noticed dead and occasionally deformed joints showing typical injuries on the distal end of one surface (November). Our personal inquiry in the United States did not lead us to regard it as being so important an enemy as Messrs. Hunter and Mitchell did. This may be explained by the fact that our visit was made curing late autumn when there was little insect activity. A little later, one member of the Commission saw considerable damage caused by an insect, apparently belonging to the same species which was destroying the buds and very young growth of Opuntia dillenii, near Guantanamo, in Cuba.

As far as known, this insect feeds exclusively on Cactaceæ, this opinion being held by Dr. Dyar, of the National Museum, Washington, a leading authority on American Lepidoptera.

The Cactus Moth Borers, Melitara, spp. (Phycitidx).

This genus of Pyralid moths consists of several species, all of which are restricted to the Cactacex, the caterpillars feeding on the internal tissues of the joints and stems, and usually bringing about their destruction, being frequently assisted in doing so by the larvæ of various scavenging diptera, as well as by the invasion of micro-organisms.

The genus has been described from a systematic standpoint by G. D. Hulst (1902, p. 429), in Dr. G. H. Dyar's "List of American Lepidoptera." The entomologists interviewed were unanimous in their opinion that Melitara, spp., are restricted to the Cactacer, especially to Opuntia and Cereus, spp. However, it should be mentioned that Mr. Hulst, in 1890, stated that $M$. prodenialis is a borer in Yucca and Agave, and that $M$. dentata lives in Yucca, but, strange to say, he docs not include the Cactacex in their dietary. However, neither the evidence of entomological literature nor that of those investigators competent to express an opinion with regard to this matter, supports him in regard to this matter, nor do our own observations.

As a rule, each species fceds on more than one kind of cactus, though certain Opuntias scem to be favoured as food-plants, the species or group of species, of course, differing in different regions.

In the Bulletin on Cactus Insects (pp. 2529), four of these moths are treated of, viz., $M$. junctolineella, Hulst, $M$. dentata, Grote, $M$. prodenialis, Walker, and $M$. fernaldialis, Hulst.' The observations of the authors, howcver, refer only to the first named. In addition to these four there is $M$. parabates, Dyar, from Mexico. 'The genus extends at least as far' gouth as Guracae, since Hulst has mentioned that $M$. prodenialis had been received by Dr. Snellen from that island. Moreover, we have observed inland from Barrahona, in South-western San Domingo, plants of Opuntia dillenii, as well as of another species, which presented the characteristic injuries accasioned by Melitara, spp., and from some of these their larvæ were taken. Similar injuries were seen also in Barbados, where an Opuntia allied to 0 . dillenii was the victim.

From what has been recorded, and from what wc have seen, it would appear that these insects are competent to very seriously injure and even kill prickly-pear plants. Since they are often heavily parasitised, their destructive activity is in such cases not as fully exercised as it would be were parasites absent. In the Bulletin on Cactus Insects (p. 46) there is given a list of those known. Of the three mentioned, one is a beetle, one a hymenopteron, and one a dipteron. Besides these, two hymenoptera are mentioned which are perhaps parasitic.

The following species may be referred to in more detail.

Melitara junctolineella, Hulst (1900, p. 173).-The adult* is a large greyish moth having an expanse of about $1 \frac{1}{2}$ inches, while the larva is at first a whitish but later a deep blue; caterpillar about 11/2 inches long, which becomes marked dorsally with brown bands before passing into the pupa stage. There is said to be only one brood each season. The larvæ on hatching from the cylindrical chain of eggs, which are fastened by one end to a spine (C.I., plate 7, fig. 1), penctrate the joint and feed on the internal tissues, forming large excavations which may extend from joint to joint downwards into the stems. As only one or two are found in a joint, it has been suggested that they may be cannibalistic. Sometimes the plant tissues react to the presence of the insect in such a way that proliferation occurs to such an extent that swellings appear on both sides of the segment, the larva at times becoming enclosed. Occasionally no larve are found in such swellings, although evidence of their work is present (C.I., pp. 25-26). Though not abundant in any particular locality, it is widely distributed in Texas.

It is suggested (C.I., p. 27) that there may be two forms, one from South-eastern Texas and a more westerly variety, since, in addition to certain differences in the structure of the cocoon there are also differences in the method of working. The larva of the former packs the excreta in the cavity formed, and does not make an aperture, while that of the latter gets rid of the excreta by means of an opening made through the epidermis of the infected segment.

A Tachinid fly, Phorocerca comstocki, Wilson, is known to parasitise this Melitara (C.I., pp. 25-27).

Melitara dcntata, Grote (1876, p. 158; 1882, p. 29).-Prof. Kellogg (1892, p. 40) has given an account of the various stages of this moth, which he recorded as attacking $O$. missouriensis in Eastern Colorado. He stated that the large,

* Hulst mentions that $M$. junctolineella is distinguishable from other species of Melitara by the presence, on the bagal line of the front wing, of an outwardly directed dentation, while on the outer line there is a similar one direoted inwardly, the two dentatione ingeting in the middle portion of the wing. 
naked, bluish larvæ fed on the internal tissues of the scgments, bringing about a withered, brown, dying condition. The eavity in the joint was nearly filled with irregularly shaped translucent casts. Hulst (1890, p. 7) has also given an account of the adult."

In the Bulletin on Cactus Insects (p. 28) there is given a figure of a hymenopterous parasite, Chelonus laticinctus, bred out from material from Colorado.

Melitara prodenialis, Walker.-This moth was bred by Riley (1891, p. 256) from an Opuntia from Florida, and by Smith (1891, p. 243) from New Jersey material. Both Hubbard $(1895$, p. 129) $\dagger$ and Smith (1892, p. 208) have given an account of some of its habits.

Its importance as a prickly-pear destroyer will appear from the following introductory paragraph in Hubbard's paper (pp. 129-130) :"Owing to the attacks of the larvæ of Melitara many of the more delicate species (of pricklypear), including most of our native Floridan Opuntias, cannot be grown successfully in that locality. I have observed that our most widely distributed species, Opuntia vulgaris, is so much subject to their attacks that large clumps of the plant are rare in internal Florida, and are to be found only near the coast, and upon small islets in the island lakes, and thus a plant which would otherwise probably form one of the most striking objects in the flora of the State is held in check and reduced to insignificant clusters and scattered isolated parts which are seldom pernitted to attain the normal size and never to produce a numerous colony. Only the wonderful vitality of the Opuntia saves it from complete extinction at Crescent City and elsewhere, yet thanks to its recuperative power it remains, there as elsewhere, one of our commonest types."

Referring to its depredations on Opuntia when acting in conjunction with a cactus weevil, Gerstoclieria hubbardi, Le Conte, Mr. E. A. Schwarz informed the Commission that it had quite exterminated prickly-pear around Crescent City, Florida. He, however, believed that the greater part of the damage was occasioned by the weevil.

This Floridan Melitara, according to Hubbard's account, is a large moth with its wings partly fuscons and partly light-grey, conforming in general appearance to the other species of Melitara. It has a wing expansion attaining 52 $\mathrm{mm}$. ( 2 in.) and a body length-palps included -of $27 \mathrm{~mm}$. (11/2 in.). "Its neutral colour is highly protective, and the difficulty of detecting it is increased by the attitude it assumes when at rest-with its wings closed and bent sharply downwards while the abdomen is curved upwards between these slanting organs." (Hubbard, p. 132).

* According to Hulat and Kellogg, this moth differs from its nearest ally $M$. prodenialis, from Florida, in being of a much lighter colour-whitish or light grey-and in possessing stronger dentations on the outer line. Besides, the basal line has a larger outward dentation in the middle.

$\dagger$ In the Bulletin on Cactus Insects (pp. 28-29) there are published some of Hubbard's notes regarding the

¥ As Hulst's diagnostic description (1890, p. 171) of Melitara prodenialis, Walker, is not readily available it is here given :-Forewings fuscous at base, half along inner margin, and on outer part except towards apex; rest light grey; whole wing sprinkled with black and marked with black on veins; hind wing pellucid whitish to fuscous.
This insect attaches its eggs to the minute true lcaves or to the spines of its host-plant in a manner similar to other Melitaras. There are generally 45 or 50 eggs in each "egg-stick." The latter, which may be $80 \mathrm{~mm}$. long, are fixed by one extremity and directed obliquely upwards from this support (Hubbard, fig. 6). The young caterpillars, after hatching out, feed for a time externally on the bud-like leaves of Opuntia, but, later, penetrate into the segment. From the wounds caused by them, there may exude a gummy fluid which, on drying, forms a scab-like crust. Under this the larvæ live more or less gregariously until about one-third grown, when they burrow deeply into the succulent substance of the stem-joints where they remain until fullgrown, their length then being about $40 \mathrm{~mm}$. The caterpillars whon young or while feeding superficially are brown, but after burrowing into the plant-pulp and having nearly attained full size, they become deep blue as in the case of the larvæ of the other species. When full-fed, they issue from the food-plant, gain the surface of the soil, and spin each a relatively large cocoon, 2 inches in length, and of an open texture, usually below a fallen stem-joint. The chrysalis is brown and measures $22 \mathrm{~mm}$. in length. Hubbard mentions that there are two broods of the insect during the year, the moths appearing in June and July and again in October.

The injury caused by $M$. prodenialis is similar to that brought about by $\boldsymbol{M}$. dentata and $\boldsymbol{M}$. fernaldialis. The attacked segment is generally eaten out before the caterpillar proceeds to the next. The wounds are often aggravated by/ various secondary organisms, and as a result a much more rapid destruction is caused (Hubbard, p. 130).

Besides Florida, New Jersey and Mississippi are mentioned as being included in the range of this species (C.I., p. 45).

The adult is a large moth with a wing expanse of 2 inches and with an outline and colouration resembling that of other species. Grote (1890, p. 172) informs us that the hind wings are pellucid fuscous, with an iridescent sheen, and are whitish towards their base; the basal line is fine and black and runs half-way out along the wing beyond its disc. This species has been recorded by Schwarz (1899) and Hubbard (1899) as breeding in Cereus in Arizona and New Mexico.

Mclitara sp. larva which were found by $\mathrm{Mr}$. Pratt in $O$. cngelmanni at Tueson, and which discharged their excreta from openings in the segments in the same manner as that referred to as occurring in the case of the Western Texan form of $M$. junetolineella, probably belong to $M$. fernaldialis. In one locality in New Mexico about 30 per cent. of the plants of $O$. arborescens were more or less injured by larvæ which were regarded as belonging to this species (C.I., p. 29).

Melitara spp. Very little of the work of these boring moths was seen by the Commission during its stay in Texas. In only one instance was a larva of Melitara ( $M$. junctolineella) found-viz., at Brownsville-the insect infesting a swollen joint whose interior contained the hard proliferous tissue referred to by Messrs. Hunter, Pratt, and Mitchell. The excreta were tightly packed in the cavity. Several instances of swollen joints ("fat pear") were met with, but in no other 


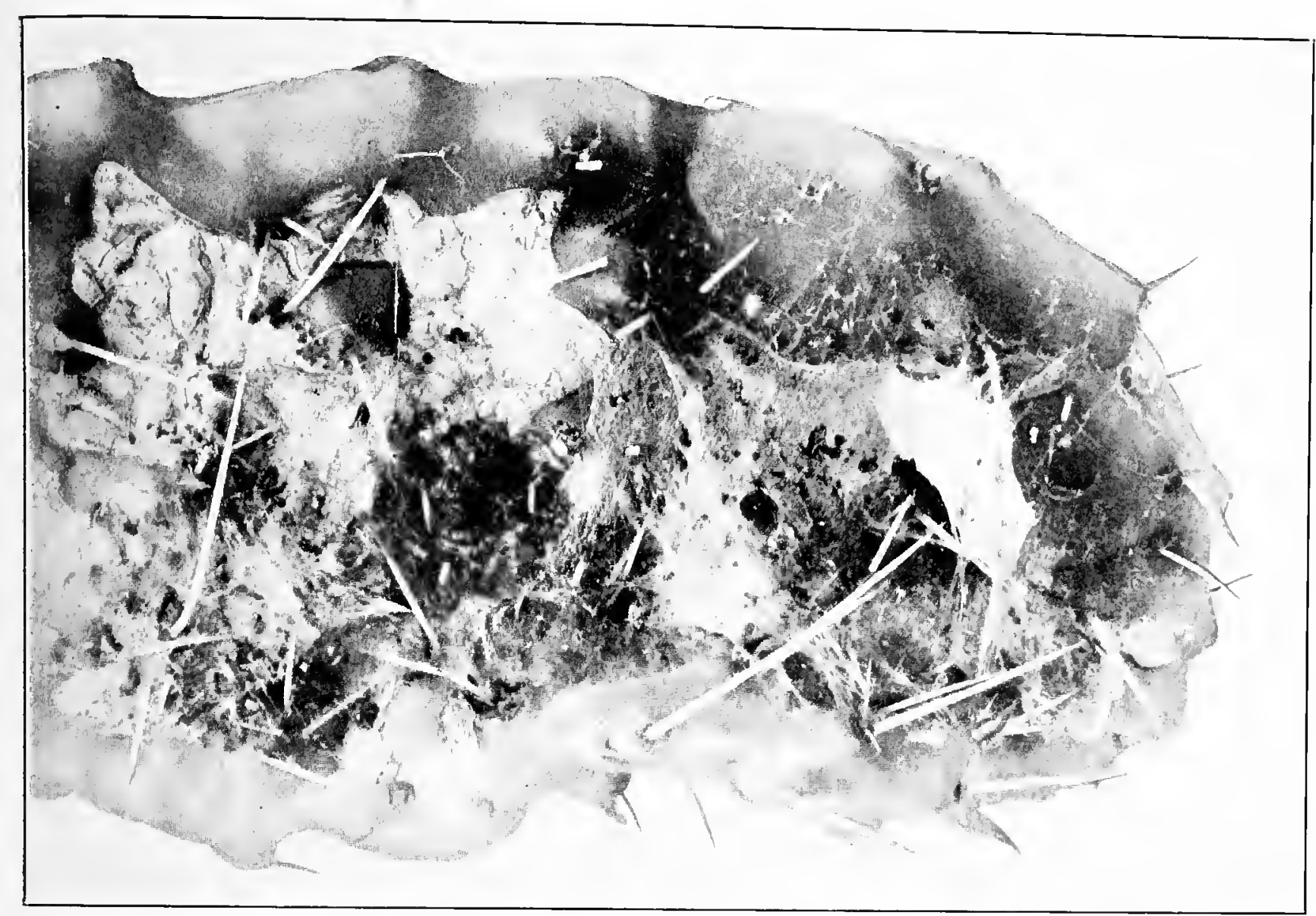

Fig. 39.-Segment of an Opuntia showing the work of the larva of a moth, Mimorista faridissimalis, a serious enemy whose attacks cause a great destruction of young joints in Texas and elsewhere in Imerica. (Reproduced from "The Principal Cactus Insects of the U.S.A.," Bull. 113, Bur. Entom. U.S.D.A., plate 3.)

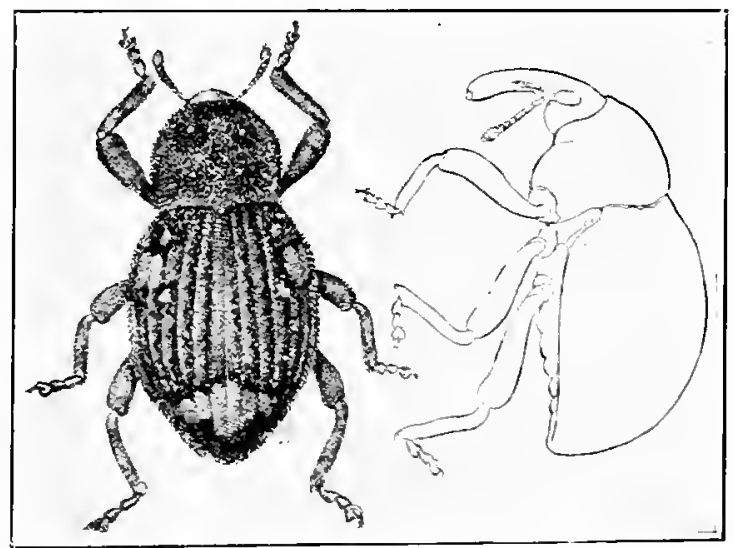

Fig. 40.-Gerstcecheria nobitis, one of the Cactus Weerils. The larra lives within the joint (ser Fig. 43). (Reproduced from Bull. 113, Burean Entomol. T.S.D.A., p. 30, fig. 3.) 

case was the larva found, though sometimes a dead, brown area was seen within each of them. This latter condition is mentioned earlier in the report under the heading of "Gumming."

In the dry cactus-belt-e.g., Arizona, New Mexico, and Western Kansas-as well as in Florida, the destruetive work of the Melitara spp. was commonly seen. In all these cases the injury was of the same type as that deseribed (C.I., p. 27) as being caused by the Western Texan form of $M$. junctolineella, though the species were different, the moth from New Mexico and Arizona being probably $M$. fernaldialis; the Kansas species, $M$. dentata; and that in Florida M. prodenialis.

At Mesilla Park, New Mexico, Melitara larvæ were found boring down into the stems of O. whipplei, while near Tueson, Arizona, they were seen to attack other Cylindropuntias, including $O$. arbuscula, $O$. fulgida, $O$. spinosior, and 0 . mammillata. Frequently no indication of the presence of these large grubs was to be seen externally, beyond the presence of a small blackened area with or without a mass of blackened gum, which marked the upper end of the tunnel in which the larva lived. Sometimes the affected stem was sickly in appearance, and not infrequently death was the result.

The effect of the same or an allied species of Melitara larva was seen to be much more marked in the ease of the flat Opuntias. At Mesilla Park, Dr. Merrill directed attention to the results of their activity on $O$. dulcis, $O$. chlorotica, and $O$. blakeana (?) growing in the grounds of the Agricultural College at Mesilla Park, New Mexico. In one joint no less than thirty small brown larvæ were found by us to be present, while attached to a spine subtending the spot where the entry had been effected was a string of eggs. Dr. Merrill believed that the loeal species attacked only the flat Opuntias. As already described, the larvæ hollow out the infested segments, which then generally dry up. An aperture is made through which a large part of the exereta is voided. Several eaterpillars, Dr. Merrill stated, might be found in one joint. After working their way downwards, sometimes reaching the base of the plant, they bore their way out of the Opuntia and may pupate at some distance from it, the adults emerging during late August. He regarded this insect as being more destructive than the cactus beetle, Moneilema, and offered to assist, if desired, in obtaining specimens for transportation to Australia. He thought that the eggs would perhaps be the best stage to send, but failing them, then the pupa might be utilised. The only parasite which he had observed was an Ichneumonid.

Besides the typical Melitara first referred to, Dr. Merrill stated that he had observed another insect whose larva acted in exactly the same way in attacking flat Opuntias, but only one at a tine was found in a joint, and apparently the grub confined itself to one segment instead of passing down into others. He observed that it pupated in the ground in a breeding cage, the moth being larger than Melitara, which it closely resembled. The insect probably belongs to this genus.

Near Tueson, Arizona, Melitara injuries wcre noticed by us oecasionally in joints of a flat Opuntia, $O$. arizonica.
Near Wallace, in Kansas, they were observed very commonly in $O$. missouriensis, caused by a Melitara which was probably $M$. dentata, whose destructive work in Eastern Colorado was referred to by Kellogg in 1892. Dead, hollow joints, each with one or more apertures associated with insect excreta, were very frequently noticed, and it was not an uncommon sight to see whole plants destroyed. Occasionally the small Mammillaria oceurring in this locality was found to be hollowed out and killed. The injury extended from joint to joint in the case of the Opuntia. Sometimes the unattacked distal segments grew after reaching the ground, the insect thus acting as a planter in the same way as has been noted in regard to Moneilema. A few cocoons and pupæ of Melitara were found under fallen joints and adjacent grass and in hollowed segments.

This locality was visited by the Commission through information received from $\mathrm{Mr}$. E. Popenoe, of the Bureau of Entomology, who stated that a beetle, Moneilema armatum, had caused considerable destruction of prickly-pear there. Though fragments of a Moneilema were found by us, there is no doubt that the greater part of the damage seen was caused by Melitara, yet it is quite probable that the beetle assisted.

Visits were paid to two localities in Florida, indicated by Mr. Schwarz, where the work of Melitara prodenialis might still be seen in progress. These were Crescent City and Lake Worth (West Palm Beach). In the neighbourhood of the former, with the exception of a few plants of the low-growing $O$. opuntia (O. nana) no pricklypear was met with during the short stay there. At Lake Worth, however, on the sandy ridges, on the east side of Palm Beach township, the weevil Gerstceckeria hubbardi, as well as the Melitara, was found to be feeding on it. Hubbard had previously recorded the presence of these two enemies (1895, p. 130), but did not consider that the beetle and moth were associated in causing the destruction of Opuntia in this district, but that the cavities excavated by the caterpillars served as "lurking places for the weevil Acalles hubbardi," as it was then called. We sometimes found both insects present in the same plant, while at other times one or other was met with Prickly-pear was growing sparsely, and the species appeared to be on the verge of local extermination. The plants were stunted, all those examined either having been damaged or else being then attacked, especially by the caterpillars of Melitara prodenialis. Partial or complete destruction was the result of the infestation, the injuries resembling those produced by $M$. dentata.

Unidentified bluish-green larvæ were found in tunnels in the fruit of $O$. versicolor at Tueson, Arizona.

Melitara, sp.?-Dr. Merrill (Mesilla Park, New. Mexico) informed the Commission that he had observed the presence of a small unidentified moth which laid its eggs in a naked mass on the outside of the flat Opuntias. The young larvæ, on hatching, at first clustered around the egg-mass and lived under a thin web, feeding on the surface of the young leaves. Later on they bored into the tissues, where they acted like the Melitara caterpillars, passing downwards from joint to joint, and ultimately pupating and hatching at the same time as Melitara, but the adult was a much smaller insect. 
The Joint Miner, Marmara opuntiella, Busck.

This small Tincid motll, which was described by Mr. Busck in 1907, is figured in C.I., p. 31. lt is referred to as the "leaf miner," a fine illustration of its work being shown in C.I., plate 6 .

The eggs are deposited below the epidermis, where the tiny orange-coloured larvæ on hatching begin to make small tunnels or galleries which may cross or coalesce, and which appear through the epidermis as whitish areas. The damage is not serious, as the insects do not penetrate deeply into the segment (C.I., p. 31).

The work of this insect was seen at San Antonio, Alice, Robbstown, and Brownsville, in Texas, where the common pear (O. lindheimeri and its allies) were found to be attacked. The spiny Mission Pear was seen to harbour this insect at Alice.

Since Marmara does not do any appreciable injury to Opuntias, its introduction need not be considered.

An unidentified green lepidopterous larva was found very commonly at Sinton, Texas, within the joints of $O$. leptocaulis. All the tissues except the epidermis were eaten ont, and a hollow joint or series of joints remained. As a result of its attacks, plants were practically stripped of all their lateral branches. It was quite common to see whole plants killed by it. Since its attacks were confined to $O$. leptocaulis, none of the flat Opuntias being attacked, although growing alongside, its introduction into Australia need not be considered.

Many other Lepidoptera are recorded in the list of Cactus Insects (pp. 44-45), but they are not regarded as important, and some of them moreover, attack other plants.

\section{The Hemipterous Enemies.}

The most important of these are species of Chelinidea and Narnia, and the Wild Cochineal Insects, all of which are restricted to the Cactaceæ.

\section{Chelinidea, spp. (Coreidæ).}

Chelinidea vittigera, Uhler.-An account of C. vitligera is given in C.I., p. 15. These insects, which are usually nocturnal in their habits, may occur gregariously, feeding on the joints of Opuntia and allied Cactaceæ. Attacked joints show the presence of lightercoloured circular spots, a concentric pattern of alternating green and light-coloured areas being sometimes seen. Each spot marks a point where feeding has taken place. These zones enlarge, and ultimately the joints may assume a sickly appearance. Exceptionally the whole plant is affected, becoming weakened to such an extent that it may fall over, the joints drying up or else becoming the seat of infection by scavengers which bring about destruction. The young and adult bugs migrate from these chlorosed plants and resume their activities on a fresh plant. Rooting of fallen segments may take place.

The breeding habits and life-history are described and a figure of the adult given by Merists Hunter, Pratt, and Mitchell (C.I. pp.
17-19). There is continuous breeding throughout the summer and autumn, but during winter the insects hibernate under fallen joints, the roots of grass, \&c., in the neighbourhood of an Opuntia. It is stated that they do not seem to travel far from the plant upon which they. were produced. This species prefers Opuntias to any other Cactaceous plant. Its range includes Texas, California, Utah, Colorado; in fact, the Western and Southern States of the United States generally, as it is also known from Louisiana, Alabama, North Carolina, and Virgina (C.I., p. 17).' Riley and Howard called attention to its presence in Texas (1893, p. 345), and Uhler to its occurrence in Southern Califormia (1894).

Chelinidea tabulata, Westwood, is said to be found in company with the preceding species in Texas, but this Mexican species is much less common (C.I., p. 19).

Chelinidea, sp.-An unidentified species of Chelinidea, smaller than $C$. vittigera, is recorded as attacking $O$. arbuscula, $O$. versicolor, and $O$. fulgida in Arizona.

In the Bulletin on Cactus Insects (p. 16) it is stated that Chelinidea and its allies are by far the most important insect pests of Opuntias in the United States, on account of their wide distribution, though the moth Mimorista is probably more destructive in the limited area where it occurs. It is suggested that, in addition to the injury directly traceable to these bugs, they may act as carriers of the Shot-hole Fingus, Glocosporium lunatum. Dr. Griffiths mentioned during an interview that these bugs caused a more or less marked chlorosis, but that, as a rule, the plants recovered.

Chelinidea spp.--In spite of the fact that the investigation was made at a time when most of these bugs were hibernating, the Commission saw Chelinidea and its work on $O$. lindheimeri and allied Opuntias in Texas, at Alice, Laredo, Sinton, and Brownsville, as well as on plants of $\boldsymbol{O}$. stricta cultivated at the last-named locality. Its presence was noted at Chico, in Northern California. In Texas, attacked plants were more or less chlorosed, but the extensive injury recorded above was not observed. Hibernating specimens were found near Tucson, Arizona, in tunnels made by Moneilema or Melitara in stems of $\boldsymbol{O}$. versicolor and $O$. fulgida; and near Wallace, Kansas, in hollowed joints of $O$. missouriensis as well as under fallen joints and under débris and grass around the base of this species.

At Tucson, plants of one of the Cylindropuntias, $O$. spinosior, were found to have diseased areas on some of the costæ which occur on the stems. These areas were dull black, and from many of them a mucilaginous exudation was evideht. No insects were detected in either case inhabiting the parts which had undergone these changes or even on other external parts of the affected plants. However, Chelinidea bugs were discovered in small numbers amongst dead and dry fallen stem-joints on the ground beneath the plants exhibiting these symptoms.

Though little was seen at the time of the Commission's visit which would lead to the belief that Chelinidea was such an injurious etiemy, yet the strong opinions held by both $\mathrm{Mr}$. W. D. Hunter" and Mr. J. D. Mitchell, entomologist who have had a long experience in Texas, 
must be regarded as possessing weight. Moreover, Mr. O. Heidemann, who has charge of the hemipterous collection in the National Museum, Washington, informed the Cornmission that noither Chelinidea nor its ally Narnia was known to attack any plants other than Cactaceæ, this statement being confirmed by other entomologists.

\section{Narnia, spp. (Coreidæ).}

These gregarious fruit-sucking bugs, though somewhat more slender insects, resemble Chelinidea in their general appearance, size, and habits. Their attacks are directed against the fruit, which is often destroyed, the common species of Narnia not being recorded as injuring the joints. The commonest species in Texas is $N$. pallidicornis, Stal., which is illustrated and fully described in C.I., p. 33 , pl. 7 , fig. 4. It is said to occur throughout the season (p. 41). N. femorata, Stal., a rather larger species, is also common in Texas, but is much more widely distributed.

N. pallidicornis is found in Southern Texas, its range extending into Arizona, California, and Mexico. It attacks the fruits of Cereus as well as those of prickly-pears. $N$. inornata, Distant, occurs in Mexico and California, and $N$. snowi in New Mexico.

Specimens of Narnia were seen feeding on the fruit of $O$. lindheimeri, $O$. ferruginispina, and allied species, at Alice and Robbstown in Texas, but in far too few numbers to be capable of causing much damage, fruits on which they occurred exhibiting merely local superficial skin injuries. At Mesilla Park (New Mexico), Tucson (Arizona), and San Diego (Southern California), species of Narnia were found beneath prickly-pear plants and their débris. At Tucson it was also found hibernating associated with Chelinidea in cavities in the stems of Opuntias.

In view of the destruction of fruit which species of Narnia are said to cause, the introduction of these insects, which feed exclusively on Cactaceæ, is recommended.

\section{Stylopidea picta, Uhler (Capsidæ).}

This small Capsid bug is briefly referred to in C.I., p. 22. It was seen in great numbers on plants at Rolbbstown, San Antonio, Brownsville, Sinton, and Alice, and frequently the entire plant was chlorosed and had a very sickly appearance on account of their attacks. This was, no doubt, due to the large numbers present. It is not recorded as being one of the serious enemies of prickly-pears, its place on the list given in C.I., p. 13 , being after that occupied by the leafminer, Marmara.

Marlatt referred to its occurrence on Opuntia in 1896, under the name Labops hesperinus. The Commission was informed by $\mathrm{Mr}$. Heidemann that its correct name is Hesperolabops picta, Reuter. Since their influence is so slight and since it is not restricted to the Cactaceæ, having been found on a variety of plants (C.I., p. 23), its introduction need not be considered.

\section{Sixeonotus luteiceps, Reuter (Capsidæ).}

This small Capsid bug is not a true Cactus insect, preferring Yuccas to Opuntias and Echinocereus, both of which it commonly attacks (C.I., p. 36); hence it need not reccive further attention.
The Cochineal Insects (Coccidæ).

Coccus cacti, L., or Dactylopius coccus, Costa. -The true cochineal insect is recorded from California and Florida by M. Fernald (1903), but Messrs. ITunter, Pratt, and Mitchell (p. 23) state that it does not appear to occur in the United States of America, and that these records probably refer to importations.

Coccus (or Dactylopius) confusus, Cockereill.- This wild cochineal insect occurs throughout practically the whole of the cactus region of the United States, being abundant in the southern parts of Texas (C.I., p. 24, pl. 5), but appears to be held in check by a great number of predatory insects which prevent it from becoming a very important enemy of the prickly-pear. In spite of these, however, it is capable of doing damage to the plants. On acsount of the presence of dense white cotton-like waxy masses under each of which several coccids live, the name "cottony cochineal" has been applied to this species in the Bulletin on Cactus Insects. The insect was described by Cockerell (1893, p. 366 ; 1896, p. 34), and an account of it is given by Grecn (1912, p. 89).

The localitics given include some in Arizona, Texas, Florida, and California, and, besides, the species is found in hothouses throughout the United States. It is not restricted to any particular species of Opuntia as its host-plant (C.I., p. 42). Mr. Green mentions Mesilla Park, New Mexico, as an additional locality.

The value of the pigment derived from this coccus has been compared with commercial cochineal obtained from Coccus cacti, and with that from C. tomentosus, another form of wild cochineal. If $C$. cacti be taken as 100 , then the same weight of $C$. tomentosus would be equivalent to 80 and $C$. confusus to 16 , thus showing that the last-named has very little commercial value (Cockerell, 1896, p. 35; Green, 1912, p. 81).

Coccus confusus is subject to the attacks of many insect enemies. In 1899 Riley (p. 28) referred to his breeding of three from it-viz., Leucopis bellula, Williston; Drosophila quinaria, Loew; and Dakruma coccidivora, Comstock (= Laetilia coccidivora). Coquillet had previously (1897) reared the first-named fly from specimens from New Mexico. The list given in the Bulletin on Cactus Insects (pp. 24, 46) includes eight species of Coleoptera and three of Lepidoptera. They are as follows:-

Coleoptera; Exochomus latiusculus, Casey (Texas) ; E. marginipennis, Le Conte (Texas); Cycloneda munda, Say (Texas); Chilocorus cacti, L., (Mexico) ; Hyperaspis trifurcata, Schaeffer (Texas, Mexico); $H$. cruenta, Le Conte (New Mexico, Texas) ; Scymnus loewii, Mulsant ('Texas, Mexico) and S. hornii, Gorham (Mexico). Lepidoptera: Latilia coccidivora, Comstock ('Texas); Zophodia ditatifasciella, Ragonot (Texas); and Saluria ardiferella, Hulst (New Mexico). Diptera: Drosophila punctulata, Loew. (Texas) ; D. ampelophila, Loew (California); Leucopis bella, Loew. (Texas and California); L. bellula, Williston (Texas, New Mexico, Mexico). The beetle Bothrideres cactophagi, Schwarz (C.I., p. 46) also at tacks Coccus confusus. 
C. confusus newsteadi, Cockerell.--This subspecies of the cochineal insect was named by Cockercll $(1898$, p. $675 ; 1899$, p. 284) after Prof. Newstead, who gave a description in which he noted that it differed from $C$. tomcntosus (1897, p. 75). Newstead's specimens came from Opuntia fulgida, from Arizona. Cockerell (1898, p. 675) gives Arizona, Texas, and Mexico as localities, while Green (1912), who gives an account of it (p. 90), adds Colorado. An allied variety, the wild cochineal of Cape Colony, has been named by Green (p. 91) as C. confusus capensis, samples of which were forwarded by the Commission from Capetown to Queensland.

Coccus tomentosus, Lamarck.-This species of wild cochineal resembles the latter in most respects, but instead of each mass of waxy secretion covering a number of individuals, each insect of $C$. tomentosus is separately covered.

It is recorded from $O$. fulgida, from Mexico, New Mexico, and Arizona (C.I., p. 42). Green (1912, p. 87) gives an account of it and mentions the same localities. He regards $C$ cacti, var. opuntia, Cockerell $(1896$, p. 35) as a synonym, and helieves that all the wild forms-i.e., $C$. indicus, $C$. confusus, and sub-species, have been derived from C. tomcntosus (Green, p. 80). The relative value of this species and $C$. confusus as dye-producers has been referred to above.

The Commission saw species of wild cochineal at Laredo, Brownsville, Alice, Robbstown, and San Antonio (Texas) feeding on $O$. lindheimeri and related prickly-pears, while near the last-named town it attacked $O$. ferruginispina also. It was seen at Mesilla Parls (New Mexico) on $O$. chlorotica, where it was apparently parasitised by a small moth; at Tucson (Arizona) on $O$. arizonica, $O$. discata, $O$. lavis, and $O$. linguiformis, the last-named form being a Texan species in cultivation; at San Diego, Southern California, on $O$. occidentalis; at Wallace (Kansas) on $O$. missouriensis; and on some low-growing undetermined species of Opuntia under cultivation at Chico, California. In some of the Texan localities, a ladybird was seen preying on $C$. confusus.

Though some joints were found to be very heavily infested, it was rare to find any other result than a more or less well-marked chlorosis. Dr. Griffith's experience is similar, as he informed the Commission that he had never seen a plant appreciably affected by the local species of cochineal. Messrs. Hunter, Pratt, and Mitchell, however, have stated (p. 24) that the insect sometimes becomes so abundant as to destroy parts of the plant and oceasionally to kill the entire plant, and that much greater injury would be occasioned were the cochineal insect itself not held in check by various predatory enemies.

In the neighbourhood of San Diego, South. ern California, a small colony of Coccus confusus was found to be almost completely destroyed by the eaterpillar of a moth.

These wild cochineal insects are evidently controlled to a great extent by various predators and parasites, and therefore the Commission did not see the full destruction that they might cause had these controlling agents been absent.
White Scale, Diaspis, spp.

Besides the cochineal, other coccids-viz., certain scale insects (Diaspis, spp.) were met with. A list of those known from the United States is given in C.I., p. 42. It includes Diaspis echinocacti cacti, Comstock, from New Mexico and Arizona, where it occurs on $O$. fulgida, $O$. arborescens, and $O$. engelmanni; from Texas, on $O$. leptocaulis and $O$. lindheimeri; while Fernald adds New York and Massachusetts (green-houses) and Iowa. A figure of this species is given in C.I., plate 5 .

Other species are $D$. echinocacti, Bouché, which Fernald records from Mexico and New York; and D. echinocacti opuntioe, Cockerell, from Texas, on $O$. arborescens and $O$. elongata.

Species of Diaspis were seen by the Commission in the St. Louis Botanical Gardens on $O$. dillenii, $O$. leucotricha, and Nopalea cochinelifera; at Tueson (Arizona) on $O$. fulgida; and at Los Angeles (California) on $O$. decumana and $O$. monacantha. In no case was any perceptible injury caused.*

\section{Aphis.}

Dr. Griffiths (1913, p. 20, pl. 7) has recently referred to the proliferation of certain parts of O. puberula caused by the attacks of the "black Opuntia louse,"' which congregates on the tips of young flower-buds, preventing their opening and rendering them sterile. These infested parts proliferate to give rise to buds which are normal and fertile unless they, too, become attacked and rendered sterile by these insects. A similar result is brought about by the agency of a small cecidomyiid fly, Asphondylia opuntice.

Various other Hemiptera are named in the list in C.I. (pp. 40-42), Aphis medicaginis, Koch, from Arizona (Texas), being included. They are probably unimportant. $\dagger$

\section{The Dipterous Enemies.-The Gall Mmges.}

Among the Diptera there are certain small insects belonging to the Cecidomyiidæe which injure the prickly-pear. Three of the species belong to the genus Asphondylia and one to Itonida.

\section{Itonida opuntio, Felt. -}

This species was first described by Felt (1910, p. 10) as Cecidomyia opuntice, but he has recently transferred it to the genus Itonida. His material came from Dr. N. Britton, Director of the New York Botanical Gardens, who found that it was a very destructive pest of the Opuntias in the hot-houses. Since the insect had manifested itself soon after the receipt of a consignment of prickly-pears from Italy, it was suspected that the fly had been introduced from Southern Europe. So troublesome had the pest become that Dr. Britton was obliged to fumigate his collection of Cactacex regularly and frequently. At the time of the Commission's visit, the insect had been controlled by him, and a search for the adult as well as an attempt to rear some from plants showing the presence of injuries caused by the larva were unsuccessful.

\footnotetext{
* Diaspir is already established in Queensland, but has not as yet proved to be of much value as a cacticide.

$\dagger$ An aphis has been found in abundance associated with prickly-pear near Goondiwindi in our own State, but it does not do much damage. (Tryon, 1911, p. 17.)
} 


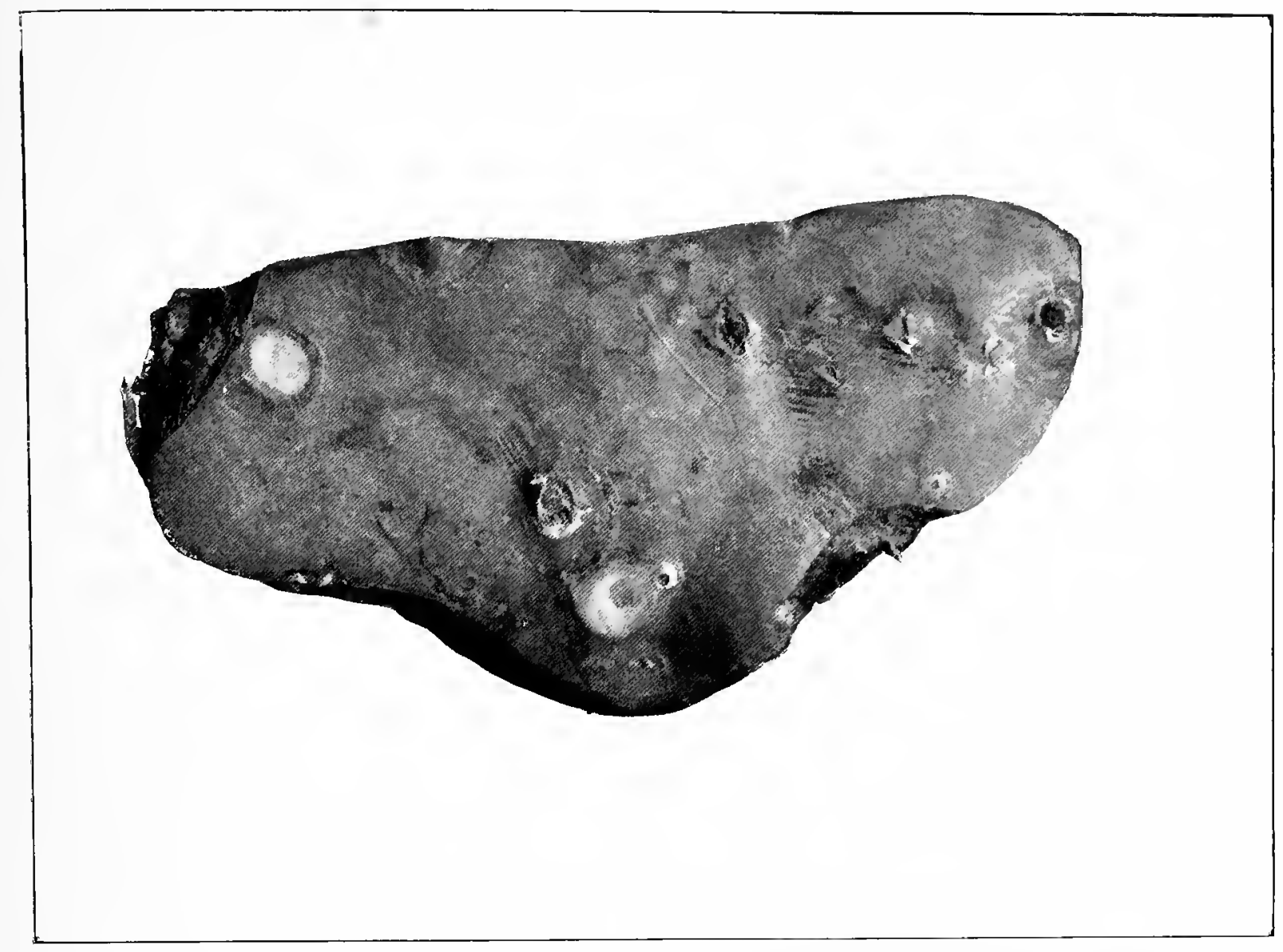

Photo., Bureau of Entomology, Dept. Agriculture, O.S.A.

Fig. 41.-Part of a joint of an Opuntia showing three pupal "cells" of a Cactus Weeril, Gcrstackeria turbidus.

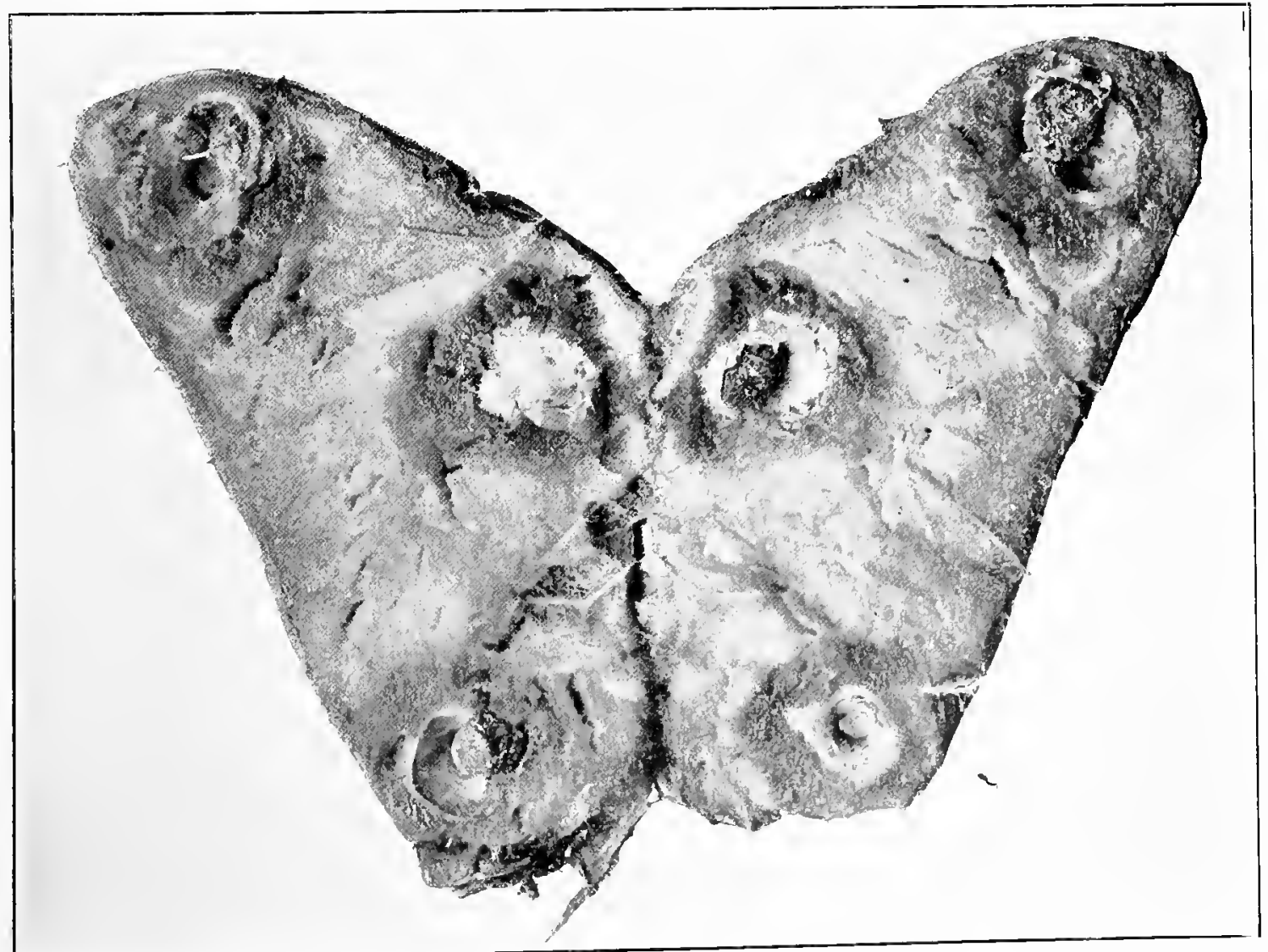

Photo., Burcau of Entomology, Dept. Agriculture, U.S.A.

Fig. 42.-The same (Fig. 41) cut open so as to show the "cell" carities with their pupa-cases within them. 

The larva gains an entrance at an areole and mines into the surrounding tissues, stimulating them to activity so that there is produced a small tumour rather paler in colour than the general plant surface. Some of the attacked joints had, in spite of the presence of galls, maintained normal growth, while in the case of others a decay had set in which either might be local or might spread from the site of insect attack so as to involve the entire segment. Occasionally a similar decay was seen in joints which did not contain any galls. Under the conditions of the glass-house, death commonly follows. Owing to the ravages Dr. Britton had lost about 150 plants -all of them flat Opuntias or Nopaleas, any of which seemed to be susceptible to attack, though no other plants were observed to have beèn infected. An examination of the bundle of labels, which belonged to dead prickly-pears, showed that amongst others the following species had succumbed:-O. tomentosa (which is the Helidon tree-pear in Queensland); $O$. inermis (the common pest pear of Queensland); $O$. streptacantha (a species related to the "Westwood Pear" of the Rockhampton district, Queensland) ; $O$. dillenii and 0 . tuna (both related to $O$. inermis) ; $O$. microdasys and $O$. nigricans (both of which occur naturalised in New South Wales); and Nopalea cochinelifera (one of the tree-pears at Gayndah).

Since this insect had proved itself to be so destructive to prickly-pears in cultivation and was, as far as known, restricted not only to the Cactacex, but to the flat Opuntias within that natural order, a visit was paid to Albany in order to consult Mr. E. P. Felt, the New York State Entomologist, who is a recognised authority on the Cecidomyiidæ, and who is the author of the original description of the insect (1910, p. 10; 1914).

With regard to the general food relations of the Cecidomyiidæ, Mr. Felt referred to two papers-(1) "A Summary of Food Habits of American Gall Midges " (Annals Ent. Soc. America, 4, 1911, pp. 55-62), and (2) "Hosts and Galls of American Gall Midges " (Journal of Economic Entomology, Oct., 1911, pp. 451475 ) - in which the information relating to this subject is condensed. The observations of himself and of other specialists in this insect group pointed to the fact that these flies, in establishing relations with plants, either confined their attention to single plant-species or to the members of single genera. When, exceptionally, this was not so they attached themselves to elosely allied plants in a single natural order. Thus Asphondylia monacha attacked the flowers of two Compositæ, Aster and Solidago, while Cecidomyiia (Phytophaga) destructor confined its attacks to the two grasses, Hordeum (barley) and Triticum (wheat).

Four kinds of Cecidomyiid flies attacked prickly-pear-i.e., three species of Asphondylia that were fruit-lovers and the one that is now under notice. These four gall-midges were quite distinct from any other insects of the group, and it was almost a certainty that no plants other than the Cactaceæ would serve as hosts for them. Of the eight or nine hundred different kinds of Cecidomyiidæ in North America, Mr. Felt had examined specimens of most of them, and of these he had reared about five hundred himself. His opinion is thus based upon a wide knowledge of the gall-midges and their plant relations.
The group Itonida, which included the New York prickly-pear midge, was a fairly large one, and in the majority of eases its members laid their eggs in and developed in the buds of plants. The speeies of the type genus Itonida itself, as shown by his recorded rearings, had very varied plant connections, but notwithstanding only three species were associated with any of the cultivated or economic plants of Australia-viz., Itonida tritici, found in the heads of rye and wheat; $I$. cucurbitu, on rough squash; and $I$. manihot, forming small leaf-scales on Cassava.

Cecidomyiids formed swellings on twigs, galls in or on leaves, \&c., and sometimes injured terminal buds, but, as a rule, they did not destroy plants. The Hessian fly and sorghum midge were exceptions.

He concurred with the Commission in concluding that whatever injury to the prickly-pear accompanied the presence of Itonida opuntice was most probably due to the action of fungoid or bacterial organisms whose presence and development were made possible by the insect attacks, simple galls being formed, but no further lesions or abnormalities being caused in the absence of these organisms.

Influenced by these and other general considerations he remarked that he did not see how anything adverse could develop from these insects when in Australia, and that faced by a similar problem to that which confronted the Commission he would not hesitate at all in attempting to establish it there. At the same time, he could not definitely predict any advantageous outcome resulting from such procedure, since it was a matter for experiment. The climatic conditions that this Opuntia gall-midge would encounter on its introduction to Queensland might or might not be favourable to its development and to its destructiveness. He would not expect it to destroy prickly-pear there unless relatively moist climatic conditions were prevalent. On the other hand, it might meet with circumstances to which it might react by ataining great vigour and undergoing such numerical increase as to become very plentiful. He considered that the Commission was quite justified in deciding to advocate the introduction into Australia, and the maintenance there under proper safeguards for the time being, of any insect which fed on Opuntia, and which was not at the same time associated with, much less an enemy of, any of the economic plants that were already grown or might be grown there. He doubted, however, if any man could predict from observations in the field alone how an insect would comport itself under novel conditions.

Owing to the special interest that attaches to this particular gall-midge by reason of its destmetiveness under certain conditions, the foldestructiveness taken from the Annual Report of the New York State Entomologist for 1913 (not yet available) may be appended:-

\section{Cactus Midge-Itonida opuntice, Felt.}

"Species of Opuntia, the flat-leaved, oval Cacti, not the columnar forms, may be injured by the deep-red larvæ of this midge and most seriously affected by a bacterial or fungous trouble which gains access to the inner tissues through the injuries. The fungus or bacterium is by far the most destructive, and is apparently dependent for favourable media, so far as Cacti dependent for apon the work of the midge larvæ. 
"Signs of Injury.-Infestation is first indicated by an indistinct swelling, usually at the base of a spinc, preventing so few characteristics that the party in charge of the plants, and therefore familiar with the work of the insect, could not be certain of the presence of maggots without cutting into the tissues. This swelling gradually becomes somewhat larger, and eventually an opening appeils. The maggots work themselves out and either crawl down the plant or drop to the ground. The desertion of the Cacti is followed by an infection which results later in a eopious exudation of a mucilaginous fluid or sap which liangs in irregular masses an inch or so in length. This infection is followed by the slow death of the affected lobe, and may eventually result in the destruction of portions of the plant or even entire plants. In some instances the work of the maggots is inhabited by a small Ptinid beetle belonging to the genus Catorama.

"Early II istory. - This pest was first brought to our notice in 1909 by Mr. George V. Nash, head gardener of the New York Botanical Gardens. The species, according to his statements, occurs in Opuntia hanburyana from Italy and an Opuntia from the British West Indies. Not much further was heard of this insect until 1913, at which time it was characterised as a very serious pest in a valued collection of Cacti. Earlier it was thought that this midge might be American, since the original distribution of the host-plant is limited to America, though subsequent statements would seem to indicate that this insect may possibly be Italian in origin. Mr. Becker, connected with the New York Botanical Garden, states that some recent cuttings received from Italy and kept in a house well separated from previously infested material were found after a few weeks to be infested by this midge. This is suggestive, though not necessarily conclusive, evidence as to the immediate source, but not to the original home of the insect.*

"Life History.-Conditions in the Cactus house indicate that this species may breed almost continuously throughout the summer months, and there would seem to be no reason why this pro. eess might not continue during the winter if the plants were not exposed to too low temperatures. The midges may be observed in the greenhouses, flying around the plants and alighting on the pots or the Cacti. They do not seem to make their way to the windows, and there was no evidence of their being captured in spider-webs. A Cactus lobe, apparently in a healthy condition, was cut into, and the interior found to be fairly honeycombed by the maggots. The larva, on attaining their development, emerge from the plants and may be found lying on the surface of the soil in the pots or in the coal-ashes covering the benches. The transformation to the pupa and emergence of the adults occur in these situations without any difficulty.

"An effort was made to ascertain the duration of a life cycle but without much success, since the midges do not appear to thrive under ordinary cage conditions, although a small greenhouse is well adapted to their requirements. Infested Cacti were received and placed in a large breeding-jar, March 10, adults emerging therefrom as follows:-April 15th, 1; 21st, many; 23rd, 12; May 9th, 8; 10th, 10; 12th, 5; 16th, $3 ; 17$ th, $4 ; 19$ th, 12 ; 21st, 5 ; 22nd, 3; 23rd, 24 ;

* If Itonida opuntice is restricted to opuntias, then its original home must be in America.-T.H.J.; H.T. 27th, 8; 28th, 2; 29th, 4; 31st, 11; June 2nd, $4 ; 4$ th, 9 ; 5th, $5 ; 7$ th, 4 ; 9 th, $3 ; 11$ th, $2 ; 13$ th, 7 ; 25th, 2; 26th, 1; July 11th, 6 ; 12th, 3 ; 14th, 4 .

"A distinct periodicity will be noted in the appearance of the midges, in that they were much niore abundant April 21 and 23, May 19 and 23. There was apparently no breeding in this jar, aside from the larva already in the soil and the plants attaining maturity. If this be the case it would appear that under certain conditions a generation may extend over a period of fonr months, the flies issuing at irregular intervals. This periodicity in the appearance of the midges was also observable in the green-houses, and in at least one case numerous midges appeared in both at the same date. There may be a period of nearly three weeks between the time the larva leaves the plant and the issuing of the imago, since on March 14 one larva and a pupa were placed in a tumbler with a little sand, and on the 3rd of April a midge issued. It is possible that this period marks the duration of the pupal stage.

"The Iarva is about $\frac{1}{8}$ of an inch or $3 \mathrm{~mm}$. long, rather stout, deep red, and with a welldeveloped bidentate breastbone.

"The midges are delicate, dark reddish brown flies, the male having a length of about $1 \mathrm{~mm}$., the female $2 \mathrm{~mm}$. Technical descriptions of both sexes have been published* by the author."

Asphondylia, spp.

Asphondylia opuntice, Felt (1908, p. 376).This insect attacks both the joint and fruit, more especially the latter, which as a result either are rendered infertile or else shrivel and die. In the former case the seeds are destroyed while the seed receptacle elongates, assumes more or less the character of a small joint, and may give rise to one or more segments which are of somewhat smaller size than normal. The insect thus loes not seriously injure the attacked plant, but decreases the seed production and thus tends to restrict the spread of Opuntias by seed. A figure showing a number of puparia projecting from a shrivelled fruit is given in C.I. (p. 35). The distribution is stated to be from Texas to San Luis Potosi in Mexico, and to Arizona and California, being very common in the last-named State (C.I., p. 34). Records in the Bureau of Entomology, Washington, D.C., show the receipt of the same species from $O$. occidentalis from Sonthern California, and $O$. arborescens from Arizona.

A cecidomyiid, presumably this insect, was met with by the Commission, as a tiny orange-coloured larva in "fruits" of $\boldsymbol{O}$. ferruginispina, $O$. convexa, $O$. leptocarpa, and $O$. lindheimeri at San Antonio, and in the lastnamed species at Sinton (Texas), as well as in o. monacantha at Los Angeles (California). The time of the year in which the inquiry was prosecuted was unfavourable for the observing of the more pronounced effects of the insect's attack.

It was in the eactus garden of Mr. B. Mackensen, of San Antonio (Texas), that many species of Opmntia were found to have been attacked, the infested fruit either becoming elongate or else proliferating so that they were not normal. Mr. Mackensen, in his deseriptions of certain new species, O. lcptocarpa (1911, p. 1914.

* Felt, Ann. Rep., New York State Entomologist 
142) and 0 . convexa (1912, p. 291), referred to to the fact that their fruits are sometimes proliferous, but did not suspect the cause of the alteration.

These larvæ were seen crawling amongst the gall-like bodies that represented the ovules formerly present when insect attack had commenced. Their occurrence was noticed even in altered "fruits" which had already, in the course of vegetative growth, given rise to fairly large stem-joints. Since there were no signs whatever of recent fly attack or of insect emergence, the presence of these insects in such cases must be accounted for either by pædogenesis such as is known to occur in another Cecidomyiid genus, Miastor, in Europe (Wagner, Meinert) and North America (Felt, 1912, p. 753), or by the occurrence of a very protracted life, extending over many months. Dr. Griffiths believes the latter to be the true explanation. He has given some attention to this parasite $(1913$, p. 20$)$, and during an interview informed us that the eggs are deposited from February to April, the larva living in the fruit and, after pupating, emerging as an adult next spring just about the time that the prickly-pear blossoms; also that the joints or fruits, which develop on the parasitised and deformed "fruit," originate during the year that infection has occurred. The Commission's observations of the occurrence of the larva were made in November and December, which would thus point to a ten or eleven months' duration of the larval state.

The proliferation of the fruit would in most cases give rise only to a single joint or a single plant, whereas if seminal development had not been frustrated by the insect, a large number of new plants would perhaps have been produced from the seeds. The effect of this parasite, then, is such that the ehances of an increased area of distribution of the plant are greatly lessened.

Subsequent to the Commission's investigations in the United States, Mr. E. P. Felt, in a letter dated February, 1914, has tendered the following information:- "Mr. E. O. Essig, Secretary of the State Commission of Horticulture, Sacramento, California, forwarded specimens of Asphondylia opuntice, accompanied by the statement that practically every fruit in a large district was absolutely ruined by this insect, many of them having several hundred in each." He. further adds that it should be comparatively easy to introduce this insect into Australia if it is desired.

Two other species of Asphondylia are known to infest prickly-pears-viz., $A$. betheli, described by Cockerell (1907, p. 324), from malformed "fruit" from Colorado, and $A$. arizonensis Felt, recorded as producing a fruit-like gall in a species from Arizona (Felt, 1908, p. $378 ; 1908 b$, p. 294). An account of the former is also given by Felt ( 1908 , p. $376 ; 1912$, p. 6). In regard to the latter, Mr. Felt has informed us that it attacks the fruit, causing the formation of a gall half the size of a man's head, one being figured in "Nature" (23, 1882, p. 77).

\section{Other Diptera.}

Various other diptera are found associated with prickly-pears and other cacti, but are mainly scavengers. They may be important since, when opportunity offers, they increase the injury caused by other insects such as Melitara and Moneilema, or even Chelinidea and Gerstæckeria.
The chief of these scavengers in the United States (C.I., pp. 37-38) are-Copestylum margi. natum, Say; four species of Volucella, two of Hermetia, and Stictomyia longicornis, Bigot.

\section{WHITE ANTS.}

The galleries of Termites or white ants were seen rather commonly in parts of Texas on the roots and stems of prickly-pears, especially those which had been injured by " pear rats " and other rodents. It has been stated (C.I., p. 40) that Termes flavipes, Kollar, may attack young Opuntias and Cereus in Texas, forming covered galleries on the segments, while the nest is not infrequently made in decaying joints.

\section{Summary of Evidence Regarding Insect}

Enemites of Prickly-Ptar IN U.S.A.

In the Bulletin on Cactus Insects (p. 13) there is given the following list of the principal species in the order of their importance as prickly-pear pests in the United States:-(1) Chelinidea, 3 spccies; (2) Mimorista flavidissimalis; (3) Narnia, 4 species; (4) Melitara, 4 species; (5) Moneliema, 8 species; (6) the Wild Cochineal Insects, Coccus confusus and C. tomentosus; (7) Marmara opuntiella; (8) Asphondylia, 3 species; (9) Stylopidea picta; (10) Diaspis ; (11) Orzamia ludicalis; (12) Platynota rostroma; (13) Polistes, 3 species. Nos. 11,12 , and 13 are Hymenoptera, which feed on the fruit. It will be noticed that in this list the Cactus weevils (Gerstackeria, spp.) are not given a place.

The period of the year during which the investigations were carried out in the United States was the autumn, and naturally insect activity was not at a maximum. The destruction caused by many of the pests which are regarded by Messrs. Huntcr, Pratt, and Mitchell as being of prime importance-e.g., Chelinidea, Narnia, and even Mimorista - was not as evident as that caused by Melitara, which seems to be the most destructive and one of the most wide-spread of all the genera of cactus insects in the, United States. It should be rcmembered that the investigations of the Bureau of Entomology were carried out mainly in Texas, where Melitara appears to do very little damage. Moneilema, spp., though wide-spread, do not seem to be sufficiently numerous to cause any great dcstruction. Judging from the results noticed in the New York Botanical Gardens, Itonida opuntice should occupy a prominent position amongst the destroyers of prickly-pear.

As a result of the investigations in the United States, the Commission considers that the following insects are the most effective enemies of prickly-pear there:-Melitara, spp.; Mimorista flavidissimalis; Moneilema, spp., Cœnopoeus palmeri; Chelinidea, spp.; Narnia, spp.; Gerstockeria hubbardi; Itonida opuntio; and Asphondylia opuntice.

\section{Proposed Introduction of Cactus Insects into QueEnsland.}

The advice of Dr. Howard, the Chief of the Bureau of Entomology, and one of his senior officers, Mr. W. D. Hunter, was sought regarding the introduction of these into Queensland. Neither the introduction of these foresaw any likelihood of the above-mentioned insects attacking plants other the above-mentioned insects atd not, however, advise the introduction of the Calandrid weevils, Cactophagus, spp. 
In regard to the question as to what species should be introduced, Dr. Howard stated that, except in the case of any insect known to be undesirable, it was the custom of his Bureau to import all insects, whether destructive in their native home to the object against which they were to be used or not, as long as they were injuriously related to it in their habits of life.

$\mathrm{He}$ generously offered to co-operate in any effort to bring about the introduction into Australia of such species as the Commission deemed suitable for its purpose. It was agreed upon that Queensland should be prepared to pay any expenses incidental to the collection and transmission of such insects. He stated in effect that his Bureau would be responsible for and supervise the work in the United States, and place it in the hands of one of its officers, Mr. J. D. Mitchell, who is joint author of the bulletin on "The Principal Cactus Insects of the United States," and who, as we know from personal experience, is well suited for such responsible duties. However, his services could be granted only up to a certain point, and this would be done, not as a matter of ordinary official procedure but as one of international courtesy. The extent to which his services would be available must depend upon Mr. Mitchell's official superior, Mr. Hunter. He might be authorised to employ such boys as might be necessary to assist him in the work.

Mr. Hunter submitted another scheme, which would cost more than the latter but would be more satisfactory. He suggested, with the concurrence of Dr. Howard, that Mr. Mitchell should supervise and generally control procedures, the Bureau of Entomology setting aside temporarily a suitable trained officer to assist him and to preserve continuity in what was undertaken. This would enable the matter to be prosecuted in a comprehensive manner. The officer, Dr. Howard stated, would be one of the regular men now working under Mr. Bishopp at Dallas, and would be furloughed for the purpose. Mr. Hunter added that this course would involve an expenditure on our part of 200 dollars per month (about $£ 40$ ), made up of 100 dollars for salary and the remainder for expenses. He thought that much could be done in this way, even in one month.

Dr. Howard offered to exercise his authority in arranging for concessions being granted to allow the passage of living insects in suitable receptacles over the railways to the port of em. barkation. In the event of the material being transmitted viâ San Francisco, Mr. Hunter stated that it could be handled by Mr. F. W. Maskew, who, besides being the Chief Inspector of the Board of Horticultural Commissioners, was also an officer of the Bureau of Entomology.

Both Dr. Howard and Mr. Hunter were emphatic in pointing out that procuring these useful insects and transmitting them to Queensland was only half the work necessary. On arrival they had to be controlled, multiplied, and distributed. Accordingly, suitable and adequate preparations must be made in good time in our State.

These officers considered it preferable to raise a large stock in Quecnsland from comparatively few imported insects than to stock up from the Inited States hy the sending of numerous consignments. This course was expedient if the admission of parasites to the useful insects was to be prevented.

Mr. Mitchell informed us of his willingness to assist in every way that he could, if instructed by $\mathrm{Mr}$. Hunter to do so.

Whilst in San Francisco, one member of this Commission interviewed Mr. Maskew with a view to obtaining a promise of his assistance, more especially as he is located at that port which is the main avenue for egress from the United States to Australia. Mr. G. Compere, the Chief Quarantine Officer, who has had a very wide experience of parasites in the field, and their transmission and utilisation, was also present. They considered the introduction into Queensland of the insects referred to quite feasible, and would be prepared to assist in the undertaking by receiving, taking safe custody of, and transmitting packages. The latter should be securely packed in the receptacles in which their transmission was to be effected, and should be conspicuously addressed with the name and address of the consignee in Australia. They should also each have an external movable covering bearing the official address of the San Francisco Quarantine Officer, California State Commission of Horticulture, Ferry Building, San Francisco, which might be detached prior to their despatch to Queensland. Such packages should be forwarded so as to arrive at the Quarantine Office not later than twenty-four hours before the time of departure of the steamer by which their transmission to Australia was to be effected. It was suggested that, in order to do this, the officer responsible for the initial despatch of the several consignments should keep in touch with the San Francisco Quarantine Office, while the latter would on its part keep such officer posted in regard to the time and date of sailing of different boats from that port to Australia.

Under special circumstances, Mr. Maskew added, consignments might be sent viâ Vancouver, where there was stationed Mr. Eichorn, a capable man, who would no doubt be found willing to assist if asked to do so.

No question of any monetary grant was raised, as Mr. Maskew expressed himself anxious to help in every way without regard to any such consideration.

In discussing details, it was agreed that the temperature of the butter-room as generally maintained on ocean-going steamers would comply with the conditions of cold storage suitable for transmission of any prickly-pear insects.

Professor Thornber of the University of Arizona, Tucson, and Prof. Merrill of the New Mexico Agricultural College, Mesilla Park, expressed their willingness to assist in any way desired, under the direction of the Bureau of Entomology.

Acting on the suggestion of Dr. L. 0 . Howard, the Commission held another conference with him, after it had visited the chief pricklypear regions of the United States and seen something of the effects of the natural enemies of Opuntias, and consulted scientific investigators and others during the journey. We informed him that it was proposed to recommend to the Government of Queensland that these enemies, 


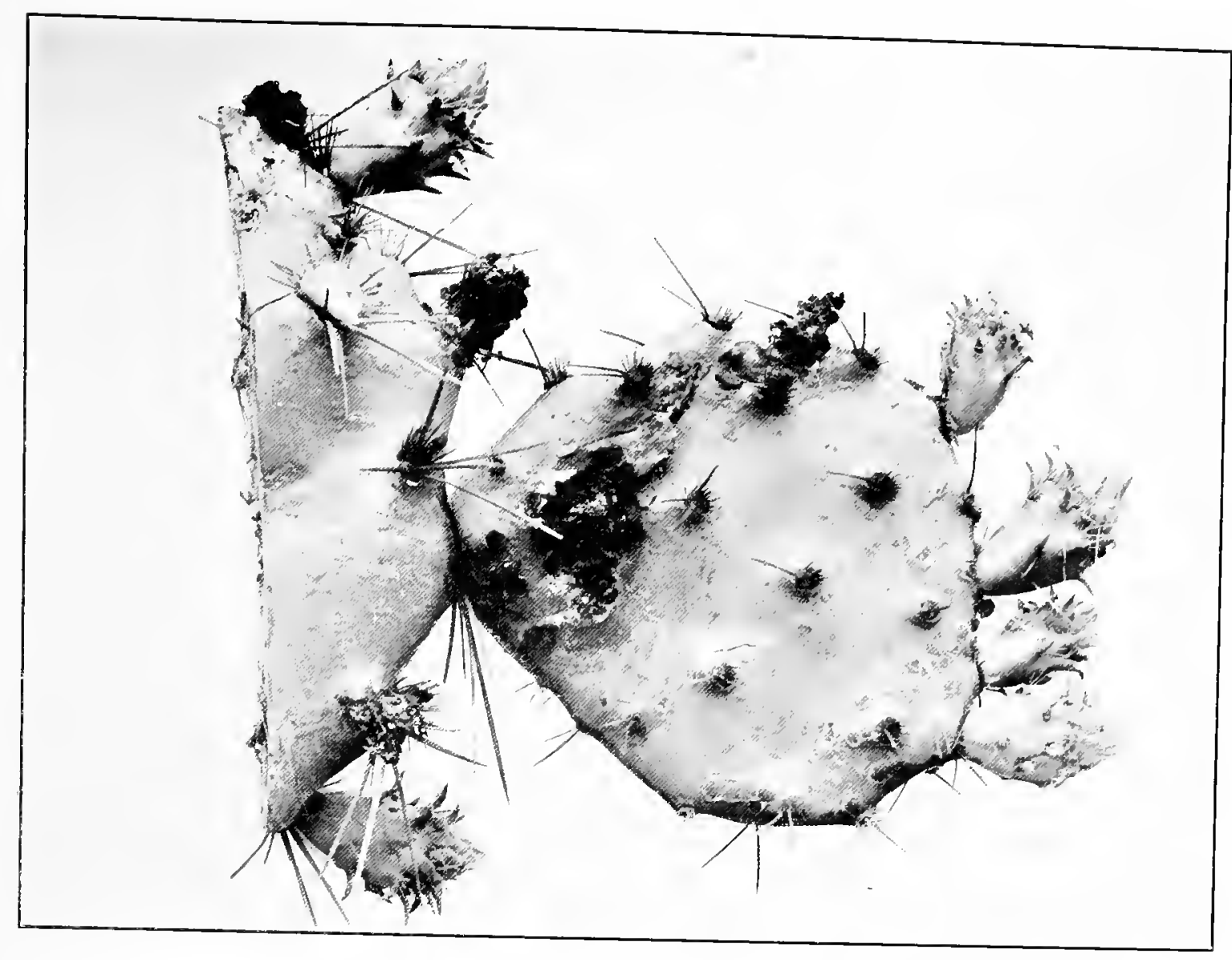

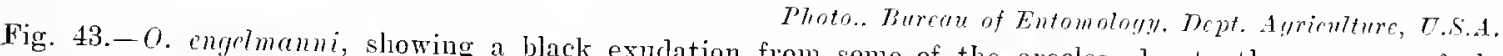
from some of the areoles, dne to the presence of the

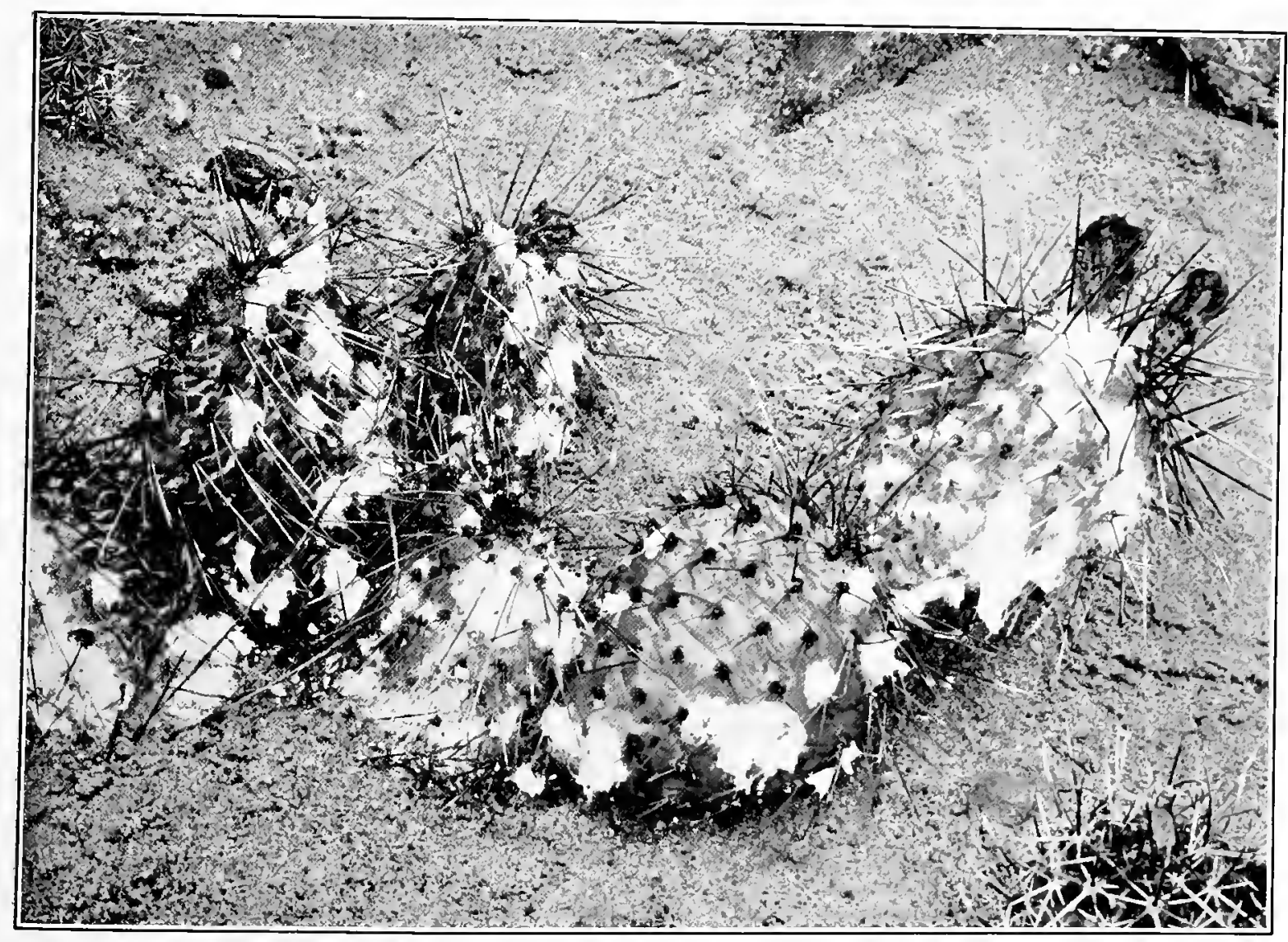

Photo., Burenu of Entomoloyy, Dept. Agriculture, U.S.A. segments is due to attacks by a cactus bug, Chrinidia intigrra. 

with certain exceptions, should be introduced and that Dr. Howard's generously proffered assistance should be availed of; but that the work eould not be immediately cntered upon without its approval and authority. Besides, it would be neeessary for the Queensland Government to provide the necessary insectary and entomological staff for handling in our State whatever insects should be reccived.

\section{The " Red Spider," Tetranychus opuntie, Banks.}

Besides the numerous insect enemies cnumerated above, there is an araehnid, Tetranychus opuntioe, Banks (1908, p. 36), which Dr. D. Griffiths regards as a serious pest of both wild and cultivated Opuntias, but particularly of the latter. He has given an account of the work attributed to it $(1908$, pp. 29,30$)$. The parts around the areoles are first attacked, a yellowish, corky tissue being formed on the surface by the plant as a result of the injury. This diseoloured area may extend over the greater part of the joint. Owing to the eraeking of this callus, a mucilage may eseape from the joint. Dr. Griffiths states that no plants were observed to have been killed by this "red spider," which is said to be most abundant in the winter, about March. The injury is more commonly seen where the Opuntias are erowded together.

The condition referred to by Dr. Griffiths was seen on $O$. lindheimeri under cultivation at San Antonio, as well as at Brownsville. The Curator of the Plant Introduction Gardens at Chieo, California, stated that Tetranyehus was very common in the greenhouses during Maren and April, and, on aeeount of the injury eaused by it, fumigation had to be resorted to in order to control the pest.

According to Hirscht (1899, p. 797), T. telarius is a formidable enemy of the Cactaceaæ in European colleetions. It eauses the formation of yellow, reddish, or red-brown spots which soon extend over the surface of the whole plant, followed by a cessation of growth, and even a dropping to the ground of the upper parts of the plant.

As "red spiders" are not restrieted in their dietary to the Cactaceæ, their introduction need not be considered.

\section{UTILISATION AS FOOD FOR MAN.}

Comparatively little use is made of the prickly-pear or its fruit as food for man in the United States, while in the neighbouring Republic of Mexico the fruit especially forms a very important article of diet (Griffiths and Hare, $1907 \mathrm{~b}$ ). This is due to the faet that the speeies found indigenous to the former country do not produce fruit comparable as a food with those derived from the various Opuntias occurring wild in the Mexican highlands. Certain species grouped under the term "Mission Pear " have been long introduced from Mexico into the warmer parts of the United States, and these are partly cultivated by the Mexican population there for the sake of the fruit, for which there is a local demand. Among the indigenous species whose fruits are occasionally utilised in this way are
Carnegiea gigantea, Opuntia dulcis, * and the group of cacti (Echinocereus, spp.) known collectively as pitalla or Mexican strawberries. A detailed analysis of the rind, pulp, and of the fruit (minus the peel and seeds) of some prieklypears native to the United State's has been published by Drs. Griffiths and Hare (1907 b, pp. 15, $16,32-42)$.

In order to meet the demand for edible priekly-pear fruit made by Southern European immigrants (chiefly Italians) in the United States, a steady importation of the fruit of $O$. ficus-indica into New York goes on from Italy and Sieily (Griffiths, 1905, p. 41).

The fruits of some of the indigenous species, e.g., $O$. dulcis, are oecasionally made into preserves. The pulpy eentral mass of the "niggerhead" or barrel caetus, Echinocactus wislizeni, Engelm., and its allies is commonly used in Arizona and Southern California in the manufacture of a produet termed "eaetus candy," this portion being eut into pieces which become infiltrated with sugar by being boiled in syrup. The eandy may be variously coloured.

Mr. Luther Burbank, of Santa Rosa, California, has given careful attention to the improvement of the fruit-bearing and stoek-feeding eapabilities of eertain varieties belonging to the $O$. decumana group of speeies.

\section{UTILISATION AS FOOD FOR CATTLE.}

A great deal has been written in the United States on this subject, particularly by Dr. Griffiths and Dr. Hare. Amongst others who have devoted mueh attention to this economic aspect are Dr. Wooten (1911) in New Mexico, and Prof. Thornber (1911) in Arizona. One of the earliest to publish the results of his analyses of pricklypear was Harrington (1888, 1895). Goss (1896, 1903), Forbes (1904), and Vinson (1911) have added further information, but the greatest amount of work along the lines of chemical analyses, followed up by feeding tests, has been earried out by the two first-named authors, Griffiths and Hare.

As the conditions of growth of prickly-pear in the United States of Ameriea are so different to those in Australia, a summary of the work done will suffice.

Prickly-pear as a Farm Crop.-The Federal Agrieultural Department at Washington, D.C., as well as those of New Mexieo and Arizona, are endeavouring to induce people to plant out eactus as an emergency fodder against times of drought. In faet, Dr Griffiths advoeates the growth of many speeies of priekly-pear as farm erops (1908 a, 1908 e, 1909 a, 1912 a), and states what conditions of elimate are neeessary for their proper development.

In his paper on "The Prickly Pear and other Caeti as Food for Stock" (1905), Dr. Griffiths referred to various methods of singeing and ehopping the pear. He pointed out its value during drought, especially if some more concentrated food be added. Its sueculenee was found to be

* Referred to by Griffiths and Hare (1907 b, p. 62) as o. loevis?, Coulter

+ Mrs. B. L. de Graffe (1896, p. 169) has referred to the chemical properties of prickly-pear as well as to some methods of utilisation of the fruit. 
of value in the case of a ration for dairy cattle, from 40 to $70 \mathrm{lb}$. of pear being used along with plenty of other nutritious food for each animal. He stated that cattle, sheep, and goats soon become accustomed to singed Opuntia, though scouring is apt to occur. In Texas, cotton-seed meal is generally added to a pear diet, while in Colorado the cane cactus (Cylindropuntia, spp.) is usually fed alone.

Next year there appeared his bulletin giving the results of his feeding experiments (1906) both beef cattlc and dairy cattle being used. The milk yield was found to be in no way adversely affected by the use of a roughage of prickly-pear. Animals fed on chopped Opuntia together with cotton-sced meal were found to have gained in weight.

In the same year (1906) Griffiths and Hare published a long article entitled "Prickly Pear and other Cacti as Food for Stock, II." In it are abundant data regarding the chemical analyses, as well as short accounts, of a large number of species examined, amongst them being some which occur in Queensland, viz., $O$. inermis $O$. monacantha, and $O$. imbricata. It was found that the stems of the low-growing Texan species were of more value than those of the tall tree forms from Mexico, as they were far less woody and more succulent. However, it was also found that the old stems of the commonest Texan species, $O$. lindheimeri, contained less water and more crude fibre and had a less food value than the younger growth, but the lower water content of the stems was a decided advantage when dealing with such succulent feed. Though the fruits of cacti were usually found to possess more fat and protein than the stems, yet it was noticed that the seeds contained nearly all the food material of the fruit, and as they are passed through cattle undigested, this food was not available. Of course those fruits which are rich in sugar have considerable nutritive value. The cane cacti were found to have a greater relative food value than the flat Opuntias, as they contained more protein, fat, and nitrogen-free extract. They were, however, generally drier and contained more fibre, and were therefore less suitable for ordinary feeding.

The question of forming a balanced ration for cattle is also discussed. Assuming that the coefficient of digestion for 0 . lindheimer $i$ is the same as that of immature green fodder, the nutrients in that spccies were calculated as protein .47 per cent., fat .26 per cent., carbohydrates 7.85 per cent., the nutritive ratio of the plant being $1: 18$. The ratio for a standard ration varies between $1: 4$ and $1: 12$ according to the animal and to the object of feeding, whether for work, beef, or milk. Hence prickly-pear alone would be too wide a ration. It is pointed out that in order to produce milk the ratio should be from $1: 5.5$ to $1: 7$, and to provide the necessary digestible fat, protein, and carbohydrate a cow would need to eat about $400 \mathrm{lb}$. of pear, whereas not mole than 50 or $60 \mathrm{lb}$. should be fed daily on aceount of the scouring which follows. The Opuntia could be used as part of a fairly balanced ration thus :$40 \mathrm{lb}$. cactus, $10 \mathrm{lb}$. of wheat bran, and $12 \mathrm{lb}$. of corn stover - a ration with a nutritive ratio of 1:7.7. Another ration suggested is as follows:$60 \mathrm{lb}$. cactus, $14 \mathrm{lb}$. brewer's grain, and $1 \mathrm{lb}$. cotton-seed meal-the nutritive ratio being $1: 4.5$. This could be readily widened by the addition of coarse dry fodder. A balanced ration consisting of prickly-pear and cotton-seed meal could not be prepared as too much cactus would have to be fed, though it is usually got over by feeding excess of the meal which becomes utilised by the animal to supply the deficiency in carbohydrates -an expensive method of supplying carbohydrates, and one which could be justified only where the meal is cheaper than more starchy foods. This paper was summarised the next year (Griffiths and Hare, 1907 a).

In an article (1908 a) dealing with "The Prickly-pear as a Farm Crop," Dr. Griffiths again referred to the value of cactus in dairy farming, on account of the succulence and of the ease with which a diet containing cactus as a roughage could be balanced up by the addition of some concentrated food, this succulence being available at a time when other juicy fodder was not obtainable. Cattle, sheep, and goats were all found to become fond of it. It was noted that $O$. lindheimeri under cultivation produced annually about 23 tons per acre, which would provide enough roughage for a bovine.

Dr. Hare carried out some " Experiments on the Digestibility of Prickly Pear by Cattle," publishing his work in 1908. He used $O$. lindheimeri and found its average composition to be as follows:-Water, 83.41, ash 3.48 , protein 0.75 , ether extract 0.31 , crude fibre 2.64, nitrogenfree extract 9.41, total organic matter 13.11 per cent. As a result of his observations on feeding it to steers, he determined the coefficient of digestion to be-Protein 58.25 per cent., fat 67.90 , crude fibre 41.32 , and nitrogen-free extract 82.59. The digestive nutrients (obtained as the product of each nutrient by its coefficient) were found to be-Proteids 0.45 , fat 0.21 , carbohydrates 7.77 -Nutritive ratio $1: 18.3$, which falls far below both the European (1:5.4) and American (1: 6.5) standard ratio for milch cows.

In comparing the results obtained when using the pear with those obtained with green corn as a fodder, it was seen that the prcteids of the former were not quite as digestible as those of the latter, though the fats were about the same in each instance. and the nitrogen-free extract nore digestible in the case of the pear, but the crude fibre less so. The total digestive nutrients were thus about the same in both, though slightly in favour of the cactus. He also found that when pear was fed along with cured fodders or grains the digestibility of both seemed to be increased. In one experiment the animals gained weight, but in another set of experiments the beasts lost weight. As a satisfactury ration for a $1,000-1 b$ milch cow he suggested $50 \mathrm{lb}$. prickly-pear, $10 \mathrm{lb}$. wheat bran, and $10 \mathrm{lb}$. lucerne, this having a mutritive ratio of $1: 5.46$. The tendency to scour, as a result of feeding on a ration of prickly-pear and cotton-seed meal such as is commonly used in Texas, could be checked either by giving some coarse feed in addition or else by allowing cattle the run of a dry-grass pasture.

As early as 1895 Goss (p. 49) had suggested that lucerne should be added to prickly-pear diets in order to increase the amount of nitrogen in the ration.

Uncultivated Prickly-pear as Fodder.-In a bulletin entitled "Cacti in New Mexico," E. O. Wooten (1911) attempted to awaken the interest of New Mexican ranchmen in 
regard to the value of prickly-pear as a reserve fodder against times of drought. $\mathrm{He}$ recapitulated the results of Griffiths and Hare, and gave botanical details regarding many of the local species.

In the same year J. J. Thornber, of the University of Arizona, published the results of his efforts in an article on "The Native Cacti as Emergency Fodder Plants" (1911). The native species were found to be able to withstand the rigorous climate of Arizona much more satisfactorily than the various spineless forms experimented with. It was shown that sheep, if fed on cactus alone, undergo nitrogen starvation, but when the prickly-pear fodder was balanced by the addition of a small amount of food rich in protein, then the ration had a decided nutritive value. These plants are looked upon by him solely as an emergency fodder and as a range crop, not as a farm crop. Hence the planting out of Chollas (Cylindropuntia) and prickly-pear (Platyopuntia) in the open country in Arizona was strongly advised. Details as to the preparation of each for fodder were given, singeing being the method recommended.

When visiting Arizona, the Commission's observations led to the conclusion that certain indigenous species of Cylindropuntia-the Chollas-supplied a very considerable part of the dietary of. cattle who fed on the abundant green perennial fruit, areas in which Chollas were abundant and in which there was little if any grass being fenced off for grazing purposes.

The nutritive value of Cholla fruit (O. fulgida)* was investigated by Dr. Vinson (1911), who used sheep as experimental animals. He found that as a ration for maintaining sheep in a fair state of nutrition it would be necessary to supply an animal with an amount of fruit far beyond its capacity, at least $45 \mathrm{lb}$. daily being needed. Besides. this would contain excessive mineral salts. The fruit alone appears to be inadequate to maintain the nitrogen equilibrium for any lengthened period. The addition of half to three-quarters of a pound of lucerne hay to a diet of 6 or more lb. of cholla fruit would probably preserve life in the case of a 120-lb. sheep. and there would perhaps be some gain in weight. It was suggested by him that similar results might be obtained with range cattle by using auantities increased proportionaliv to the live weight-i.e.. about 4 to $6 \mathrm{lb}$. alfalfa or its equivalent and 50 or more lb. of cholla fruit daily (p. 518). It was found that sheep in confinement could not be forced to eat other forms of cactus except the fruit, but ate the latter quite readily when the supply of lucerne was limited. Range cattle eat considerable quantities of cactus, especially their succulent acid fruits.

The information obtained by the Commission from various sources pointed to the fact that nrickly-pear was generally regarded as a nuisance if abundant. and as a plant possessing some value only during times of drought when other stock food was scarce. The Mexican teamsters in Texas are in the habit of giving cactus to their animals, which generally have to find most of their own food. Stockmen occasionally make use of the pear after burning off the spiues by means of a brushwood fire or a torch. In one place,

* O. imbricata, which occurs sparingly in Now South Wales and Queensland, is allied to $O$, fulgida. prickly-pear was seen to be cultivated, the plants being singed and dairy cattle then turned in to feed on the cactus as a roughage. This was at Mr. Sinclair's farm near San Antonio, and it was here that Dr. Griffiths carried out some of his experiments.

The experience in the United States in regard to using prickly-pear as a stock fodder is thus fairly similar to that in Australia, though the eactus there is relatively less abundant, being largely controlled by climate and to a considerable extent by various natural enemies.*

Farmers get rid of the cacti by cutting them down, and either burning them after partial drying, or else ploughing them into the soil.

\section{UTILISATION FOR THE MANUFACTURE OF ALCOHOL.}

Professor Hare and his colleagues, S. R. Mitchell and A. P. Bjerregaard, have published (1909) a paper dealing with the question of obtaining denatured alcohol from Opuntias. They found that about 10 per cent. of the total weight of a prickly-pear plant consisted of carbohydrates, mainly plant mucilage and soft cellulose tissuc, there being no starch except in spring. Since the amount of sugar present at any season was quite small, there was consequently very little material available for the production of alcohol, and hence the possibility of obtaining that product commercially from the plant as a whole was negligible.

In regard to the utilisation of the ripe fruit for the manufacture of alcohol, it is pointed out that the fruits of many species are used largely by Mexicans as articles of food, their value being due to the high sugar-content-mainly dextrosewhich in the best varieties amounts to from 10 to 15 per cent. Where prickly-pear ( $O$. lindheimeri) had been cultivated, as near San Antonio, Texas, the fruit obtained averaged 8 tons per acre, from 10 to 12 tons being obtained sometimes; but in New Mexico the plants when wild did not grow sufficiently close to make fruit collection for alcohol manufacture profitable. Besides this, the cost of hauling the fruit to a distillery would have to be considered. Then, again, it was estimated that if fruits have 10 per cent. of sugar about $140 \mathrm{lb}$. of fruit would be required to produce a gallon of alcohol, and this would necessitate considerable labour being used, only hand labour being available in New Mexico.

It was found that various types of yeast could be employed, but substances other than alcohol were also produced, e.g., acetic acid, \&c., whereas, by using pure cultures of an active distillery yeast, practically all the sugar was converted into alcohol. The details of the method are described (pp. 36-40). The addition of Pasteur's mineral nutrient did not increase the amount obtained. It was suggested that the sterilisation of the fruit, or the fruit-juice, followed by cooling before adding the ferment, would probably be beneficial. It was found that the fruit-juice if evaporated to a

* Mr. Carne (1913, p. 975) has recently published some observations made during a visit to the United States. observations made duread of prickly-pear there depends on He believes that the spread of pricke of frosts. The fact a sufficiency of moisture and an absence of frosts. The fast that grass-fires are much less common now than formerly has led to a much more rapid spread of cacti. Distribution by cattle is also a factor in the spread. Mr. J. D. Mitchell, who accompanied the Commission in Texae, held the same views regarding the cause of the increase in Opuntias in parts of that Stato. 
thick syrup would not ferment, but would do so if diluted. Evaporation would, however, be an expensive matter.

The conclusions of these authors may be stated briefly. In order to make alcohol manufacture from prickly-pear fruit a profitable undertaking, the following conditions would seem to be necessary:-(1) The production of a large amount of fruit from small areas averaging about 10 tons of fruit to the acre; (2) Some rapid method of collecting fruit, as hand-picking even with Mexican labour is too expensive.*

It should be mentioned, however, that these findings have reference to the manufacture of raw spirit, and not to an immediately potable beverage which, as already known, prickly-pear fruits may be made to yield.

\section{UTILISATION OF THE MUCILAGE OF PRICKLY-PEAR.}

Dr. Hare (1911), in his "Preliminary Study of the Carbohydrates in the Prickly Pear and its Fruits," deals with the mucilage contained in the stem-joints as well as in the green fruits. This substance disappears from the latter as ripening progresses, and is absent from mature fruits, being replaced by sugars, largely "glucose and fructose with small amounts of sucrose and perhaps a pentose in small amounts, but no galaetose." His analysis of the mucilage from the stem showed that it contained galactan $\dagger$ and a pentosan. The carbohydrates of the stem were found to consist mainly of this mucilage together with small quantities of gum, sugar, and starch, the latter being present during summer, but scarce or absent at other times of the year. Dr. Hare thought that $O$ 'Sullivan's view that mucilages and gums are not polysaccharides as usually believed, but are glucoside derivatives of certain organic acids-the latter being different for each mucilage-was the correct one in the case of Opuntia.

The prickly-pear mucilage was observed to be insoluble in water, as its "solution" in water will not pass through unglazed porcelain, though if dilute it will pass through filter paper. It was also found that this substance could be separated by certain treatment with alcohol into two constituents, one of which contained a high percentage of pentosans while the other was free from them, but was easily hydrolised to produce hexoses. The composition of the dried mucilage "when separated by precipitation with alcohol from a 2 per cent. solution contained 15 per cent. of galactan, 31 per cent. of pentosan, and 12 per cent. of ash," whereas the iuice of the ripe fruit contained 1.57 per cent. of pentosans, and only traces of galactan, but considerable quantities of fructose and glucose (p. 28).

In regard to the question of utilising the mucilage, Prof. Hare found that though a 10 per cent. solution was very viscous, its adhesiveness was very poor. He mentioned that experiments

* Mexican labour is obtained at an extremely cheap rate in Mexico and the neighbouring parts of the United States, when compared with the cost in such a country as Australia (see Griffiths, 1905, pp. 42-43).

$\dagger K$. Yoshimura, in his "Note on the Chemical Composition of some Mucilages," in the Bull. Coll. Agricul. Imp University, Tokyo, Japan, $(2,1895$, pp. 207-8), found that the mucilage from the stem of prickly-pears consisted chiefly of galactan, whereas Ladd (New York Agric. Exp. Station, 6th Ann. Rep.) thought it contained pectins, hi oonclusions being doubted by Griffiths and Hare (1907 b, p. 40). carried out by a manufacturing firm to test the usefulness of prickly-pear mucilage as a glaze for paper showed that it was unsatisfactory on account of the feebleness of its adhesive qualities. Mr. Luther Burbank informed the Commission that he believed that the substance had been used to some little extent in the United States of America as a glaze for cheap cotton stuffs.

The mucilage obtained from $O$. engelmanni in Southern California is used as a dressing for eanvas tents employed in fumigating fruit-trees. Joints are chopped up and then soaked in water for twenty-four hours, the mucilage obtained being thickened by the addition of ochre or venetian red and then applied to both sides of the canvas.*

The industrial arts may, however, furnish other opportunities for the use of prickly-pear mucilage, an instance of this being given in the section of the Report dealing with India, where the substance is utilised in the making of a kind of plaster (ehunar).

\section{THE COLOURING MATTER OF PRICKLY- PEAR FRUIT.}

The fruits of many prickly-pears contain a bright magenta colouring, which in the case of $O$. dulcis has been investigated by Dr. Hare $(1911) . \dagger \mathrm{He}$ first removed the mucilaginous material from the juice by the addition of one or two volumes of alcohol. The addition of two volumes of acetone to the filtrate precipitates the magenta pigment in a syrupy condition. The latter can be dried and its colour is permanent.

Experiments were made with wool, silk, and cotton, mordanted and not mordanted, but it was found that the colour did not form a sufficiently fast dye. As an article for colouring foods and drugs, it was proved unsatisfactory in cases where it was necessary to leep the colour in solution in the presence of oxidising agents or light, but was found to give quite satisfactory results when used to colour ice-cream, beverages, eandies, and fruit preserves.

He believed that on account of the eheapness and abundance of the fruit. and the ease with which the pigment eould be separated and concentrated into a harmless paste suitable for use in colouring certain foodstuffs, its introduction to the trade would be justified.

\section{SUMMARY OF INVESTIGATIONS IN THE UNITED STATES.}

The Commission visited the main cactus areas and obtained advice and assistance from various scientific workers and others who had given attention to prickly-pear matters.

In regard to destruction by disease, there is one malady, anthracnose or "shothole," caused by the fungus Gloosporium lunatum, which, under certain conditions of climate, is capable of causing considerable damage, the "black rot" which then sets in bringing about the destruction of attacked segments. Cultures of this fungus have been brought to Queensland by the Commission.

* Year book of Agriculture, U.S.A., 1896, p. 230.

$\dagger$ A short preliminary account was published by Griffiths and Hare (1907 b, p. 62), the species being identified as 0 . lavis ?, Coulter. 


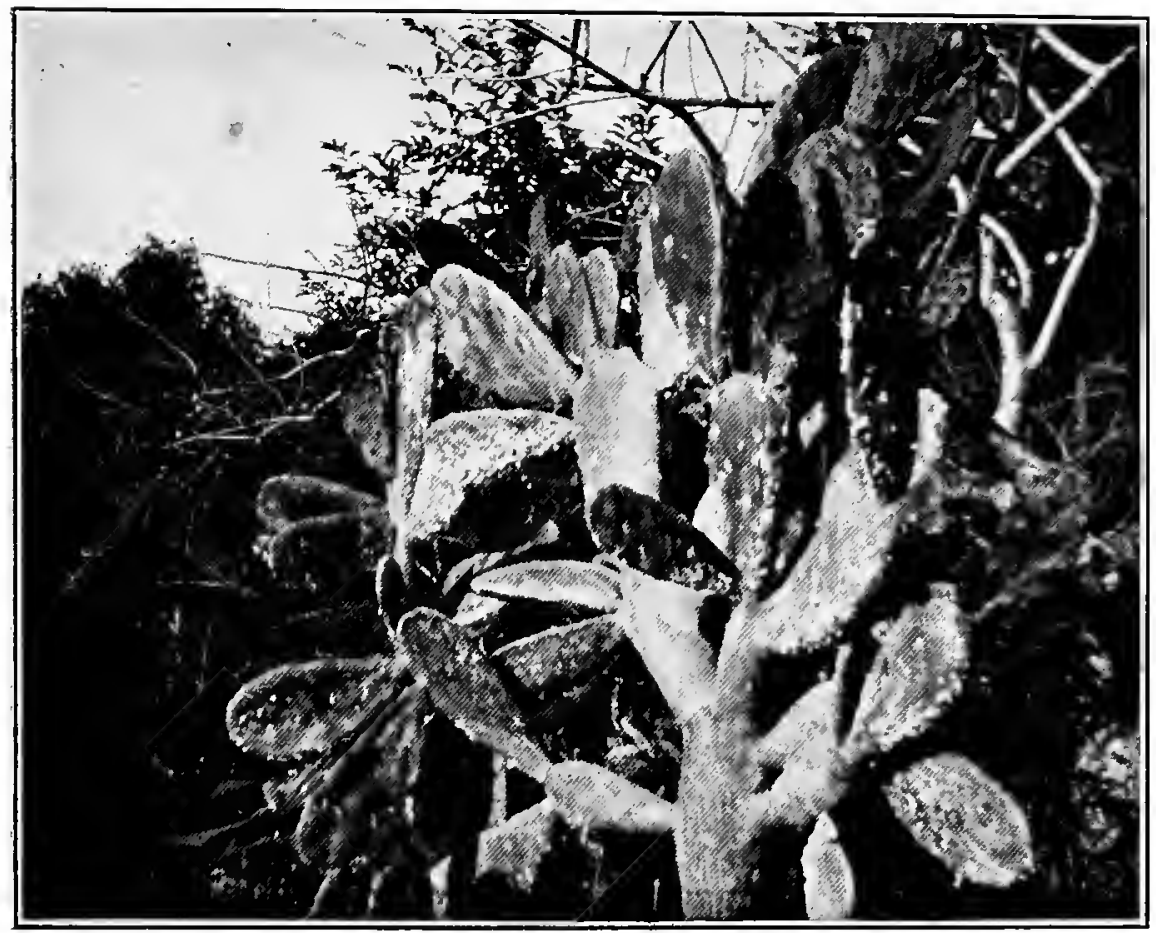

Fig. 45.-Wild Cochineal-Coccus confusus Newsteadi-on Nopalea ccchinelifera, Antigua, West Indies.

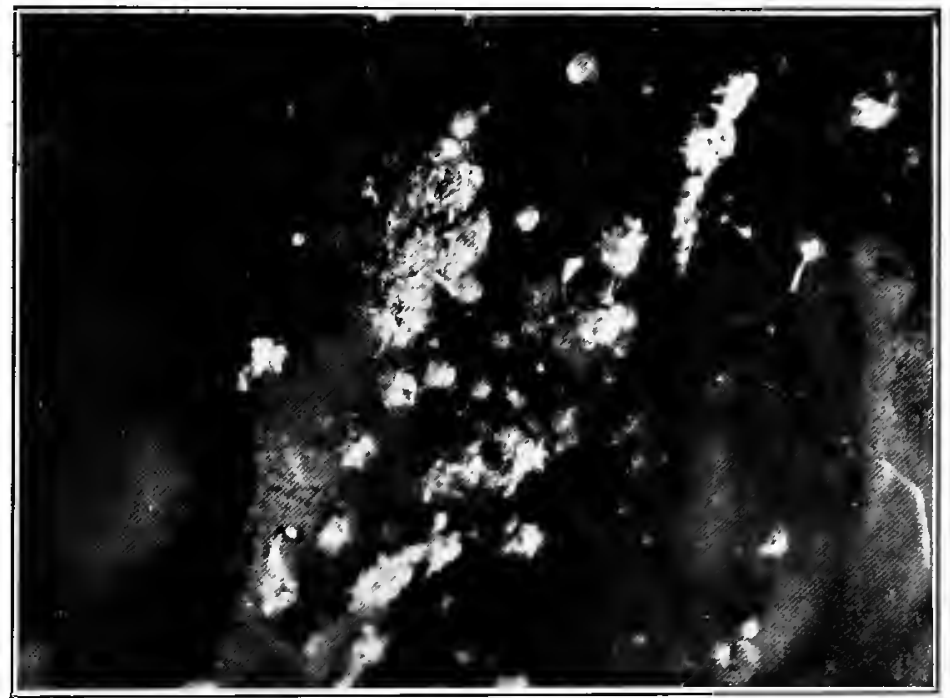

Fig. 46.-The Cape Wild Cochineal-Coecus confusus capensison O. monacantha. Capetown, South Africa.

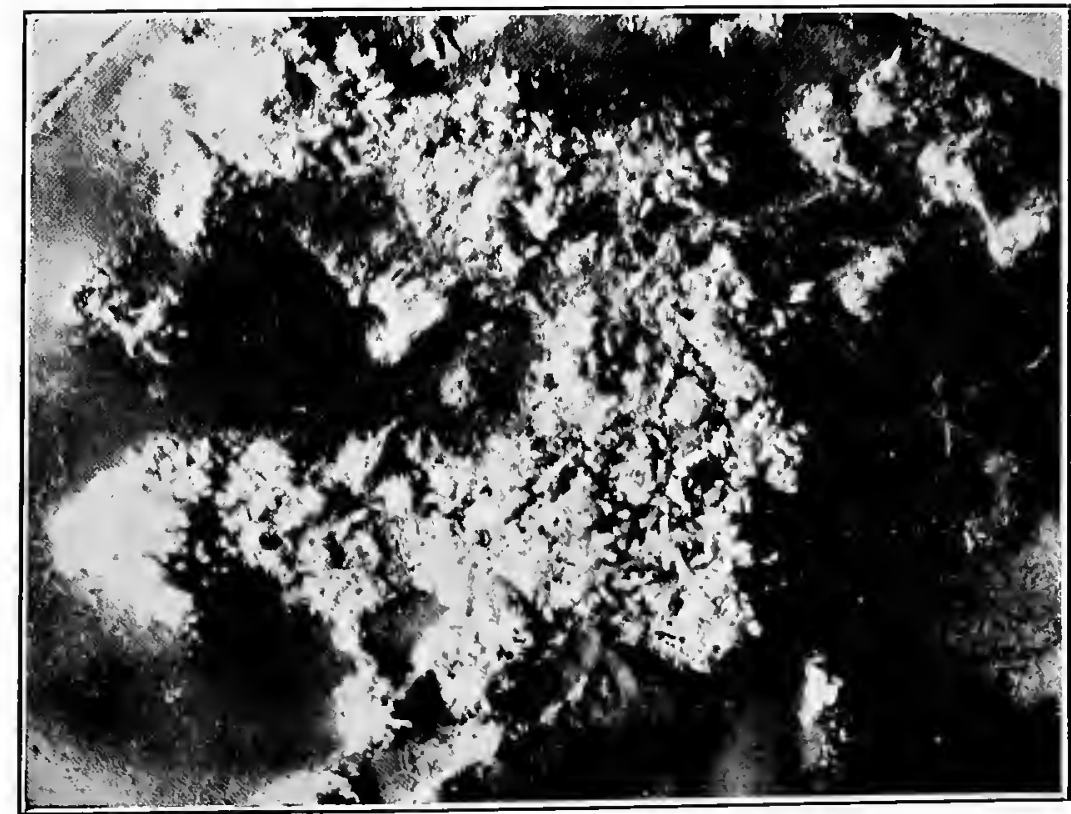

Photo., E. O. Essig, State Commission of Horticulture of California.

Fig. 47.-Wild Cochineal on Opuntia. Bonita, Southern California. The tubular coverings of the male insects are recognisable. 

Certain rodents, especially species of Neotoma, are capable of doing a great deal of damage to and not infrequently destroy pricklypear plants, but their dietary is not restricted to the Cactacer.

In regard to the action of insects as destroyers of prickly-pears, a large amount of evidence has been collected. The most destructive are the beetles Moneilema spp., Canoporus palmeri, and Gerstocckeria spp.; the moths Melitara spp., and Mimorista flavidissimalis; the hemiptera Chelinidea spp., and Narnia spp.; and the diptera Asphondylia spp., and Itonida opuntice. All of these are stated to be restricted to the Cactacer.

The larva of Moneilema forms tunnels in the joints, stems, and roots, while the adult feeds on the young segments. Cernopceus acts similarly. The eactus weevils, Gerstockkeria spp., oceasion more or less damage in the larval stage, the injuries caused by the adult being unimportant. The larvæ live within the joints.

The species of Melitara are the most destruetive of the natural enemies of the prickly-pear, the larvæ hollowing out the joints and sometimes even the stems and roots, totally destroying the plant. They are assisted by the larvæ of scavenging flies and by invading micro-organisms.

Mimorista commonly causes the destruction of young segments and is therefore a powerful factor in controlling the spread of prickly-pear.

The bugs Narnia and Chelinidea attack the fruit and stem-joints respectively and are said to be at times a serious menace to the health of the host plant. It is also suggested that the latter may act as the transmitting agent for the shothole fungus Gloeosporium.

The species of Asphondylia cause the more or less complete destruetion of the ovules and developing seeds of prickly-pears, the resulting deformed " fruit" giving rise to a joint or to a "fruit" which in its turn is likely to become infested. Hence Asphondylia is capable of acting very efficiently in preventing the spread of Opuntias by seed.

Itonida causes gall-like swellings in the stem joints and has been the cause of heavy loss amongst greenhouse Opuntias. Its native home is not known.

Many other insect enemies are known, but they are either not restricted in their dietary to cacti or else their influence in destroying or controlling prickly-pear is not of much importance.
Dr. Howard and Mir. Hunter, of the Bureau of Entomology, Washington, D.C., have suggested certain means by which the introduction of desired insect enemies could be most satisfactorily brought about, and other scientists in California, New Mexico, and Arizona have offered to co-operate.

In regard to utilisation of prickly-pear as stock fodder, a considerable amount of work has been done, the growing of Opuntias as a farm crop being recommended. It is admitted, however, that prickly-pear, whether grown as a farm crop or as a range crop, is only a roughage and needs to be supplemented by the addition of some more nutritive fodder such as cottonseed meal, lucerne, bran, \&c. Amongst the many rations suggested as suitable for eattle, the following may be mentioned as one for a 1,000-lb. milch cow:-50 lb. of pear, $10 \mathrm{lb}$. wheat bran, and $10 \mathrm{lb}$. lucerne daily, the nutritive ratio being $1: 5.4$.

In regard to utilising prickly-pear or its constituents in the industries, investigators have been at work in the United States to test the possibility of manufacturing alcohol. The plant mucilage, and the colouring matter contained in the fruits of certain species, have also been examined with a view to determining their usefulness.

It has been ascertained that if fruits have an average of 10 per cent. of sugar then $140 \mathrm{lb}$. of fruit are needed to produce one gallon of alcohol. In order to render this a profitable undertaking it is necessary (1) that there should be a large production of fruit per acre, about 10 tons per acre being needed; and (2) that there should be some rapid and cheap means of collecting the fruit, as gathering by hand, even using cheap native labour, is far too expensive. Then, again, proximity to the distillery is a consideration. This does not exclude its use as a source for immediately potable alcohol.

The plant mucilage contains galactan and a pentosan. A 10 per cent. "solution" is very viscous, but possesses very poor adhesive qualities and has not been found satisfactory as a glaze even for cheap paper. However, it may serve the needs of other industrial purposes.

A bright magenta colouring matter is obtainable from the fruits of certain kinds of pricklypear, but it does not form a sufficiently fast dye for cotton, silk, \&c. It is not suitable as a colouring medium for foods or drugs if subjected to light or to oxidation. It is, however, of some use as a colouring matter for ice-cream, beverages, and confectionery. Its extraction does not involve any difficult technical process. 


\section{MEXICO AND CENTRAL AMERICA.}

Owing to the unsettled state of Mexico, particularly the prickly-pear regions, the British Ambassador at Washington, D.C., and the Officials of the Department of Agriculture at Washington, as well as thosc along the Texan border, strongly deprecated any attempt on the part of the Commission to enter that country. As the Mexican Highlands, especially the northern portion of it, possess a particularly rich Cactus Flora, it is to be regretted that opportunity did not allow of systematic search and inquiry being made there. The Commission had to content itself with a few visits to certain northern towns just within the Mexican frontier.

The following report is mainly a compilation of information gained from various sources during the course of inquiry in the United States of America.

Since more species of Prickly-pears occur indigenously in Mexico than in any other part of America, the Index Kewensis enumerating upwards of fifty nominally described endemic species, the literature referring to Mexican and Central American Opuntias is very extensive. Earlier work, based largely on specimens cultivated in European gardens, is included in Schumann's Monograph (1899-1903). Since then Dr. Griffiths (1908-1912) and Dr. Rose (18901913) have been working steadily at the systematic side of the group.

Some of the Mexican species have become naturalised in Australia, e.g.: -

(1) 0 . tomentosa, the tree pear of Helidon, Rockhampton, Gayndah, and other districts in Queensland;

(2) The "Red Mexican" or "Westwood Pear"; and

(3) The "Yellow Mexican" species, both found in the Rockhampton district;

(4) O. microdasys, which Mr. Maiden has stated is now to be found in the Pillaga Scrub (N.S.W.) ;

(5) O. imbricata, which occurs in scattered situations in New South Wales and in one locality in Queensland;

(6) Nopalea cochinelifera, which is found at Gayndah and Emerald, is probably a native of Mexico.

\section{DESTRUCTION BY FUNGOID DISEASES.}

Dr. Griffiths (1908, p. 28) gave a short account of the "shot-hole" disease, whose range is stated to be from Texas to Mexico City, and whose causal agent was identified as Perisporium Wrightii. As pointed out by Wolf (1912) the parasite is Glcesporium lunatum, $P$. Wrightio being a comparatively harmless enemy of the Prickly-pear in those regions. This "shot hole" is referred to at some length in the report on the investigations in the United States. Perisporium Wrightii also occurs in Northern Mexico.

\section{DESTRUCTION BY RODENTS}

The range of several of the rodents, such as Neotoma spp. and others, whose activity in attacking and even destroying Prickly-pear in Texas. New Mexico, and Arizona, has been mentioned in the report on the Commission's work in the United States, extends into Mexico. As already stated in that section of the report, these animals are gencral fecders, whose introduction could not with safety be recommended (see Bailey: 1905).

\section{INSECT ENEMTES.}

Since most of the insects mentioned below or else species allied to them, have been referred to in the report on the investigations in the United States, there is not any need to dwell on them again. The geographical range of many of them extends from Texas, Arizona, and New Mexico into the Republic of Mexico. Besides these there are others not represented in the United States, thougl related species may occur there. Many are recorded in the Bulletin on Cactus Insects (C.I., 1912) from localities on the Northern bank of the Rio Grande, e.g. Brownsville, Laredo, Eagle Pass, and El Paso, the range of at least some of them, no doubt, extending across that river into Mexico. The effects produced by the various insect enemies have been described earlier in the report.

\section{COLEOPTERA.}

Amongst the cactus beetles belonging to the genus Moneilema are certain Mexican species, M. variolare, Thomson (Dugès, 1886), and $\boldsymbol{M}$. lœevithorax, White (Dugés, 1901). Horn (1885) has recorded the following as occurring in Lower California:- $M$. semipunctatum; $M$. subrugosum Blanch.; M. spoliatum Horn.

Cactophagus spinoloe, Gyllenhal (syn. C -validus Le Conte), is recorded by Dugès (1886), Champion (1910), Tryon (1911, p. 19), and Messrs. Hunter, Pratt, and Mitchell (p. 44), as infesting certain Mexican species of Opuntia. Champion (1910, p. 8t) mentions that Cactophagus striatoforatus, Gyllenhal, attacks Cereus in Costa Rica.

The Cactus weevils have received attention lately from Mr. W. D. Pierce (1912), in whose paper several Mexican and Central American species are referred to. They belong to the genus Grrstockeria, which has been subdivided by him into a number of subgenera. They are $G$. (Xenosomina) inflata, Champion, from Guatemala; $G$. (Xen.) turpis, Champion, also from Guatemala; G. (Gcrstceckeria) bifasciata, Gerstæcker, from Mexico; G. (Philopuntia) leseleuci, Champion, from various Mexican localities; $G$. (Philop.) lacti, Champion, from Southern Mexico; G. (Philop.) cruciata, Champion, from N.E. Mexico; as well as G. (Phil.) curvilineata. Champion; G. (Phil.) tolucana, Champion; and G. (Phil.) lineatocollis, Champion, from various localities in Mexico. Besides these there are many species from the Mexican border of Texas, e.g., G. clathrata, Le Conte, $G$. cactophaga, Pieree, and $G$. nobilis, Le Conte.

\section{LEPIDOPTERA.}

No serious Lepidopterous parasites of Prickly-pear are quoted in the Bulletin on Cactus Insects as occurring in Mexico. Since certain species of Melitara are to be found in Arizona, New Mexico, and Texas near the Mexican frontier, it is not unlikely that the range of some of them cxtends into Northern Mexico. One, $M$. para. bates Dyar, has been recorded from the Republio, 


\section{HEMTPTERA.}

Amongst the hemiptera recorded in C.I. (1912, pp. 33-40, \&c.) as infesting Cactus plants in this region, are representatives of the destructive genera Narnia and Chelinidea. $N$. femorata, Stal., whose range extends into Texas, is found in North-Eastern Mexico, where it is reported as attacking the fruit of Opuntias and Cereus. $N$. inornata Distant, feeds on the joints of Pricklypear at Durango. Chelinidea tabulata Westwood is found in the same Mexican localities as the last-named. Other plant bugs-e.g., C. vittigera, Uhler, Stylopidea picta, Uhler, Sixeonotus luteiceps, Reuter, and Narnia pullidicornis, Stal., are recorded from the Texan frontier. Corythuca decens, Stal., has been taken on Opuntias near Aguas Calientes (C.I., p. 41).

Another important group of Hemipteraviz., the Coccidæ, which includes the Cochineal insects, is well represented in Mexico on Cactacer.

The true cochineal Coccus (or Dactylopius) cacti, Linn., is a native of Mexico. On account of its commercial importance in former times a considerable amount of literature has accumulated regarding it. A good description of this ancient industry was given by A. Von Humboldt (1811), and many other writers, prominent amongst whom are M. de Russcher, Lopez, and Thierry de Menonville. Many of the accounts have been based on Alzate's treatise published in 1794 in the "Gazeta de Literatura" of Mexico. The bulk of the world's supply was exported previously from Vera Cruz, but the industry is now confined almost entirely to the Canary Islands, though a small quantity is still being raised in Guatemala, Central America (Green, 1912, p. 84).

Several species of wild cochineal have been found in Mexico as well as in the adjacent portions of the United States. Coccus tomentosus, Lamarck*, infests Opuntia fulgida in Northern Mexico ('́.I., p. 42), while $C$. confusus and $C$. confusus newsteadi, Ckll., have also been recorded from North Mexican localities (Cockerell, 1896, pp. 34, 35). Tryon (1910, p. 188), Burkill (1911, p. 304), and Green (1912, p.86), all refer to the introduction by G. A. Prinsep of a wild cochineal (C. indicus, Green) from Mexico into India, viâ England. The native home of this lastnamed insect is, however, as yet, not known, unless it be identical with that mentioned in the footnote. $\dagger$

* When dealing - with Coccus tomentosus Lam. obtained on plants of Opuntia fulgida imported from Arizona into Kow Gardens in 1896 , Newstead $(1903$, p. 225) stated that Mexico was apparently the home of the species, as Curtis and Dugès had collected specimens of it in that country.

$\dagger$ The occurrence of a wild cochineal insect in Mexico wes announced as early as 1725 , its presence in various places in the neighbourhood of Oaxaca, Yxtala, \&c., being incidentally mentioned in accounts of the habits and mode of farming the more precious insect. As an instance, one may cite the following testimony of Matheo de Ognero may cite the following tostior de Russcher's " Natuerlyke Histor, contained van de Couchenille bewezen met Authentique Documenten " (Amsterdam-H. Uytwerf-1729) :-

There is still another kind of cochineal which resembles the fine but which is named the sylvestre or wild, since, without being an object of care, it provides for itself on other kinds of Nopals which are more spiny and rough. When crushed between the fingers, a reddish coloured fluid escapes from the body. This cochineal has neither the escapes from the body. This cochineal has neither the a bad odour and damages the fine cochineal if mixed with it on little value, it is not an object of trede, although it may be put to other uses. (Translation of pp. 132, 133.)
One member of this Commission has adduced emphatic evidence of a wild cochineal insect prevalent in Mexico and destructive to opuntias there. Thus he writes: "Regarding this more vigorous cochineal insect, Thierry de Menonville states: "They multiply themselves so rapidly as to exhaust and destroy the plants, on which account in Mexico they are almost all collected at the end of every two months and the plants perfectly cleansed by wiping them with wetted cloths.' ', (Giberne, G., 1836.)

Again, in a report published by the Royal Cadiz Economic Society, it is remarked: "The cultivators of Oaxaca sedulously destroy the sylvestre, saying that it weakens and destroys the Nopals."

Thierry de Menonville's observations were made in Mexico in 1777, but the destructiveness towards prickly-pear plants exhibited is still exercised by them there now. Thus in a work, "Las Plagas de la Agricultura," published in Mexico in 1902, p. 202, it is stated that "The wild cochineal is a terrible enemy of the Nopal, and can accomplish its destruction, unless steps be taken to prevent jts doing so." (Tryon, 1910.)

A number of parasites of the wild cochineal, C. confusus, are quoted in the list given in the Bulletin on Cactus Insects, as occurring in Mexico (C.I., pp. 46-47). They are Chilochorus cacti, L., Hyperaspis trifurcata, Schaeffer, Scymnus loewi, Muls., and S. hornii, Gorham, amongst the Coleoptera; and Leucopis bellula, Williston, a dipteron. The last-named, which parasitises Coccus confusus in the United States, was reared by Coquillet (1898) from a Mexican coccid Acanthococcus sp. (C.I., p. 47). Other parasites of the wild cochineal are recorded from localities along the Texan frontier.

Amongst the less important coccids known to attack Cactaceæ in Mexico are Pseudoparlatoria parlatorioides, Comstock, and Opuntiaspis philococcus, Ckll. (C.I., p. 42), as well as certain species of Diaspis-e.g., D. echinocacti, Bouché (Fernald, 1903), and $D$. echinocacti opuntio, Ckll., the latter variety infesting $O$. arborescens and $O$. elongata (C.I., p. 42).

\section{DIPTERA.}

A Cecidomyiid fiy, Asphondylia opuntio, Felt, which is widely distributed in the southera portion of the United States, extends as far southward as San Luis Potosi, in Mexico (C.I., p. 34). This enemy of Prickly-pear, which attacks the fruit causing it to develop into a short joint, is referred to in the report on the investigations in the neighbouring Republic.

Many Mexican species of Opuntia, growing in the New York Botanical Gardens, were found to be destroyed by another Cecidomyiid, Itonida opuntice, Felt., whose native home is not yet known.

A long list of scavengers found in Cacti in Mexico is given in C.I., pp. $47-49$.

\section{ACARID.}

Tetranychus spp. Though not insects, these acarids may be conveniently referred to here. Dr. Griffiths has given an account (1908, pp. 28-30) of a disease caused by a " red spider," Tetranychus opuntice, Banks, the condition being somewhat similar to that produced by 
the attacks of an allied species in European collections of Cactacce (Hirscht, 1899). The malady, which is referred to earlier in this report, extends as far south as Mexico City. Mexicans regard it as a serious disease, particularly where Prickly-pears are growing in a more or less crowded state. It is said to be more prevalent during dry weather.

\section{Utilisation as Food for Man.}

Drs. Griffiths and Hare, in their paper on "The Tuna as Food for Man" (1907 a), have given an interesting account of the uses to which Prickly-pear, especially the fruit, is put by the Mexicans. The following is a summary of the information contained in their article.

The fruits or tunas form a very important constituent of the diet of the poorer classes. Some of the relatively spineless species of Prickly-pear, known as "mansa" and related to $O$. ficus-indica naturalised in the Mediterranean region, receive a certain amount of cultivation, which generally consists of planting cuttings and protecting them from cattle by surrounding the plants with a fence or a hedge of spiny Opuntias or columnar Cereus. Certain spiny forms, such as "Cardona" $\rightarrow$ O. streptacantha (an ally of our "Westwood Pear") - are also propagated, as they yield a fruit much appreciated by the Mexican. The production of fruit is the first consideration, stock-feed being secondary.

The spinules are removed in various ways and the skin or rind separated off as is done in the Mediterranean littoral. In the case of certain fruits ( $O$. leucotricha) both pulp and rind are eaten. Seeds are generally swallowed, though it is recognised that those of the "mansas" cause indigestion, while those of the "tapon" ( $O$. robusta) may cause serious intestinal obstruction which has been known to end fatally. The "cardona" (O. streptacantha) is said to be the favourite as an article of diet, and there is an absence of ill-effects after eating freely of it.

Analyses of the fruit rind and pulp, as well as of fruit from which the peel and seeds had been removed, have been published by these workers, nearly all the species examined being from Mexico (pp. 15, 16, 32-42). It was found that the Mexican samples averaged 9.53 per cent. sugar, while the fruits which were analysed from species growing in the United States averaged 5.61 per cent., certain Mexican species found there in a naturalised state being included, their inclusion considerably increasing the average sugar content. Samples of indigenous Opuntias from San Antonio, Texas, were found to average less than 3 per cent. Amongst the Mexican Prickly-pears examined were the "tuna amarilla," "cardona," "chavena," and the fruit of o. imbricata. The three first-named are allied to the "Yellow Mexican" and "Westwood" pears of Queensland, and the last-named species occurs in parts of New South Wales and Queensland. It may be remarked that practically no sugar was found in fruits of $O$. imbricata.

In addition to those used in a fresh state, vast quantities of Prickly-pear fruits or tunas are dried for use. These are prepared mainly from those of the cultivated species, since they are larger and paler in colour, the popular "cardonas" being less suitable as they are rather too small and possess too many spinules, and, moreover, their red colour becomes altered to black-regarded as an objection by the Mexicans-during the process of drying. The fruits are thinly peeled, and the remaining rind and pulp is set out in the sun on a framework for from ten to fifteen days, a yellow deposit of sugar and mucilage forming on the outside as drying progresses. They are then packed loosely in crates for about six months to allow further evaporation. "The "tuna amarilla" is especially suitable for drying on account of its size, flavour, and sugar content. Dried tunas are used as food after being cooked in a similar manner to the ordinary dried fruits of commerce-e.g., apricots, \&c.

Schumann (1899) in his account of various Mexican cacti mentions in many cases that the fruit is edible. In addition to certain species of Cereus, Pilocereus, Echinocereus, and Phyllocactus, the following Opuntias are mentioned :-

opuntia leucotricha-the durasnillo; $O$. ficus-indica, L.; O. streptacantha-the cardona; and $O$. robusta, Wend-the tapona. In addition, the fruits of certain species of Mamillaria ( $p$. 570) are sold in Mexican markets under the name Chilitos, on account of their resemblance to small chillies (cayenne peppers). The fruits of Cereus trigonus are recorded by Schumann (1903, p. 57) as being used in Costa Rica. A. Weber (1902) has referred to the high opinion which Mexicans hold regarding the durasnillo on account of the flavour of the fruit. R. Gosselin, in 1904, briefly described the fruits of eight Opuntias of Mexican origin, grown in the French Riviera near Nice.

In the Catalogue of the Darrah collection of cacti in the Alexandra Park, Manchester, in addition to those mentioned by Schumann, the fruit of many other Mexican and Central American species of Cereus is said to be used for food.

Prof. Hare (1911, p. 26) has stated that the natives of Mexico and of South-Western U.S.A. make richly coloured preserves from the fruits of $O$. dulcis, the evaporated juice containing from 30 to 60 per cent. of glucose, but apparently free from pectin substances, since it will not jellify anless it be mixed with plenty of other fruitjuices rich in pectins. A preliminary account of the alcohol precipitates from Prickly-pear fruit pulp was published earlier by Griffiths and Hare (1907 a, p. 40). It was found that the average amount in all the pulps examined was only .29 per cent., that in the rinds being about four times as much-viz., 1.29 per cent. These authors were unable to make jelly from either the pulp or the rind, there being apparently little, if any, pectin present in the fruits. Forty per cent. of the alcohol precipitate from the rind, and 25 per cent. of that from the pulp, was found to consist of ash. The ash from the whole fruit amounted to about .29 per cent., whereas in the stems it is very considerable, 33 per cent. of the dried stem being found to consist of ash in one instance. Salts of lime and potash constitute the greater part of it, phosphates being very low, only 1.39 per cent of phosphoric acid being found as the average of 28 samples examined.

Roderiquez (1912, p. 207) has recently stated that the amount of sugar in the fruit can be considerably augmented by selection and good cultivation, and that it is possible to obtain a juice with as much as 24 per cent. of sugar. 

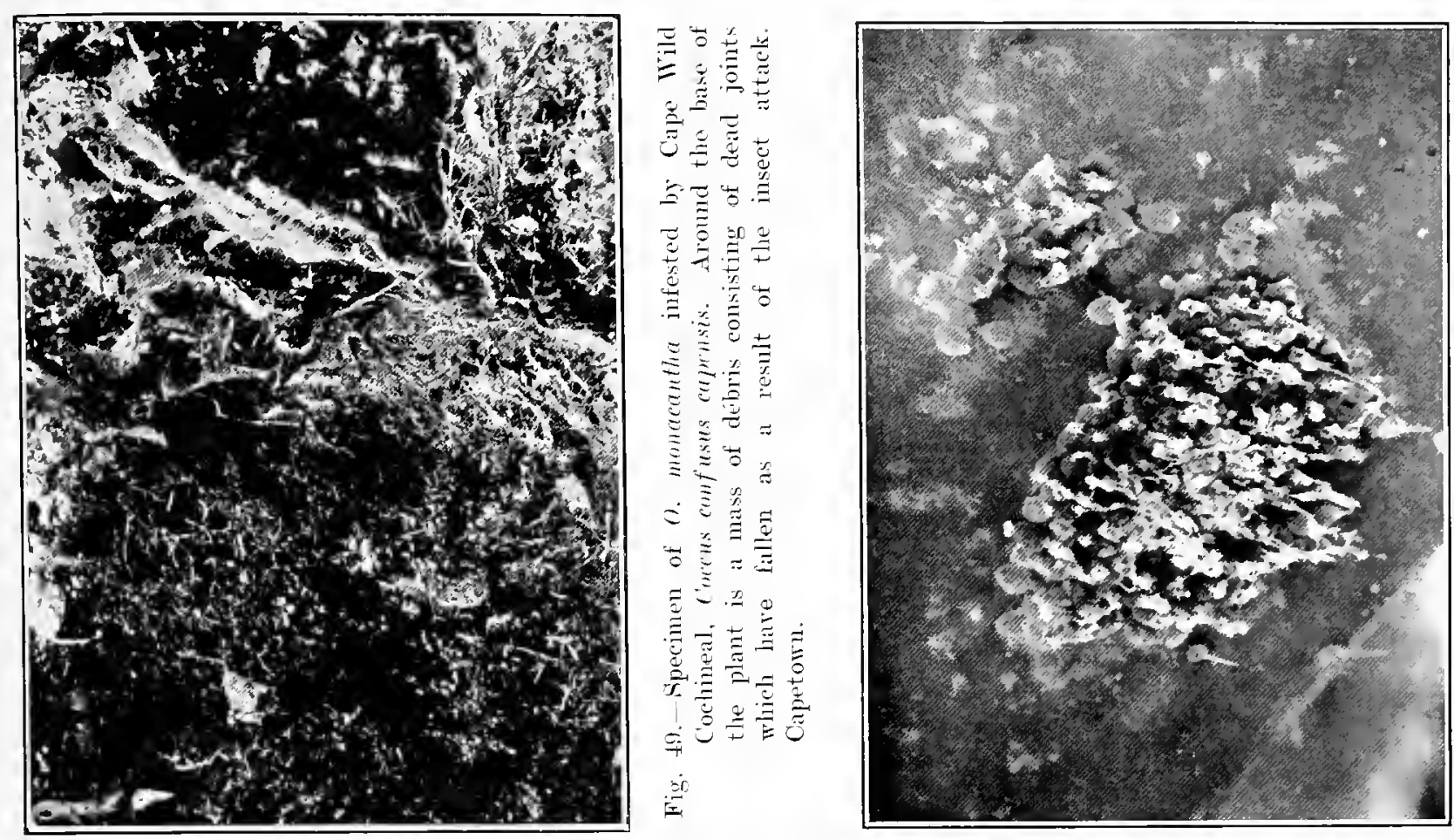

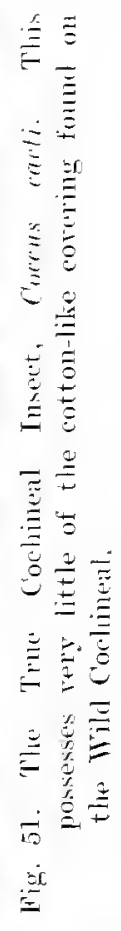
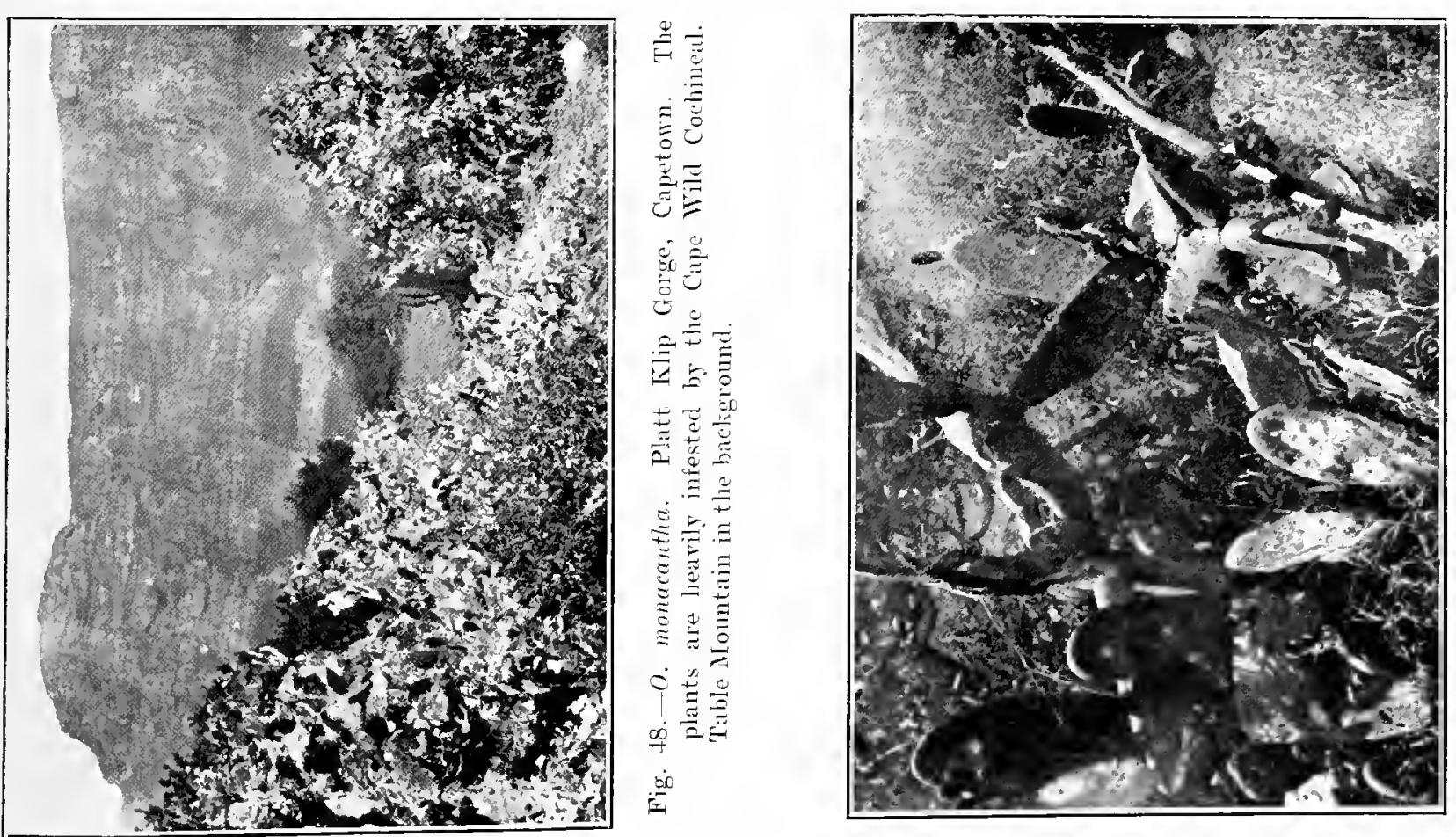

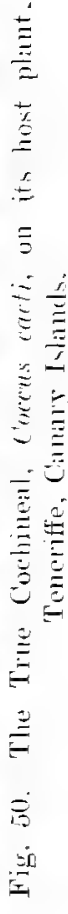



Various food products-e.g., "miel,", "melcocha," "queso," and "colonche," are manufactured from the fruits by Mexicans by means of extremely primitive machinery, which is described by Griffiths and Hare (1907 b, p. 21), who also give an interesting account of the products.

Miel.-In the preparation of this syrup or " loney" the fruits are not usually seeded. After being peeled they are boiled in kettles for some time, when the seeds drop to the bottom and are strained off. The syrup is evaporated for some hours until it possesses the consistency of honey, and is then drawn off and cooled in wooden troughs, constant stirring being resorted to in order to hasten the process. After the "Miel" is set, it is bottled, becoming in time completely candied.

Melcocha.-The fruit is peeled, seeded, and then boiled in fruit juice, which gradually thickens until a certain degree of consistency is reached. The syrup is then cooled rapidly in a trough by being well stired, After having been left alone for a day it is thoroughly worked up in a manner similar to dough, and flavourings may be added. 'The material is stored in wideinouthed jars. After a time crystallisation begins.

Queso.-This product is made in a similar manner to "Melcocha," but the evaporation is carried further and the puddling is done more thoroughly. The queso or "cheese" is moulded into various forms and may be covered with tin foil. It leeps indefinitely if dry, becoming harder but never crystallising.

Colonche.-This is a fermented drink made from the liquid obtained by slowly boiling and evaporating to a certain degree the unseeded pulp of almost any species of Prickly-pear. After being cooled and drained the juice is allowed to ferment, some old "colonche" being sometimes added to initiate the fermentation. The resulting liquid is a violent intoxicant, which does not keep, probably on account of imperfect sterilisation. Colonche is sometimes distilled in order to procure a spirit. Formerly the peelings were allowed to ferment and were then distilled, but the resulting spirit had such ill-effects that other materials, such as maguey (Agave), are now being used instead.

\section{Utilisation as Fonder for Cattle.}

As in other countries where Prickly-pear plants and other Cactaceæ form an important clement of the vegetation, so also in Mexico they have been used generally as a large contributor to the sustenance of cattle both as an emergency food in dry weather and as a substitute for other aliment in the winter season. In a special Bulletin (Ramirez, 1907) issued by the Agricultural Experiment Station of Juarez, Chihuahua, - on Nopal and Sotol. Dasylirion Wheeleri) as winter fodder, it was concluded that when Prickly-pear was given to cows in such quantity as they could consume with facility, the yield of milk from them was maintained, notwithstanding the lowering of temperature, and so in some cases in winter the use of more expensive foodstuffs might thus be avoided. Its use also would correct defects arising from a regimen of $d r y$ pasturage. It might therefore take the place of ensilage in feeding milch cows.
Again, the French writer, Léon Diguet, when treating of certain Mexican plants employed as forage (Diguet, 1911), refers to the use of both the flat-stemmed and cylindrical Pricklypears in the district north of Sonors and elsewhere, and of the various species of Echinocactus -the "visnagas" -in the region southwards from Sonora through Central Mexico to Oaxaca. $\mathrm{He}$ states that in these desert regions of the republic one encounters a certain number of different kinds which can be regarded there as forage plants. Owing to their marvellous adaptation for overcoming the exigencies of the hottest and driest climate, they are able to survive when all trace of herbaceous vegetation has disappeared, and in consequence constitute an appreciable adjunct which is the means of saving many valuable animals that would otherwise dic during the many months of famine. He mentions that all species are evidently not suitable for this purpose. Use is made of the fruit of some, the stem joints of others, the entire plant of certain others, while in some cases (e.g., Cereus) the flowers are used. He goes on to state (p. 246) that in the preparation of some cacti (e.g. Echinocereus) for fodder, a cutlass-like instrument, the machetc, is used; while for the Cylindropuntias, a machine providing a combined blast and rotary movement is employed in order to remove the numerous spines.

Besides, in Mexico, spincless prickly-pears are being cultivated for stock-feeding purposes, the Department of Agriculture there having issued recently two separate bulletins on the subject-one by E. Roderiquez (1912, pp. 203 . 207 ), and the other by M. Calvino (1911). The latter, which is well illustrated, describes and advocates a special method of propagating spineless prickly-pears by grafting.

Griffiths and Hare (1905, 1906, 1907 a) have given considerable attention to the question of utilising Prickly-pear as fodder for stock, their work being summarised in the section of the Commission's report dealing with the United States. In these papers there are references to Mexico, and the result of the analyses of some Mexican species is given $(1906,1907$ a, p. 16). Since the trunks of many of these Opuntias are woody and tree-like, it is mainly the young growth which is fed to cattle. Though all species of flat Opuntias are fed to cattle, especially where fodder is scarce, apparently only one Cylindropuntia, $O$. imbricata, is used to any extent (1907 a, p. 12). Occasionally Echinocactus orcuttii is used in this way in Lower California. "The average Mexican peon* cannot afford to feed to stock what he himself can use so profitably in other ways. The Prickly-pear is to him primarily an article of human food, and its place cannot be taken by any other plant"hence only such parts are fed to cattle as can be spared from tuna culture (1907 a, p. 15). The fruit rinds are fed to pigs, dairy cattle, and donkeys (1907 b, p. 13), while native species form a food supply for working oxen during the season when other fodder is scarce.

Dr. Vinson (1911, p. 519) has mentioned that in Sonora, a State in North-Western Mexico, cattle exist on cactus and furnish a small amount of milk, but no doubt some legumes are also picked up during feeding. 


\section{Minor Uses.}

The tuberous roots of Echinocereus tubcrosus Rumpl, are said to be steeped in alcohol and the decoction applied externally by Niexicans as a remedy for rheumatism.

Amongst minor uses made of cacti in Mexico, it may be mentioned that young joints of Opuntias are boiled and used as a vegetable, or even made into pickles; the pulp is often employed for making poultices (Griffiths, 1905, p. 41), while the pith of certain bulky Echinocacti is used in the making of cactus candy, as indicated earlier in the report.

The juices expressed from segments of Opuntia are utilised in Mexico for mixing with whitewash (Griffiths, 1905, p. 41). The "wool," which is produced in abundance at the top of Echinocactus ingens, Zucc., is made use of by the inhabitants of the highland regions as a material for stuffing cushions (Schumann, 1903, p. 4). The dry fruits of Cereus pecten aboriginum, Engelm., are used by the native population as combs or rather hair-brushes (Schumann, 1899, p. 75).

The stems of Cylindropuntias-e.g., O. imbricata and its allies, are utilised as fuel in Mexico and the adjacent dry parts of the United States of America (Schumann, 1899; Griffiths, 1905; Griffiths and Hare, 1907 a, p. 15), where vegetation more suitable for this purpose is scanty. Cereus pringlei Wats. is used similarly in Isower California.

Some species are still used as hosts for the true cochineal insect, and have accordingly an economic value.
Drugs may be obtained from certain species. Ewcll (1896) has examined the alkaloids present in the Mexican genus, Anhalonium-i.e., Ariocarpus, whose species are regarded as being poisonous.

Various species of Opuntia and Cereus, as well as a Pereskia are used as hedge plants in Mexico, Cereus aragonus Web. being employed for the same purpose in Costa Rica.

\section{SUMMARY.}

The Commission was unable to make inquiry in Mexico. From information received elsewhere, however, it appears that the biological conditions in that country, at least in its northern portions, resemble those in Texas, Arizona, and New Mexico, though the cactus flora is more abundant.

The recorded parasitic insects and fungi are the same as, or closely related to, those found in the United States of America, but except in the case of certain of the wild cochineal insects, whose pernicious influence had already been brought under notice by one of us, information as to their effects on the host-plants was not obtained.

The Mexican methods of utilisation, save possibly those subserving special stock-feeding purposes, would not be of much service in our State in the efforts to subjugate the commoner pest species. The fruit of the Prickly-pears naturalised in Queensland is less suitable, Australian labour is much dearer than Mexican, and there would not be much demand for such products.

\section{WEST INDIES.}

In order to cover ground more expeditiously, it was decided that one member of the Commission should conduct the inquiry in South America, while the other carried out the necessary investigations in the various West Indian Islands. The itinerary pursued was the outcome of advice received from Drs. Britton and Rose, who had made several visits to the West Indies in order to assist themselves in their study of the local Cactacex, and from Dr. Francis Watts, C.M.G., the Commissioner of the Imperial Department of Agrieulture, who controls agricultural matters in the Lesser Antilles. The particular islands visited, as well as the time spent on each, was largely influenced by the nature of the communication between them-often little and irregular. On this same account several which possess a rich cactus flora, e.g. Curacao, Tobago, and the Grenadines, had to be omitted from the tour.

Each member of the Commission paid a short visit to Cuba; Barbados was examined by both, Jamaica and Trinidad visited by one, while the r'emaining islands, viz., the Lesser Antilles (Dominica, Guadeloupe, the Saints, Antigua, St. Kitts, Nevis, St. Thomas, and the Virgin Islands), Porto Rico, Haiti (San Domingo), were visited by the other during the time that his colleague was travelling in South America. A more detailed examination of Cuba was also made at this time.
In addition to the officials and others named below in this section of the Report, we are indebted to the following for services rendered:Rev. M. Fuestes, botanist, San Domingo; Dr. J. F. Roig and Dr. E. Cuesto, Cuban botanists; H.E. Sir Hesketh Bell, the Governor of the Leeward Islands; Mr. J. L. Roxburgh, Administrator, St. Kitts; Mr. M. Gomez, Acting Administrator, Virgin Islands; Mr. W. J. Howell, Nevis; Dr. W. V. Tower, Entomologist, Board of Commissioners of Agriculture, Porto Rico; Mr. J. T. Crawley, formerly Director of the Experiment Station of the Porto Rico Sugar Producers' Association; Dr. J. F. Morse, Guanica, Porto Rico; R. F. Cambioso, San Domingo; Capt Hardy and Dr. H. Tambourini, Azua, San Domingo ; J. F. Hatton, Barahona, San Domingo; as well as H.M. Consular representatives in the rarious foreign islands visited.

Previous to the visit of the Commission, very little information was available regarding the possible occurrence of disease, or of injurious insects affecting Opuntias in the West Indies. Berkeley and Cooke had reported the existence of the fungus Perisporium wrightii on $O$. macrorhiza in Cuba (Cuban Fungi, No. 987). One of the wild cochineal insects, Coccus (Dactylopius) confusus newsteadi, Ckll., had been recorded from Jamaica and Antigua, and a seale insect, Diaspis echinocacti, Bouché, was known to occur commonly in the region, Miss Fernald (1903) record- 
ing it from Porto Rico. A variety of this latter species, D. echinocacti opuntice, Ckll., is known to be present in Jamaica (C.I., p. 42). A species of Coccus near $C$. confusus is recorded in C.I. (p. 42) as coming from Barbados. From information obtained by the Commission it was ascertained that the specimens on which this record was based were obtained in Antigua and sent to Washington, D.C., viâ Barbados. A species of Margarodes, identified by Cockerell as $M$. formicarium, was taken on the roots of Cereus sp. in Montserrat (C.I., p. 41). The true cochineal, Coccus cacti, $\mathrm{L}$., was at one time introduced into the West Indies (C.I., p. 42), but its occurrence there at the present time is not noted.

\section{JAMAICA.}

A very short visit was paid to Kingston, the capital of the island, where Mr. Cousins, the Director of Agriculture, and Mr. Wm. Harris, the Government Botanist, gave assistance.

The prickly-pears* seen growing commonly in the neighbourhood of the city were $O$. dillenii and $O$. tuna, the former being more abundant nearer the sea. These two species are closelv related, but the latter possesses rather long straight thorns, which soon become white, whereas those of $O$. dillenii are usually curved and remain yellow, though they may darken somewhat with age. Schumann (1899, p. 724) regarded them as being the same, but Dr. Britton has satisfactorily differentiated them. They are readily distinguished from one another in their native habitat, both commonly growing side by side. In addition to these two, there is a third and rarer species, $O$. jamaicensis, Britton and Harris, specimens of which were pointed out in the Botanic Gardens by Mr. Harris. It resembles $O$. tuna in many of its characters, but possesses a definite stem. Nopalea cochinelifera grows wild on the island.

Grisebach in 1864 (p. 301-2) mentioned the oecurrence in Jamaica of a Rhipsalis, several species of Cereus, and of the following.Opuntias -O. tuna, $O$. ficus-indica, $O$. cochinelifera, and $O$. spinosissima, Mill., the last-named being reported as common on the dry southern savannas.

\section{Destruction by Insect and Fungoid Enemies.}

Mr. Harris was not aware of the presence of any pest controlling the spread of Opuntias. Shothole, due to the fungus Gloosporium lunatum, was seen by the Commission on the following -O. tuna, O. dillenii, and $O$. jamaicensis, but in no instance was it causing any serious injury to the attacked plants.

Wild cochineal, Coccus confusus newsteadi, was found in some abundance on Nopalea cochinelifer $a$ in the Botanic Gardens, where it produced a local chlorosis, though its full activity appeared to be prevented by the presence of various parasites. Scale insects (Diaspis sp.) were found on the Nopalea as well as on $O$. ditlenii, but, as elsewhere, did not exert any marked harmful effect except when very numerous, and then a local chlorosis was observed. Injuries resembling those caused in Texas by Mimorista favidissimalis were seen on joints of $O$. dillenii

* Cactacer other than prickly-pears were seen on nearly all the islands visited, but, as a rule, little attention was given to them. and $O$. megacantho in cultivation, the latter species being closely related to the "Westwood" pcar of the Rockhampton district, Queensland. In segments of the former species there was noted the presence of tunnels, due to some unidentified boring insect.

Cacti were not utilised in the island in sueh a way as would destroy them. A tall native Cereus, Lemaireocereus hystric, ealled the "Dildo," is sometimes used for making hedges.

\section{TRINIDAD.}

The few hours that the steamer stayed in Port of Spain did not allow of investigations being carried out. The northern and more mountainous part of the island has a moist elimate, such as is unsuitable for the development of a rich Opuntia flora. The southern regions are much drier, but there was no opportunity to visit those localities. In the neighbourhood of the capital, the only prickly-pear seen growing was Nopalea cochinelifera, all the plants noticed being in cultivation.

\section{BARBADOS.}

Interviews were held with the Commissioner, Imperial Department of Agriculture, Dr. Francis Watts, C.M.G., as well as two members of his staff, Mr. H. A. Ballou, the Entomologist, and Mr. F'. N. South, the Mycologist. Besides, personal investigations were prosecuted in the country immediately around Bridgetown, and at spots along the sea-coast of the island.

The Commissioner himself, who had already been interviewed in London, had not hitherto directed his observation to the subject of pricklypear plants and thcir enemies. He, however, ealled attention to certain literature bearing on the distribution of the different speeies in the West Indies - the Windward Island espeeiallydrew up an itinerary for visiting several of them, and arranged for assistance on the part of members of his staff resident on those islands whose agricultural interests were the concern of his office.

The Entomologist, Mr. Ballou, stated that he had especially examined prickly-pear plants for the presence of seale inseets, especially the wild eochineal Coccus confusus newsteadi, but had not found it. The only parasite which he had seen was a species of Diaspis. Mr. South, who had not been long on the island, had not observed the occurrence of any disease on local Opuntias.

The island of Barbados is almost entirely devoted to agrieulture, so that little of the native vegetation is still to be found. Within the cultivated area one may see oeeasional plants of Nopalea cochinelifera and a speeies resembling $O$. dillenii, the former grown apparently on account of its reputed medicinal value, and the latter used as a hedge plant and seen at times as an escapee. All along the rocky easterly coast the latter species may be seen growing more or less after the manner of native vegetation. At the extreme north of the island there are small but Jense patehes of this Opuntia growing on the barren soil which thinly covers the coral rock. This plant is very like $O$. dillenii, and has been regarded as belonging to that species. It seems, however, to 
be distinct, differing from it in possessing more numerous areoles, these being more elevated and bear'ing spines which, though generally curved, were of a deeper yellow and were more widely divaricate than in 0 . dillenii. These spines become a dirty white when old. The flowers also differed from those of $O$. dillenii in being orange or orange-red in colour. The fruits appeared to be shorter and less pedunculated.* It is ealled the "Flathand Pimploe" by the islanders.

\section{Injury by Insect and Fungoid Enemies.}

A brown sealy condition of the epidermis of o. dillcnii (?) sometimes associated with a more or less dried appearance of the affected joints was probably due to uncongenial soil conditions. Some injuries suggestive of the presence of the shothole fungus, Glocosporium lunatum, were seen on this species of prickly-pear.

Near the village of Crane, there were seen occasional injuries in joints of $O$. dillenii (?) exactly like those produced in the drier parts of U.S.A. by species of Melitara. Dead hollowed-out segments or parts of segments were noticed, each with one or more small round openings. and containing rounded insect excreta. The borers were not found (December).

The only insect pest noticed was a species of Diaspis. It has been mentioned that a wild cochineal near Coccus confusus has been recorded from Barbados (C.I., p. 42), but it has been ascertained that the specimens were collected in Antigua and forwarded through the Agricultural Department at Barbados to the Bureau of Entomology, Washington, D.C.

\section{MARTINIQUE.}

A very brief stay at Fort de France, and observations made with a field-glass in skirting the coast to the north of it, whilst aboard a small steamer, served only to reveal the presence of a broarl-leaved Opuntia growing sporadically there.

Subsequently, however, opportunities occurred for consulting Rev. R. P. Duss, the author of the "Flore Phanérogamique des Antilles Francaises," whose plant investigations on the island had covered a period of upwards of twenty years. He confirmed what he had already stated (1897, p. 318), that Opuntia tuna, Miller (evidently referring to $O$. dillenii, Haworth) grew abundantly in certain parts of the island, where it was known under the name of Raquette au bord-de-mer or Raquette $\grave{a}$ piquants, and that Nopalea cochinelifera, Miller-the Raquette sans piquants-grew there also, but less abundantly.

Although he had very commonly observed them under different modes of occurrence, he had not found that any natural check of the nature of disease or insect had served to control their spread. A special local inquiry appeared then uncalled for.

* R. Schomberg (1841, p. 619) also mentions thre日 kinds as growing there, viz., O. tuna, Mill. (= 0 . dillenii, Haw.), O. curassavica, Mill. ("Orange-flowered Opuntia"), $O$. coccinelifera, Mill. ( $=N$. cochinelifera), assigning to them as native homes-(1) Brazil; (2) West Indies (Leeward Islands); and (3) South America respectively. The firstmentioned he designated Pimploes, Hughes; the second "Pincushion."

\section{DOMINICA.}

Of the 291 square miles contained in this island, a very small portion indeed supports any growth whatever of prickly-pear, a fact no doubt due to its relatively high rainfall and the prevalent humid conditions that characterise it. Opuntia spp. are, however, to be met with along the west coast in proceeding from Roseau northwards, especially at the Grand Savanna near the Batalie River. In the portion of the area traversed, in which these plants grow, only $O$. dillenii was met with. This plant occurred in fairly large clumps on the foreshores, and was not affected by disease or other natural enemy. In the course of the limited investigation that was practicable, the two other species of Opuntia-i.e., $O$. catacantha and $O$. catacantha taylori-which we were informed by Dr. Britton, grew on Dominica, were not encountered.

Again, the Curator and Assistant Curator of the Botanic Gardens, Messrs. E. J. Jones and G. A. Jones, as well as other local residents, stated that they had not found that the prickly-pear plants were controlled in any way by natural enemies on Dominica.

\section{GUADELOUPE AND THE SAINTS ISLANDS.}

The explored portions of these islands included the west coast for some miles on each side of Basse Terre, the east coast from Lies Trois Rivières to Point à Pitre, and the interior; also the mountainous island Terre de Haut. With the exception of a few isolated plants of $O$. dil lenii that grew on the east coast, Opuntia spp. were, so far as our observations extended, restricted in their occurrence to the first and last of the areas mentioned. However, it was elicited from the veteran botanist, Rev. R. P. Duss, who most generously identified himself with the work of the Commission throughout the period occupied in Guadeloupe, that these plants not only occurred on the small island named, but were more or less prevalent on the Saints group generally, being especially abundant at Desirade on the arid rocky savanna that stretches between La Broserie and the sea.

The kinds of prickly-pear present were-(1) $O$. dillenii (O. tuna, Mill., Duss, 1897, p. 318); (2) O. triacantha, Willd. (O. spinosissima, Mill., Duss, l.c.) ; and (3) Nopalea cochinelifera, Mill. of these the first-mentioned grew generally wherever prickly-pear plants occurred, whereas $O$. triacantha was met with only on the Saints islands and to the north of Basse Terre in approaching Vieux Habitants, on the rocky foothills near the sea. The red-flowered thornless prickly-pear $N$. cochinelifera was restricted to gardens adjacent to dwellings or to spots that had once been eultivated as gardens. As a rule the plants of all three kinds grew isolatedly; but in certain places $O$. dillenii and $O$. triacantha formed small thickets, especially where the soil in which they grew was unsuitable for agriculture and therefore little liable to be disturbed.

\section{Insect and Fungoid Enemies.}

The only insect enemy noticed was Diaspis echinocacti, Bouché.

Examples of retarded growth were seen, but such result was evidently not in any way due to parasitic invasion. 


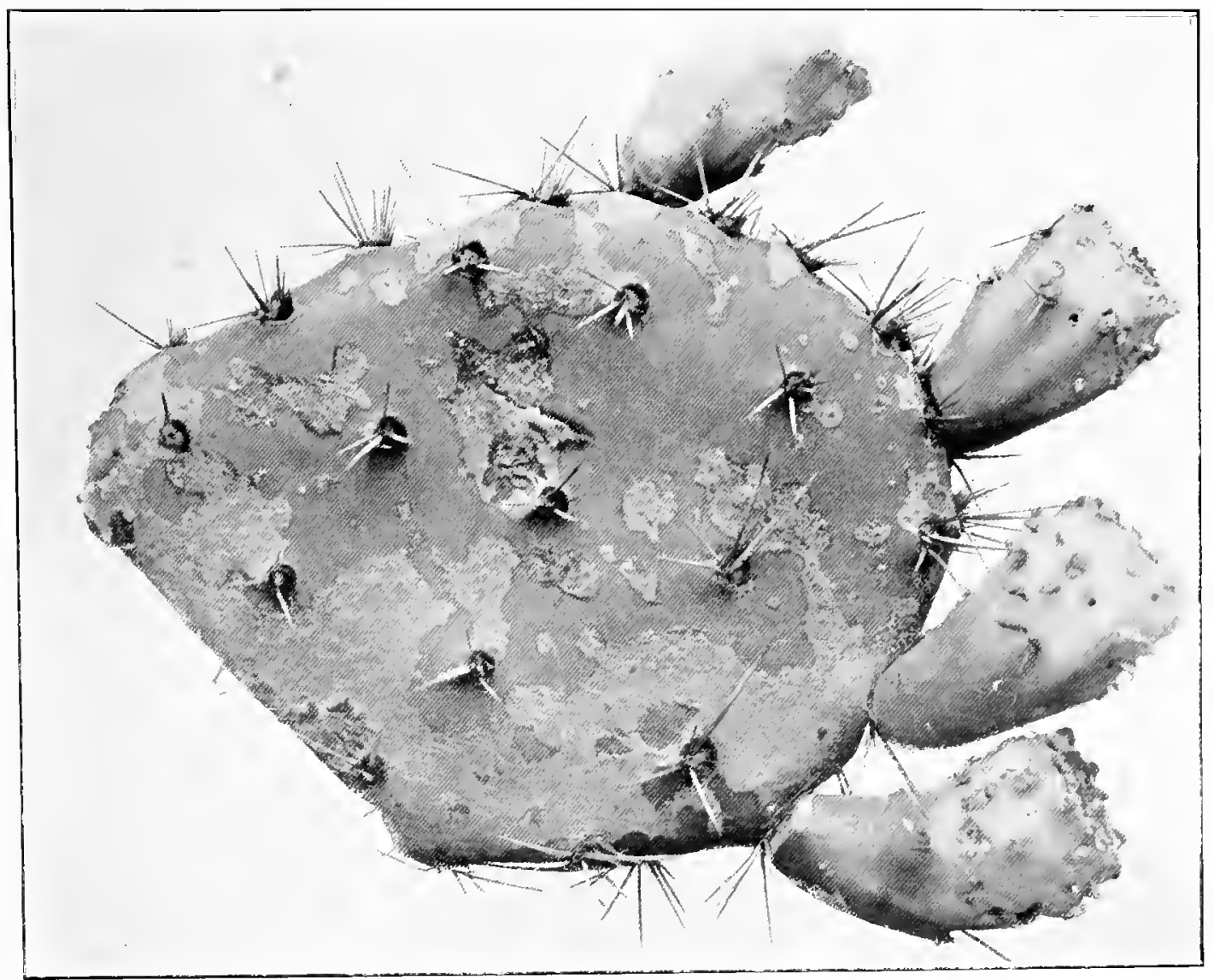

Photo., Buscau of Eutomology, Dept. Agriculture, U.S.A

Fig. 52.-Segnent of a Prickly Poar showing injuries attributed to a so-called "red spicer," Tetran!chus "ipuntir. The fruts show nunerous pupe of a Cecidomyid Hy, protrnding from apertures (sir Fig. 53).

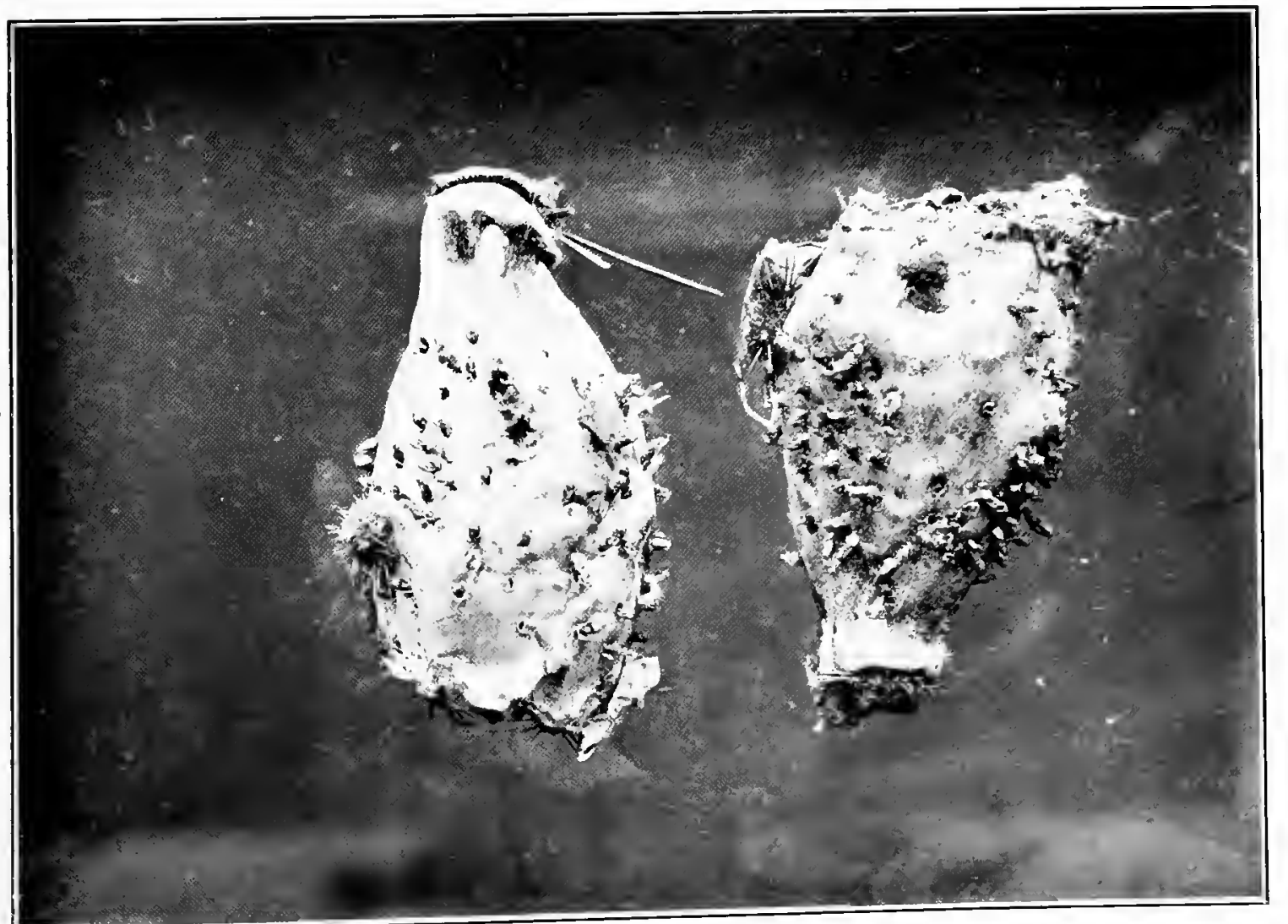

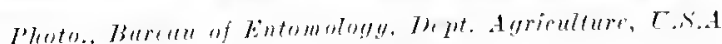

Fig. 53.-Fruit of O. cnmelmanni showing great numbers of pupe of a Cecidomyid fly, regarded by the Bureau of Entomology, Washington, D.C., C.S.A., as Asphontlia opuntio. The larre live with (They come to the surface in order to pupate (sie Fig. 5t). Texas. 

Near Vieux Habitants a small patch of priekly-pear $(O$. triacantha) was noticed to be badly attacked by a fungus related to and perhaps identieal with Gloesporium lunatum, Ellis and Ever., which produees an anthraenose disease or "shot-hole" in $O$. lindheimeri and other speeies in Texas. Within the area, the plants are very eommonly less than a foot in height, the majority being seedlings or young plants which had risen from seeds or segments of plants that had been killed by the parasite. The symptoms were similar to those deseribed by Wolf (1912 a, p. 124), and met with by the Commission during its investigations in Texas. In addition, the presenee of shot-holes and erosions of the edge of affected segments - the " blaek rot" stage-was also evident; death of the attacked joint being the result. It appears to be especially virulent at a certain period of the year (rainy season), a faet already referred to by Wolf in his aceount of the malady in Texas.

The species of priekly-pear ( 0 . triacantha) vietimised being strikingly different from any of the eommoner Australian naturalised prieklypears, it would not be surprising if the diseaseprodueing organism whose distinctness from Gloosporium lunatum, Ellis and Ever., might be physiologieal only, would prove wholly ineffective in damaging any of them. This is indeed suggested by the observation that plants of $O$. dil. lenii, a speeies more nearly related to our introduced forms, although growing only a few feet from affeeted plants of $O$. triacantha, had remained wholly unattacked by the malady so prejudieial in this instance to the last-mentioned species.

\section{ANTIGUA}

This island of the Leeward Group, 108 square miles in extent, is one of the drier of the West Indies, and is generally favourable to the growth of plants of the prickly-pear group.

The investigations made there included a plant survey of (1) eaeh side of St. John's Harbour, on the west coast, and the country between it and Five Islands Harbour, south therefrom; (2) of the country adjaeent to Falmouth and English Harbours, on the south coast; and (3) of Parham and Belfast Bay districts, on the north-east coast.

The speeies of priekly-pear encountered were :-

(1) O. dillenii, Haw.

(2) Opuntia sp. allied to $O$. dillenii.

(3) O. triacantha (Willd.), D.C.

(4) O. catacantha, Link and Otto.

(5) Nopalea cochinelifera (L).

Of these the seeond mentioned is identieal with the Opuntia already referred to as growing eommonly at Barbados, and the fourth is a plant having very elongate stem-joints, and attaining the dimensions of a small tree. Grisebach (1864, p. 302) refers to two of them as being known to him as Antiguan plants, viz., No. 1, that he names 0 . tuna, and No. 3 , that he correetly designates as above.

o. dillenii was found to be the most prevalent species, and although-as was the ease of one or more of the other kinds-often absent where it might be expeeted to oeeur, was some- times met with in fairly dense masses, espeeially where unaffected by disease and favoured by soil-eonditions. Its orange-flowered ally eommonly occurred growing with it, but was comparatively rare in the Parham and Belfast Bay districts. Both it and $O$. dillenii had been used extensively as a hedge plant. $O$. triacantha often formed large, impenetrable, low patches adjaeent to Falmouth and English Harbours, and was said to be spreading. $O$. catacantha was notiecd on ridges and in rock-faces at the eastern end of the island.

\section{Disease Occurrence.}

(1.) Wild Cochineal Insect (Dactylopius confusus newsteadi, Ckll.):- It had been recorded that a special kind of wild cochineal insect was to be met with on prickly-pear at Antigua, but it appeared to be rare, having beels found only on a single plant here in 1901; Mr. Ballon, the Entomologist of the Imperial Department of Agrieulture, stating that he had not sueceeded in rediscovering it. Again, Mr. T. Jackson, the Curator of the Botanic and Agricultural Experiment Stations, had not seen this natural enemy, although eonversant with the Opuntiainfested areas of the island. However, in the small village on the south side of St. John's Harbour, adjoining the capital, $N$. cochinelifera, which occurs there either as a hedge plant or as a garden-escapee, is, in many instances, so white by reason of the presenee of the insect that its abnormal appearance is discernible for a eonsiderable distance. On nearer approach the entire surface of the infested plants was found to be covered with a flour-like dust, and large conspicuous whitish patches of the insects themselves, congregated together, were seen on many of their stem-joints. Their presence was attended with little or no injury to the host-plant, a superficial brown discolouration being sometimes discernible when the parasite was removed from the spot where it had been feeding.

Two other species of prickly-pear ( $O$. dillenii and its gilvous-flowered ally, Opuntia sp.) grew commonly near where the plants of the species favoured by it occurred, but as far as could be observed they had wholly eseaped infestation by it.

(2.) Anthracnose or Shot-hole Disease (Glcosporium lunatum, Ellis and Ever.).-In the same locality plants of the gilvous-flowered priekly-pear (Opuntia sp.) were seen to exhibit the chaarcteristic injury attendant on the presenee of this disease. The malady was, however, in a non-active condition at the time of the inquiry and was restricted to one or two plants only, and even these it had but little cheeked in their growth. Injuries of old standing elsewhere on the prickly-pear plants suggested that during eertain seasons of the year the disease might be more marked.

What appeared to be a similar disease, if not one originally of baeterial origin, was pointed out by Mr. Jackson as eausing considerable injury to a plant of $O$. robusta, growing in the Antigua Botanic Gardens under his management.

(3.) Zone Spot Disease.-This disease was found exclusively assoeiated with $O$. dillenii, Haw., and was remarked also in the neighbour- 
hood of St. John's and in other parts of the island. It causes the plant affected to become stunted in liabit, and indeed parts may perish, brown spots with zoncd marlings gradually covering the entire green surface of all parts of the plants victimised, and so interfering with important functional activities.

As it does not appear to have been generally noticed, some account of its outward features may be given. It commences with the development of small, slight raised, sub-cireular spots, each 2-3 millimetres in diameter, having a palebrownish colour with a distinet nueleus of a darker hue. These spots increase in size and meanwhile lose their cireular outline, their margins, however, maintaining an irregularly waved pattern. They are now from 5 to $10 \mathrm{~mm}$. in diameter and are better defined on the general green stem-joint surface than previously, having become buff-eoloured, resembling blotches of yellowish-white paint. They are usually bordered by a paler and more translucent eneircling zone, indicating the fact of their gradual extension to form larger spots. Meanwhile, innumerable greyishblack, densely distributed points have appeared, these being arranged in lines or bands running one within the other, following the outline of the spot-henee the term "zone-spot." These spots often merge, but their general coneentrie character and independent origin are always manifest.

The points when viewed under the lens are seen to be short, racemose, grey-coloured, raised figures, with minute linear fissures exposing a blackened interior, evidently indicative of fungus growth. They occupy the affeeted surface with less or greater completeness, aeeording no doubt to the time that has elapsed since the spot originated. Meanwhile these zone-spots become larger and larger until they may attain individually a diameter of 5 centimetres or even more, their dark, striated appearance being now very noticeable. Usually, before the dimensions stated have been attained, neighbouring spots have coaleseed, but the separate origin of adjoining spots is, however, still shown in those that have become so confounded. Thus a larger and larger area of the stem-joint may be involved, until this may be outwardly wholly affected, more or less numerous originally isolated spots eontributing to this result in different cladodia.

With regard to the effects produced where these spots occur, the epidermis of the stem-joint often dies, and so the surface implieated may become fissured. For a while the segment which has been attacked remains alive, but under some circumstances-perhaps rainy weather-evidently often realised, gradually dies, becomes deeayed internally, and ultimately dries up, there being left a mere shell, still exhibiting the original surfaee areas of fungus.growth.

This peeuliar disease, which oceurs also on other West Indian islands as will be subsequently seen, was found to oecur exclusively on $O$. dillenii, even when related kinds of prickly-pear were growing adjacent to affected individuals of this speeies.

No natural enemy was observed in association with the low-growing $O$. triacantha, but, many caetus areas on the island having remained unvisited by the Commission, it eannot safely be conclucled that this plant evcrywhere maintained this healthy eharacter. The remark applies also to other Antiguan species of Opuntia.

\section{ST. KITTS.}

On this island the bigh and rugged uncuitivated eountry to the south of Basse Terre was examined, and the road along the foreshore all around the island traversed. In the roeky and dry brush-elad situations, prickly-pear ( $O$. dillenii and $O$. triacantha) was very plentiful, being sufficiently dense in some places to impede one's progress. Along the seaboard outside the agricultural land, apparently only the former of these species occurred, and then grew sometimes in clumps but more commonly as isolated plants.

The Agricultural Superintendent, Mr. F. R. Shepherd, stated that the prickly-pear could never obtain any hold in the agrieultural areas as it was the eustom to extirpate and burn it, and on certain lands where no cultivation had been carried on it apparently was ehoked out by other vegetation. He also stated that, although he had not paid alose attention to the loeal Opuntias, no natural enemy affecting the plant had come under his notice-not even the coehineal inseet.

The only disease notieed on this island was the Zone-spot Disease occurring sparingly on $O$. dillenii, and the White Diaspis Scale of Cactaceous plants.

\section{NEVIS}

On visiting this island the more or less barren area along the new road, that extended for some miles, was examined; also the interior between the town and Gingerlands. The cireuit of the island by the eoast road was also made.

The kinds of priekly-pear endemic on Nevis are (1) O. dillenii, (2) O. triacantha, and (3) a peculiar hybrid combining the characters of these two, of which specimens had been pointed out to us in the New York Botanic Gardens by Dr. Britton, who, in company with Dr. Rose, discovered the hybrids on St. Kitts.

(4.) In addition, Nopalea cochinelifera was met with as a garden plant. The first two of these Opuntias grew in abundanee, especially to the west of the town and in much of the arid and barren eountry traversed by the new road.

As bearing on the question as to whether priekly-pear plants have always been a eomponent of the island's flora, or whether they were introduced at some remote period, it may be mentioned that whereas Smith, in his "Natural History of Nevis," printed in 1745 , makes mention of several other plants, he omits all reference to such eurious members of the vegetable world as are the Opuntias.

\section{Disease Occurrence.}

Plants of $\boldsymbol{O}$. dillenii were commonly affected by the Zone-spot Disease, and the aetion of the latter in rendering its host-plant stunted with a great arrest of growth was very noticeable, espeeially along the roadside in approaching Gingerlands. 
At a spot along the new road there were seen a few priekly-pear plants $(\boldsymbol{O}$. dillenii) that had almost succumbed to some illness, the following features being exhibited by, them. Individual branehes of the affected plant were dying back, as might happen were some root trouble present. The terminal stem-joints wore apparently the first to become injured. Those on which the discase was noticed presented the following symptoms:-Pale yellowish patches had arisen, liaving an irregular waved outline, well marked on the general green surface. Within these altered areas that would gradually involve the entirely stemjoint, grey, more or less circular, blotches appeared, and these had sprinkled over them minute black speeks, the reproduetive organs of some epiphyllous fungus. Ultimately the entire surface became mottled with grey and pale olivaceous brown. In addition there was present another fungus with the fruiting bodies exceptionally large and more widely separated; also a third fungus sparingly developed, resembling that associated with Zone-spot Disease. Some or all of the organisms were probably saprophytie. Notwithstanding the presence of these features, the stemjoints remained alive for a while without producing any new growth; but in those in which the trouble had proceeded to its full length, the internal tissue had died, disintegrating into a semi-liquid pulp, only the fibrous skeleton remaining intact. Specimens submitted to microscopieal examination exhibited no additional features sueh as might throw light on the etiology of this prickly-pear malady.

\section{ST. THOMAS.}

This island, whose annual rainfall is comparatively low, has evidently been eultivated to a much larger extent formerly than at present. This may account for priekly-pear plants not as yet occupying the flats near the coast and for their occurrence elsewhere as isolated plants only. $O$. dillenii and $O$. catacantha oceur along the seaboard and on the arid foothills overlooking it, the central mountain ridge extending east and west being devoid of priekly-pear.

In addition to the species mentioned, $O$. curassavica, var. Taylori is very common, often extending in the direction of the roads, as might be expeeted from its portability owing to the readiness with which it beeomes attached to stock. It usually occurred on the steeper stony slopes. It is distinguished from $O$. triacantha (Willd.), DC. (O. spinosissima, auct.) in possessing spines which when young are reddish-purple, not lemonyellow. $O$. catacantha, the tree-like Opuntia, grows on the steep rocky foreshores at the southeast extremity. Nopalea cochinelifera was found exclusively in the precincts of dwellings.

Investigation was prosecuted along the south coast, throughout the central elevated country, and at the eastern extremity (Smith's Bay).

\section{Disease Occurrence.}

The plants seen were not affected by any natural enemy except in the case of $O$. taylori, that occasionally harboured Diaspis enchinocacti, but with little injury to itself.
THE VIRGIN ISLANDS (TORTOLA, VIRGIN GORDA, AND ANEGADA).

\section{TORTOLI.}

The parts of this island visited were the entire southern seaboard, the western extremity, and the portion of the central mountain ridge lying east of the town of Broad Town. Generally speaking, the island is made up of rather steep deelivities, the level area being comparatively small in extent. Although its, roeky nature would suggest its unsuitability for agriculture, the soil is good and the island was formerly almost entirely devoted to agrieulture (eotton, sugar-eane, \&e.).

The kinds of prickly-pear found growing on it were-(1) 0 . dillenii; (2) O. catacantha (both spineless and spiny forms); (3) 0 . curassavica var. Taylori; and (4) a natural hybrid between Nos. 1 and 3 . Of these, the first was prevalent throughout the eoastal region, usually forming isolated patehes, and eompeting with the second for a decidedly maritime loeation as a site for abode, espeeially along the southern coast, where, erecting its tall stem amongst the débris at the bases of the steep roeky esearpments, it was almost laved by the sea. $O$. taylori was exceedingly common in the lower foothills, growing almost everywhere and often forming an impediment to walking owing to its readily detachable stem-joints armed with long, stiff, penetrating spines.

\section{Disease Occurrence.}

The Commissioner (the Hon. Leslie Jarvis), the Agricultural Instruetor (Mr. C. Fishlock), and Mr. J. P. Romney, an agricultural settler of long standing, deposed that they had not noticed any natural enemy, either disease or insect, associated with prickly-pear plants at Tortola. Personal investigation led to the same conelusion with this exception: that some plants of $O$. dillenii were damaged by the Zone-spot malady, more particularly referred to in dealing with observations at Antigua. In the different patches of the natural hybrid between this pear and $O$. taylori examined, no instance of the oceurrence of this disease was remarked.

\section{ANEgada.}

This small coral island, measuring about 10 miles in length, and elevated but a few feet above sea-level, is situated about 38 miles from Broad Town, Tortola. It is difficult of approach, being almost surrounded by dangerous reefs. $~ O$. dillenii oecurs abundantly on it in a more or less sporadic manner, especially near the settlement, its fruit being gathered as food for pigs.

\section{Disease Occurrence.}

Growing under conditions so peculiar, for some of the plants seemed to spring almost from the bare, level, coral roeks, arising as they did from mere soil-filled chinks in them, it was expeeted mere soll-hlled disease might be induced. However, two known diseases were alone met with, viz., Prickly Pear Anthracnose or Shot-hole, and Zone-spot Disease. The latter had apparently exereised some check on the plant it had attacked, but, generally speaking, natural enemies had had little influence in controlling its spread, eonditions of growth being alone adequate to aceomplish this. 
3. VIRGIN Gorda.

This island is about 15 miles east of Tortola. $A$ visit was made to that part of it most remote from Tortola and opposite Anegada, the country at the back of North and South Sounds being explored. Isolated patches of two kinds of prickly-pear were met with, namely, $O$. dillenii and $O$. curassavica taylori. No disease or injurious insect was remarked as being present.

In approaching North Sound, Prickly Pear Island was skirted, and the same two species of Opuntia noticed growing on it as on the main island, of which it is an outlier.

Similarly, in sailing for Tortola near approach was made to Great Dog Island and also to Beef Island. On both of these $O$. dillenii was noticed growing on exposed, steep, rocky dcclivities under circumstances that would seem to exclude any suggestion that it was not a native plant.

\section{ST. JOHN.}

Coasting near this island, plants of two species of prickly-pear proper to maritime situations were seen, viz., $O$. dillenii and $O$ catacantha. W. C. Fishlock, late Instructor in Agriculture for the Virgin Islands, when traversing the island in the interests of this inquiry, and examining whatever prickly-pear plants he encountered, noticed an example of $O$. dillenii exhibiting a very unhealthy appearance. Specimens secured on the occasion and afterwards submitted by him for inspection served to show that he had before him an instance of a common physiological disease, Dry Rot, already known in Queensland.

\section{PORTO RICO.}

It was the intention of the Commission to make two visits to this island, one in proceeding to, the other while returning from, the Dominican Republic. Unforeseen contingencies, however, rendered one of these alone practicable; hence the inquiry was not as exhaustive as it had been hoped. The localities visited were the neighbourhood of San Juan and Guanica, as well as certain coastal districts in the north, west, and south of the island.

Urban, in his "Flora portoricensis" ( $p p$ 432-4), records the following species from the island :-O. catacantha, Link and Otto ; O. repens, Bello; O. curassavica, Miller; O. tuna, Mill.; O. guanica, Sch. and Gurke, and Nopalea cochinelifera, L. Messrs. Britton and Rose have examined the Porto Rican species, but have not fully adopted Urban's identifications. O. repens; Bello (not Karw.), is regarded by Schumann (1899, p. 749) as a synonym of $O$. curassavica, while Dr. Britton has shown that it is $O$. stevensiana, Brit. and Rose. Urban's $O$. catacantha is the variety Taylori Br. and Rose, while $O$. guanica is the typical 0 . catacantha (fide Britton). His $O$. tuna is really $O$. dillenii. The locality assigned to these species by Prof. Urban is the dry coastal region near Ponce, which is evidently the main cactus area.

Of the Porto Rican prickly-pears mentioned, $O$. catacantha, $O$. stevensiana, and $O$. dillenii were found growing at Guanica, whilst two naturalised species. Nopalea cochinelifera and $O$. ficus-indica, L., were observed in or adjacent to gardens in various parts of the island. $O$. dil lonii was also seen to occur in large clumps at Arceibo on the north coast.

Occurrence of disease.

When interviewed, the Entomologists and Mycologists attached to the Sugar Experiment Station and the Board of Commissioners of Agriculture stated that they were not aware of the presence of any diseases occurring locally.

The diseases met with in the Guanica district (Ponce Division) werc Shot-hole and the Zonc Spot Diseasc, both occurring on $O$. dillenii. A rusty appearance of segments caused by unsuitable conditions was seen occasionally.

Two coccids were met with in the same district, one of them Diaspis echinocacti, Bouché, being quite prevalent near Guanica on all kinds of prickly-pear, as well as on two species of Cereus seen there. In some places it had seriously injured the Cereus spp., but was evidently assisted in its destructive work by the very arid conditions prevailing there.

In this locality there was found a much more conspicuous coccid, one which had not been previously met with. In places, plants of $O$. dil lenii were whitened by the presence of this large active insect, whose body, when ecdysis had recently taken place, was brownish dorsally with lines of bright red circular spots, whilst at other times it was covered with a dense mealy excretion which was also plentifully sprinkled over the green surface of its host plant. The small male insects in their larval and pupal conditions were present in much larger numbers than their consorts.

This peculiar coccid had attacked, in addition to $O$. dillenii, two Cereus plants growing where it occurred, but in neither case did it appear to occasion any marked injury. It was, however, evidently parasitised by some hymenopterous insect; a fact that would, of course, serve to lessen the injuries that might otherwise result from its presence. In some cases it was found associated with Zone-spot Disease, and at times under conditions that might suggest that it had served as the inoculating agent, since it, like other coccids, punctures its host-plant and then extracts its juices. As this parasite does not seem to have been treated of in entomological literature relating to prickly-pear, specimens were submitted to Dr. L. O. Howard, Chief of the Bureau of Entomology, Washington, D.C., for an opinion as to its identity and its plant relationship, but no information has as yet been received. It was evidently related to Icerya, differing from it, however, in not producing an ovisac.

\section{SAN DOMINGO.}

Although the ocurrence of prickly-pear $(O$. dillenii) is reported from many points along the lengthy coastline of the Republic of San Domingo, there are special districts where Opuntiæ and other Cactaceæ are especially prevalent. Two of these are Monte Christi near the western, and Matanzas towards the eastern extremity of the north coast, and the other is between Bani, Azua, and Barahona, on the south coast. The latter of these only was explored by 


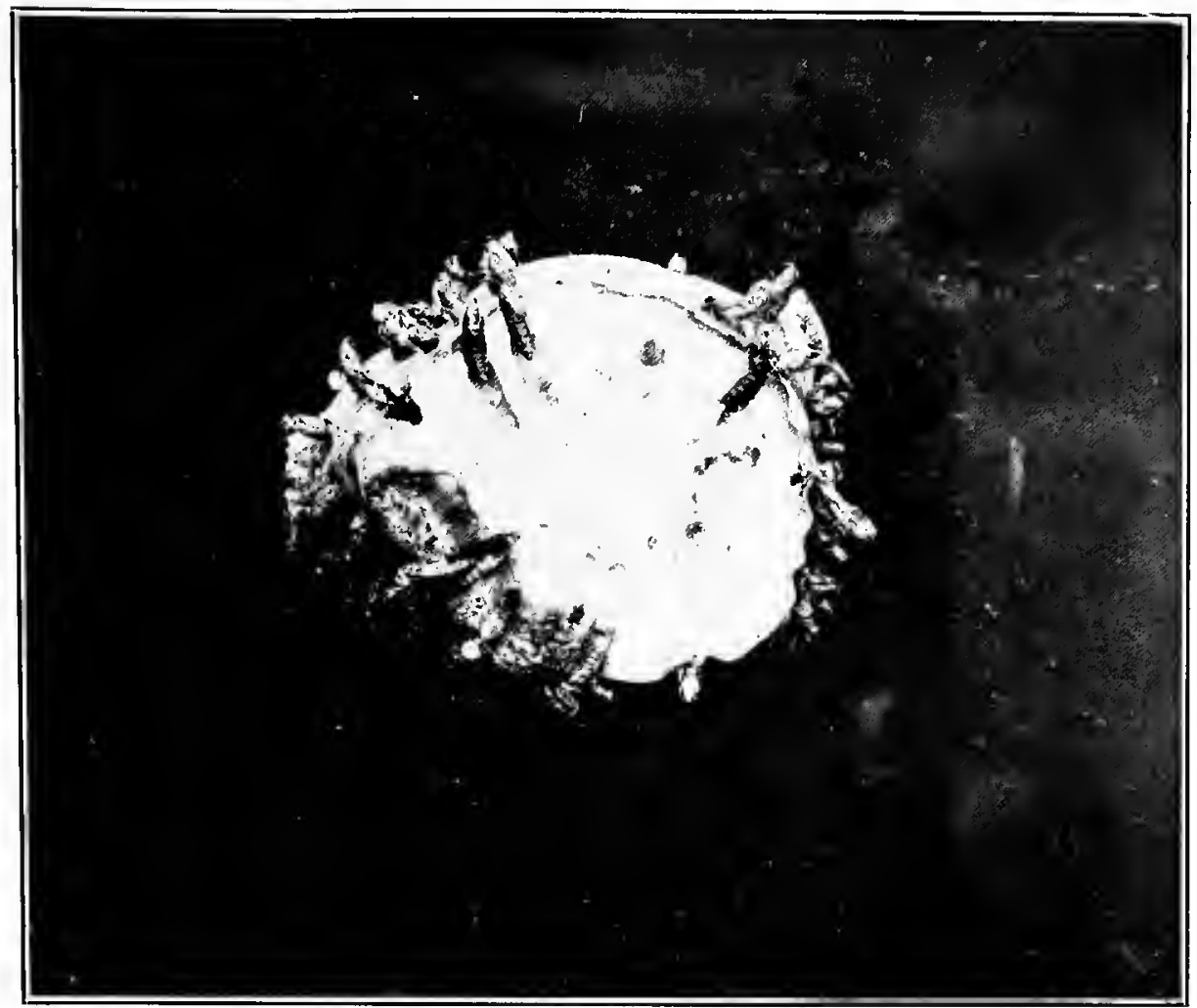

Photo., Bureau of Entomology, Dept. Agriculture, U.S.A

Fig. 54,-Transverse section of a fruit of 0 . cngelmanni showing the burrows and pupa-cases of a Cecidomyiid fly regarded as Asphondylia opuntice. Note the destruction of the seeds. (See also Fig. 53.)

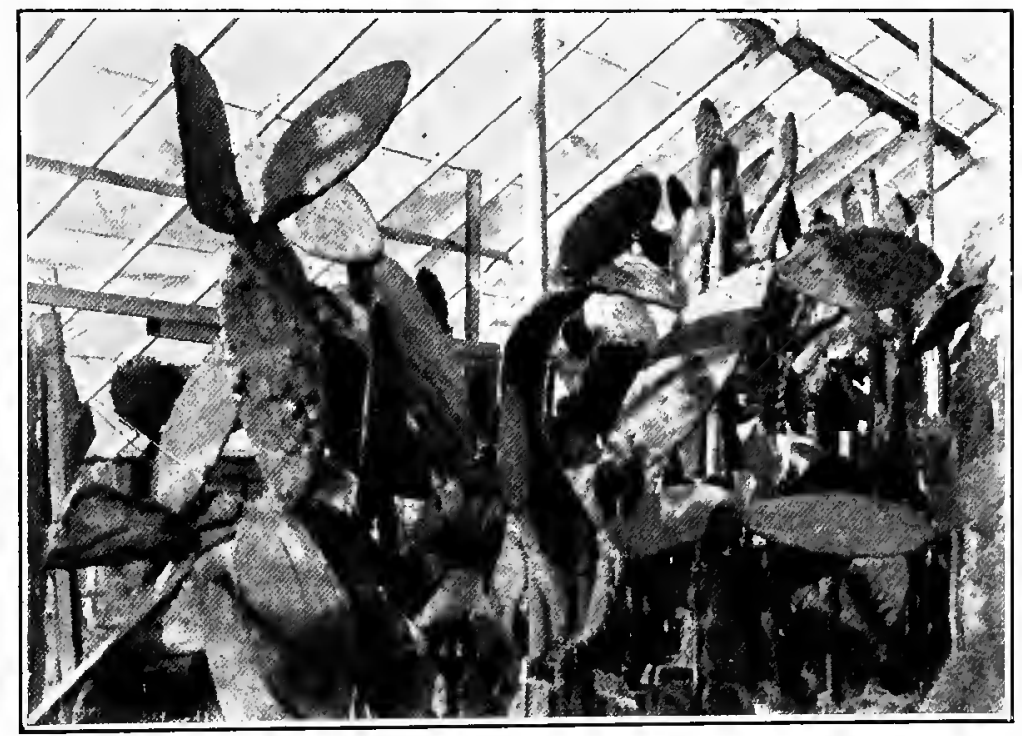

Fig. 55. A spineless Opuntia-0. ficus-imdica-showing the presence of galls at the arroles, the galls being cansed by the larva of a Cecidomyid fly-Itonida opuntia-a very destructive enemy of prickly pears in the greenhouses of the New York Botanic Gardens, where the photo. was taken.

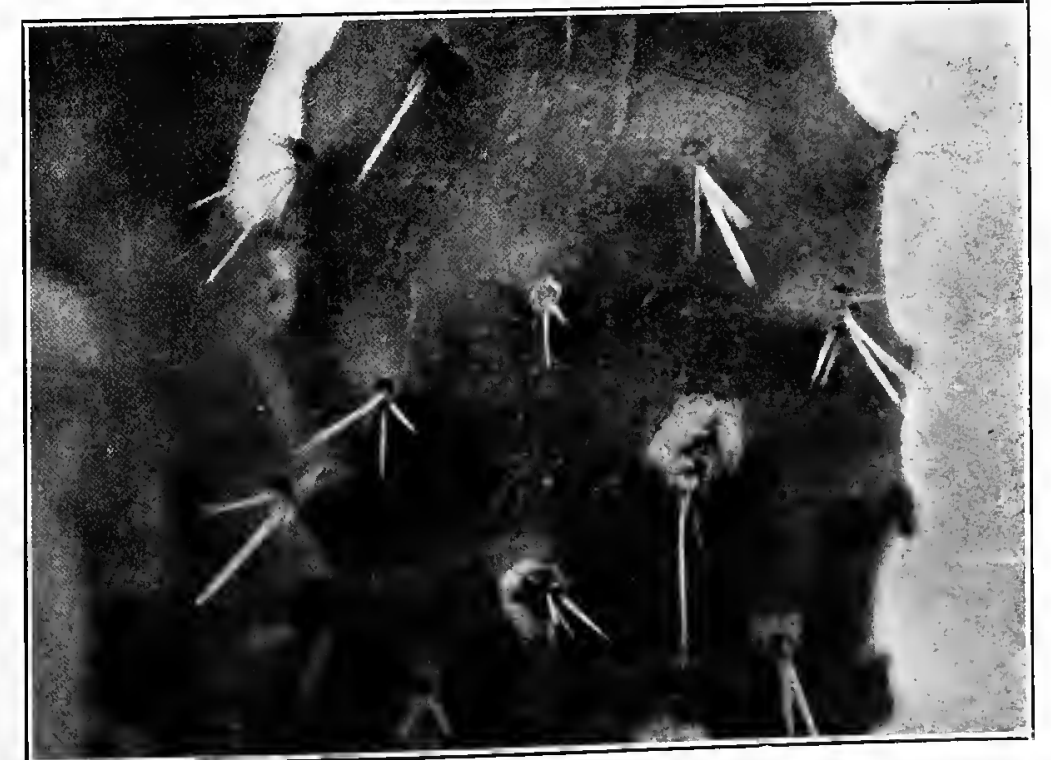

Fig. 56. - A riew of a gall in O. streptacantha, New lork Botanic Gardens. 

the Commission, being reached viâ Romana, San Pedro de Macroris, and San Domingo City, i.e., by a route that enabled the general aspect of the vegetation between the first-named place and the port of Azua to be examined from the decks of the small coastal steamers in which the journey was effected.

R. M. Mocoso incidentally refers to different kinds of prickly-pears growing in this large island in his "Las Familias Vegetales" (1897, p. 79), which has been issued as a preface to a larger work "Botanica Flora de Sto. Domingo" that apparently has not yet been published. These lie names Opuntia tuna, Mill., the "Tuna brava"; O. spinosissima, Mill., the "Alpargata"; O. triacantha, Haw., the " tuna de perro" ; and $O$. ficusindica, the "Alquitira" (cultivated), (Alcaquitira $=$ Nopalea cochinelifera, fide Cambioso).

Dr. N. L. Britton, who with his colleague, Dr. J. N. Rose, has given especial attention to the Cactacer of San Domingo, specified for our information in the following list the Opuntias that are to be met with there, viz.:-Opuntia dillenii Haw. (the O. tuna of Mocoso) ; O. hattoniana, Brit. and Rose; $O$. cubensis, Brit; $O$. domingensis, Brit. and Rose; $O$. catacantha, Link and Otto; and $O$. ficus-indica (L.), ; whilst for 0 . taylori, Brit., and O. haitensis, Brit., syn. O. microcarpa, Sch. (not Engelm.), he assigns Haiti as a locality.

The following species were seen in San Domingo in the course of the present inquiry :1. Opuntia dillenii, the "Tuna espina"-evidently the $O$. tuna of Mocoso-found growing in San Domingo city and adjacent coast to the north, Azua, Barahona, and the Valley of Yaquey River, in the latter case being very scattered.

2. Opuntia (cubensis, Brit. ?) An Opuntia that is probably this species was met with commonly at Azua and between that town and the River Tabura, and sometimes forming more or less extensive patehes. When growing side by side with $O$. dillenii it was to be distinguished by its different general colour, being greyish or purplish-brown, by its smaller and narrower stemjoints which were oval, somewhat obliquely narrowed basally and with the border entire, by its acicular and nearly straight spines of a pale yellowish-grey colour (never banded), and by its slightly drooping habit. Neither flowers nor fruit were present.

3. Opuntia sp._- Alpargata," included in the genus Consolea of Lemaire. A tree-like Opuntia with a tall, stout, unbranched trunk measuring $30 \mathrm{~cm}$. or more in diameter above the ground; having elongate parallel-sided stem-joints that are dull greyish-green colour; the areoles in oblique lines of nine, each situated at the distal end of an oval polygonal figure defined by an impressed line with similar lines dividing the space between the areoles into polygonal tensseræ of different sizes; spines on stem-joint disappearing with age, pale yellow on the younger growth but whitening with age, those on the disc about $2 \mathrm{~cm}$. long, those on the border $4 \mathrm{~cm}$. to $4.5 \mathrm{~cm}$. spines on the trunk in rosettes usnally inclined downwards, the longest attaining a length of 8 $\mathrm{cm}$. arising from a cushion of pale yellowish "wool" amid deeper yellow spinules, each 12 to
15 mm. long. At Azua, it lurms a conspicuous objeret amongst the low, brush-like vegetation nowing on level, stony ground.*

4. Opuntia spinosissima, Mill._."Alpargata" (Mocoso). Included also in the genus Consolea of Lemaire. It is a tree-like Opuntia with a tall stout unbranched trunk, 15 to $20 \mathrm{~cm}$. or more in diameter at a short distance from the ground, with stout primary branches, the thin oval vivid green joints are from $14 \mathrm{c}$. to $16 \mathrm{~cm}$. long and 6 $\mathrm{em}$. broad. The areoles, if present, are very indistinct, and without the inscribed surrounding figure and interareolar tesselation. The lower half of young spines is pinkish-purple. Those on the trunk radiate in all directions, forming a rosette arising from a cushion of whitish tomentum without the spinules of the previous species. The spines on stem-joints disappear with age. Flower-buds are reddish-brown, the flowers being small with the interior perianth lobes abbreviated, coneave and yellowish-red. This species was seen on the left bank of the Yague River near Oya, in scrubby country between Yague and Barahona, and at Barahona in level eoral-limestone country to the east of town.

5. Opuntia sp. (one of the cacti designated "'Tuna perro"). It is a dark-green prickly-pear of lowly habit, having rather small eliptical stemjoints with three or four areoles in each linear oblique series, each areole bearing white acicular, straight and long, spines. Flowers are yellow. This species is very common on loamy level country on left bank of the Yague River, near Barahona.

6. Opuntia sp. (another of the Opuntias designated "Tuna perro"). A dark-green prickly-pear of very humble habit, the stout segments being curved over horizontally at a level of a few inches from the ground. The pubescent stem-joints are elongate-oblong $6-8.5 \mathrm{~cm}$. long by $2 \mathrm{~cm}$. to $2.5 \mathrm{~cm}$. wide and $1.1 \mathrm{~cm}$. to $1.2 \mathrm{em}$. thiek with three areoles in each oblique series. Spines are straight and acicular (the longest being 3-5 $\mathrm{cm}$.) and arranged in groups of 2 or 3 . Spinules are almost absent. The fruit is small $(4 \mathrm{~cm}$. or more long) with large tuberculate areoles. The species occurs commonly at Canoa and Alpargatu, on the left bank of the Yague River, Barahona.

7. O. hattoniana, Brit. and Rose-Curassavica group-a prickly-pear of prostrate habit, the colonies attaining a height of 9 or 10 inches, covering at times several square feet. The pubeseent stem-joints are circular or shortly ova! in section $(1.5$ by $1 \mathrm{~cm}$.) the terminal ones eircular. Spines are pale purple when young. The pinkish-red fruit is small $(4.5 \mathrm{~cm}$. long), the end being truncate and possessing a łeep concavity. It grows near Oya, Fundacion, and Canva on the left bank of the Yague River, Barahona, resembling a tangled mass of some small, green, rope like article. The terete cladodia, a feature in this plant, are very unusual in West Indian priekly-pears.

* A photograph of this species has been published in Dr. MacDougall's report for 1913 (Carnegie Institution of Washington) Plate 2, Fig. C. 
8. Opuntia domingensis, Brit. and Rosethe "Guazabarra." This is a copiously branching Opuntia with ruldish-brown sheathed spines which oceurs very commonly at Azua, forming in places often large patches in loamy country on the left bank of the Yague River, Barahona.

9. Opuntia ficus-indica, Lin.-." Nlyuitira" or "Alcaquitira." It has been suggest d that this species, which was seen growing in or near cultivations, is a native of San Domingo, growing wild there. Mocoso, on the other hand, regards it as being a cultivated plant, and $\mathrm{Mr}$. R. O. Cambioso, the veteran naturalist of San Domingo eity, states the same as the outcome of observations made during his extensive travels. Tambourini, of Azua, who designates it 'Tuna di Espana, regards it as an indigenous prickly-pear, naming three localities, on the Oregano and Arroyo Salado, on the Yague River, and Tubano, a small town to the north of Azua-where it grows.

10. Nopalea cochinelifera occurred here and there as a cultivated plant.

11. In approaching the Rive Tabura by the trail that leads from Azua to Barahona, an Opuntia of the Curassavica group may be seen growing sparingly, also clumps of one resembling a natural hybrid between $O$. dilleni and $O$. catacantha.

\section{Disease Occurrence.}

No natural enemies of prickly-pear of sjecial significance were seen in the island of San Domingo, though, however, a more extended exploration might have led to the discovery of some. Those remarked were as follows :-

1. Caterpillars of a large moth (? Melitara sp.) were found feeding internally in the stemjoints of both $O$. dillenii and another Opuntia (No. 5) on the left bank of the Yague River, 12 to 16 miles from Barahona. The following account will serve to describe the appearances due to the attacks of this insect, in the case of the former kind of prickly-pear. The plant was of normal size and had developed vigorously, but had not produced flower or fruit, nor was there any indication of their former presence. Many of the stem-joints, especially the terminal or younger ones, were badly injured or were quite killed. A typically injured segment presented on one face three large blotches, almost black, but greyish and scarious in places where tissue beneath had been quite consumed. Several holes were also present-usually within the area of the lighter coloured blotches. On the opposite face of this stem-joint were also holes, and through these had issued a mucilaginous matter; now dry and appearing like strings and bands of gum tragacanth. In addition to the stem-joints affected as described, many half-grown terminal segments were quite dead and dry; and of these many had already become detached, whilst others still remained hanging down on the plant. It was obvious that in this instance the inseet implicated served to arrest any further growth on the part of its victim and to stop its natural reproduction.

2. Wild Cochineal. A single plant of $O$. catacantha slightly affeeted by some kind of Coccus was observed along the trail between Azua and Barahona, on the steep face of a hill ascended after first reaching the Yague River. It had evidently occasioned but little injury.

3. Opuntia Wrevil. The tree-like Opuntia at Azua commonly presented the characteristic injury associuted with the attacks of the weevil bcetle, Gerstackeria sp. On the green surface of the stem-joint numerous grey perforated spots of reatl tissue were seen, each about $4 \mathrm{~mm}$. in diameter. Other stem-joints had dark spots where the surface had been eroded. A single specimen of the weevil was observed, but, simulating drath in fall, elnded observation and capture.

4. Flower-consuming Caterpillar. At Baralona the small yellow-red blossoms of the tree prickly-pear O. spinosissima, Mill., were almost without exception damaged by some small caterpillar. This insect not only consumed the perianth lobes, but also ate or damaged the stamens and pistil, and thus rendered the flower perfectly sterile, and, in consequence of this, every tuberculated receptacle became compressed and assumed the character of a small stem-joint, when it fell and soon started to grow and give rise to a new plant.

Diseases.-Prickly-pear diseases of any kind appeared to be wanting. In the absence of adequate checks of this kind, the Opuntias in some places - as in the neighbourhood of Azuawore sufficiently prevalent to make the passage of a pedestrian through the country occupied by them very difficult. On the Yague River, wild pigs, apparcntly, kept the large kinds in check by consuming the roots.

\section{HAITI.}

It may be of interest to point out that from the adjoining Republic of Haiti the following Opuntias have been noted:-Opuntia taylori, Brit.; O. haitensis, Brit., (O. microcarpa, Sch., not Engelm.), as we are informed in a communication from the author of these species. Moreover, F. R. de Tussac (Flora Antillarum, II., p. 34) records $O$. inermis DC., as being met with there between Artibonite and Gonaives. This is a matter of interest, since the commoner Queensland prickly-pear is usually regarded as $O$. inermis DC., also.

\section{CUBA.}

The ports of Cuba visited included Havana, Monte Tinaja (north coast), Pinar del Rio towards the west, and Santiago and Guantanamo (south eoast) towards the eastern extremity of the island.

The Opuntias have quite a local distribution in this island and are seldom, if ever, met with far from the sea-shore or the immediate influences of the sea-breezes, so much so that the local botanist, Dr. Eugenio Cuesta, even suggested to us that the prickly-pears now growing naturalised in Cuba had been derived from outside sources borne over intervening seas by wind and tide.

Writing on the plants of Cuba in 1745, D. Ramon de la Sagra (1745, pp. 311, 313) especially refers to certain Cactaceæ then growing there. He, however, makes no mention of Opuntias, 
exeusing his omission with the statement that it was diffieult to preserve specimens, if there, and that he dealt in his work only with those plants that were befor him.

The speeies enumerated by A. F. Sauvalle (1868, p. 59) are Opnntia tuna, Mill.; O. triacantha, Haw.; O. macracantha, Griseb.; and O. hystrix, Griseb. The list of J. T. Roig y Mesa (1912, p. 38-43) eomprises the following:-Opuntia macracantha, Griseb., O. microcarpa, Sehumann, O. dillenii, Haw., O. tuna, Mill., and Nopalea dejecta, Salm-Dyck; but although his memoir nominally embraces Cuba in its entirety, the loealities given as habitats for the several specios described are West Cuban only.

Dr. Gomez de la Maza (1897, pp. 270-271) mentions only two speeies of Opuntia growing in the distriet of Havana, i.e., O. tuna, Mill., in the grandispinosse group of Haworth, and $O$. vulgaris, Mill., in the parvispinosa division of the same author.* Sehumann, 1899, p. 752) gives Cuba as the habitat of Nopalea auberi, S.D.

Dr. N. L. Britton kindly furnished us with a list of Cuban speeies known to him-Opuntia dillenii, Haw., $O$. inermis, DC., and $O$. cubensis, Brit. (all belonging to the dillenice group), $O$. - macracantha, Griseb. (spinosissimce group), $O$. militaris, Brit: and Rose (curassavica group), and Nopalea de jecta, S.D.

The following observations relate to the speeies of Opuntia which eame under notice:-

o. dillenii, Haw. This plant was found growing in the precinets both of Havana and Santiago de Cuba. It oeeurred eommonly in the eountry between Guantanamo City and Guantanamo Bay (South-east Cuba) from Novali Junetion onwards. Here it grew in the open and light-brush eountry, often in dense masses of considerable extent, but the individual plants were more or less isolated where the serub was eomposed of larger growth. Mueh of it had, however, already reeeived a considerable check in its growth owing to the attaeks of certain naturai enemies. The same species was also found growing through the lightly timbered country on Monte Tinaja near Quebra Hacha, on the north coast to the west of Havana. Here again it wis being subjected to the ill-effeets due to disease.

0 . cubensis, Britton.-A few plants of an Opuntia resembling both $O$. dillenii and $O$. tuna, as defined by Dr. Britton, were seen a few miles inland from Santiago de Cuba. The thorns were straight and rather long. The species was doubtless O. cubensis, Brit. The name "tuna brava" is applied locally to $O$. dillenii as well as to this priekly-pear.

* o. hystrix, Gris., according to Schumann (1899, p. 784), is identical with O. tunicata, Lk. and Ot., which is a Mexican and not a Cuban species. Nopalea dejecta, Salm-Dyck, is not known to be a native of Cuba, although that is the type locality, but is a species in cultivation there. $O$ triacantha of Sauvalle may be Messrs. Britton and Rose's O. militaris. O. tuna, Sauvalle, and O. tuna, Roig, offer some difficulties. Dr. Gomez's O. tuna is probably $O$. dillenii, Haw., and Dr. Roig's $O$. buna, which he distinguished from $O$. dillenii, is apparently $O$. cubensis, Brit. and Rose. Finally, $O$. vulgaris, Gomez, may be 0 . inermis, DC.

O. cubensis, Brit. (ined.), is an Opuntia belonging to the Dillenice group, whose author distinguishesit from his 0 . tuna of South Central Jamaica by its longer spines, and from 0 . dillenii, Haw., by tho charaster of its fruit and by its terete or acicular (not basally compressed) spines. This species, he informs us, grows in South-east Cuba.
O. macracantha, Griseb.-A prickly-pear, probably referable to this species, was found growing at the back of Guantanamo Bay on the drier serub-elad ground, where it attained the dimensions of a small tree, having a thick trunk and stout main branehes. The bark was eomposed of large, brown, flaky scales, one superimposed on another. It is armed with rosettes of numerous long, pale spines that spring from a whitish tomentum. The elongate, parallel-sided stem-joints hang downwards. They are dull and greyish, but never possess inter-areolar tesselation, even in very old plants, the young spines on emerging having their lower halves purplishpink, those on the older growth being wliite, straight, acicular, and very long, sometimes attaining $9 \mathrm{~cm}$. in length.

O. militaris, Brit. and Rose.-This low-growing brittle plant, we were informed, grew at Guantanamo Bay in a loeality which it was not eonvenient to visit. Living examples of the species in the New York Botanic Gardens had narrow elongate, rather glossy green stem-joints with 3.4 areoles in each oblique series, and the spines on these, white with translueent tips.

U. inermis, DC.-This species was originally named by $P$. de Candolle when figuring it in his Plantes Grasses (1799, tab. 138), and characterised in the volume of his Prodromus Regni Vegetabilis dealing with the Caetacex (1831, III., 473). Since it is the commoner of the naturalised prickly-pears of Queensland, it is of interest to learn that $O$. inermis also is a plant to whieh Cuba, along with Haiti and Florida Keys, has been assigned as a habitat. With the exception of de Tussac's statement (p. 34) that it grew between Artibonite and Gonaives, in Haiti, and Sehumann's (1899, p. 718) that he had seen two dried specimens from the West Indies, there has been until lately no suggestion as to its native home.

Descriptions having been based on examples of this plant which had become naturalised and had " run out" in other countries, or had been eultivated in gardens (ef. Weber, 1893-1899, p. 894; Griffiths and Hare, 1906, p. 49; Maiden, 1912 , p. 713), * Dr. N. L. Britton, in the course of our inquiry, tendered the definite information that it grew on one of the Florida Keys and also in Western Cuba, and he, moreover, pointed out three plants in the New York Botanic Gardens labelled as having been derived from these two localities; but it does not appear that any deseription of the West Indian $O$. inermis has been published, based on specimens derived either from Florida or Cuba. On visiting Western Cuba, a journey was made to Pinar del Rio, Dr. Britton having stated that it was to be met with between that eity and the hills to the north. Dr. Emilio Cuesta, the well-known Cuban botanist of Pinar del Rio, indicated localities within a few miles of the eity where he had colleeted $O$. incrmis. The few plants seen by us, on visiting some of the places indieated, appeared to be garden eseapees.

* That Opuntia inermis was very early disseminated we may infer from the fact that, according to Dr. Schumann (1899, p. 715), it is now growing wild in the South of France, in Catalonia, and the Balearic Islands. The plants now occurring in the insular region last mentioned Dr. Weber named Opuntia vulfaris balearica (Bois. Dict., 894). 
The following deseription of $O$. inermis, D.C., is based on field notes made while examining specimens of the plant growing at Colonna and Ceja Negro, Pinar del Rio, respectively. General colour rather dark dull green. Stem-joints oval but somewhat obliquely narrowed towards the base; measurements of terminal segments, 16 em. $x 8 \mathrm{~cm} ., 16 \mathrm{~cm}$. $\times 7 \mathrm{~cm}$., $15.5 \mathrm{cml}$ x $8 \mathrm{em}$., 12.5 em. x $12 \mathrm{~cm}$. Intermediate joints larger, $23 \mathrm{c}$. $x 9 \mathrm{~cm}$. to $30 \mathrm{~cm}$. $\times 9 \mathrm{~cm}$. Areoles, 4 to 5 in an oblique row. Leaves about $4 \mathrm{~mm}$. long, small, conical, tipped with greenish-red. Spines often absent, generally wanting in young stem-joints when present, 2-3 cm. long, straight, somewhat suddenly narrowed distally, often flattened towards the base, the lower parts yellowish, then gradually passing from pale yellowish-brown to reddish-brown distally. Spines never present in quite young stem-joints and few on the older ones persisting-these singly in twos and 2.5 em. to $4 \mathrm{~cm}$. long. Spinules (glochidia) on a yellowish coloured brush at the distal end of areole, each about $5 \mathrm{~mm}$. long, springing from a little pale tomentum. These spinules may increase with age, but are generally evanescent. Flower-receptacles with a few weak spines on the upper areoles, distal end somewhat festooned and slightly costate also at each areole. Flowers, yellow suffused with red towards the base of each perianth segment-these being glossy and translucent. Pistil : Stigma cream coloured, 7 lobed; stipes pale purplish-pink. Fruit not seen.

This plant, as may be inferred from a comparison of descriptions, has much in common with Dr. Roig's $O$. tuna (1912, p. 39), which he contrasts with $O$. dillenii, and which he states is very abundant in the Playa de Marianao, in Puentes Grandes and Calabuzar, and in other places in Cuba.

Nopalea cochinelifera. This species was commonly seen cultivated in various parts of the island.

\section{Disease Occurrence.}

o. inermis, D.C., being so nearly related to the Queensland prickly-pear-the Gayndah variety espeeially - the plants found representing it in the Pinar del Rio district were all carefully examined in the hope of finding injurious in sects, \&c., specifically related to it, and, therefore, more likely to be useful in eoping with our pear than the insects associated, perhaps exclusively, with other kinds not represented in Australia. However, nothing resulted from the search.

Bud-destroying Lepidopterous Caterpillars. In the Guantanamo district, in the neighbourhood of Novali railway station, although the pricklypear plants $(O$. dillenii) were very numerous, their growth had evidently come to a temporary standstill through the action of the caterpillar of a small moth, related to if not identical with Mimorista flavidissimalis, a serious enemy of Opuntia in the United States. These insects had attacked the growing shoots when they were still quite young, with the result that they had withered and decayed, the dry, shrunken, blackish buds occurring on all sides, still on the plants, or already fallen to the ground. Sometimes only ahout half the shoots on a plant had been vic- timised, at other times almost all, so that green shoots could be discovered only with difficulty. As an instance of typical injury of this kind, that had not proceeded as yet to its full length, we may instance one affected shoot amongst many similarly affected. Its terminal or free end was shrunken and blackened. On both surfaces small holes and patches of eroded tissue with a greyish colonred surface were present. Three yellowish, diminutive, lepidopterous larvæ were discovered, two on one face and one on the other, protected by a delicate web which covered them; one larva being partly buried in the subjacent tissue.

In examining a young green shoot to discover how the injury had been started, small excavations were found behind the true leaves (still attached) in two places. In each of these were two small pallid larvæ that had evidently recently hatehed from eggs. In another instance, five of these minute caterpillars were found gnawing at the tissue behind a single leaf. Of course, to such attacks as these the infested bud soon succumbs under ordinary conditions. Sometimes, however, after considerable surface damage is done, the insect that has occasioned it disappears, having possibly been removed by a wasp or other predaceous insect, the young shoot then recovering, but always showing subsequently. irregularity in its outline. At times a young shoot is eaten quite down to its thorny cushion-base in the areole from which it has sprung. When older stem-joints, especially terminals, are attacked, they remain stunted with their borders more or less scarious and indented, while scales or ribbons of blackish, dry, gum-like matter may be present. It is very evident that a marked effect may be exerted by these insects in preventing the growth of the plants which they have once assailed.

Melitara sp. Injuries exactly resembling those produced by Melitara prodenialis and its allies in the United States of America were seen in joints of $O$. dillenii growing along the seashore near Santiago. A considerable amount of destruction had been oceasioned, numerous dead hollowed-out segments with insect excreta within them and near them testifying to former activity. $M$. prodenialis is the species occurring in the adjacent peninsula of Florida.

Chelinidea sp.? Circular chlorosed areas found on segments of $O$. dillenii at Santiago suggested the presence of a plant bug, the injuries being similar to those caused by Chelinidea spp. in Texas.

Leaf-eating Ant. A single instance of an old plant of $O$. dillenii completely arrested in growth through the action of an ant addicted to consuming vegetable tissue, was met with near Novali in scrub country. In this case the young shoots were almost entirely eaten, so that the fresh internal tissue became exposed, the ants themselves being seen in operation. Older shoots that persisted were small and stunted, and very irregular in outline-a condition suggestive of their having been damaged at an early stage in their growth. The ant itself was a large one of very lethargic habits, having two thorns on each side of its cordate occiput and six arming the crux, those of the prothorax being curved and djrected forward. 


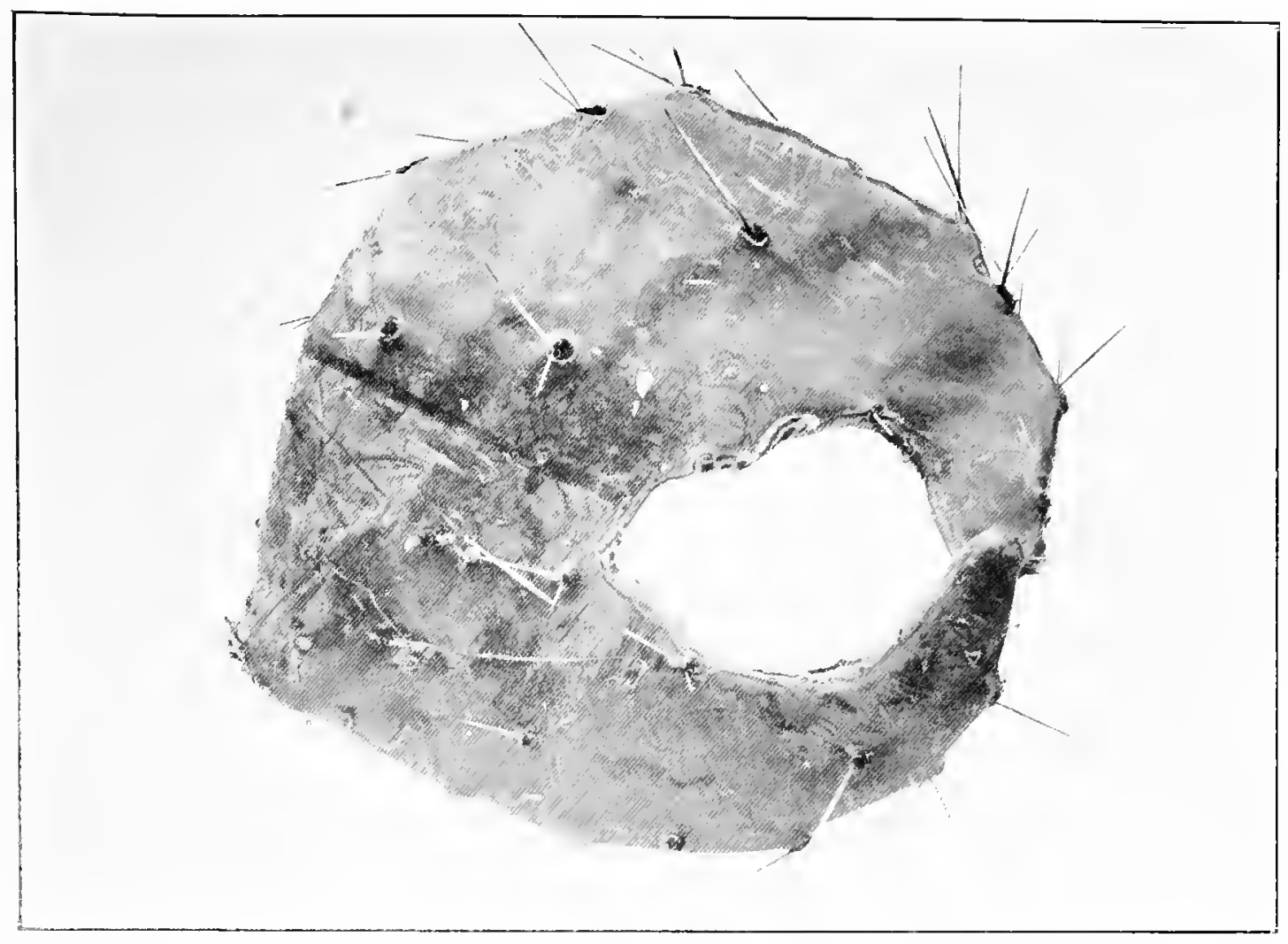

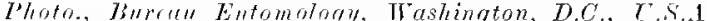

Fig. 57.-A large "shot-hole" in a prickly pear joint, calkerl by the fungus fitonsprium Tunatum. Texas.

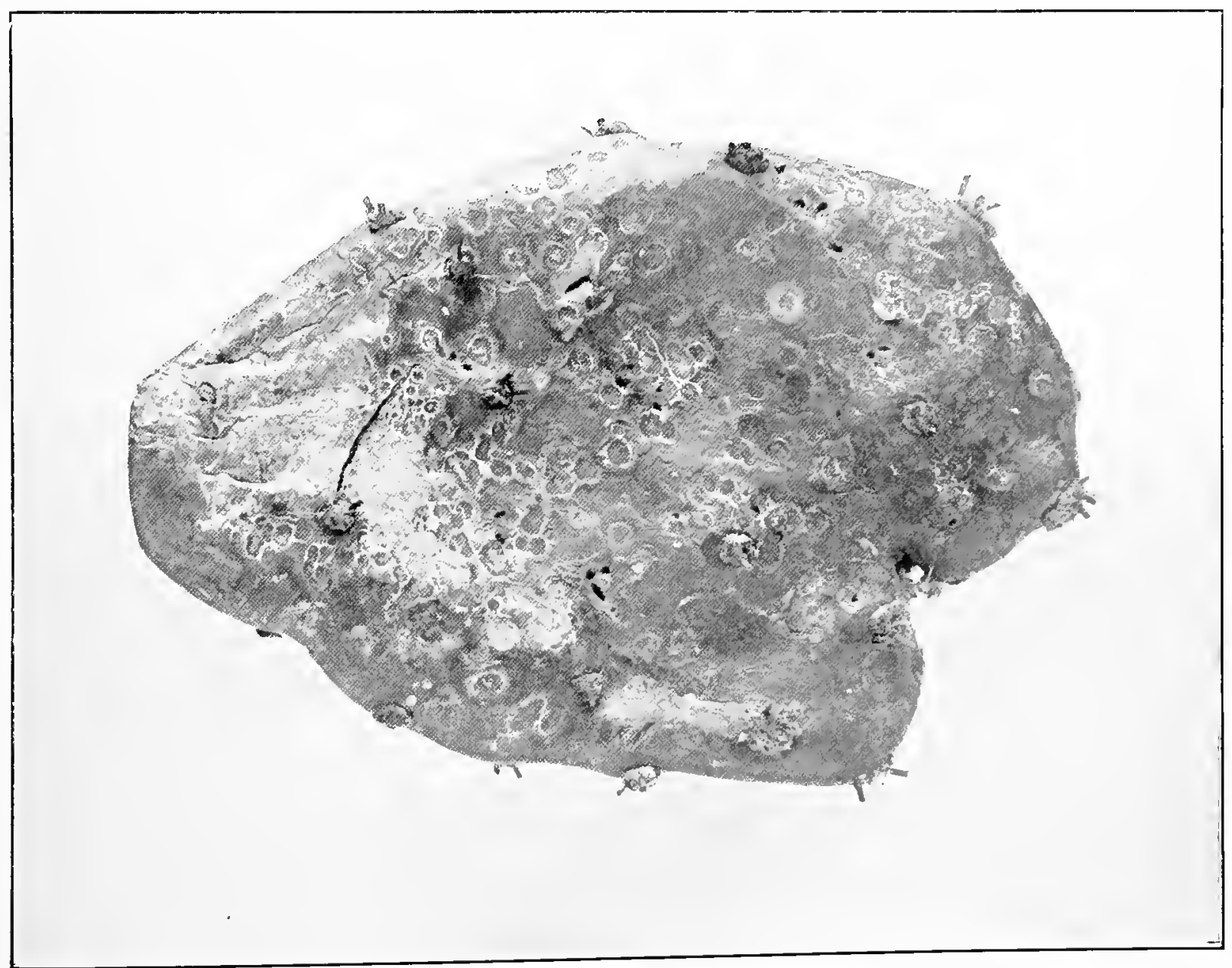

Photo., Dept. Agriculture, Brisbane.

Fig. 58.-_"Black spot" on 0 . Aillenii cansed by the fungus Perisporium urightii. Antigna, West Indies. 

Zone-spot Disease. This fungus-malady, first noticed at Antigua, was prevalent both in the Guantanamo district and that of Monte Tinaja, near Quebra Hacha; in both instances affecting $O$. dillenii only and causing a stunte 3 habit as well as bringing about the destruction of some of the stem-joints.

Superficial Black Spot (Perisporinm wrightii) . This malady was observed associated with $O$. dillenii in the latter locality, as well as at Santiago de Cuba. It had but little prejudicial effect on its host-plant, producing merely a scarious surfacc in spots where it was situated.

Shot-hole (Glosporium lunatum, E. and E.). This disease was seen to attack, though not striously, both $O$. cubensis and $O$. dillenii at Sillitiago.

\section{ISLANDS UNVISITED.}

For reasons already mentioned it was found impracticable to visit many of the West Indian Islands. The more important of these and their Opuntia flora are now referred to:-

\section{Curacao.}

This has been spoken of as an exceedingly dry island, and as one very rich in cactus growth (Austen Clark). Dr. N. L. Britton, as the outcome of personal investigation, has informed us that the species to be met with there are Opuntia curassavica (L.), Mill.; O. tunoides, Brit. and Rose, ined.; and $O$. elatior, Mlill. The lastmentioned, he informs us, is distinct from that recorded under this name by Burkill as occurring in India. At Curacao there are both spinebearing and nearly spineless forms. Boldingh (1909, p. 142) mentions that Nopalea cochinelifera is cultivated on this island. Hulst has referred to the occurrence of the destructive pricklypear moth, Melitara prodenialis, on this island.

\section{Margarita}

Prickly-pear is said to grow in plenty here (A. Clark-List of Flora in Proc. Boston Soc. Nat. Hist.).

\section{Tobago.}

"Cactus" occurs plentifully on this island (List-A. Clark).

\section{Grenada.}

"Cactus" occurs on the dry southern end (List-A. Clark).

\section{St. Vincent, St. Ludia, and Montserrat.}

No information obtained. The two firstnamed have a rather moist climate-a condition unsuitable for most Opuntias.

\section{MartiniQue.}

The Rev. R. P. Duss has informed us that o. tuna (Mill.), Duss $(=0$. dillenii, Haw.), grows abundantly on this island; that $O$. coch $i$ - nelifera, Mill., occurs there also, but that $O$. spinosissima, Mill., Duss (= O. triacantha, Link and 0 tto), is wanting.

\section{Dutch Leeward IsLinds ( $S t$. Martin, $S t$. Eustatius, and Saba).}

Boldingh (1909, p. 141,2) records O. triacanthe, Haw. (? O. taylori, Britton); O. tuna, Mill. (=O. dillenii, Haw.); and O. ficus-indica, Mill., as occurring on all three islands, and $O$. spinosissima, Mill $(=0$. triacantha) as being found on the two first-named of the group.

\section{St. Croix.}

Boldingh (p. 141) has mentioned that $O$ spinosissima, Mill., is to be found on this island as well as on St. Martin and St. Eustatius.

\section{The Bahamas.}

According to the researches of Dr. N. L. Britton and Dr. J. N. Rose, these islands contain Opuntia lncayana, Brit. and Rose; O. nashi, Brit.; and $O$. millspanghii, Brit.

\section{TURK's ISLAND.}

These same authorities have informed us that $O$. darrahi and $O$. veberi belong to this island.

\section{The Bermudas.}

This island harbours $O$. dillenii, which not infrequently is thornless under shade conditions (fide Dr. Britton).

\section{SUMmary OF Investigations IN THE WEST INDIES.}

A large number of islands were visited, and their prickly-pear flora examined as fully as circumstances permitted.

In regard to the occurrence of destructive insect cnemies, only a small amount of evidence was obtained. Various coccids, such as certain wild cochineal insects and Diaspis, were met with on some of the islands, but were not found to injure the plants to any marked degree. Certain lepidoptera, apparently species of Melitara and Mimorista, occur in some of the islands, and have the same destructive effects on prickly-pear as do their allies in the United States. They, however, appear to be rather uncommon in the West Indies.

The chief maladies met with were the Anthracmose or "Shot-hole" disease caused by Gloosporium, and another apparently previously undescribed, which we have termed the "Zone-spot Disease." Certain climatic conditious seem to be necessary before these fungi can exercise their maximun effect. The former disease is similar to that met with in the United States. The "Zone-spot" disease not infrequently brings about the destruction of the attacked stem-joints.

The methods of utilising eacti in the West Indies would not be of much service in Queensland in counteracting the spread of prickly-pear. 


\section{SOUTH AMERICA.}

One menber of this Commission (Tryon, 1911, pp. 15, 19) had already drawn attention in Queensland to the presence of two serious enemies of Prickly-pear in Argentina, viz., the "gangrena blanca" due to a fungus parasite, and the "agusanamiento", an insect borer. Moreover, while making inquiry in Italy, he met in Rome Dr. C. Spegazzini, the well-known botanist of La Plata, who has written extensively on the Cactaces and fungi of the Argentine Republic. Dr. Spegazzini stated that there was a rich cactus flora in that country. In regard to the possibility of using insects or disease in destroying pricklypear, he thought that Argentina should be searched for such enemies, and called attention to some that he had met with there. Amongst the insects were the following:-(1) A Coccus or Pseudococcus related to $C$. cacti and which was common on indigenous speeies of Opuntia, but apparently not fatal to any of them, though it appeared to be capable of checking the plant's growth; (2) a Diaspid scale insect which he regarded as a serious enemy of Cereus, but not so injurious to Opuntias; and (3) the caterpillar of a lepidopteron, which burrowed into the stem joints and with which there was associated the larva of a fly. In regard to diseases, he referred to a serious malady caused by a fungus, Sclerotinia opuntiarum, which was capable of attacking all kinds of Cactaceæ, but especially Opuntia decumana (ficus-indica) and Pilocereus formosissimus. The stem joints, roots, and fruit becoming infected during the winter months.

In view of such information, it was deemed advisable to carry out investigations in South America. In order to economise time, it was decided that this should be carried out by one member of the Commission, while the other was engaged in studying the Cactaceæ and their enemies in the various West Indian islands.

\section{COLOMBIA.}

On the voyage from Jamaica to Barbados, the steamer called at Cartagena and Puerto Colombia, two ports on the North coast of the Republic of Colombia, affording a brief opportunity to inspect the Cactaceæ. Between Puerto Colombia (Savanilla) and Barranquilla one may see various kinds of Cerens, including $C$. pterogonus, Lem., and, in addition, a low.growing Opuntia closely resembling the Jamaican O. tuna in the general characters of the plant, particularly the spines. This latter species was especially abundant in the low sandy country around the mouth of the Magdalena River.

\section{SOUTH BRAZIL.}

A journey was made from Barbadoes to Rio de Janeiro, at whose Botanical Gardens Dr. J. C. Willis (the Director) and Dr. A. Loefgren were interviewed. These botanists suggested that that portion of the State of Bahia which is near the valley of the San Francisco River should be visited, as that region is very dry and supports an abundant cactus flor, one of the species, $O$. inamona, Schum. (they believed), closely resembling the pest pear of Queensland. Although certain other indigenous Brazilian species such as $O$. monacantha and $O$. nigricans* occur naturalised in Eastern Australia, yet they are found only in scattered situations in the moister parts of South-Eastern Brazil which are not readily accessible. The adjacent States of Ceara and Pernambuco also have dry tracts with a cactus flora similar to Bahia.

It was decided to visit Bahia on the roturn journey from Chili and Argentina and to oun it visiting certain other countries-e.g., Peru, Northern Chili, and Bolivia, on account of the amount of time which would bc necessary to make even a casual examination of the Pricklypear of those regions.

\section{ARGENTINA AND CHILI.}

After arrival at Buenos Aires a visit was paid to the Botanical Gardens at Palermo and also to the neighbouring city of La Plata, where much assistance was rendered by Dr. C. Spegazzini, whom the Commission had met in Rome, and who, as already mentioned, has given considerable attention to the fungi and Cactacex of Argentina. The collection of Opuntias at La Plata was examined and certain enemies were pointed out by this botanist. From him it was ascertained that though species of Opuntia occurred in the moist wooded regions near the Paraguayan and Brazilian frontiers, yet the chief Prickly-pear region was in the West and North-West of the republic, along the foothills of the Cordillera, particularly in the States of Mendoza, Salta, Jujuy, Tucuman, Catamarca, Santiago d'Estero, La Rioja, and Cordoba, where arid conditions prevailed. As Mendoza is situated on the transcontinental railway line from Buenos Aires to Valparaiso, it was łecided to examine the region surrounding that city on the return journey from Chili.

While crossing the Andes, it was noticed that abundant low-growing Prickly-pears (O. sulfurea, Gillies) and Cereus (Echinopsis leucantha, Walp.; Pilocereus rhodacanthus, S.D.; Cereus candicans, Gillies; C. strigosus, S.D.; and others) were present in the lower altitudes, but that they all disappeared from the flora after an elevation of about 6,000 feet had been reached, $C$. strigosus, a plant of about 4-6 feet high, extending to a somewhat higher altitude than the others. On the Chilian side, after the 6,000-feet level has been passed on the downward journey, one meets with great numbers of a tall species of Cereus, presumably $C$. chilensis, Colla, whose range extends to the coast, this plant growing at Valparaiso. $O$. ficus-indica may be seen fairly commonly in parts of Chili such as Los Andes, Llaillai, Santiago (de Chili), and Valparaiso, where it is grown for its fruit just as in Southerm Europe.

A visit was paid to Dr. Soehrens, Director of the Botanical Gardens at Santiago, where a small collection of Cactaceæ is housed. Amongst them

* Dr. Loefgren stated that $O$. nigricans is met with as a rather rare plant near Itabira de Matto Dentro in the State of Minas Gereas; and that $O$. monacantha was to found as scattered plants in wooded country in the States of San Paulo, Minas Gereas and Rio Grand de Sul. $O$ brasiliensis was also to be found in the latter localities. Schumann (1899, p. 728) thought that the home of $O$ nigricans was probably Mexico. 
is the type specimen of $O$. airampo, Phil., * a species which Schumann (1899, p. 718) considered to be a synonym of O.vinermis. $\dagger$ They are distinct though they bear certain resemblance in their habit and in the characters of their fruit and joints. The specimen of $O$. uirampo came from Arequipa, Peru. The term "airampo" is applied by the inhabitants of parts of Peru, Bolivia, Northern Argentina, and Northern Chili to any Opuntia whose fruit possesses a red juice.

As Dr. Sochrens stated that Opuntias are rarities in Chili, except in the extreme northern part-a very arid region-the return journey to Mendoza was made. Mendoza is situated at an elevation of about 2,500 feet in an arid zone which extends northwards along the Andean foothills on the Argentine side. The whole of this dry area contains an abundant flora belonging to the Cactacer, especially to the genera Opuntia, Echinocactus, Echinopsis, Cereus, and Pilocereus. The more northern parts of the region are richer in individual species, as may be seen from Dr. Spegazzini's work (1905) on the Cactacere of Argentina and Uruguay. On the bills close to the city, both $O$. sulfurea, Gillies, and $O$. (Tephrocactus) diademata are extremely common (Schumann, 1899, pp. 692 and 745; Spegazzini, 1905 , p. 518 ; p. 510). Besides these there are a thin, semi-prostrate species of Cereus; an Echinopsis; a small Echinocactus (?E. intricatissima, Speg.); and two very common forms of clumpy Cereus, one of which is probably $C$. baumanni. Spegazzini (1905) mentions a large number of species of Cereus and also Opuntia (Tephrocactus) aoracantha as occurring in the neighbourhood of Mcndoza, some of them being seen by us on the higher lands on the transandine journey.

On reaching Buenos Aires, it was found that there was not sufficient time to allow of an examination of the Opuntias occurring near Montevideo, in Uruguay. It is in that locality that there occurs indigenously $O$. aurantiaca, Gillies (Spegazzini, 1905, p. 514), a plant which is the notorious "jointed cactus"' of Cape Colony, and which has become naturalised near Roma and Warwick, in Queensland.

\section{NORTH-EAST BRAZIL.}

The field investigations in Brazil were carried out in two localities, Bomfin (Villa Nova) and Barrinha (Angico), situated in the dry "catinga" country in the State of Bahia and near the valley of the San Francisco River. The following forms, indicated by their local names on account of the uncertainty of scientific indentification of some, were met with at the latter place, cacti being rather more abundant there than at the former.

1. ESPINHA DE SAO AN'TONIO (ST. ANTHONY'S ThorN ). - This Peireskia is also recorded for Bahia by Schumann (1899, p. 760) under the

* This name has been published in Schumann's monograph as $O$. acrampo, and it is under this latter name that Mr. Maiden (1912) has referred to it when comparing it with the pest pear of Queensland and New South Wales.

† Schumann also includes both 0 . stricta, Haw., a cultivated form, and $O$. loevis, Coulter, from Árizona as synonyms of $O$. inermis. They are both distinct from it, O. stricta apparently being related to the group of species which occur in North Eastern Argentina-e.g., o. retrorsa, Speg., O. chakensis, Speg., \&c. O. inermis is a West Indian plant (Cuba). name $P$. aculeata, Mill., with $P$. brasiliensis as a synonym. As it is a Linnean species (Cactus peireskia, L.) its name should be $P$. peirestia, a combination used by Spegazzini (1905, p. 521) in recording the occurrence of the plant in Argentina.

\section{Cabeca de Frade (The Priest's Head).-} This plant is Melocactus depressus, Hook (Schumann, 1899 , p. 457 ), the names $M$. pentacentrus, Lem., and $M$. goniodacanthus, Lem., being evidently synonyms. $M$. oreas, Miq., should probably also be included.

3. Mandagaru de Facho.-A very tall treelike Cereus which somewhat resembles Cereus peruvianus in general appearance, and commonly attains a greater height than any of the surround. ing vegetation. The branches are practically round, with numerous low ridges armed with small spines. The term "mandagaru" is used for tree-forms of Cereus in both localities visited.

4. Mandagaru DE BoI.-This is also a tall Cereus, but it is much commoner and appears to be more widely distributed in the State of Bahia than the preceding species. The stems are greyish or greenish and have typically six ridges, each of whose areoles has one long and several short spines, the former reaching 6 inches in length. It is known simply as Mandagaru in Bomfin. It appears to be C. jamacaru, D.C. (Schumann, 1899, p. 112), whose specific name is said to be its native name.

5. Chiquechique Verdadeiro.-This Cereus is a very spiny form reaching up to eight feet iu height, and whose stem bears nine ridges closely beset with spines from one to nearly four inches in length. It forms a clump whose individual st:iLs inay lean over and become more or less plostrate. It is more common at Bomfin than at Angico. The term chiquechique is applied to those species of Cereus, Pilocereus, \&c., which do not form trees.

6. CalXa Cubt; Chiquechique de Rabo de Cachorra (The Dog-tail Chiquechique).-This slender branching species of Cereus is known by the former name in Angico and by the latter in Bomfin, where it is much more common. Its branches reach a length of 3 or 4 feet.

7. At Angico there may be met with oceasionally a greyish, semi-prostrate, branchirig Cereus resembling No. 6 in habit, but whose stem is about an inch in diameter and bears three or four prominent ridges with areoles about $11 \%$ inches apart and bearing five or six long brown spines. The tendency to form joints is quite noticcable. There does not appear to be any local name for this species.

8. Chiquechique de Rabo de Raposa (ThF Fox-TAII Cimquechique).-This species of Cereus is also a semi-prostrate branching plan possessing a diameter of $11 / 2$ to 2 inches, with a jointed stem, the joints being separated by in mass of rather long, red-brown spines. The round stem bears numerous small ridges whese closely set arcoles are well supplied with small spines. It is rather thinner than the Caixa Cube. The joints are capable of growth and romind one a little of some of the Cylindropuntias. Its appearance suggests Schumann's series "clavatae, of Opuntia, all of which are natives of Mexico and the adjacent regions. This plant was seen only at Angico. 
9. Chiquechique de Cabeca Branca; Cabeca Branca (The White-hended ChiqueCH1QUe).-This species of Cephalocereus is extremcly common between Bomfin and Angico and at the latter place, though it does not seem to occur at Bomfin. It branches at the ground to form numerous tall, simple round stems from 6 to 10 or more feet in height, each stem bearing abundant small ridges with very numerous thin yellowish spines an inch long, as well as a great quantity of "wool," especially on the distal portion.

10. Between Jaguarary and Bomfin in the schist country, one may see from the train a very tall, thin, straight Cereus with a rounded stem. With the exception of an occasional tree-cereus (Mandagaru de boi), cacti were not evident in that type of country.

11. Palmadora (The Spiny Palmadora).The name palmadora is often applied to any Opuntia, but in the districts visited, it is generally used to designate a species with rather small, thin joints armed with abundant brittle, white or pale yellowish spines (darkening with age) four to six on each areole, the longest being about an inch in length. It is an erect plant and seems to prefer shade conditions, where it may reach a height of 8 feet, its usual height being about 5 feet. The green fruit on reaching the ground readily grow. This Prickly-pear is very common and is far less restricted in range than the next species to be mentioned.

12. Culpa (the Palmadora without evident spines).-This very low-growing plant, $O$. cuipa Web. Syn. O. inamœna, Sch. (1899, p. $742 ; 1890$ p. 306) is common near Angico, though it is also to be met with occasionally near Bomfin in drier situations. In the former locality it is known as Cuipa, whereas in the latter it does not seem to have received a special name. Weber has attached the name to a plant of quite similar habit, but armed with two or three weak spines in each areole (Schumann, 1903, p. 162). The edible fruits are orange or yellowish in each case. Its locality is stated to be Pernambuco. In $O$. ina mona one may find one or two very small spines on each areole as described for $O$. cuipa, but they readily fall off. This explains Schumann's description of the species as unarmed. The two names are synonymous, $O$. cuipa possessing priority.

13. Palmadora Grande.-This plant, which is not indigenous, resembles the Mission Pear ( $O$. castilla, Griffiths) of South-Western United States of Ameriea, and probably belongs to that species or to $O$. ficus-indica. The young plants have abundant white spines and resemble $O$. amyclea in appearance, but the spines generally drop off later. It is more or less cultivated for the sake of its joints, which are fed to stock.

Schumann (1899, p. 718) in his account of Pilocereus exerens, Sch., mentions that it occurs in the States of Bahia and Pernambuco and that it is called "Fascheiro" by the natives. As detailed descriptions of the various species met with were not taken, the identification of this Pilocereus with any of the above is not attempted. The same author refers to a few other cacti from Bahia, e.g., O. monacantha, Rhipsalis, \&c., but they probably belong to the moister and more wooded areas of that large State.

\section{DESTRUCTION BY DISEASE.}

No fungoid or bacterial disease of any value in controlling the spread of Prickly Pear was seen during the investigations in South America.

Shot Hole Disease.-The Shot Hole Fungus (probably Glocosporium lunatum) was encountered in widely separated localities. The injuries produced by it have already been referred to in the section dealing with our work in the United States of America. The black rot which it causes under damp weather conditions in Southern Texas, does not seem to occur under the more arid climate of Western Argentina and Bahia. It was found on the Uruguayan species $O$. arechavaleto, Speg. (allied to $O$. monacantha) and on $O$. chakensis, Speg., at La Plata; on O. ficus-indica in Buenos Aires; at Bomfin and Angico on both $O$. cuipa and the spiny Palmadora. Occasionally gumming was associated with the injury.

Wolf (1912, p. 112) refers to the presence of a Glœosporium, $G$. opuntice, Ell. and Ever., on $O$. brasiliensis, which is a South American species.

White Rot; Sclerotium Disease.-What is regarded as a much more serious fungoid disease is that caused in Argentina by Sclerotium opuntiarum, Speg. (1898, p. 354), whose perfect stage is Sclerotinia opuntiarum, Speg. (1899, p. 18). In his description of the latter stage of this fungus Dr. Spegazzini states (p. 19) that the parasite is a formidable enemy of all Cactacex, especially during winter. A white cotton-like mass of mycelium becomes developed below the epidermis in the parenchyma, which becomes destroyed and putrefies. Sclerotia are produced and then liberated, and from them develops the ascopore stage in the following autumn. A search in company with Dr. Spegazzini failed to reveal its presence at La Plata (Jan., 1914). This botanist in 1910 recorded the occurrence of the Sclerotinia stage, $S$. opuntiarum, in rotten trunks of Pilocereus formosissimus, Lab. (= Cereus posacana, Weber, in Schumann, 1899) near Mendoza.

The same malady is referred to under the name of gangrena blanca, i.e., the white rot, by an anonymous writer in the Chronica Agricola (Buenos Aires), 1908, pp. 147-8, who calls the fungus Sclerotinia cactorum. In order to decrease the ravages, he suggests the frequent inspection of plants and the destruction of those found to be infected.

The introduction of this Sclerotinia into Queensland is not at present recommended.

In 1898 Dr. Spegazzini (1898, p. 353) gave an account of another Sclerotium, $S$. cactorum, but has not included it as such in his later work on the Argentine fungi. Perhaps it is synony. mous with his $S$. opuntiarum.

Other fungi have been described as occurring parasitically or saprophytically on South Americau Cactacere by Spegazzini, but they are of little or no economic importance.

Aunongst these are Perisporium mendozanum, Speg., 1899, p. 227, found on $P$. aoracantha near Mendoza ; Ascidium opuntice, Magn., found by Magnus (1898, 1. 151) on a Bolivian Opuntia and by Spegazzini on $O$. digitalis in Argentina (Speg., 1909, p. 321); Trulla nigerrima on 


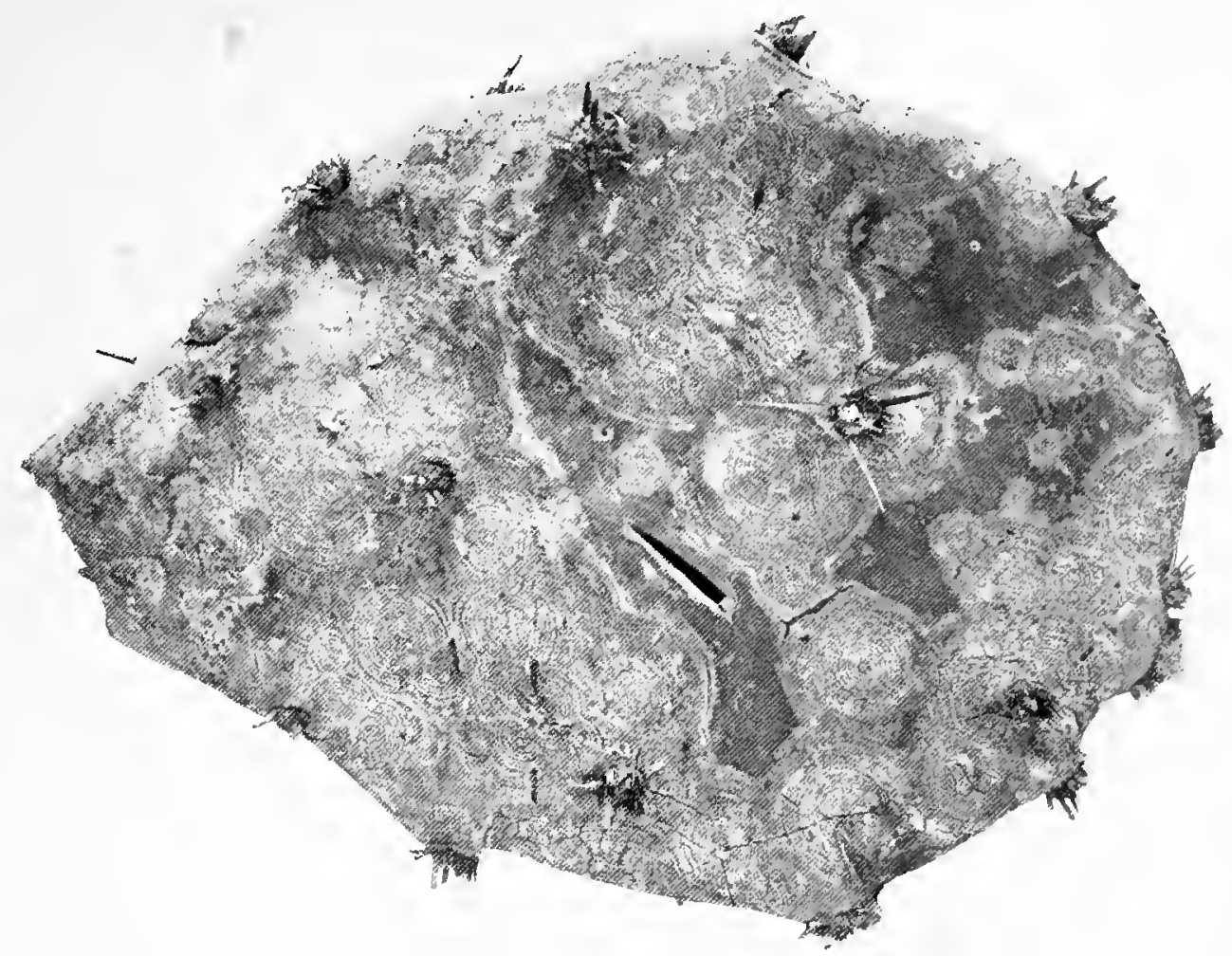

Fig. 59.-Joint of 0 . dillenii showing stages of the "Zone Spot Disease." Photo.. Dept. Agrirulture. Brisbane. Antigua, West Indies.

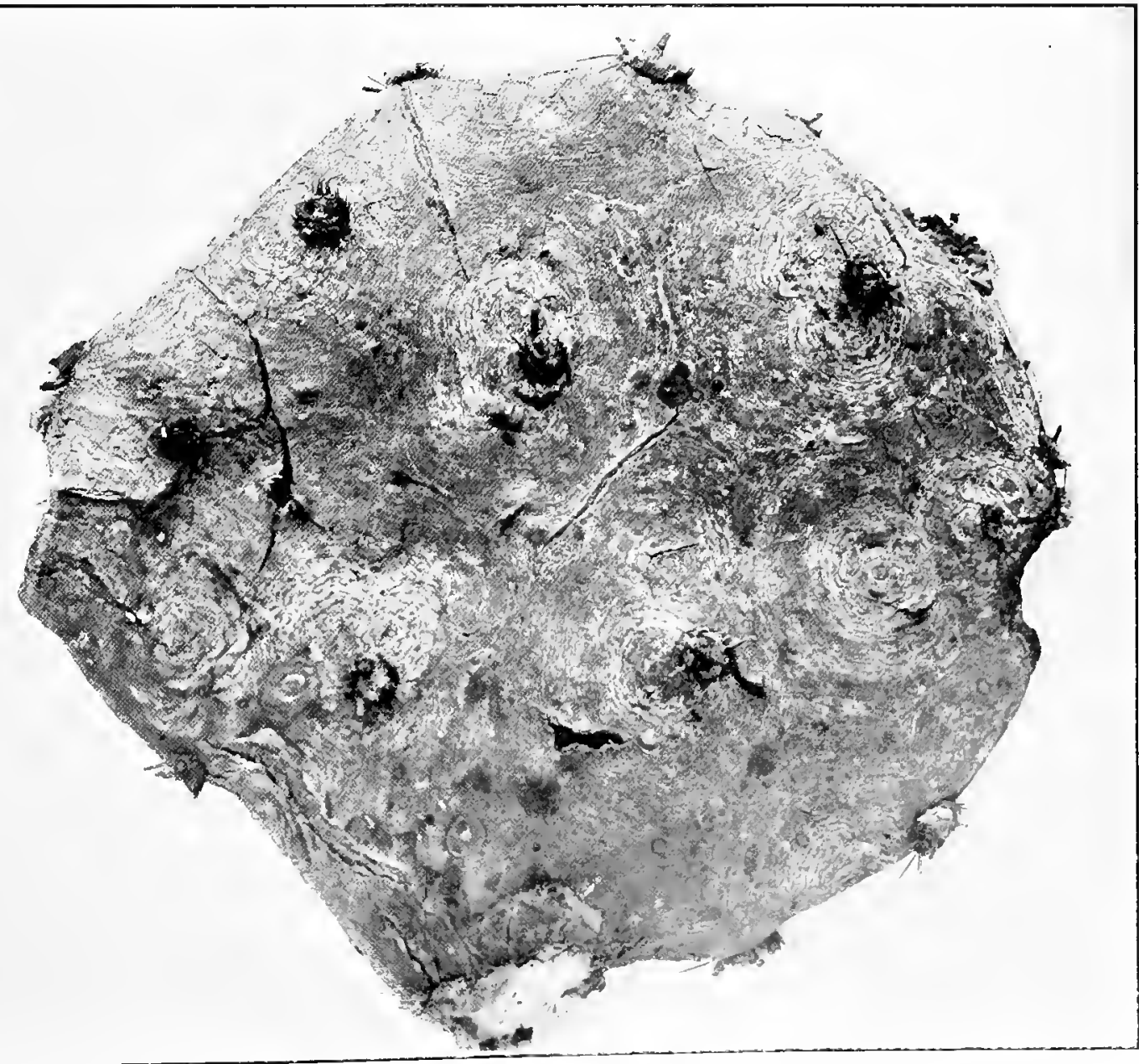

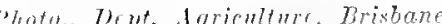

Fig. 60.-Later stage of "Zone Spot Disease" on O. dill"nil, showing destruction of the superficial tissues in progless. Antigna. 

Rhipsalis lorentziana at La Plata (Speg., 1910 , p. 407) ; Macrophoma phyllocacti, Speg., on cultivated Phylloeactus at La Plata (1910, p. 349); Pyrenochoeta cereicola, Speg., on Cereus haenkeanus in Misiones, North Argentina (1910, p. 353); Sphoropsis cereicola, Spcg., on Cereus triangularis cultivated at La Plata (1910, p. 361) ; Didymochceta opuntiicola, Speg., on fruits of $O$. diademata, (N.W. Argentina $(1910$, p. 369) ; Diplodia cerei-triangularis, Speg., on Cereus triangularis cultivated La Plata $(1910$, p. 370$)$; Staganospora opuntice, Speg., on $O$. aurantiaca at Mendoza (1910, p. 372) ; Didymella acanthophila, Speg., on spines of $O$. aurantiaca at Mendoza (1912, p. 53) ; Montagnella opuntiarum, Speg., var. minor, on Rhipsalis lumbricoidis at La Plata, and var. microcarpa on Cerens candicans near Mendoza (Speg., 1909, p. 422; Rosellinia opuntiicola, Speg., on 0 . ficus-indica in Argentina (1909, p. 338); Ophiochceta cereicola, Speg., on Cereus lamprochlorus salinicola, cultivated La Plata $(1902$, p. 73) and- on Echinopsis from Santiago del Estero (Speg., 1909, p. 403; Pyrenochoeta spinicola, Speg. (1902, p. 81) on $O$. aor cantha; Teichospora cercina, Speg., Cereus spegazzinii, cultivated La Plata (1909, p. 396) ; Broomeia congregata, var. argentinensis, Speg., on dead Opurtias in Western Argentina (1912, p. 15) ; Phomo rhipsalidicola, Speg., on Rhipsalis lorentziana--cultivated La Plata (1512, p. 112); Uromyces peireslice, Diet., on Peireskia sacharosae from Salta, Argentina (Speg., 1909 , p. 313).

\section{INSECT ENEMIES.}

The most important insect enemies seen during the investigations in South America were the two allied moths whose larvæ bore into the joints of certain Prickly Pears and other cacti and eventually bring about their destruction. One of these is Zophodia cactorum, Berg. (1885, pp. 13-14), belonging to the Phycitideæ, the other"the Mendoza moth-borer"-being not yet identified, though apparently also a Phycitid. Our attention was drawn to the former by Dr. C. Spegazzini, at La Plata.

Zophodia CACTORUM, Berg. (The Argentine Moth Borer).-The larva when mature is a yellowish or orange-coloured grub about $3 / 4$-inch in length. It has a dark, shining head and there are usually dark, sharply-defined, transverse bands on part of the dorsum of each segment. A rather thin cocoon is spun, generally on the ground under fallen joints. Specimens which were being transported to Queensland by the Commission passed through the pupa stage in about three weeks. The grey moth is about twothirds of an inch in length and has a wing expanse of from one to nearly one and a-half inches. Eggs are laid in a long single row which is attached by one end in a similar manner to those of Melitara referred to in the section of this report dealing with the work in the United States of America (Hunter Pratt and Mitehell, 1912 , plate 7 , fig. 1).
The young on hatching are very active and begin to bore into the segment under cover of a delicate silky web, many of them entering through one aperture. One or more holes are made and once an entry is gained the fleshy parenchyma of the joint is rapidly eaten, severa. grubs being usually found at work there. The dèbris is moist and bright green-the colour of the plant pulp-and is rejected through one of the apertures made in the segment. If left to themselves the result of their invasion is the eating out of all or most of the tissues, merely the epidermis being left. The larvæ can frequently be seen quite readily in the tissues, which become translucent during the attacks. They are very active and travel from joint to joint and begin work again. Berg mentions that the flowers are also attacked. The injury caused by the Zophodia is greatly increased by the invasion of lowly organisms and of scavenging Diptera which breed in the affected joint, the larvæ of the latter soon reducing the rest of the tissues of the segment to a dark-coloured fetid liquid which may remain in the dead hollowed-out joint for a long time, as the epidermis forms a bag.

The insect was noticed at work at La Platn and in the Botanical Gardens, Buenos Aires, during January and February, 1914. No plant other than Cactaceæ was known to be affected by it. Amongst the Prickly Pears seen to be attacked in these two localities were the following:-

1. Opuntia quimilo, Sch.-cultivated at La Plata. This is an arboreseent species with a few long spines indigenous to the North-west of Argentina and allied to the spineless $O$. anacantha, as woll as to $O$. stricta, both of which are very closely related.

2. O. anacantha.

3. O. decumana-cultivated at La Plata.

4. O. maxima (=o. robusta)-a Mexican species cultivated at La Plata.

5. 0 . argentina-cultivated at Buenos Aires-allied to and regarded by Schumann $(1899$, p. 657) as identical with the common Southern Brazilian treepear, $O$. brasiliensis, though Spegazzini (1905, p. 508) believes that they are distinet.

6. O. monacantha-cultivated at Buenos Aires. This is one of the Queensland pest pears (Suttor River, Rockhampton, \&c.).

7. O. chakensis, Speg.-cultivated at La Plata. This arborescent species closely resembles $O$. stricta in regard to its joints.

8. O. ficus-indica-cultivated at Buenos Aires. This species is widely cultivated in Argentina and Chili, particularly in the drier zones, for the sake of its fruit (Speg., 1906, p. 512)-hence the suggestion in the "Chronica Agricola" that all parts fonnd to be attacked by the borer should be removed and bnrnt. The Westwood and particularly the Tellow Mexican, Prickly Pears of Queensland are related to this species. 
9. O. cmoryi-enltivated at Buenos Aires. i) plant under this name in the Palermo Botanie Gardens was found to be attacked. The specimen appeared to be a typical $O$. aurantiaca, whicls is a native of Uruguay and ocenrs naturalised near Roma, Queensland. O. emoryi as described by Sehumanm (1899, p. 664) is a different plant whose habitat is Northern Mexico and the adjacent dry parts of Arizona.

10. It was found experimentally that it would feed on $O$. cuipa, from North eastern Brazil, though not partial to it.

11. The pest pear of Oahu (Hawaiian Islands) is readily attaeked and sinee this white twisted-spined species is related to the $O$. ficus-indica group and is very mneli like the Westwood pear of the Roekhampton district, there is no doubt that it will prove an enemy to it as well as to the related Yellow Mexican pear whieh oceurs sparingly in the same distriet.

12. Since arrival in Queensland it has been found to be able to attaek the common pest pear of the Brisbane distriet.

Berg, in his original account, mentioned that the larva of Zophodia cactorum was taken in flowers of Rhipsalis lumbricoides, S.D., in Truguay and on Opuntia sp. in Buenos Aires. He stated that this species was closely related to $Z$. bollii Zell, and was indigenous to Uruguay and Argentina. Dr. Spegazzini, who indicated to the Commission the presence of this inseet at La Plata, mentioned that it was more eommon in the former republie.

The aecount given by an anonymous writer in the "Chronica Agricola" for 1908 (p. 147-ruoted by Tryon, 1911, p. 19) of a boring insect enemy of the Prickly Pear shows that the same organism is being referred to. Its destructive effects on Opuntias are there regarded as being sufficiently serious to give rise to a suggestion that measures should be taken to cope with it.

Zophodia cactorum, as far as we have been able to aseertain, is restricted to cactaceous plants for its food supply.

It should be mentioned that another species of Zophodia, $Z$. dilatifasciella, Ragonot, has been identified from various localities in Texas, where it is said to feed on Coccus confusus, the common wild cochineal of that region. (Hunter, Pratt, and Mitehell, 1912, p. 46.)

A considerable number of more or less fullygrown eaterpillars and a supply of $O$. decumana. one of its food plants, were colleeted at La Plata towards the end of last January, and about a week later many of them had pupated. A fair proportion, however, failed to do so, this being no doubt due to injury during transportation. As already stated above, about three weeks was spent in the chrysalis stage. Some of the moths laid "egg sticks," and it was from these eggs that the spreeimens whieh the Commission brought to Queensland were hatched.
This introduetion of the inseet to Qucensland has not, however, resulted in its establisinment there. This apparently is the outcome of certain of its habits being unknown and aecordingly not taken into consideration. The eaterpillars in question had originally issued from eggs about the end of Mareh just before the arrival of the Commission at Honolulu, and were fed on segments of $O$. monacantha, $O$. cuipa \&c., until that port was reached, when they were given joints of the Opuntia prevalent there to feed upon. This they partook of with eharacteristic activity. On arrival at Sydney at the end of April they were still in the eaterpillar condition and feeding. Thenee they were transmitted to Queensland. Here the employment of the Honolulu Priekly-pear was eontinued for awhile, but it having been meanwhile found that they would feed on the common loeal Opuntia (O. inermis) this was soon substituted, and they proved only slightly less partial to it than the Honolulu pest pear. However, they eonstantly emerged from the interior of the stem-joints, and wandered around spinning a little silk as if to pupate. They did not, however, on these oceasions turn into the ehrysalis condition, but gnawing into fresh "pear" resumed their feeding. This they did again and again. It was evidently, from what was afterwards inferred, the display of an attempt on their part to overwinter, but the temperature experieneed during our so-called cold months was evidently not suffieiently low to promote the condition of lethargy that for their overwintering as eaterpillars was essential. It was considered, however, that their temporary abandonment of the Opuntia joints was due to decay of the tissne surrounding that in which they subsisted in accordance with the requirements of a habit commonly pursued, and aceordingly they were not provided with especially cold quarters. Under the eircumstances they became weaker and weaker and died off one after another, usually outside the plant in whieh they had thrived. Two eventually spun cocoons but were not able to transform to chrysalides, and suceumbed within these, becoming dried up. However, they had lived several months, and now (8th October) after this protraeted period of activity the forty examples brought to Brisbane by the Commission have been reduced to three. This has resulted notwithstanding the fact that the insects had been cared for by one of the Commission personally and by two of his assistant entomologists since their arrival here.

It has, however, been established that Zophadia cactorum will feed upon the common "Pest Pear" of Queensland and is destructive to it, possibly to the extent exereised on other Opuntias in its native eountry, but that under our conditions it apparently would undergo very slow numerical increase.

Dr. C. Spegazzini, La Plata, Argentina, has kindly offered to assist, if desired, in forwarding specimens of this formidable enemy of so many of the Cactaeex.

The Mendoza Moth Borer.-The injury produced by the larva of this moth is similar to that caused by Zophodia. The exereta, however, are yellowish or brownish and are dry. 'The rotten eondition previously noted, together with abundant fly infection, is very common. 
The joint may become hollowed out to such an extent that only the spines and epidermis are left either dry or as a bag containing a putrid dark fluid. At other times a black, more or less spongy mass remains in the place of the tissues. It is quite conmon to see whole branches, or even entire plants, killed. Sometimes the attacked joint collapses and then the distal seginents may come in eontact witl the ground and grow. The effects of this moth, assisted no doubt by the scavenging diptera, ean be seen very commonly in the arid country surrounding Mendoza and extending up the Andes for many miles on each side of the transandine railway line.

The effect on the invaded segment and the appearance of the insect excreta reminded one strikingly of what was found as a result of the attacks of Melitara spp. on Prickly Pears in the dry zones of the United States.

The host-plants are $O$. sulfurea especially, and quite commonly both species of Cereus which abound on the Cerro Pilar, near Mendoza, are attacked. It is exceptional to find O. (Tephrocactus) diademata invaded, this being perhaps due to its tougher epidermis. The Cereus spp. are hollowed out in a similar manner to the $O$. sulfurea. In the latter case the injury commonly extends from joint to joint and may involve the portions below ground. Old and young joints alike are attacked.

At Mendoza no plants other than Cactacese were noticed as being attacked in a similar manner to that described above.

A prolonged search of several days failed to reveal more than a few of the grubs at work (early February, 1914). They were seen to resemble the Zophodia larvæ in size, but lacked the colouring and transverse bands of the latter. Two cocoons with pupæ were found, one in a hollow joint of $O$. sulfurea and the other under a segment lying on the ground. Oue of these bred out into a grey moth of the same size and nakedeve appearance as the Zophodia.

Undetermined Larva.-A small insect larva about $1 / 4$-inch in length, with a cream-coloured body and a reddish-brown head was found on a few occasions on $O$. sulfurea near Mendoza, living in a cavity or tunnel which it had eaten out underneath a mass of cochineal in each case. The base of a joint was the situation which seemed to be preferred. A loose web was also present. As dead cochineal insects were seen in each instance and as the head of the larva was sometimes stained with cochineal dye, it may be that the larva was predatory on that insect. Sometimes the tunnels were fairly extensive and then the dèbris was like that produced by the Mendoza moth. Whether the larva belonged to the latter or whether it was an enemy of the coccid, was not satisfactorily determined.

CEceticus Platensis, Berg.-This small larva, which lives in a conical " house" and is popularly known in Argentina as " bicho de canasto," was found feeding on the surface of joints of $O$. decumana cultivated by Dr. Spegazzini at La Plata. It commonly causes the destruction of young segments, but those which are rather older recover, the injury healing over and a scar being produced exactly like that caused in Texas by Mimorista flaridissmalis, Grote, on $O$. lindhemeri and other species. On arcount of the destruction of young joints this insect, like the Mimorista, evidently assises in coutrolling the sprearl of Opuntias.

Similar injuries were secn on 0 . sulf urea near Mendoza, and the same rumark applies also to $O$. ruipa and the "spiny palmadora" at Bomfin and Angice (Bahia), where a (*onsiderable destruction of young joints had evidently taken plaee, especially in the case of the last-named plant. However, in these instances no insects were found associater with the condition and there is no direct evidence as to the kind of insect producing them.

Wild Cochineal, Coccus spp.-A species of wild eochineal was found to be rather common on $O$. sulfurea in the neighbourhood of Mendoza. Though sometimes found in abundance on a segment of $O$. sulfurea, no injury beyond a slight chlorosis was recognisable. It should be mentioned, however, that the coccids were being preyed on by other insects. A description of Coccus argentinus, Dominguez, 1907, whieh is said by Autran to feed on $O$. ficus-indica and $O$. aurantiaca, was not available for comparison. Dr. Spegazzini informed us that a wild cochineal occurs also at Santiago del Estero, but he did not mention the host species.

Another species of cochineal insect which seems to be rare, was found at Angico in the State of Bahia, in North-west Brazil, on the spiny Opuntia which is frequently encountered there. It has the woolly appearance common to all "wild cochineals," as distinct from the true Coccus cacti L. No injury appeared to be occasioned by the presence of the insect. From specimens obtained, there have bred out a hymenopterous parasite (Ichneumonidse) as well as diptera belonging to the Stratiomyiidre. Hempel, in his work on Brazilian Coccids (1900), does not refer to the last-mentioned cochineal, but mentions only Coccus cacti, Lin., as oecurring in Brazil.

One member of this Commission has shown that the Wild Cochineal (Coccus indicus, Green), which has been so destructive to $O$. monacantha in India and Ceylon, was first introduced into India by a Captain Neilson, who brought it from Brazil (Tryon, 1910, 1911). This matter has sinee been referred to in the Commission's report on the investigations in India, as well as in a paper by Mr. E. E. Green (1912, p. 87). Inquiry in Rio de Janeiro failed to gain any information regarc ing the occurrence of any Coceus on $O$. mona cantha, a plant indigenous to Southern Brazil and adjacent wooded cointry in Uruguay and Argentina. In India and Ceylon the insect is found to live only on that species, while the allied variety, $C$. capensis, from Cape Colony, attacks only that speeies and Nopalea cochinelifera. It would thus seem reasonable to believe that $O$. monacantha is at least one of the host plants. Perhaps a careful search in Southern Brazil (Sao Paulo and Rio Grande do Sul) might reveal its presence. The Argentine species from Mendoza would not make any attempt to leave its special host-plant in order to feed on segments of $O$. monacantha placed in the same box. There is the possibility that $C$. indicus* is not a South American species at all, but that it may have

* This matter has been referred to earlier in the sections dealing with India and Mexico. 
been introdnced just as the trne cochineal $(C$. (an:ti) evidently has been. The insect from Bahia is prohably a distinet speeies which has not yet recerived attention.

The true cochineal insect (Coccus cacti, L.) was introduced long ago into Peru (Hunter, Pratt, and Mitchell, 1912, p. 42). Hempel (1900, p. 380) has recorded its presenee in Rio Grande do Sul in Southern Brazil.

Insects Producing Minor Injuries.-A few segments of $O$. cuipa from Angico (Bahia) were found to be attacked by a larva living in tunnels just below the epidermis. The injured portion was apparent as a series of intererossing white traeks, the tissues above which later became enticularised or suberised and then appeared as brownish areas. The injury is similar to that produeed in Texas by Marmara opuntiella.

At Angico (Bahia), the foxtail ehiquechique (Cereus sp.) was found to be attacked by a boring larva (lepidopterous or coleopterous?) whose tunnels were seen to pass down into the stems alongside the vascular bundle, and passing from joint to joint. At the point of entry (exit?) a small dark deeayed area was found in eaeh ease. Sometimes the injury was less extensive and no tunnel was produced, merely a small hollowedout area being the result. The insect, speeimens of whieh were not found, frequently attacks the stem near the junetion of joints and may kill the part, though the distal portions of the branch continue to grow-probably only until the store of food beeomes used up. No exereta were found at the aperture leading into the eavity, but otherwise the injury reminded one of that eaused by the larvæ (Moncilema and Melitara, spp.) found in Cylindropuntias in Arizona, United States of America.

In joints of the "spiny palmadora" at Angico, there was found on very few occasions, a elean aperture leading into a large eavity where some insect larva had evidently been at work, the dèbris being tightly packed along one side of the cavity in such a way as described for certain speeies of the eactus moth Melitara in Prickly Pears (O. lindheimeri, \&e.), in Texas. The attaeked joints were not destroyed, the formation of a tumour being the main result.

Another larva was sometimes found which burrowed into the joint of this Opuntia forming a fairly large cavity, but whieh did not kill it. Green exereta were deposited outside the apertrure (Angieo).

A small larva was found on one occasion destroying a flower-bud of this same species (Angieo).

A beetle, Cactophagus striatoforatus, Gyllenhal, is recorded by Champion (p. 84) as attaeking Cereus in Colombia.

Various species of grasshoppers were seen making small lesions by feeding while resting on Cereus spp., and $O$. sulfurea at Mendoza, and on O. cuipa and the "spiny palmadora" at Angico and Bomfin (Bahia).

A plant-bug resembling a large Narnia was found to attack both $O$. cuipa and the spiny Opuntia at Angico and Bomfin, as well as the tall Cereus (Mandagaru de boi). Like the plant bugs Narnia and Chelinidea in the United States, it is gregarions. It produees effeets on segments similar to those caused by Chelinidea.

Another plant bug, resembling the conmon green hemipteron met with on cultivated crops, was seen on a few occasions on the spiny Opuntia at Angieo (Bahia)-perhaps an accidental association.

Mussel scale, Mytilaspis sp., was found on a enitivated speeimen of $O$. chakensis in Dr. Spegazzini's garden at La Plata.

The eommon Opuntia scale insect, Diaspis sp., was seen on Cerous sp., at La Plata, and on $O$. monacantha, $O$. decumana, and $O$. argentina in Buenos Aires. Its effects were unimportant. Fernald (1903) quotes Brazil as a locality for $D$. echinocacti, var. cacti, Comstoek. Demerara (British Guiana) appears to possess two forms, viz., D. cchinocacti, var. opuntice, Ckll. (Hunter, Pratt, and Mitchell, 1912, p. 42) and D. opunticola, Newstead.

In 1882 Ernst (p. 77) deseribed an abnormal fruit of $O$. ficus-indica from Caraeas, Venezuela, which Hunter, Pratt, and Mitehell (p. 35) believe to have been the result of attack by a ceeidomyiid fly, probably Asphondylia opuntio, Felt, an inseet referred to in the report on the investigations in the United States. $\dagger$

\section{UTILISATION.}

As Food for Man.-The fruit of $O$. ficusindica is used to some extent as a food for man in the States of Rio Janeiro and Sao Paulo in Brazil, as well as in various parts of Chili, plantations being seen at Llaillai, Santiago, Los Andes, and Valparaiso. It is grown also at Mendoza in Argentina. Spegazzini (1905, p. 512) quotes a list of Argentine localities where this speeies is eultivated for its fruit. In the State of Bahia, the fruits of certain species of Cereus such as the mandagaru de boi, the chiquechique verdadeiro and the caixa cube, as well as the small fruits of $O$. cuipa, are used for human consumption. Sehumann (1899) mentions that amongst others, the fruit of Cereus forbesii (p. 112) and Echinopsis schickendantzii, Web. (p. 237) are used as food in Argentina and those of Opuntia geissei in Chili (p. 152). The fruit of Cereus deficiens, Otto, is similarly used in Caraccas, Venezuela.

During times of drought, the pith of the chiquechique verdadeiro, the caixa cube, and the Melocaetus are used as food in the State of Bahia. The spines and the cortex are cut away and the remainder roasted. Sehumann (1899, p. 760) states that Peireskia is used as a vegetable. Meloeactus is used medicinally in Bahia.

As a Dye.-Phillippi (p. 493) mentions that the fruit juice of $O$. airampo is used in Arequipa (Peru) for colouring food. Dr. Soehrens, when interviewed, stated that the fruit of this species and of others which produce fruit with a red juice, was sold in North-western Argentina, and adjacent parts of Bolivia and Peru for colouring food, water (as a drink) and wine, the name

† According to Dr. A. Loefgren, of the Botanical Gardens, Rio de Janeiro, rats occasionally prove trouble some to hedges of $O$. monacantha in Sao Paulo by gnawing the stems. 


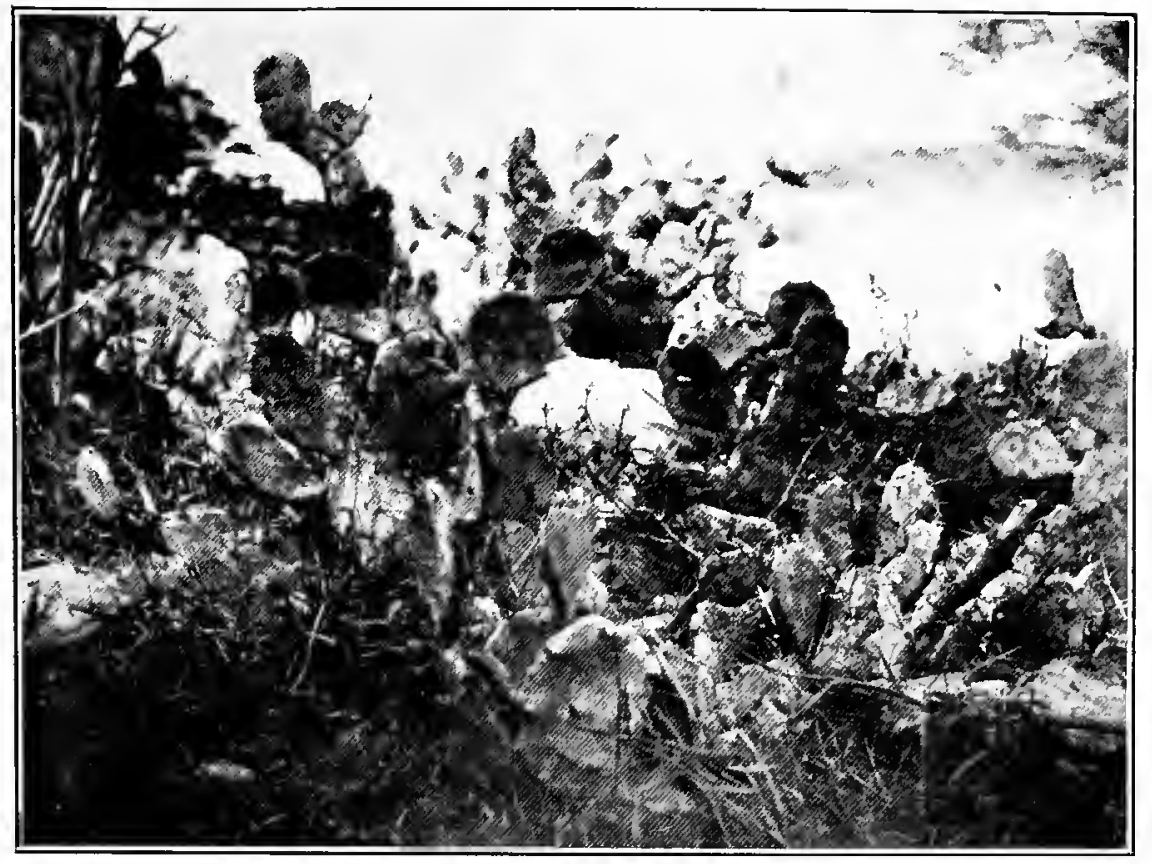

Fig. 61.--0. dillenii whose sickly appearance is due to the "Zone Spot Disense." Antigua.

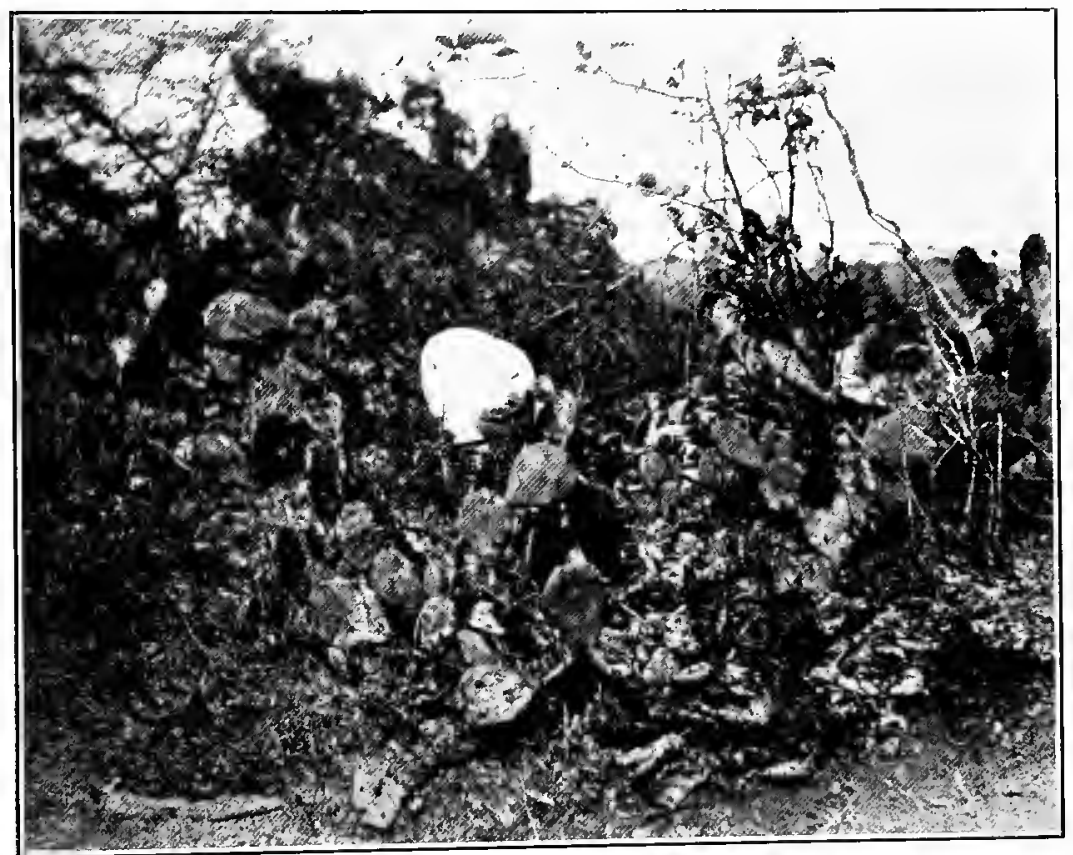

Fig. 62,-O. Aillenii showing considerable destruction of its segments as a result of the "Zone Spot Disease." Antigua.

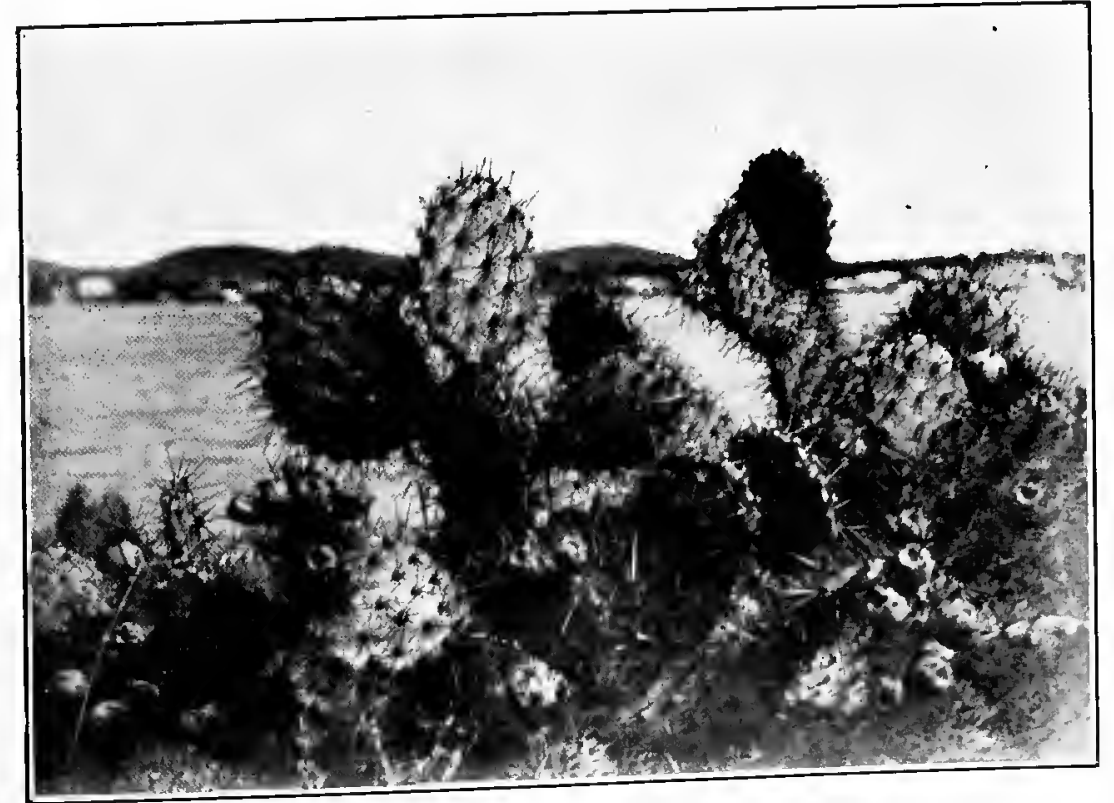

which Dr. N. Britton regards as a new species. Thongh growing beside plants of Fig. 63. -An Opuntia which Dr. Ne Bpot" (Firs. 61, 62), this species remained muaffected by it. Antigna. 

"airampo" being a native term applied locally to any such Prickly-pear. In addition to $O$. airampo, which is a spineless species, there is a small low-growing spiny form which Dr. Soehrens stated was grown on the Andes at Arequipa and Cuzco (Peru) and also in adjacent parts of Bolivia for the sake of its fruit, which was used in the same way as $O$. airampo. The species is evidently 0 . microdasia, Webr., as described by Schumann (1899, p. 743). Spegazzini (1905, p. 514 ), in referring to this Opuntia, which occurs in Argentina on the high mountains in Salta and Tucuman, states that the red fruit is used by the inhabitants for staining wool and is called airampo.

As Cattle Fodder.-Various cacti are used, as in Australia, Mexico, the United States, and South Africa, as a fodder for stock during times of scarcity. In some localities a few plants may be grown as a stand-by. At Joazeiro (State of Bahia) there is said to be a Government plantation of " palmadora grande" (the Mission Pear of North America?) and the local Melocactus ( $M$. depressus), while in other parts of that State a few individual plants are not infrequently cultivated by villagers in order to feed their animals. Those most commonly used in Bahia are, naturally, those found wild. Both indigenous species of Opuntia ( $O$. cuipa and the spiny palmadora), the Melocactus, botll species of mandagaru, the chiquechique cabeca branco and verdadeiro as well as the caixa cube, are all used as fodder for cattle, sheep, goats, and donkeys. Mules do not take to the diet. The thorns are burnt off the spiny species and then the animals ent the standing plants. Tall forms, such as the mandagaru, are cut down. Since the spines are small and soon fall away from the mandagaru de facho, burning is not necessary and cattle eat the branches as they lie on the ground. No other fodder is fed to stock during times of drought, so that they must live on the cacti and such other food as they can pick up. In Argentina, $O$. ficusindica is thus used and no doubt native species are also made use of, for the same purpose.

An unarmed species, $O$. anacantha, Speg., occurring in Northern Argentina, was sent by Dr. Spegazzini to Algeria, where it has been cnltivated as an accessory stock food. This is closely allied to $O$. retrorsa and $O$. stricta and possesses long, narrow green joints with prominent areoles bearing neither spines nor spinules. It is quite distinct from the Burbank cactus known as " anacantha," which is a large-jointed form with very few small spines, and is apparently a variety of $O$. decumana.

A chemical examination of some South American Opuntias has been made by Guthrie (p. 671), who dealt with $O$. monacantha and $O$. nigricans from New South Wales under the name 0 . brasitiensis and $O$. elatior, respectively; and by Griffiths and Hare (1906), who analysed $O$. monacantha (p. 62). The latter authors also examined chemically the Mission Pear (pp. 72-3), which appears to be the same species as that known as the "palmadora grande" in Bahia.

On the hot plains of South America during the dry season, horses, mules, and even travellers, at times quench their thirst by using the fluid obtained by pounding up the fleshy Melocactus found in those regions. It may be mentioned that Echinocactus is similarly utilised in Mexico and the adjoining dry regions of the United States.

Timber.-The larger torms, ".g., Cereus, Cephalocereus, and Pilocereus, spp., supply fuel in North-eastern Brazil. Timber is obtained from both unandagaru de boi and mandagaru de facho. Poles up to 25 feet in length and over 9 inches in thickness at the base may frequently be got from the latter species of mandagaru. These are used very largely as rafters and supports in house construction in the dry regions of Balia State, where other straight timber is not easily obtainable. Both kinds of mandagaru supply wood which is made into planks and üsed for making doors, window shutters, rough furniture, \&c. The narrow vascular cylinders of the foxtailed chiquechique are sometimes used as pipe-stems (Bahia).

IIedgcs.-Many species of Cereus and Opuntia are utilised in South America (Colombia, Venezuela, Brazil, Argentina, Peru, Chili, \&c.) for making hedges as in other parts of the world. Peircslicia amapola, Web., is similarly used in Paraguay.

\section{SUGGESTED DESTRUCTION BY OVER- GROWTH OF GRASS, ETC.}

Dr. Derby, Director of the Geological Survey of Brazil, in an interview, stiggested that a Brazilian fodder grass known as a honey grass, called "capin mellado" in Rio 'Janeiro and " catinguero roxo" in Sao Paulo, might act as an exterminator of Prickly-pear without itself becoming a pest. He stated that this grass is liked by cattle. It takes almost complete possession of the ground, particularly if the soil be a light clay loam.

From an editorial article in the Journal d'Agriculture Tropicale (No. 12, 1902, p. 167), it appears that M. Patin, the Consul for Belgium in Colombia, published in 1900 or 1901 a method for destroying Prickly-pear by fire, which was in use in certain regions of South America. The inhabitants first planted around the condemned mass of Opuntia a leguminous plant capable of quickly spreading so as to envelop eventually every part of the Prickly-pears in a close network consisting of its very numerous branches. Then at the proper time the stems of these climbers are cut, and as soon as the plants are dry they are set fire to. The Opuntias become so much damaged that it appeared to M. Patin that a repetition of the operation would bring about their complete destruction in a very simple manner, the only objection to the method being the length of time required.

\section{SUMMARY.}

Investigations were made in certain parts of Colombia, Brazil, Argentina, and Chili, which comprise only a small portion of the area where Prickly-pears exist in abundance.

No disease was seen which appeared to be capable of doing much serious harm to Opuntias, a possible cxception being that produced by Gloosporium which is known to oceasion much destruction in Texas under certain climatic conditions. 
A serious disease - a whito rot-caused by Sclerotium cactorum has been described as occurring in Argentina during the winter. Many species of Sclerotium are not confined to one hostplint. Its introrluetion is not at present recommended.

A great deal of destruction of Prickly-pear was seen to be occasioned in eertain parts of Argentina by the larvæ of moths, one of which is the Argentine moth-borer Zophodia cactorum, while the other-the Mendoza moth-borer-has not been identified by the Commission thougl apparently related to the former. Both of thesc are capable of attacking several species of cactus, including some Opuntias naturalised in Queensland, and their food supply appears to be restricted to that family of plants. The former oceurs in Uruguay and the adjacent regions of Argentina, while the latter is found commonly in the country surrounding Mendoza, on the Andean foot-hills. A small number of larvæ of the former, bred out during the voyage and free from parasites, were brought to Brisbane by the Commission, but most of them have since died.

A considerable destruction of young plants is eaused by other insects in Bahia as well as an Argentina, but the results of their attack are insignificant when compared with those just mentioned.

The Hemiptera-plant bugs and various coccids - do not appear to be sufficiently injurious to warrant the labour which would be necessary to introduce them from South America. Howev( ${ }^{\circ} r$, botli the Brazilian and the Argentine species of Wild Cochineal have been transported to this State. The latter died about the time of arrival owing to their inability to feed upon the species of Prickly Pear offered to them after the death of their proper food plant. The Brazilian Coceus has established itself here on young growing plants of its host species, the "spiny palmadora" of Bahia.

Cactus plants are not utilised in South America in any manner (except for feeding stock) which would be of service in Queensland in destroying them. The feeding of eacti to stock is carried out only during times of seareity.

Destruction of Prickly-pear by an overgrowth of a certain quick-growing grass has been suggested. In the north of the continent, a climbing leguminous plant is used, and when the Opuntias are quite overgrown, the elimber is cut, allowed to dry and then set on fire, the Pricklypear becoming badly scorched. It is suggested that a repetition of the operation would quite destroy the eactus.

\section{HAWAIIAN ISLANDS.}

The Commission stayed for a fortnight on the island of Oahu, awaiting a steamer en route to Sydney from San Francisco.

Prickly-pear was seen to be abundant in ccrtain rocky parts of the island, especially near Ionolulu and Haleiwa. In places the growth was found to be quite dense, especially on rocky hillsides and other localities unsuited for agriculture, as well as in certain dry areas. This was due in part to the fact that the land was not being utilised and in part to the absence of any controlling agents.

The species which is locally called 0 . tuna (Hildebrand, 1888, p. 140) reminds one of the "Westwood Pear" of the Rockhampton district in Queensland. There are two varieties, the fruit of the red fruiting kind being eaten by the native population. The plants reach a height of 10 or 12 feet, and may assume a tree-form by the removal of the lower branches, or they may remain more or less shrubby. The greyish joints are sometimes small but generally very large, reaching about 14 inches in length by about 7 in width, though it is by no means uncommon to see segments nearly 2 feet in length by 15 inches in breadth. They are almost symmetrical. There are eight or nine areoles in oblique series, each bearing from one to seven white twisted spines arranged in a radiating manner, three or four of them heing usually nearly an inch in length. The spinules are reddish-yellow or reddish-brown. The spines vary considerably in number and size on segments of the same plant or on different areoles of the same joint. Young as well as mature joints are often spineless, or almost so. The stems are spiny.

The flowers are orange, the fruit (in the edible variety at least) being large and plump with dark red skin and pulp resembling the fruit of certain varieties of $O$. ficus-indica as well as the Mexican "Cardona," $O$. streptacantha, thougl it is much larger than the latter. New joints are produced laterally from the edge of older segments in a manner similar to the Queensland pear already referred to.

The plant differs from our "Westwood or Red Mexican" species in possessing a larger and more eylindrical fruit; a less distance between the areoles; and the segments rather thinner and less rounded. Some plants, more especially the relatively spineless forms, remind one very much of the Mission Pear of Mexico and Southern United States, and the Indian Fig of the Mediterranean coasts.

The speeies is evidently near $O$. streptacantha, Lem., or $O$. chavena, Griff., and is eertainly not the same as the $O$. tuna, L., which Drs. Britton and Rose have identified as the common Jamaican species, a low-growing, straightthorned form allied to $O$. dillenii. Schumann, in his monograph (1899, p. 723), did not differentiate the two species, but included both under the name O. tuna, Mill.

Hildebrand refers to another species which he thinks may be 0 . tomentosa, S.D. 
Insect Enemies.

A species of Diaspis is very commonly met with in great quantity on this Prickly-pear, but does not seem to have any marked effect.

In the Bulletin on Cactus Insects of the United States of America (p. 52), it is stated that Calandra remota, Sharp, is a species commonly occurring in the stems of bananas and pricklypear's near Honolulu (Mem. Coleopt, Hawaiian Islands, p. 183).

The specimens of the Argentine moth borer, Zophodia cactorum, which the Commission was transporting to Queensland, fed readily on the Ilawaiian Prickly-pear, attacking it in the same manner as it does $O$. ficus-indica and others in the Argentine and Uruguay.

\section{Fungoid Diseases.}

The plants as a rule were found to be very vigorous, though, in a few cases, gumming together with the decay of part of a joint was seen occasionally. Though subsequent fungoid infection was evident, the cause of the condition was not recognised. It was not of importance in controlling the spread of the prickly pear.

\section{SUMMARY.}

A species of Opuntia resembling the "Westwood Pear ' of our own State occurs indigenously in the Hawaiian Islands, where it is apparently not held in check by any insect or fungoid cnemies, and as a result, is spreading.

\section{SUMMARY OF INFORMATION AVAILABLE IN EASTERN AUSTRALIAN STATES OTHER THAN QUEENSLAND.}

A great deal of attention has been given in Queensland to the prickly-pear question, and much has been published in the Queensland Agricultural Journal as well as in the Annual Reports of the Departments of Public Lands and of Agriculture. It has been deemed advisable to include in this report a summary of the information available in the other States of the Commonwealth, particularly New South Wales, regarding it.

The botanical side of the question has received a great deal of attention from Mr. Maiden, who in 1896 brought under Australian notice Bourde's article (1894) on the utilisation of prickly-pear for fodder. Two years later he published the result of his preliminary studies (1898), in which he referred to the Acts regarding destruction which were in force in New South Wales, and also gave an account of the species then known to occur in the continent, as well as of a few others. The naturalised species were then regarded as $O$. tuna, Mill., O. monacantha, Haw., O. brasiliensis, Haw., and $O$. stricta, Haw.* The first has since been identified by him as $O$. nigricans, the second and third belong to $O$. monacantha, while the common pest pear is now recognised as a variety of $O$. inermis, D.C. Mueller's $O$. dillenii, from Victorian localities, is regarded as being $O$. monacantha (Maiden, 1898, p. 1003).

In $1911 \mathrm{Mr}$. Maiden began to publish an interesting and well-illustrated series of articles on "The Prickly Pears of interest to Australiäns" (1911, 1912, 1913, 1914), most of which have appeared in the Agricultural Gazette of New South Wales since our departure from Australia. ITe gave a list of eleven species known to him in 1912 (1912 d, p. 39). The presence in Queensland of at least two others was made known through specimens and photographs which this Commission took to Sydney at the time of its visit.

O. aurantiaca, Gillies, to which attention has already been called in the section dealing with our work in South Africa, is recorded by Mr. Maiden from Windsor and Scone in New South Wales and from Goondiwindi and Warwizk in

* It is evidently from this paper that Mr. Burkil (1911, p. 292) has compiled his information regarding the species found in Australia. our State (1911 a, 1912 a, p. 210). We have referred to its presence at Roma.

o. imbricata, Haw., is reported from Sofala, Scone, Warialda, and Muswellbrook, New South Wales (Maiden, 1911 b). We have received specimens from the Laidley district.

O. nigricans, Haw., occurs commonly at Windsor and near Muswellbrook, and is also found near Yelarbon in Queensland (Maiden, 1912 a).

$O$. microdasys is a garden escapee which $\mathrm{Mr}$. Maiden states is now to be met with in the Pillaga scrub, N.S.W. (1914 a).

o. tomentosa, S.D., is the tree-pear of the Helidon district, and occurs also at Gayndah and in the district to the west of Rockhampton. Mr. Maiden (1912 c) reported its presence in at least two localities in South Australia and at Warwick and Goondiwindi in this State.

o. ficus-indica, Mill., a species cultivated in various parts of the world for the sake of its fruit, is recorded by him (1913 a) as a garden escapee in certain localities in the Hunter River district as well as in Queensland.

O. monacantha, Haw., is the most widespread of all prickly-pears now naturalised in Australia. It is the Suttor River pear of our own State, and is to be met with commonly near Rockhampton, Jowen, and Charters Towers, and occasionally at Gympie and near Brisbane. Mr. Maiden (1898, 1913 b) mentions as localities Sydney, Windsor, Scone, and Singleton, in N.S.W.; Melbourne; the Suttor River, Queensland; and refers to its presence in cultivation in other States. It is also found in Sonth Australia. Ewart and Tovey $(1908,1910)$ mention its oceurrence in Victoria. where Mueller had previously recorded it under the name O. dillc nii (fide Maiden, 1898, 1913 d, p. 1075).

Nopalea dejecta, S.D., is reported (Maiden, 1913 c, p. 974) as being found in a naturalised state near Rockhampton.

o. dillenii, Haw.-Mr. Maiden (1913 d) identifies as belonging to this species the more spiny of our two commonest pest pears, which, as we informed him, occurs in abundance in the Gayndah, Bundaberg, and Rockhampton districts, and less commonly near Brisbane. Mr. 
Maiden reports its presence at Dutton Bay, in South Australia. We doubt the correctness of the identification, and preter to use the name "Gavndah pear" or "spiny pest pear" for it. It is '"rtainly relater to $O$. dillonii, but differs from it notably in the character of its spines and flowers. We have seen the latter species growing naturalised in India, Ceylon, and Candry Islands, and the Mediterranean littoral, and indigenously in the West Indies.

o. inermis, DC., var.-This is the common pest pear of Queensland and New South Wales, and has been referred to under various names, amongst them being $O$. tuna, $O$. vulgaris, and o. stricta.

Prickly-pear is mentioned as being one of the plants taken on board the first fleet when it touched at Rio de Janeiro.* The plant introduced by Governor Phillip in 1788 was referred to in one account as the cochineal fig, Cactus cochinilifer, L. $\dagger$ The early cultivation of the plant received notice from Mr. J. V. Chataway (1898, p. 136). It has been assumed that it was the pest pear which was then introduced. Is it not possible that $O$. monacantha, which is a native of South-eastern Brazil, and perhaps 0 . nigricans, whose home is some distance inland from Rio de Janeiro, may have been included?

The pest pear was taken to Scone about 1839 (Maiden, 1912 b, p. 713), and from that centre specimens were conveyed to Warwick, whence it has spread over great areas of Queensland and Northern New South Wales.

It has been referred to in the account of our investigations in the West Indies, its home being probably Cuba (and Haiti) and perhaps the Florida Keys. A closely allied and perhaps identical species described by Dr. Griffiths under the name $O$. bentonii, is indigenous to Louisiana and adjacent portions of the United States of America.

Opuntia, sp.--It is under this designation that Mr. Maiden has described the "Westwood pear " found in the neighbourhood of Westwood and Rockhampton.

It is related to the " Cardona" (O. streptacantha) of Mexico. Dr. Griffiths, of Washington, U.S.A., informed the Commission that it was closely allied to $O$. megacanth $a$ and $O$. chavena. The common naturalised species in the Hawaiian Islands has been already referred to as resembling it.

Nopalea cochinelifera-Amongst the species whose presence has not so far been recorded in scientific literature is Nopalea cochinelifera, $\mathrm{L}$. an unarmed tree-pear found at Gayndah and Emerald. It is not a pest.

Another species apparently uncommon, and known locally in the Rockhampton district as the "Yellow-fruiting Mexican pear," resembles certain spiny forms such as $O$. amycloca and other members of the $O$. ficus-indica group.

Mr. Froggatt (1912, p. 943) has' collected evidence regarding the action of birds as distributors of prickly-pear seeds in their droppings. It is stated that the emu feeds on the fruit and

* Ida Lee. "The Coming of the British to Australia," 1788-1829." (London, 1906, p. 9.)

$\dagger$ Mr. Maiden (1898, p. 980) also has reforred to the introduction. assists in scattering seeds of the pest, seedlings being obtained from the droppings of that bird. Other fruit-eating birds, not named by him, are saicl to act in the same way, as also do horses and rattle.

\section{Utilisation in the Industries.}

Professor Dunstan, of the Impcrial Institute, London, as well as Mr. E. Harris, Editor of the Agricultural Gazette, New South Wales (1909, p. 245), referred to a statement in the Press that a Brisbane chemist, who had so far remained anonymous, had discovered commercial possibilities in the prickly-pear, the production of spirits, feed-cake, strawboard, and sugar being mentioned.

The question of producing feed-cake, alcohol, and sugar from Opuntias has been referred to elsewhere in this report.

Mr. J. C. Brünnich, the Agricultural Chemist of our State, examined prickly-pear with a view to testing the possibility of procuring alcohol, and found that very little was obtainable $(1909$, p. 3$)$. Some has been made in a Sydney laboratory (Harris, 1909, p. 246).

Mr. F. H. Campbell has recently examined the products derived from the destructive distillation of prickly-pear, his results being published in the last report of the Australasian Association for the Advancement of Science (1914). He examined the species $O$. monacanth $a$ and $O$. inermis. From the former he obtained a faintly luminous gas which was found to be composed mainly of hydrogen, carbon monoxide, and nitrogen, with smaller quantities of methane, carbon dioxide, and oxygen. The liquid distillate consisted of acetic acid and tarry substances. Ammonia, pyridine, and a trace of phenol were found, but the amount of methyl alcohol was shown to be negligible. The crude tar constituted about 1 per cent. of the original green material. It had very little tenacity. The charcoal obtained was clean and porous, and amounted to about 4 per cent. of the green material examined. The results from $O$.inermis were similar. The quantity of acetic acid worked out at $3.45 \mathrm{lb}$. per ton of green stuff, crude tar $22 \mathrm{lb}$, , charcoal $89.6 \mathrm{lb}$., the remainder being composed of water and small amounts of pyridine and ammonia.

The ash of $O$. monacantha was examined and was found to be readily fusible, thus indicating a high alkalinity. There was 36.67 per cent. of lime and traces of copper were present.

Mr. Campbell concludes by stating that if crude calcium acetate be valued at $8 \mathrm{~d}$. per lb., refined pyridine at $4 \mathrm{~s}$. $6 \mathrm{~d}$. per $1 \mathrm{~b}$., and charcoal at $20 \mathrm{~s}$. per ton, then the value of products per ton of green plant is approximately 8s., which amount he believes would probably not cover the cost of clearing the land. The value of the gas produced was not taken into account in making the estimate, as it would be most profitably used as fuel for heating the retort.

Mr. Maiden (1913 a, p. 55) believes that the utilisation of pear as a producer of alcohol, fibre, \&c., is not likely to be a commercial suceess, but may help to reduce the cost of clearing pearinfested land. This opinion is already held by many in our own State. 


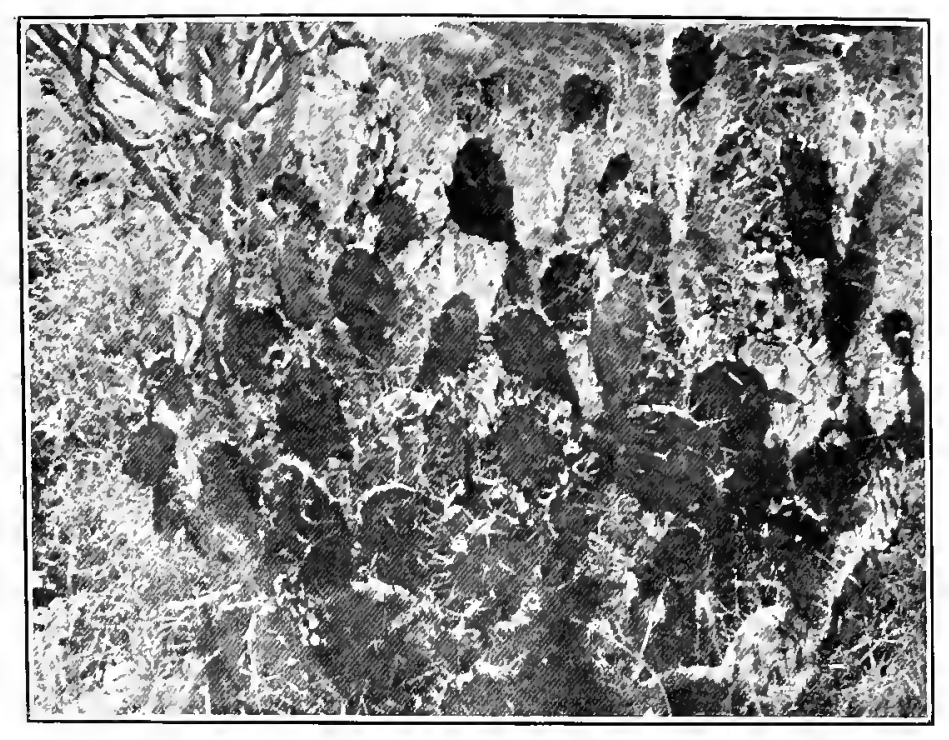

Fig. 64.-O. dillcnii. Tenerifte, Canary Islands. This is the pest pear of fisuthern Indial, and is met with elsewhere in that country, but to a less extent.

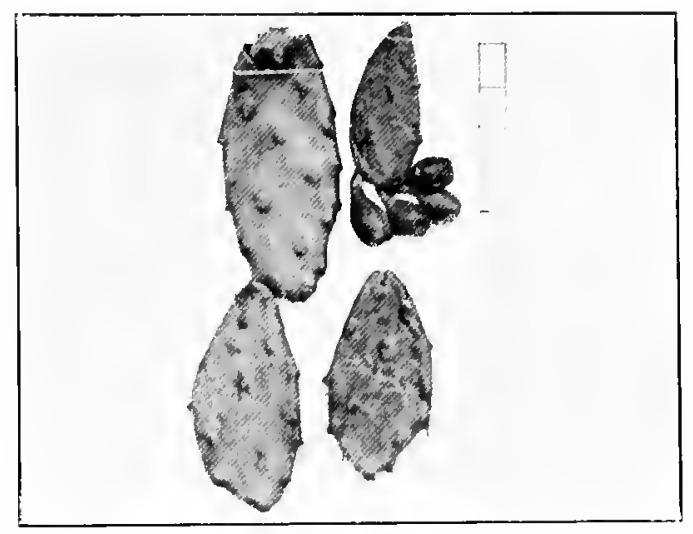

Fig. 05.-1 few segmonts ancl fruit of the "Punjab Pear," which in its general appearance resembles the pest pear of Queensiand. (boule in inches,

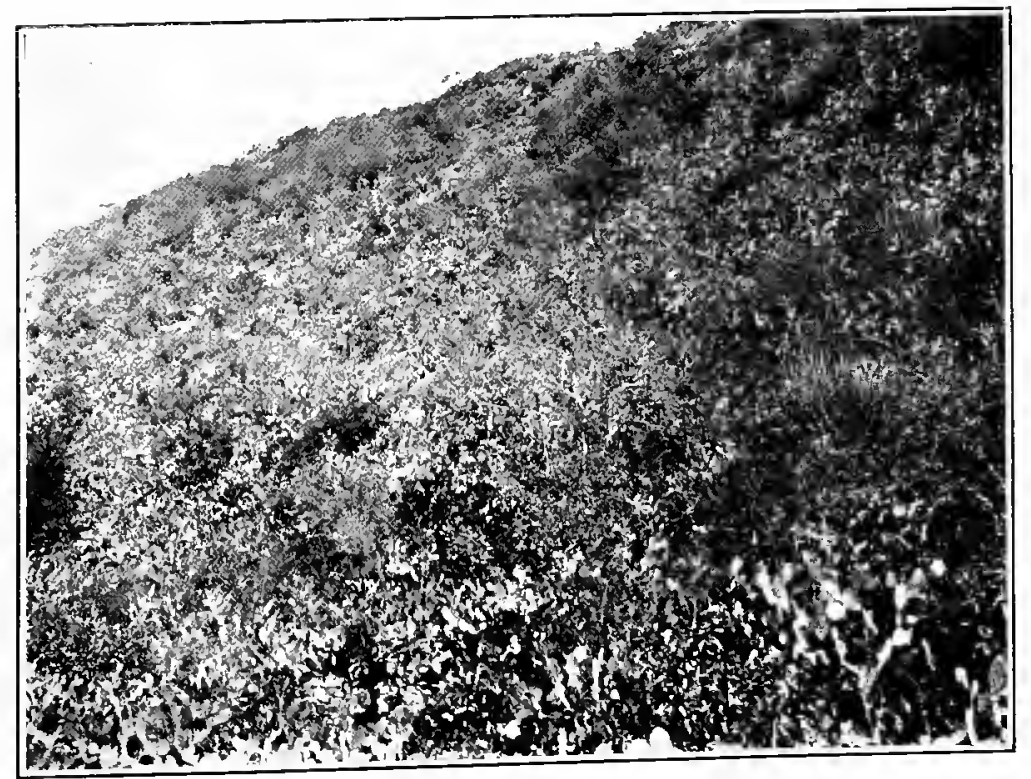

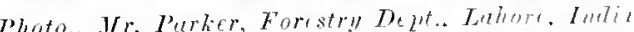

Fig. 66... A hillside at Amber, Central India, covered with 0 . nigricans. This is the pest pear of the Bombry Presidency, and is commonly met with in parts of Northern and Central India in company with O. alllenii. This species is nituralised in New Sonth Wales and in at least one locality in Gurenuland. 

Utilisation as Fodder for Stock.

As in Queensland, prickly-pear has been used in New South Wales as an emergency fodder during times of scarcity (Harris, 1909, p. 242-5).

Mr. Guthrie (1900) made analyses of grcen and dry segments of species of Opuntia named in his list as $O$. ficus-indica, $O$. elatior, $O$. brasiliensis, and $O$. cochinelifera, but, according to $\mathrm{Mr}$. Maiden's later determinations, the second and third should be $O$. nigricans and $O$. monacantho respectively. He believed that the feeding value was fairly high. In other sections of this report, however, it has been shown that the fodder value is so low that some more concentrater food must be added to it in order to build up a suitable ration. Mr. Brünnich, who has carried out numerous analyses of the species naturalised in Queensland, has suggested the addition of such materials as bran, cotton-seed meal, oilcake, molasses, \&c. (1906, p. 54; 1909, p. 4).

The pear is usually boiled or steamed to soften the spines, and some more nntritious fodder is added (Maiden 1913 a, p. 52; Scott, 1902, p. 1052; O'Shea, 1897, p. 434; \&c.). It has been found that pigs eat greedily prickly-pear plants which have been boiled for some hours with meat or refuse, as well as those steamed or boiled in water, if some molasses be added (Gorus, 1896, p. 658). An account of the method of steaming is given by Maiden (1913a, p. 53) as well as by Boyce (1897, p. 260), who used the prepared material for pigs and dairy cattle.

Though it appears to be possible for some animals to exist on a diet consisting solely of prickly-pear (Coggins, 1913, p. 244), they do not thrive, while on the other hand many die (Keys, 1908). There is no doubt that some addition is necessary, and this is often obtained by grazing on whatever vegetation is available (Scott, 1902, p. 1052). Mr. G. Valder (1902, p. 62) has stated that bran, chaff, or molasses may be used to supplement a boiled pear ration, and then a good fodder for cattle and pigs is obtained.

Attempts have been made to produce an ensilage in which prickly-pear served as a constituent. A Mr. Boyce (1897, p. 261, p. 504) used alternate layers of $O$. inermis and either maize or sorghum, some salt being added to increase the palatability. The thorns became softened. Dairy cows were fed successfully on this ensilage as well as on steamed prickly-pear and barley, preferring the former to the latter. Mr. Brünnich (1909, p.p. 3, 20) examined a four-months-old ensilage made from alternate layers of pear and maize, and found it in excellent condition, its nitrogen content being higher than that in green joints, though this, he suggested, was perhaps due to the absorption of nitrogen from the maize.

Professor Ewart (1910), in referring to the work of Drs. Griffiths and Hare in regard to the use of Opuntias in the United States of America as fodder plants, shows the futility of growing for this purpose $O$. monacantha, the species naturalised in Victoria.

Apparatus for scorching the spines and cutting up plants for stock fodder is illustrated and described in the Queensitund Agricultural Journal (21, 1908, July and August). Coggins (1913) has also illustrated a prickly-pear torch.
Dcstruction by Mechanical, Chemical, and other Means.

More attention has evidently been given to the destruction of prickly-pear by chemical means in Quecusland than in any of the other States, the information having been made known by $\mathrm{Mr}$. Brünnich in official publications in this State. His latest recommendations have been republished in New South Wales (1912).

Mr. C. T. Musson (1911, p. 58) has stated that prickly-pear does not thrive under certain Australian trees, such as the wild apple, cabbage gum, and stringybark, but becomes starved and stunted. He also mentioned that seeds of the white cedar had been scattered amongst the Opuntias in India, where the resulting trees had a detrimental effect on the latter, owing to their broad leaves cutting off a great deal of the supply of light. He therefore suggested that the latter experiment might be tried in Australia.

Mr. Darnell Smith (1913, p. 152) tried to destroy $O$. inermis by means of injections of various unnamed fungi as well as certain bacteria, e.g., B. coli communis, B. proteus vulgaris, B. lactici, \&c., but without success. He also tried the effect of spraying some plants with a black liquid in order to cut off the supply of light.

Bruce-Suttor, in 1893, gave an account of a method of rolling and crushing pear, suitable only in open or lightly timbered country.

Mr. Valder (1901, 1902) carried out experiments for two years. He injected into the basal joints a large number of chemicals, including sulphuric acid, carbolic acid, oxalate of potash, ferricyanide of potash, arsenite of soda, caustic potash, salt, sulphate of iron, powdered copper sulphate, and two proprietary poisons, one of them being Murchison's Exterminator, which was found to be so effective in South Africa. Arsenite of soda was found to be the cheapest and most effective of these injections; salt had a considerable effect; but the rest of the substances caused only a local disturbance. The most satisfactory result was obtained by using a spray consisting of $1 \mathrm{lb}$. of arsenite of soda in about 10 gallons of water, the most suitable time to apply it being after heavy rain. Cntting or slashing the plant before spraying was not found to be of material benefit.

Mr. Darnell Smith (1913, p. 152) injected sodium arsenite, lysol, formalin, carbolic acid, sulphuric acid, ammonia, a solution of copper sulphate in ammonia, a solution of cuprous chloride in ammonia, 20 per cent. copper sulphate, and 12 per cent. copper sulphate, the best result being obtained from the last-named. He then stabbed the plant and inserted a crystal of copper sulphate, which caused the death of comparatively small Opuntias in about four days. This led him to suggest that the same results would probably be obtained if the experiment were tried on a large scale.

An anonymous writer (1910, p. 195) mentioned that he had driven copper nails into Opuntias, but that no serious result was caused except the decay of the parts surrounding the injury.

The spray used in the experiments which have been carried out at Scone, New South Wales, is made of $1 \mathrm{lb}$. arsenic and $1 \mathrm{lb}$. of washing soda dissolved in 20 gallons of water (Maiden, $1912 \mathrm{~d}$, p. 40). 



\section{REFERENCES TO LITERATURE.}

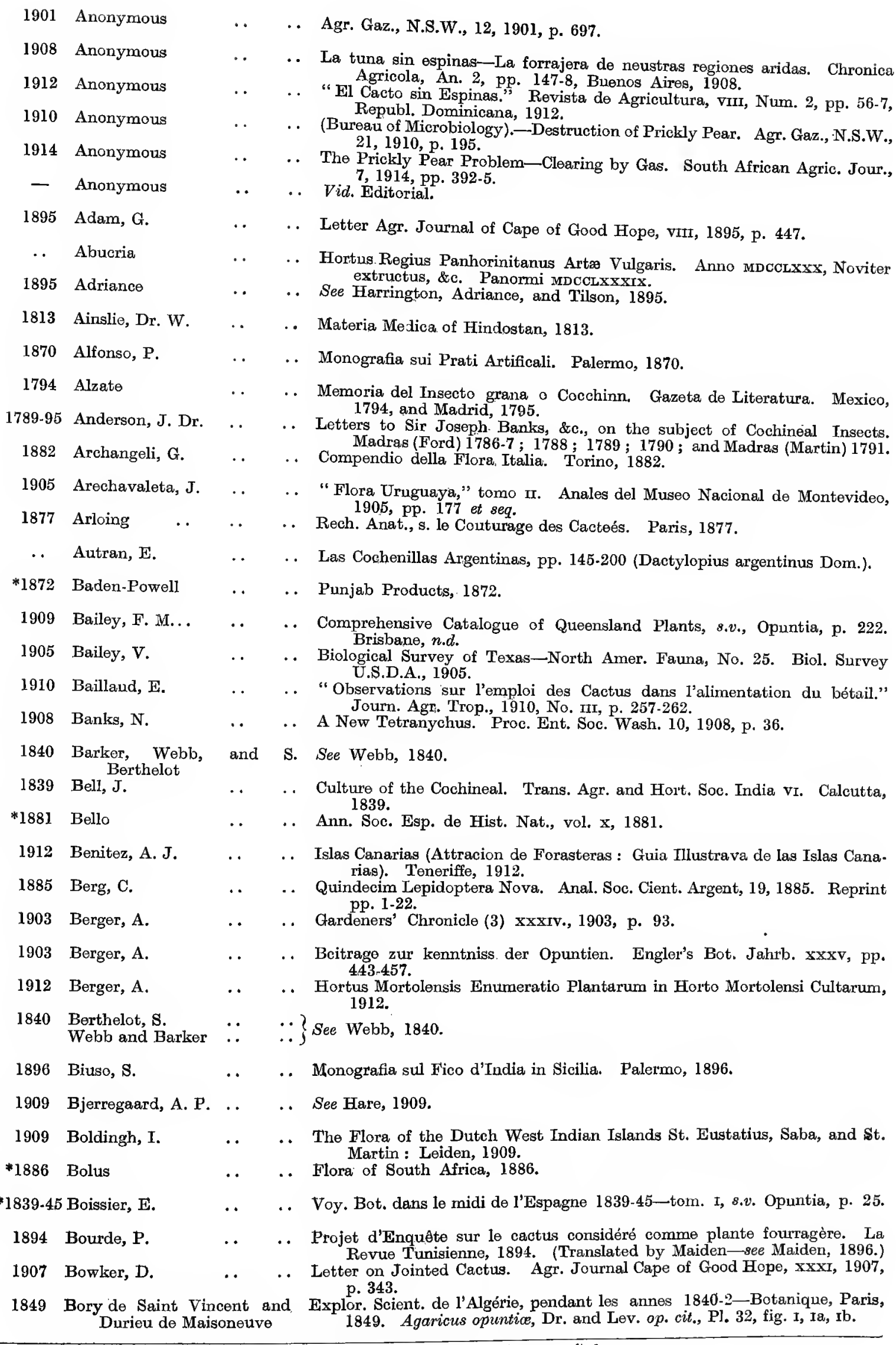




\section{REFERENCES TO LITERATURE-continued.}

1897 Britton, N. L.

1907

1912

1893

1906

1909

1912 Brünnich, J. C.

1842 Buddingh, Dr. S. A.

1907 Burbank, L.

1911 Burkill, I. H

1912 Burkill, M.

1909 Burt, B. C.

1910 Burt, B. C.

1909 Burtt Davy, J.

1913 Burtt Davy, J.

1907 Busck, A.

1911 Calvino, $\mathrm{M}$.

1914 Campbell, F. H.

1911 Cannon, W. A.

1914 Cannon, W. A.

1913 Carne, W. M.

1892 Casey, T. L.

1883 Caspari, H.

1890 Cavara and Briosi

1913 Cettolini, Sante

1910 Champion

1898 Chataway, J. V.

1871 Chicoli

1912 C. I.

*1857 Claus

1893 Cockerell, T. D.

1896 Cockerell, T. D.

1898 Cockerell, T. D.

1899 Cockerell, T. D.

1907 Cockerell, T. D.

1913 Coggins, H. C.

1891 Comes, 0.

1905 Cooke, M.

1906 Cooke, M.

1898 Coquillet, D. W

1835 Costa, A
.. Prickly Pears as Fodder. Agr. Gaz. N.S.W. 8, 1897, pp. 260-261 ; pp. 504-5.

- Funghi parassiti Fasc. 118, 1890

"Cactaceæ" in Illustrated Flora of the Northern States and Canada, 1897, pp. 460-465 (edit. 2, 1913, pp. 568-573).

merous important papers in Smithsonian Misc. Coll. 1907, 1908 ; Contr. Nat, Herb. 1909 to 1913 ; Carnegie Instit., Washington, 1913 and 1914 A preliminary treatment of the Opuntioidea of North America. Smiths. Misc. Coll. 50, 1908, pp. 503-539.

Undescribed Species of Cuban Cacti. Torreya, 12, 1912, pp. 13-16.

Clearing Prickly Pear (O. vulgaris, Mill.) Agr. Gaz. N.S.W., 4, 1893, pp. $878-880$.

Analysis of Prickly Pear (Giant Mexican, Spineless). Q'ld. Agr. Journal, May, 1906 , p. 514.

- Ann. Report of the Agricultural Chemist for the year ending 30th June 1909 (Brisbane).

Destruction of Prickly Pear by means of Arsenical Poison (Summary of Appendices 1 and 2 to Interim Report of Queensland Board of Advice on Prickly Pear Destruction). Agr. Gaz. N.S.W., 23, 1912, pp. 406-7.

"Nopal-kultur en Cochenille-teelt op Java." Tijds. v. Ned. Indie Jaarg. 2d., Batavia, pp. 361-368, 1842.

. The new Agricultural-Horticultural Opuntias. California, 1907.

- Determination of the Prickly Pears now wild in India. Rec. Botanical Survey India, vol. rv, No. 6, 1911, pp. 287-322 (contain references action Wild Cochineal).

- Opuntias in the Canary Islands. Bulletin of Miscellaneous Information, Royal Botan. Gardens, Kew, 1912, No. 9.

- Report of the Agric. Station at Orai (Bundelkund) for the year ending June, 1909.

. Report of the Agric. Station at Orai (Bundelkund) for the year ending June, 1910.

- Prickly Pear and the Spineless Cactur for Stock Food. Farmers' Bulletin No. 90, Transvaal Dept. Agric., 1909, $15 \mathrm{pp}$.

Descriptions and Illustrations of Noxious Weeds. Govt. Printer, Pretoria, $1913,22 \mathrm{pp}$.

.. New American Tineina. Proc. Ent. Soc., 'Wash., 8, 1907, pp. 86-88.

. El Injerto de las Cacteas. Boletino de la Direccion General de Agr., An. 1, No. 1, p. 50-51. Mexico, May, 1911.

- The Destructive Distillation of Prickly Pear. Austr. Assoc. Adv. Sci. 14,1913 (1914), pp. 104-7.

. The Root Habits of Desert Plants. Publication 131, Carnegie Instit., Washington, 1911.

- See under MacDougall, 1914.

.. Studies in Prickly Pear in the Western United States. Agr. Gaz. N.S.W., 24, 1913, pp. 975-7.

. Coleopterological Notices IV. Annals New York Academy of Sciences, August, 1892 (Cactophagus).

. Zur Kenntniss des Hautegewebes der Cacteen. Halle, 1883.

. See Briosi, 1890.

Società degli Agricoltori Italiani, Boll. 5, Ann. xvII, 12, pp. 456-459. Rome, 1913.

.. Biologia Centrali Americana. Coleoptera, vol. 4.

.. Q'ld. Agric. Journ., 1898.

. Atti della Societa di Acclimazione e di Agricultura in Sicilia, XI, 1871, and $\mathrm{xIV}, 1874$

.. See Hunter, Pratt and Mitchell, 1912

. Zur Kenntniss von Coccus Cacti. Müller's Arcb. 1859, pp. 150-154, 1860. (Verh. Medic. Physc. Gesellsch.)

. Trans. Amer. Ent. Soc., 20, 1893.

. Notes and Descriptions of the New Coccidre collected in Mexico by Prof. C. H. Townsend. Bull. 4, Tech. Ser., U.S. Dept. Agr., 1896.

. Science I., 1898.

.. Some Insects of Salt River Valley. Bull. 32, Ariz. Exp. Sta., 1899.

. A Gall Gnat of the Prickly Pear Cactus. Canad. Entom., 39, 1907, p. 324.

Prickly Pear Burner. Agr. Gaz. N.S.W., 24, 1913, pp. 243-4.

. Crittogamia agraria. Naples, 1891.

. Gardeners' Chronicle, 1905.

. Fungoid Pests of Cultivated Plants. London, 1906.

.. On the Habits of the Oscinidæ and Agromyzidæ reared at the U.S. Dept, Agr., Bull. 10 Bur. Ent. U.S.D.A., 1898, pp. 70-79.

. Fauna del Regno di Napoli, Cocciniglie, 1835, pp. 15-16 \& v. Dactylopius. 


\section{REFERENCES TO LITERATURE-continued.}

$\begin{array}{cll}1896 & \text { Coulter, J. M. } \\ 1913 & \text { Darnell-Smith, G. P. } \\ 1893 & \text { Davenport and Holmes } \\ 1877 & \text { De Bary } & \ldots \\ 1799 & \text { De Candolle, A. } & \text { P. } \\ 1829 & \text { De Cand Redlouté, P. } & \text { P. } \\ 1841 & \text { De Candolle, A. P. } & . . \\ \text {.. } & \text { Delbrouck } & \ldots \\ 1865 & \text { Deventer, s. van } & \text {.. }\end{array}$

1911 Diguet, L.

\section{Dominguez \\ *1886 Dugès, E. \\ *1901 Dugès, E.}

*1897 Duss, R. P.

1903 Duthie, J. F.

1902 Dyar

1907 Editorial

1909 Editorial

1910a Editorial

1910b Editorial

$1910 \mathrm{c}$ Editorial

\section{.. Editorial \\ 1910 Eichlam, F. \\ 1759 Ellis, J.}

1891 Ellis, J. B., and Everhart, B.

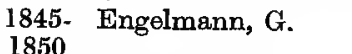

1856

Engelmann, G., and Bigelow, J.

1882 Ernst, A.

1909 Essig, E. O.

1837 Evans, Dr. G.

1891 Everhart, B., and Ellis, J. B.

1909 Ewart, A. J.

1910 Ewart, A. J.

1908 Ewart, A. J., and Tovey

*1896 Ewell, E. E.

1904 Fairchild, Dr.

1888- Farlow, G., and Seymour, 1891 A. B.

1891 Fawcett

1908a Felt, E. P.

1908b Felt, E. P.

1910 Felt, E. P.

1911 Felt, E. P.
Contrib. U.S. Nat. Herbarium 3, 1896.

. Destruction of Prickly Pear. Agr. Gaz. N.S.W., 24, 1913, p. 152.

. S See Holmes, 1893.

.. Vergleich Anat. d. Vegetations organe d. Phanerog. u Fane. Leipz, 1877. Plantarum Historia Suculcntarum, ou Histoire Naturelle des Plantes
Grasses. Paris 1799. 3 vols.

. Revue de la Famille de Cact.

.. Prodromus Regni Vegetabilis III, Cacteæ.

. Vid. Solereder.

. Overzight van de invoeringen en bevordering der Nopalkultur en Koch. enielje teelt op Java. T. sz. Tidjv. Ned. Ind. n.s. 3 jahr. II, 261, 243, 1865.

. Notes sur quelques plantes mexicaines employées eventuellement comme fourrage. Bull. Soc. Nationale d' Acclimatation de France, Oct., 1911. Reprinted in L'Agronomie Tropicale 3. Ann., No. 12, Dec., 1911, pp.
246-248.

(i) Trab. Mus. Farm. Fac. Cienc. Med. No. 17 (1907), and (ii) Boletim Min. Agr. vII., 3, pp. 148-150. Buenos Aires, 1907 (Dactylopius argentinus).

. Metamorphoses de quelques Coléoptères Mexicains. Ann. Soc. Ent. Belg. 21, pp. 26-45.

. Catalogo de la coleccion de Coleopteros Mexicanos del Museo Nacionali Cat. Mus. Nac. Mexico, 5 (2), pp. 1-148.

. Flore Phanérogamique des Antilles Francaises Avec Annotations sur l'emploi des Plantes par Le Professeur Eduard Heckel. Annales de l'Institut, Colonial de Marseille, 3, 4th Ann (1896), Macon, 1897.

. Flora of the Upper Gangetic Plain and the adjacent Siwalik and SubHimalayan Tracts (Calcutta), 1903.

.. See Hulst. .. Prickly Pear and Jointed Cactus. Agr. Journal Cape of Good Hope, xxxr.
1907, pp. 137-8.

. Agr. Journal Cape of Good Hope, xxxv, Oct., 1909.

. The Destruction of Prickly Pear by the Use of Jansen's Extirpator. Agr. Journal Cape of Good Hope, xxxvI., March, 1910.

.. The Destruction of Prickly Pear by the Use of Jansen's Extirpator. As Reprint No. 19, 1910.

. Destruction of Prickly Pear-Experiments with St. O'Gorman's Prickly Pear Exterminator. Agr. Journal Cape of Good Hope, xxxvr, Feb., 1910.

.. See also under "Anonymous."

.. Beitrage zur Kenntniss der Kakteen von Guatemala, Monats. f. Kaktenk. 20 Jahr. s, 1910.

- Philosophical Transactions of Roy. Soc., vol. 52. [Desce. Coccus, South Carolina.]

B. Proc. Acad. Philad., 43, 1891.

. Numerous important Papers in Boston Jour. Nat. Hist., U.S. Senate Misc. Documents, Mem. Amer. Acad.; Proc. Amer. Acad. Arts, Science; U.S. and Mexico Boundary Surveys.

, Pacific Railway Report 4, 1856 ; Proc. Amer. Acad. Arts, Science 3, 1856.

. Nature, Nov., 1882, p. 77.

. Pomona Jnl. Entom. I, 2, p. 43, fig., 1909. (sv. Pseudococcus obscurus.)

. Report on the Quality of Wild Cochineal, \&e. Trans. Agr. and Hort. Soc.. India, II, p. 77.8. Calcutta, 1837 . India, III,
Ellis, 1891.

. Prickly Pear: A Pest or a Fodder Plant, Journ. Dept. Agric. Victoria, vII., 1909, pp. 574-577.

Prickly Pear: A Fodder Plant for Cultivation? Jour. Dept. Agric. Victoria, March, 1910.

Jour. Agr. Victoria, June, 1908.

.. The Chemistry of Cactaceæ. Journ. Am. Chem. Soc., 18 July, 1896 (Alkaloids of Anhalonion.)

- Singed Prickly Pear as Forage. Agr. Journ. Cape of Good Hope, xxv., 1904, pp. 1245. Provisional Host Index, Pt. I, 1888; Pt. II, 1891.

.. Bull. 23, 1891, Dept. Agric., Madras, abstracted in Fischer, 1892a, p. 24, and 1892b, pp. 113-4.

.. Studies in Cecidomyiidæ, II. Bull. 124, New York St. Mus., 1908, pp. $307-422$.

. Ann. Rep. N. York State Entomologist, 23, 1908.

. Two New Cecidomyiidæ. Entomol. News, 21, 1910, pp. 10-12.

. "Cartus Midge-Itonida Opuntioe," Felt. Journ. Een. Entom. 4, 1911, p. 464. 


\section{REFERENCE TO LITERATURE-continued.}

1914 Felt, E. P.

1903 Fernald, M. E.

1874 Ferrero, Dr. O.

1896-8 Fiori, Dr. A.

1891a Fischer, A.

1891b Fischer, A.

1892a Fischer, A.

1892b Fischer, A.

1857 Fleming, A.

1892 Fletcher, B. C.

1886 Foerster, K. F.

1904 Forbes, R. H., and Skinner, W. W.

1912 Froggatt, W. W.

1847 Froideville, L. M. de

1902 Gamble

1894 Ganong

1842 Gasparini, G

1898 Gennadius, P.

1839 Giberne, G.

1903 Giglioli, Prof. T.

1885 Girard, M.

1890 Gomez de la Maza, M.

1893 Gomez de la Maza, M.

1897 Gomez de la Maza, M.

1896 Gorus, J. F.

1895 Goss, A.

1903 Goss, A.

1905 Gosselin, R.

*1896 de Graffe, Bertha L.

.. Grandeaux

1912 Green, E. E.

1905 Griffiths, D.

1906 Griffiths, D.

1908a Griffiths, D.

1908b Griffiths, D.

1908c Griffiths, D.

1909a Griffiths, D.

1909b Griffiths, D.

1910 Griffiths, D.

1912a Griffiths, D.

1912b Griffiths, D.

1913 Griffiths, D.

1906 Griffiths, D., and Hare, R. F.

1907a Griffiths, D., and Hare, 1907b Griffiths, D., and Hare, R.
.. Annual Report State Entomologist of New York, 1913 (1914).

- A Catalogue of the Coccidæ of the World. Bull. 88, Mass. Hatch Agr. Coll., 1903 (s.v. Coccus, p. 82)

. Atti della Societa di Acclimazione e di Agricultura in Sicilia XIV, 1874

. Flora Analitica d'Italia, I, Padova, 1896.8.

.. Evidence in R.S.C., 1891, pp. 41-5, and also letters in R.S.C., 1891, Appendix.

- Notes of the Dept.- "Prickly Pear." Agr. Journ. Cape of Good Hope, Iv., 1891, p. 133.

. In Report in Agric. Journ. Cape of Good Hope, v, 1892, pp. 109, 113, \&c.

Jour. Agric. Hort. Soc. India, 9, 1857.

. Prickly Pear in Mexico. Agr. Journ. Cape of Good Hope, v, 1892, p. 135.

.. Handbuch der Kakteenkunde. Ed. Rumplen (I). Leipsig, 1886.

(1) Bull. 51, Arizona Agr. Exp. Sta., 1904. (2) Report for 1904 Arizona Agr. Exp. Station XV, 1904

Birds and Prickly Pears. Agr. Gaz. N.S.W. 23, 1912, pp. 943-4.

Bijdragen tot de Kennis van de Nopal-Kultur en van de Cochenille-teelt of Java, Batavia, 1847.

. Manual of Indian Timbers, 1902.

. vid. Solereder.

- Osservazione intorno alla struttaria dell frutta dell' Opuntia. 4to. 1842.

.. Prickly Pear-Opuntia. Agr. Gaz. N.S.W. 9, 1898, pp. 38-40.

- Memorandum on the Cultivation of Cochineal. Trans. Hort. and Agr. Soc. India VI. Append., p. 7-11 Calcutta, 1839.

. Malessere Agrario ed Alimentare in Italia, Portici, 1903, pp. 7-11.

.. Traite Elementaire d'Entomologie, t. Ir, s.v. Coccus, pp. 927-930. Paris, 1885.

- Catalogo de las Periantiades Cubanas, Ann. de la Soc. Espanola de Hist. Nat., xIX., Madrid, 1890

.. Nociones de Botanica sistematica, Havana, 1893.

.. Flora Habanera-Fanerogamas, Havana, 1897.

Feeding Experiments with Prickly Pear. Agr. Gaz. N.S.W., 7, 1896, pp. 658-9.

- Principles of Stock Feeding and some New Mexico Feeding Stuffs. Bull. 17, Agr. Exp. Sta., New Mexico, 1895 (1896).

Ash Analyses of some New Mexican Plants. Bull. 44, Agr. Exp. Sta., New Mexico, 1903.

. Las Opuntia-Fruits, Comsstibles. Journ. D'Agr. Trop. 45, Mar., 1905,

.. Opuntia vulgaris, Mill. Amer. Journ. Pharmacy, 68, 1896, p. 169 sqq. (quoted in Maiden, 1898, p. 993).

.. Journal d'Agr. Trop., 38, Mar., 1904 quoted (Utilization).

.. On the Cultivated and Wild Forms of Cochineal Insects. Journ. Econ. Biol., Sept., 1912, vir, No. 3, pp. 79-93, Pl. 1 (incl. Bibliography)

The Prickly Pear and other Cacti as Food for Stock. Bull. 74, Bur. Plant Ind., U.S.D.A., 1905.

. Feeding Prickly Pear to Stock in Texas. Bull. 91, Bur. Animal Ind., U.S.D.A., 1906.

Tho Prickly Pear as a Farm Crop. Bull. 124, Bur. Plant Ind., U.S.D.A., 1908.

Illustrated Studies in the Genus Opuntia, I. Ann. Rep. Missouri Botan. Gardens (St. Louis), 19, 1908, pp. 259.272,

.. Prickly Pear, its Yield and Uses. Proc. Texas Dairymen's Assoc., 1908,

.. .. Thэ Spineles.s Prickly Pears. Bull, 140, Bur. Plant Ind., U.S.D.A., 1909

.. .. Illustrated Studies in the Genus Opuntia, II. Ann. Rep. Missouri Botan, Gardens, 20, 1909, pp. 81-95.

.. .. Illustrated Studies in the Genus Opantia, III. Ann. Rep. Missouri Botan. Gardens, 21, 1910, pp. 165-174.

.. .. The Thornless Prickly Pears. Farmers' Bull. 483, U.S.D.A., 1912.

.. .. Illustrated Studies in the Genus Opuntia, IV. Ann. Rep. Missouri Botan. Gardens, 22, 1912, pp. 25-36.

Behaviour of Species of Cacti known as Opuntia under cultural conditions. Bull. 31, U.S.D.A., December, 1913.

rickly Pear and other Cacti as Food for Stock, II. Bull. 60, Agr. Exp. Sta., New Mexico, 1906. Bull. 102, Bur. Plant. Ind., U.S.D.A., 1907. also published as Bull. 64, Agr. Exp. Sta., New Mexico, 1907. 


\section{REFERENCES TO LITERATURE-continued.}

$\left.\begin{array}{c}1864 \\ * 1868 \\ \text { (prior } \\ \text { trs). }\end{array}\right\}$ Grisebaoh, A. H. R.

1891 Grobelaar, A. L. .

1850 Guérin-Meneville, F. E.

1913 Guastella (Dr. G.) ..

1827 Gussono

1907 Gurke, M.

1908 Gurke and Schumann

1900 Guthrie, F. B. ..

1868 Hallier, E.

1860 Hardy

1908 Hare, R. F.

1911 Hare, R. F.

Hare, R. F.

1909

Hare, R. F., Mitchell, S. R., and Bjerregaard, A. P.

*1888 Harrington, $\mathrm{H}$.

*1895 Harrington, H., Adriance and
Tilson

1909 Harris, E.

*1842 Harting

1819 Haworth

1821 Haworth

1908 Hayman, J. M.

1912 Heald, D., and Wolf, F. A.

1900 Hempel, A.

n.d. Herculais, J. K. de ..

1888 Hildebrand

1875 Fill, W.

1899 Hirscht, $\mathrm{K}$.

*1903 Holmes

1893 Holmes and Davenport

1885 Horn, H. G.

1914 Horn, E. W., and Mutkekar

1889 Horn, H. G.

1893. Hooker, J. D., and Jackson,

1908 B. D.

1877 Hooykaઘs, J. C., and Du Rieu, W. N.

1893

1895 Howard, L. O., a

.

1897 Hubbard, H. G.

1811 von Humboldt, A. ..

1852 von Humboldt, A. ..

1818 von Humboldt, A. . .

1890 Hulst, G. D.

1902 Hulst, G. D.
- Flora of the British West Indian Islands, London, 1864.

.. Catalogo Flora Cubana.

. Paper on Prickly Pear (O. vulgaris) and its cradication, \&c. Agr. Journ. Cape of Good Hope, Irr. 1891, p. 246.

- Notice sur la Culture de la Cochenille en Algerie. Soc. Nat. et Centrale d'Agre., 1850.

. Coltivazione del Fico d'India. Catania, 1913.

.. (1) Prodromus Floræ Siculæ, I, $1827: 1842$ (2) Floræ Siculæ Synopsis.

.. Monatschrift fur Kakteenkunde, $20 \mathrm{Jahrg}, 5$, Này, 1910.

.. See Schumann, K., 1908.

.. Analyses of Prickly Pear. Agr. Gaz. N.S.W., XI, 1900, pp. 671-4.

.. Phytopathologie.

.. Culture du Nopal et Education do la Cochenille en Algérie. Algérie, 1860.

.. Experiments on the Digestibility of Prickly Pear by Cattle. Bull. 106, Bur. Animal Ind., U.S.D.A., 1908 ; also published as Bull. 69, Agr. Exp. Sta., New Mexico, 1908.

A Study of the Carbohydrates in the Prickly Pcar and its Fruits. Bull. 80, Agr. Exp. Sta., New Mexico, 1911.

See Griffiths 1906, 1907a, and 1907b.

Denatured Alcohol from Tunas and other Sources. Bull. 72, Agr. Exp. Sta., New Mexico, 1909, and in New Mexico Agr. Exp. Stat. Report, 1909, pp. 18-21.

. Report Agr. Exp. Sta., Texas, I., 1888, p. 28 (Chemistry).

Bull. 35, Agr. Exp. Sta., Texas, 1895, p. 604 (Analyses and Food Value).

. The Prickly Pear, its Utilisation. Agr. Gaz. N.S.W., 20, 1909, pp. 237-246.

- Anat. de Cact. Tijds. Voor Nat. Geschied. en Phys., pp. 181-242.

.. Supp. Plant. Suc.

.. .. Revue Plant. Suc.

. Report of the Cawnpore Agric. Sta., United Provinces (India) for the year ending June, 1907 (Allahabad, 1908).

A Plant Disease Survey in the vicinity of San Antonio, Texas. Bull. 226, Bur. Plant Ind., U.S.D.A., 1912.

. As Coccidas Brazileiras. Revista do Museu Paulista 4, 1900, pp. 365-537.

.. Les Inscetes s.v. La Cochenille, op. cit., pp. 510-512.

.. Flora of the Hawaiian Islands, 1888.

.. Catalogue of the Plants in the Queensland Botanic Gardens, s.v. Opuntia,

pp. 232-233. Brisbane, 1875.
. "Die Pflege und Zucht der Kalkteen" in Schumann's Gesamtbeschreibung d. Kalst., pp. 769-808. d. Kalst., pp. 769-808.
. Museum Report Pharmac. Soc. Gt. Brit. for 1895-1902 (1903), quoted by
Burkill.

.. Arsenite of Soda. Agr. Journ. Cape of Good Hope, vr, 1893, p. 64.

.. Description of some new Cerambycidæe, with Notes. Trans. Am. Ent. Soc., XII, May, 1885, p. 180-190.

The Feeding of Prickly Pears. Agr. Jnl. Ind. 1x, 2, pp. 190-196.

Insect Life, 2, 1889, p. 162.

Index Kewensis, Plantarum Phanerogamarum Nomina et Synonyma Omnium Generum et Specierum, etc., 7 vols. and 3 supp. vols., 1893. 1908.

Repetorium of de Koloniale Litteratuur. 2 s.v. Cocchenille, pp. 449-451 and 825-849, Amsterdam, 1877.

See Riley, C., 1893. The Oviposition of Melitara prodenialis, Walker. Proc. Ent. Soc., Wash.,
3, 1895, pp. 129-132

. Insect Fauna of the Giant Cactus of Arizona. Psyche, I, Suppl. 1897, .. Essai Politique sur le royaume de la Nouvelle Espagne. Paris, 1811-2. .. Personal Narrative of Travels to the Equinoctial Regions of America, 1799.
1804. Trans. Ross. Lond., 1852, passim.

Ensaya Politico (sobre) El Regno de Nueva Espana, vol. I, pp. 417-431. Madrid, 1818.

.. Trans. Amer. Ent. Soc. 17, 1890, p. 172.

.. In G. H. Dyar's List of American Lepidoptera. 


\section{REFERENCES TO LITERATURE-continued.}

1912 Hunter, W. D., Pratt, F. C. and Mitchell, J. D. India - Bibliography Opuntia

1872 Insenga, Prof. G. ..

1879 Insenga, Prof. G. ..

1904 Jehanne, M. A.

1906 Jehanne, M. A. • .

1892 Juritz, C. F

1810 Juritz, C. F.

1894 Kasimir

1892 Kellogg, V. L.

1908 Keys, R. T.

1852 Knox, J. P

1898 Kuhlgatz

1850 Labouret

1914 Lamont, W. J.

1889 Lauterbach C.

1906 Lee, Ida

1902 Lefroy, H. Maxwell

1895 Iuewis, J. P.

1878 Lima

1753 Linnaeus, C.

1911 Lichtenheld, G.

1908 Lindinger, Dr. T. . .

1907 Livingston, B. E. . .

1879 Longo

Longo

1897 Longo

1868a Lowe, R. T. G.

1868b Lowe, R T. G.

1909 MeColl, J. H.

1891a Macdonald, A. C.

1891 b Macdonald, A. C.

1892a Macdonald, A. C.

1892b Macdonald, A. C.

1892c Macdonald, A. C.

1893 Macdonald, A. C.

1894 Macdoneld, A. C.

1897a Macdonald, A. C.

1897b Macdonald, A. C.

1910 MacDougall, D. T., and Spalding, E. S.

1912 MacDougall, D. T. ..

1914 MačDougall, D. T. ..

Cannon, W. A.
The Principal Cactus Insects of the United States of America. U.S. Dept. Agr. Bur. Entom., Bull. 113, Washington, D.C., Dec., 1912.

of Vid. this Report, section India, passim.

.. Monografia dell' Opuntia Dillenii in Sicilia. Annali di Agricultura Siciliana, 1872.

Le Cactus dans L' Alimentation du betail (Etat de la question en Algerie, Tunis).

- "Mal di Verme" (Boll. d. Società d. Sc. Natur. e Economiche d Palermo 10, 1879.

.. Journ. d'Agr. Trop. No. 33. 4 Mar., 1904 (Utilization, \&c.).

- La Culture du Figuier de Barbarie. Journal d'Agr. Tropicale No. 57, 31 Mar. 1906 (Utilization, \&c.).

.. Analysis of Prickly Pear Poisons. Rept. Dept. Agric., 1891-2 (1892), p.-15.

- A Study of the Agricultural Soils of the Cape Colony, 1910.

"Cristaux chez Opuntia et Pereskia." Bull. Herbı, Boissier t Ir, pp. 499-500, 1894.

. Notes on Melitara dentata, Grote. Kansas Univ. Quarterly, I, 1892, pp. 39-41.

- Prickly Pear as Fodder. Q'ld. Agr. Journ. 1908, pp. 61-62.

- A Historical Account of St. Thomes, West Indies. New York (C. Scribner), 1852.

. Monatschrift f. Kakteenkande, No. 11 pp. 166.179 pl. 1898.

- Monographie de la famille des Cactacées, Dusacq. Paris, n.d. (1850).

-Winter Feed for Stock in the Karoo. South African Agric. Jour., 7, 1914,

.. Bander Sekret-behalter bei den Cacteen, Bot. Centbl. c, 1889, p. 257, 289, 329,369 , and 409 .

.. The Coming of the British to Australia, 1788-1829 (London, 1906).

. Scale Insects of the West Indies. West Indies Bulletin III, No. 3, p. 266, 1902.

.. Manual of the Vanni Districts, Ceylon. Colombo (by authority) 1895.

.. Vid. Mancusa-Lima.

-. Species Plantarum, 1753.

. " Uber die Strauffenzucht, Krankheiten der Strauffe und ihre Behandlung" Tropenpflanzer. 15 Jahrg. No. 11, Nov., 1911, p. 595 (Prickly Pear as Food for Ostriches)

.. Jahr. Hamb. Wiss. Anst. XxvI, 1908 (Asp eglandulosus).

.. Relative Transpiration in Cacti. Plant World, 10, No. 5, pp. 110-114, Fige. (1907).

.. Intorno a Canali delle opunzie. Ann. R. Inst., Bot di, Roma, vII.

. Idioblasti nuciferi dell. Cactee, op. cit.

.. Mucilagine delle Cactee Bull. d. Soc., bot, 1896, p. 50-2.

. A Manual Flora of Madeira and the adjacent Islands, s.v., Cactacea, vol, 1, pp. 313-320. London, 1868 .

. Botanic Magazine, 1868. Plates.

.. The Prickly Pear. Journ. Agr. Victoria, 1909, pp. 763-768.

. Prickly Pear in South Africa. Agr. Journ. Cape of Good Hope, Iv., 1891, pp. 21-5; also in $1891 \mathrm{~b}$ and $1897 \mathrm{a}$.

. Prickly Pear in South Africa. In R.S.C. 1891, pp. 20-35, and further evidence in pp. 35-40.

.. Report in Report Dept. Agric., Cape of Good Hope, for 1891.2 (1892), pp. 21-3-same as 1892c.

. Notes of the Dept.-A New Cactus. Agr. Journ. Cape of Good Hope, 1892, pp. 93-4-game as 1897b.

. Report on Chemical Scrub Exterminator in Fischer's Annual Report. Agr. Journ. Cape of Good Hope, v, 1892, pp. 112-3-same as 1892a.

. Arsenite of Soda as an Exterminator for Prickly :Pear. Agr. Journ. Cape of Good Hope, vi, 1893, pp. 276-7 (see also Palmer, 1893).

. Extirpation of Prickly Pear. Agr. Journ. Cape of Good Hope, vIr, 1894,

.. The Prickly Pear in the Eastern and Midland Districts. Agr. Miscell., Cape of Good Hope, 1897, pp. 26-36-same as 1891a, 1891b.

.. The Prickly Pear-A New Species. Agric. Miscell., Cape of Good Hope, 1897, pp. 36-9-same as 1892b.

The Water Balance of Succulents. Publication 141, Carnegie Instit., Washington, 1910.

. The Water Balance of Desert Plants. Annals Botany, 26, 1912, pp. 71-93.

. Annual Report of the Director of the Dept. of Botanical Research, Year Book No. 12, Carnegie Institution of Washington, for the year 1913. pp. 57-87. This report includes summaries of papers partly or wholly referring to investigations into the physiology of the Cactacer.

. Root Variation in Desert Plants, pp. $72 \frac{2-73}{}$ 


\section{REFERENCES TO LITERATURE-continued.}

Shreve, E. B.

Spoehr, H. A.

Richairds, H. M.

Johnson, D. S.

Britton, N. L., and. Rose, J. N.

1911 Mackensen, B.

1912 Mackensen,.B.

1888 a Mas Owan, $P$.

1888 b MacOwan, $P$.

1890 MacOwan, P.

1891 MacOwan, $\mathrm{P}$

1897 MacOwan, $P$

*1898 Magnus, $P$.

1896 Maiden, J. H.

1898a Maiden, J. H.

1898b Maiden, J. H.

191 la Maiden, J. H.

1911b Maiden, J. H.

1912a Maiden, J. H.

1912b Maiden, J. H.

1912c Maiden, J. H.

1912d Maiden, J. H.

1912e Maiden, J. H.

1913a Maiden, J. H.

1913b Maiden, J. H.

1913c Maiden, J. H.

1913d Maiden, J. 且

1914a Maiden, J. H.

1914b :Maiden, J. H.

1878 Manouso-Lima, Prof: G.

1904 Mancuso-Lima, Prof. G.

1905 Manousa-Lima, Prof. G.

1905 Mancusa-Lima, Prof. G.

1896 Marlatt, C.

1892a Marloth, Dr. R.

1892b Marloth, Dr. R.

1906 Marloth, Dr. R.

*1855 Martius, T.

1899 Maskell, W. M.

1840 Masters, J. W.

1570 Mattioli, P. A.

1860 Méneville

1787 de Menonville, Thierry

1890 Merriam, C. H

1899 Merriam, C. H.
.. Autonomic Movements of Stems of Opuntias, pp. 79-81.

.. The Photolysis of Plant Acids, pp. 82-83.

. Acidity, Gaseous Exchange, and Respiration of Cacti, pp.84-86.

.. Fruit Development in the Cactaceæ, pp. 86-87.

The Relationships and Distribution of the Cactaceæ, p. 87.

Two New Species of Opuntia. Bull. Torrey Bot. Club, 38, 1911, pp. 141-3.

. Three New Species of Opuntia, with a discussion of the identity of O. lindheimeri. Bull. Torrey Bot. Club, 39, 1912, pp. 289-292.

. The Prickly Pear and the Kaalblad. Agr. Journ. Cape of Good Hope, vol. 1,1888 .

. Kew Bulletin, 1888.

.. In answer to a Letter. Agr. Journ. Cape of Good Hope, IIr, 1890, p. 61.

.. On the Introduction of Opuntia tuna into the Colony.

. The Prickly Pear and the Kaalblad. Reprinted in Agric. Miscell., Dept. Agric., Cape of Good Hope, 1897, pp. 1-6.

"Einneues Aॄcidium auf Opuntia sp. aus Bolivien." Ber. Deutsch Botan. Gesell, 1898, p. 151, pt. I.

- Plan of an Inquiry into the Merits of Prickly Pear as a Forage Plant (translated from the French of Paul Bourde). Agr. Gaz. N.S.W., 7. 1896, pp. $651-7$.

- Botanical Notes-Prickly Pear. Agr. Gaz. N.S.W., 9, 1898, p. 38.

.. A Preliminary Study of the Prickly Pears naturalised in N. S. Wales. Agr. Gaz. N.S.W., 9, 1898, pp. 978-1008.

. . The Prickly Pears of Interest to Australians, I. Agr. Gaz. N.S.W., 22,1911, pp. 321-328.

. The Prickly Pears of Interest to Australians, II. Agr. Gaz. N.S.W., 22, 1911, pp. 696-698.

. The Prickly Pears of Interest to Australians, III. Agr. Gaz. N.S.W., 23, 1912, pp. 208-210.

. The Prickly Pears of Interest to Australians, IV. Agr. Gaz. N.S.W., 23, 1912, pp. 713-716.

. The Prickly Pears of Interest to Australians, V. Agr. Gaz. N.S.W., 23, 1912 pp. 1027-1028.

. Note on Opuntia aurantiaca. Agr. Gaz. N.S.W., 23, 1912, p. 888.

- Presidential Address. The Prickly Pear. Journ. Proc. Roy, Soc. N.S.W., 46, 1912, pp. 38-41.

. The Prickly Pears of Interest to Australians, VI. Agr. Gaz. N.S.W., 24, 1913, pp. 49-55.

. The Prickly Pears of Interest to Australians, VII. Agx. Gaz. N.S.W., 24, 1913 , pp. 863-6.

.. The Prickly Pears of Interest to Australians, VIII. Agr. Gaz. N.S.W., 24, 1913, pp. 973-4.

The Prickly Pears of Interest to Australians, IX. Agx. Gaz. N.S.W., 24, 1913, pp. 1073-6.

. The Prickly Pears of Interest to Australians, X. Agr. Gaz. N.S.W., 25, 1914, pp. 137-8.

. The Prickly Pears of Interest to Australians, XI. Agr. Gaz. N.S.W., 25, 1914, pp. 519-520.

- (1) La Compagna e gli Annali de Agricultura Sicl., 1879.

.. (2) Nuovi Annali di Agricultura Siciliana, Ann. $\mathbf{x V}$, fasc. 1, 1904.

. (3) Op. cit. Ann. xचI, fasc. I, 1905 (Analysis of Fruits, Seeds, etc.).

- (4) Le Stazioni sperimentale Agrarie Ital. Modena. 28, p. 805, 1905.

.. Proc. Ent. Soc., Wash., 4, 1896, p. 44.

. The Prickly Pear in South Africa. Agr. Journ. Cape of Good Hope, V, 1892, pp. 111-2.

. The Prickly Pear in South Africa. In Rep. Dept. Agric., 1891-2 (1892) pp. 18-21.

.. Evidence in R.S.C., 1906, pp. 15-24.

.. Culture of the Cochineal in the Canary Islands. Pharm. Journ., 14, 1855, pp. 553-6.

.. (On Indian Cochineal Insect), Indian Museum Notes, Iv, 4, p. 212, 1899.

. Calcutta Flora-Synopsis of Plants indigenous or cultivated in the vicinity of Calcutta. Trans. Agr. and Hort. Soc. of India, VIr., 1840.

" Commentarii", etc., Editions 1544 (Italian), 1553, 1558, 1560, 1565, 1570 (Latin).

. Vid. Guérin-Menoville.

. Traité de la culture du nopal et d l'Educatiun de la Cochenille, \&c. In (Voyage to Guaxaca). Paris, 1787.

. North American Fauna, Nu. 3, Div. Ornithology and Mammals, U.S.D.A. 1890.

. Results of a Biological Survey of Shasta, California. 
1768 Miller, $\mathrm{P}$.

1912 Mitchell, Pratt

1909 chell; S. R., Hare, and Bjerregaard

1897 Moscoso, R.

1911 Musson, C. T.

1897 Newstead, $R$

1903 Newstead, R. 1906a Nobbs, Dr. E. 1906b Nobbs, Dr. E.

1907a Nobbs, Dr. E.

1907b Nobbs, Dr. E.

1908 Nobbs, Dr. E.

1849 de Nobrega, G. J.

1907 Noel, L. I.

1892 Oliver, $\mathrm{H}$.

1897 O'Shea, J.

1893 Palmer, G.

1909 Palmer, G.

1912 Parker; R. N.

1912 Perkins, A. J.

1834 Perrotet

.. .. Gardeners' Dictionary, virl, 1768. 8th Wd.

See Hunter, 1912.

See Hare, 1909.

Las Familias Vegetales. Santo Domingo (Luis A. Weber), 1897. (Described as being a portion of Moscoso's La Flora de Santo Domingo ? unpublished.)

Eradication of Prickly Pear-A Suggestion. Agr. Gaz. N.S.W., 22, 1911, p. 58.

. Entom. Monthly Mag., vIrr, 1897.

. Monograph of the Cocoidæe of the British Isles, II, pp. 223-6, Pl. LxxiI, s.v., Coccus tomentosus, L. London, 1913.

. Evidence in R.S.C., 1906, pp. 7-15; pp. 24-30 ; pp. 37-42.

Notes on the Jointed Cactus. Agr. Journ. Cape of Good Hope, 1906, pp. 812-814.

. Experiments upon the Destruction of Priokly Pear, 1907. Agr. Journ. Cape of Good Hope, Dec. 31, 1907, pp. 676-682.

.. Experiments upon the Destruction of Prickly Pear, 1907, as Reprint, No. $26,1907$.

.. Experiments upon the Destruction of Jointed Cactus, 1907. Agr. Journ. Cape of Good Hope, xxxIr, 1908, pp. 341-6-reprinted as No. 12, 1908.

.. On the Cultivation of Cochineal. Pharm. Journ., 8, 1849, pp. 342-8.

Culture du Cactus inerme en Tunisie comme Fourage et pour le fruit. Journ. d' Agric. Trop., 1907, p. 190.

.. Letter. Agr. Journ. Cape of Good Hope, จ., 1892, p. 89.

.. Prickly Pear. Agr. Gaz. N.S.W., 8, 1897, pp. 434-5.

.. . . Letter in Macdonald, 1893.

.. $\quad$.. Index Generum Mammalium. Bur. Biol. Survey, U.S.D.A., 1909.

.. .. Notes on Cacti in North-West India. Journ. Bombay Nat. Hist. Soc., 21. 1912 , p. 1095.

. Agriculture in Other Lands-Tunisia. Journ. Agr. South Austr., April, 1912 , p. 889 (Utilization).

... Annales, Maritimes, Paris, Mar. and Nov., 1834. (Introd. Grana sylvestre to Senegambia)

1867 Perez, Dr. V., and Sagot, La Vegetation aux Tles Canaries. Journ. de l’Agr. des pays chauds,1865. Dr. $P$ 1866, Paris, 1867.

1.894 Phillippi, R. A. $\quad$. $\quad$. . Plantas Nuevas Chilenas, \&c. Anal. Univ. Chili, vol. 85, 1894.

1906 Pierce, W. D.

1911 Pierce, W. D.

. On the Biologies of the Rhynohophora of N. America. Rep. Nebraska State Bd. Agric. 1906, pp. 249-319.

- Systematic Notes and Descriptions of some Weevils of Economic or Biological importance. Proc. U.S. Nat. Museum, 42, 1911, pp. 155-170. (Cactus Weevils, pp. 159-170.)

1908 Pitard, J., and Proust, L. .. Les Iles Canaries : Flore de l'Archipel. Paris (Paul Klinchsieck), 1908.

1891 Pojer

1877 Popenoe, E. A.

.. Flora Sicula, I, p. 2, 1891.

1878 Pópenoe, E. A.

1912 Pratt, F. C. Mitchell

1908 Preble, E. A.

1839 Prinsep, G. A.

.. A List of Kansas Coleoptera. Trans. Kansas Acad. Sci., 5, 1877, pp. 21-40.

1908

1907 Ramirez, R.

. Additions to the Catalogue of Kansas Coleoptera. Trans. Kansas Acad.

unter and See Hunter, 1912.

A Biological Investigation of the Athabasca-Mackenzie Region. North Amer. Fauna No. 27, Biol. Survey U.S.D.A., 1908.

- Account of the Method of Cultivating the Cochineal Insect in the Provinee of Oaxaca, 1820. Trans. Agr. Hort. Soc. India, 6, 1839, Appendix, pp. $73-84$.

1888 Riley, C.

"El Nopal y el Sotol oomo Forrajes de Invierno." Estacion Agricola Experimental de Ciudad Juarez, Chihuahua, Mexico, Sect. de Fomento, Bol., 6 Jan., 1907.

1889 Riley, C. 1888 .

1891 Riley, C.

.. . Notes on the Cochineal Insect. Insect Life I, 1889, pp. 258-9.

1893 Riley, C., and Howard, L. O. Insect Injury to Cactus plants. Insect Life, 5, 1893, p. 345.

1844 Risso

.. Flore de Nice, Nice, 1844.

*1896 Riviere and Lecq .. .. Manuel Pratique de l'Agriculture Algérien, pp. 218.220. Paris, 1910 (Utiliza. tion).

1912 Rodriguez, E.

.. El. Nopai sin Espinas (Cactu* inermis), Revista de Agr. An. 2. No. 3, Pt. I, pp. 203-7, Mexico, Mar. 1912 (Utilization).

1912 Roig y Mesa, Juan T. .. Cactaoeas de la Flora Cubana—Tosis para el Gravo de Doctor en Ciencias

.. (1) Aliquot fungi novi Galliæ. Bull. de la Soc. Mycol. de Fr. xIr, 1896.

1905 Rolland, L. (2) Revue Mycologigue xxi, 1905 (3), Bulletin de la Soc. Mycol. de France, t. xxт, pp. 26-7, 1905. 


\section{REFERENCES TO LITERATURE-continued.}

1892- Rose, J. N. … ․ . Various papers in Contr. Nat. Herbar., Washington, 1892 to 1911 ; Journ.

1913 N. York Bot. Gardens, 1911 ; Smithsonian Mise. Coll., 1907 to 1913.

.. Rose, J. N., and Britton, N. See Britton and Rose, 1907-1914, 1908, 1912.

1890-1 Rose, J. N., and Vasey, G... Papers in Contr. Nat. Herbar. Washington, D.C., 1890-1891.

1890 R.S.C.

1891 R.S.C.

1898 R.S.C.

1906 R.S.C.

1729 Russoher, Melichior de

1745 Sagra, D. Ramon de la

1867 Sagot, P., and Perez, V.

1828 Salm-Dyck, P. J. de

1850 Salm-Dyck, P. S. do

1908 Sanna, A.

1901 Sarcoli and Ulpiani ..

1868 Sauvalle, F. A. ..

1897 Savastano, L

1910 Savastano, I.

1893 Schenck, H.

1839 Sohleiden, $\mathrm{J}$.

1841 Schomburgh, R.

*1856 Schott, A.

1890 Schumann, $\mathrm{K}$.

1899a Schumann, $\mathrm{K}$.

1899b Schumann, K.

1903a Sehumann, K.

1903b Schumann, K.

1908 Schumann, K., and Gurke

1896 Sehwarz, E. A.

1899a Schwarz, E. A.

1899b Schwarz, E. A.

1901 Schwarz, E. A.

1902 Seott, E. K.

191

1875

\section{0}

\section{7}

1725
1891

S. B.

1892 Smith, J. B.

1908 Solereder, Dr. Hans.

1898 Sotyia, Dr. G

1898 Spegazzini, C.

1899 Spegazzini, C.

1902 Spegazzini, C.
. Report of the Select Committee on the Prickly Pear. Capetown, 1891.

- Report of the Select Committee on the Eradication of the Prickly Pcar and Poisonous Melkbosch. Capetown, July, 1890.

. Report of the Select Cornmittee on the Eradication of Prickly Pear. Capetown, Dec., 1898.

-. Report of the Select Committee on Prickly Pear. Capetown, 1906.

. NatuerIyke Historie von de Couchenille bewery en met Authentique Docu. mentem. Amsterdarn, 1729.

.. Historia Fisica Politica y Natural de la Isla de Cuba-2 Parte, Historia Natural, tome $\mathrm{x}$, Botanica. Paris, 1745 .

- See Perez, 1867.

. In P. de Candolle's Prodromus, IIr.

. Cacteæ in Horto. Dyckensi cultæ, Anno, 1849.

. Staz. Sper. Agr. Ital., 1908, No. 9-11, pp. 550-561. Abst. Chem. CcntbI., 1909 ; I, No. 8, p. 675, and Journl. Chem. Ind. 28 (1909) 5, 255.

. See Ulpiani, 1901.

- Flora Cubana-Revisio Catalogi Grisebachiani vel Index Plantarum Cubensium, 1868.

. Del Marciume del Fico d'India nel Catanzarese. BoIl. Soc. Nat. Napoli, xi., 1897, p. 110.

. Patologia Arhorea Applicata. Lezioni, Napoli, 1910, s.v. Il Marciume, pp. $209-10^{\circ}$

. Vid. Soleredor.

.. Beiträge Zur Anatomic der Cacteen, Mem. Acad. Soi. scr. 6, t. 4 St. Petersb., fol. 1839 , fol. and 4 to 1842 .

.. History of Barbados, 1841.

.. $\quad$. Proc. Amer. Acad. Arts Science, 3, 1856.

. . . Cactaceæ in Martius, "Flora Brasiliensis." Iv, pp. 184-334.

. Die Verbreitung der Cactacer. Abt. K. Preuss. Akad. Wiss. Berlin, 1899 Published separately, Berlin, 1899.

.. . . Gesamtbeschreibung der Kakteen, 1899.

.. . . Gesamtbeschreibung der Kakteen, Supplement, 1903.

.. . Keys of the Monograph of the Cactaceæ, 1903.

- Monatsschrift f. Kakteenkunde, xvmI; 1908.

.. $\quad$.. Proc. Ent. Soc. Wash., 3, 1896, p. 48.

.. . . Descriptions of New Species of Coleoptera. Psyche, 1, Suppl. 1899, pp. 8-13.

. $\quad$. Classified List of Species observed by H. G. Hubbard on the Giant Cactus. Psyche, Suppl. I, 1899, pp. 13-14.

. . Proc. Ent. Soc. Wash., 4, 1901, pp. 368-9, 431

.. . . Hand-feeding Stock in the Moree District. Agr. Gaz. N.S.W., 13, 1902, pp. 1051-3.

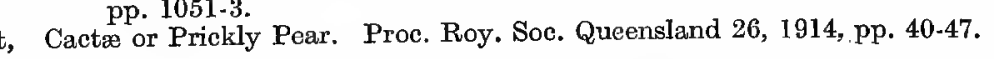

.. Essai sur les Cochenilles. Ann. d. 1. Soc. Ent. d. Fr. (1868-75) s.v. Coccus op. cit., p. 44 (Bibliography) and 380.

- See Forbes and Skinner.

. Voyage to the Islands of Madeira, Barbadoes . . .

Jamaica, \&c., $1707-1725$.

.. Habits of Volucella. Canad. Ent., 23, 1891, pp. 242-3.

-. Entom. News, 3, 1892, p. 208.

. Systematic Anatomy of Dicotyledons. Ed. and Transl. Boodle, Fritsh and Scott. Oxford Clar. Press, 1908, Anatomy I, pp. 406-415, and Litera ture Anatomy.

. Studio Chemico-zootechnico circa razionale impiego delle Palette de Fico d' Chemico-zootechnico circa dillimentazione delle Vache di Latte in Sardegna. Le

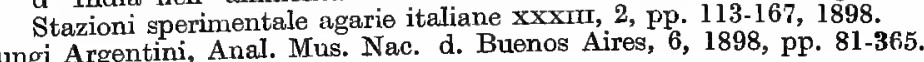

.. Fungi Argentini, Anal. Mus. Nac. d. Buenos Aires, 6, 1898, pp. 81-365.

.. Mycetes Argentinensis, series I., An. Soc. Cientif. Argentina, 47 and 50, 1899 , reprint, $48 \mathrm{pp}$.

. Mycetes Argent., ser. Il., An. Soc. Cicutif. Argentina, 8, 1902, pp. 49-89. 


\section{REFERENCES TO LITERATURE-continued.}

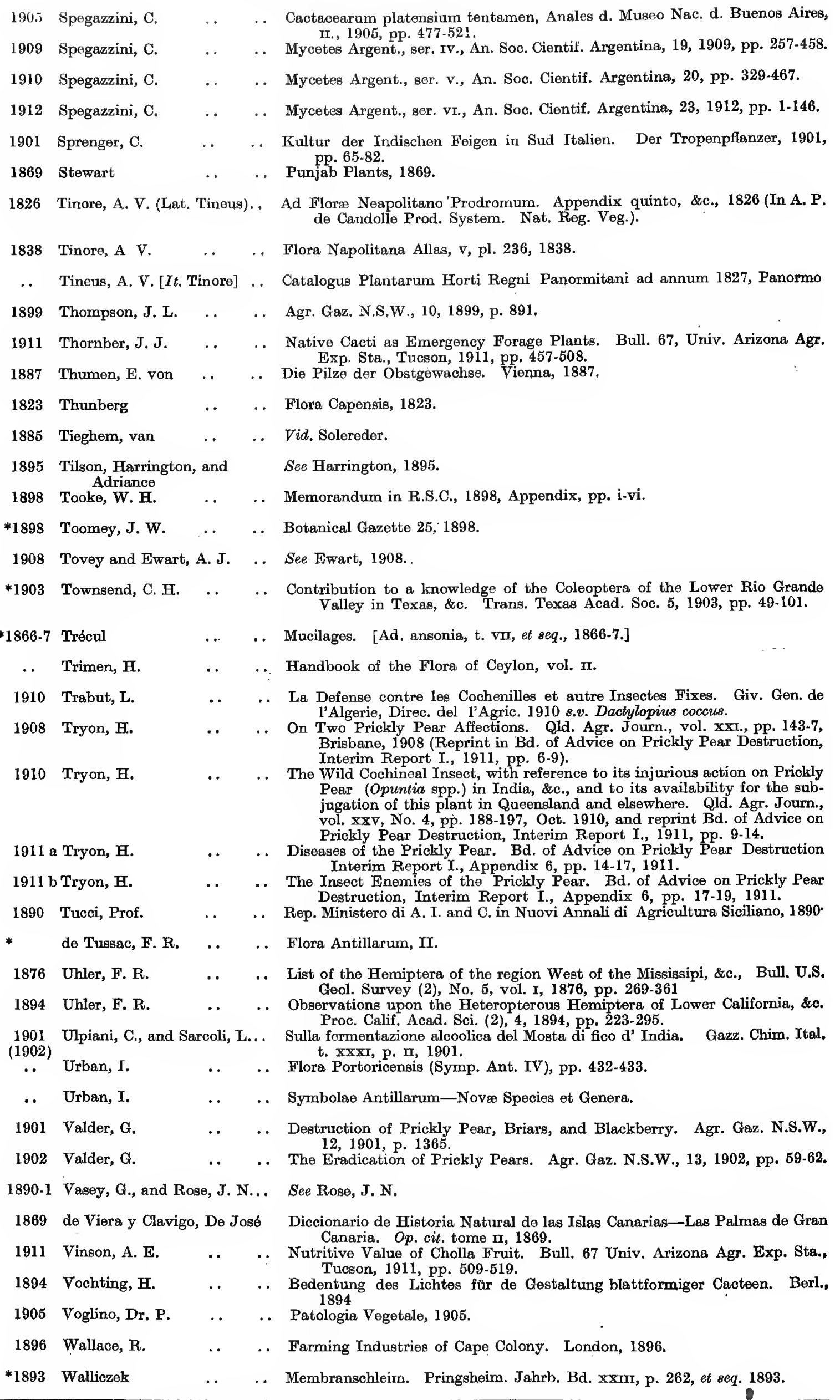

* References marked thus have not been consulted. 
REFERENCES TO LITERATURE-continued.

1903 Ward, Osbert

1914 Warren, E.

1889 Watt, Sir G

1891 Watt, Sir G.

1908 Watt, Sir G.

1840 Webb, Barker, and Berthelot, $\mathbf{S}$.

*1893. Weber, Dr. A.

1899

1902 Weber, Dr. A.

1888 Wetterwald

1913 White, Jean

1914 White, Jean

1850 Wight, D.

1912a Wolf, F. A.

1912b Wolf, F. A.

. The Vale of Orotava. London, 1903.

. The Prickly Pear Pest. South African Agric. Journal, 7, 1914, pp. 387-391. Abstract in Review of Applied Entomology, Ser. A. Agricultural, 2 (7) July, 1914, p. 440.

. Dictionary of Economic Products of India, vol. 2, 1889.

. Dictionary of Economic Products of India, vol. 5, 1891.

. . . Commercial Products of India, 1908.

Phytographia Canariensis : Histoire Naturelle des Iles Canarias, tome II, pt. 3, Paris, 1840.

. Bois. Dict. d'Hort., 1893-1899.

. Etudes sur les Opuntias. Bull. se la Société Nat. d'Acclimatation, 1902.

. $\quad$. Blatt-und Sprossbildung bei Euphorbien und Cacteen. Basle., 1888.

. . . Report of the Officer in Charge of the Prickly Pear Experimental Station, Dulacca. Appendix 4 Ann. Rep. Dept. Public Lands, Qld., for the year 1912 (1913).

.. . . Report of the Officer in Charge of the Prickly Pear Experimental Station, Dulacca. Appendix 4 Ann. Rep. Dept. Public Lands, QId., for the year 1913 (1914).

.. .. Illustrations of Indian Botany II, pt. 114, 1850 .

1912 Wolf, F. A., and Heald, D... See Heald, 1912

1911 Wooton, E. C. $\quad$.. $\quad$.. Cacti in New Mexico. Bull. 78, Agr. Exp. Sta., New Mexico, 1911.

1911 Zimmerman, A. .. .. Report of work at Amani, A.D., W. Africa. Der Pflanzer, Jahr. vயr, 1,

1910 Zimmerman, A. .. .. Die p. 231, 1911.

Opuntien als Nahrungsmittel für Menschen und Tiere. Der Pflanzer, Jahr. VI, No. 4, pp. 51-64; No. 5, pp. 72-77; Nos. 6-7, pp. 81-84. Tanga, 1910 .

* References marked thus have not been consulted. 


\section{SUPPLEMENTARY NOTES.}

\section{(1.) FEEDING CATTLE WITH PRICKLY-PEAR UNDER TEST CONDTTIONS AT KTRKEE, POONAH, BRITISH INDIA.}

In the Report (vid.p.24) reference is made to experiments being prosecuted to which the above description applies. The account of these investigations has now been made public in a joint contribution to The Agricultural Journal of India (Vol. IX. Pt. 2, Ap. 1914,pp. 190-196), bearing the title "The Feeding of Prickly-pear," by Messrs. E, W. Horn and S. G. Mutkekar, the latter being Agricultural overseer at Ahmednagar. It is just to hand, and the following is a summary of it :-

These feeding experiments conducted at the Government Civil Dairy, Kirkee, by its Manager, E. W. Horn, were commenced in January, 1913, and had been continued for six months when the report referred to was made.

In the first experiment whose object "was to place beyond doubt the possibilities of cactus as an emergency ration in times of scarcity, to decide the best method of preparing and feeding it, and the cost of preparation," six bullocks were used. These had been purchased in the famine-stricken district of Ahmednagar for the purpose, and "were in exceptionally poor condition. on arrival, with the exception of one bullock, which was in fair condition." This experiment "clearly demonstrated that the prickly-pear, if properly prepared and mixed with 6 per cent. of its weight of cotton seed, is not only enough to support life, but will enable an animal to regain condition even after it has become very poor from semi-starvation, and that the cultivators could save their cattle in times of famine by feeding the above, the cost of preparation being very low."

At the beginning of the experiment there was a loss of weight varying from 2 pounds to 60 pounds (a very emaciated animal that only commenced to eat pear at all readily towards the end of the experiment) : this, however, was very soon overcome, and a steady gain in weight was made, until a maximum was reached, after which the weight was practically constant, the greatest gain being 70 pounds. The average quantity of pear consumed was 32 pounds per head per day, varying according as the pear contained more or less moisture. This average works out to 72 pounds per 1,000 pounds live weight. The rations as compared with Haeker's standard $(.7 \mathrm{lb}$. protein, $7 \mathrm{lb}$. carbohydrates, and $1 \mathrm{lb}$. fat), showing a deficiency of $.58 \mathrm{lb}$. of carbohydrates after the surplus fat and protein had been converted to this nutrient. The pear used was Opuntia elatior,* a far more spiny species than the Queensland pest pear, and this, after being singed to remove the "prickles," was passed through a Smalley chaffcutter.

In the second experiment the object was to find out if the succulence of the prickly-pear was of any value for increasing the milk yield when no other green fodder was available. In this case 19 cows in milk were utilised. Pear up to 14 lb. per head per day was used, mixed with the ordinary food, which was proportionately decreased in quantity. The report with reference to this states: "for various reasons we were obliged to discontinue this part of the experiment without getting any decided results. This will be tried later on."

* One of the Commissioners (H. T.) concludes that the Indian Opuntia named in Section II. (India) O. nigricans is O. elatior, Miller, and thus follows Mr. I. H. Burkill, who has both ably and fully discussed the question (1911-p. 316-317), and would add that not only doss it agree with Miller's deseription of $O$. elatior (1768, No. 4), but it also accords with Dillen's figure (Hortus Eithamensis, tab. 194), which Miller citez as representing the type, and with Dillen's description of this as having "flowers passing from yellow (flavus). to purple." 
In the third experiment the dry cattle and young stock of the dairy at Marjiri were used. These were fed with pear and a mixture of cotton-seed hulls, cotton seed (1 lb.) and molasses (1 lb.). "The animals had fallen off condition, owing to the grazing having become scanty, but when put on the feed abovenamed they rapidly regained their former condition. They exhibited no signs of abnormal looseness of the bowels at any time, neither did they require any coaxing to eat the mixture, even on the first day. The bullocks did not take any water worth mentioning, except when salt was added to the pear, but with the addition of $2 \mathrm{oz}$. of salt they drank a normal quantity."

The fourth experiment partook of the nature of a demonstration, and was made at Ahmednagar whilst famine conditions obtained; eleven bullocks were used, which, when taken in hand, were in poor condition. "The consumption of pear per 1,000 pounds live weight averaged $58 \mathrm{lb}$., but, in addition to this, $10 \mathrm{lb}$. of hay per 1,000 pounds of live weight were fed and cotton seed was added to the ration as at Kirkee." "The animals were given light continuous work such as harrowing, sowing, and bringing the prickly-pear. They remained practically in the same condition throughout the demonstration."

During the course of the demonstration the native graziers had overcome their prejudice to the use of prickly-pear in stock feeding, so that the camp at Ahmednagar that had commenced with these eleven bullocks increased by additional animals being brought in to a total of 800 .

Similar demonstrations with like results were made at Lakh and at Miri, and "when the camps were closed owing to improvement in local conditions, a number of cultivators at Lakh borrowed the stoves (one of several types of primus stoves that had been deemed most suitable) and continued to feed the pear to their cattle at their own expense."

\section{(2.) INTRODUCTION OF PRICKLY-PEAR TO AUSTRALIA.}

With regard to the part alleged to have been taken by Captain A. Phillip, in introducing in 1788 the prickly-pear into Australia (vid. p. 112), it may be of interest to cite the testimony of one who saw living plants of Opuntia in his possession during the course of his memorable voyage hither.

On Phillip calling in at the Cape of Good Hope, Captain John Cox, who is referred to in this statement, went aboard his vessel and was shown not only the plants, but also the cochineal insects that were being conveyed to the new settlement that was to be formed at Botany Bay. "The insect, he wrote, was fixed on the plant under a very white down, and Commodore Phillip, who brought both from South America with him, did not wish that either should be in the least disturbed."

Previous to this incident, Cox had visited Madras, and whilst there had seen Opuntia monacantha, Haworth (Roxburgh's Cactus indicus) that Dr. J. Anderson had been growing there, with a view also to the cultivation of the cochineal insect, and instituting a comparison between Captain Phillip's Opuntia and the latter, and relying on his memory, Captain Cox wrote, on 27th November, 1787, to Dr. Anderson regarding the former, that " the prickly-pear appeared to me to have more thorns and to be not nearly so luxuriant," and again on 29th November, 1787: "Having had an opportunity of inspecting both the cochineal, as well as the prickly-pear on which it is cultivated," I find that: "They resemble both as nearly as possible that I have seen in your garden, except that the prickly-pear appeared to me to have many more thorns." [Anderson (J.) Letters to Sir Joseph Banks, Madras, 1788. Appendix.] 
Thus Captain Phillip was taking with him on his voyage to Australia a plant of South American origin, that possessed thorns, and that supported a growth of Wild Cochineal. That the latter was not the precious cochineal insect may be inferred from Dr. De Simœn's testimony of the quality of Brazilian cochineal quoted by Dr. Anderson in a previous letter also to Sir J. Banks (Anderson, J., Letters, 1789, p. 12.)

\section{(3.) ANATOMICAL STRUCTURE OF PRICKLY-PEAR.}

As the destruction of prickly-pear by its utilisation may involve considerations relating to its anatomical features, it may be pointed out these have not been overlooked by botanical investigators. The best summary of their work is perhaps that contained in Dr. Hans Solereder's comparatively recent memoir On the Systematic Anatomy of the Dicotyledons. Of this, the English translation, edited by Messrs. L. A. Boodle, F. E. Fritsch, and D. H. Scott, and issued in 1908, devotes nearly ten pages (pp. 406-415) to the consideration of the subject. Solereder summarises what has been recorded regarding the stomata, cuticle, epidermis, hypodermis (collenchyma), woody-tissue and its components, thorns, excretory and secretory structures (mucilage cells and canals, crystal cells (oxalate of lime), lactiferous vessels, idioblasts, \&c., citing many authorities often with regard to each. Several of these, together with the particular feature in the plant's anatomy that has engaged attention, are more fully mentioned in the references to Bibliography, with which this report concludes. Of the principal writers thus referred to may be mentioned J. Schleiden (1839), Gasparini (1842), Arloing (1877), De Bary (1877), Longo (1879) ; H. Caspari (1883); Lauterbach (1889); and H. Vochting (1894).

With regard to the oxalate of lime that is so conspicuous a feature in the group plants under consideration, W. Pfeffer has stated in his "Physiologie" that "in some Cactaceæ even 80 per cent. of the dry weight" consists of this substance (vid. Edition Ewart, vol. I., p. 486, 1900) and Solereder also remarks that oxalate of lime is sometimes excreted in enormous quantities in this order, and quotes Schleiden to the effect that "as much as 85 per cent. of the weight of the ash of the entire plant (in Cephalocereus senilis), is composed of it (Op. cit., p. 413). In this connection, reference also may be made to Tryon (1911, p. 7) and Shirley and Lambert (1914, p. 42).

\section{(4.) ADDITIONAL NOTES ON WILD COCHINEAL.}

\section{A. Quegnsland Pest Pear and Wild Cochineal.}

Our inquiries have led us to conclude that, whereas the several kinds of Wild Cochineal Insect (Grana sylvestre) attach themselves to different kinds of prickly-pears, and sometimes with fatal results to their plant-hosts, there is with regard to some a decided exclusiveness in their dietary. This especially seems to obttin with Coccus indicus, Green, that is alike so injurious in India, South Africa, and Queensland to Opuntia monacantha. Again, there is the association of Nopalea cochinelifera, Linn., and Coccus confusus newsteadi in the West Indies.

With regard to our particular quest-the discovery of a Wild Cochineal insect or insects inimical to the growth of, or even feeding upon, our commoner Queensland pest pears, Opuntia inermis, DC., and the denizen of the Burnett River Valley that Mr. J. H. Maiden has referred (we deem erroneously) to $O$. Dillenii, Haw., it may be added that we met with no satisfactory evidence pointing to their existence. 
As regards Opuntia Dillenii the late Sir William Hooker in 1879 (cf. Flora of British India, III., p. 657-8) has stated that it was the kind in India upon which cochineal formerly brought from America multiplied abundantly; but this was an error into which he had fallen through identifying the species named with Roxburgh's Cactus indicus as Wight had done forty-five years earlier.

In the matter of our more prevalent pest pear (O. inermis, DC.), however, there are grounds for concluding that a wild cochineal insect may still exist in the "Black Republic" of the West Indies, although we failed to discover it on visiting Barahona, near where it unites with San Domingo ; also, that it may attack not only it but also $O$. Dillenii, Haw.

We have it on record that de Menonville, on his return to Port au Prince, Hayti, in 1777, from Guaxaca, Mexico, brought with hin not only the Grana fina (Coccus cacti) or the precious cochineal insect, but also a wild cochineal insect or Grana sylvestre; also that whereas the former insect shortly after this died out, the latter persisted and multiplied, and did so to such an extent, that shortly after this enterprising man had died (Ob. 1780), a large amount of this Sylvestre was sent from Hayti to France, especially during the years 1787-88 (Anon : Culture of the Cochineal, Trans. Agr. and Hort. Soc., India; VI., 1839. Appendix, p. 17).

Moreover, de Menonville stated that at the time when this importation was made a wild cochineal insect, or Sylvestre, already occurred on Cactus at Hayti, and this he also pronounced to be the same as that which he had brought with him.

Some years subsequent to this the French Marine in Paris-the official body that had exploited this Hayti cochineal business-decided to introduce the Wild Cochineal to the West African French possession, Senegal.

This introduction was accomplished in 1825, and Mons. Perottet, the Agricultural Botanist of the French Government, who has incidentally mentioned this in a pamphlet detailing methods for freeing the Sylvestre. Cochineal from its downy covering (Annales Maritimes-March, April, 1834, Paris), adds that the insects, derived from the French Antilles (i.e., Hayti), were attached to species of Cactus inermis, DC. Perrotet also mentions that it greatly prefers this kind, which he names the "Spanish Raquette"; but that it also lives on a second prickly-pear species which he refers to as the "Thorny Raquette" (the Indian Fig of San Domingo), or the Opuntia tuna of botanists.

Indeed, after its transference to Senegal it had " increased so much that the branches (of Opuntia inermis) became quite white at the end of a few months, and bent by degrees under the weight of their numerous parasites." With regard to the living insect itself he states that it is covered with a thick, extremely tenacious down.

With regard to the identification of its host-plants, Perottet would no doubt defer in this matter to his compatriot and contemporary, P. De Candolle. The one to which it was less partial was doubtless Opwntia Dillenii, Haworth, which de Menonville (1787) thus refers to :- "Le tuna de Dillenius : c'est celle que les colons de Saint Dominique appele "raquette de bords du mer."

That the other is De Candolle's Opuntia inermis, and our pest species, will also appear from Perottet's description of it. After mentioning that the "long hard and pointed thorns which, covering Opuntia tuna, do not admit of touching it without cruelly injuring the hand," he adds : "this latter is entirely devoid of these organs, but is provided with sharp silky bristles (glochidia) united in numerous clusters, which are excessively troublesome because they insinuate themselves into the skin with great ease" (Transl.). 
This information is embodied in a now obscure publication that has apparently been overlooked since Perottet's time. When the Commission was in parts whence it might have visited Senegal it was not at its disposal, and the exigencies of travelling did not admit of explorations in the disturbed republic of Hayti later on.

\section{B. Wild Cochineal Insects (Grana sylvestre).}

The following facts will serve to indicate the many years that the pricklypear-loving insects designated "Wild Cochineal" or Grana sylvestre, the Coccus of Ratzeburg, have been known and their habits observed :-

1. West Indian Wild Cochineal (Dactylopius tomentosus Newsteadi, Ckll.).-Writing with regard to Jamiaca in 1707-1725, Sir Hans Sloane mentioned, in describing the Opuntia that we now know as Nopalea cochinelifera (Linn.), its harbouring a cochineal insect, whence the technical name assigned to it by Linné in 1736 , by which it is distinguished. Sloane does not state that it occurred there on any other species. It has persisted in Jamaica, as the Commission found, and as is mentioned already by it, is still confined there to its original host-plant. The latter remark applies, too, to its occurrence in Antigua, where we found it on the Nopalea referred to but never on any plants of two different kinds of prickly-pear growing close at hand. From Jamaica the insect had often been sent to Europe prior to 1818, and its habits observed there (Humboldt, A.-1818, p. 424).

2. Mexican Wild Cochineal Insect, Melichior de Ruusscher (1729, passim), writing in 1729 and quoting many authentic Mexican documents dating 1725, describes the Grana sylvestre as occuring in several parts adjacent to Oaxaca on Wild Opuntias, but also attacking those on which the Precious Cochineal Insect (Grana fina) fed, the Opuntia cochinelifer of Miller (probably O. decumana, Haw.). And, moreover, we find de Menonville stating that in 1777 it was prevalent at Guaxaca, and that he transferred it therefrom to Port au Prince (Hayti). Moreover, G. A. Prinsep took it to England from Vera Cruz, Mexico, established it too at Chelsea, and thence " brought a supply to Bombay in 1821. A second followed next year, both of which arrived in a living state." It occurs in these parts of Mexico mentioned to this day, and both de Ruusscher's correspondents, and the French naturalist, de Menonville, early made it an object of special study.

San Domingo Wild Cochineal.-When de Menonville returned to Port au Prince (Hayti) in 1777, he found a Grana sylvestre there, which apparently was one that there are grounds for concluding attacked the Opuntia inermis (the Queensland pest pear), as well as to a less degree Opuntia Dillenii. This apparently was the insect afterwards conveyed to Senegal (vid. supra).

Brazilian Wild Cochineal.-G. A. Prinsep, writing in 1839, stated that a wild cochineal insect probably existed in more than ordinary perfection in Brazil, and that he made trial about the year 1787 of some sent thence by way of Lisbon to England (Prinsep, 1839, p. 26). Also that Captain Neilson conveyed Wild Cochineal therefrom to India in 1795 (Tryon, 1910).

Western S. American Wild Cochineal.-Alexander A. Humboldt, writing descriptive of his travels in 1799 , stated that in addition to his observations at Oaxaca (Mexico) he had occasion to observe the Cochenilla silvestre in the kingdoms of New Granada, Quito, and Peru (Humboldt, A., 1818, p. 424). 
United States Wild Cochineal Insect.-John Ellis, in 1757, ascertained from Dr. Alexander Gorden, of Charles Town, South Carolina (U.S.A.), the fact of a Wild Cochineal Insect oceuring there on Cactus opuntia (? Op. nana), and combined his own description of it and that of the latter in a comprehensive account of the insect and its habits, describing both male and female individuals. (Vid. Philosophical Transactions of Royal Society, London, Vol. 52).

Indian and South African Wild Cochineal.-In addition to these, there are also the Coccus capensis, Green, of South Africa, and C. indicus, Green, of India and Ceylon, the former introduced about 1832, and the latter in 1795 and on subsequent occasions. These need not be dwelt on, except to mention that they and their specific relations to particular kinds of Opuntia have been observed from time to time since, for they have persistently existed in these countries.

It is obvious to remark that it is not to be inferred that the Cochineal Insects mentioned under these several different countries are in all cases distinct.

Price, 5s. 6d.]

By Authority: Anthony James Cumming, Government Printer, Brisbane. 








